\title{
THERMO-TECTONICS OF THE CALABRIAN ARC, SOUTHERN ITALY \\ CONSTRAINTS FROM FISSION TRACK ANALYSIS
}

\author{
Stuart Nigel Thomson
}

A thesis submitted for the degree of Doctor of Philosophy

at the University of London

Department of Geological Sciences

University College

University of London

September 1992 
ProQuest Number: 10044517

All rights reserved

INFORMATION TO ALL USERS

The quality of this reproduction is dependent upon the quality of the copy submitted.

In the unlikely event that the author did not send a complete manuscript and there are missing pages, these will be noted. Also, if material had to be removed, a note will indicate the deletion.

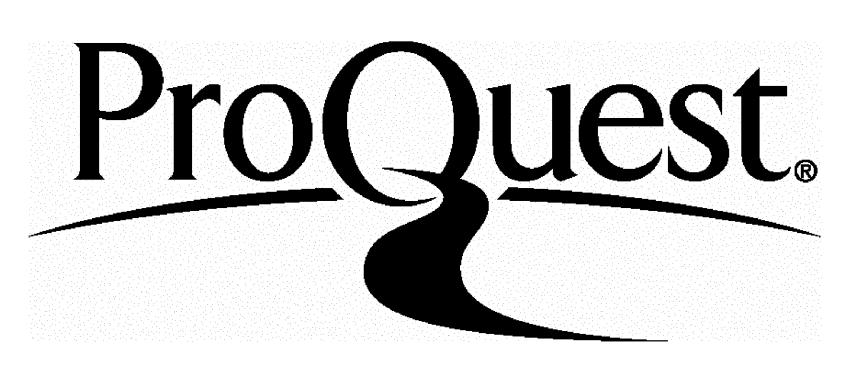

ProQuest 10044517

Published by ProQuest LLC(2016). Copyright of the Dissertation is held by the Author.

All rights reserved.

This work is protected against unauthorized copying under Title 17, United States Code. Microform Edition $\odot$ ProQuest LLC.

\author{
ProQuest LLC \\ 789 East Eisenhower Parkway \\ P.O. Box 1346 \\ Ann Arbor, MI 48106-1346
}


This study uses fission track analysis to provide temperature and time constraints on the cooling and exhumation history of the basement rocks of the Calabrian Arc of southern Italy. Fission track analysis also provides information on the provenance and burial history of the terrigenous Oligo-Miocene Stilo-Capo d'Orlando Formation.

65 samples from the basement rocks have yielded 57 apatite fission track ages, 54 zircon fission track ages and 25 apatite track length distributions. 9 samples from the StiloCapo d'Orlando Formation have yielded 8 apatite fission track ages, 8 zircon fission track ages and 6 apatite track length distributions.

Qualitative and quantitative analysis of the fission track data reveals that the majority of the basement rocks underwent a phase of increased cooling related to exhumation between about $35 \mathrm{Ma}$ (Early Oligocene) and $15 \mathrm{Ma}$ (Middle Miocene). Evidence from the local sedimentary record indicates that erosion played an important role in the exhumation process. Extensional tectonism also contributes to some of the increased exhumation.

Analysis of the fission track results obtained from the Stilo-Capo d'Orlando Formation confirm a Calabrian basement provenance for the sediments. The previously debated origin of volcanic conglomerate clasts from the formation is also resolved. Finally apatite fission track analysis indicates post-depositional burial at the base of the formation to temperatures greater than $80^{\circ} \mathrm{C}$.

The final part of this thesis uses the fission track age and temperature constraints to produce an improved tectonic model for the Oligo-Miocene tectonic evolution of the Calabrian Arc. This model proposes that increased exhumation is a consequence of the dynamics of an overthickened orogenic wedge. The model is related to the overall plate dynamics of the western Mediterranean orogeny. 


\section{ACKNOWLEDGEMENTS}

This project was supervised by Dr. Robert Hall, who has provided much advice and encouragement, when not away in the field, and whose valuable criticisms of the initial drafts of this thesis were much appreciated. I must also thank Professor Claudio Vita-Finzi, who proposed southern Italy as the field area after problems developed with the original project proposal. Finally, I am greatly indebted to Dr. Tony Hurford for allowing the use of the facilities of the London Fission Track Research Group. Funding for this project was provided by the Natural Environment Research Council. Financial assistance from the London Fission Track Research Group and Eurotrack was also greatly received.

Samples were collected from throughout Calabria and Sicily, and special recommendation must go to Le Pensione Sirene, in Scilla. Assistance and company in the field from Bill Murphy, Dr. Robert Hall, Professor Claudio and Penelope Vita-Finzi and Mark Ferry was invaluable. Also, thanks to Gert Jan Weltje for a valuable discussion in the field, and for providing a pre-print of his work on the Stilo-Capo d'Orlando Formation. Finally thanks to the FIAT garage at Villa san Giovanni for keeping the car going!

In the Fission Track Laboratory, Andy Carter must be thanked for showing me the ropes, and teaching me all the essentials of the technique. Also Kerry Gallagher and Andy Yelland are appreciated for providing much advice and criticism on the initial drafts of the fission track bits of the thesis. Thanks also to all the other members of the Lab, including Kit, Ruth, McAndy, Cherry, Susie, Alùn and Vijay and to Sean for thin sections and Mike Gray for photographic work. Special mention must also go to my fellow suffering research students at UCL, including Angus, Faz, Spencer, Mark, Jeff, Simon et al.

Finally, last, but not least, special thanks must be extended to my parents who have provided continued support and accommodation during the duration of this thesis. 


\section{TABLE OF CONTENTS}

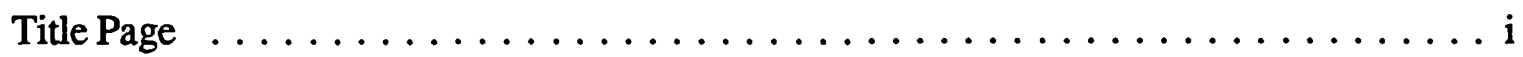

Abstract $\ldots \ldots \ldots \ldots \ldots \ldots \ldots \ldots \ldots \ldots \ldots \ldots$ ii

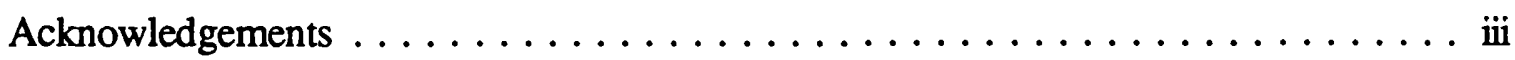

Table of Contents $\ldots \ldots \ldots \ldots \ldots \ldots \ldots \ldots \ldots \ldots$ iv

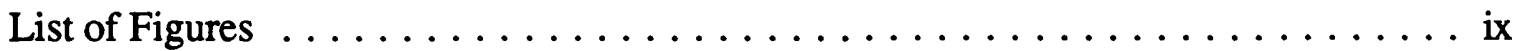

List of Tables $\ldots \ldots \ldots \ldots \ldots \ldots \ldots \ldots \ldots \ldots \ldots \ldots \ldots \ldots \ldots \ldots \ldots$

List of Plates $\ldots \ldots \ldots \ldots \ldots \ldots \ldots \ldots \ldots \ldots \ldots \ldots \ldots \ldots \ldots \ldots$

CHAPTER 1

INTRODUCTION

1.1 General Background $\ldots \ldots \ldots \ldots \ldots \ldots \ldots \ldots \ldots \ldots \ldots$

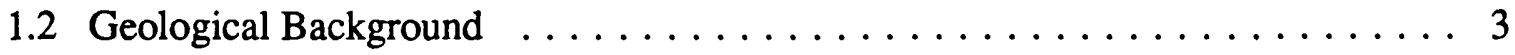

1.3 Thesis Aims $\ldots \ldots \ldots \ldots \ldots \ldots \ldots \ldots \ldots \ldots \ldots$

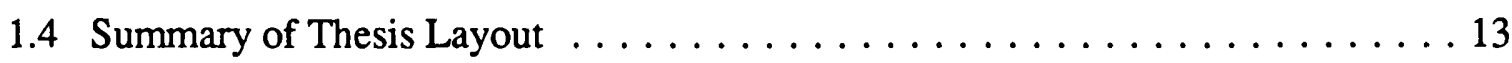

\section{CHAPTER 2}

THE GEOLOGY OF SOUTHERN ITALY AND THE TYRRHENIAN SEA

\section{A REVIEW}

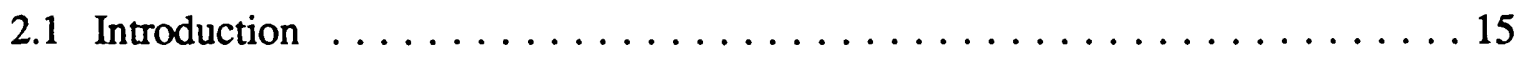

2.2 The Undeformed Foreland and Ionian Sea . . . . . . . . . . . . . . 15

2.3 The Foreland Basins and Calabrian Ridge $\ldots \ldots \ldots \ldots \ldots \ldots$

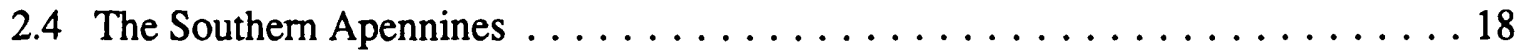

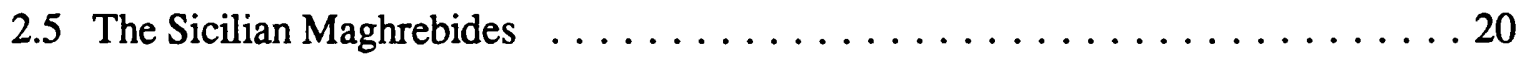

2.6 The Liguride or Neotethyan Complex . . . . . . . . . . . . . 21

2.7 The Calabrian Arc Crystalline Basement Complex . . . . . . . . . . . . . 22

2.8 Syn-Orogenic Cover Sequences . . . . . . . . . . . . . . . . 23

2.8.1 The Stilo-Capo d'Orlando Formation . . . . . . . . . . . . . . 23

2.8.2 The Argille Varicolore . . . . . . . . . . . . . . . . 23

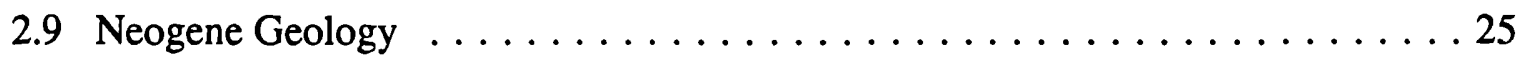

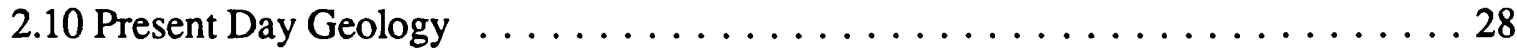

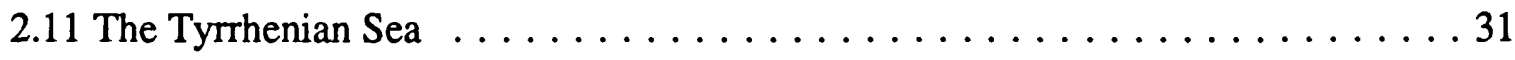

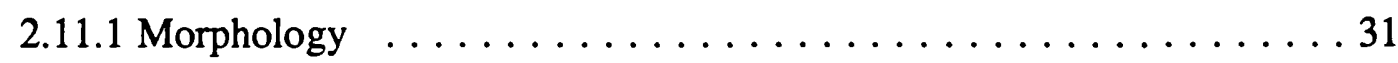

2.11.2 Nature of Basement $\ldots \ldots \ldots \ldots \ldots \ldots \ldots \ldots \ldots \ldots \ldots$

2.11.3 Recent Volcanism . . . . . . . . . . . . . . . . . . 33 
2.11.4 Sedimentology and Stratigraphy $\ldots \ldots \ldots \ldots \ldots \ldots$

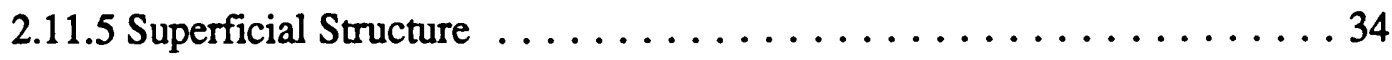

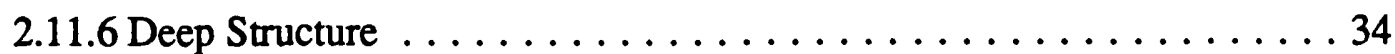

\section{CHAPTER 3}

\section{THE CALABRIAN ARC BASEMENT ROCKS}

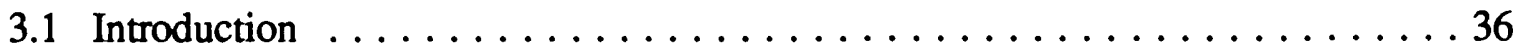

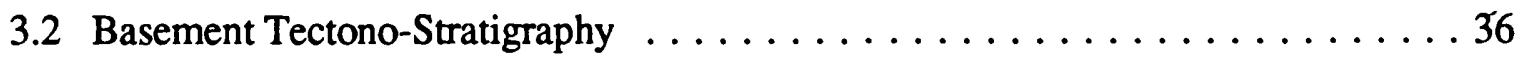

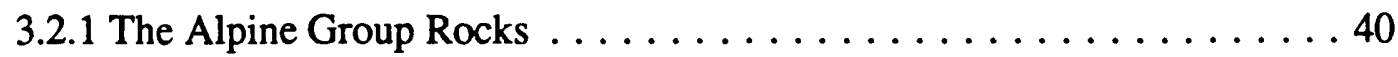

3.2.2 The Hercynian High-Grade Rocks $\ldots \ldots \ldots \ldots \ldots \ldots \ldots . \ldots 42$

3.2.3 The Hercynian Plutonic Rocks $\ldots \ldots \ldots \ldots \ldots \ldots \ldots \ldots . \ldots . \ldots . \ldots$

3.2.4 The Hercynian Low-Grade Rocks and Sedimentary Cover . . . . . . 44

3.3 A Synthesis of Isotopic Age Data Collected from the Calabrian Arc Basement

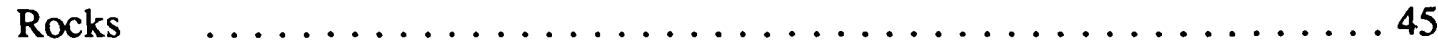

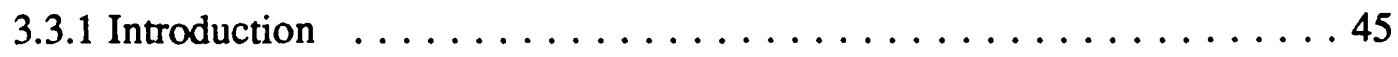

3.3.2 The Concept of Closure Temperature $\ldots \ldots \ldots \ldots \ldots \ldots \ldots 45$

3.3.3 Relevant Closure Temperature Values ............... 54

3.3.4 Interpretation of the Isotopic Age Data from the Calabrian Arc Basement

Complex ........................... 55

\section{CHAPTER 4}

\section{FISSION TRACK ANALYSIS}

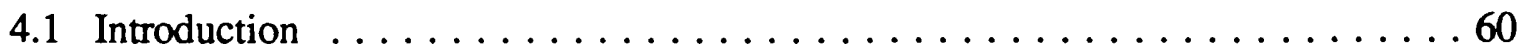

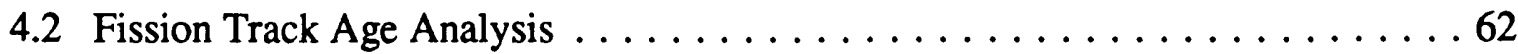

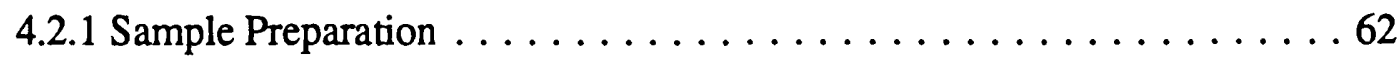

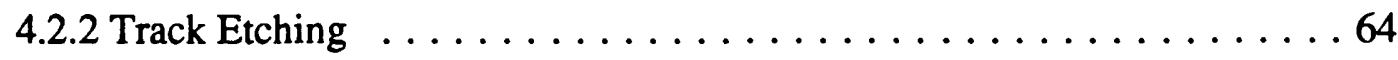

4.2.3 Principal Dating Methods $\ldots \ldots \ldots \ldots \ldots \ldots \ldots \ldots 67$

4.2.3.1 The Population Method .................6 67

4.2.3.2 The External Detector Method . . . . . . . . . . . . 69

4.2.4 Derivation of the Fission Track Age Equation . . . . . . . . 69

4.2.4.1 The Problem of the Decay Constant $\lambda f$ of $238 U \ldots \ldots \ldots 72$

4.2.4.2 The Problem of Absolute Measurement of the Neutron

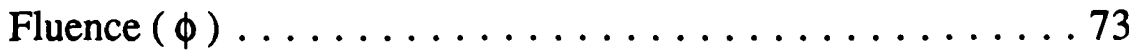

4.2.5 The Zeta Calibration in Fission Track Analysis $\ldots \ldots \ldots \ldots \ldots \ldots 73$

4.2.5.1 The Use of Age Standards . . . . . . . . . . . 75

4.2.5.2 The Use of Dosimeter Glasses . . . . . . . . . . . . 76

4.2.6 The Statistical Analysis of Fission Track Data Sets . . . . . . . 77 
4.3 Fission Track Annealing $\ldots \ldots \ldots \ldots \ldots \ldots \ldots \ldots \ldots \ldots \ldots \ldots \ldots$

4.3 .1 Introduction $\ldots \ldots \ldots \ldots \ldots \ldots \ldots \ldots \ldots \ldots \ldots \ldots$

4.3.2 Apatite Fission Track Length Analysis . . . . . . . . . . . . . 85

4.3.3 Quantitative Modelling of Apatite Fission Track Annealing . . . . . 888

4.4 Applications of Fission Track Analysis . . . . . . . . . . . . . . . 99

4.4.1 Direct Dating . . . . . . . . . . . . . . . . . . . . . . 100

4.4.2 Discrimination of Sedimentary Provenance . . . . . . . . . . . . . 100

4.4.3 Thermal History of Rifted Margins . . . . . . . . . . . . . . 101

4.4.4 Thermal History of Sedimentary Basins . . . . . . . . . . . . . 102

4.4.5 Thermal History of Mountain Belts . . . . . . . . . . . . . . 102

\section{CHAPTER 5}

THE RESULTS OF FISSION TRACK ANALYSIS FROM THE BASEMENT COMPLEX OF THE CALABRIAN ARC, SOUTHERN ITALY

5.1 Sampling Procedure . . . . . . . . . . . . . . . . . . . . . . . . . . 104

5.2 Apatite and Zircon Fission Track Age Data . . . . . . . . . . . . . . 105

5.3 Apatite Confined Track Length Analysis Results . . . . . . . . . . . . . . . . . 107

CHAPTER 6

ANALYSIS OF FISSION TRACK RESULTS FROM THE BASEMENT COMPLEX OF THE CALABRIAN ARC

6.1 Qualitative Analysis . . . . . . . . . . . . . . . . . . . . . . . 119

6.1.1 Closure Temperature Derived Cooling Histories . . . . . . . . . . . 119

6.1.2 Constraints Provided by Apatite Fission Track Length Analysis . . . . 128

6.2 Quantitative Analysis . . . . . . . . . . . . . . . . 133

6.3 Cooling Histories : Their Geological Interpretation and Significance . . . . . . . 142

6.3.1 Cooling, Exhumation and the Geotherm . . . . . . . . . . . . . . 142

6.3.2 Definition and Processes of Exhumation . . . . . . . . . . . 145

6.3.3 Exhumation Data from the Crystalline Basement Rocks of the Calabrian

Arc Provided by Fission track Analysis $\ldots \ldots \ldots \ldots \ldots$

6.4 Summary of Results . . . . . . . . . . . . . . . . . . . 153

\section{CHAPTER 7}

THE STILO-CAPO D'ORLANDO FORMATION

A STUDY USING FISSION TRACK ANALYSIS

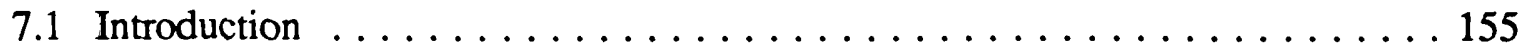


7.2 Geological Outline of the Stilo-Capo d'Orlando Formation $\ldots \ldots \ldots \ldots \ldots$

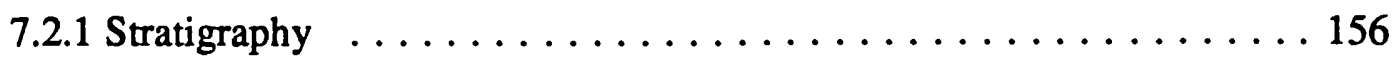

7.2 .2 Sedimentology . . . . . . . . . . . . . . . . . 158

7.2.3 Depositional Environments and Facies $\ldots \ldots \ldots$. . . . . . . 160

7.2.4 Tectonic Environment . . . . . . . . . . . . . . . . . 160

7.3 Previous Work on the Sedimentary Provenance of the Stilo-Capo d'Orlando Formation . . . . . . . . . . . . . . . . . . . . . . 162

7.4 Analysis of the Fission Track Results . . . . . . . . . . . . 165

7.4.1 Analysis of Fission Track Results from Seven Conglomerate Clasts . . 165

7.4.2 Analysis of Fission Track Results from Two Sandstone Samples . . . . 170

7.5 A Discussion of the Fission Track Results Obtained from the Stilo-Capo

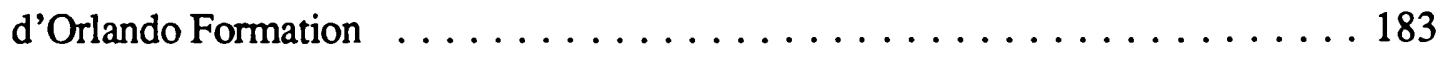

7.5 .1 Constraints on Provenance . . . . . . . . . . . . . . 183

7.5.2 Origin of the Volcanic Conglomerate Clasts . . . . . . . . . . . 186

7.5.3 Re-heating of the Stilo-Capo d'Orlando Formation . . . . . . . . . . . 187

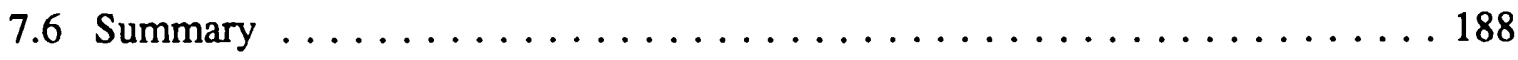

\section{CHAPTER 8}

\section{DISCUSSION AND GEOLOGICAL INTERPRETATION}

8.1 Introduction . . . . . . . . . . . . . . . . . . . . . . 190

8.2 Implications of the Derived Low-Temperature Cooling Histories on the

Exhumational History of the Calabrian Arc . . . . . . . . . . . . . . . 191

8.2.1 Introduction . . . . . . . . . . . . . . . . . . . . 191

8.2.2 Evidence for Erosional Processes . . . . . . . . . . . . . . . . . 195

8.2.3 Evidence of Extensional Tectonism . . . . . . . . . . . . . . . . . . 199

8.2.4 Discrimination Between Erosional and Extensional Processes . . . . . 203

8.2 .5 Summary . . . . . . . . . . . . . . . . . . . . 203

8.3 Other Factors Influencing the Results of Fission Track Analysis . . . . . . . . 204

8.4 A Revised Model for the Late Tertiary Tectonic Evolution of the Calabrian Arc . 206

8.4.1 Introduction . . . . . . . . . . . . . . . . 206

8.4.2 Pre-Oligocene Evolution (Before $30 \mathrm{Ma}) \ldots . . \ldots . . . . . . . . .206$

8.4.3 Oligo-Miocene Evolution (30 to $20 \mathrm{Ma}$ ) . . . . . . . . . . . . . . . 209

8.4.4 Miocene-recent Evolution (Post $20 \mathrm{Ma}$ ) . . . . . . . . . . . . . 210

8.5 The Calabrian Arc in Western Mediterranean Orogenesis During the

Oligo-Miocene . . . . . . . . . . . . . . . . . . . . 215 
CHAPTER 9

SUMMARY

9.1 Thesis Conclusions . . . . . . . . . . . . . . . . . . . 220

9.2 Some Suggestions for Further Work . . . . . . . . . . . . . 223

APPENDICES

Appendix I

Preparation of Samples for Fission Track Analysis and Analytical Procedures 225

\section{Appendix II}

Details of Samples Collected from the Calabrian Arc Crystalline Basement Rocks

for the Purpose of Fission Track Analysis

\section{Appendix III}

Apatite and Zircon Zeta Calibration Values 


\section{LIST OF FIGURES}

\section{CHAPTER 1}

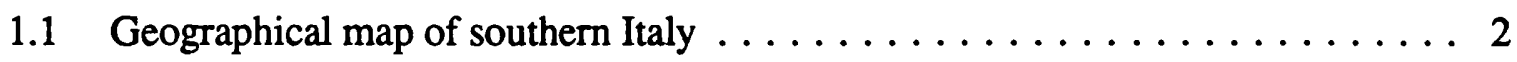

1.2 Geological map of the western Mediterranean . . . . . . . . . . . 4

1.3 Reconstruction of Neotethys at $\sim 150 \mathrm{Ma} \ldots \ldots \ldots \ldots \ldots$

1.4 Tectonic reconstruction of the western Mediterranean . . . . . . . . . . 10-11

\section{CHAPTER 2}

2.1 Geological sketch map of southern Italy $\ldots \ldots \ldots \ldots \ldots \ldots \ldots \ldots$

2.2 Geological map of the Neogene of Calabria $\ldots \ldots \ldots \ldots \ldots \ldots$

2.3 Average surface uplift rates since the late Pleistocene . . . . . . . . . . . . 29

2.4 Schematic drawing of the tectonic setting of the Tyrrhenian Sea . . . . . . . 32

\section{CHAPTER 3}

3.1 Geological sketch map of the basement rocks of the Calabrian Arc . . . . . . 38

3.2 Schematic cross-sections of the basement rocks across the Sila massif . . . . . . . 39

3.3 Location map for isotopic ages obtained by other authors $\ldots \ldots \ldots \ldots \ldots$

3.4 Examples of interpretations of isotopic age data $\ldots \ldots \ldots \ldots \ldots \ldots \ldots$

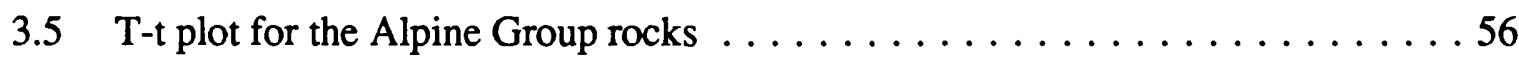

3.6 T-t plot for the high-grade Hercynian rocks $\ldots \ldots \ldots \ldots \ldots \ldots \ldots$

3.7 Cooling history for the high-grade Hercynian rocks of the NW Serre . . . . . 58

3.8 T-t plot for the Hercynian plutonic the low-grade Hercynian rocks $\ldots \ldots \ldots$

\section{CHAPTER 4}

4.1 The "ion spike explosion mechanism" .................63

4.2 The relationship between sample age, uranium content and fission track density .63

4.3 The principles of fission track etching $\ldots \ldots \ldots \ldots \ldots \ldots \ldots \ldots \ldots \ldots \ldots \ldots$

4.4 The different fission track dating procedures $\ldots \ldots \ldots \ldots \ldots$

4.5 The principles of the external detector method $\ldots \ldots \ldots \ldots \ldots \ldots$

4.6 Values for the $238 \mathrm{U}$ decay constant of $\lambda_{\mathrm{f}} \ldots \ldots \ldots \ldots \ldots \ldots \ldots$

4.7 Variations of the $\mathrm{B}$ calibration ratio with time $\ldots \ldots \ldots \ldots \ldots \ldots$

4.8a Probability distribution curves from Wealden sandstones $\ldots \ldots \ldots \ldots$. . . 80

$4.8 \mathrm{~b}$ The principles of the radial plot $\ldots \ldots \ldots \ldots \ldots \ldots$

4.9 Annealing data for apatite, zircon and sphene $\ldots \ldots \ldots \ldots \ldots$. . . . . 82

4.10 Estimation of the zircon fission track closure temperature $\ldots \ldots \ldots \ldots 2$

4.11 Apatite age profiles from two boreholes in the Otway Basin . . . . . . . . 84

4.12 Different types of confined fission tracks in apatite $\ldots \ldots \ldots \ldots 6$ 
4.13a Relationship between standard deviation and mean track length $\ldots \ldots \ldots$. . 87

4.13b Three characteristic track length distributions $\ldots \ldots \ldots \ldots$. . . . . . 87

$4.14 \mathrm{~T}$-t paths and resultant apatite track length distributions $\ldots \ldots \ldots \ldots$. . . . 89

4.15 Arrhenius plots of apatite annealing data . . . . . . . . . . . . . 90

4.16 The "equivalent-time" principle . . . . . . . . . . . . . . . . . 92

4.17 Heating and cooling responses of the equivalent time principle . . . . . . 99 93

4.18 Relationship of apatite track density and mean track length $\ldots \ldots \ldots \ldots$. . 94

4.19 A predicted response of the apatite fission track system . . . . . . . . . . . 94

4.20 An example of Monte carlo modelling . . . . . . . . . . . . . . 96

4.21 A comparison of apatite data with predicted results . . . . . . . . . . 98

4.22 Relationship between apatite fission track age and apatite composition . . . . . 98

\section{CHAPTER 5}

5.1 Location map of samples collected for fission track analysis $\ldots \ldots \ldots \ldots$. . . 108

5.2 Map of fission track data from the Sila and Catena Costiera . . . . . . . . . . . 113

5.3 Map of fission track data from the Serre, Aspromonte, and Peloritani Mts . . . 114

5.4 Map with apatite track length distributions $\ldots \ldots \ldots \ldots \ldots \ldots$

\section{CHAPTER 6}

6.1 T-t plot for the Alpine Group rocks with fission track data . . . . . . . . . 120

6.2 T-t plot for the high-grade Hercynian rocks with fission track data . . . . . 120

6.3 T-t plot for the Hercynian plutonic the low-grade Hercynian rocks with fission track data . . . . . . . . . . . . . . . . . . . . . 122

6.4 Low temp. T-t plot for Alpine Group and high-grade Hercynian rocks . . . . 123

6.5 Low temp. T-t plot for Hercynian plutonic and low-grade Hercynian rocks . . 123

6.6 Fission track data traverse across the NW Serre . . . . . . . . . . . . . . . . . . . 124

6.7 Fission track data traverse across the Sila Massif . . . . . . . . . . . . . . 127

$6.8 \mathrm{~T}$-t plots of individual sample data from Table $6.1 \ldots \ldots \ldots \ldots$

6.9 Mean apatite fission track length vs fission track age $\ldots \ldots \ldots \ldots \ldots \ldots 131$

6.10 S.D. of apatite track length distribution vs fission track age . . . . . . . . 131

6.11 comparison of mean track length with standard deviation $\ldots \ldots \ldots \ldots \ldots$

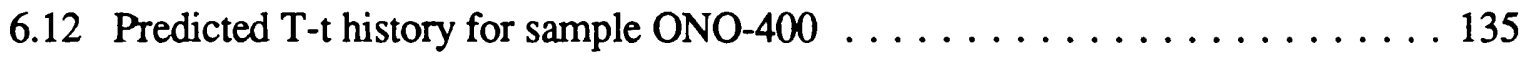

6.13 Predicted T-t histories for Alpine Group and high-grade Hercynian rocks . . . 136

6.14 Predicted T-t histories for Hercynian plutonic and low-grade rocks . . . . . 138-139

6.15 Predicted best-fitting T-t histories of the sample data $\ldots \ldots \ldots \ldots \ldots 141$

6.16 Predicted $\mathrm{T}$-t histories incorporating unconformity constraints . . . . . . . 143

6.17 Time-depth plot for the individual sample data of Table $6.1 \ldots \ldots$. . . . . . 147

6.18 Apatite age vs elevation for Alpine Group and high-grade Hercynian rocks . . 149

6.19 Apatite age vs elevation for Hercynian plutonic and low-grade rocks . . . . . . 149 
6.20 Zircon age vs elevation for Alpine Group and high-grade Hercynian rocks . . . 150

6.21 Zircon age vs elevation for Hercynian plutonic and low-grade rocks . . . . . . 150

6.22 Apatite age vs elevation with Pleistocene uplift component removed . . . . . . 152

\section{CHAPTER 7}

7.1 Map showing the location of the Stilo-Capo d'Orlando Formation $\ldots \ldots \ldots 157$

7.2 Two simplified stratigraphical columns . . . . . . . . . . . . . . . . . 159

7.3 Map of sediment isopachs, palaeocurrents and syn-sedimentary faults . . . . . 159

7.4 QFL Ternary plot of Stilo-Capo d'Orlando Formation sandstones . . . . . . . . 163

7.5 QFL Ternary plot of Stilo-Capo d'Orlando Formation conglomerates . . . . . 163

7.6 Apatite track length data for some conglomerate clasts $\ldots \ldots \ldots \ldots$. . . 168

7.7 Apatite fission track length vs fission track age (with conglomerate data) . . . 169

7.8 S.D. of apatite track length vs fission track age (with conglomerate data) . . . 169

7.9 Predicted T-t histories for conglomerate clasts . . . . . . . . . . . . 171

7.10 Predicted best fitting $\mathrm{T}$-t histories for conglomerate clasts $\ldots \ldots \ldots \ldots$. . . . 172

7.11 Apatite track length data for the sandstone samples . . . . . . . . . . . . 173

7.12 Apatite age probability distribution curves for the sandstone samples . . . . . . 174

7.13 Radial plots for the sandstone apatite data . . . . . . . . . . . . . . 177

7.14 Monte Carlo runs that fit both age and length data for sample SCO-6 . . . . . 178

7.15a Monte Carlo runs that fit length data for sample SCO-6 . . . . . . . . . . 178

$7.15 \mathrm{~b}$ Monte Carlo runs that fit age data for sample SCO $-6 \ldots \ldots \ldots \ldots$

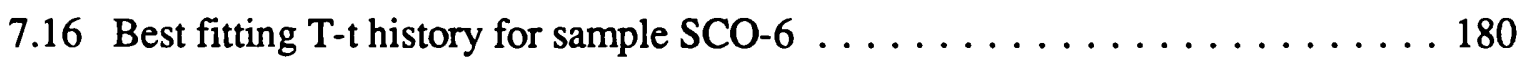

7.17 Monte Carlo runs that fit both age and length data for sample SCO-9 . . . . . 181

7.18 Zircon age probability distribution curves for the sandstone samples . . . . . 182

7.19 Radial plots for the sandstone zircon data . . . . . . . . . . . . . 182

7.20 Erosional model for the Stilo-Capo d'Orlando Formation . . . . . . . . . . 184

\section{CHAPTER 8}

8.1 Simplified exhumation model . . . . . . . . . . . . . . . . . . . . . 194

8.2 Oligo-Miocene flysch palaeogeography . . . . . . . . . . . . . . 198

8.3 Map showing fission track ages of the Aspromonte . . . . . . . . . . . 201

8.4 Map showing change in zircon ages across the Sila Massif . . . . . . . . . 205

8.5 Tectonic reconstruction of the Calabrian Arc (between 50 and $40 \mathrm{Ma}$ ) . . . . 207

8.6 Tectonic reconstruction of the Calabrian Arc (at $\sim 25 \mathrm{Ma}) \ldots \ldots \ldots \ldots 211$

8.7a Model for the post-orogenic unloading of an orogen by extension . . . . . . . 214

8.7b Comparison with the post 15 Ma evolution of the Calabrian Arc . . . . . . . . 214

8.8 Simplified explanation of "roll-back" . . . . . . . . . . . . . . 217

8.9 Model for the development of a basin due to outward arc migration . . . . . . 217

8.10 Tectonic model for the evolution of the Calabrian Arc between 40Ma and 20Ma 219 


\section{LIST OF TABLES}

\section{CHAPTER 3}

3.2 Previously obtained isotopic age data from the Calabrian Arc basement . . . 47-51

\section{CHAPTER 4}

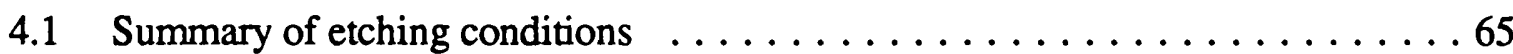

\section{CHAPTER 5}

5.1 Apatite fission track age data from the basement rocks . . . . . . . . . 109-110

5.2 Zircon fission track age data from the basement rocks . . . . . . . . . . 111-112

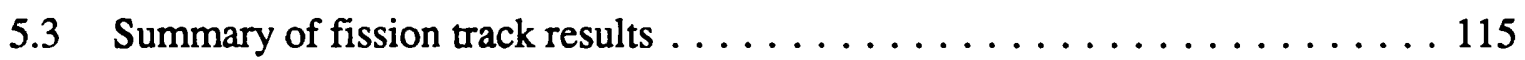

5.4 Summary of fission track results (grouped by region) $\ldots \ldots \ldots \ldots \ldots \ldots$

5.5 Apatite Confined track length data from the basement rocks . . . . . . . . . 117

\section{CHAPTER 6}

6.1 Individual sample isotopic age and fission track data . . . . . . . . . . 129

\section{CHAPTER 7}

7.1 Apatite fission track age data from Stilo-Capo d'Orlando conglomerate clasts . 166

7.2 Zircon fission track age data from Stilo-Capo d'Orlando conglomerate clasts . . 166

7.3 Apatite and zircon fission track age data from the two sandstone samples . . . . 173

\section{LIST OF PLATES}

\section{CHAPTER 2}

2.1 The "Argille Scagliose" in southern Calabria (Aspromonte) . . . . . . . . . . 24

2.2 Mt. Etna . . . . . . . . . . . . . . . . . . . . 24

\section{CHAPTER 3}

3.1 Bagni Unit phyllites from the southern Sila . . . . . . . . . . . . 41

3.2 A banded gneiss from the high-grade Hercynian metamorphic rocks of the Serre . 41

\section{CHAPTER 4}

4.1 Confined apatite fission tracks in apatite $\ldots \ldots \ldots \ldots \ldots$ 


\section{CHAPTER 1}

\section{INTRODUCTION}

\subsection{GENERAL BACKGROUND}

The Calabrian Arc is the name given to describe the narrow arcuate mountainous region of the Calabrian peninsula, or "toe", of southern Italy and northeastern Sicily that is composed largely of metamorphic and plutonic rocks. It is usually defined as the area between two major fault zones; the Sangineto Line to the north and the Taormina Line to the south. Figure 1.1 illustrates the location of the Calabrian Arc, including the main geographical features and locations within the arc.

Topographically it can be subdivided into several regions of high elevation separated by low-lying grabens. To the north of the Catanzaro trough is the Sila, a large $\left(2000 \mathrm{~km}^{2}\right)$ plateau with an average elevation of $1100-1200 \mathrm{~m}$ and high point of $1928 \mathrm{~m}$ and the Catena Costiera (Coastal Range). These two regions are split by the north-south Crati Graben. To the south of the Catanzaro Trough are the Serre and Aspromonte regions that show considerable relief with a high point of $1955 \mathrm{~m}$ only $16 \mathrm{~km}$ from the coast. The Serre and Aspromonte are bounded to the north by the Mesima Graben and to the west by the Straits of Messina. The part of the Calabrian Arc within northeastern Sicily is formed by the Peloritani mountains which reach a height of $1287 \mathrm{~m}$.

Much of highland Calabria is covered by thick chestnut, oak, birch and pine forest. This leads to a poor level of rock exposure. The rocks that do outcrop are susceptible to high amounts of weathering. This, along with high relief, heavy seasonal rainfall and periodic seismic activity means a high proportion of the region is susceptible to landslip. Therefore considerable caution has to be taken when undertaking geological studies to ensure that any outcrop and rock samples collected are in situ. The best outcrop occurs along the sides of deeply incised valleys, usually floored by "torrente," dry river beds subject to periodic flooding and in numerous roadside cuttings. Outcrop is also noticably more frequent on the arid Ionian Sea coast of Calabria. This lies in the rainshadow of the mountains, hence vegetation cover is much reduced, leading to more rock exposure. 


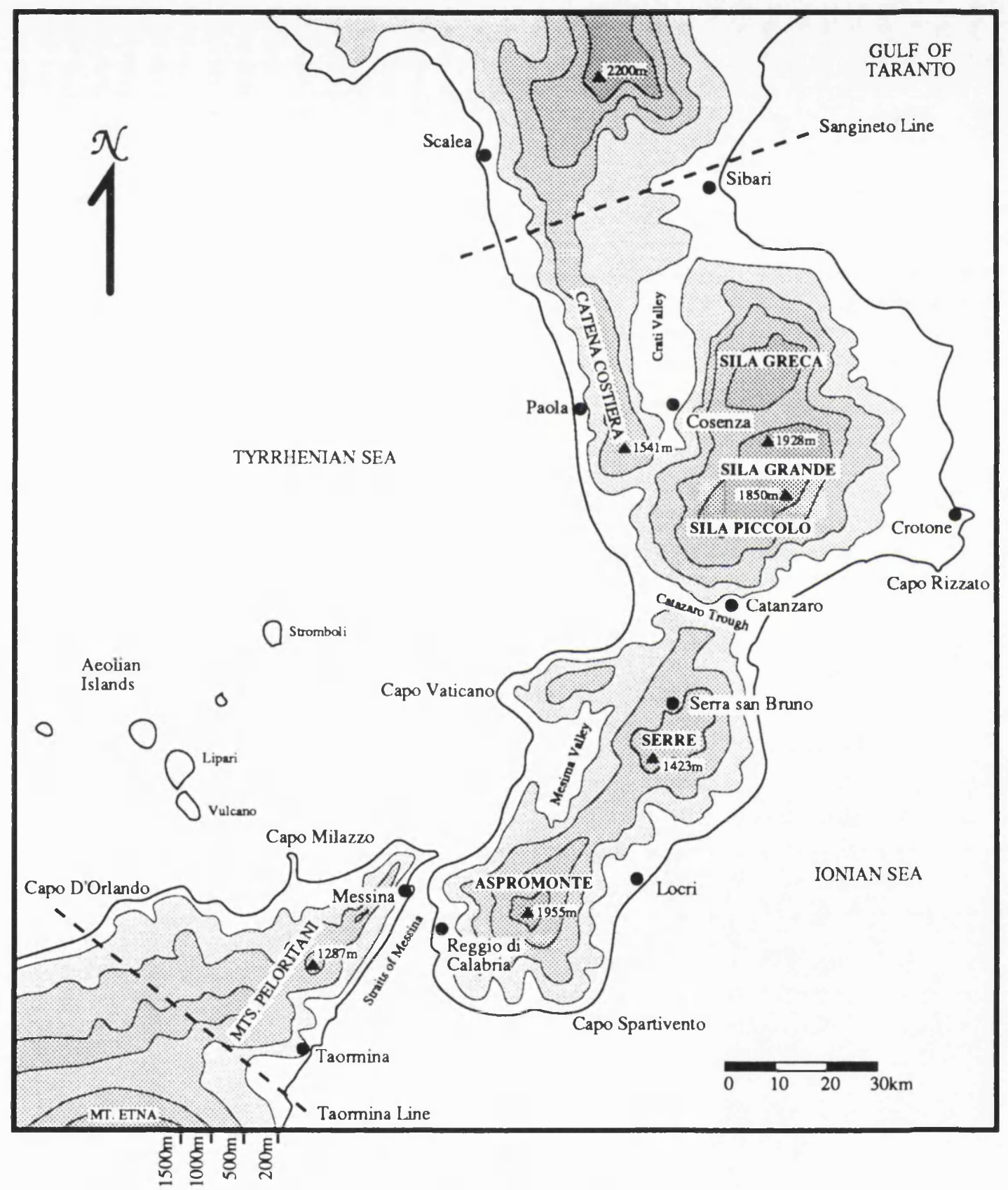

Figure 1.1 The main geographical features and locations of Calabria and northeastern Sicily 


\subsection{GEOLOGICAL BACKGROUND}

The location of the Calabrian Arc, in the western Mediterranean part of the Alpine orogenic belt, is illustrated in Figure 1.2. The map shows the Alpine orogenic belt split into two main allochthonous elements (after Dietrich, 1988): a younger Oligo-Mio-Pliocene element, consisting mainly of deformed sedimentary rocks from both the European and African margins of the original Tethyan ocean and a Paleogene element, consisting of ophiolitic and metamorphosed crystalline basement rocks with associated sediments. The Calabrian Arc is one of several regions where such allochthonous crystalline basement rocks can be seen, in this case emplaced upon the African and Adrian plate margin. Other similar regions include the Kabylie massifs of Algeria and the Betic-Rif Arc of Morocco and southern Spain. Rocks in a similar tectonic position also occur in Corsica and the western Alps. However these differ in having been emplaced upon the European plate margin. Surrounded by these orogenic belts are several major basins that constitute the western Mediterranean Sea. These basins have all formed since the Late Oligocene, subsequent to the collision between the African Plate and European Plate. Several, such as the Alboran Sea and Tyrrhenian Sea now show active spreading and all the major basins are floored by semi-oceanic and oceanic crust.

Unravelling the tectonic evolution of the western Mediterranean part of Alpine orogeny is difficult requiring explanation of several major questions. These include the presence of large regions of active extension within an essentially compressive regime. In addition, a major change in tectonic transport direction must be accounted for. The western Alps and Corsica show emplacement upon the European Plate margin whereas the Apennines, Calabrian Arc and Maghrebide orogen of northern Africa are emplaced upon the African and Adrian plate margins.

Since the advent of plate tectonic theory in the late 1960's, many attempts have been made to explain the present day geology of the western Mediterranean part of the Alpine orogenic belt. It is largely agreed is that the Alpine orogeny is the result of compressive motion between the African, Adrian and European plates. Prior to this, the area between the African and European plates was occupied by a small ocean basin known as 


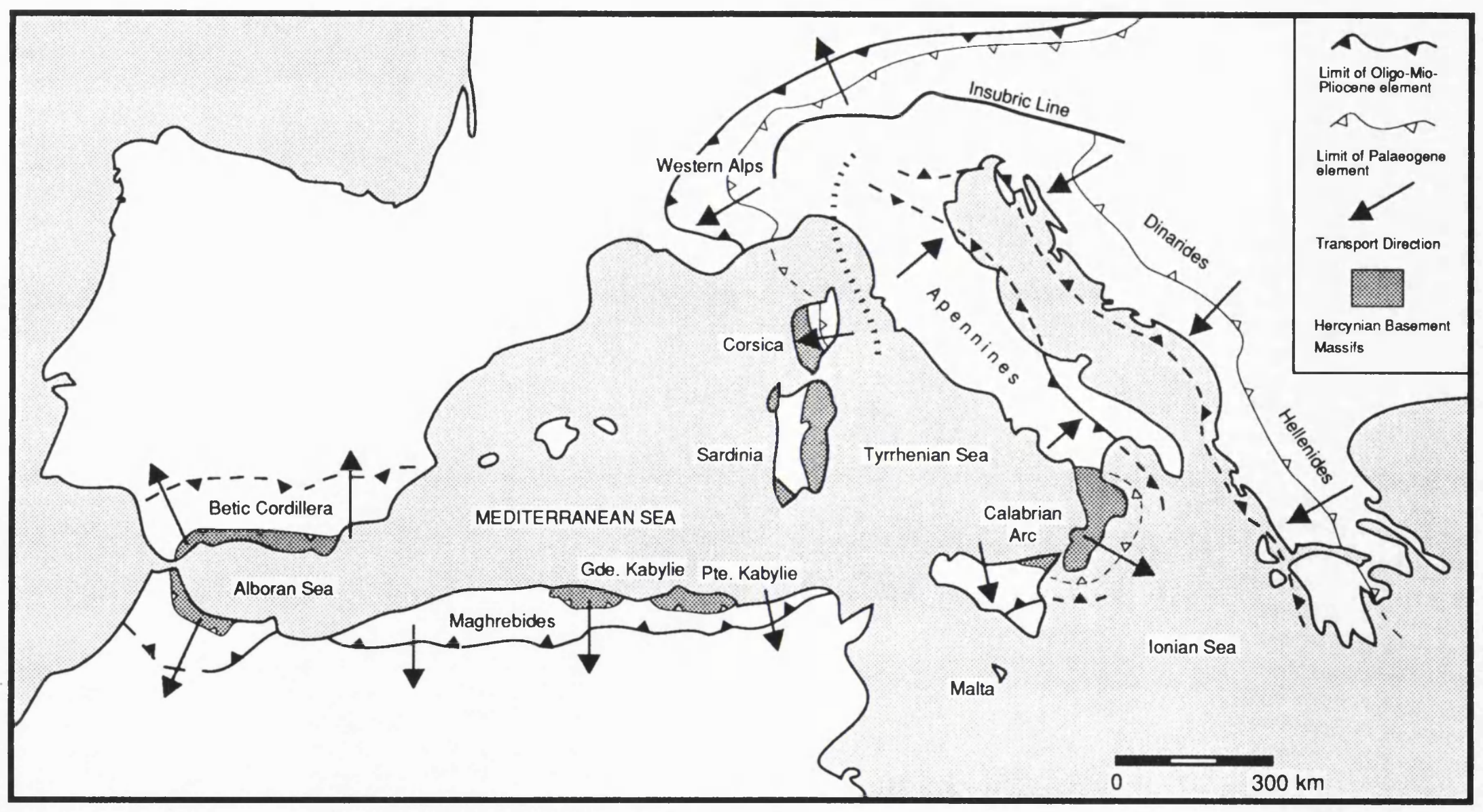

Figure 1.2 The situation of the Calabrian Arc within the present day Alpine and western Mediterranean orogenic belts 
Neotethys.

Neotethys is known to have formed during the Triassic to the Early Cretaceous, when widespread carbonate platforms developed on both its northwestern and southeastern margins. Radiometrically dated ophiolites from the western Alps and Corsica also show Neotethyan oceanic crust was formed during the Jurassic (Ohnenstetter et al., 1981). The latest reconstruction of Neotethys (Coward and Dietrich, 1989) suggests it formed as a large pull-apart basin (Figure 1.3), probably about 300km wide (Knott, 1988). This basin is bounded to the north and south by major left-lateral transform fault margins. The northern margin marks the site of the future western Alps and probably linked into the Tethyan Ocean sensu stricto, whereas the southern margin linked into the central Atlantic Ocean. It follows that the relative plate motions of Africa and Europe can be deduced by restoring magnetic anomaly data formed during the opening of the central Atlantic. Figure 1.3 also illustrates that the African margin of Neotethys was separated from the margin of the Tethyan Ocean sensu stricto by the Adrian promontory (Channell et al., 1979). This promontory acted as part of the African plate until the late-early Tertiary (Lowrie, 1986). After this some authors suggest Adria rotated $27^{\circ}$ anti-clockwise with respect to the African Plate, probably caused by transtensional tectonics between Sicily and north Africa (Boccaletti et al., 1987).

During the Late Cretaceous the relative plate motion between Africa and Europe shows a major change from left-lateral motion to a northeast-southwest directed compression. This is a result of the initial opening of the southern Atlantic Ocean. This marks the initiation of the Alpine Orogeny. For the western Mediterranean region, Dewey et al. (1989), from a new analysis of central Atlantic magnetic anomalies propose an age of $\sim 92 \mathrm{Ma}$ for this change in plate motion.

The tectonic models for the subsequent collision process, resulting in the geometry of the present day western Mediterranean, can be categorised into two main approaches.

The earliest suggested models were based on correlation of similar crystalline basement rocks seen in both the western Mediterranean and the western Alps. Haccard et al. (1972) and Alvarez (1974) proposed a Cretaceous to Eocene southerly directed 


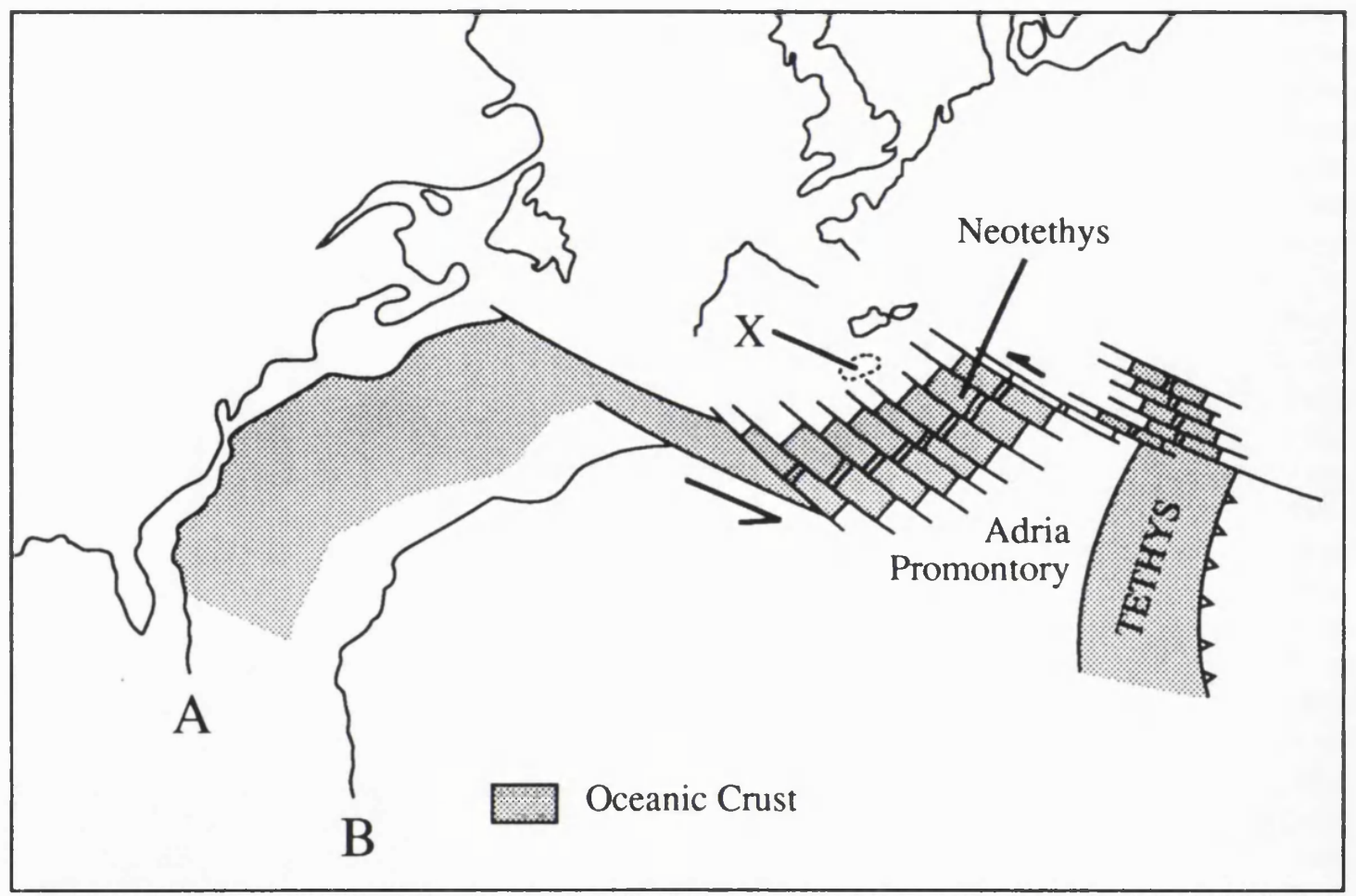

Figure 1.3 Reconstruction of Neotethys at $\sim 150 \mathrm{Ma}$ (after Coward and Dietrich, 1989)

(A - B indicates the positions of Africa at $175 \mathrm{Ma}$ and $149.5 \mathrm{Ma}$ according to Dewey et al., 1989)

(X - Indicates the probable approximate position of the present day Calabrian Arc Hercynian basement rocks) 
subduction of Neotethys beneath the African and Adrian Plates along the whole of the Alpine orogenic belt from the Betics through to the eastern Alps. However, to explain the opposite sense of vergence now seen in the western Mediterranean a subduction reversal is required sometime during the Oligocene that resulted in the emplacement of the Apennines, Calabria and the Maghrebides of north Africa upon the African and Adrian plate margin. Such a double vergence model is supported in models by Amodio-Morelli et al . (1976), Scandone (1979) and (1982), Cohen (1980), Boccaletti et al. (1984), Scandone and Patacca (1984) and Réhault et al. (1987) and other studies of this period.

More recently the double vergence approach has been replaced by models that propose two regions of opposed subduction or vergence separated by a major transform fault active since the initiation of collision during the Cretaceous. Such a model was proposed by Bouillin (1984) and Bouillin et al. (1986) after comparing the geology of the Calabrian Arc with that of the Kabylie basement rocks of Algeria. This model has since been supported by Knott (1987) and Dietrich (1988) who describe pre-Oligocene (Paleogene) structures with "African" vergence from the Calabrian Arc. "European" vergent structures used to argue the double vergence model by Alvarez (1976) and Faure (1980) are considered localised backthrusts by Knott (1987). The exact position of the transform zone needed to explain the reversal of vergence in the internal Paleogene element rocks is still debated. Knott (op. cit.) and Dietrich (1988) place it between Corsica and Calabria. However Bouillin (1984), Bouillin et al. (1986) and Dewey et al. (1989) place a transform zone that links into the western Alps, where evidence of strike-slip style tectonics has been argued by Ricou and Siddans (1986) and Coward and Dietrich (1989). It seems likely that this transform zone is a later development of the northern transform margin of Neotethys, and may also link into the Pyrenean orogenic belt, as suggested by Knott (1987).

The above models explain the change in tectonic transport direction seen in the present western Mediterranean. However the subsequent evolution of the western Mediterranean, from Oligocene time onward, into a series of semi-oceanic basins within a convergent plate regime requires further explanation. 
Most authors suggest the formation of the basins was the result of Pacific-style back-arc basin extension behind northwesterly-directed subduction of Neotethys between Corsica and the Balearic Islands. This process occurs in two stages. The first stage was the formation of the Ligurian Sea and the Gulf of Valencia during the Late Oligocene to Early Miocene (Réhault et al., 1987, Guieu and Roussel, 1990) as a back-arc basin. Sardinia, Corsica and probably Calabria acted as the island arc above the northwesterly directed subduction zone. This resulted in rotation of Sardinia and Corsica away from the French mainland (Westphal et al., 1986, Montigny et al., 1981) and the opening of the Gulf of Valencia. This was accompanied by calc-alkaline volcanism between $29 \mathrm{Ma}$ and $14 \mathrm{Ma}$ on the island of Sardinia (Coulon et al., 1977, Dupuy et al., 1979). The cause of formation of this back-arc basin when subduction had been active for some time previous to this is uncertain. The most likely explanation is the small change in African plate motion described by Dewey et al. (1989) at 35.5Ma.

The final consumption of Neotethys at around 19Ma, led to collision and emplacement of the Liguride Complex (Knott, 1987; 1988), the fore-arc accretionary wedge of Sardinia, Corsica and Calabria, onto the margin of the Adria promontory. Emplacement of the Kabylie massifs onto the north African plate margin also took place at this time.

The second stage in the evolution of the western Mediterranean basins was the formation of the Tyrrhenian Sea. Rifting of this basin began during the Tortonian $(\sim 11 \mathrm{Ma})$, dated from the oldest sediments found on the present day Sardinian margin (Réhault et al., 1987, Kastens et al., 1988). The development of this basin resulted in the separation of the Calabrian Arc basement from that of the Corsica and Sardinia. Calabria subsequently migrated to the southeast with the development of semi-oceanic crust within the Tyrrhenian basin.

Many models have been advanced to explain the evolution of the Tyrrhenian basin from a zone of collision into a region of major extension and why extension in the basin was synchronous with compression in the southern Apennines. Several models have proposed that a narrow ocean basin separated the Adria promontory from the main African 
Plate, thereby linking Neotethys with Tethys sensu stricto (Scandone, 1982; Bouillin, 1986; Réhault et al., 1987; Le Pichon, 1988; Malinverno and Ryan, 1988). The remnant of this basin is now represented by the Ionian Sea. The opening of the Tyrrhenian basin can then be explained by back-arc extension. However there are strong arguments against this model. The evidence for such a narrow ocean basin is lacking, the continental margin carbonates of Adria and north Africa being lateral equivalents. Dewey et al. (1989) have therefore advocated that the Ionian Sea oceanic crust partially dissects only the eastern part of the Adrian promontory. Calabria could therefore have advanced over the Adrian carbonates and into the Ionian Sea. This still results in a back-arc extension model, but with major extension initiated only 7 million years ago.

Another approach to explain the formation of the Tyrrhenian basin are models that invoke mantle processes. Van Bemmelen (1972) and Wezel $(1981 ; 1985)$ proposed the collapse of a domal uplift caused by mantle upwelling. In contrast, Channell and Mareschal (1989) argue for the delamination of a large section of continental mantle lithosphere, a result of asymmetric lithospheric thickening when Calabria initially collided with the Adria plate margin. Van Dijk and Okkes (1991) have recently proposed a model that combines aspects of all the above ideas. This model proposes an early back-arc extension phase with associated mantle upwelling. Subsequent transpression on the basin margins, forming the Apennines and Maghrebides, then resulted in the cessation of back-arc extension followed by back-arc basin collapse.

A summary of some of the above ideas are incorporated into a tectonic reconstruction illustrated in Figure 1.4. This is based largely on the model of Dewey et al. (1989).

\subsection{THESIS AIMS}

Although there is still no general consensus regarding the tectonic evolution of the western Mediterranean, the above information and ideas do provide several reasonable and testable models. The present day Calabrian Arc is one of the regions of the western Mediterranean where such models can be tested using geological evidence. First it has been involved in 
Figure 1.4 Tectonic reconstructions of the western Mediterranean (based on the model of Dewey et al. 1989)

(KEY : c - Corsica, s - Sardinia, ca- Calabria, ba - Balearic Islands, gk - Grande Kabylie, pk- Petite Kabylie)

\section{a) $38 \mathrm{Ma}$ (Early Oligocene)}

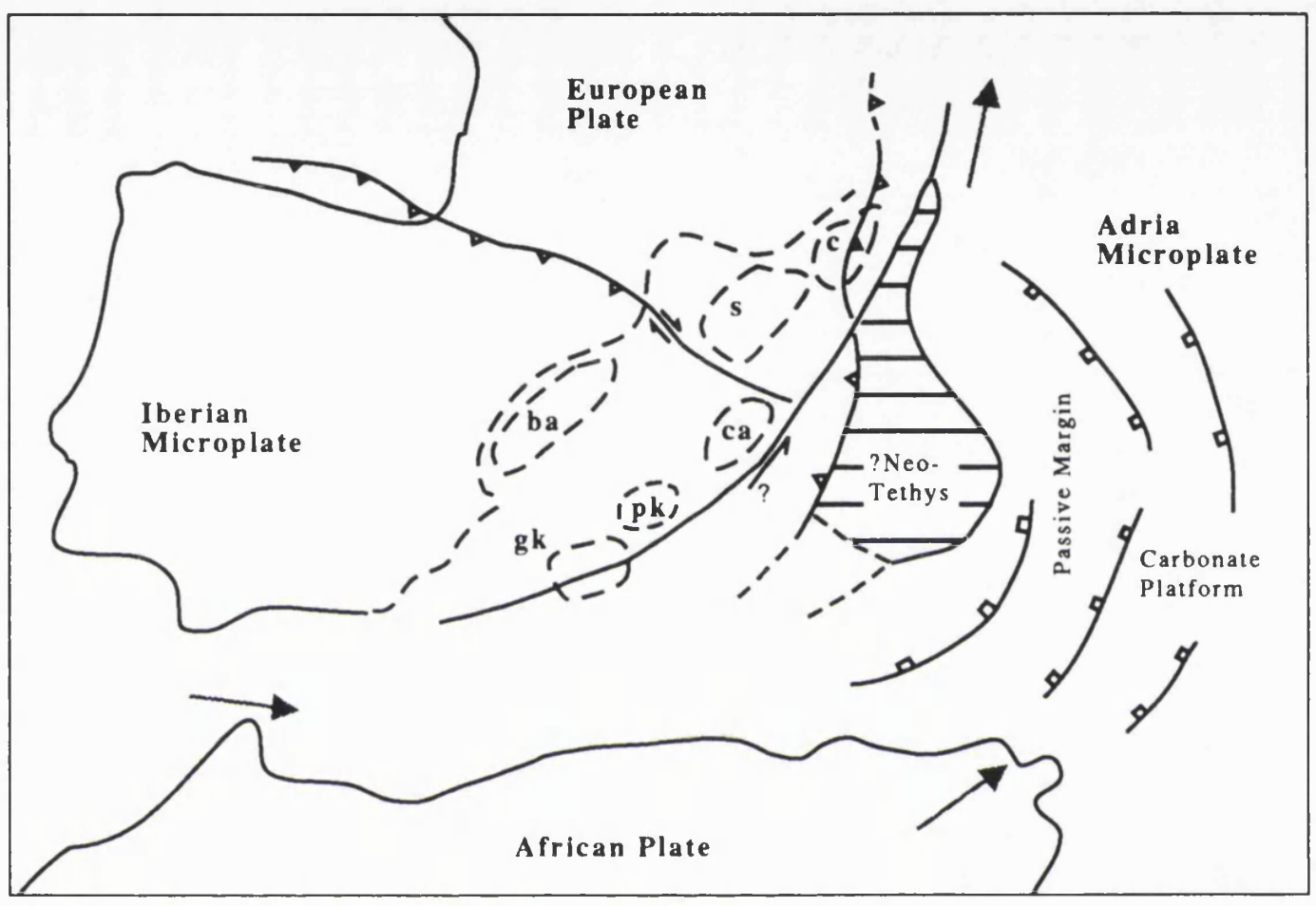

b) $23 \mathrm{Ma}$ (Late Oligocene - Early Miocene)

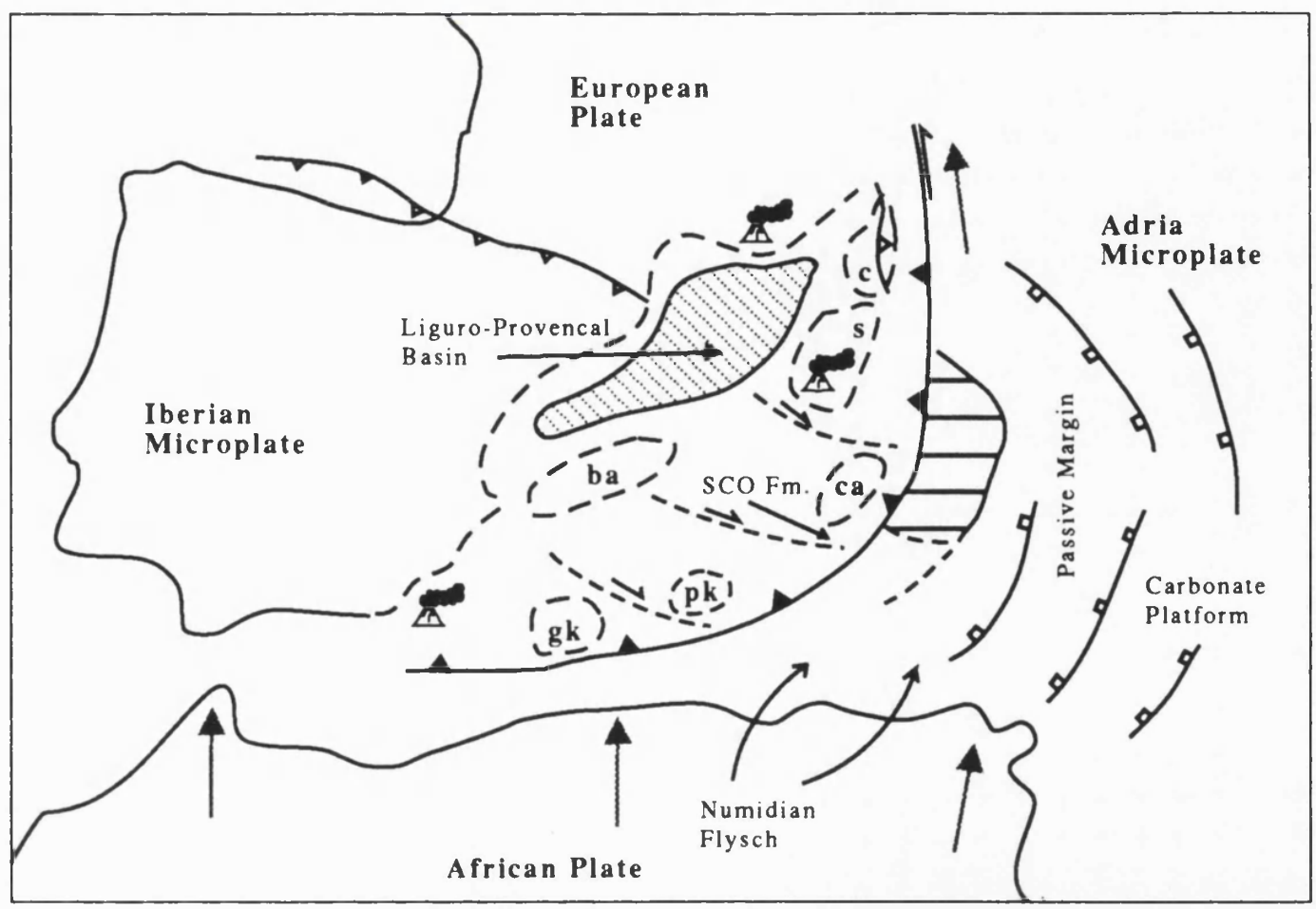


Figure 1.4 (continued)

c) $16 \mathrm{Ma}$ (Middle Miocene)

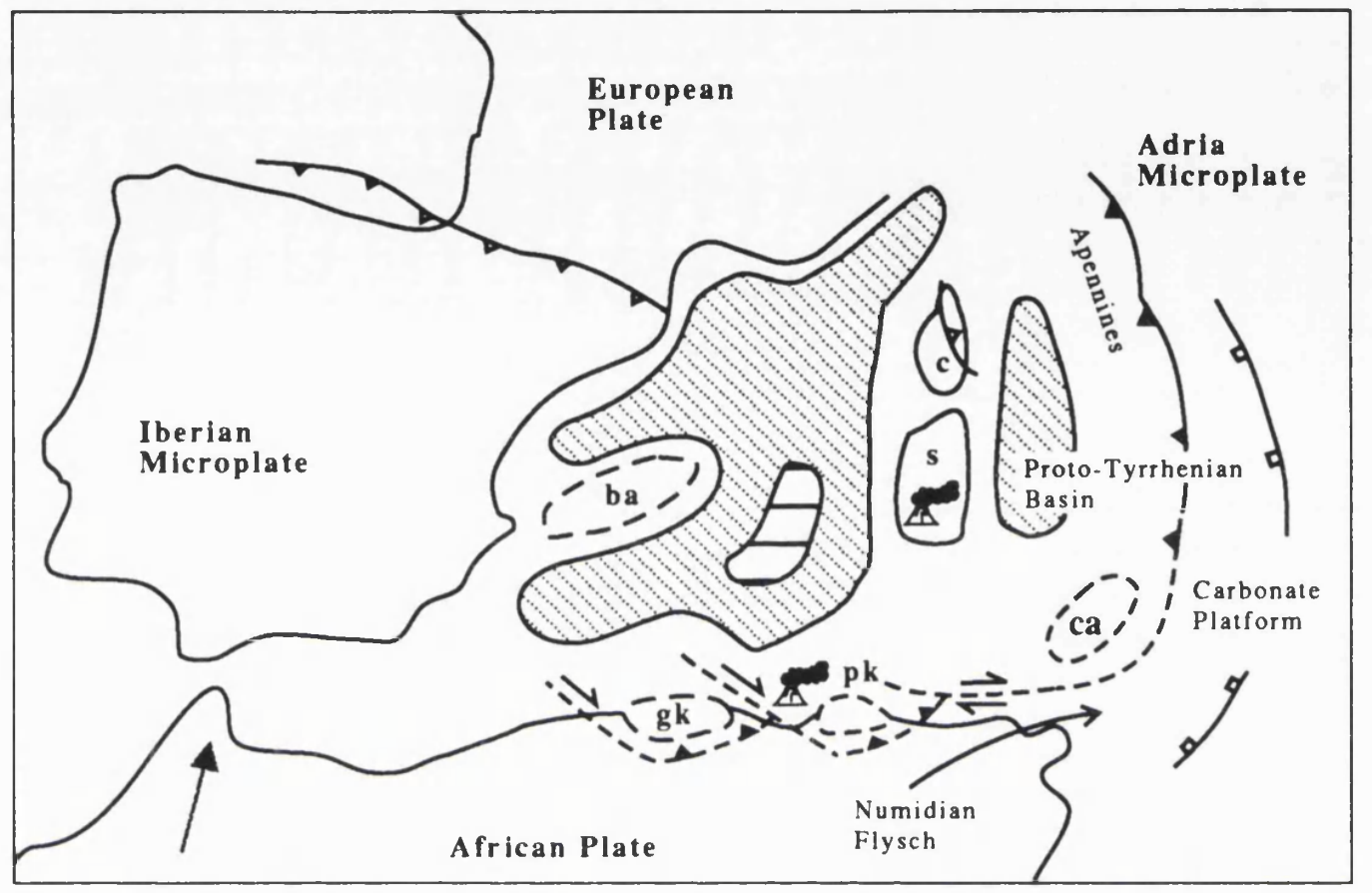

d) 5 - $0 \mathrm{Ma}$ (Pliocene - Recent)

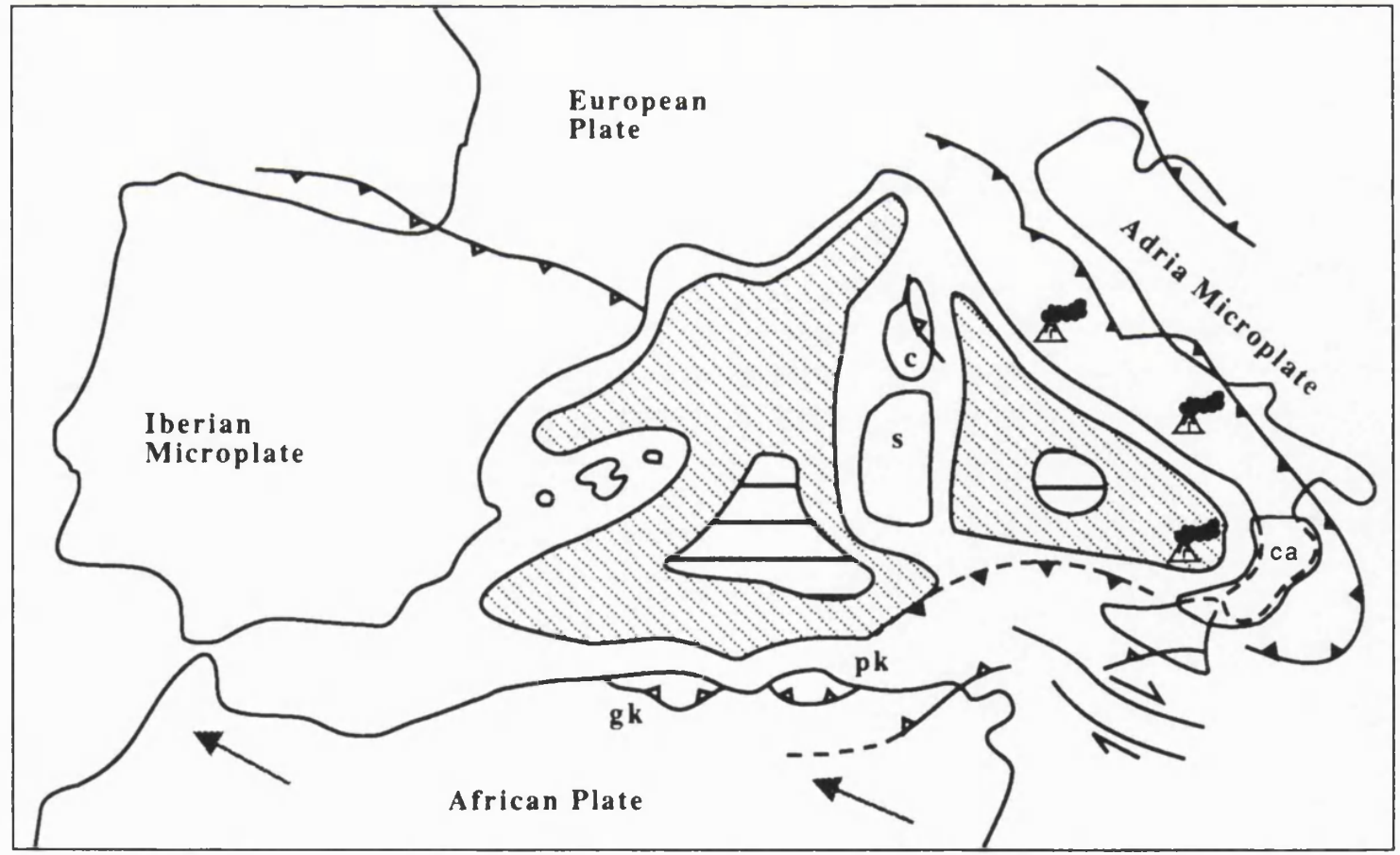


most phases of formation of the western Mediterranean basins. Second it represents an important region of crystalline basement rocks situated at a major bend within the main Alpine orogenic belt. However, because of its complex geological history, the present day Calabrian Arc still has many geological features of its own that remain unresolved.

What this thesis will aim to do is to use the technique of fission track analysis to provide important new constraints to help unravel this complex geology. The study concentrates on the plutonic and metamorphic basement rocks that form the major part of the Calabrian Arc. The study of these rocks in the past has largely been concerned with their petrographic characteristics and geochronological work has mostly been limited to providing information on their pre-Alpine history. By obtaining zircon and apatite fission track ages and apatite fission track length analyses from these rocks, new information can be provided on their low temperature cooling histories. This data will thus largely fill the present gap in the detailed chronological data available from the Calabrian Arc crystalline basement between previously acquired pre-Alpine, high temperature isotopically derived cooling data and the considerable amount of information available on Neogene to recent vertical motions of these rocks.

Low temperature cooling histories are also influenced by changes in the rate of exhumation (removal of overburden) throughout the history of the rocks being analysed. Therefore any significant changes in the rate of cooling seen in the overall cooling history determined from a particular sample or rock group is usually deemed to signify a change in the rate of exhumation. Consequently, another objective of this thesis will be to determine any such changes using cooling histories derived from fission track analysis of different rock samples from the Calabrian Arc basement. The results will then be analysed in detail, in combination with other available geological information, and the cause of such changes assessed. It should be mentioned that assessing total amounts of exhumation using cooling histories, rather than rate changes, is more problematical. If this is to be done with any accuracy, then a detailed knowledge of past temperature/depth profiles is required. This problem will be discussed later in the thesis.

There is strong evidence that the basement rocks of the Calabrian Arc have 
undergone significant pre-Neogene exhumation likely to affect the results of fission track analysis. This will be reviewed in more detail in the following chapters, but cover sequences include Cretaceous flysch that has undergone high-pressure metamorphism, signifying burial to over $30 \mathrm{~km}$ (Knott, 1988), that is now exposed at the surface, and there are major Oligocene unconformities in the southern part of the arc that show significant post-depositional tilting. A study published after this thesis began has also revealed local Alpine metamorphism with $\mathrm{Rb}-\mathrm{Sr}$ ages between 25-30Ma in the Aspromonte region of southern Calabria (Platt and Compagnoni, 1990) indicating a significant pre-Neogene exhumation event within some basement rocks.

The other main component of this thesis involves assessing the history and provenance of the terrigenous Oligo-Miocene Stilo-Capo d'Orlando Formation. This was also undertaken using fission track analysis. The study was initially undertaken to determine the previously debated provenance of volcanic conglomerate clasts found within the formation. However, after initial fission track results were obtained from the nearby crystalline basement it was found that the sediments of the Stilo-Capo d'Orlando Formation, derived from the basement, provide important constraints on the rates, timing and processes of exhumation interpreted from the cooling histories derived from these basement rocks.

The interpreted results of fission track analysis from the Calabrian Arc can then be discussed with other geological information available from the region. This information will then be compared with similar basement complexes found in present western Mediterranean region, including the Sardinian-Corsican Massif and the Kabylie massifs of Algeria.

\subsection{SUMMARY OF THESIS LAYOUT}

Following this introductory chapter, the general geology of southern Italy, which includes the Calabrian Arc and Tyrrhenian Sea, will be outlined in the second chapter. The third chapter will deal in more detail with the tectono-stratigraphy of the metamorphic and plutonic basement rocks, the focus of the fission track study. This chapter will also include 
the collation of all the available isotopic age data obtained from these rocks, allowing the high temperature thermal histories of these rocks to be assessed. Chapter four, on the technique of fission track analysis, will review the methodology and theory behind the calculation of apatite and zircon fission track ages. It will also include a review of apatite fission track annealing. This will include apatite fission track length analysis and recently derived models that can predict the behaviour of apatite fission track annealing with respect to both time and temperature. Some examples of the application of fission track analysis to rocks in various tectonic environments will conclude this chapter. The results of fission track analysis from the metamorphic and plutonic rocks of the Calabrian Arc will be presented in chapter five. Chapter six will be devoted to the analysis of these results which yield detailed low temperature thermal histories. The study initiated on the Stilo-Capo d'Orlando Formation will be the subject of chapter seven, including a synopsis of previous work on the formation. The eighth chapter will be a discussion the fission track results obtained involving interpretation and explanation of the derived thermal histories and comparison of the data with other similar regions of the western Mediterranean. Finally, the main conclusions of the thesis will be presented in chapter nine. 


\section{CHAPTER 2}

\section{THE GEOLOGY OF SOUTHERN ITALY AND THE TYRRHENIAN SEA \\ A REVIEW}

\section{$2.1 \quad$ INTRODUCTION}

Before fission track analysis can be applied to the rocks of the Calabrian Arc it is important that the geology of the region and its surrounding areas is understood. For the purpose of this review the geology of southern Italy will be subdivided tectono-stratigraphically, based on major tectonic contacts and unconformities, into a number of different units. These units are shown in Figure 2.1. The basic geology and interpretation of these units will be discussed starting with the lowest tectonic unit and finishing with the much studied recent geology of the region. The Tyrrhenian Sea will be dealt with separately at the end of the chapter.

\subsection{THE UNDEFORMED FORELAND AND IONIAN SEA}

Undisturbed rocks of the African / Adria continental margin occur in the Iblea region of southern Sicily and the Apulia region of southern Italy, separated by the Ionian Sea. Their successions represent the foreland external to the deformation front. Both domains consist of Mesozoic-Tertiary platform carbonate stratigraphy discussed in detail by Grandjacquet and Mascle (1978) and summarized by Channell et al. (1979) and Amodio-Morelli et al. (1979).

Both the Iblean and Apulian domains are very similar. The sequence begins with Upper Triassic dolomites, overlain by Jurassic marls and limestones including many neptunian dykes indicating intermittent periods of emergence. Above this are Cretaceous cherty limestones and marls, Eocene-Miocene calcarenites, Middle-Upper Miocene marly limestones, Messinian evaporites and Pliocene "Trubi" marls. These sequences are often very thick, up to $4000 \mathrm{~m}$ in southern Apulia.

The two domains are separated by the Ionian Sea. This includes a roughly triangular abyssal plain, up to $4103 \mathrm{~m}$ deep. It is bounded to the north by the active 


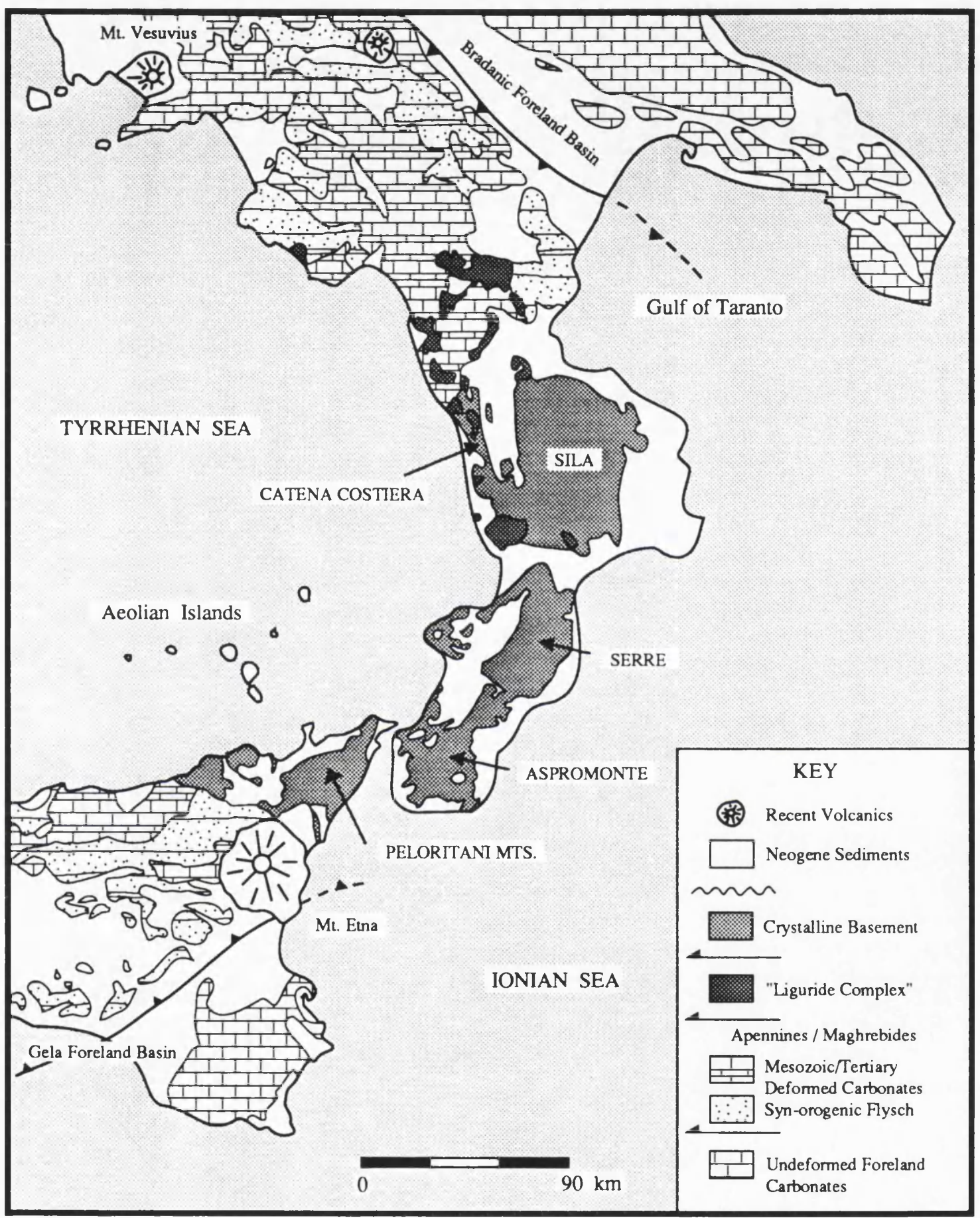

Figure 2.1 Geological sketch map of southern Italy illustrating the location of the main tectono-stratigraphic subdivisions that will be mentioned in this chapter. 
accretionary complex associated with the Calabrian Arc, to the east by the Hellenic Arc, to the west by the Malta escarpment and rises gently to the African shoreline in the south. Dredging and seismic profiling has revealed Messinian evaporites and some recent fine grained detrital and pelagic deposits. However the nature of the crust beneath these sediments is the subject of some controversy. Some argue for the presence of oceanic crust (Bija-Duval et al., 1976; Malinverno and Ryan, 1986; Underhill, 1989), based on the presence of a Benioff zone beneath Calabria and linkage to oceanic crust of the eastern Mediterranean. Others argue for an attenuated continental crust. The main argument for this is the similarity of the Apulian and Iblean domains which suggests that they were originally linked, ruling out an intervening oceanic basin. (Channell et al., 1979; Channell and Mareschal, 1989; Dewey et al., 1989). Bouguer gravity data (Weigal, 1978; Boccaletti, 1984) does show an anomaly, but modelling shows it is insufficient to be caused by oceanic crust, and suggests attenuated continental crust. Hill and Hayward (1988) also point out that the present day elevation of the Calabrian Arc implies that it is not underlain by oceanic crust.

\subsection{THE FORELAND BASINS AND CALABRIAN RIDGE}

Between the present day Adrian foreland and the mountain belts of the southern Apennines, the Calabrian Arc and the Sicilian Maghrebides are several foreland basins.

The Bradano Foreland Basin has an eastern margin and basement consisting of Apulian Platform deposits. The western margin is formed by the thrust units of the southern Apennines. Thrusting of these units ceased in the Middle Pliocene, since which time the foredeep has accumulated up to $3000 \mathrm{~m}$ of conglomerates, sands and clays from the erosion of these southern Apennine units. The oldest sediments are unconformable Upper Miocene sandy conglomerates, followed by Tortonian marls, Messinian evaporites, with intercalations of arkoses, marls and sands and some allochthonous mélange (Argille Scagliose). The marine continuation of the Bradano Foreland Basin is represented by the Gulf of Taranto Basin (Rossi et al., 1983; Pescatore and Senatore, 1986). Similar lithologies are found along the Ionian Sea margin, including the Crotone Basin 
(Grandjacquet and Mascle, 1978; Van Dijk, 1991)

Extending southwestwards from the Gulf of Taranto to the Malta escarpment is a feature known as the Calabrian Ridge (Belderson et al., 1974). This is a series of topographic ridges, generally parallel to the Calabrian coast. Seismic profiles (Grandjacquet and Mascle, 1978; Finetti and Morelli, 1973) and ODP cores from the Ionian Sea show a thick sequence of sediments, mainly scaly clays and chaotic breccias, with prominent Messinian evaporites. The seismic profiles reveal that the ridges represent the sites of major overthrusts.

In Sicily the Plio-Quaternary Caltanisetta Foreland Basin (Grandjacquet and Mascle, 1978) sequence begins in the middle Pliocene with blue/grey marls passing up into sandy marls and calcareous sandstones. There are olistostromes and Miocene marls with flysch deposits in rocks as young as the Quaternary, derived from the advancing Sicilian Maghrebide thrust front to the north. This basin shows classic foreland basin progradation, with shallow water coastal facies becoming progressively younger away from the advancing allochthon.

\subsection{THE SOUTHERN APENNINES}

The southern Apennines are primarily comprised of allochthonous carbonates, deeper water flysch and external foreland basin units. For a detailed account of the southern Apennine stratigraphy see Grandjacquet and Mascle (1978) and Ippolito et al. (1976). In the literature the rocks of the southern Apennines are frequently divided into a series of platforms with intervening deeper water basinal units. These represent the continental margin of the Adria microplate. The definition of these units are the result of tectonic and palaeogeographic reconstructions which involve progressive destruction of the Adria continental margin from the southwest during the Apennine Orogeny. Ippolito et al. (1976), Grandjacquet and Mascle (1978), D'Argenio and Alvarez (1980) and Pescatore and Senatore (1986) recognise three platforms; externally to internally these are the Apulia, Abruzzi-Campania and Latium-Luciana Platforms, with two intervening basins; the more external Molise Basin and the Lagonegro basin. Recently Deweyet al. (1989) have suggested that the 
Molise and Lagonegro Basins are equivalent, being broken up subsequent to formation by strike-slip faulting during the Apennine Orogeny. Thus their tectonic reconstruction of the southern Apennines only requires two carbonate platforms, which they name the Panormide and Apulia Platforms. The majority of the carbonates exposed in the southern Apennines are derived from this platform.

Caught up within these disrupted continental margin units are rocks which represent a large foreland basin environment formed during the Aquitanian to Tortonian. These deposits are known as the Irpinian Basin Units (Ippolito et al., 1976), and include 'Numidian Flysch', quartzose sandstones derived from the African Plate.

Within the Calabrian Arc two units of the Panormide or Latium-Luciana Platform are exposed. The San Donato Unit (also called the Pollino or Camptonese Unit) and the Verbicaro Unit.

\section{The San Donato Unit:}

This unit constitutes the major part of the Panormide Platform. It consists of Triassic to Paleocene limestones and dolomites, transgressed by Aquitanian calcarenites and Langhian Flysch. The whole unit shows much deformation and low-grade metamorphism. This metamorphism is dated as either Eocene or Aquitanian in age, but predates the deformation, which affects unmetamorphosed Aquitanian rocks (Dietrich et al., 1976).

\section{The Verbicaro Unit:}

This is the most internal of the southern Apennine units. The unit is composed of Triassic dolomites and Jurassic-Aquitanian limestones. These rocks are strongly deformed and have suffered low-grade metamorphism. Upper Cretaceous carbonates intercalations of basaltic pillow lavas have been dated by Pierattini et al . (1975). An Aquitanian K-Ar age of 18.6 $\pm 0.1 \mathrm{Ma}$. has been interpreted as the age of metamorphism, but is more likely to represent a cooling age.

Palaeomagnetic studies have also been carried out on the rocks of the southern Apennines. Incoronato et al. (1985) show that Jurassic rocks of the Lagonegro Basin have rotated anticlockwise by $139-147^{\circ}$ when compared to similar Jurassic rocks of the stable 
African craton. It is suggested that this rotation took place during nappe emplacement. This is substantiated by a detailed structural analysis of the Verbicaro Unit in the Cetraro Region of Calabria (Dewey et al., 1989). This shows progressive anti-clockwise rotation of the structural units up until about $7 \mathrm{Ma}$. The tectonogenesis of the southern Apennines ceased in the Middle Pliocene and has since been followed by Quaternary uplift of the mountain belt and subsidence in the Bradanic Foreland Basin (Pescatore and Senatore, 1986).

\subsection{THE SICILIAN MAGHREBIDES}

The main mountain belt in the western part of Sicily shows a sequence of units remarkably similar to those of the southern Apennines, the main difference being that the present day trend of these units is east-west. It too is the result of Neogene breakup of the African continental margin. Stratigraphic studies and tectonic reconstructions of the Sicilian Maghrebides have been summarized by a number of authors (Oldow $e t$ al., 1990; Roure $e t$ al., 1990; Grandjacquet and Mascle, 1978; Catalano and D'Argenio, 1978).

This Neogene deformation of the African continental margin was accompanied by substantial rotation. Palaeomagnetic evidence from Sicily (Channell et al., 1990) shows clockwise rotations of $90-140^{\circ}$ in the Panormide Platform and $47-70^{\circ}$ in the Trapanese Platform relative to the autochthonous Iblean Platform. The intervening basins show similar clockwise rotation. Palinspastic restoration thus requires that the Panormide and Trapanese platforms were originally elongated more or less north-south.

African continental margin carbonates do not outcrop in the Calabrian Arc. Some authors have used this to invoke the existence of a narrow Mesozoic ocean separating the Adria continental margin of the southern Apennines from the African continental margin of the Sicilian Maghrebides (see arguments on the existence of oceanic crust in the Ionian Sea in section 2.2). However Amodio-Morelli et al. (1976), Channell et al. (1979), Scandone (1979), Channell and Mareschal (1989) and Dewey et al. (1989) advocate a continuity of this continental margin. They cite evidence including obvious facies similarities, analogous timing of tectonism and stratigraphic continuity of the Oligocene Numidian Flysch. In addition the palaeomagnetic data indicates a pattern of clockwise rotation of thrust sheets in 
Sicily and anti-clockwise rotation in the southern Apennines indicating that the arcuate nature of the deformed margin is tectonic in origin and not due to its original shape (Channell and Mareschal, 1989). Attempted correlations of the Sicilian and Apennine units by Grandjacquet and Mascle (1978) and Channell et al. (1979) link the Panormide Platform with the Latium-Luciana Platform, the Imerese Basin with the Lagonegro Basin, the Trapanese Platform with the Abruzzi-Campania Platform, the Sicani Basin with the Molise Basin and finally the Saccanese / Iblean Platforms with the Apulian Platform. Dewey et al. (1989) simplify this correlation, grouping the southern Apennine platforms of Apulia and Abruzzi-Campania, with the Trapanese Platform as a single entity. However they do place an ocean basin between the Iblean and Apulian carbonate platforms.

\subsection{THE LIGURIDE OR NEOTETHYAN COMPLEX}

Tectonically overlying the allochthonous units of the Africa / Adria margin are CretaceousEocene flysch deposits originating from an oceanic or deep basinal setting. These ophiolitebearing allochthonous flysch units are now considered to be part of the Liguride Complex of rocks, found in northern Italy and the western Alps (Knott, 1987; 1988).

Early interpretations of these rocks (Amodio-Morelli et al., 1976) led to their subdivision into the metamorphic Frido Unit, the unmetamorphosed Cilento Unit and the “ophiolitic" Gimigliano, Diamante-Terranova, Fuscaldo and Malvito Units.

The Frido Unit is composed of weakly foliated Upper Cretaceous shale, slate, calcschist and quartz-arenites, with occasional kilometre-scale masses of continental and oceanic crust. This unit mainly shows low grade greenschist facies metamorphism, with a localised high pressure lawsonite to glaucophane schist facies overprinting event, especially in the Calabrian Coastal Ranges (De Roever, 1972).

The Cilento Unit comprises of three sedimentary formations. They include the Albian-Aptian Crete Nere Formation of black shales, quartz-arenites and calcarenites and the Middle to Upper Eocene Saraceno Formation of calcarenites and calcilutites. Unconformably overlying both these formations is the Upper Oligocene to Burdigalian Albidona Formation of conglomerates and quartz-arenites. 
The ophiolitic units consist of Jurassic-Lower Cretaceous metabasites, radiolarian cherts and crystalline limestones with some pillow lavas, gabbros and serpentinites. These show a blueschist facies overprint upon an earlier greenschist facies metamorphism (De Roever, 1972). These units are often dismembered and are regarded as disrupted oceanic slices and not complete ophiolites by Knott (1987).

A more recent interpretation by Knott (1987) has identified Cilento Unit sediments within Frido unit successions, implying that the sediments of both units are coeval. The suggestion is that these sediments represent a direct sedimentary cover to the oceanic slices indicating deposition upon oceanic crust. Structural and other data indicate that during the Upper Jurassic this ocean basin (Neotethys) lay to the west of the Apenninic units and to the east of the Eurasian Plate. The Liguride Complex can thus be interpreted as an accretionary wedge resulting from northward subduction of Neotethys during the Palaeogene. It was later emplaced upon the Africa / Adria margin during the Burdigalian.

Comparable Neotethyan units, but without any evidence of oceanic slices are found in northern Sicily and are usually referred to as the Sicilide Complex (Ogniben, 1976). They are made up of an Jurassic to Eocene pelagic sequence, including limestones, argillites and terrigenous flysch, overlain unconformably by an Oligocene quartz-rich terrigenous sequence. This sequence occurs as two tectonic units, The Monte Soro Nappe and the Reitano Nappe.

Evidence of the presence of oceanic crust in the form of disrupted oceanic slices is absent south of the Catanzaro Trough. Scandone (1982) suggests that this marks the margin of the former Neotethyan ocean basin against a major transform fault, possibly the Curinga-Girifalco Line of Schenk (1981).

\subsection{THE CALABRIAN ARC CRYSTALLINE BASEMENT COMPLEX}

These rocks are the main focus of study in this thesis and will be dealt with in more detail in the following chapter. In summary the basement complex can be divided into two distinct groups based on their petrographic characteristics (Amodio-Morelli et al., 1976). In the Calabrian Coastal ranges and in the southern and western Sila is the Alpine Group. This 
group of rocks shows a pervasive greenschist facies metamorphic overprint, with some local higher pressure lawsonite and glaucophane schist facies, over an earlier high grade, probably Hercynian, event. In the rest of the Calabrian Arc, exposed in the Eastern Sila, Serre, Aspromonte and Peloritani Mountains of northwest Sicily is the Hercynian Group. This group of rocks is made up of high grade Hercynian metamorphic rocks and granites, often with a Mesozoic cover, that show only localised post-Hercynian (Alpine) retrograde metamorphism, usually near tectonic boundaries. Three distinct units within the Hercynian Group can be recognised. A lower unit of high-grade amphibolite and granulite facies rocks, a suite of late Hercynian granitoids and an upper unit of lower Palaeozoic phyllites with intercalated limestones and basalts.

\subsection{SYN-OROGENIC COVER SEQUENCES}

\subsubsection{The Stilo-Capo d'Orlando Formation (Bonardi et al., 1980)}

This is an important terrigenous sequence of Upper Oligocene to Middle Miocene age found only in southern Calabria and Sicily. The geology of the Stilo-Capo d'Orlando Formation will be discussed in detail in Chapter 7 as part of a detailed provenance study incorporating fission track analysis. In summary it consists of a $\sim 750 \mathrm{~m}$ thick terrigenous sequence, composed mainly of conglomerates and sandy turbidite facies. It is considered to be the lateral equivalent of the Numidian Flysch basins of Sicily and the southern Apennines. Van Dijk and Okkes (1991) compare these rocks to similar deposits found in Algeria (Durand-Delga, 1988) and the rift basins of Sardinia (Cherchi and Montadert, 1982). This suggests that the Stilo-Capo d'Orlando Formation may have an intra-arc or back arc origin.

\subsubsection{The Argille Varicolore}

The Argille Varicolore or "varicoloured clays" (Amodio-Morelli et al., 1976) overlie the Stilo-Capo d'Orlando Formation in Calabria. Similar clays are found between central Italy and the Maghrebides of Morocco. They consist of reworked chaotic scaly clays, originally of Cretaceous-Palaeogene age often containing blocks of Cenomanian marls and 


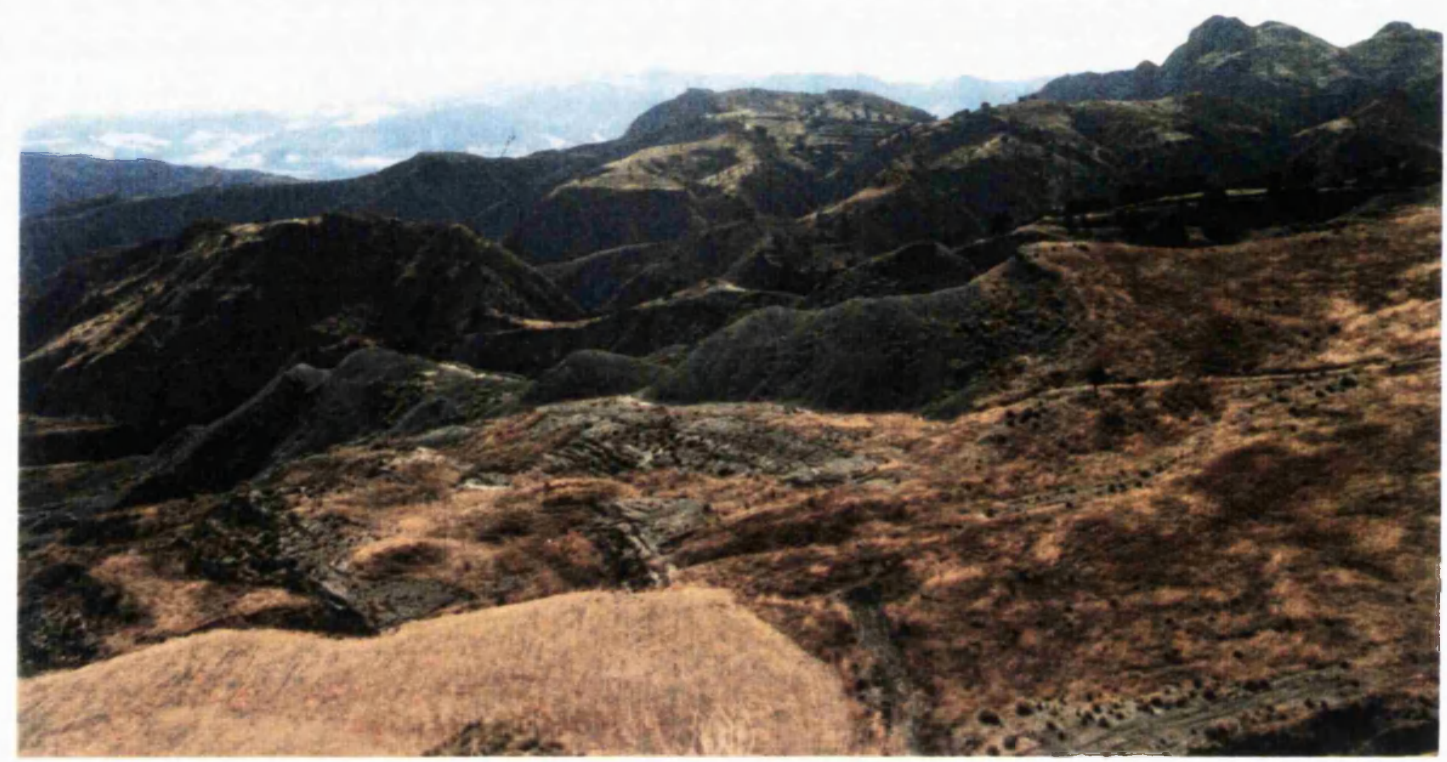

Plate 2.1 The "Argille Scaliose" (scaley clay) in the southern Aspromonte, Calabria

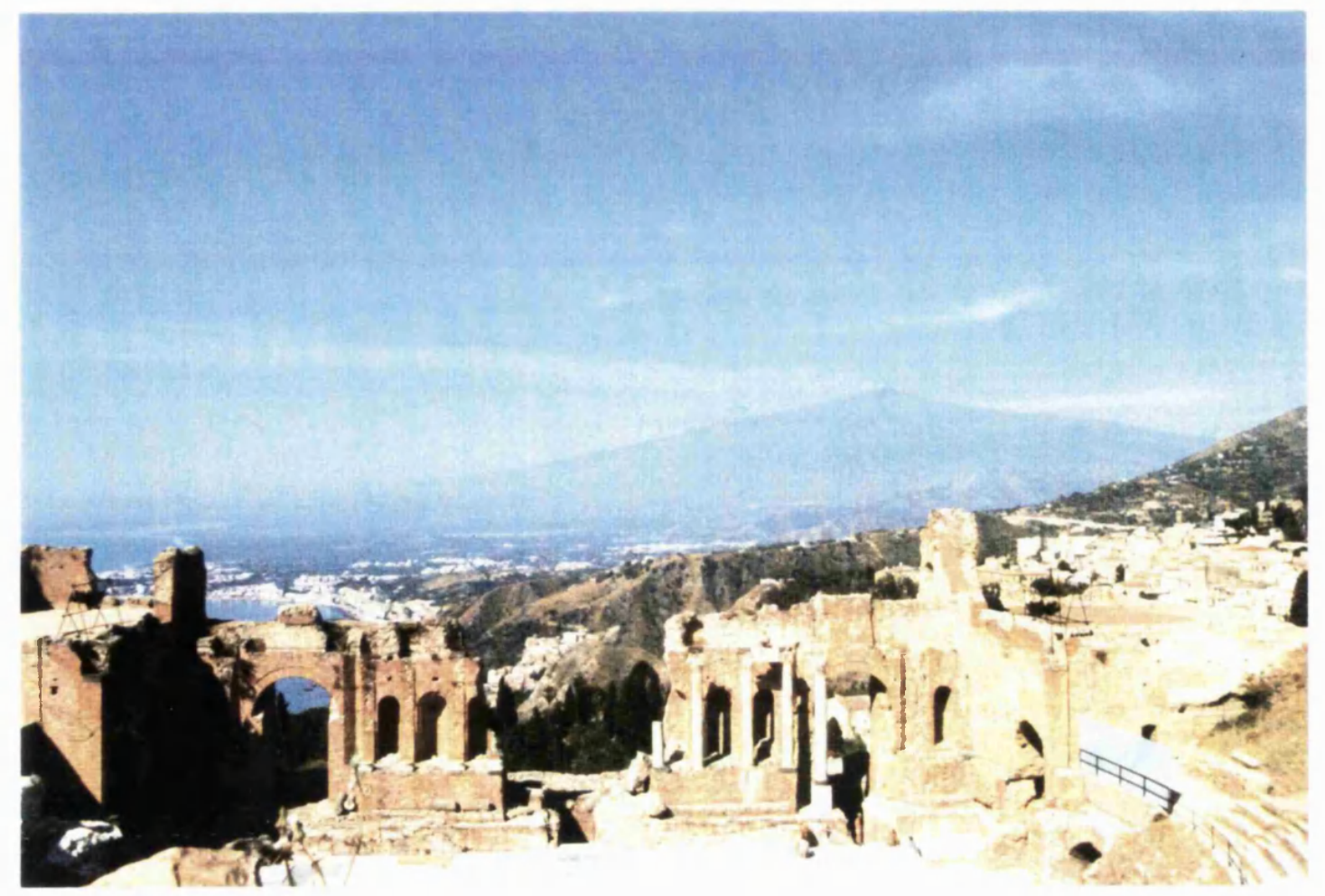

Plate 2.2 Mt. Etna from the Greek Theatre, Taormina, Sicily 
Numidian flysch (Plate 2.1). As they overlie sediments of Miocene age they have often been interpreted as tectonic nappes. However they are now widely interpreted as a mélange (Görler, 1978; Barrier et al., 1987; Cavazza, 1989). The tectonic transport of these rocks is largely ruled out as the contact with the underlying sediments in often conformable with no cleavage seen within the clays (Görler, 1978). This mélange has not been studied in detail, thus its origin and timing of emplacement are still uncertain. It may be related to the emplacement of the Liguride Complex upon the Adria/Africa margin during the Burdigalian (Knott, 1987). Dewey et al. (1989) suggest that these clays were backthrust over the Calabrian Arc and the units of the Lagonegro Basin and the Latium-Luciana or Panormide Platform during the Tortonian. However this is unlikely in Calabria as Langhian Calcarenites (Les calcarénites de Floresta) are seen unconformably overlying the Argille Varicolore (Barrier et al., 1987).

\subsection{NEOGENE GEOLOGY}

The Neogene geology of southern Italy is dominated by the development of several sedimentary basins, whose evolution is controlled by complex fault dynamics.

The main patterns of Neogene faults have been mapped both on the ground and from satellite images (Bodechtal and Munzer, 1978; Ghisetti and Vezzani, 1981; Ghisetti, 1984; Meulenkamp et al., 1986; Knott, 1988; Van Dijk and Okkes, 1990; 1991; Knott and Turco, 1992). Figure 2.2 shows a schematic structural map indicating the main Neogene tectonic elements compiled by Van Dijk and Okkes $(1990 ; 1991)$ from an extensive literature review and supported by detailed mapping in the Crotone basin of central Calabria. Three main structural elements can be recognized. The most important of these are a number of NW-SE trending transpressional strike-slip fault zones. These zones are often $5-10 \mathrm{~km}$ in width and divide the main Calabrian Arc into a series of segments. In the northern sector of the arc these faults show sinistral movement, while dextral movement is dominant in the southern sector. The movement in the central sector, around the Serre, is unclear. Two of these zones, the Petilia-Sosti Line and Condofuri Line, are thought to represent reactivation of earlier large scale basement thrusts. These faults are related to the 


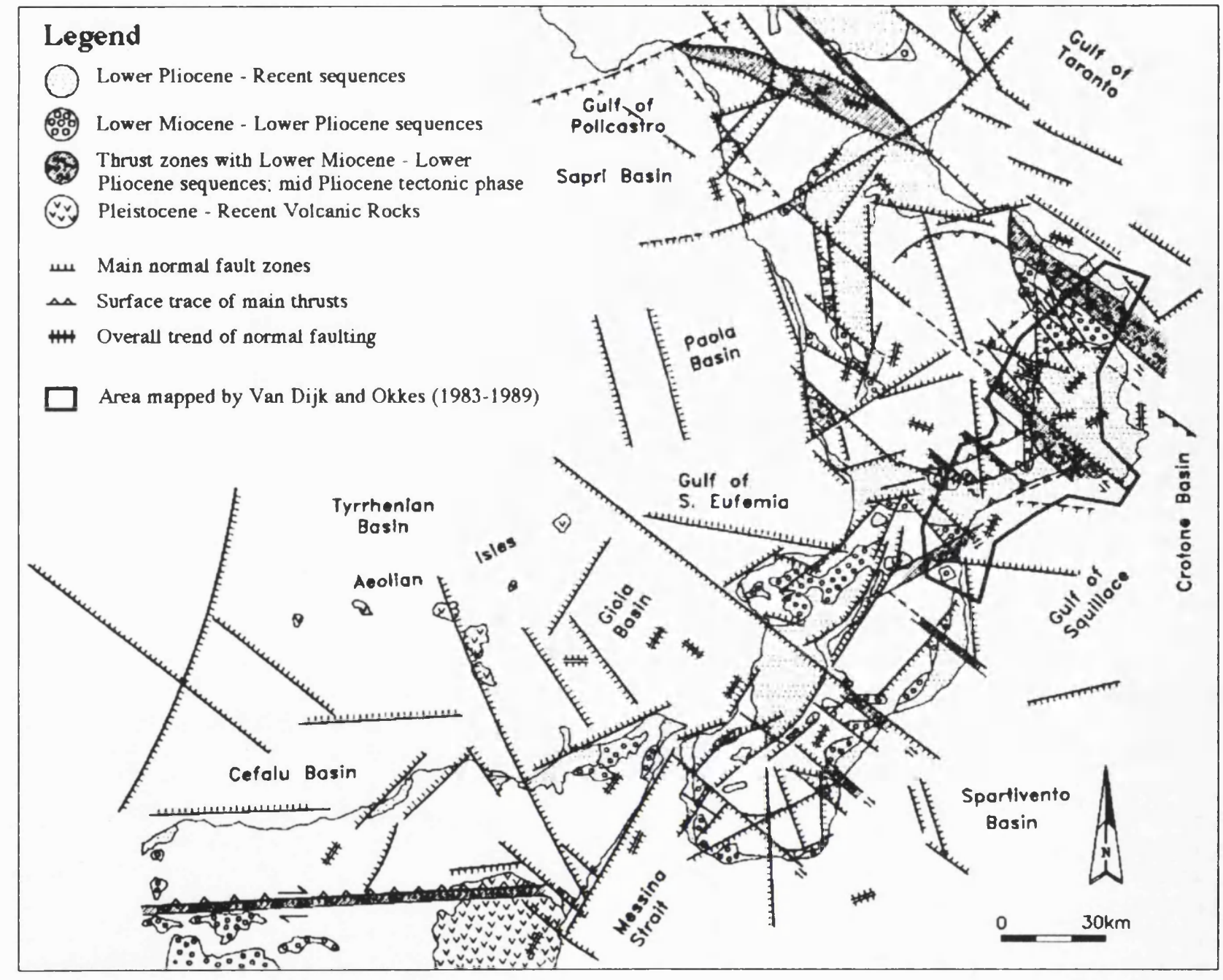

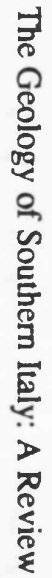

Figure 2.2 Geological map of the Neogene of Calabria (taken from Van Dijk and Okkes, 1991) 
Serravallian-Early Pliocene opening of the northern and central Tyrrhenian Sea. Subordinate to these trancurrent fault zones are several SW-NE trending thrust zones. These thrusts are linked to the southeast migration of the Calabrian Arc. They are the equivalent of similar thrusts seen at the present day in the Calabrian Ridge accretionary complex (section 2.3). They show vergence both in a northwest direction (as backthrusts) and towards the southeast. The final and most recent structural elements are several radial and concentric fault systems. These are mainly extensional faults related to the opening of the southern Tyrrhenian Basin and the recent uplift centres of the Aspromonte and southern Sila.

The interaction of these fault systems has resulted in the formation of the Neogene sedimentary basins seen in the Calabrian Arc. This has produced two types of basin. Piggyback basins, controlled by the SW-NE thrust systems include the Straits of Messina, the Mesima Graben, Crati Trough. Pull-apart basins controlled by the NW-SE shear zones include the Monte Torre palaeostrait, the Catanzaro Trough and Sibari Trough. The Crotone Basin is a complex interaction of both piggy-back and pull-apart basin types.

The sedimentary history of some of these basins has been studied in detail. The Crati Basin is dominated by Pliocene-Pleistocene marine fan-deltas and later coarse grained Gilbert-type fan deltas (Colella et al., 1987). The later Gilbert-type fan deltas are thought to be a response to Pleistocene uplift of the basin margins. They also suggest little influence from tidal currents. This is in contrast to the tidal dominated transverse graben of the now exposed Monte Torre Palaeostrait (Colella and D'Alessandro, 1988) and the active Straits of Messina (Barrier et al., 1987). These basins show a transition from a low energy environment of marls and turbidites, to high energy tidal dominated facies consisting of thick-bedded turbidites and sand waves and some seismically induced megabreccias.

During the Pleistocene the Calabrian Arc has been dominated by extreme vertical movements. Estimations of the amount and rates of surface uplift in southern Italy have been produced by several authors (Ergenzinger et al., 1978; Tortorici, 1981; Ghisetti, 1981; Hearty et al., 1986; Montenant and Barrier, 1987; Cosentino et al., 1989). Their methods rely on the dating of Pleistocene terraces using biostratigraphy, ${ }^{14} \mathrm{C}$ dating, amino 
acid racemization and K-Ar dates of tephra deposits. The results of these studies show the amounts and rates of uplift are highly variable. The Aspromonte shows the most dramatic amounts of uplift, with possibly up to $1700 \mathrm{~m}$ since the beginning of the Pleistocene. Present day rates approach $2.5 \mathrm{~mm} /$ year (Montenant and Barrier, 1987). Uplift of 600$1100 \mathrm{~m}$ is seen in the Calabrian Coastal Ranges, with $400-500 \mathrm{~m}$ in the Sila and $400 \mathrm{~m}$ in the Crati Basin. The average rates of uplift since the late Pliocene for the whole of Calabria have been collated by Cosentino et al. (1989) and are shown in Figure 2.3. It should be noted that the amount of Pleistocene uplift drops dramatically to the north of the Sangineto Line.

There are two processes thought to be responsible for these extreme vertical movements. These are the collapse of a mantle diapir in the southern Tyrrhenian Sea, with subsequent uplift on its margins (Wezel, 1985), and the detachment of a lithospheric slab, resulting in large scale isostatic readjustments (Görler and Giese, 1978; Channell and Mareschal, 1989).

\subsection{PRESENT DAY GEOLOGY}

Present day southern Italy is dominated by intense seismic activity, which includes the catastrophic Messina earthquake of 1908 which killed up to 150,000 people. This seismicity has been examined by Cello et al. (1982), Gasparini et al. (1985), Del Pezzo et al. (1984), Cristofolini et al. (1985) and Bottari et al. (1986). They show the earthquakes fall into two categories: shallow focus epicentres with extensional or transcurrent motion and deep focus epicentres with compressional motion. The shallow focus earthquakes are related to the continued activity of the Neogene fault systems, with a few related to the Aeolian Island volcanism of the Tyrrhenian Sea. The deep focus earthquakes have been interpreted to define a Benioff zone beneath the Calabrian Arc. However, seismicity is concentrated at certain depths, mainly at about $300 \mathrm{~km}$. This led Scandone (1979) to propose that the seismicity represented a remnant slab of the Mesozoic Neotethys, subducted between the Oligocene and Lower Miocene, with present day earthquakes related to horizontal stresses within the slab, not active subduction. This is supported in part by 


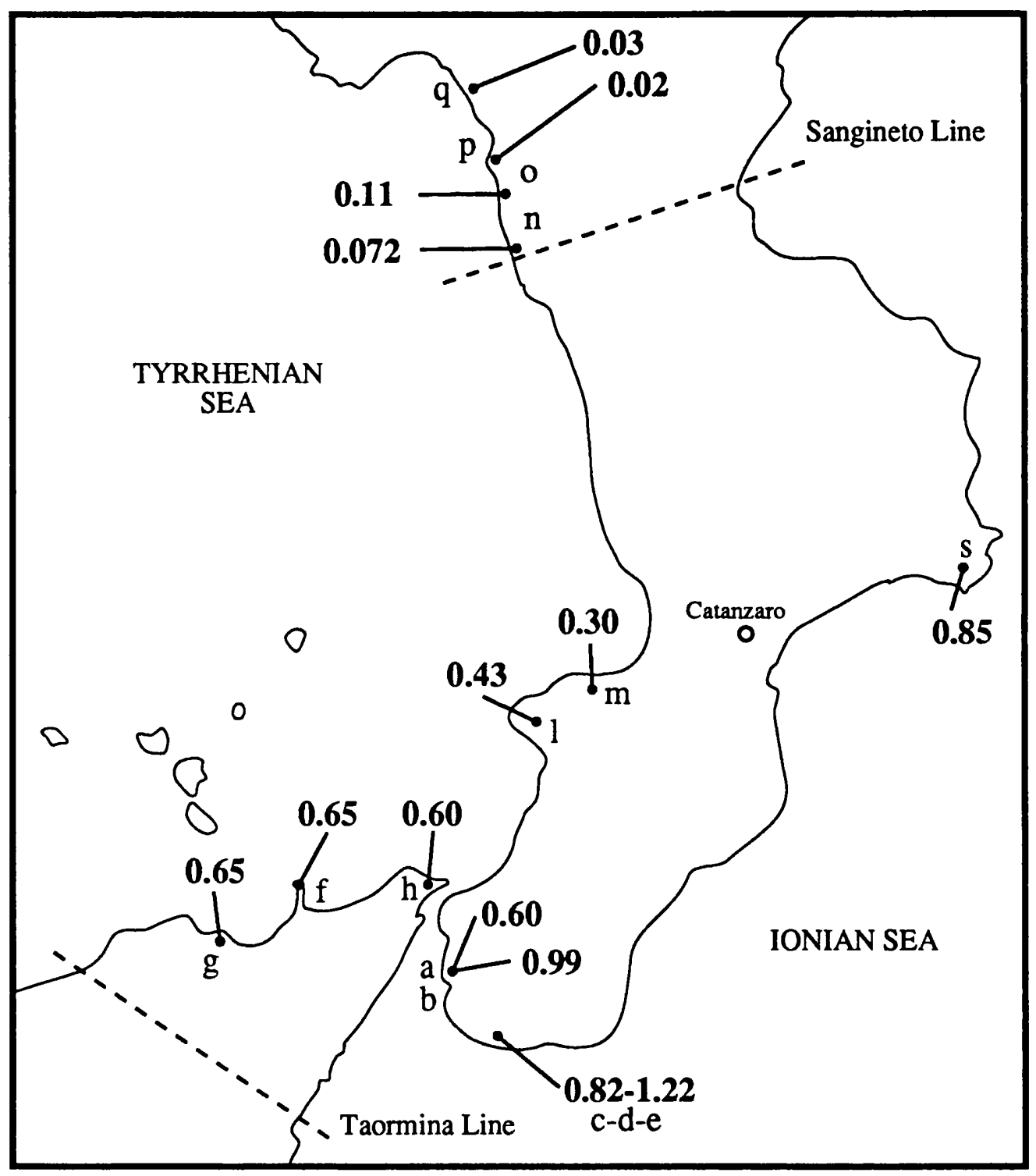

Figure 2.3 Average surface uplift rates since the late Pleistocene (mm / year)

\section{(After Cosentino et al., 1989)}

(a - Bovetto, b - Ravagnese, c - Nocella, d - Capo dell'Armi, e - Lazzaro, f - Milazzo, g - Capo Tindari, h - Capo Peloro, 1 - Monte Poro, $\mathrm{m}$ - Vibo Valentia, $\mathrm{n}$ - Cetraro, o - Scalea, p - Praia, q - Maratea, s - Crotone) 
Malinverno and Ryan (1986).

Seismic refraction profiles (Schütte, 1978), magnetic anomalies (Schwarz, 1978), heat flow data (El-Ali and Giese, 1978) and gravitational studies (Moretti and Royden, 1988), indicate that the present crust under Calabria is thickened relative to the Ionian and Tyrrhenian Seas, being up to $40 \mathrm{~km}$ thick. The data indicates a crustal overlap, with the continental crust of Calabria being underlain by a layer of thinned continental crust derived from the Ionian Sea. The recent surface uplift of the Calabrian Arc may be explained by isostatic compensation of this crustal overlap. Snoek (1978) argues that strong horizontal forces evident in Calabria may prevent such vertical compensation. This horizontal motion has been measured across the Straits of Messina using geodetics by Caputo et al. (1981), Baldi et al. (1983) and Mulgaria et al. (1984). It shows that over a nine year period Sicily has moved about $5 \mathrm{~cm}$ north relative to Calabria.

Recent volcanism on mainland southern Italy is confined to Mount Etna in the south (Plate 2.2), and Vesuvius and Mt. Vulture to the north. Evidence of past volcanism is also found as numerous tephra horizons. The volcanism of the Aeolian Islands is related to the Tyrrhenian Sea and is discussed in section 2.11. Mt. Etna is a large, active alkali tholeiitic volcano and has been discussed in detail by Chester et al. (1985). The origin of the magmas is uncertain, possibly related to a lithospheric discontinuity (Cristofolini et al., 1983). The chemistry appears to rule out the possibility of an oceanic crustal source for the lavas, supporting the geophysical data showing a present day continental crustal overlap (Cristofolini et al., 1985). The volcanoes to the north of the region show a markedly different chemistry to Mt. Etna. Mt. Vulture is in a similar structural position to Mt. Etna, but is older (0.8-0.4 Ma) and shows a strongly silica-undersaturated chemistry, characterized by trachytes related to a rift or continental margin type environment. The tensional environment required for the formation of this volcano is thought to be related to NW-SE lineaments seen throughout southern Italy. Plio-Pleistocene tephra horizons have been documented in sediments from the Straits of Messina and Mesima Graben (Cello et al., 1983; Calanchi, 1987) and are thought to originate from the volcanism of Pantelleria in the Straits of Sicily and the Aeolian Islands of the Tyrrhenian Sea. 


\subsection{THE TYRRHENIAN SEA}

The Tyrrhenian Sea is the youngest of the Mediterranean basins. The formation and evolution of this basin during the Neogene has had a profound effect on the geology of southern Italy and the Calabrian Arc.

\subsubsection{Morphology}

The morphology of the Tyrrhenian Sea is complex (Figure 2.4). This and the nature of the basement are discussed by Rehault et al. (1987). The morphologic characteristics have been clearly defined by echo sounding (Selli, 1970 ; Morelli, 1970) and more recent Sea Beam surveys. The region off Sardinia consists of a typical continental margin, $\sim 185 \mathrm{~km}$ wide. The edge of this margin is marked by the Central Fault fracture zone, a major scarp. This scarp gives way to the main bathyal plain of the Tyrrhenian Basin, divided into the western Vavilov Basin and the smaller eastern Marsili Basin. These have an average depth of $3100 \mathrm{~m}$ and are interrupted by numerous steep sided seamounts. The margins of the Tyrrhenian Basin with peninsula Italy are narrow with a rough relief, characterised by horst and graben. Superimposed upon this margin are numerous volcanic edifices, including the Aeolian Islands and Palinuro seamount.

\subsubsection{Nature of the Basement}

The nature of the basement of the Tyrrhenian Sea has been examined by several dredging and drilling projects.

DSDP leg 42A (Barberi et al., 1978) and ODP leg 107 (Kastens et al., 1988) show that the Vavilov and Marsili Basins are floored by basaltic crust with a within-plate basalt to MORB chemistry (Cristofolini et al., 1985). This crust has been dated as Upper MioceneLower Pliocene in the Vavilov Basin and as Upper Pliocene in the Marsili basin. This implies evolution of the Tyrrhenian basin towards the southeast.

The seamounts come in two types. Those surrounding the central bathyal plain, for example the Issel and Poseidone seamounts which separate the Vavilov and Marsili Basins, are generally composed of Hercynian metamorphic rocks, often with Jurassic sedimentary 


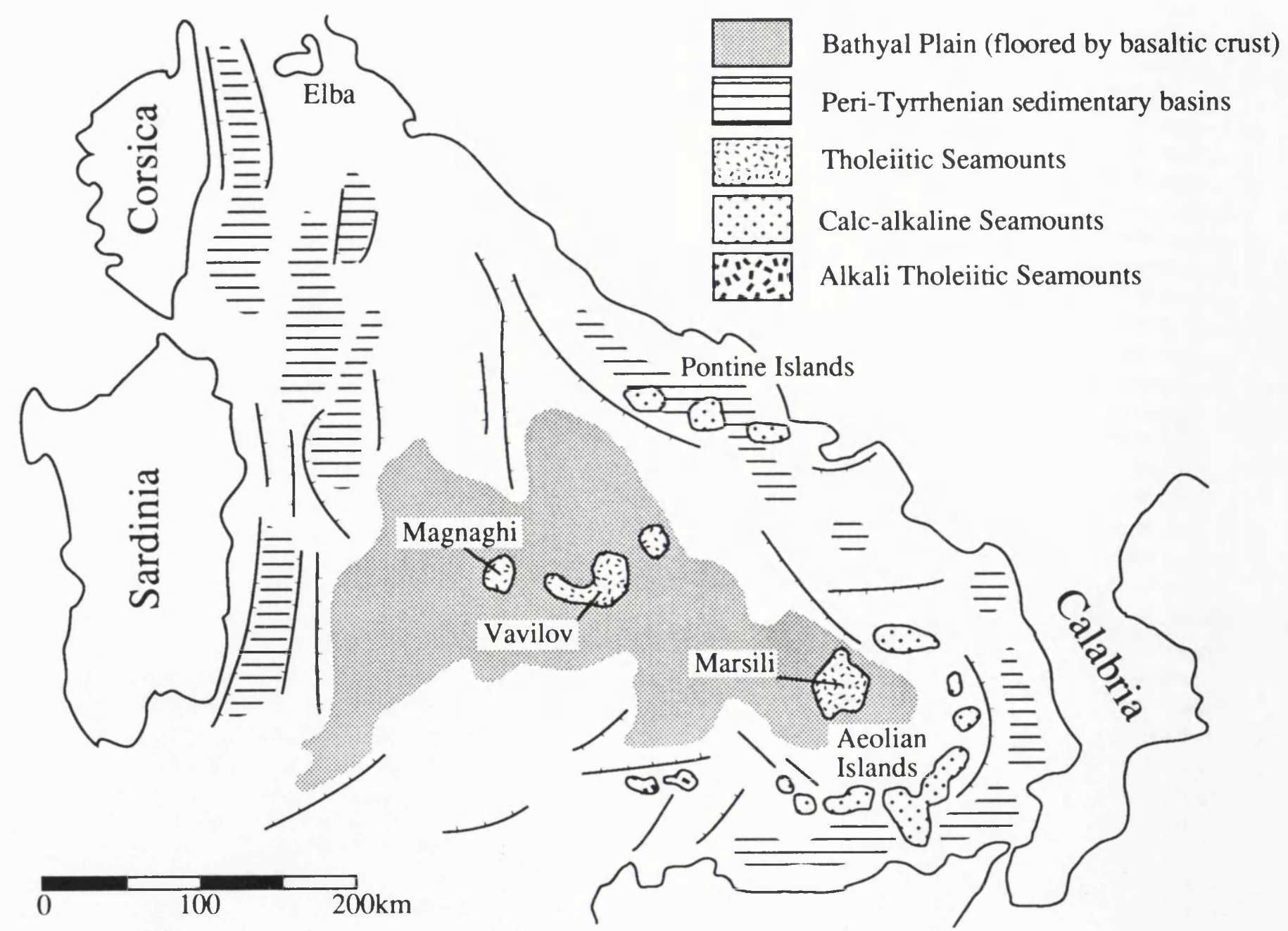

Figure 2.4 Schematic drawing of the tectonic setting of the Tyrrhenian Sea (after Wang et al., 1989) 
cover. These are probably equivalent to the basement found in mainland Calabria. The second types of seamount are found in the central bathyal plain and include the Magnaghi, Vavilov and Marsili seamounts. These are built of tholeiitic volcanic rocks and their derivatives, although the Marsili seamount includes some younger more alkaline rocks (Del Monte, 1972; Boccaletti and Manetti, 1978)

\subsubsection{Recent Volcanism}

The recent volcanism of the Tyrrhenian Sea is dominated by the Aeolian Islands (Barberi $e t$ al., 1973; Boccaletti and Manetti, 1978; Beccaluva et al., 1981; Cristofolini et al., 1985). It is the result of two stages of activity. First an early-middle Pleistocene phase forming Alicudi, Filicudi and parts of Salina and Lipari. This phase was dominantly calc-alkaline. Then after a brief lull, more recent activity occurred on Salina, Lipari, Volcano and Stromboli. This volcanism has a high-K calc-alkaline to shoshonitic chemistry, suggesting a "senile" phase of activity. The geochemistry of recent magmas indicates that they are of continental margin and rift type environments (Cristofolini et al., 1985).

\subsubsection{Sedimentology and Stratigraphy}

The sedimentology and stratigraphy of the Tyrrhenian Sea is known from dredging, deep sea cores and seismic sections. These are reviewed by Rehault et al. (1987), and augmented by ODP leg 107 (Kastens et al., 1988).

The oldest sediments are found on the upper part of the Sardinian continental margin, consisting of syn-rift deposits. The Tortonian age of these sediments indicates the probable timing initiation of rifting of the Tyrrhenian basin. The sediments from the lower part of the Sardinian Margin are 1-2 Ma younger, signifying a migration of rifting towards the southeast at this time.

The oldest sediments found in the Bathyal Plain are Pliocene in age, with no indication of Messinian evaporites. This seems to be in agreement with the age of the basalts, dated as Pliocene in age from magnetic polarity patterns (Barberi et al., 1973; Kastens et al., 1988). These sediments are dominated by turbidites with volcaniclastics 
which increase up section with the increased activity of the Aeolian Islands.

Using stratigraphical evidence and the age of volcanism, a NW-SE spreading rate of approximately $3.5 \mathrm{~cm} / \mathrm{yr}$ has been estimated (Mousatt et al. 1985; Kastens et al., 1988). A higher estimate of between 5 and $7 \mathrm{~cm} / \mathrm{yr}$ has been suggested by Wang et al. (1990). Subsidence rates for the Tyrrhenian Basin have also been calculated. Benthic foraminifera, discovered in association with pillow basalts, indicate that they were erupted at very shallow water depths. To reach their present day depth the Tyrrhenian Basin must have subsided at up to $700 \mathrm{~m} / \mathrm{Ma}$.

\subsubsection{Superficial Structure}

The superficial structure of the Tyrrhenian basin is complex with several trends recognised (Boccaletti and Manetti, 1978 ; Boccaletti et al., 1984 ; Rehault et al., 1987). N-S to NWSE trends of the Sardinian margin are related to tensional tectonics during the initial rifting of the basin. They are Tortonian-Pliocene in age. These lineaments are offset by a dominant set of NW-SE structures interpreted as strike-slip faults. These are related to similar trending lineaments seen on the Calabrian mainland (Knott, 1988; Van Dijk and Okkes, 1990; 1991; Knott and Turco, 1992). A minor set of E-W lineaments north of Sicily are also seen.

\subsubsection{Deep Structure}

Using various geophysical techniques, much information regarding the deep structure of the Tyrrhenian Basin has been acquired.

Magnetic Data :

The data of Finetti and Morelli (1973) and AGIP (Rehault et al., 1987), show two main trends of anomalies. The main trend is NNE-SSW, probably related to rift axes. These are offset by NW-SE to WNW-ESE magnetic lineaments, interpreted as being related to the transform faults mentioned earlier. The regional intermediate magnetism is indicative of oceanic type basement (Boccaletti et al., 1984).

Gravity Data : 
The main feature of the Bouguer gravity data of the Tyrrhenian Sea (Rehault et al., 1987 after Morelli et al., 1975) is the presence of large positive anomalies, reaching amaximum of $+260 \mathrm{mGal}$. These maximums are found in the Vavilov and Marsili basins. Such anomalies suggest a thinned crust and probable mantle upwelling.

Heat Flow Data :

The heat flow data (Wang et al., 1990) shows a pronounced high of over 150 $\mathrm{mW} / \mathrm{m}^{2}$ in the central bathyal plain, with values of $250 \mathrm{~mW} / \mathrm{m}^{2}$ in the Vavilov and Marsili regions related to volcanic activity. This heat flow decreases rapidly towards the basin margins. Values of $50 \mathrm{~mW} / \mathrm{m}^{2}$ are obtained along the Sardinian margin, and $40 \mathrm{~mW} / \mathrm{m}^{2}$ along the Calabrian Margin. This again supports evidence for thin crust and significant mantle upwelling beneath the central Tyrrhenian Basin.

\section{Seismic Reflection and Refraction Data :}

Seismic soundings have been widely carried out in the Tyrrhenian Sea area to detect the Moho discontinuity. In the Vavilov and Marsili basins it is found at a depth of $10 \mathrm{~km}$ (Boccaletti et al., 1984 ; Rehault et al., 1987). These are separated by a region of slightly thickened crust of between $15-20 \mathrm{~km}$. The seismic velocity distribution of the central bathyal plain shows a typical oceanic-type crustal signature (Recq et al., 1984). The crustal thickness increases rapidly to $30 \mathrm{~km}$ away from the bathyal plain. The crustal profile of the Sardinian margin is very similar to that of the Atlantic margin in the Bay of Biscay. Malinverno et al. (1981) use this to suggest that the Tyrrhenian Sea has reached the limit of continental crustal extension and is now undergoing active oceanic spreading. 


\section{CHAPTER 3}

\section{THE CALABRIAN ARC BASEMENT ROCKS}

\subsection{INTRODUCTION}

The bulk of the Calabrian Arc is composed of metamorphic and plutonic basement rocks and their associated cover sediments. Their importance as the only crystalline basement rocks found in the Italian peninsula was first noted by Lugeon and Argand in 1906. Since then the origin, structure and tectonic history of these rocks have been the subject of much previous and presently ongoing research. The main aim of this thesis will be to complement this research with the production of new and detailed low temperature cooling histories using fission track analysis. However, before the results of this work are presented the geology of the basement rocks will be discussed.

\subsection{BASEMENT TECTONO-STRATIGRAPHY}

Since the first descriptions of the basement rocks of Calabria, most syntheses have postulated a complex Alpine nappe structure. However, the poor exposure, limited structural and petrological data and complexities of the basement rocks have resulted in a number of different basement tectono-stratigraphic schemes. Important early syntheses

were made by Ogniben $(1969 ; 1973)$ and Dubois (1970) from detailed geological mapping, but over limited areas. The first attempt to collate information from the whole of the Calabrian Arc was published by Amodio-Morelli et al. (1976). This synthesis provided the tectono-stratigaphic framework for much of the subsequent work on the basement rocks. Refinements to this descriptive tectono-stratigraphy have been made by Zanettin-Lorenzoni (1982) and Lorenzoni et al. (1983). However, many authors have argued against a complex pre-Oligocene nappe structure. Görler (1978) and Messina et al. (1991a) suggest that many of the tectonic contacts used to define different units by Amodio-Morelli et al. (1976) and Lorenzoni et al. (1983) are the product of localised superficial Neogene tectonism. Bouillin (1986) and Messina et al. (1991a) also suggest that most of the metamorphic rocks and all of the plutonic rocks are lateral equivalents. These rocks are 
subdivided on the basis of lateral discontinuity by the scheme of Amodio-Morelli et al. (1976) and subsequent refinements.

The most recent tectono-stratigraphic schemes fall into two categories. Messina et al. $(1991 \mathrm{a} ; 1991 \mathrm{~b})$ define the rocks on the basis of petrology and pre-Neogene structural relationships. Van Dijk and Okkes $(1990 ; 1991)$ use an alternative approach based on Neogene structural relationships. Figure 3.1 is a sketch map illustrating the basic tectonostratigraphy of the Calabrian Arc basement, based on Messina et al. (1991a). It also incorporates some of the terminology from the schemes of Lorenzoni et al. (1983) and Van Dijk and Okkes $(1990 ; 1991)$. Simplified structural cross-sections of the Sila massif show how the various tectono-stratigraphic schemes differ in structural interpretation (Figure 3.2).

In summary, the basement rocks of the Calabrian Arc can be subdivided into two groups. The lowest group, directly overlying the Liguride Complex rocks, is labelled the Alpine Group. These rocks have all experienced Alpine (post-Hercynian) greenschist facies and localised high pressure dynamic metamorphism. Above the Alpine Group are found Hercynian granites, gneisses and phyllites with Mesozoic cover rocks, labelled the Hercynian Group. These rocks show no evidence of a pervasive Alpine metamorphic overprint and can be subdivided into three sub-groups; a lower group of high-grade metamorphic rocks, an intermediate suite of Hercynian plutonic rocks and an uppermost group of low-grade metamorphic rocks with associated Mesozoic cover. It is thought by Bouillin (1984) and Messina (1991a) that the plutonic rocks form a batholith intruded along a major sub-horizontal discontinuity separating the low-grade metamorphic rocks from the high-grade metamorphic rocks. This contact may represent a tectonic contact between two Hercynian nappes or an unconformity between a pre-Hercynian poly-metamorphic basement and its mono-metamorphic Hercynian cover. The Hercynian Group can therefore be considered to have behaved as a single Alpine tectonic unit.

In contrast to this, Van Dijk and Okkes (1990; 1991) suggest the basement complex was constructed during the Neogene. They propose three structural elements. The lowgrade metamorphic rocks and associated plutonics form a lower "African" vergent nappe. 


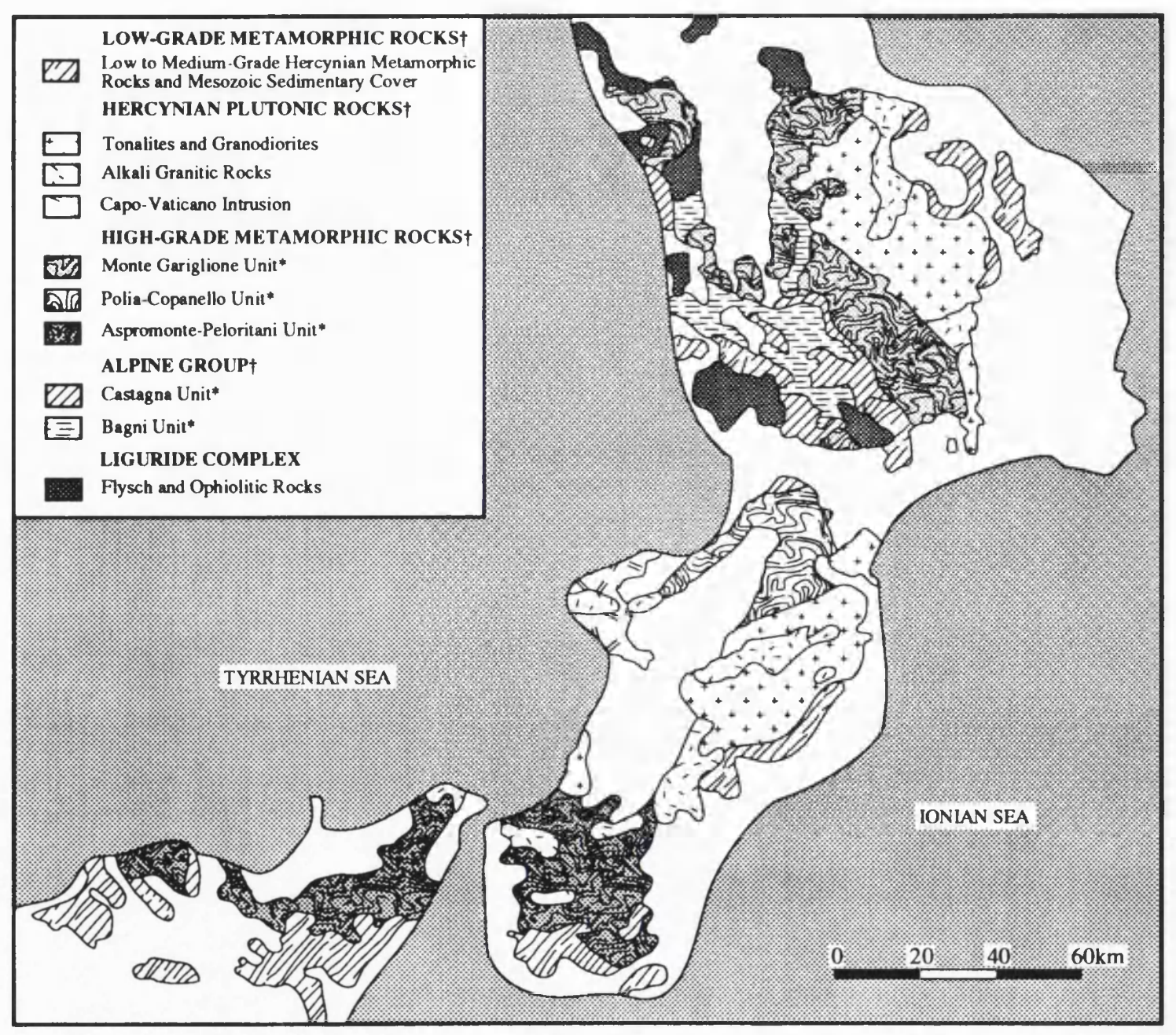

Figure 3.1 Geological sketch map of the basement rocks of the Calabrian Arc (after Messina et al., 1991b).

(* - units used by Amodio-Morelli et al., 1976 and Lorenzoni et al., 1983)

( $\dagger$ - rock groups used in this study, based on Messina et al., 1991b) 
Figure 3.2a Schematic E-W cross-section across the Sila Massif, according to the tectono-stratigraphic scheme of Messina et al., 1991a/b)

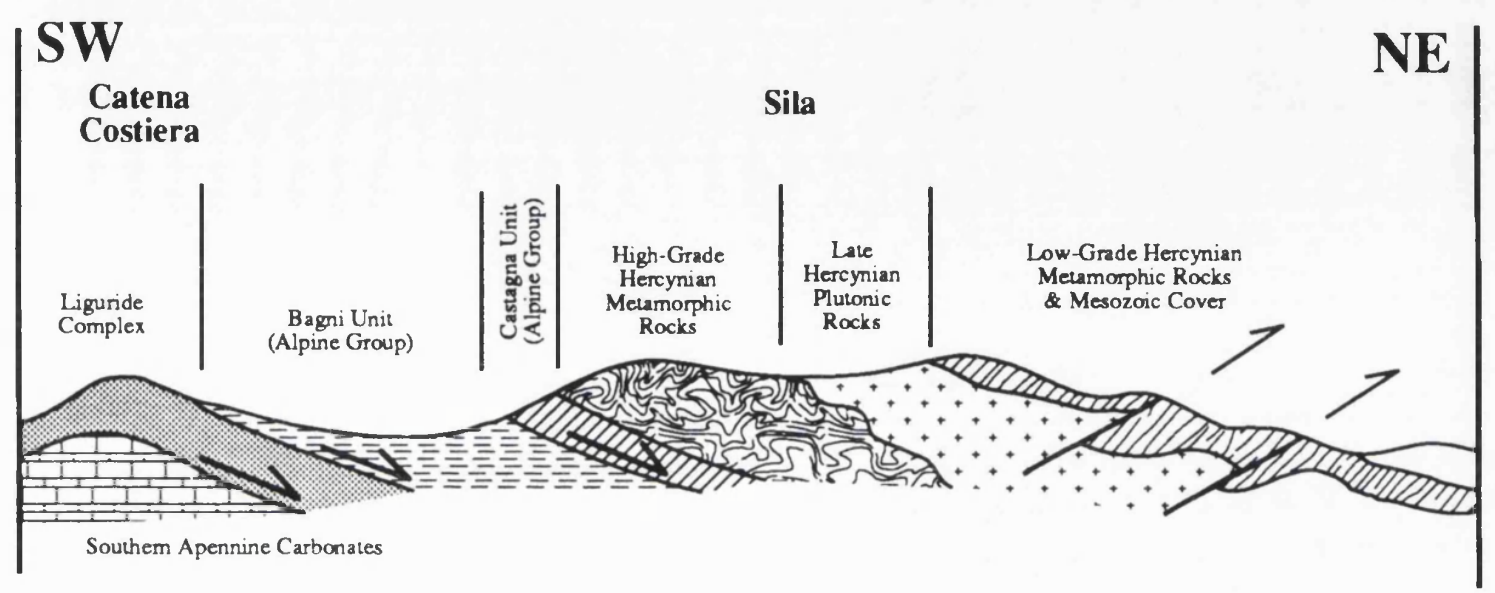

Figure 3.2b Some of the alternative tectono-stratigraphic schemes proposed for the basement rocks of the Sila Massif (after Van Dijk and Okkes, 1991)

i) Dubois (1970)

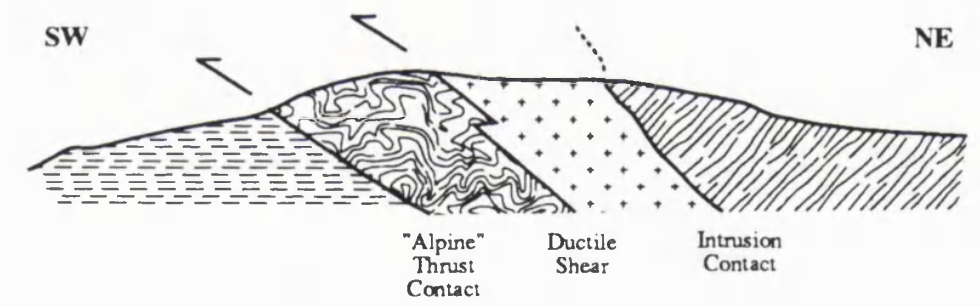

ii) Amodio-Morelli et al., (1976)

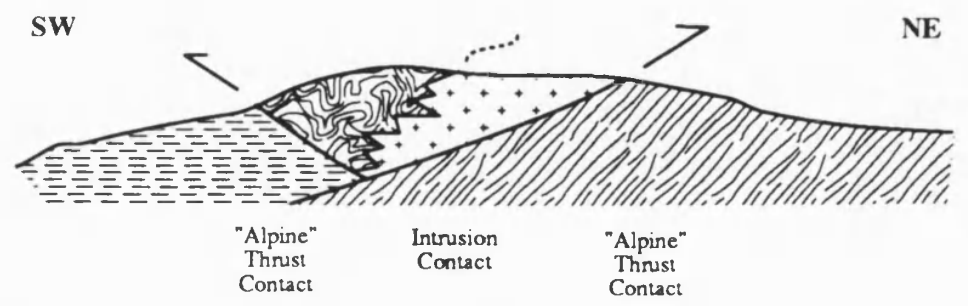

iii) Zanettin-Lorenzoni (1982)

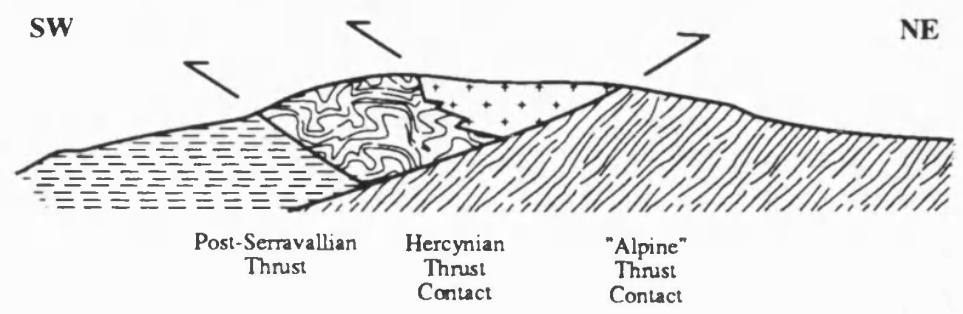


This is overthrust along two major boundaries, the Petilia-Sosti Line in the northeastern Sila and the Condofuri Line in the southwest Aspromonte, by a central nappe or klippe composed of the Alpine Group rocks and the high-grade Hercynian metamorphic rocks. The plutonic rocks in the central part of the Calabrian Arc are explained as a backthrust of the rocks of the lower "African" vergent nappe.

To describe the rocks of the basement complex a modified scheme based on Messina et al. (1991a/b) will be used.

\subsubsection{The Alpine Group Rocks}

This group of rocks directly overlies the ophiolitic Liguride Complex. Both have similar structural and metamorphic histories (Knott, 1987; Dietrich, 1988) suggesting that they are tectonically related. The Alpine Group is often split into two main sub-units:

The Bagni Unit (Dietrich et al., 1976 : Plate 3.1) is considered the lowest Alpine tectonic unit. It is formed of several hundred metres of phyllite, metamorphosed greywackes and local basic rocks (chloritoid and amphibole schists). The Bagni unit has a ?Triassic-Cretaceous sedimentary cover of marbles, cherts and meta-conglomerates. Parts of this unit show a high pressure Lawsonite facies metamorphic overprint.

The Castagna Unit (Dubois, 1966) lies tectonically above the Bagni Unit. It consists of micaschists, gneisses and granites that show a pre-Alpine metamorphic history with events in the Amphibolite facies. All the rocks of this unit show dynamic retrograde metamorphism to Greenschist facies, with in part evidence of a high-pressure event producing lawsonite and glaucophane (Dietrich, 1988).

A third Alpine Group sub-unit was proposed by Lorenzoni and Zanettin-Lorenzoni (1983), and is known as the San Sofia d'Epiro Unit. It consists of high grade biotitegarnet gneisses with sillimanite and cordierite and metabasites retrograded to greenschist facies, with part of the sequence showing evidence of a high pressure / low temperature event. However most authors consider this unit part of the high-grade Hercynian metamorphic group (Amodio-Morelli et al., 1976; Scandone, 1982; Maccarrone, 1983; Dietrich, 1988). 


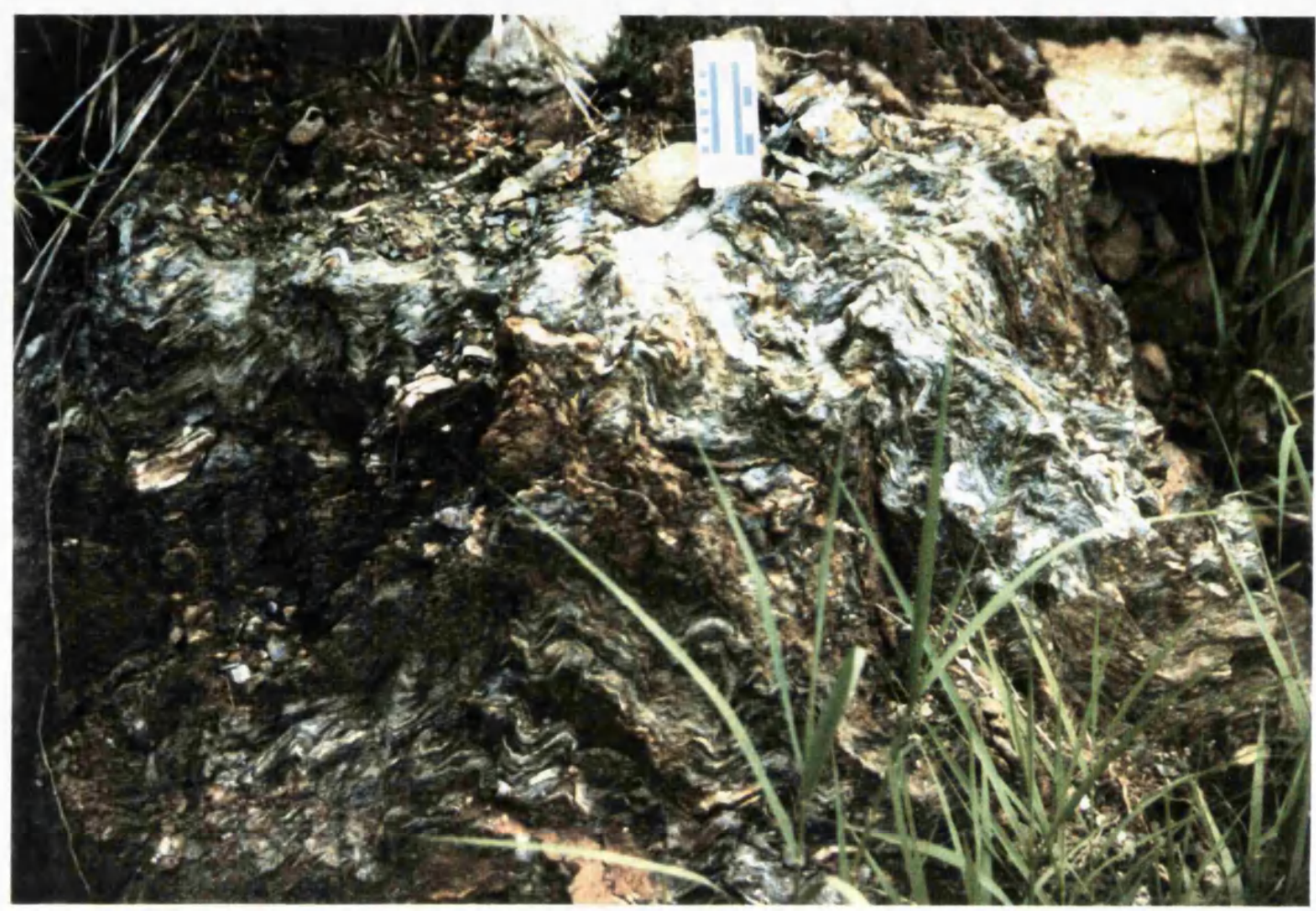

Plate 3.1 Phyllites of the Bagni Unit, taken from near Lamezia Terme, southern Sila, Calabria

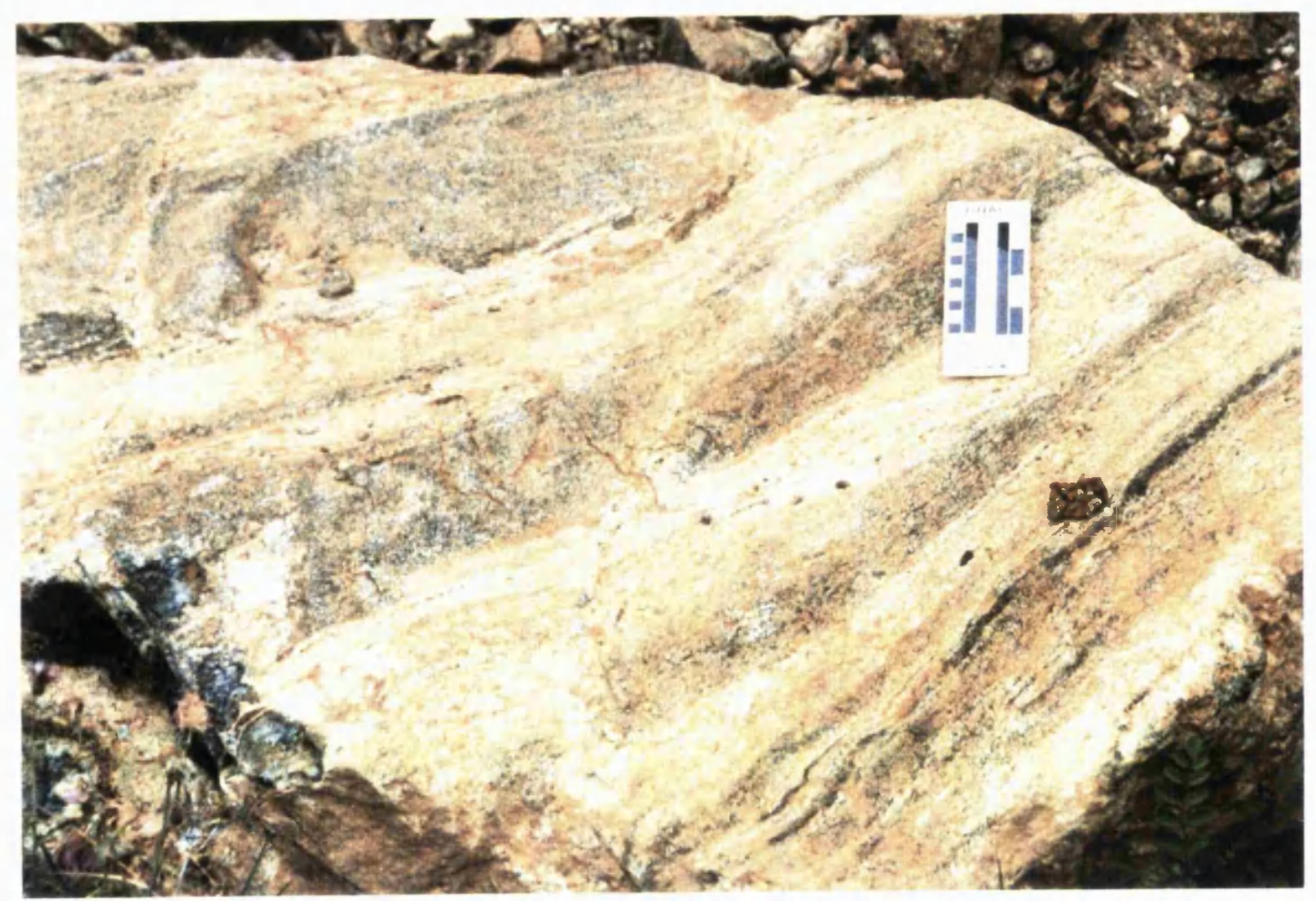

Plate 3.2 A banded gneiss form the high-grade Hercynian metamorphic rocks of the northern Serre, Calabria 
Several structural studies have been made of Alpine Group rocks in the Calabrian Coastal Ranges. An Alpine east-west lineation in the Bagni and Castagna Units is recognized by Carrara and Zuffa (1976). Using mylonites of the Castagna Unit, Faure (1980) records an early west-directed shear sense overprinted by a later east-directed shear sense. Knott (1987) and Dietrich (1988) used microstructural data to show that the rocks of the Alpine Group and the underlying Liguride Complex both record an easterly directed shear sense.

\subsubsection{The Hercynian High-Grade Rocks}

This group of rocks incorporates the Polia-Copanello Unit of Amodio-Morelli et al . (1976) and the Monte Gariglione Unit of Lorenzoni et al. (1980). Early workers labelled these rocks as the "Dioritic-Kinzigitic" Unit (Dietrich et al., 1976; Borsi et al., 1976) from the name given to similar rocks in the western Alps. This group of rocks should also include the medium to high-grade Hercynian rocks of the Aspromonte Unit of southern Calabria and northeastern Sicily (Amodio-Morelli et al., 1976), referred to as the Monte Lesti unit by Lorenzoni et al. (1980).

These rocks comprise granulite facies metasedimentary and meta-igneous rocks, usually showing retrogression to the amphibolite facies. A wide variety of lithologies are represented including biotite-garnet gneisses (kinzigites) with cordierite and sillimanite, biotite gneisses, amphibolite gneisses, diorite gneisses, siliceous marbles and aplitic / pegmatitic veins (Plate 3.2). Detailed petrological studies (Schenk and Schreyer, 1978; Moresi et al., 1980, Maccarrone et al., 1983 and Schenk, 1981; 1984) have suggested this group of rocks is a fragment of former lower continental crust.

The contact of these rocks with the underlying Alpine Group rocks along the Curinga-Girifalco Line of the northern Serre has been investigated by Schenk (1980; 1981). Here the high-grade Hercynian rocks appear to overthrust the Alpine Group rocks along a cataclastic fault zone. The age of this contact is uncertain, but it is pre-Tortonian.

The upper contact of the high-grade Hercynian rocks is usually marked by the intrusion of the late-Hercynian plutonic rocks. This contact is characterised by a layered 
migmatite, with felsic dykes constituting up to $50 \%$ of the rock (Messina et al., 1991a). The contact of high-grade Hercynian rocks directly beneath low-grade Hercynian rocks is also seen in several places such as the northeastern Sila and the southern Aspromonte (Lorenzoni et al., 1980). This contact is Hercynian in age.

Ogniben (1973), Amodio-Morelli et al . (1976), Lorenzoni and Zanettin-Lorenzoni (1983) and Van Dijk and Okkes (1990; 1991) have suggested that the low-grade Hercynian rocks underlie the high-grade Hercynian rocks. However the structures used to justify this relationship are probably a result of Neogene thrusting. The unmetamorphosed Mesozoic cover rocks and presence of low maturity Jurassic coals (Görler, 1978) imply that this thrusting is minor and localised.

Recently Bonardi et al. (1984) have discovered widespread greenschist facies metamorphism and related ductile deformation of post-Hercynian (Alpine) age within highgrade Hercynian rocks in the Aspromonte. Platt and Compagnoni (1990) have shown this deformation is extensional in nature, probably due to Late Oligocene uplift and exhumation. Detailed structural analysis has revealed a north to northwesterly shear sense, differing from the easterly shear sense seen in the rocks of the Alpine Group (Faure, 1980; Dietrich, 1988). A similar metamorphic event has been reported from the Peloritani Mountains (Messina et al., 1990).

\subsubsection{The Hercynian Plutonic Rocks}

The high and low-grade Hercynian Rocks of the Calabrian Arc basement complex are intruded by large areas of late-Hercynian acidic plutonics. Two suites of plutonic rocks are recognised (Atzori et al., 1983; Messina et al., 1991a). First there is an earlier widespread subaluminous to peraluminous suite, consisting of tonalites and granodiorites. These are characterised by the presence of primary muscovite, and absence of aluminium silicates and hornblende. The less widespread second suite of peraluminous plutonic rocks (D'Amico et al., 1982; Messina et al., 1991b) varies in composition from monzogranites to leucogranodiorites. These rocks are characterised by the occurrence of fibrous sillimanite and local cordierite, andalusite and garnet. They are probably of crustal origin, resulting from 
the partial meting of metapelites (Del Moro et al., 1982; Atzori et al., 1990). Both suites are cut by aplitic dykes, pegmatites and occasional porphyritic rhyolites and dacites.

Amodio-Morelli et al. (1976) originally proposed that the plutonic rocks of the Sila region belonged to two tectonic units (the Monte Gariglione Unit and the Longobucco Unit) separated by a major tectonic contact. This view has largely been accepted in the literature, but recently Messina et al. (1991a) have found that field and petrographic data does not support this interpretation. Consequently it is now thought that the Sila plutonic rocks form a single batholith.

\subsubsection{The Hercynian Low Grade Rocks and Sedimentary Cover}

These rocks overlie the late-Hercynian Plutonic rocks along an intrusive contact, making them the highest structural element with the Calabrian Arc basement complex. They include lower Palaeozoic phyllites, metamorphosed greywackes, limestones and meta-basalts. Their metamorphism, generally of greenschist facies, occurred prior to the intrusion of the late-Hercynian plutonics. The detailed petrology and age of these rocks is dealt with in detail by Acquafredda et al . (1983; 1988a). Unmetamorphosed Mesozoic cover sediments unconformably overlie these rocks. The most extensive outcrop of these rocks is in the Longobucco area of the northeastern Sila where a $1500 \mathrm{~m}$ thick sequence of Liassic limestones and turbidites are found (Zuffa et al., 1980; Young et al., 1986). Cover rocks of a similar age, although comprising generally more massive limestones and dolomites, also occur in the Stilo region of southern Calabria and the Taormina region of northeast Sicily.

These rocks have previously been incorporated into the Longobucco Unit in the northeastern Sila, the Stilo Unit and part of the Aspromonte Unit in southern Calabria and the Mandanici and Longi-Taormina Units of northeastern Sicily (Ogniben, 1973; AmodioMorelli et al., 1976; Borsi et al., 1976). Lorenzoni et al. (1980) were the first to suggest these low-grade Hercynian rocks were laterally equivalent throughout the Calabrian Arc, but proposed several sub-units based largely on petrographic characteristics. These included the phyllitic Bocchigliero and Pentadattilo Units and the higher grade Mandatorricio, Capo san Giovanni and Monti Lesti Units. These latter units are probably 
small slivers of the high-grade Hercynian rocks that overlie the Hercynian Plutonic rocks.

\subsection{A SYNTHESIS OF ISOTOPIC AGE DATA COLLECTED FROM THE}

\section{CALABRIAN ARC BASEMENT COMPLEX}

\subsubsection{Introduction}

All the published isotopic age data that have been obtained from the Calabrian Arc basement rocks are collated in Table 3.2. The ages obtained prior to 1976 have been recalculated using the latest recommended IUGS standards (Harland et al., 1989). Locations for the data sets are shown in Figure 3.3. The majority of this data have been collected from the high-grade Hercynian rocks and the late-Hercynian plutonics. Data from the rocks of the Alpine Group are limited to a few analyses by Borsi and Dubois (1968) and Schenk (1980).

\subsubsection{The Concept of Closure Temperature}

This subject has been reviewed in detail by Dodson (1979), Cliff (1985) and Zietler (1989). It is now widely recognised that the isotopically determined ages measured on metamorphic minerals very rarely record a geological 'event'. The principle of isotopic age determination relies on the fact that radioactive parent isotopes decay to daughter isotopes at a constant rate known as the half-life. However, for an age to be recorded this isotopic system or isotopic clock must remain closed, so that no parent or daughter isotopes can escape. When parent or daughter isotopes become redistributed or lost then the system will be reset or partially reset and the system is said to become open.

It is now thought that the transition of an open system to a closed system and vice versa within a mineral lattice is controlled by the reaction kinetics of volume diffusion. The exact nature of the kinetics of this process are unknown. However the dominant factor is widely, but not universally, believed to be temperature. Supporting evidence comes from numerous practical and laboratory experiments (see Zeitler, 1989 for list of references). The dominance of temperature on the isotopic system led Dodson (1973) to propose the concept of 'closure temperature'. This was defined as "the temperature of an isotopic 


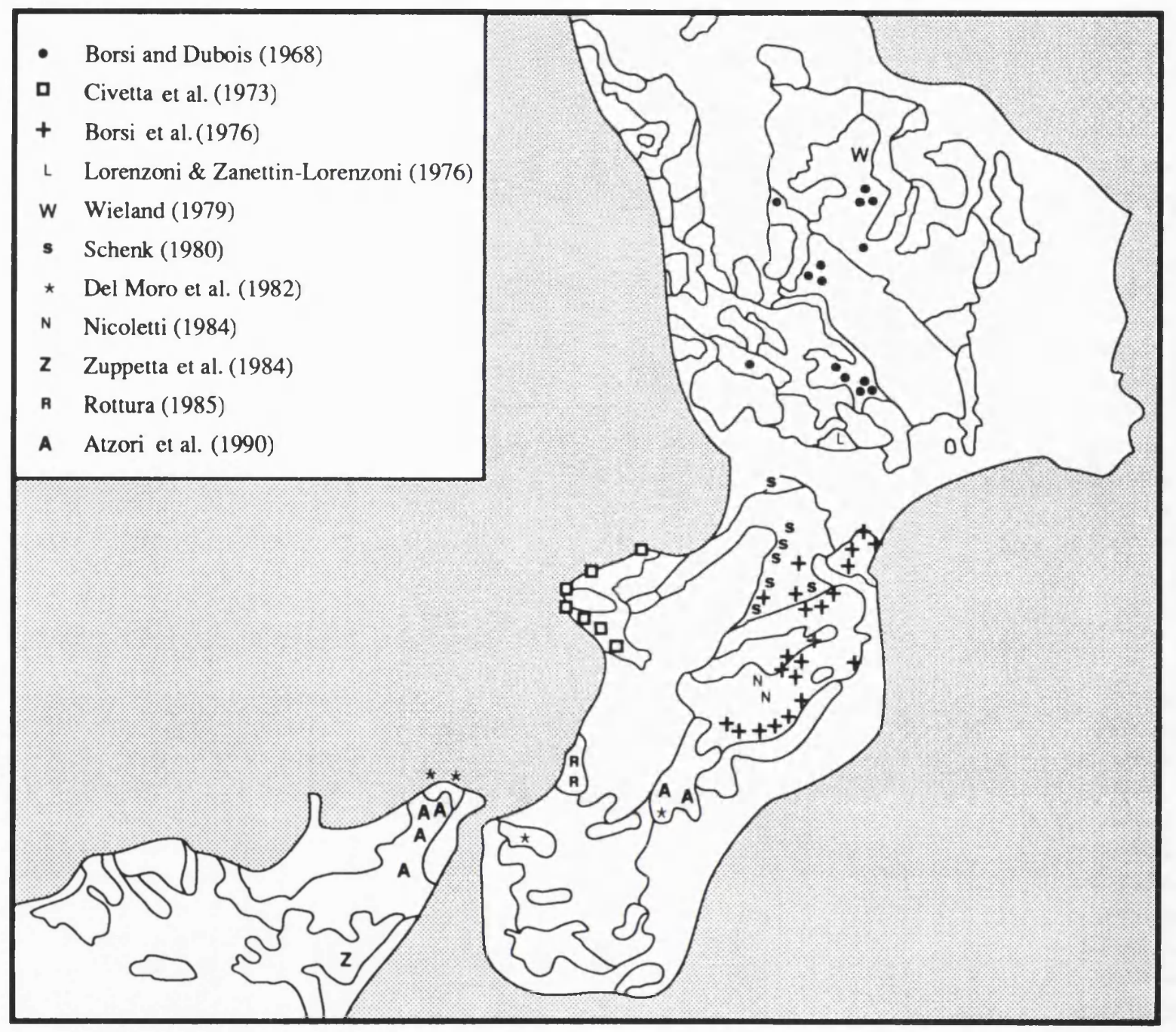

Figure 3.3 Map showing approximate locations of samples isotopically dated by other authors 
TABLE $\quad 3.2$

Previously obtained isotopic age data from the Calabrian Arc

Sample

Unit

$\mathrm{K}-\mathrm{Ar}(\mathrm{Bi})$

$\mathrm{Rb}-\mathrm{Sr}(\mathrm{Bi})$

$\mathrm{K}-\mathrm{Ar}$ (Ms)

$\mathrm{Rb}-\mathrm{Sr}(\mathrm{Ms})$

$\mathrm{Rb}-\mathrm{Sr}$ (Fs)

$\mathrm{K}-\mathrm{Ar}(\mathrm{WR}) \quad \mathrm{Rb}-\mathrm{Sr}(\mathrm{WR})$

$\mathrm{U}-\mathrm{Pb}(\mathrm{Zr})$

$\mathrm{U}-\mathrm{Pb}(\mathrm{Mz})$

\section{ALPINE GROUP}

Borsi and Dubois (1968)

$\begin{array}{lc}\text { 3f } & \text { Bagni } \\ \text { 3h } & \text { Castagna }\end{array}$

$3 \mathrm{i} \quad$ Castagna

Castagna

$217 \pm 6^{*}$

$\begin{array}{ll}4 \mathrm{~b} & \text { Castagna } \\ 4 \mathrm{c} & \text { Castagna }\end{array}$

$120 \pm 4 \dagger$

$118 \pm 4 *$

$191 \pm 6+$

$262 \pm 8 *$

$4 \mathrm{~d} \quad$ Castagna

$4 \mathrm{f} \quad$ Castagna

Frido

* Recalculated using $\lambda^{87} \mathrm{Rb}=1.42 \times 10^{-11} / \mathrm{yr}$

$\dagger$ Recalculated using recommended IUGS standards

Schenk (1980)

KAL-42 Castagna

KAL-51

$43 \pm 1$

$259+8 *$

$237 \pm 7^{*}$

$259 \pm 8 *$

$254 \pm 8 *$

(5)

\section{HERCYNIAN GROUP}

Ferrara and Longinelli (1961)

- Plutonic

High-grade Met

* Recalculated using $\lambda^{87} \mathrm{Rb}=1.42 \times 10^{-11} / \mathrm{yr}$

Borsi and Dubois (1968)

$1 \mathrm{a}$

1b Plutonic

lc Low-grade Met

ld Low-grade Met

Plutonic

$\begin{array}{lr}2 \mathrm{~b} & \text { Plutonic } \\ 2 \mathrm{c} & \text { Plutonic }\end{array}$

$\begin{array}{lr}2 \mathrm{~b} & \text { Plutonic } \\ 2 \mathrm{c} & \text { Plutonic }\end{array}$

$58 \pm 2 *$

$49 \pm 2 \dagger$

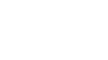

High-grade Met

High-grade Met 


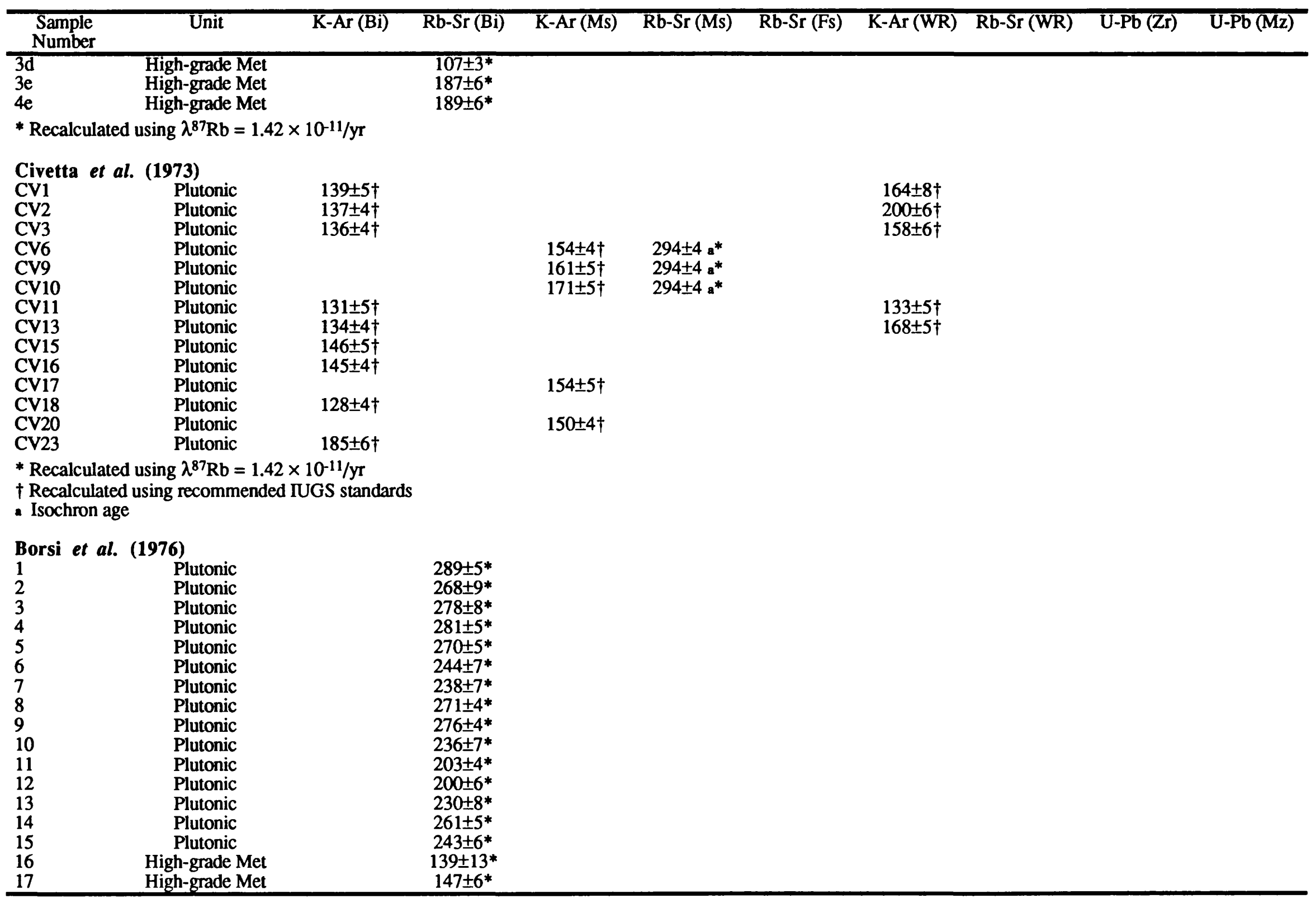




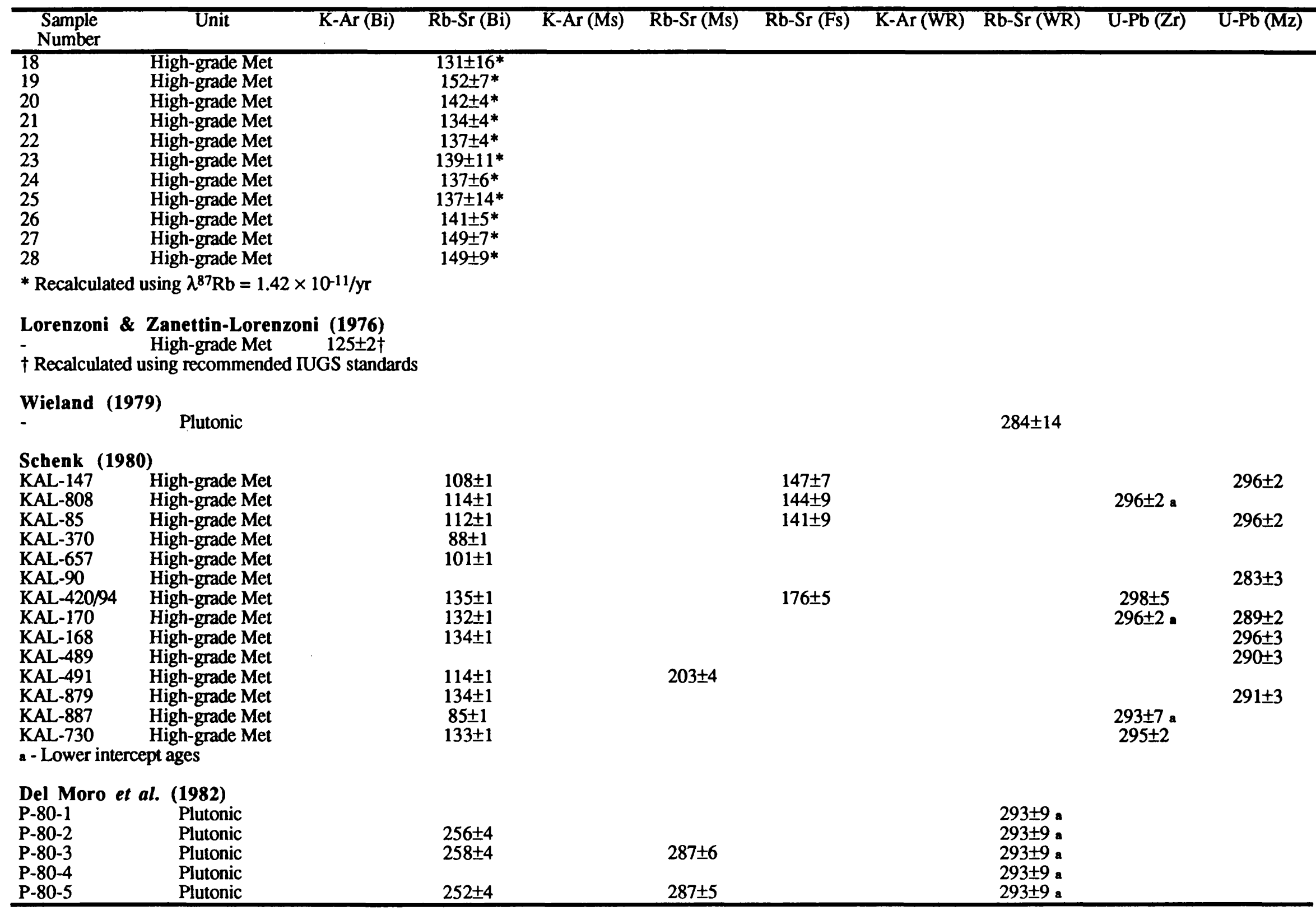




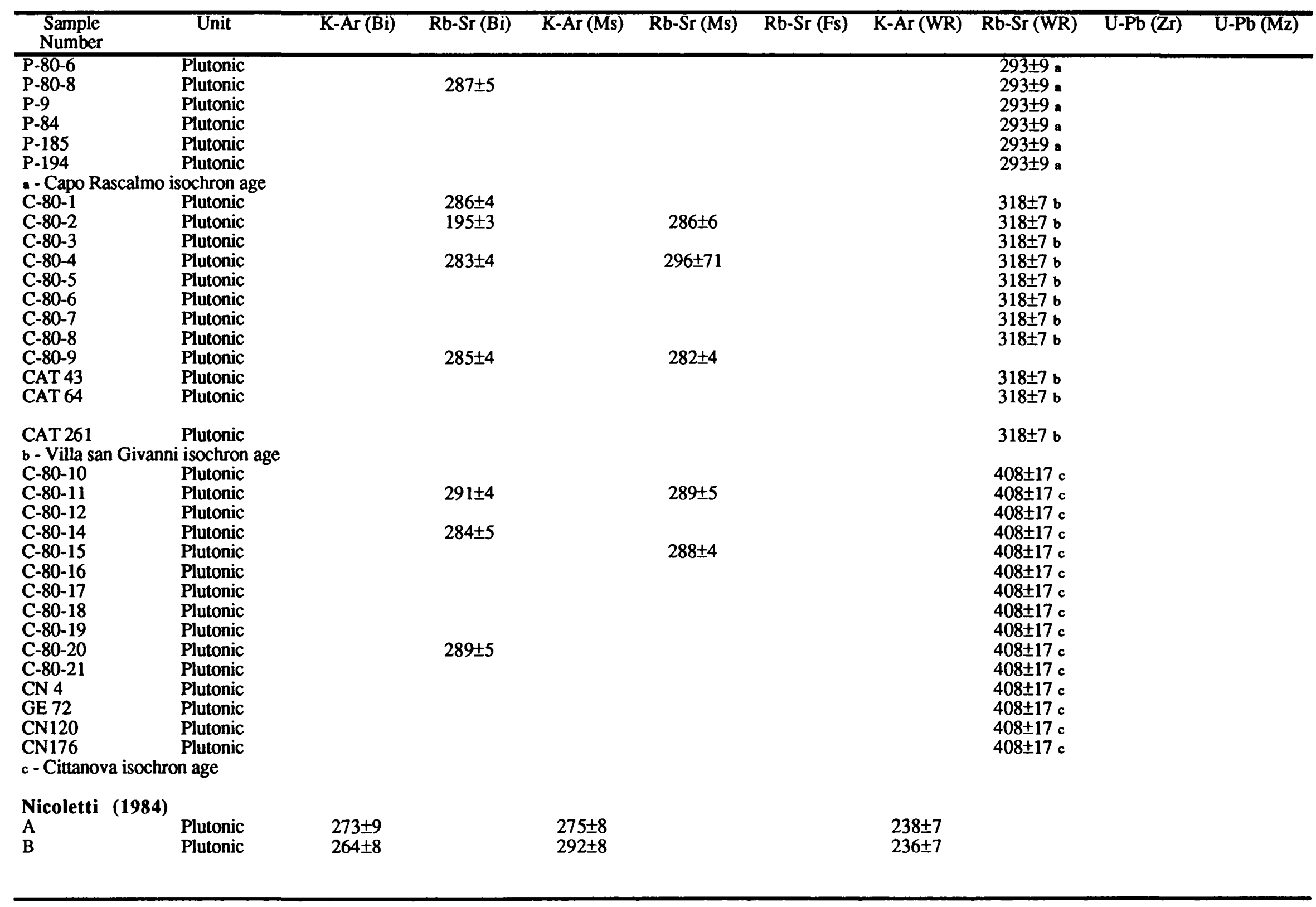




\begin{tabular}{|c|c|c|c|c|c|c|c|c|c|c|}
\hline $\begin{array}{c}\text { Sample } \\
\text { Number } \\
\end{array}$ & Unit & $\bar{K}-\mathbf{A r}(\mathrm{Bi})$ & Rb-Sr (Bi) & K-Ar (Ms) & Rb-Sr (Ms) & Rb-Sr (Fs) & K-Ar (WR) & $\mathrm{Rb}-\mathrm{Sr}(\mathrm{WR})$ & $\mathrm{U}-\mathrm{Pb}(\mathrm{Zr})$ & $\mathrm{U}-\mathrm{Pb}(\mathrm{Mz})$ \\
\hline Zuppetta & $\begin{array}{l}\text { al. }(1984) \\
\text { Low-grade Met }\end{array}$ & & & & & & $217 \pm 3$ & & & \\
\hline $\begin{array}{l}\text { Rottura ( } \\
\text { B232 } \\
\text { B246 } \\
\text { B83 }\end{array}$ & $\begin{array}{l}\text { 5) } \\
\text { High-grade Met } \\
\text { High-grade Met } \\
\text { High-grade Met }\end{array}$ & $\begin{array}{l}103 \pm 4 \\
135 \pm 5\end{array}$ & $89 \pm 1$ & & & & & & & \\
\hline Bonardi & $\begin{array}{l}\text { (1987) } \\
\text { High-grade Met }\end{array}$ & & & & & & & $25-30$ & & \\
\hline $\begin{array}{l}\text { Atzori et } \\
\text { P-85-1 } \\
\text { P-85-4 } \\
\text { P-85-5 } \\
\text { P-85-6 } \\
\text { P-85-7 } \\
\text { G2 } \\
\text { G32 } \\
\text { G67 } \\
\text { G100 }\end{array}$ & $\begin{array}{l}\text { (1990) } \\
\text { High-grade Met } \\
\text { High-grade Met } \\
\text { High-grade Met } \\
\text { High-grade Met } \\
\text { High-grade Met } \\
\text { High-grade Met } \\
\text { High-grade Met } \\
\text { High-grade Met } \\
\text { High-grade Met }\end{array}$ & & $\begin{array}{l}262 \pm 8 \\
280 \pm 8 \\
137 \pm 4 \\
173 \pm 5 \\
281 \pm 8 \\
289 \pm 8 \\
292 \pm 9 \\
291 \pm 9 \\
291 \pm 9\end{array}$ & & $\begin{array}{l}284 \pm 10 \\
286 \pm 10 \\
282 \pm 9\end{array}$ & & & & & \\
\hline \multicolumn{11}{|c|}{ Determinations with other isotopic techniques } \\
\hline \multicolumn{11}{|c|}{$\begin{array}{l}\text { Ferrara et al. (1959) } \\
\text { High-grade Metamorphic : U-Pb (Uraninite) - 200 } 330\end{array}$} \\
\hline \multicolumn{11}{|c|}{$\begin{array}{l}\text { Rottura (1985) } \\
\text { High-grade Metamorphic : K-Ar (Homblende) - 323 } \pm 11\end{array}$} \\
\hline $\begin{array}{l}\text { Schenk ( } \\
\text { High-grade }\end{array}$ & $\begin{array}{l}\text { 9) } \\
\text { tamorphic : Sm-N }\end{array}$ & amet) -214 & & & & & & & & \\
\hline
\end{tabular}


system at the time represented by its apparent age".

Kinetic theory predicts that the closure temperature will be highly influenced by activation energy, and be sensitive to grain size and the rate of change in temperature. A large activation energy is required for volume diffusion, which means that the process will occur over a narrow temperature interval (i.e. the closure temperature). The effects of grain size and cooling rate on closure temperature have been investigated by Harrison (1981) for argon diffusion in homblende. This shows that for most realistic geological cooling rates these effects can be incorporated into an error of $\pm 50^{\circ} \mathrm{C}$.

One major problem with the closure temperature concept is the difference in the kinetic behaviour of the diffusion process during heating and cooling. The closure temperature of a mineral is often assumed to be identical to the opening temperature (i.e. the temperature of an isotopic system when its age is reset to zero). However this is very rarely true. The temperature that isotopes start to become lost from the system is often quite different from the closure temperature. Zeitler (1989) quotes a rough rule of thumb that states that if a mineral is heated to a defined closure temperature then the isotopic system will become reset to zero age after approximately $10 \mathrm{Ma}$. To achieve total resetting after $1 \mathrm{Ma}$ would require heating the system some $50-100^{\circ} \mathrm{C}$ above its defined closure temperature. From this it follows that although most isotopic ages will represent a cooling age, it is also possible that the age may have been partially reset by a short-lived heating event.

The interpretation and nature of cooling histories derived from isotopic age dating methods have been dealt with in detail by Harrison and Clarke (1979) and Harrison et al. (1979). The simplest case scenario is when a pluton is intruded into a cool host rock, producing a large thermal contrast. The result is that the pluton cools rapidly and a concave temperature-time curve results. In cases where no thermal contrast exists, such as a regional metamorphic terrain, then the rock will cool slowly a first, then progressively quicker as overburden is removed. This produces a convex cooling curve.

Examples of the variations of model that can be produced by the resetting of isotopic systems are shown in Figure 3.4 ( $\mathrm{x}$ denotes partial melting and different mineral age systems are denoted as $\mathrm{m}$ ). Figure 3.4 a shows the cooling history of a pluton intruded 


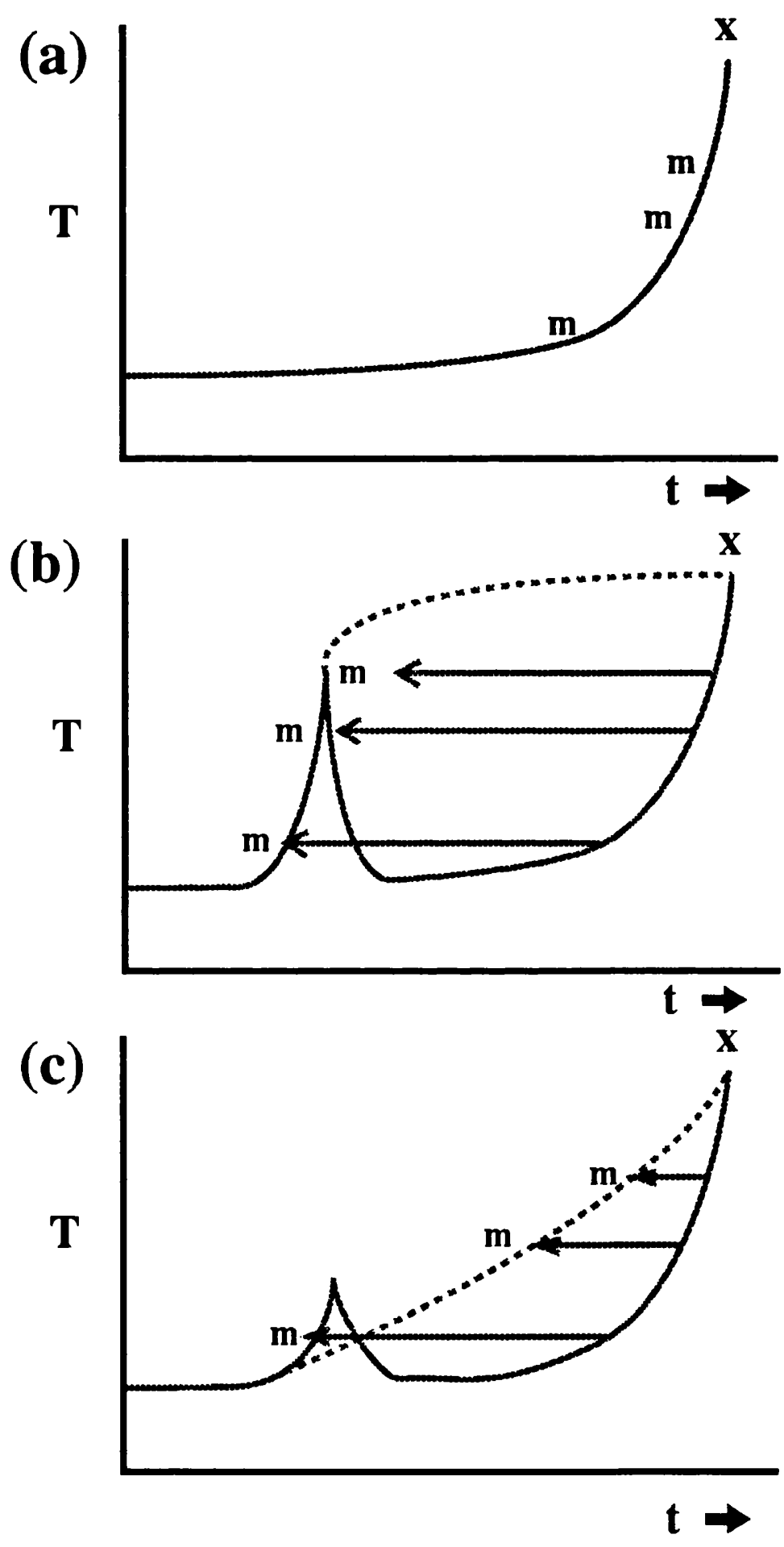

Figure 3.4 (a) Simple cooling history of pluton unaffected by any post-emplacement thermal events. (b) Cooling history interrupted by thermal event that resets all mineral ages.

(c) Complex cooling history affected by a thermal event that only partially resets the mineral ages. The apparent cooling histories are shown by the dashed line. (x-partial melt, m-mineral age)

(after Harrison et al., 1979) 
into a cool host rock. However if a thermal event occurs that resets all the mineral ages, as is shown in Figure 3.4b, then the data may be interpreted as either a rapid cooling event or a resetting event. In the most complex case a short-lived thermal pulse could occur that only partially resets the mineral ages (Figure 3.4c). The effect of this pulse is to differentially reset the different mineral ages, with the more resistant high temperature systems less affected than the low temperature systems. Therefore what appears to be a gradual steady cooling curve could be masking a genuinely episodic thermal history.

\subsubsection{Relevant Closure Temperature Values}

The calculation of closure temperature values for different isotopic systems and minerals and the problems associated with their use have been reviewed by a number of authors, including Cliff (1985), Harland et al . (1989) and Hurford (1991). However, it should be borne in mind that despite the widespread use of isotopically determined mineral ages in the geological literature there are still a large number of uncertainties involved with the application of the closure temperature concept. Therefore when attempting to quantify cooling histories large errors are unavoidable.

The relevant closure temperature values for the main isotopic systems used to determined ages for the basement rocks of the Calabrian Arc are summarised below with important references:

K-Ar (biotite) $\quad: 300 \pm 50^{\circ} \mathrm{C} \quad$ (Purdy and Jäger, 1976; Turner and Forbes, 1976;

Del Moro et al., 1982; Cliff, 1985)

$\mathrm{K}-\mathrm{Ar}$ (white mica) $\quad: 350 \pm 50^{\circ} \mathrm{C} \quad$ (Purdy and Jäger, 1976)

$\mathrm{K}-\mathrm{Ar}$ (hornblende) $\quad: 500 \pm 50^{\circ} \mathrm{C} \quad$ (Harrison and McDougall, 1980; Harrison, 1981;

Zietler, 1989)

$\mathrm{Rb}-\mathrm{Sr}$ (biotite) $\quad$ : $300 \pm 50^{\circ} \mathrm{C} \quad$ (Purdy and Jäger, 1976; Cliff, 1985)

$\mathrm{Rb}-\mathrm{Sr}$ (white mica) $\quad: 500 \pm 50^{\circ} \mathrm{C} \quad$ (Purdy and Jäger, 1976)

$\mathrm{Rb}-\mathrm{Sr}$ (feldspar) $\quad: 350 \pm 50^{\circ} \mathrm{C} \quad$ (Harland et al., 1989)

$\mathrm{Rb}-\mathrm{Sr}$ (whole rock) $\quad: 650-800^{\circ} \mathrm{C} \quad$ (Harland et al., 1989)

$\mathrm{U}-\mathrm{Pb}$ (zircon) $\quad:>750^{\circ} \mathrm{C} \quad$ (Parrish and Tirrul, 1989; Searle and Tirrul, 1991) 
$\mathrm{U}-\mathrm{Pb}$ (monazite) $\quad$ : $700-730^{\circ} \mathrm{C} \quad$ (Copeland et al., 1988; Searle and Tirrul, 1991)

\subsubsection{Interpretation of the Isotopic Age Data Collected from the Calabrian Arc Basement Complex}

The closure temperature values above can be combined with the isotopic age data obtained from the basement rocks of the Calabrian Arc (Table 3.2) to produce a number of timetemperature histories.

The T-t plot for the Alpine group rocks is shown in Figure 3.5. Figure 3.4 shows this plot can be interpreted in two ways. The simplest interpretation is one of a gradual cooling of the rocks from a temperature peak during the Hercynian Orogeny. However the second option is that a thermal event occurred at around 50Ma, which totally reset three of the biotite ages and partially reset the other mineral ages. Schenk (1980) correlates the young biotite ages with the pervasive greenschist facies metamorphic overprint seen in these rocks. However this event has not greatly affected the higher temperature mineral systems. This indicates that the "Alpine" metamorphic overprint of these rocks did not reach a very high temperature. The presence of high pressure minerals and evidence of large strain implies that this metamorphism is subduction related. It is probably related to similar metamorphism seen in the Liguride complex rocks (De Roever, 1972; Knott, 1987; 1988), related to subduction from the late Cretaceous to early Oligocene.

The T-t plot for the high-grade Hercynian metamorphic rocks is shown in Figure 3.6. The mineral ages fall into two categories. The majority of the samples show high temperature Hercynian ages and a wide range of lower temperature biotite and white mica ages between $85 \mathrm{Ma}$ to $203 \mathrm{Ma}$. Again these ages are open to two interpretations. Schenk $(1980 ; 1989)$ suggests they are the result of slow cooling of the lower Crust during the Mesozoic, with final rapid exhumation to the surface during the Neogene Apenninic orogeny (Figure 3.7). In contrast Del Moro et al . (1982), Rottura (1985) and Atzori et al. (1990) propose that the biotite and white mica ages have been partially reset by an "Alpine" thermal event. This second interpretation more adequately explains the large spread in the biotite and white mica ages. However there is a second category of mineral ages seen in 


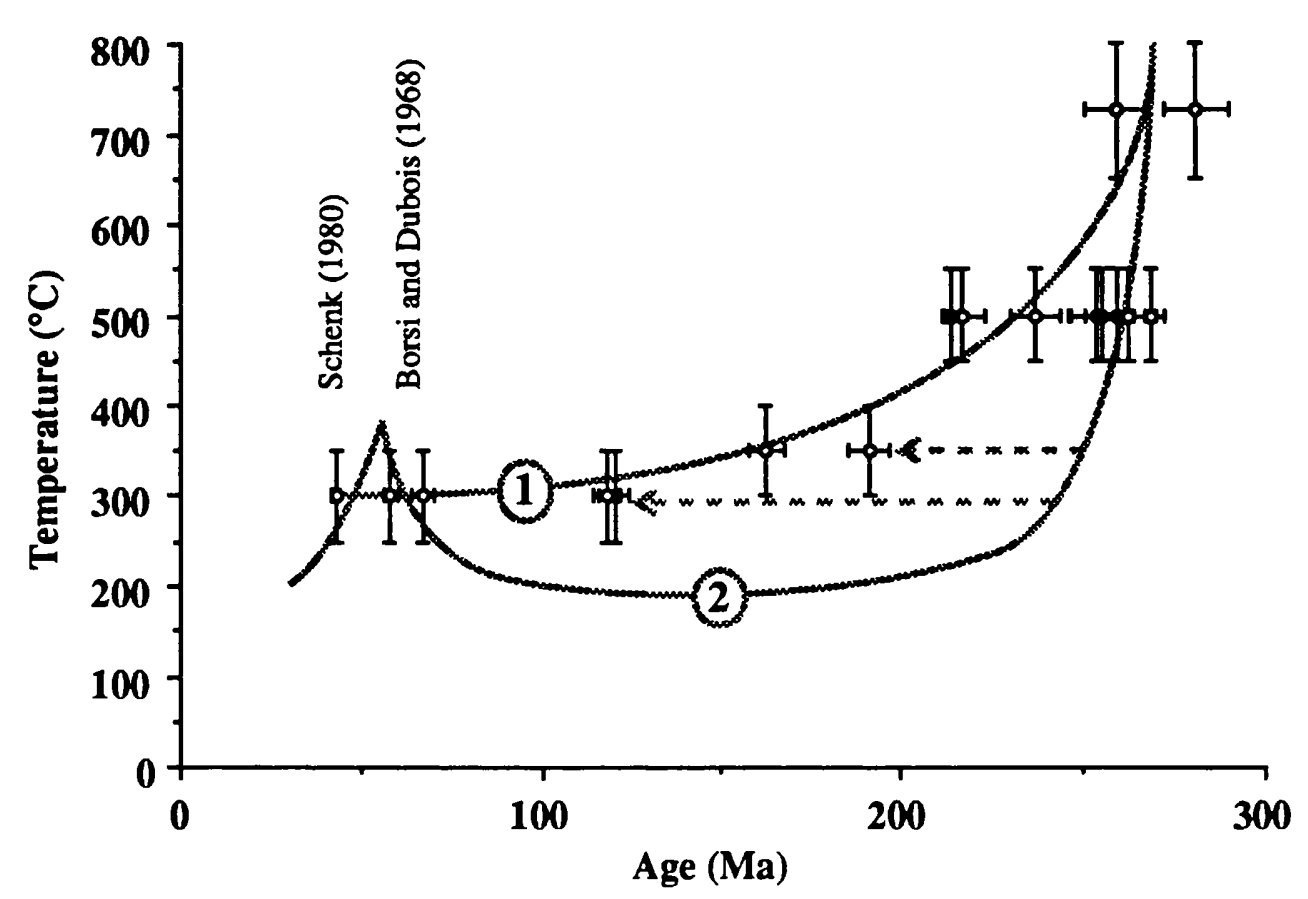

Figure 3.5 Time-Temperature plot for the isotopic age data obtained from the Alpine Group rocks

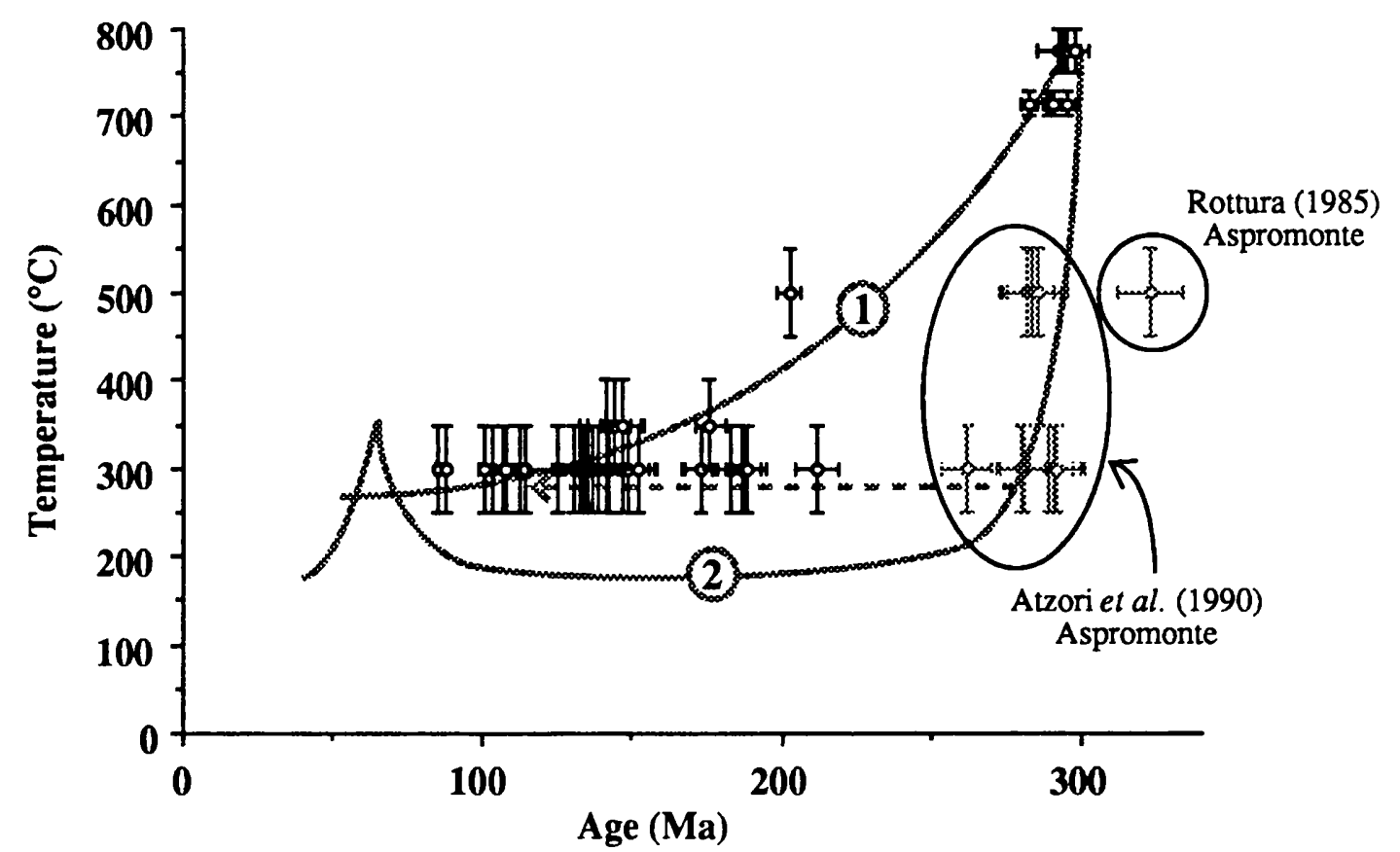

Figure 3.6 Time-Temperature plot for the isotopic age data obtained from the high-grade Hercynian metamorphic rocks 
these high grade metamorphic rocks. This group of ages, obtained only from the Aspromonte and Peloritani regions by Rottura (1985) and Atzori et al. (1990), show biotite and white mica and hornblende ages ranging from $262 \mathrm{Ma}$ to $323 \mathrm{Ma}$. Therefore, it is clear these rocks have not suffered a post-Hercynian thermal event. The similarity of these ages to the ages of the local acidic plutonics indicates that rapid exhumation of these basement rocks must have occurred subsequent to the Hercynian orogeny. Young Rb-Sr mica ages between 25Ma and 30Ma have also been obtained from the rocks of the Aspromonte region (Bonardi et al., 1987). Platt and Compagnoni (1990) propose that such ages are related to extensional mylonites associated with rapid tectonic exhumation of these rocks during the late Oligocene. However these effects are clearly localised, as the majority of the rocks in this region show no effects whatsoever of this exhumation event. Rottura (1985) comments on similar mylonites in the Serre region, suggesting they are Eo-Alpine in age and that the deformation event that produced them was responsible for the partial resetting of the highgrade metamorphic rocks in this region.

Finally the T-t plot for the plutonic and low-grade metamorphic rocks are shown in Figure 3.8. The three ages obtained from the low-grade metamorphic rocks range from $217 \mathrm{Ma}$ to $292 \mathrm{Ma}$. The young age of $217 \pm 3 \mathrm{Ma}$ obtained from a phyllite in the Peloritani region of Sicily has been interpreted as representing a Triassic tectonic event by Zuppetta $e t$ al. (1984). The isotopic ages obtained from the plutonic rocks again fall into two categories. The vast majority of the plutonics, from the Sila, Serre and Aspromonte regions, show mineral ages indicative of rapid cooling after intrusion. Such a cooling curve is typical of intrusion into cool host rocks (Harrison and Clarke, 1979 and Figure 3.4a), indicating that these plutonics were emplaced at a high crustal level. However plutonic rocks from the Capo Vaticano intrusion (Civetta et al., 1973) differ by showing K-Ar biotite and white mica ages between $131 \mathrm{Ma}$ and $181 \mathrm{Ma}$, similar to the ages obtained for the nearby high-grade metamorphic rocks. Therefore these rocks have either cooled slowly or been partially reset by a post-Hercynian thermal event. Three ages fall between these two categories and are identified in Figure 3.8. Sample $\mathrm{C}_{80-2}$ of Del Moro et al. (1982) is an aplite dyke that is thought to have undergone post-magmatic alteration and Samples 11 and 


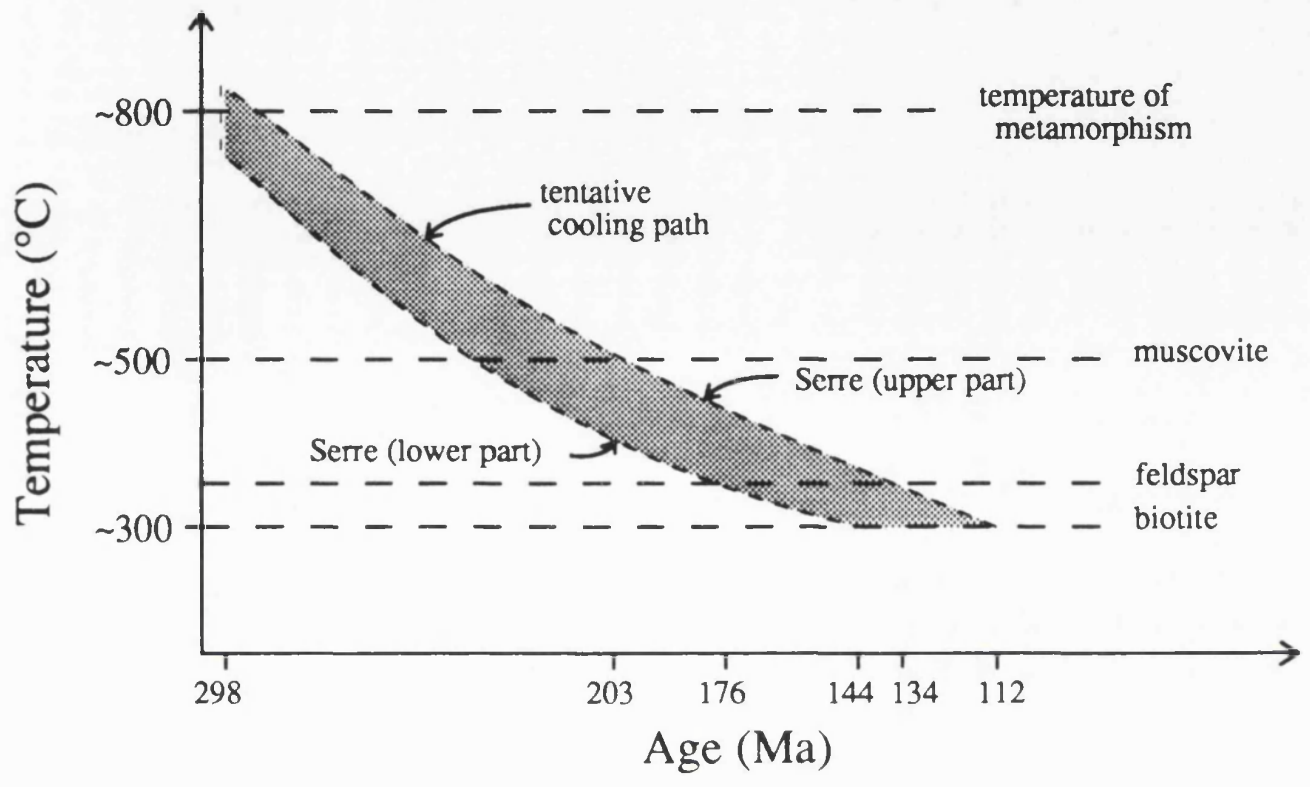

Figure 3.7 Tentative cooling history for the high grade Hercynian metamorphic rocks of the NW Serre (after Schenk, 1980)

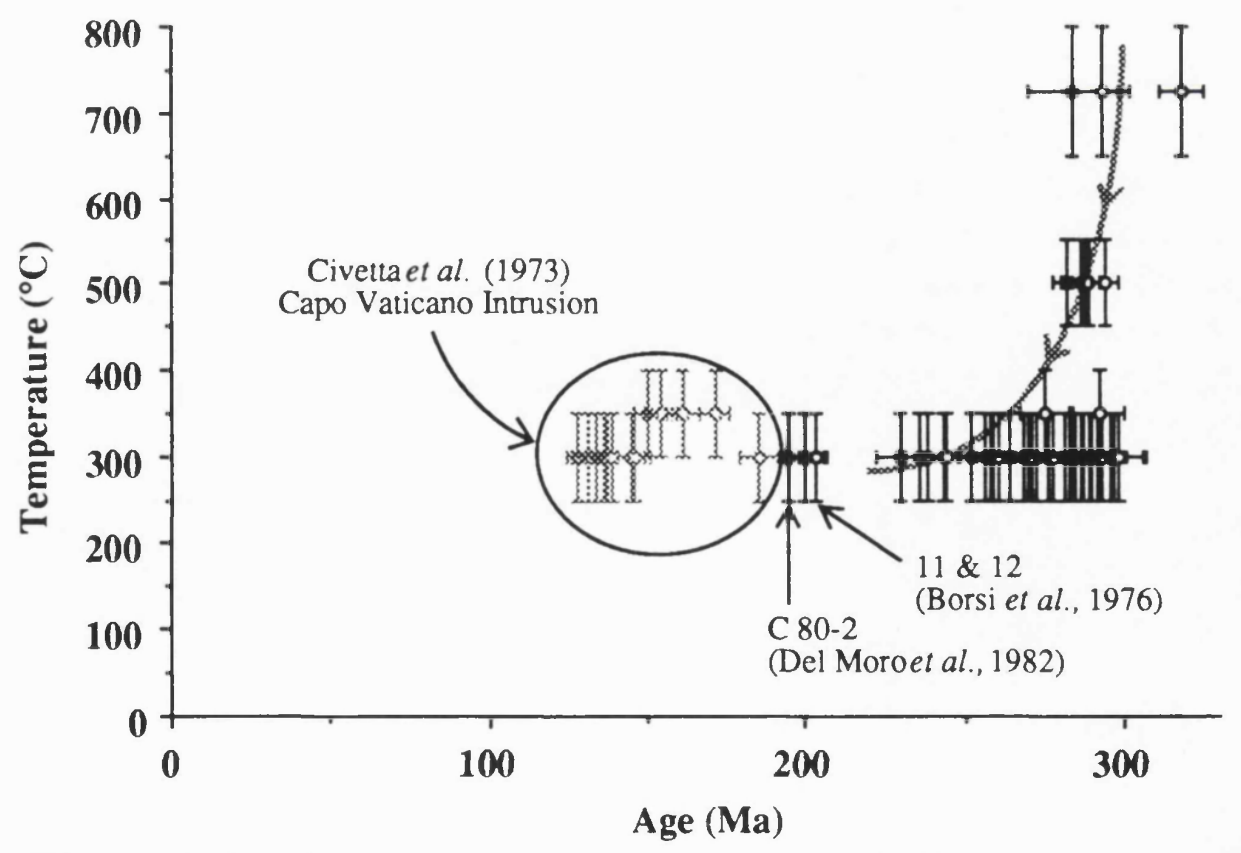

Figure 3.8 Time-temperature plot for the isotopic age data obtained from the late Hercynian plutonic and low-grade metamorphic rocks 
12 of Borsi et al. (1976) are very close to a post-Hercynian tectonic contact. Both events have caused partial loss of radiogenic argon and partially reduced the true isotopic age.

In summary, the isotopic age data obtained from the basement rocks of the Calabrian Arc are open to two main interpretations. The first possibility is that they represent steady cooling paths, slow in the Alpine group rocks, most of the high-grade Hercynian metamorphic rocks and one intrusion of Hercynian plutonics, and more rapid in most of the plutonic rocks and some of the high-grade metamorphic rocks of the Aspromonte and Peloritani regions. The second possibility is that all the basement rocks underwent rapid post-Hercynian cooling, and have suffered to a greater or lesser degree from a low-temperature "Eo-Alpine" thermal event at around 50Ma. The rest of this thesis will constrain the above interpretations with low-temperature data provided by fission track analysis and will provide further details and new information on the late-Oligocene exhumation event recognised in the Aspromonte region. 


\section{CHAPTER 4 \\ FISSION TRACK ANALYSIS}

\subsection{INTRODUCTION}

The discovery of nuclear fission was first made by the German scientists Hahn and Strassmann in 1938 , ultimately leading to the discovery of the nuclear chain reaction and the atomic bomb. Nuclear fission is the splitting of a radioactive nuclide into two or more highly charged fragments induced by bombarding the isotope with neutrons, protons, alpha particles, gamma rays and $\mathrm{X}$-rays. The fission event is accompanied by emission of alpha particles, neutrons and other particles, along with a considerable amount of energy $(\sim 200 \mathrm{MeV})$. Common natural radiogenic isotopes include $235 \mathrm{U}, 238 \mathrm{U}$ and $232 \mathrm{Th}$.

Spontaneous fission of $235 \mathrm{U}$ was first reported by Flerov and Petrjak (1940), although it was first postulated by Bohr and Wheeler (1939) who suggested that when a nucleus reaches a critical size, the force of nuclear (coulomb) repulsion will exceed that of the forces holding the nucleus together, thereby leaving the nucleus prone to spontaneous fission.

When spontaneous fission occurs within a solid medium, such as a crystal lattice, the two resultant fission fragments have enough energy to create a zone of disruption within the solid framework. This zone of disruption is linear in form and is referred to as latent fission damage or more commonly as a fission track. Such tracks were first observed by Silk and Barnes (1959), using an electron microscope to observe tracks in irradiated micas. Price and Walker (1962) discovered that these tracks could be enlarged, and made visible for optical microscopy, by chemically etching the solid with a suitable etchant solution due to the increased solubility of these zones of disruption.

The process of formation of fission tracks within a crystal lattice is still not completely understood. The most widely accepted hypothesis is that of Fleischer et al. (1965) and is known as the ion explosion spike mechanism (Figure 4.1). The model suggests that during the fission event the diverging fission fragments carry an excess positive charge. This results in the stripping of electrons from suurounding atoms in the 
lattice. After the passage of the fragment, along with stolen electrons, positively charged ions are left behind. These then repel each other leaving a zone of latent fission damage. In insulating solids such as silicates, these tracks are meta-stable, but in semi-conducting and conducting solids the lattice structure immediately reforms leaving no record of the event.

Within natural terrestrial minerals all spontaneous fission tracks can be considered as effectively resulting from the decay of $238 \mathrm{U}$, and only in extreme cases can tracks from other sources be expected (Price and Walker, 1963); for example 232Th (thorium) in very lead rich samples and $235 \mathrm{U}$ tracks induced by neutrons from the spontaneous fission of $238 \mathrm{U}$ in uranium-rich ores. In contrast, cosmic and lunar samples may have had numerous possible track sources, including extinct $244 \mathrm{Pu}$ (plutonium) (Fleischer et al., 1967), the fission of these nucleides being induced by cosmic rays early in the life of the solar system.

It was Flerov and Petrjak (1940) who first observed that the spontaneous fission of $238 \mathrm{U}$, the major isotope of uranium, occurs at a constant rate of about 10-16 fission events per year. Hence, if the ratio of spontaneous track density to uranium content of a material is known then an age can be calculated. With the discovery of the etching technique, the dating of materials using fission tracks has become a viable practice. The number of spontaneous tracks within a material is dependent on four factors:

a) Time of residence of $238 \mathrm{U}$ in the material.

b) Concentration of $238 \mathrm{U}$ in the material.

c) The rate of spontaneous fission of $238 \mathrm{U}$.

d) Amount of track removal due to subsequent heating of the material (annealing).

The most important factor is the amount of $238 \mathrm{U}$ in a material. This is determined by subjecting a sample to a known dose of thermal neutrons in a nuclear reactor (the neutron fluence). These neutrons induce fission in the other isotope of uranium, $235 \mathrm{U}$. Since the isotopic ratio $235 \mathrm{U} / 238 \mathrm{U}$ is known to be constant in nature $\left(7.2527 \times 10^{-3}\right)$, the concentration of $238 \mathrm{U}$ can be determined. The neutron fluence $(\phi)$ is estimated by including a standard dosimeter glass, with a uniformly distributed and known amount of uranium, alongside the sample. Induced fission tracks from $235 \mathrm{U}$ are then produced, which can be etched and counted as an estimate of $\phi$. 
The first use of the fission track dating technique was by Fleischer and Price (1964), who used it to date tektites from Libya, with resultant dates agreeing satisfactorily with previously published K-Ar dates from the same samples.

The fission track technique is now used for dating a variety of minerals. The suitability of various minerals for fission track analysis is shown in Figure 4.2. The most widely used minerals are apatite, zircon, sphene, together with natural and man-made glasses. Other minerals such as micas (muscovite, biotite), epidote and garnet can also be used, but their uranium content is usually too low for general use.

The first part of this chapter will deal with the calculation of a fission track age from the minerals apatite and zircon. However, as has been mentioned above, the fission track age is sensitive to the effects of temperature. This is the result of fission track annealing (track length reduction) causing reduction in fission track density and hence age. The second part of this chapter will deal with this annealing process, including the measurement of confined fission track lengths in apatite and how the annealing process in apatite has been quantified to allow prediction of apatite fission track age and length distributions from given thermal histories.

\subsection{FISSION TRACK AGE ANALYSIS}

\subsubsection{Sample Preparation}

To date a specimen of mineral or glass by fission track analysis, an internal surface needs to be exposed, then polished. This surface is then etched to expose any fission tracks present. An internal surface is used to avoid the possibility of any external contamination by uranium fission events from adjacent mineral phases or groundwater. The methods of mounting different mineral grains have been discussed by several authors (Naeser, 1967 ; Gleadow et al., 1976). Apatite grains are mounted in epoxy resin on a glass microscope slide, whereas zircon and sphene are mounted in FEP-Teflon. They are then polished, finishing with $1 \mu \mathrm{m}$ or $0.25 \mu \mathrm{m}$ grade diamond abrasive, taking $\sim 25 \mu \mathrm{m}$ off the external surface (the complete preparation details are provided in Appendix I). 

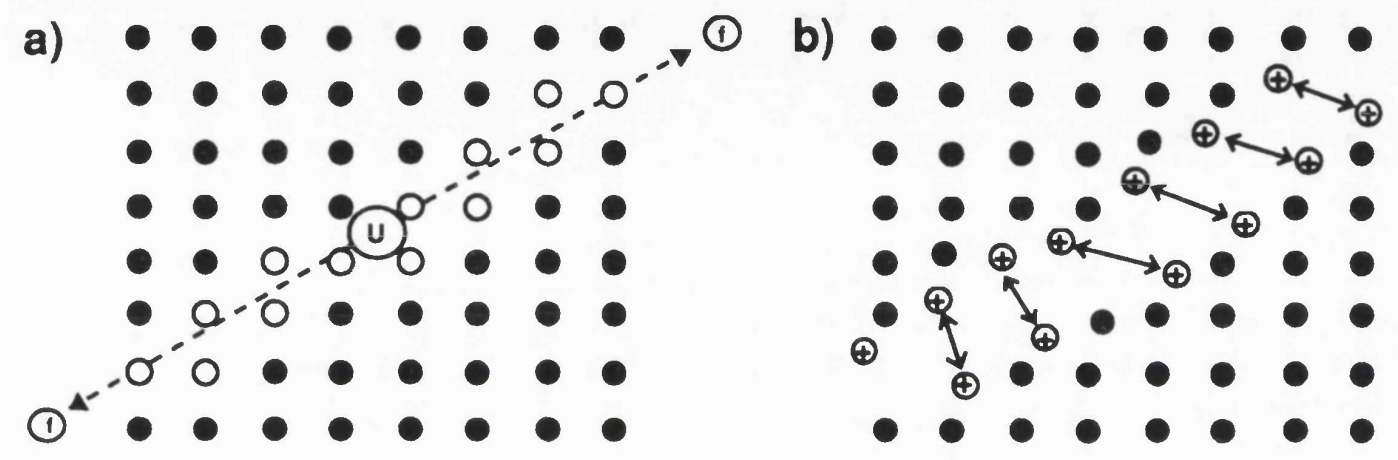

Figure 4.1 The "Ion Explosion Spike Mechanism" (after Fleischer et al., 1965)

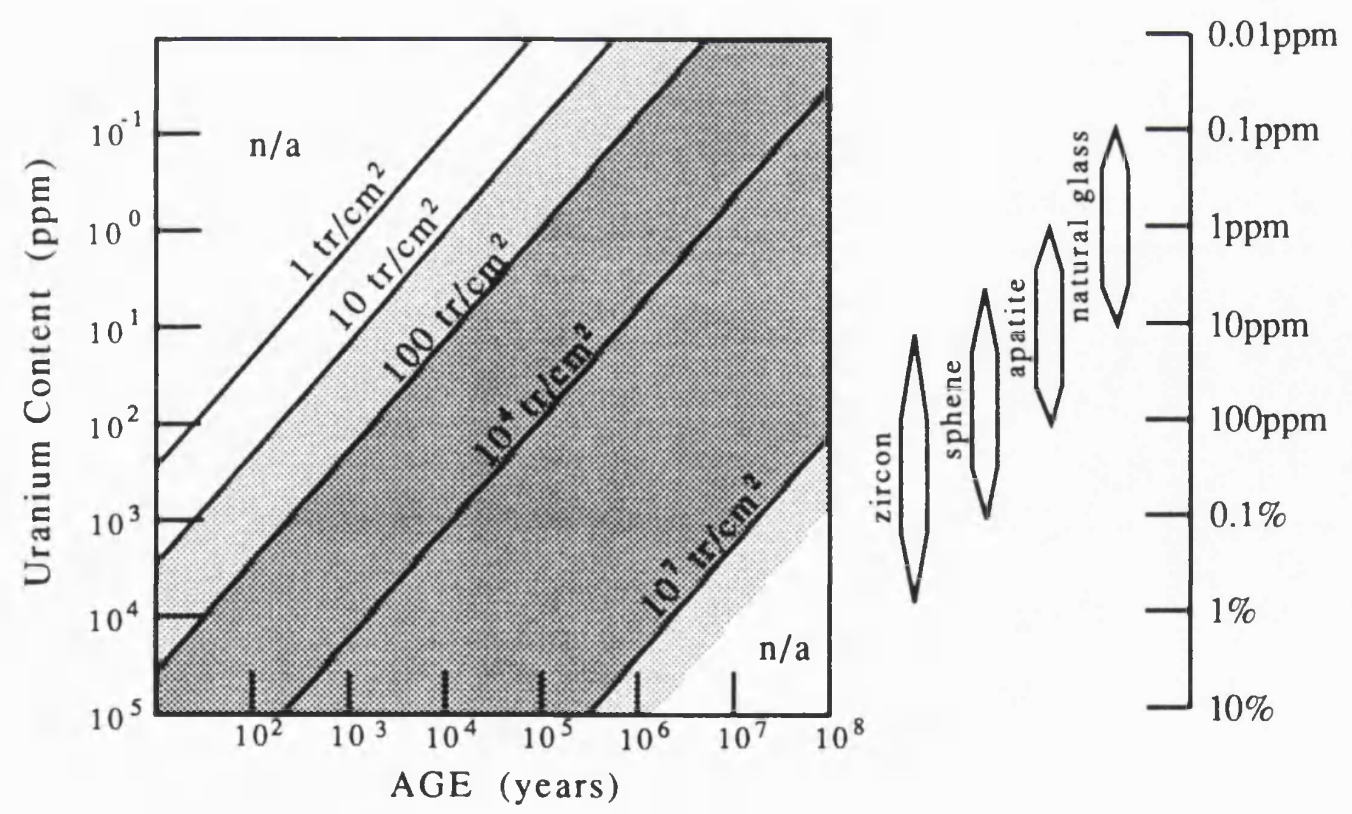

Figure 4.2 Schematic representation of the relationship between sample age, uranium content and fission track density 


\subsubsection{Track Etching}

In order to reveal the fission tracks intersecting the internal mineral surface, chemical etching is required. This is a process whereby the mineral is attacked by a chemical reagent, usually an acid or a strong alkali, preferentially revealing the more soluble zones of fission damage. The principles of track etching are summarized in Figure 4.3 (after Hurford, 1986b). Recently computer modelling of the etching process has also been carried out (Membrey et al., 1990). The etching conditions required for different minerals vary considerably, and a detailed summary is shown in Table 4.1.

Great care has to be taken to ensure a mineral is properly etched. Most minerals show anisotropic etch rates depending on the orientation relative to the crystallographic axes. The appearance of a track may thus vary according to its orientation in the plane of the etched surface. In zircon and apatite, the etching efficiency can vary from $100 \%$ on sections parallel to the c-crystallographic axis to close to $0 \%$ on sections perpendicular to the c-axis (Naeser et al., 1980). The sections counted are those parallel to the c-axis with the highest etching efficiency. This therfore avoids any possible undercounting associated with underetched tracks. Such sections can be distinguished by the parallelism of surface etch pits.

Within some minerals, particularly zircon and sphene, damage to the crystal lattice can be caused by alpha-recoil associated with the more common alpha-decay of uranium and thorium. This is a process whereby when an alpha particle is emitted, the energy released causes a recoil in the product nucleus, which in turn causes damage to the surrounding crystal lattice. In older zircons and sphenes alpha-recoil damage can be quite severe, causing the crystal lattice to become metamict (glass-like in structure), leading to isotropic etching properties.

To ensure a mineral is adequately etched, a technique known as progressive etching can be used. The track density of a mineral is measured at different etch-time intervals until a plateau value for the track density is reached. The ideal etch time is usually twice the value of $E_{\min }$ (the time when the plateau track density is reached). This process is used only for samples whose etching characteristics are unknown. 
TABLE 4.1

Summary of Etching Conditions

\begin{tabular}{|c|c|c|c|c|}
\hline Mineral & Etching Solution & $\operatorname{Temp}\left({ }^{\circ} \mathrm{C}\right)$ & Duration & Reference \\
\hline Apatite & $\begin{array}{l}\text { conc. } \mathrm{HNO}_{3} * \\
5 \% \mathrm{HNO}_{3}\end{array}$ & $\begin{array}{l}25 \\
20\end{array}$ & $\begin{array}{l}20-25 \mathrm{sec} \\
45 \mathrm{sec}\end{array}$ & $\begin{array}{l}1 \\
2\end{array}$ \\
\hline Sphene & $\begin{array}{l}50 \mathrm{~N} \mathrm{NaOH} * \\
1 \mathrm{HF}: 2 \mathrm{HCl}: 3 \mathrm{HNO}_{3}: 6 \mathrm{H}_{2} \mathrm{O}\end{array}$ & $\begin{array}{l}120 \\
20\end{array}$ & $\begin{array}{l}30 \mathrm{~min}-5 \mathrm{hr} \\
1-25 \mathrm{~min}\end{array}$ & $\begin{array}{l}3 \\
4\end{array}$ \\
\hline Zircon & $\begin{array}{l}\mathrm{KOH}: \mathrm{NaOH} \text { eutectic } \\
\mathrm{HF}: \mathrm{H}_{2} \mathrm{SO}_{4}\end{array}$ & $\begin{array}{l}220 \\
165\end{array}$ & $\begin{array}{l}3-100 \mathrm{hr} \\
1-10 \mathrm{hr}\end{array}$ & $\begin{array}{l}3 \\
3\end{array}$ \\
\hline $\begin{array}{l}\text { Muscovite } \\
* \text { Recommended }\end{array}$ & $\mathrm{HF}(48 \%)$ & 20 & $45 \mathrm{~min}$ & 4 \\
\hline Epidote & $\begin{array}{l}6 \mathrm{~g} \mathrm{NaOH}+4 \mathrm{ml} \mathrm{H}_{2} \mathrm{O} \\
(37.5 \mathrm{~N} \mathrm{NaOH})\end{array}$ & 159 & $150 \mathrm{~min}$ & 5 \\
\hline Volc. Glass & HF (24\%) & 25 & $60 \mathrm{sec}$ & 6 \\
\hline
\end{tabular}

References :

1. Naeser (1967)

2. Wagner \& Reimer (1972)

4. Gleadow \& Lovering (1974)

5. Bar et al. (1974)

3. Hurford (1986)

6. Lakatos \& Millers (1972) 


\section{Figure 4.3 The Principles of Fission Track Etching}

Fission tracks crossing the polished surface of a material are revealed by chemical etching that causes preferential attack of the weakened, disordered structure

Figure 4.3(a) shows the progressive etching of a track perpendicular to the surface. The mineral surface undergoes chemical attack at a general rate of etching, $V_{G}$, and the track at an accelerated rate of etching, $V_{T}$. The difference between the two rates of etching determines the shape of the etch pit. If $\mathrm{V}_{\mathrm{T}}$ is much greater than $\mathrm{V}_{\mathrm{G}}$ then the pit appears as a long narrow cylindrical tube. This is the form found in most minerals. In glass and metamict minerals, where $V_{T}$ is only slightly greater than $V_{G}$, then the pit is broad and shallow.

Figure 4.3(b) illustrates that a fission track at an angle to the surface, less than a critical angle $\theta_{\mathrm{C}}$ will have, after time $t$, a vertical component of $\mathrm{V}_{\mathrm{T}} \mathrm{t}$ less than $\mathrm{V}_{\mathrm{G}} \mathrm{t}$ and the track will be completely lost.

The fraction of tracks crossing a surface that are revealed by etching is termed the etching efficiency of that surface. This is high for most minerals, but for glass it is low $(<0.5)$.

a)
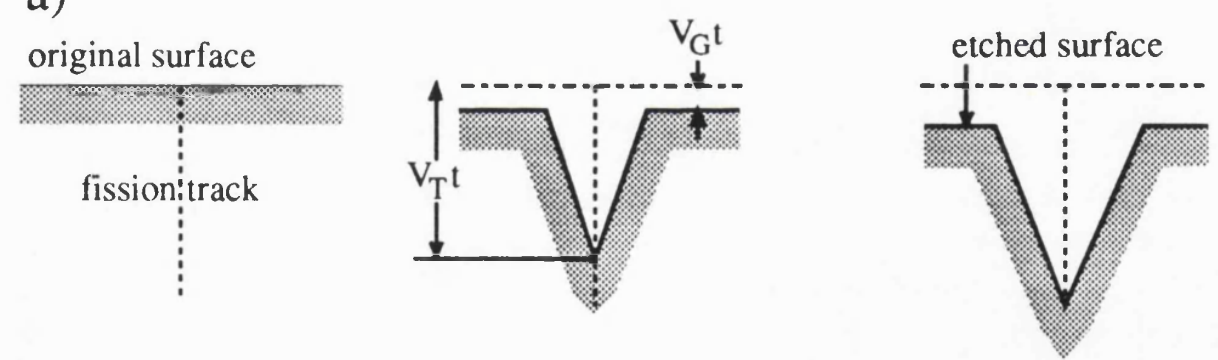

b)
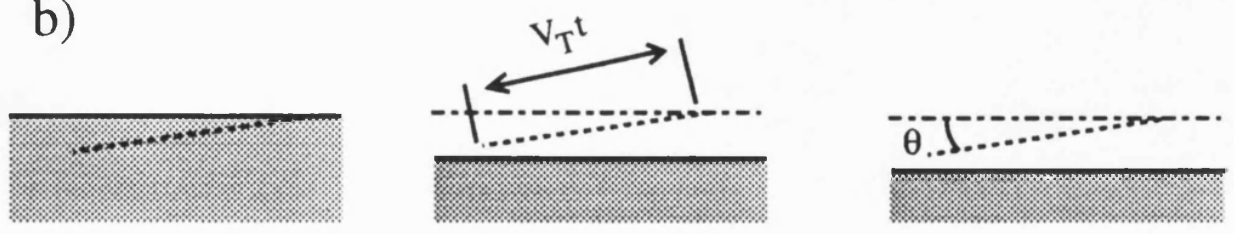

Time 0

Time $\mathrm{t}$

Time $2 \mathrm{t}$ 


\subsubsection{Principal Dating Methods}

The first step in acquiring a fission track age is to calculate the density ratio of the spontaneous fission tracks $\left(\rho_{s}\right)$ to the tracks induced in the nuclear reactor $\left(\rho_{i}\right)$. In order to do this several factors need to be taken into consideration, such as the geometry of the etched surfaces, radiation damage, anisotropic etching and inhomogeneous uranium distribution within a mineral. There are five different dating procedures which have been used. These are described and compared in detail by Gleadow (1981). Figure 4.4 is a flow diagram showing the sequence of techniques involved in each of the five procedures. Today the two techniques most widely used are the population method and the external detector method.

\subsubsection{The Population Method}

This procedure involves counting the spontaneous and induced track densities on two separate aliquots of the same sample. In one aliquot the spontaneous tracks are etched and counted, and in the other aliquot the sample is heated to anneal any spontaneous tracks. The annealed aliquot is then subjected to a neutron irradiation and the resultant induced tracks etched and counted. This method has the advantage of using the same etching conditions to reveal both the spontaneous and induced tracks on internal surfaces with identical geometries and track registration efficiency (see Fleischer et al., 1964). The population method is only used with apatite and glass, in which variation of uranium concentration between individual crystals is usually small. In individual zircon and sphene crystals the uranium content is generally highly variable. After annealing, both the spontaneous tracks and radiation damage are destroyed. This leads to highly anisotropic etching of tracks within individual crystals resulting in potential underestimation of track density (see Gleadow, 1978). The population method is used mainly with young apatite samples with very low track densities, in which only a small number of crystals contain any tracks. The population method allows a larger number of crystals to be counted, but results in less rigorous crystal selection and the possibility of errors associated with uranium inhomogeniety. 


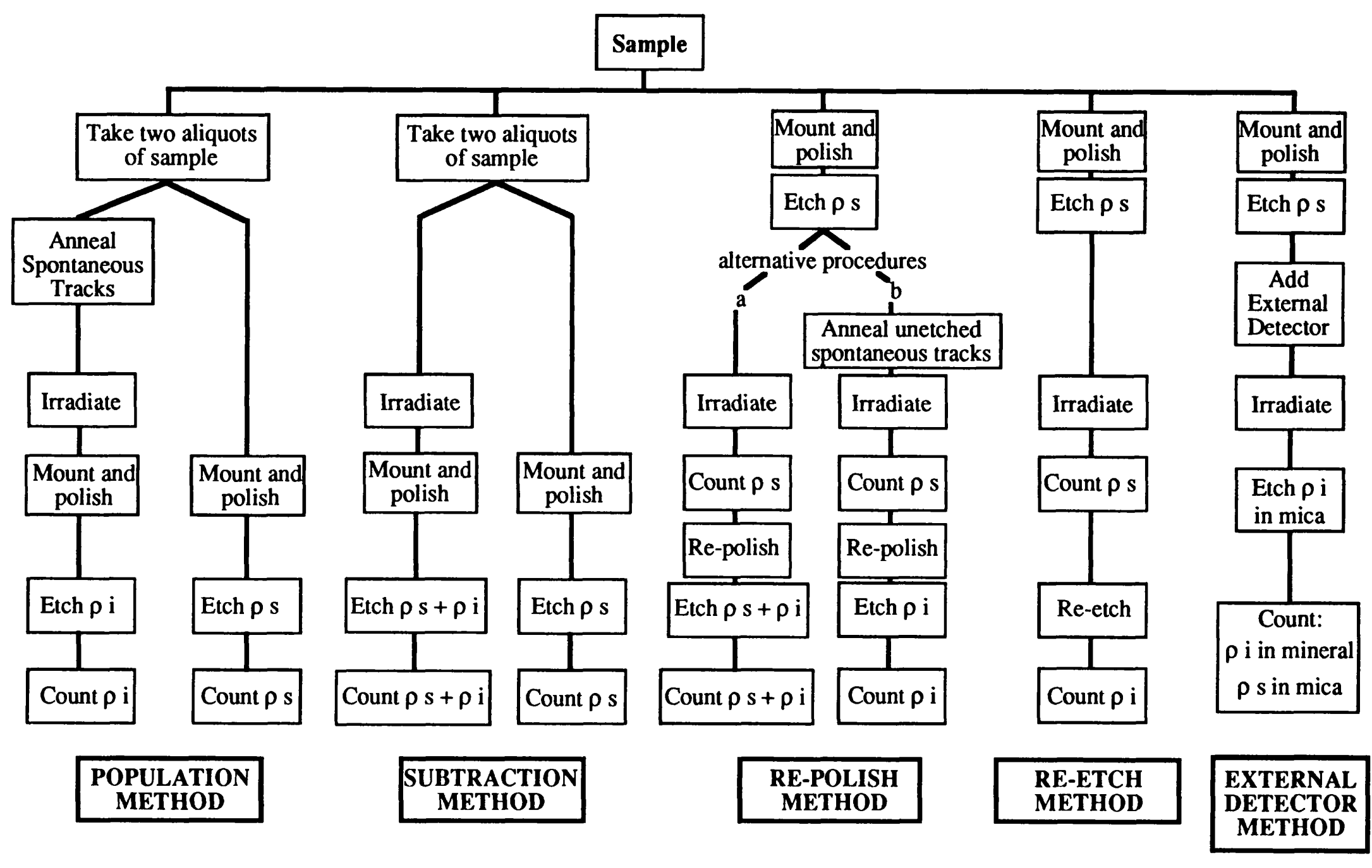

Figure 4.4 Schematic representation of different fission track dating procedures 


\subsubsection{The External Detector Method}

This procedure involves counting the spontaneous tracks on the internal surface of an etched mineral and counting induced tracks in an external detector. This is usually a low uranium muscovite mica, which is placed next to the mineral surface during a neutron irradiation. The external detector registers any $235 \mathrm{U}$ fission event induced within the adjacent mineral which can be subsequently etched and counted. The external detector method is explained diagramatically in Figure 4.5. The advantages of this method are that the spontaneous and induced tracks are counted from the same planar surface of the mineral or crystal. This accounts for any inhomogeneous uranium distribution within an individual crystal. It also allows better selection of individual crystals, so that any badly etched, poorly orientated (basal sections) and inclusion- or dislocation-rich crystals can be excluded from the analysis. The main drawback with this technique is due to the geometrical problems caused by using an internal surface. This requires the use of a geometry factor. Detailed discussion of the geometry problem is given by Gleadow and Lovering (1977) and Green and Durrani (1978). In summary, a track within a crystal could have been produced from a uranium atom anywhere within a sphere with a radius of half the track length. This is termed $4 \pi$ geometry. However the tracks induced in the external detector must be the product of uranium atoms from the adjacent crystal, in effect from anywhere within a hemisphere with a radius of half a track length, hence $2 \pi$ geometry. It is thus assumed that a simple factor of 0.5 will correct this difference. However recent work (Gleadow and Lovering, 1977; Green and Durrani, 1978) suggests this can only be assumed in surfaces with a low bulk etch rate (i.e. when the mineral surface etching efficiency is close to that of the external mica detector, which is usually $100 \%$ ). Such surfaces thus have to be carefully selected and are characterized by the parallelism of surface etch pits. The most suitable surfaces are those parallel to the c-axis.

\subsubsection{Derivation of the Fission Track Age Equation}

The spontaneous fission of $238 \mathrm{U}$ is similar to other radioisotopic systems, in that the ratio of the remaining number of parent atoms, to those that have undergone spontaneous fission 

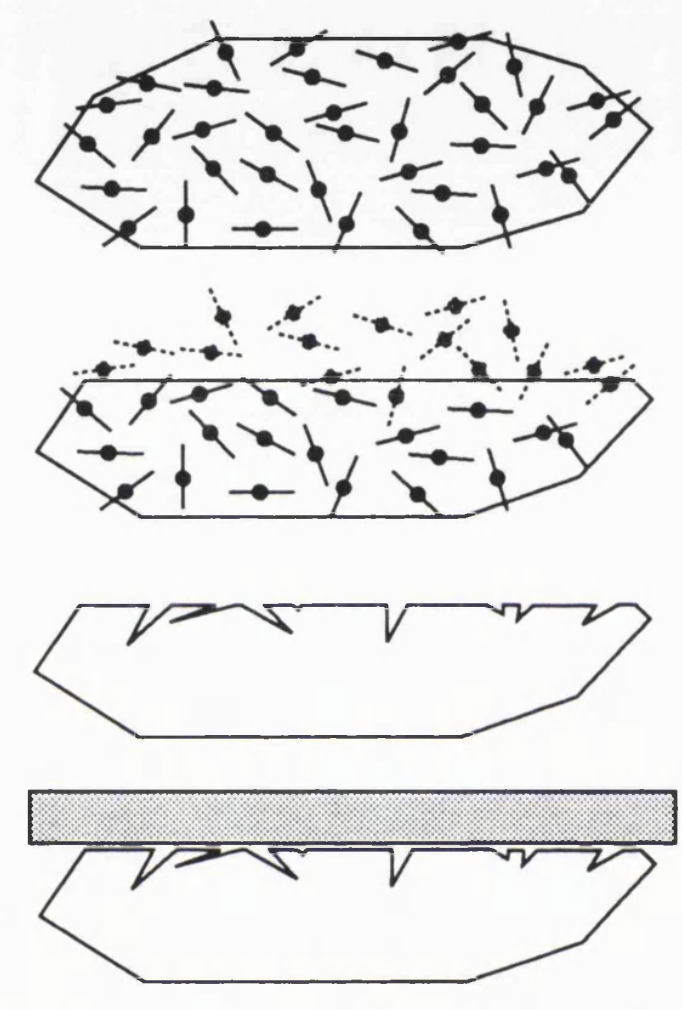

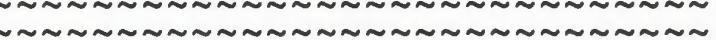

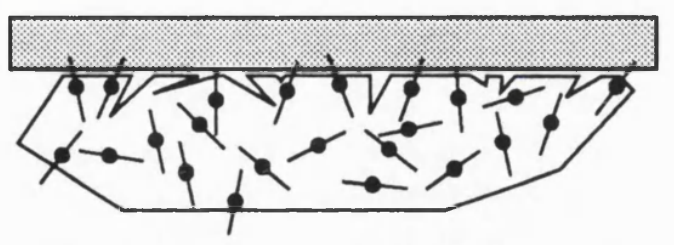

accumulation of spontaneous

fission tracks

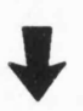

polished section through crystal

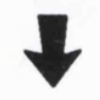

spontaneous tracks etched

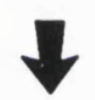

external mica detector affixed

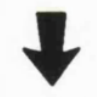

thermal neutron irradiation

neutron induced fission tracks register in detector

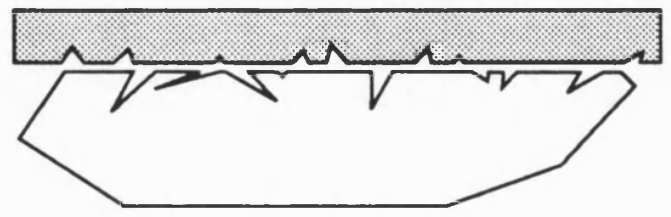

induced tracks etched in detector

Figure 4.5 The principles of the external detector method of fission track dating (taken from Hurford and Carter, 1991) 
is time dependent. The fission track age equation was first formulated by Price and Walker (1963). Various reviews of the detailed derivation of the fission track age equation are given in Fleischer et al. (1975), Naeser (1979) and Faure (1986).

If we consider a sample containing evenly distributed $238 \mathrm{U}$ atoms, then the total number of decays of $238 \mathrm{U}$ of a given volume in time $t$ is given by:

$$
D=238 \mathrm{U}\left(\mathrm{e}^{\lambda} \mathrm{D}^{\mathrm{t}}-1\right)
$$

where $D=$ The no. of decay events per unit volume

$238 \mathrm{U}=$ The no. of $238 \mathrm{U}$ atoms per unit volume

$\lambda_{D}=$ The total decay constant for $238 \mathrm{U}$

(Note: 238U decays by both alpha emission and spontaneous nuclear fission with individual decay constants $\lambda_{\alpha}$ and $\lambda_{\mathrm{f}}$. These are usually summed together to provide the total decay constant for $238 \mathrm{U}$, symbolised by $\lambda_{\mathrm{D}}$. Since $\lambda_{\mathrm{f}}$ is known to be six orders of magnitude lower than $\lambda_{\alpha}$ (Wagner et al., 1975; Theil and Hur, 1976) it can be assumed that $\lambda_{D} \approx$ $\left.\lambda_{\alpha}\right)$.

Thus the small fraction of all decay events due to spontaneous fission can be written:

$$
\mathrm{D}_{\mathrm{s}}=\left(\lambda_{\mathrm{f}} / \lambda_{\mathrm{D}}\right) 238 \mathrm{U}\left(\mathrm{e}^{\lambda} \mathrm{D}^{\mathrm{s}}-1\right)
$$

The spontaneous track density $\left(\rho_{s}\right)$ is determined by the number of tracks that cross an internal surface (q) and the etching efficiency $(\alpha)$. Thus, as the spontaneous track density results from $D_{s}$ fissions per unit volume, (4.2) can be re-written as:

$$
\rho_{s}=\left(\lambda_{f} / \lambda_{D}\right) 238 U\left(e^{\lambda} D-1\right) q \cdot \alpha
$$

The number of fissions of $235 \mathrm{U}$ induced by thermal neutron irradiation is given by:

$$
\mathrm{D}_{\mathrm{i}}=235 \mathrm{U} \cdot \phi \cdot \sigma
$$

where $235 \mathrm{U}=$ The no. of $235 \mathrm{U}$ atoms per unit volume

$\phi=$ The neutron fluence (the time integrated dose of neutrons per $\mathrm{cm}^{2}$ received by the sample)

$\sigma=$ the cross section of $235 \mathrm{U}$ for fission induced by thermal neutrons

The induced track density $\left(\rho_{i}\right)$ is also determined by $q$ and $\alpha$ (hence the need for minerals with similar etching efficiencies for both spontaneous and induced tracks). Thus 
as the induced track density results from $D_{i},(4.4)$ can be re-written as:

$$
\rho_{i}=235 U \cdot \phi \cdot \sigma \cdot q \cdot \alpha
$$

Combining equations ( 4.3 ) with ( 4.5 ) and representing the atomic ratio $235 \mathrm{U} /$ 238 $\mathrm{U}$ by the symbol $\mathrm{I}$, The unknown age ( $\mathrm{t}$ UNK $)$ can be solved to provide the fission track age equation:

$$
t_{U N K}=\left(1 / \lambda_{D}\right) \ln \left[1+\left(\rho_{S} / \rho_{i}\right)_{U N K}\left(\lambda_{D} / \lambda_{f}\right) \phi . \sigma . I\right]
$$

It should be noted that $\ln (1+x) \approx x$, when $x<1$, which is the case when $t$ (the fission track age) is $<500 \mathrm{Ma}$, thus equation ( 4.6 ) can be simplified to:

$$
t_{\text {UNK }}=\left(\sigma \cdot I \cdot \phi \cdot \rho_{\mathrm{s}}\right) /\left(\lambda_{\mathrm{f}} \cdot \rho_{\mathrm{i}}\right)
$$

This equation relies on four fundamental assumptions:

a) The decay constant for the spontaneous fission of $238 \mathrm{U}$ does not vary with time.

b) The material being dated is a closed system with respect to fission tracks and uranium content. The stability of fission tracks is very important in this respect (see section 4.3).

c) The isotopic ratio $235 \mathrm{U} / 238 \mathrm{U}$ is constant. Variations have only ever been found in cosmic samples (Cowan and Adler, 1976).

d) Tracks are the result of fission of $238 \mathrm{U}$. This is valid for most terrestrial samples.

The values for $I, \sigma$ and $\lambda_{D}$ are all well-defined physical constants. However, difficulties arise in determining the values for $\phi$ (the neutron fluence) and $\lambda_{\mathrm{f}}$ (the decay constant for the spontaneous fission of $238 \mathrm{U})$.

\subsubsection{The Problem of the Decay Constant $\lambda_{f}$ of $238 U$}

The value of the decay constant for spontaneous fission of $238 \mathrm{U}\left(\lambda_{\mathrm{f}}\right)$ has been in doubt for some time. Bigazzi (1981), in a comprehensive review, gives more than 40 values of $\lambda_{\mathrm{f}}$ that have been derived since 1940 (Figure 4.6). In the work carried out since 1960 , two possible values have emerged, one at about $6.9 \times 10^{-17} \mathrm{yr}^{-1}$, supported by work using solid-state track detectors on minerals and glasses of known age, and one at about $8.5 \times 10^{-17} \mathrm{yr}^{-1}$, supported by direct measurements using bubble chambers and ionisation chambers. Such differences are probably due to systematic variations inherent in the approach. The main problem in accurately evaluating $\lambda_{\mathrm{f}}$ is the complexity of determining absolute values for the neutron fluence. 


\subsubsection{The Problem of Absolute Measurement of the Neutron Fluence $(\phi)$}

The problem of estimating the absolute neutron fluence has beset fission track workers for many years, and has been the subject of several reviews (see Hurford and Green, 1983; Green and Hurford, 1984; Crowley, 1986). In fission track analysis the neutron fluence needs to be measured to an accuracy of $\pm 2 \%$, otherwise errors become unacceptable. The main method used to determine the fluence is using a standard uranium glass. This induces tracks in an external detector, whereby $\phi=B \cdot \rho_{d}$, where B is a calibration factor. B can be evaluated from independent measurement of the fluence using neutron-induced gamma activity in gold, copper or cobalt foils. However, in a study carried out over six years, Hurford and Green (1982) demonstrated variations in the calibration factor B of $\pm 20 \%$ (Figure 4.7). Such large errors are clearly unacceptable for accurate fission track age determinations. The reasons for such variations are discussed in Green and Hurford (1984). They note that the problem is accentuated in poorly thermalised neutron fluxes, where induced fission of $235 \mathrm{U}$ and $232 \mathrm{Th}$ will occur. Thus the selection of a suitable reactor is extremely important for fission track dating (see Hurford, 1990a; $1990 \mathrm{~b}$, for discussion on reactor specification). The inter-relationship of $\lambda_{\mathrm{f}}$ and $\phi$ may be evaluated by reference to a standard whose age is independently known. This has given rise to the zeta calibration in fission track analysis

\subsubsection{The Zeta Calibration in Fission Track Analysis}

Calibration was first suggested by Fleischer and Hart (1972), but the detailed approach using a zeta calibration factor was proposed by Hurford and Green (1983). It can be approached in two ways, either by direct reference of an unknown sample to an age standard or by reference to a uranium dosimeter glass calibrated against an age standard.

In the first approach we can rewrite the fission track age equation (4.6) by replacing all the parameters that are in doubt into a calibration factor named zeta, symbolised by $\mathrm{Z}$, and rewrite it thus:

$$
t_{\mathrm{UNK}}=\left(1 / \lambda_{\mathrm{D}}\right) \ln \left[1+\left(\rho_{\mathrm{s}} / \rho_{\mathrm{i}}\right)_{\mathrm{UNK}} \mathrm{Z} \lambda_{\mathrm{D}}\right]
$$

where: 


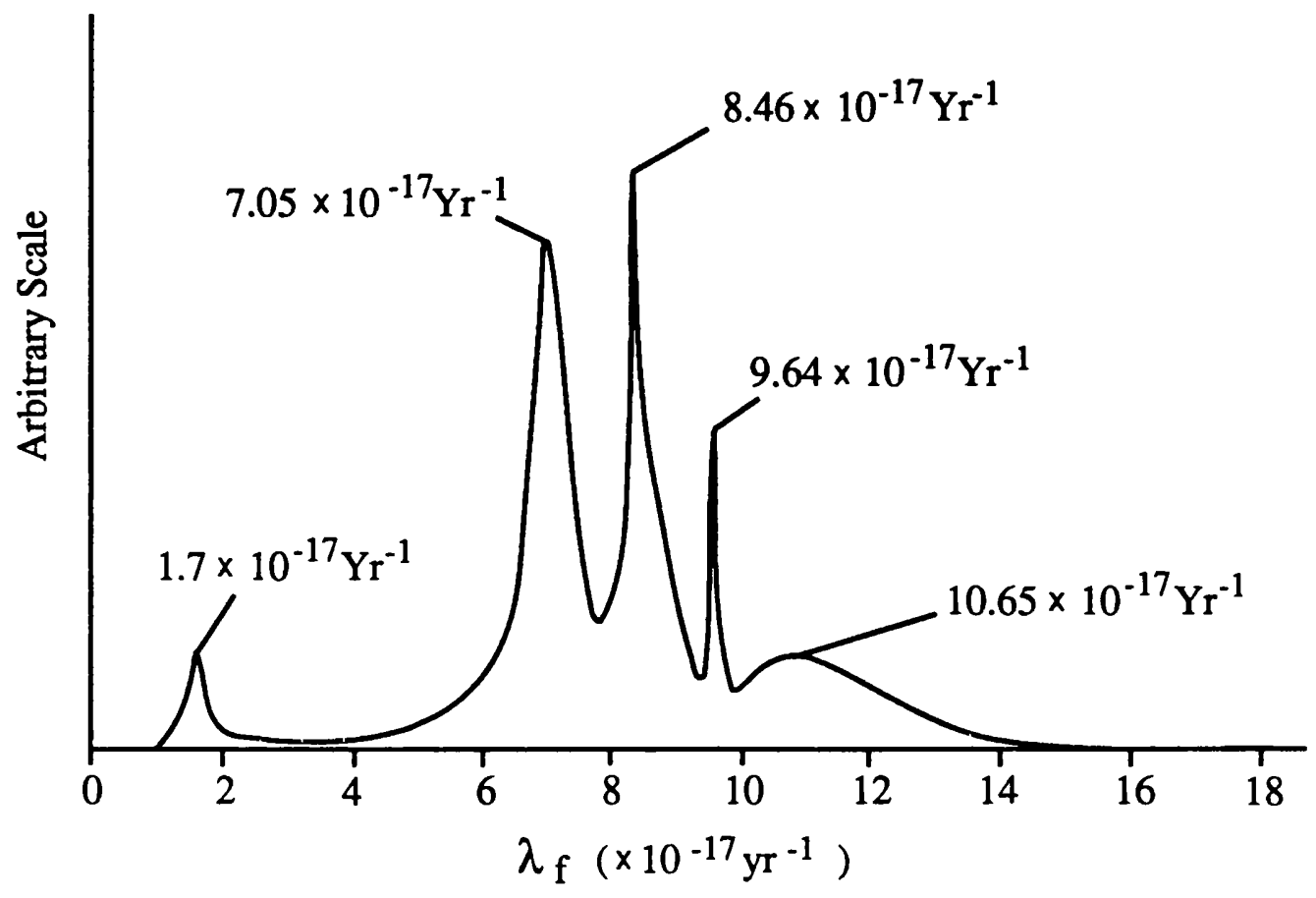

Figure 4.6 Addition of standard-area Gaussian curves corresponding to the various values derived for the value of the ${ }^{238} \mathrm{U}$ decay constant $\lambda \mathrm{f}$.

(after Bigazzi, 1981)

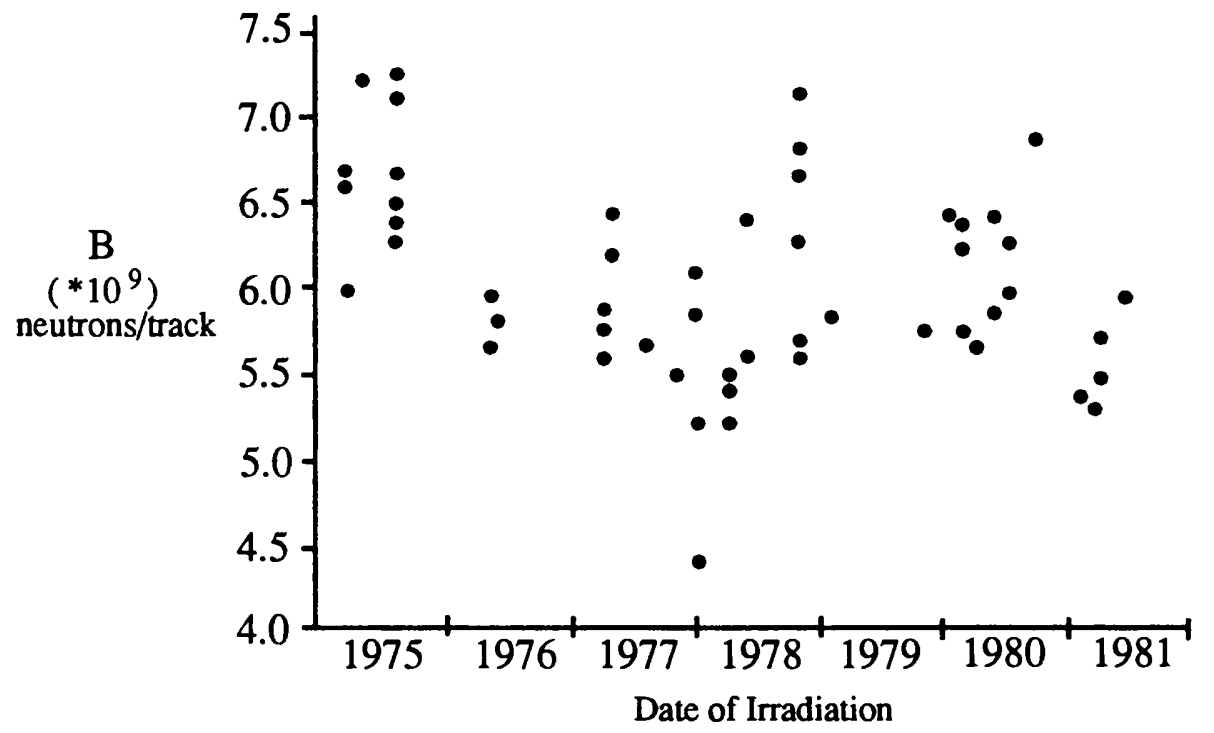

Figure 4.7 Variations of the B calibration ratio with time (after Hurford and Green, 1982) 


$$
Z=(\phi . \sigma . I) / \lambda_{\mathrm{f}}
$$

The value of zeta can then be determined by irradiating a mineral standard of known age, included with a batch of unknown samples. The age of the unknown samples can then be calculated by using the zeta value calculated for the age standard. However, a single age determination may be subject to large uncertainties, and thus will result in a compounding of errors, yielding inaccurate age determinations (Hurford and Green, 1983). Therefore this method has now largely been abandoned in favour of a second approach which uses age standards to provide a calibration baseline for a uranium-bearing glass dosimeter. By substituting the equation $\phi=$ B. $\rho_{D}$ into the fission track age equation ( 4.6 ), we can redefine zeta (this time using the symbol $\zeta$ ) as:

$$
\zeta=(\mathrm{B} . \sigma . \mathrm{I}) / \lambda_{\mathrm{f}}
$$

Leaving the age equation:

$\mathrm{t}_{\mathrm{UNK}}=\left(1 / \lambda_{\mathrm{D}}\right) \ln \left[1+\left(\rho_{\mathrm{s}} / \rho_{\mathrm{i}}\right)_{\mathrm{UNK}} \lambda_{\mathrm{D}} \cdot \mathrm{g} \cdot \rho_{\mathrm{D}} \cdot \zeta\right]$

(where $\mathrm{g}=$ geometry factor)

By irradiating a dosimeter glass with a mineral standard of known age, a $\zeta$ value (quoted with respect to the particular dosimeter being used) can be obtained according to the equation below (after Hurford and Green, 1982):

$$
\zeta=\left[\exp \left(\lambda_{\mathrm{D}} \mathrm{t} \operatorname{sTD}\right)-1\right] /\left[\lambda_{\mathrm{D}} \cdot\left(\rho_{\mathrm{s}} / \rho_{\mathrm{i}}\right) \operatorname{sTD} \mathrm{g} \cdot \rho_{\mathrm{D}}\right]
$$

Thus the age of an unknown sample can be determined by substituting the $\zeta$ value into equation (4.11). For each dosimeter glass a range of $\zeta$ values for individual minerals are calculated using different age standards from several irradiations. Such values vary between individuals and should be used only by the individual analyst concerned. A uniform set of recommendations for the use of age standards, uranium glasses, reactor specification, age determination and data reporting has been the subject of a recent report to the International Union of Geological Sciences Subcommission on Geochronology (see Hurford, 1990a; 1990b).

\subsubsection{The Use of Age Standards}

Age standards are materials whose geological age is known or can be confidently inferred, and which satisfy the following criteria (see also list by Wagner, in Hurford and 
Green, 1981):

a) The sample must come from a well-documented, accessible, and readily available horizon.

b) The sample must be homogeneous in age.

c) Independent radiometric ages must be unambiguous and agree with known stratigraphy.

d) Independent ages should be precise, preferably determined from more than one laboratory.

e) The fission track age must be a direct date, not an age of cooling.

These criteria are best met by rapidly cooled volcanic rock showing no postdepositional alteration. Current recommended standards include (see also Hurford, 1990a; 1990b):

Apatite :

Fish Canyon Tuff : (San Juan Mts., Colorado) $\quad \mathrm{t}$ STD $=27.9 \pm 0.7 \mathrm{Ma}$

Mt. Dromedary Banatite : (NSW, Australia) $\quad \mathrm{t}$ STD $=98.7 \pm 0.6 \mathrm{Ma}$

Durango Iron Ore Deposit : (Mexico) $\quad t_{S T D}=31.4 \pm 0.5 \mathrm{Ma}$

Zircon :

Fish Canyon Tuff : (San Juan Mts., Colorado) $\quad \mathrm{t}$ STD $=27.9 \pm 0.7 \mathrm{Ma}$

Mt. Dromedary Banatite : (NSW, Australia) $\quad t_{\mathrm{STD}}=98.7 \pm 0.6 \mathrm{Ma}$

Buluk Member Tuff : (Kenya) $\quad \mathrm{t}$ STD $=16.2 \pm 0.2 \mathrm{Ma}$

Tardree Rhyolite : (Northern Ireland) $\quad \mathrm{t}_{\mathrm{STD}}=58.7 \pm 1.1 \mathrm{Ma}$

\subsubsection{The Use of Dosimeter Glasses}

The choice of which glass to use during the irradiation is largely determined by the uranium content of the mineral being used to provide a countable track density. With high$\mathrm{U}$ minerals, such as zircon, a high-U concentration glass is used as the neutron fluence dose given is correspondingly low, whereas with lower uranium concentrations, such as in apatite, where the neutron fluence dose is higher, a glass with a low- $U$ concentration is used. Suitable high uranium glasses include $\mathrm{CN}-1$ (39 ppm natural $\mathrm{U}$ ), and CN-2 (36 ppm natural U), prepared by Dr. Schreurs at the Corning Institute. Suitable low concentration glasses include CN-5 (11 ppm natural U), and the more commonly used SRM612 from the 
National Bureau of Standards (N.B.S., 1970), with 37.38ppm U, although this glass is depleted in 235U, so its effective uranium content is nearer 10-11 ppm. The SRM612 glass also contains $232 \mathrm{Th}$, a possible source of tracks if the neutron flux is poorly thermalised, and also several other elements, including boron and rare-earth elements that can cause thermal neutron absorption. Thus when available, $\mathrm{CN}-5$ is considered more reliable as a low-U dosimeter glass.

\subsubsection{The Statistical Analysis of Fission Track Data Sets}

This section will concentrate on the statistical analysis of data using the external detector method of fission track analysis. For detail concerning the statistical analysis of the population method, the reader is referred to Galbraith $(1984 ; 1985 ; 1986)$.

Counts from the external detector method are collected as a data pair; the number of spontaneous tracks in a unit area $\left(\mathrm{N}_{\mathrm{s}}\right)$ and the number of induced tracks counted in an identical area of an adjacent mica $\left(\mathrm{N}_{\mathrm{i}}\right)$.

As fission tracks result from the random process of radioactive decay it has been assumed that they follow a Poisson distribution (Green, 1981). A detailed derivation showing the applicability of the Poisson distribution is given by Galbraith (1984). It should be noted that when the number of events, such as the track count is very high (usually when $\mathrm{N}>20$ ) the Poisson distribution approximates to a Normal distribution.

When applied to the external detector method the standard deviations of the spontaneous and induced track densities are given by :

$$
\sigma\left(\rho_{s}\right)=\sqrt{ }\left(N_{s}\right) / A_{s} \text { and } \sigma\left(\rho_{i}\right)=\sqrt{ }\left(N_{i}\right) / A_{i}
$$

Where $A_{s}$ and $A_{i}$ are the count areas of the crystal and mica respectively.

From a standard statistical approach we can combine $\rho_{i}$ and $\rho_{s}$ to provide the conventional error analysis (Green, 1981) as shown below :

$$
\sigma\left(\rho_{s} / \rho_{i}\right)=\left(\rho_{s} / \rho_{i}\right) \sqrt{ }\left[\left(\sigma\left(\rho_{s}\right) / \rho_{s}\right)^{2}+\left(\sigma\left(\rho_{i}\right) / \rho_{i}\right)^{2}\right]
$$

However in order to provide an error for the fission track age an uncertainty factor in the neutron fluence $(\phi)$ needs to be included. This is done by counting $235 \mathrm{U}$ induced tracks in a uranium dosimeter glass or its detector. This also has a Poisson distribution, so 
that $\sigma\left(\rho_{D}\right)=\sqrt{ }\left(N_{D}\right) / A_{D}$.

However for practical purposes, when $\mathrm{N}>20$, an approximation to the normal distribution can be used, leaving the simplified error analysis:

$$
\sigma(t)=t \sqrt{ }\left[\left(1 / N_{s}\right)+\left(1 / N_{i}\right)+\left(1 / N_{D}\right)\right]
$$

This is the standard error estimate used by most workers, and can also be applied to the zeta calibration calculation. The error from the zeta analysis can be used to provide a working mean total for individual zeta values, but the resultant error from this worked mean is not used in the calculation of the fission track age.

So far the error analysis has assumed a Poisson distribution for $\mathrm{N}_{\mathrm{s}}, \mathrm{N}_{\mathrm{i}}$ and $\mathrm{N}_{\mathrm{D}}$, however it has proved useful to test this data using the $\chi^{2}$-test. This shows if the total count data for $\mathrm{N}_{\mathrm{s}}$ and $\mathrm{N}_{\mathrm{i}}$ conforms to the Poisson ideal. This method is described for the external detector method by Galbraith (1981) and Green (1981). Data is usually passed at the $>5 \%$ level, with (n-1) degrees of freedom ( $n$ is the number of crystals used in the age determination). If the $\chi^{2}$ value is accepted then the conventional data analysis outlined above is carried out, using the total track count values.

If the data fails the $\chi^{2}$-test, then either the data has an extra source of error outside the Poisson distribution, or the sample consists of crystals with more than one population of ages (a mixed age). Extra sources of error outside the Poisson distribution in a single age population can be caused by several factors, which are listed in Green (1981). They include poor counting (such as counting crystal defects), a poor mica detector containing significant uranium, poor crystal-mica contact, and the underetching of spontaneous fission tracks. To allow for this, Green (1981) devised a model that calculates the age using the mean of each individual crystal $\left(\rho_{\mathrm{s}} / \rho_{\mathrm{i}}\right)$ ratio, whereby:

$$
\begin{aligned}
& \text { mean }\left(\rho_{s} / \rho_{i}\right)=\sum_{j=1}^{n}\left(\rho_{s} / \rho_{i}\right)_{j} / n \quad \text { (where } n=\text { no. of crystals) } \\
& \sigma\left(\rho_{s} / \rho_{i}\right)=\sqrt{ }\left\{\sum_{j=1}^{n}\left(\rho_{s} / \rho_{i}\right)_{j}-\left[\sum_{j=1}^{n}\left(\rho_{s} / \rho_{i}\right)_{j}\right]^{2}\right\} / n(n-1)
\end{aligned}
$$

This yields an estimate similar to the conventional analysis, but the corresponding error is usually greater, as a result of additional uncertainty in the data set. Data that does fail the $\chi^{2}$ - 
test should not be discarded, but the larger error should be quoted to allow for the additional uncertainty.

When a sample consists of crystals of mixed ages, termed a finite mixture, the use of a single mean and error is meaningless. It is often more useful to make an estimate of the component ages within a finite mixture. Numerical methods for such estimations have been developed (see Galbraith, 1988; Galbraith and Green, 1990). However, component ages within a sample can be discerned far more readily by using graphical methods. Age estimates can be displayed in the form of a weighted histogram of age versus frequency, taking into account the differing standard errors (see Hurford et al., 1984). This method looks superficially attractive, such as Figure $4.8 \mathrm{a}$ which clearly shows a bimodal distribution. However this histogram combines two sources of variation: the uncertainty of individual crystal ages and the variation between the ages of individual crystals. The shape of the histogram is often overduly affected by the uncertainty of individual crystal ages, disguising the effects of variation between the ages of individual crystals. In order to separate these two sources of variation Galbraith $(1988 ; 1990)$ developed a graphical assessment known as the Radial Plot. The basic design and principle of the radial plot is shown in Figure 4.8b. The radial plot separates the uncertainty of individual crystal ages allowing the variation between component ages, to be judged more easily. Thus it is more informative than the weighted histogram, and easier to interpret. Galbraith (1988) suggests that weighted histograms should only be used in combination with a radial plot.

Such a graphical assessment is applicable only when the individual component ages are homogeneous. Due to differing chemical compositions within crystals, a heterogeneous distribution of true crystal ages often occurs due to differential track annealing (section 4.3). In this situation some measure of the sample age is usually required. For such a situation the central age has been devised (Galbraith, pers. comm., Lewis et al., 1992). This is a weighted modal age, which uses an iterative algorithm to provide estimates of the 'modal' age and the corresponding standard error of the central age estimate. The standard deviation of the distribution of true ages is known as the "age dispersion" or relative error, and is quoted as a percentage. A value of above $20 \%$ is taken as indicating that the sample 
Figure 4.8 a Two examples of probability distribution curves ('age spectra') from zircon ages obtained from Wealden sandstones.
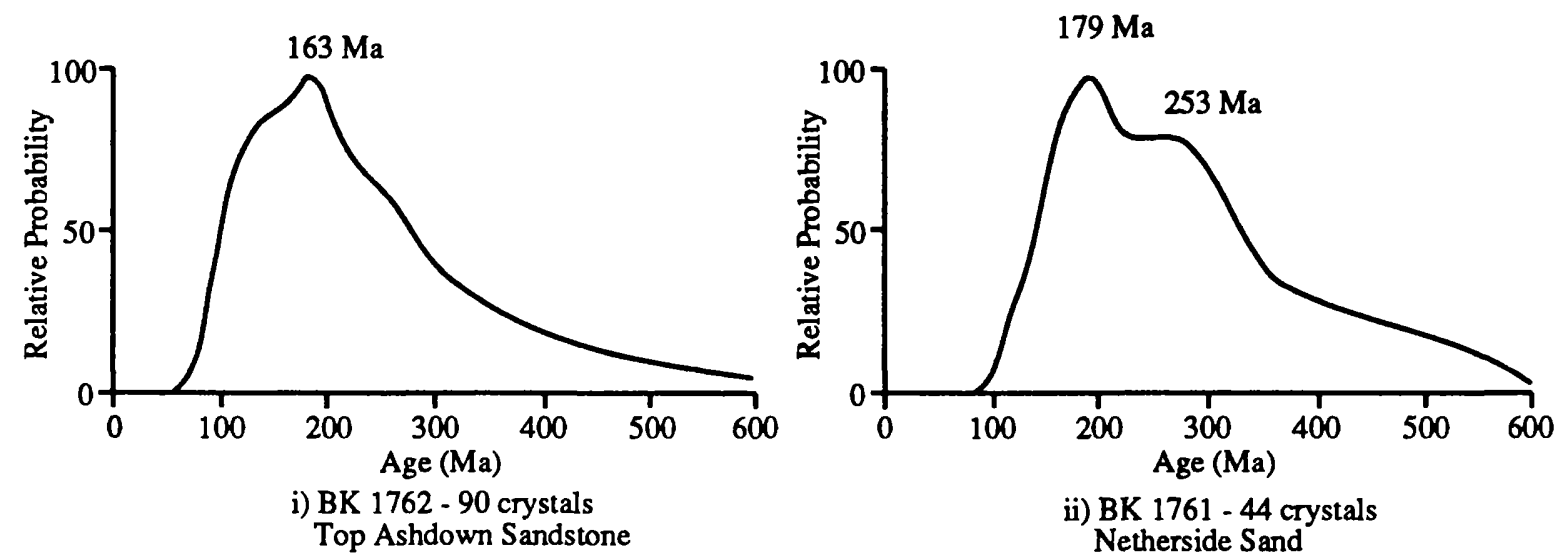

Figure 4.8 b The principles of the Radial Plot (after Galbraith, 1990)

Single crystal ages $(z)$ with standard error $\sigma$ are plotted as the point $(x, y)$ where: $x$ (the precision) $=1 / \sigma$ and $\mathrm{y}$ (standardised estimate $)=\left(\mathrm{z}-\mathrm{z}_{0}\right) / \sigma$ ( $\mathrm{z}_{0}$ is the central age)

Each estimate has a standard error that can be measured off the y scale The value of $z$ and $z \pm 2 \sigma$ can be read by extrapolating lines from $(0,0)$ through $(x, y \pm 2)$ onto the $z$ scale

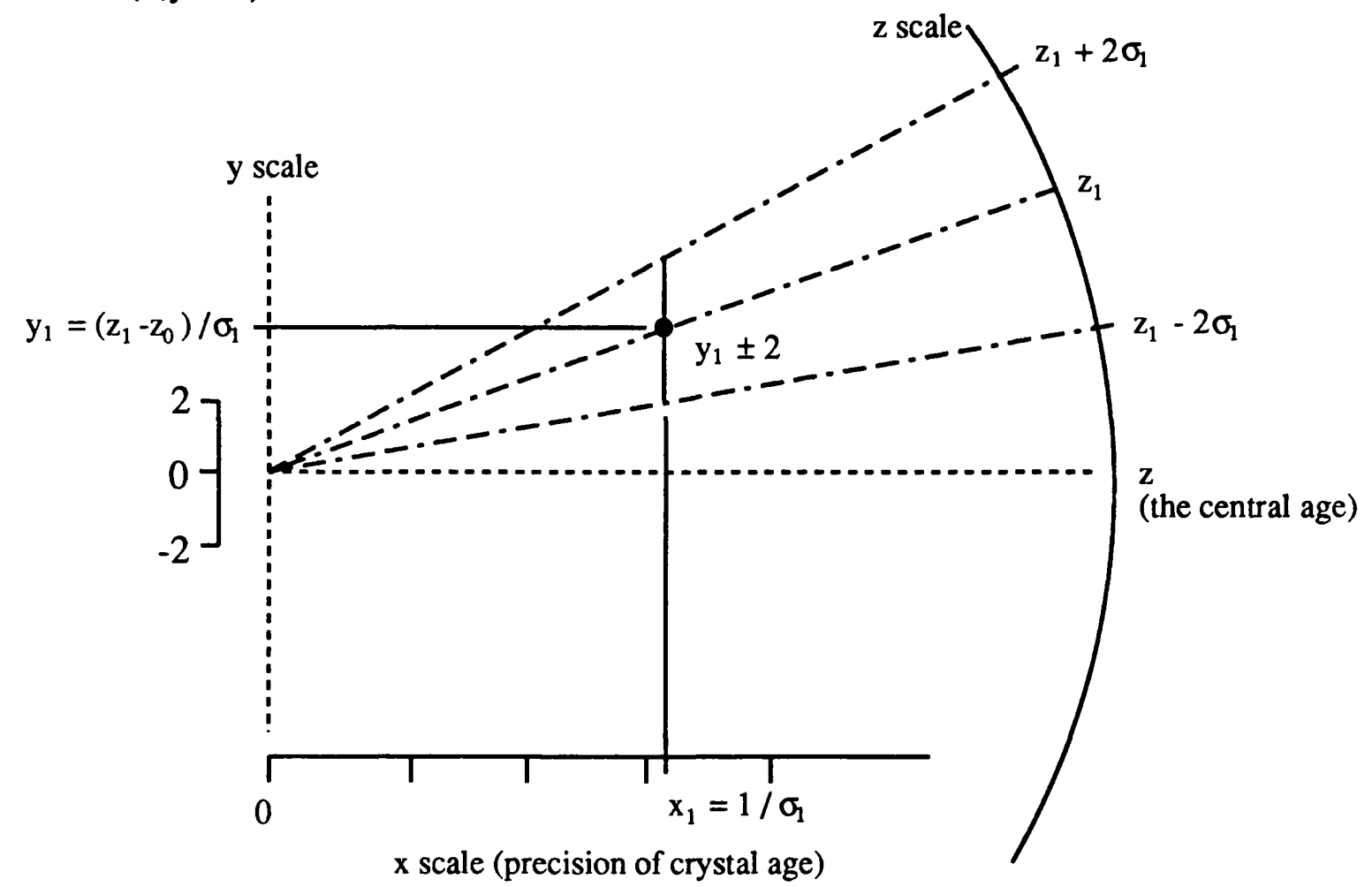


has a mixed age. This method indicates spreads in individual crystal ages, often not obvious using the conventional approach. The central age approach is now the recommended standard for the statistical calculation of the fission track age and will be used in this study.

\subsection{FISSION TRACK ANNEALING}

\subsubsection{Introduction}

An important assumption made so far in dealing with fission track analysis, is that no tracks have been lost since the time of formation of the fission track / uranium system. However, since the earliest work on fission track analysis it has been known that temperature has a profound effect on the stability of fission tracks over a geological time period, usually in excess of 1 million years (Fleischer et al., 1965). Other factors such as pressure, fluids and weathering have also been studied, but have little or no effect on track stability (Gleadow and Lovering, 1974; Fleischer et al., 1975; Naeser, 1979).

All minerals used for fission track dating show a fading of tracks with increasing temperature, known as track annealing. It is thought that the heating of the damaged mineral lattice causes the diffusion of atoms back into their more stable lattice positions. This process seems to progress from the end of the track towards its middle, thus causing a shortening of the track. It also causes a reduction in the track density in the mineral, causing a reduction in the fission track age, although the relationship between track shortening and track density is complex (see Laslett et al., 1984). The rates of annealing vary greatly between minerals. Figure 4.9 shows annealing data collected from various laboratory experiments (Naeser and Faul, 1969; Krishnaswami et al., 1974; Hurford, 1986b).

The complete erasure of fission tracks is often discussed in the terms of a closure temperature (Dodson, 1973). The laboratory determined closure temperature for apatite (Figure 4.9) is between $80-170^{\circ} \mathrm{C}$, and that of zircon is $\sim 300^{\circ} \mathrm{C}$. However Hurford (1986a) has shown that the closure temperature of zircon is probably much lower than this in geological samples. By extrapolating between the more constrained closure temperatures of 


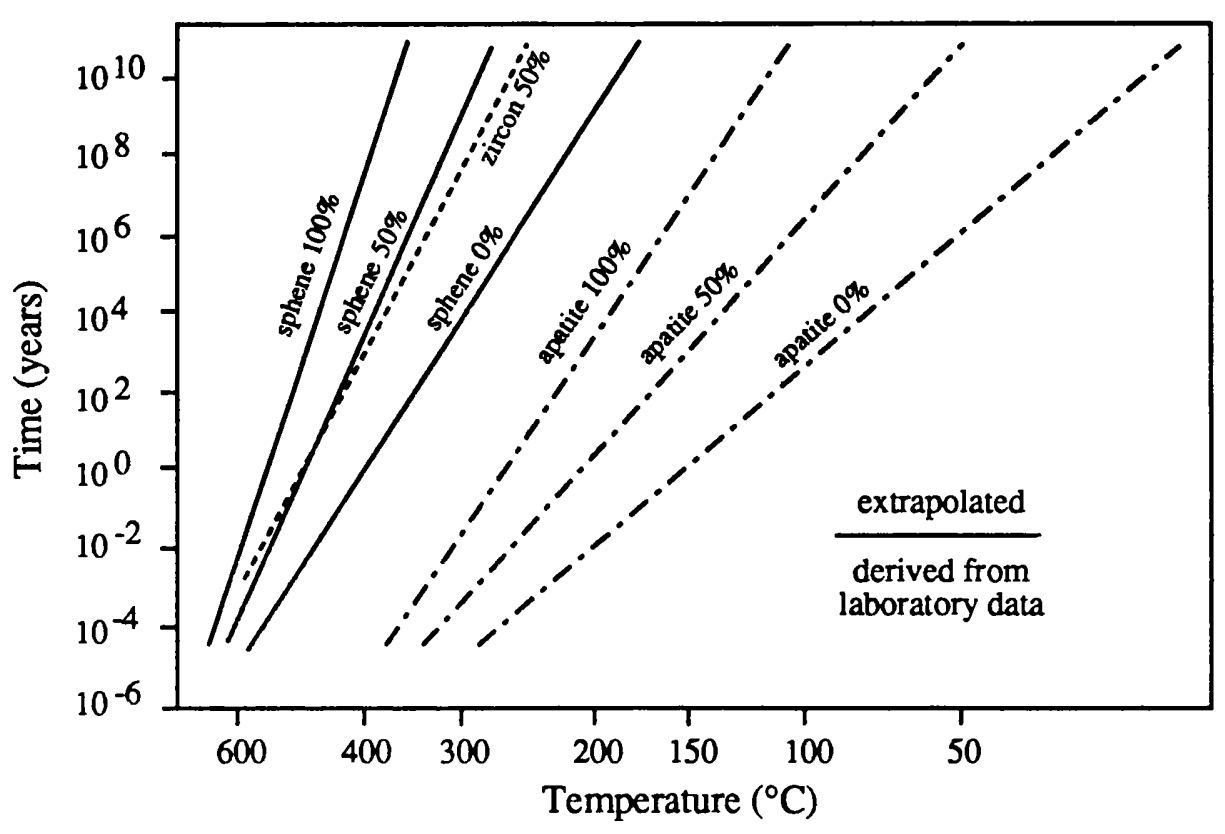

Figure 4.9 Annealing data for apatite, zircon and sphene (after Hurford, 1986) (\% $=$ percentage track loss)

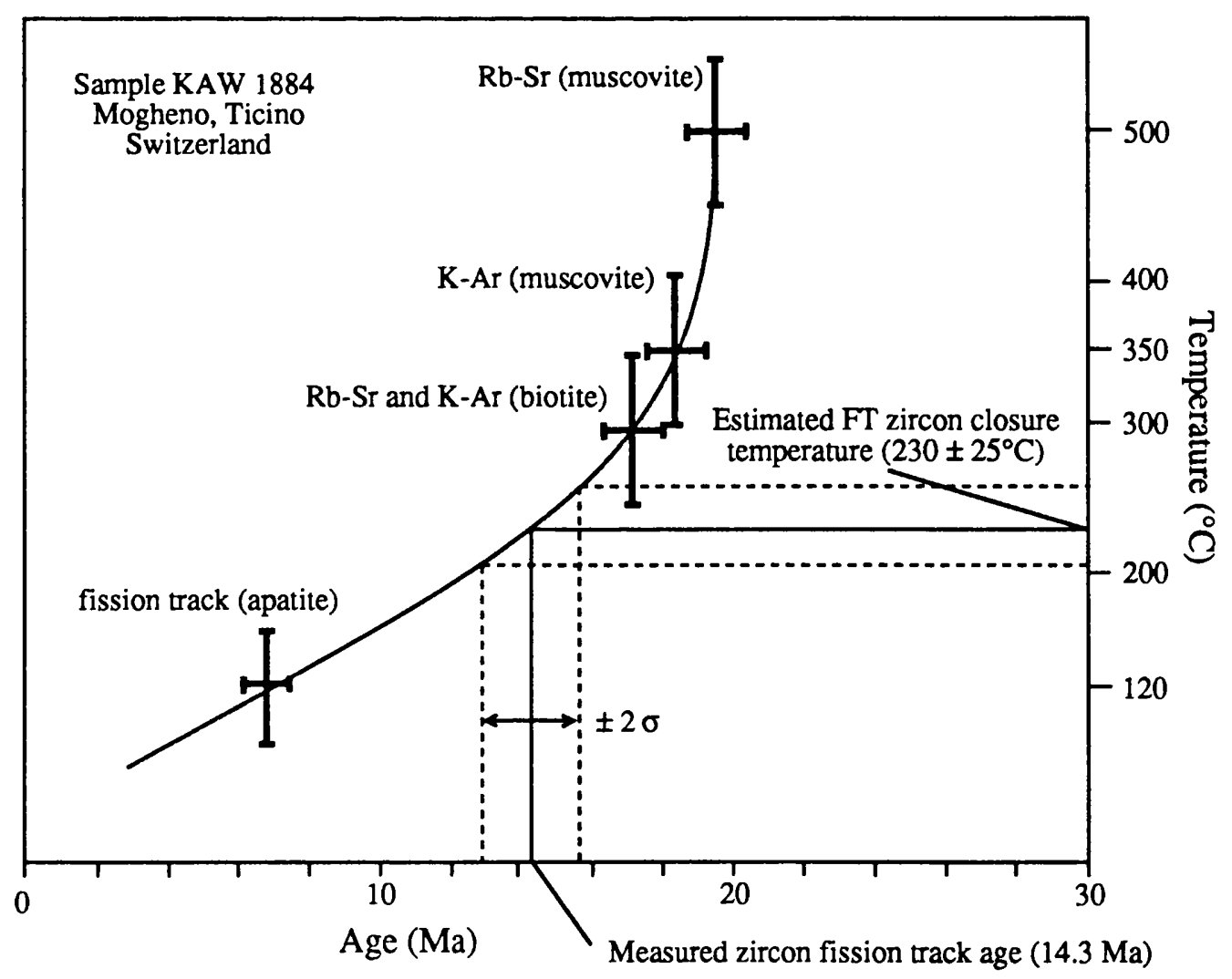

Figure 4.10 Estimation of the zircon fission track closure temperature derived from a detailed cooling curve.

(after Hurford, 1986a) 
apatite fission track and $\mathrm{K}-\mathrm{Ar}$ (biotite) an estimate of $\sim 200-250^{\circ} \mathrm{C}$ is derived (Figure 4.10). Variations may be due to pressure effects, presence of fluid phases, or alpha recoil damage within zircons in geological samples.

Over long time periods ( $>1 \mathrm{Ma}$ ) fission tracks in apatite are annealed at temperatures considerably lower than the closure temperatures of other radiometric systems. This closure temperature $\left(\sim 100 \pm 20^{\circ} \mathrm{C}\right)$ is also very similar to the temperature window over which heavy hydrocarbons mature. A number of techniques have been developed to assess the maximum palaeotemperature estimate of rocks in hydrocarbon provinces (see Naeser and McCulloh, 1983 for a review). However, only fission tracks are formed throughout the history of a particular sample, providing information of temperature and time. As a result the annealing process of apatite fission tracks has been the focus of much fission track research.

Early work involved measuring induced track densities on step heated apatite samples (Naeser and Faul, 1969; Wagner and Reimer, 1972; Nagpaul et al., 1974). It was found that time/temperature points representing the same degree of track fading lay on straight lines on an Arrhenius Plot (a $\log$ (time) vs $1 /$ temp graph) that could then be extrapolated for geologically realistic time intervals. However, Gleadow et al. (1983) showed that induced tracks have a significantly different annealing behaviour to fossil or natural fission tracks. They argued that to more accurately represent the behaviour of tracks under natural geological conditions fossil tracks should be used.

A more direct way to assess track annealing in apatite under geological conditions is to study samples at their maximum present day temperatures from deep boreholes (Naeser, 1981; Gleadow et al., 1983). Such boreholes show that the age recorded by apatite starts to decrease above about $70^{\circ} \mathrm{C}$ and reaches zero age at about $125^{\circ} \mathrm{C}$. This region of the temperature profile is termed the track annealing zone. One of the first detailed studies was carried out in the Otway Basin of southern Australia (Gleadow et al., 1983). Data from two boreholes are shown in Figure 4.11. The first borehole (Flaxmans-1) shows a profile in which the apatite ages of the collected samples reflect present day maximum temperatures. The second borehole (Eumeralla-1) contains samples that show a decrease in age above the 

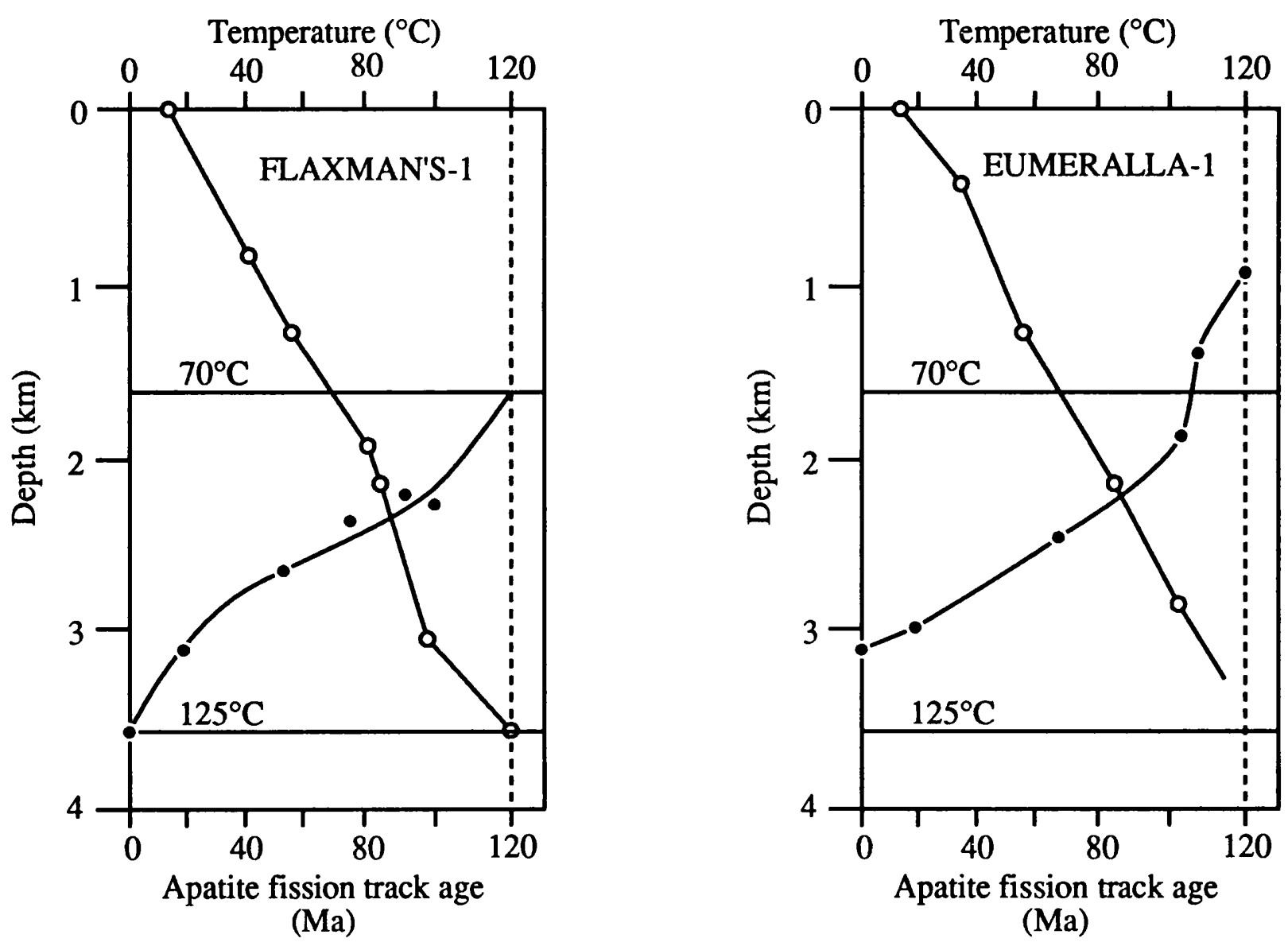

Figure 4.11 Apatite fission track age profiles for two wells in the Otway basin.

Solid circles show apatite age and open circles show temperature.

The present day apatite fission track annealing zone is indicated by the $70^{\circ} \mathrm{C}$ and $125^{\circ} \mathrm{C}$ isotherms.

(taken from Gleadow et al., 1983) 
$70^{\circ} \mathrm{C}$ isotherm suggesting the $70^{\circ} \mathrm{C}$ isotherm previously lay above its present position. This indicates that the geothermal gradient had decreased from a previous maximum. Such information can be vitally important in assessing hydrocarbon maturity.

\subsubsection{Apatite Fission Track Length Analysis}

In addition to the fission track age, the distribution of apatite fission track lengths can also be used to assess annealing behaviour. The apatite track length is very sensitive to an increase in temperature. The result is, that when used in conjunction with the fission track age, more detailed constraints can be applied to the thermal history of a particular sample. In practice track lengths are measured on horizontal to sub-horizontal confined tracks (i.e. parallel to the etched surface). These are tracks which are fully contained within a crystal. They occur in two forms, Tracks IN Cracks (TINCLES) and Tracks IN Tracks (TINTS), illustrated in Figure 4.12 and Plate 4.1. The use of confined track lengths as a tool in thermal history analysis was first developed by Gleadow et al. (1986).

The measurement procedure is outlined in Appendix I. Such measurements, usually on 100 individual track lengths, are presented in the form of a length versus frequency histogram. It should be mentioned that track length measurement is subject to some bias, the problems of which are dealt with by Laslett $e t$ al. (1982). Such bias is usually the result of undercounting of short tracks, due to problems of identification and the reduced probability of such a track intersecting a crack or another track.

When using apatite fission track lengths as an interpretive tool, it is important to remember that tracks are produced throughout the history of a sample, and when formed they are all initially the same length. Therefore each track has experienced a different portion of the thermal history of the sample in question. When Gleadow et al. (1986) sampled apatites from a wide variety of geological environments, they identified five main types of measured track length distributions: bimodal, mixed, undisturbed basement, undisturbed volcanic and induced. These are shown on a plot of mean track length versus the standard deviation of the track length distribution (Figure 4.13). For the purposes of this thesis the two important distributions when dealing with cooling are the undisturbed 


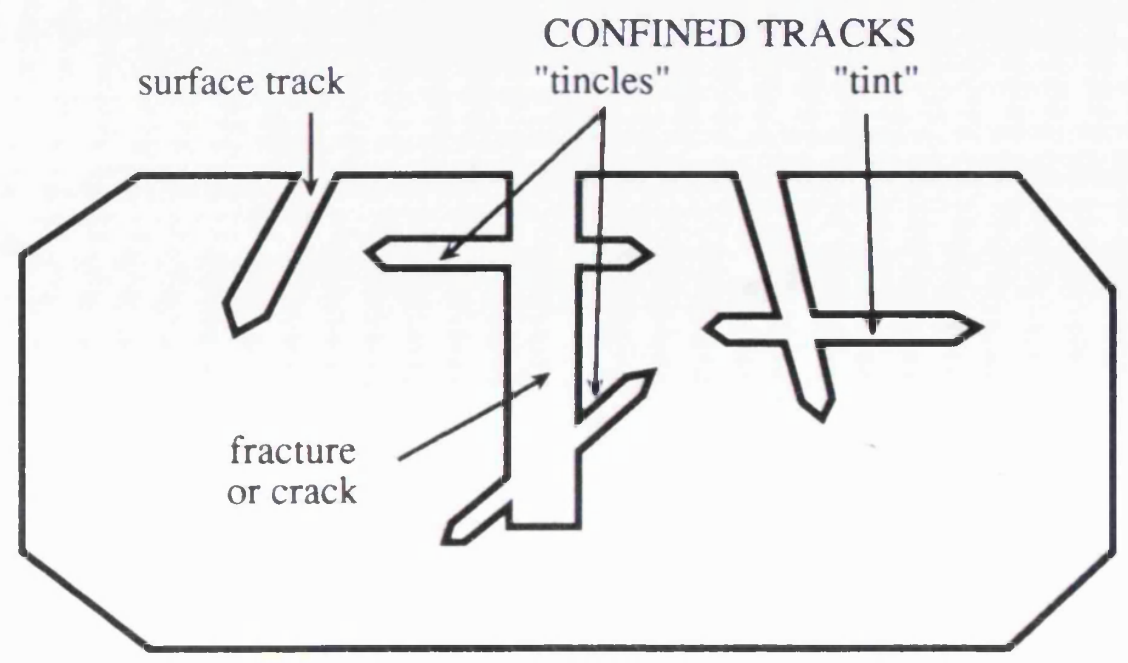

Figure 4.12 Stylised section through an apatite crystal to illustrate the different types of confined track (after Gleadow et al., 1983)

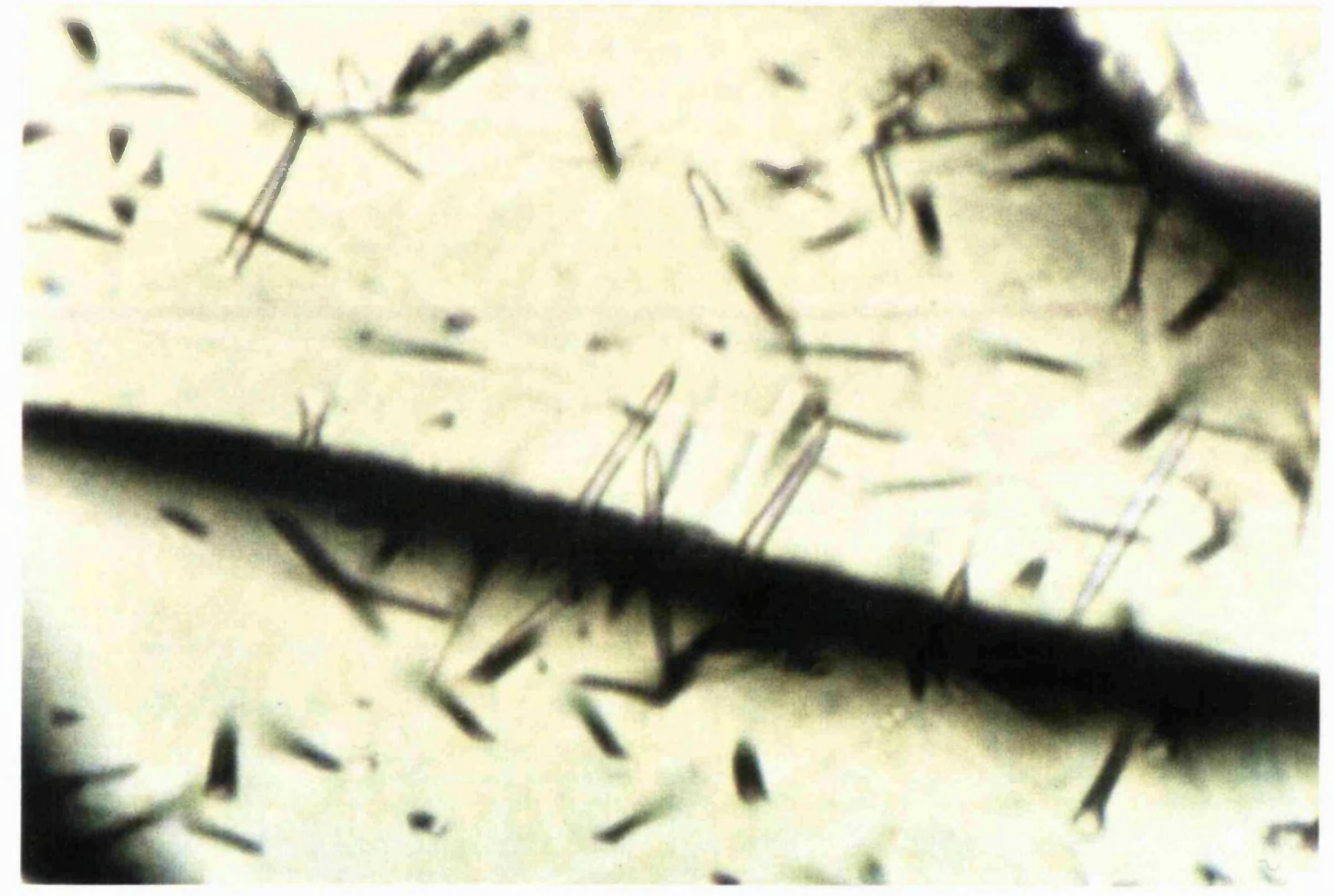

Plate 4.1 Confined tracks, in this case "tincles", within an apatite crystal 
- Bimodal

$\triangle$ Mixed

- Undisturbed Basement

- Undisturbed Volcanic

- Induced

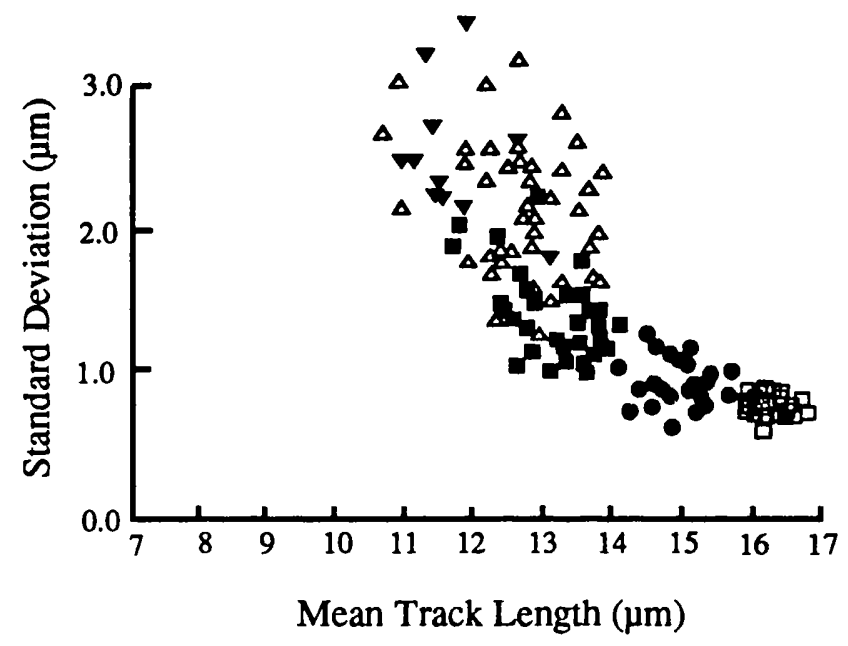

Figure 4.13a Relationship between standard deviation and mean track length from data collated by Gleadow et al.,1986)
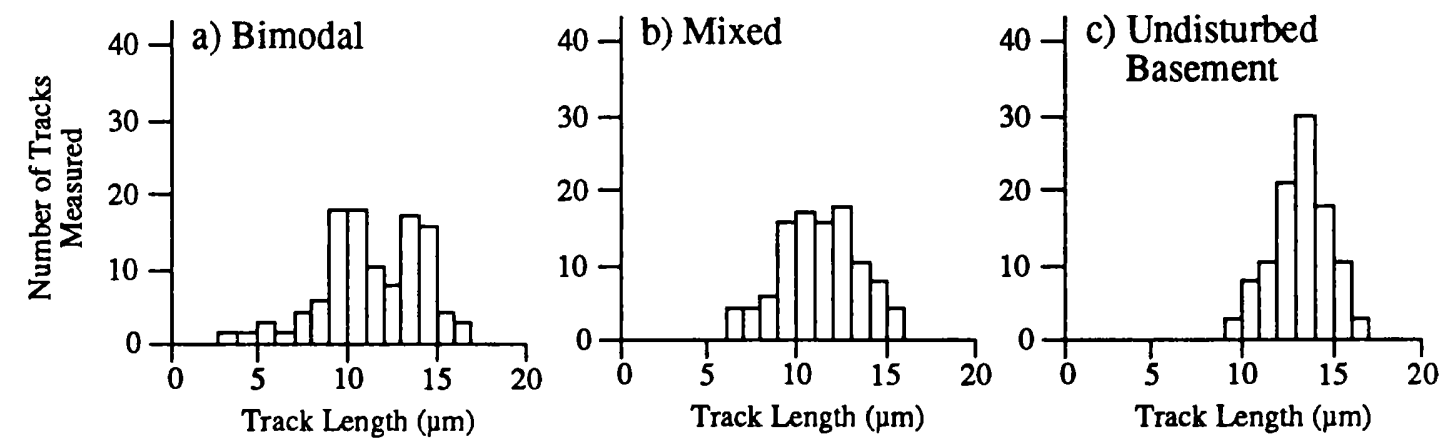

Figure 4.13b Three characteristic track length distributions commonly found in continental basement and sedimentary rocks (after Gleadow et al.,1986) 
volcanic, representing fast-cooled rocks (typically with mean track lengths of 14-15.6 $\mu \mathrm{m}$ and standard deviations of 0.8-1.2 $\mu \mathrm{m}$ ) and the undisturbed basement, representing slow cooling (typically with mean track lengths of $12.5-13.5 \mu \mathrm{m}$ and standard deviations of 1.3$1.7 \mu \mathrm{m}$. Invariably some degree of overlap between the two will occur when interpreted in terms of cooling. Typical time-temperature paths and the resultant apatite track length distributions are illustrated in Figure 4.14.

As an apatite fission track age alone can be interpreted in several possible ways (i.e. as a cooling age, a reset age or mixed age), it is essential to try and constrain such an interpretation. This can be achieved both uniquely and with confidence with the use of confined apatite fission track analysis.

\subsubsection{Quantitative Modelling of Apatite Fission Track Annealing}

The quantitative analysis of the annealing process in apatite has been studied in detail by Green and coworkers in Melbourne, resulting in a series of papers (Green et al., 1986, Laslett et al., 1987, Duddy et al., 1988 and Green et al., 1989). From detailed isothermal experiments, using apatite from Durango in Mexico, they derive a kinetic model based on a fanning Arrhenius plot (Figure 4.15). This relates the variation in fission track annealing with temperature and time (Laslett et al., 1987). More recently other annealing models have been proposed. Carlson (1990) invokes a two stage annealing process for apatite, with an initial axial shortening followed by segmentation. The kinetics of this process are derived using a physical model that postulates that shrinkage of the disrupted crystal lattice in response to the elimination of crystal defects during heating. Crowley et al. (1991) use a similar approach to Laslett et al. (1987) deriving kinetic models based upon the geometry of Arrhenius plots derived from laboratory annealing experiments.

Green et al. (1989) have shown that with the aid of a computer the fanning Arrhenius model can be used to predict the response of the apatite fission track age and length from a given thermal history. This can then be applied to geological samples of unknown thermal history. As mentioned earlier, fission tracks in apatite are formed throughout the history of a sample and when formed are all initially the same length (15-16 

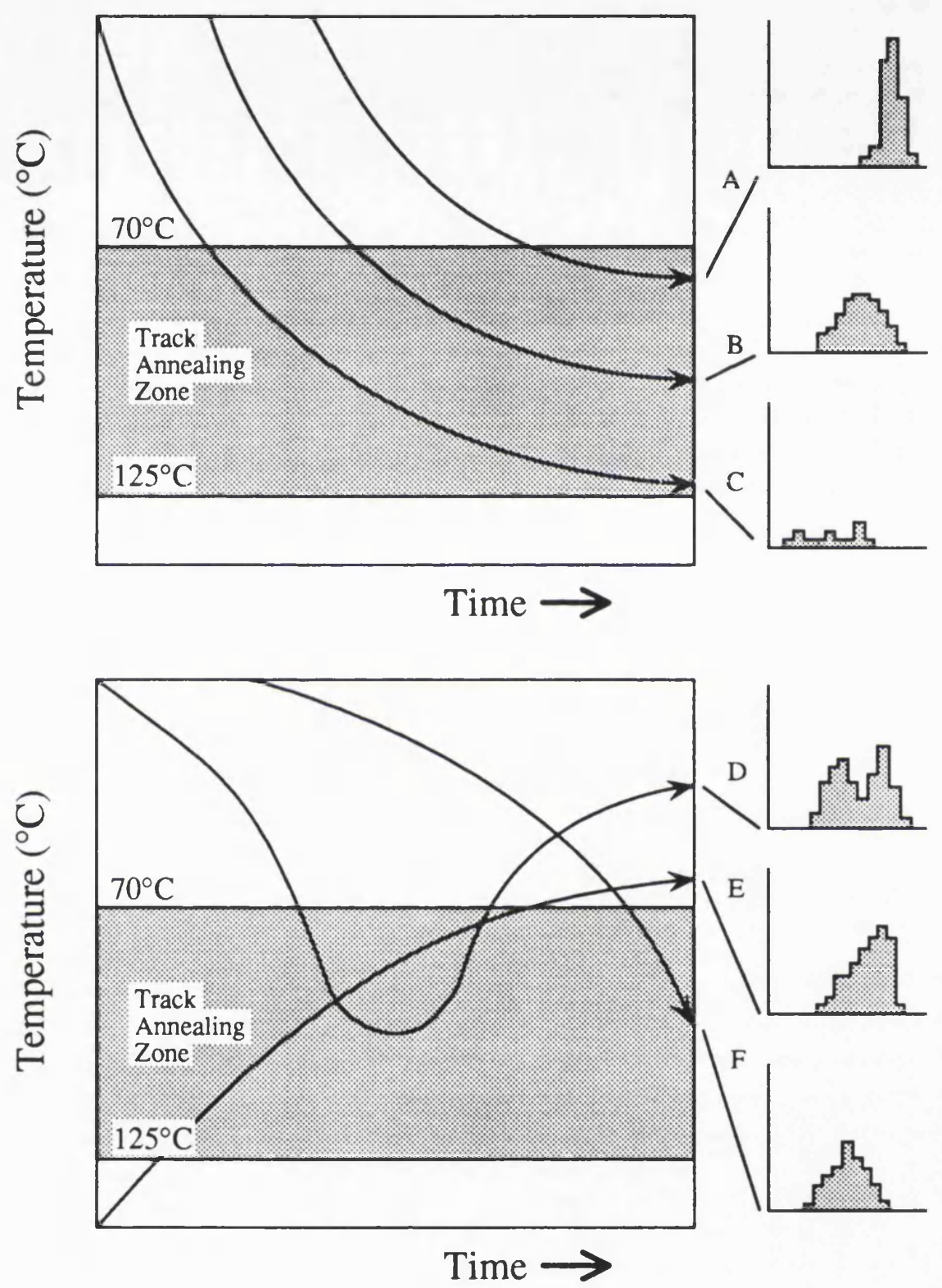

Figure 4.14 Temperature-time paths and the resulting apatite track length distributions for rocks showing varying thermal histories.

$\mathrm{A}, \mathrm{B}$ and $\mathrm{C}$ show progressive burial to different levels in the track annealing zone. The lower three distributions show the pattems for (D) a past thermal event, (E) slow cooling and $(\mathrm{F})$ a recent thermal event 


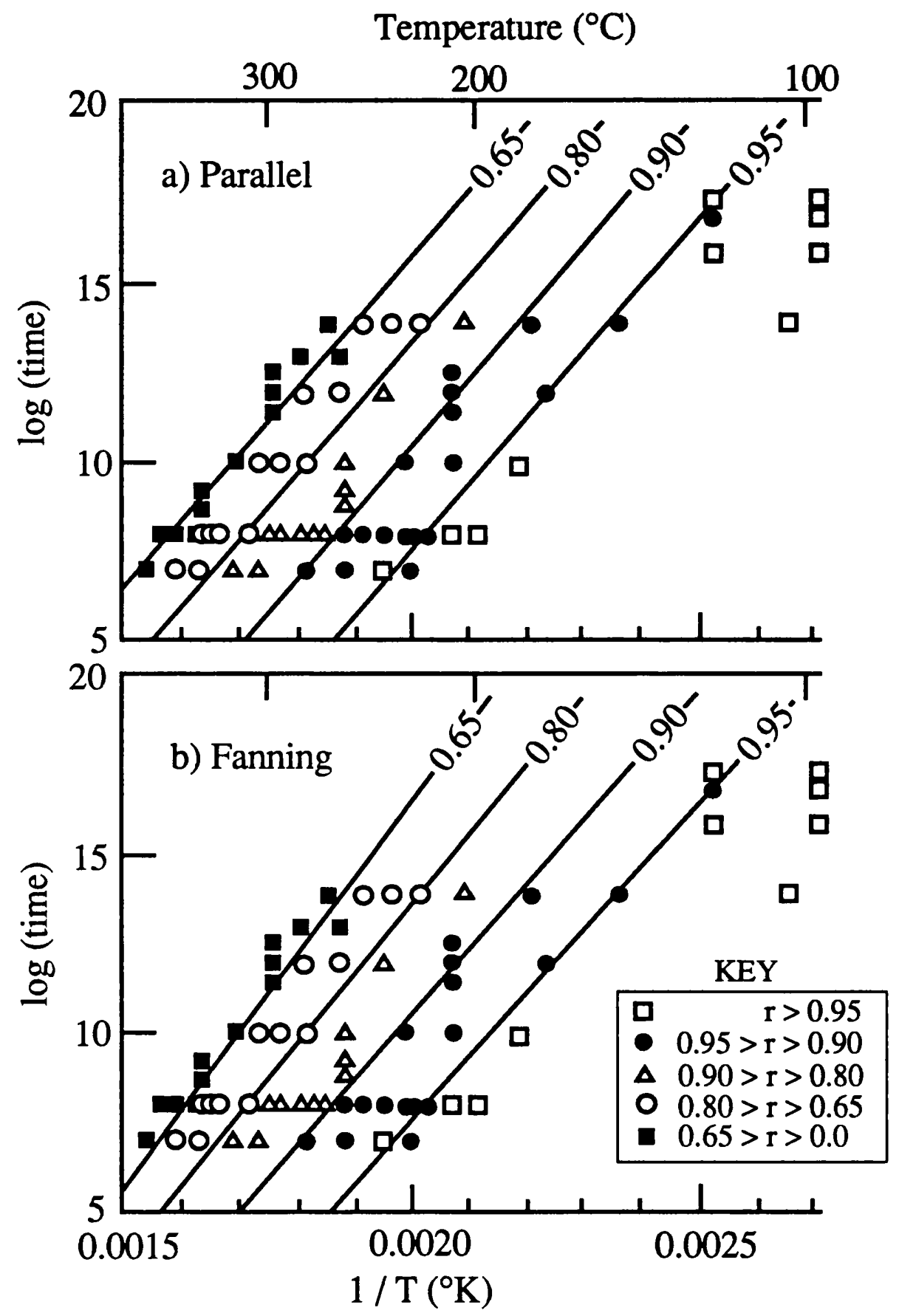

Figure 4.15 Annealing data from the Durango apatite, presented in Arrhenius form.

(a) depicts the contours of equal length reduction as a parallel model.

(b) fits the contours using a fanning model.

(Note: the fanning model is preferred as it shows a significantly better fit to the data than the parallel model)

(taken from Laslett et al., 1987) 
$\mu \mathrm{m})$. Therefore to simulate the response of a real system, the given time-temperature path can be split into a number of time intervals. Then using the 'equivalent-time' principle of Duddy et al. (1988), the final mean track length produced for each time interval can be calculated. These intervals are then summed to produce an overall track length distribution after an account of geometrical bias is taken into consideration (see Green et al., 1989). An explanation of the 'equivalent-time' principle is shown in Figure 4.16 (after Duddy et al., 1988). Although shown in a graphical context, the principle can also be modelled mathematically (Laslett et al., 1987, Duddy et al., 1988). This allows the process to handled by computer. Examples of how apatite fission track annealing responds to cooling and heating through time using this principle are shown in Figure 4.17.

As well as the fission track length an estimate of the response of the fission track age can also be calculated. This is done by summing the component age for each time interval. This component age is calculated from the relationship between track length reduction and track density (hence age) shown in Figure 4.18 (after Green, 1988). It follows that the more time intervals that are used, the more precise the age estimate will be.

An example of the predicted response of the apatite fission track system is given in Figure 4.19 (after Green et al., 1989). Here a linear cooling pattern is modelled using 20 time intervals. It can be seen that the final track length from each interval progressively increases, producing a skewed final track length distribution with mean length of $13-15 \mu \mathrm{m}$. The evolution of the fission track age through time is also shown. Due to annealing early in the history of the plot, the fission track age will always lag behind the age at to, in this case $200 \mathrm{Ma}$. Examples of predicted responses from other more complex thermal histories are dealt with in detail by Green et al. (1989).

The modelling approach used by Green et al. (1989), whereby a thermal history is proposed for a particular geological sample, and attempts are made to fit sample apatite fission track data by a process of trial and error, is known as 'forward modelling'. However this approach has several problems. First it is time consuming and second, even if a fit to the data is obtained, it is unlikely to be the only unique fit to the sample data because the method is unable to directly assess the effect of the uncertainty of the sample 
Figure 4.16 The Equivalent time principle of Duddy et al. (1988)

For an initially unannealed population of fission tracks in the Durango apatite, the reduction in track length ( $r$ ) as a function of time and temperature can be decribed as below (according to the fanning Arrhenius model).

$\left[\left\{\left(1-\mathbf{r}^{2.7}\right) / 2.7\right\}^{0.35}-1\right\} / 0.35=-4.87+0.000168 \mathrm{~T}[\ln (\mathrm{t})+28.12]$

The equivalent time principle is explained graphically below:
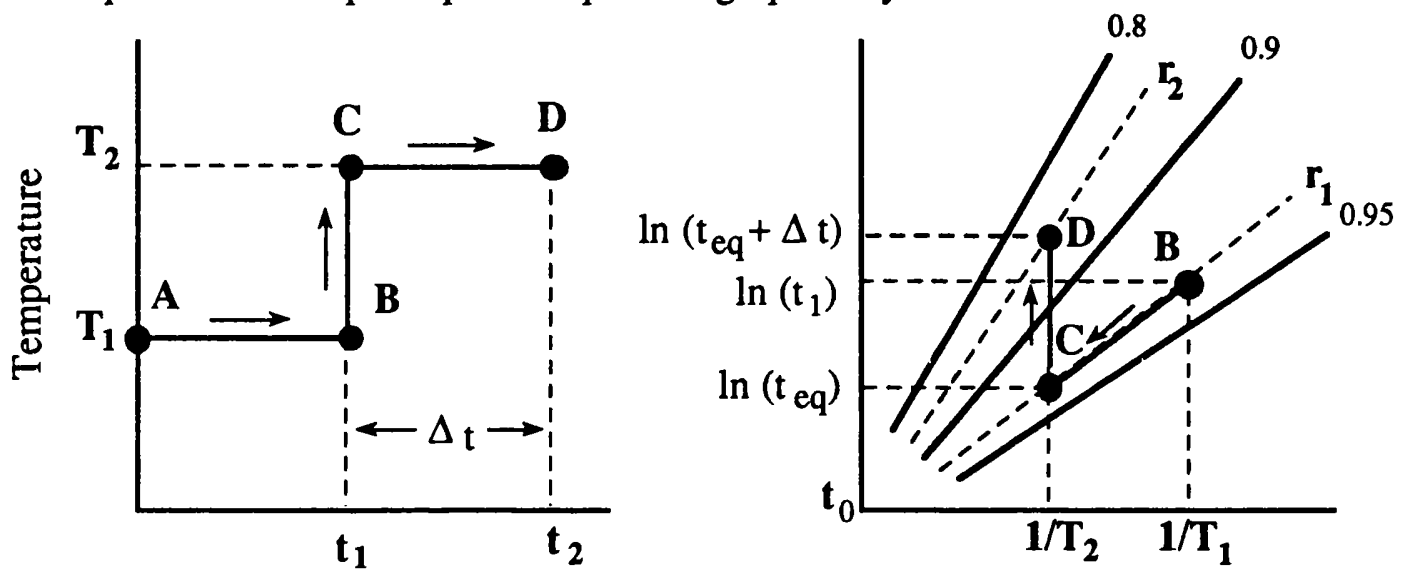

Time

The first graph shows a time-temperature path split into separate time and temperature elements.

On the second graph the initial track length reduction $r_{1}$ is represented by point $B\left(T_{1}, t_{1}\right)$ and is calculated from equation (1).

At point $\mathbf{C}$, at temperature $t_{2}$, the equivalent time to produce annealing of an amount $r_{1}$ $\left(t_{\text {eq }}\right.$ ) can be calculated by rearranging equation (1) and solving it using the values for $T_{2}$ and $r_{1}$.

Point $\mathbf{C}$ will then anneal to point $\mathbf{D}$ where the subsequent track length reduction $\left(r_{2}\right)$ can be calculated by solving equation (1) where $t=\Delta t+t_{e q}$ and $T=T_{2}$ 
a) Linear Heating

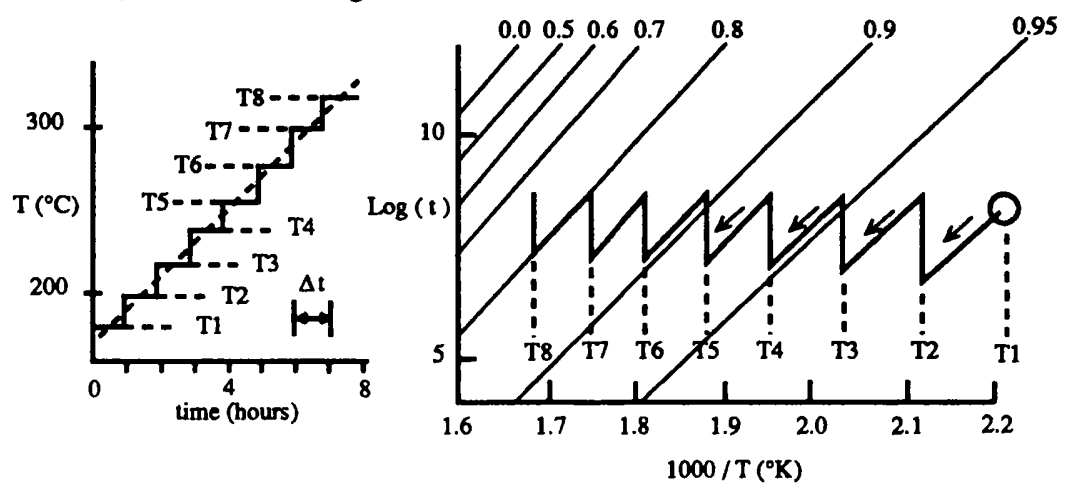

b) Linear Cooling

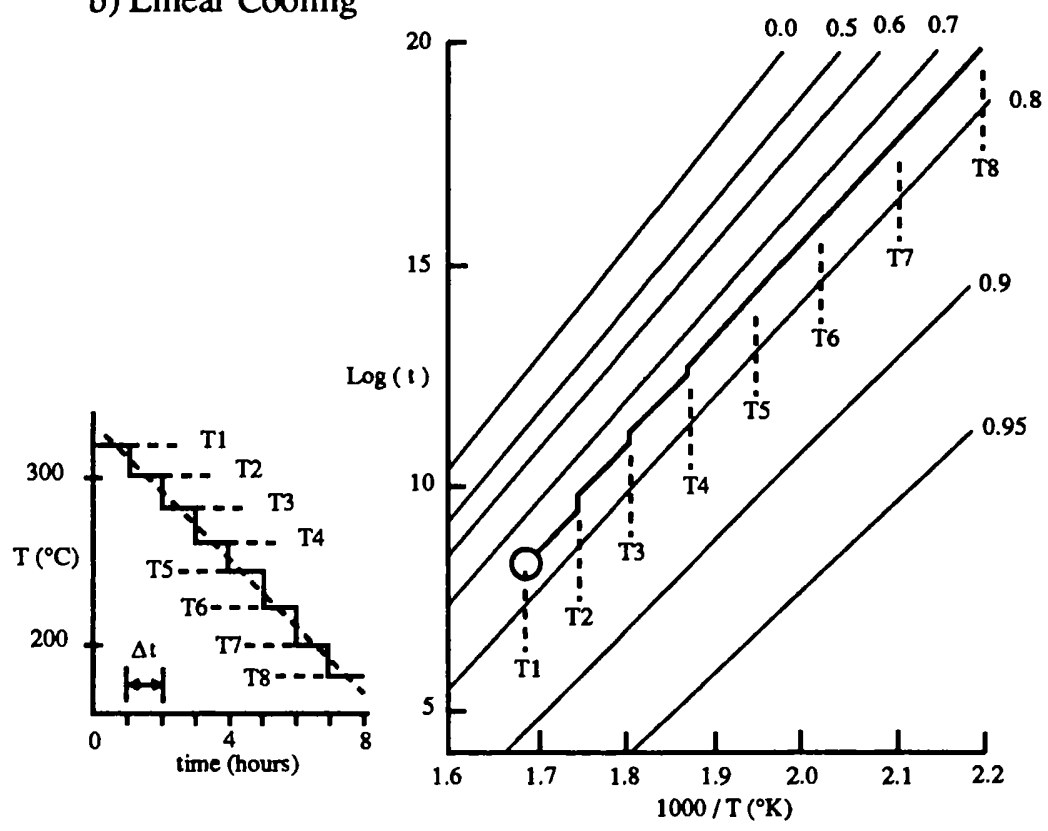

Figure 4.17 The responses of a fission track, projected onto a fanning Arrhenius plot, when subjected to linear heating and linear cooling using the equivalent time principle.

a) When temperature increases with each temperature interval, the equivalent time at the new temperature is always small, when compared to $\Delta \mathrm{t}$. This results in considerable lowering of $\mathrm{r}$ (hence shortening)

b) When temperature decreases with time, the equivalent time at each interval soon becomes so large that $\Delta t$ becomes insignificant, and no further annealing will take place. 


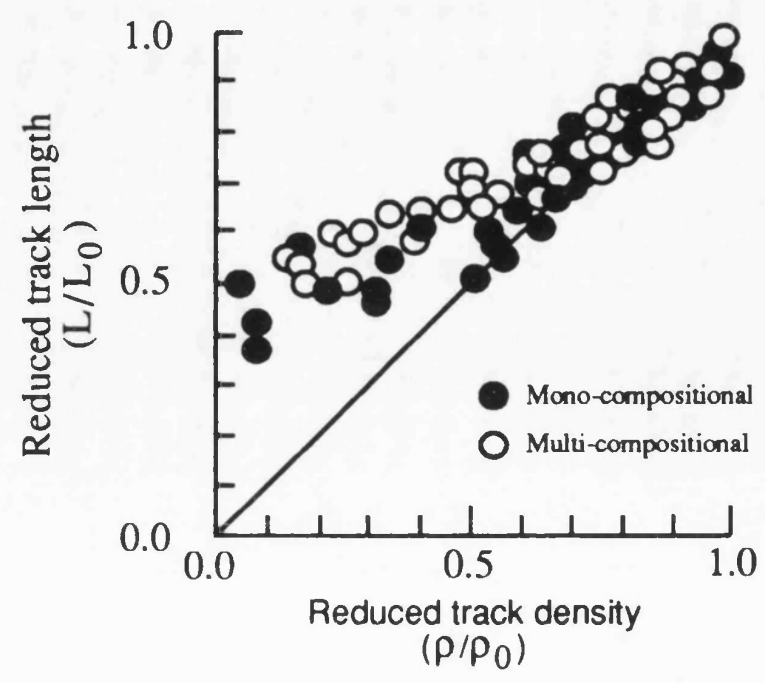

Figure 4.18 Graph to show relationship of apatite track density with apatite mean track length (after Green, 1988)

(Note: The two values are equal until length reduction is $\sim 0.6$. Deviation away from equal track length and density reduction is because of the bias against revelation of short confined tracks)
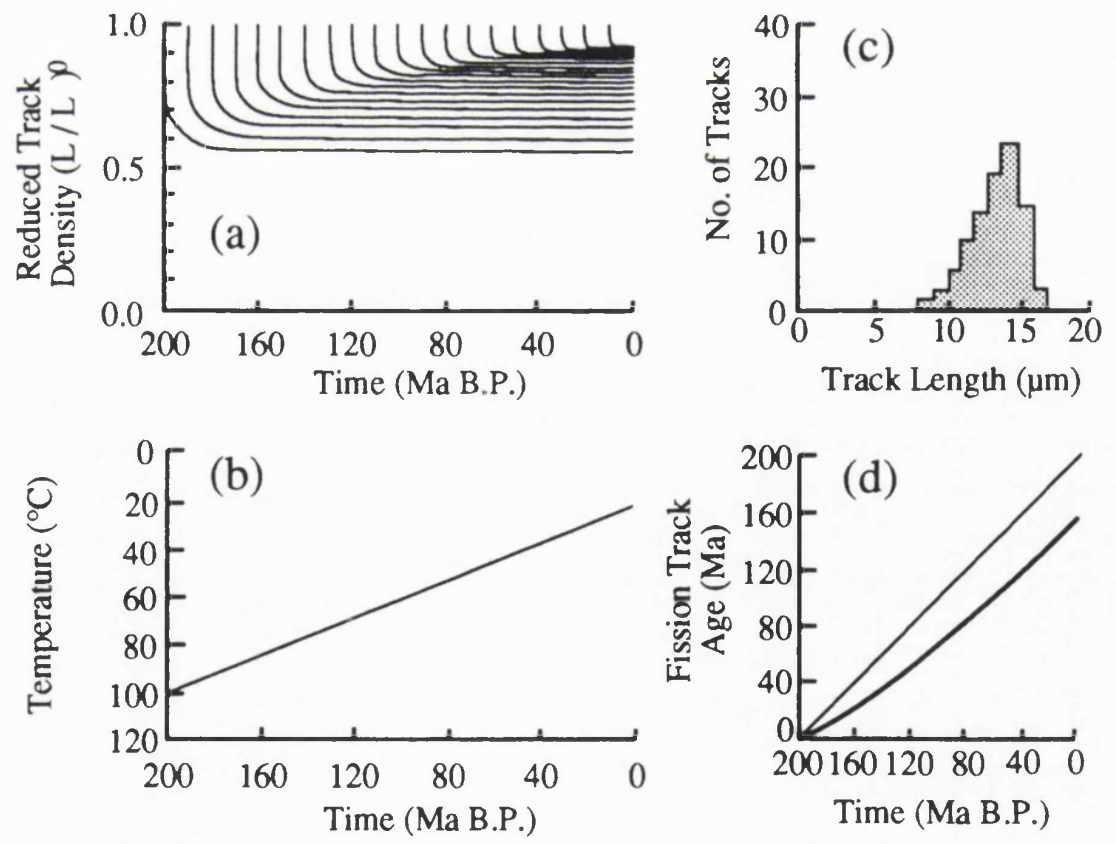

Figure 4.19 Evolution of the length of tracks (a) produced at various times through a thermal history shown in (b). (c) shows the final predicted track length distribution and (d) shows the evolution of the fission track age through time. (from Green et al.,1989) 
data on the resolution of the predicted thermal history.

To address these problems the use of 'inverse modelling' has been proposed (Corrigan, 1991; Lutz and Omar, 1991). This approach allows an estimation of the thermal history of a sample using the calculated apatite fission track age, mean track length and standard deviation of the track length distribution.

In this thesis a computational inverse modelling approach will be applied to samples that uses a Monte Carlo random selection method. This has been incorporated into a computer program written by K.Gallagher (pers. comm.) of the London Fission Track Research Group. The program is similar to that used by Lutz and Omar (1991), but does not use minimisation algorithms. The sample age, mean track length and standard deviation of the track length, with appropriate errors are fed into the program. A number of appropriate time-temperature boxes are then defined. Within each box the program picks a T-t point at using random selection, the so-called 'Monte Carlo' method. The points from each box are then joined to give a thermal history. The fission track annealing response to this thermal history is then calculated using the 'equivalent-time' model of Laslett et al. (1987) and Duddy et al. (1988). The predicted age, mean track length and standard deviation are then tested against the actual sample data to see if the calculted thermal history lies within the sample data limits. With the aid of the computer the random selection process can be repeated as many times as necessary. The runs that fit the data can then be shown graphically. An example of this approach is shown in Figure 4.20. If no runs fit the data then the defined T-t boxes can be altered or the error margins on the sample data increased. The definition of the sample errors and the time temperature boxes are clearly crucial in obtaining a successful run. The way this is approached is to start with the simplest model possible, using one $\mathrm{T}$-t box, and then adding and altering boxes until a successful run is made. Constraints can be applied if independent information is available on the thermal history, such as the present day surface temperature (usually taken as $12^{\circ} \mathrm{C}$ ) and the zircon fission track age that can be defined in a box between $200-250^{\circ} \mathrm{C}$. A constraint that should be noted is that the inverse method is only as sensitive as the input sample data. Corrigan (1991) notes that the resolution of such predicted thermal histories is 
Figure 4.20 An example of Monte Carlo modelling

a) First input the sample apatite fission track age, mean track length $( \pm 1 \mu \mathrm{m})$ and standard deviation of the track length distribution $( \pm 1 \mu \mathrm{m})$

For this example the results produced by the apatite annealing model for a known thermal history will be used.

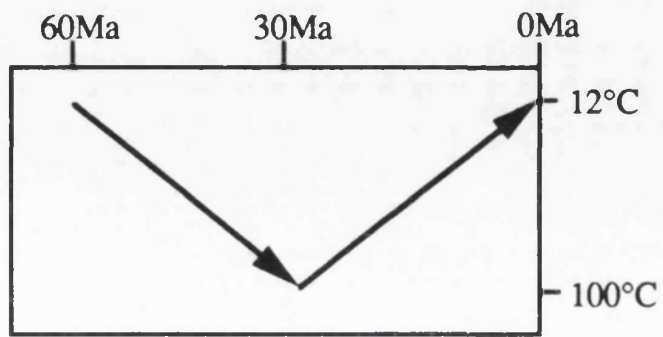

Data predicted by this known thermal history

Age $=47.2 \mathrm{Ma}$

$\mathrm{MTL}=12.3 \mu \mathrm{m}$

$\mathrm{SD}=2.2 \mu \mathrm{m}$

b) Assuming the thermal history is unknown, some T-t boxes appropriate to the sample data are chosen.

3 boxes are defined : i) $60 \pm 15 \mathrm{Ma}, 70 \pm 60^{\circ} \mathrm{C}$

ii) $30 \pm 15 \mathrm{Ma}, 70 \pm 60^{\circ} \mathrm{C}$

iii) $0 \mathrm{Ma}, 12^{\circ} \mathrm{C}$

c) 200 Monte carlo (random) T-t histories are then chosen by a computer.

Each T-t run is then modelled using the fanning Arrhenius model of

Laslett et al. (1987), and then tested against the sample data.

The following T-t Plots are produced:

ALL RUNS

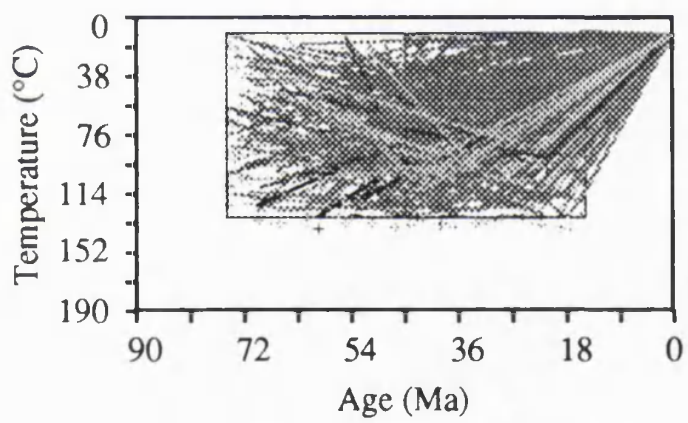

RUNS THAT DO NOT FIT DATA

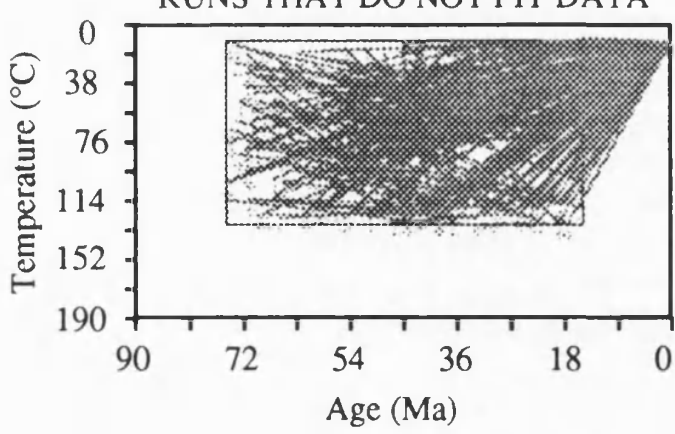

RUNS THAT PREDICT LENGTH DATA

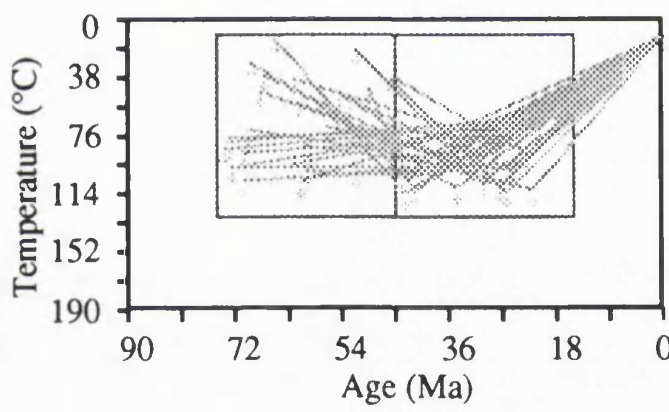

RUNS THAT PREDICT AGE DATA

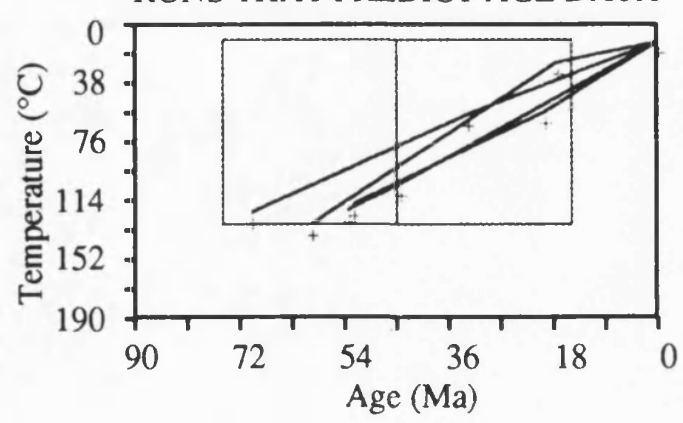

RUNS THAT PREDICT LENGTH \& AGE DATA

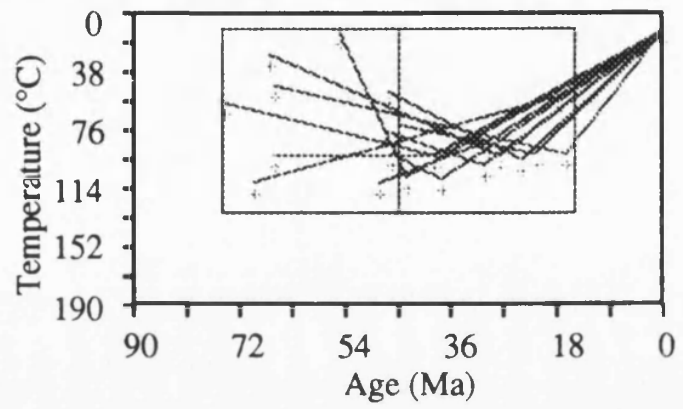


no better than $\pm 10^{\circ} \mathrm{C}$, even with ideal data. In addition the method requires considerable computer power, without which the program will run very slowly.

Both the predictive modelling approaches are dependent on the validity of the fanning Arrhenius model of Laslett et al. (1987). However there are still several unresolved problems with this model. The first problem is that the original fanning Arrhenius plot was derived from laboratory experiments, undertaken over periods of up to 500 days. However to apply these results to geological time scales requires extrapolation over several orders of magnitude. To test the validity of such extrapolation Green et al. (1989) have applied quantitative models derived from the fanning Arrhenius plot model to samples from the Otway Basin, southern Australia, where the detailed thermal history is well known. The results of this are shown in Figure 4.21. Although in general there is agreement some discrepancy is seen. Green et al. (1989) suggest these discrepancies are systematic, and are caused by effects of apatite composition. This is a second major problem. Apatite has the chemical formula $\mathrm{Ca}_{10}\left(\mathrm{PO}_{4}\right)_{6}(\mathrm{~F}, \mathrm{Cl}, \mathrm{OH})_{2}$. According to Green et al. (1986) it is found that the $\mathrm{Cl} / \mathrm{Cl}+\mathrm{F}$ ratio can significantly affect the annealing characteristics of apatite (Figure 2.22), with $\mathrm{Cl}$-rich apatites being more resistant to annealing. The experiments that resulted in the fanning Arrhenius model are derived from Durango apatite, where $\mathrm{Cl} / \mathrm{Cl}+\mathrm{F} \approx 0.1$. Therefore predictions based on this model are only strictly valid for apatites with similar $\mathrm{Cl} / \mathrm{Cl}+\mathrm{F}$ ratios. Work is at present in progress to try and find a quantitative relationship between annealing and apatite composition in order that appropriate corrections may be applied to derived thermal models. Crowley et al. (1991) have investigated the annealing response of fluor-apatite and strontium-rich apatite and have found no significant difference between the annealing characteristics of the two apatites. Other problems include differences between induced and spontaneous track lengths discussed by Green (1988). However this only requires application of a simple correction factor. The problem of anisotropic annealing in relation to the c-axis of the apatite crystal form has also been looked at (Galbraith and Laslett, 1988; Donelick, 1991). However Green et al. (1989) do not include a correction factor for this, arguing that the predictions of track length from the fanning Arrhenius model are satisfactory without adding such further restrictions to the 


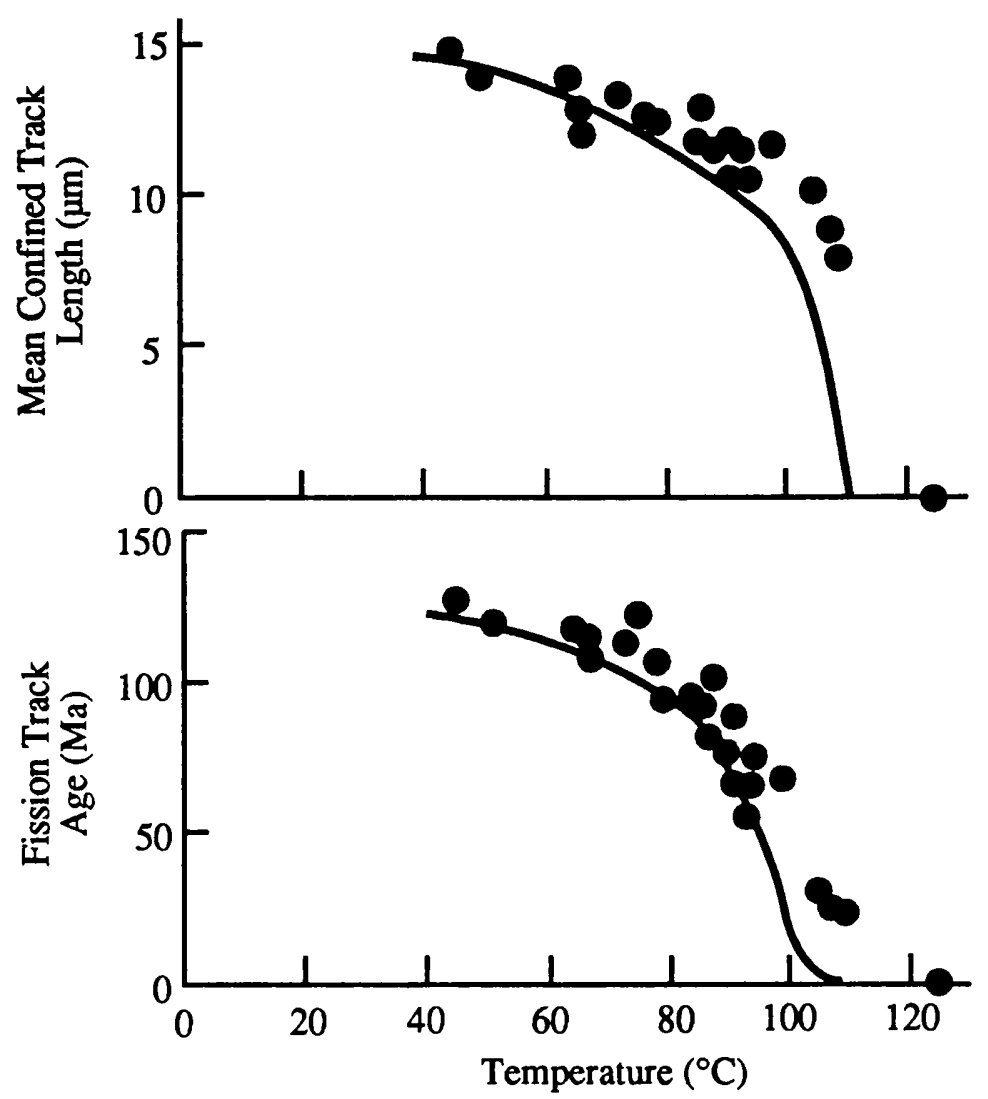

Figure 4.21 Apatite data from the Otway Basin (southern Australia), compared with the predicted results, illustrated by the solid line. (after Green et al.,1989)

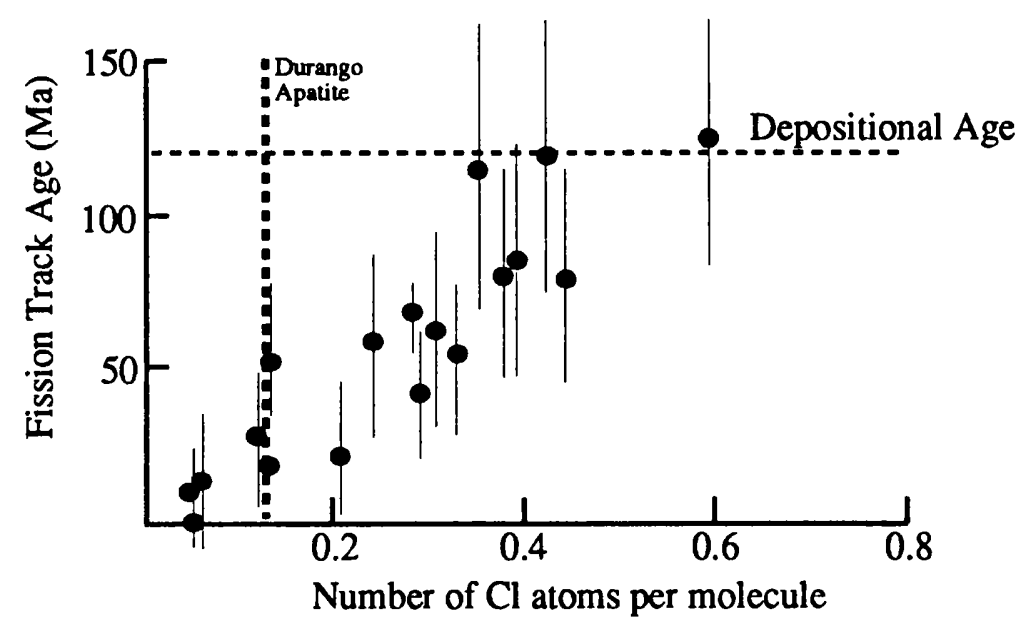

Figure 4.22 Relationship between apatite fission track age and apatite composition (in terms of chlorine present) for samples from the Otway Basin. The composition of Durango is shown for reference.

(after Green et al.,1989) 
model. Donelick (1991) has recently produced an empirical model that relates the crystallographic orientation of apatite fission tracks and their mean track length. One further limitation to the model is the problem of bias in revealing confined tracks with lengths of less than $10 \mu \mathrm{m}$. This has been studied by Laslett et al. (1982). Again work is in progress to improve understanding of such bias at low track lengths.

In future it is hoped similar approaches may be possible using zircon fission tracks to provide thermal history models for temperatures up to $250^{\circ} \mathrm{C}$. However, there are several problems associated within the annealing of zircons. Firstly, the etching of zircons is a much less well defined process than for apatites with large variations in etch time between individual samples. Why this variation occurs is not known, although it is probably related to the crystal chemistry. Furthermore, the zircon crystal lattice is often metamict, due to alpha-recoil damage. This leads to a marked anisotropy in its annealing characteristics which can have a major influence on measured track length, dependent on orientation. Zircons are commonly zoned with respect to uranium which causes problems in selecting suitable count areas for fission track analysis. Thus, even if annealing models for zircons are produced they are unlikely to be as good as those available for apatite.

\subsection{APPLICATIONS OF FISSION TRACK ANALYSIS}

Although this thesis will concentrate on applying fission track analysis to assessing low temperature cooling histories in a young mountain belt, the technique can also be used in a wide variety of other situations. These include the direct dating of certain rocks and minerals, discrimination of sedimentary provenance and assessing low temperature thermal histories in other tectonic environments such as rift margins and sedimentary basins. The purpose of this section is not to provide detailed reviews of these applications, but to provide some brief background information. 


\subsubsection{Direct Dating}

The direct dating of a mineral by fission track analysis requires that the material being dated has undergone no thermal annealing or uranium loss since formation. This applies to only a small of rocks and minerals, such as tephra-derived volcanic glass and zircon and rapidly cooled rocks such as dykes. The widest use of direct dating by fission track analysis has been in tephrochronology. As the technique is grain discrete it has a distinct advantage over $\mathrm{K}-\mathrm{Ar}$ and ${ }^{14} \mathrm{C}$ dating techniques in distal ash-fall tephra deposits where contamination is often a problem.

Examples include work by Naeser et al. (1973) on the Pearlette Ash of the western USA, Seward (1974) and Ninkovich et al. (1978) on Pleistocene biostratigraphical and $\delta 180$ substages of New Zealand, Obradovich et al. (1978) on the Pliocene / Pleistocene type section at Vrica (southern Italy) and Hurford et al. (1976) in an area of early hominid remains near Lake Rudolf (Kenya). There have been few studies using the direct dating method due to problems of annealing, low track densities in young samples giving large analytical errors and the small grain size of most tephra deposits.

\subsubsection{Discrimination of Sedimentary Provenance}

After Gleadow and Lovering (1974) discovered fission track dates were unaffected by weathering processes, it was found that the technique could be used in the discrimination of sedimentary provenance. As the method is grain discrete, statistical evaluation of individual crystal ages, such as weighted histograms and radial plots (Section 4.2.6) can be used to reveal different age populations, and hence potentially discriminate between different source areas. This approach requires the measurement of significant numbers of crystals, usually 100 , and can only be applied to sediments that have undergone no significant post depositional heating and hence track annealing. Most fission track provenance studies are therefore carried out using zircon, which does not undergo annealing until about $200^{\circ} \mathrm{C}$. Apatite can also be used, but only on recent sediments, or sediments that have not been deeply buried.

Examples of work using fission track analysis in sedimentary provenance studies 
include McGoldrick and Gleadow (1977) on sandstones in Victoria, Australia, Hurford et al. (1984) on Lower Cretaceous of the English Weald, Wagner et al. (1979) on Oligocene conglomerates in the central Alps and Bigazzi et al. (1990) on obsidian bodies and Neolithic artifacts in central Europe. Most of these studies have been reviewed in detail by Hurford and Carter (1991).

\subsubsection{Thermal History of Rifted Margins}

The first rifted margin investigated using fission track analysis was by Kohn and Eyal (1981). They found that a profile of fission track ages across the Red Sea Rift show a decrease in the apatite fission track age towards the rift flank. Similar reductions in the fission track age have also been observed on older uplifted rift flanks preserved along passive margins in southwest Africa and the Transantarctic mountains (Brown et al., 1990; Gilchrist and Summerfield, 1990). These results can be explained as being a result of differential denudation or exhumation (Gilchrist and Summerfield, 1990). The coastal side of such rift margins have high slope gradients resulting in high denudation rates, however the inland side of the rift flank has a very low relief giving rise to low denudation rates.

When the apatite fission track age is plotted against the elevation of an uplifted rift margin, a break in slope is commonly observed, accompanied by a decrease in mean track length (Gleadow and Fitzgerald, 1987; 1988; Brown et al., 1989; Stump et al., 1990 Brown, 1991). This break in slope is thought to mark a previous base to an apatite partial annealing zone representing a palaeo-isotherm of $\sim 125^{\circ} \mathrm{C}$. Using this data Brown (1991) has developed an interpretative technique known as backstacking. When a so-called 'fossil partial annealing zone' is observed, the amount of exhumation may be calculated and 'backstacked' (reloaded) onto the present day crust. The resultant isostatic surface rebound may then be determined, and using independent evidence for the elevation of the initial surface it is possible to calculate the surface (tectonic) uplift component. However this approach is only of limited use because fossil partial annealing zones are rarely observed and difficult to distinguish. 


\subsubsection{Thermal History of Sedimentary Basins}

The advent of models that relate apatite fission track age and length to temperature has led to its use in assessing the thermal history of sedimentary basins. Additional interest has also been stimulated by the fact that apatite annealing occurs over the same temperatures as the maturation of heavy hydrocarbons. The first application of apatite fission track analysis to sedimentary basin thermal modelling and hydrocarbon resource evaluation was made by Gleadow et al. (1983). It was shown that apatite fission track ages and track lengths obtained from borehole samples in the Otway basin of southern Australia could be used to indicate that present day down-hole temperatures had decreased from an earlier maximum. More recently the development of the apatite fission track annealing model (Green et al., 1989) has allowed the thermal and hence burial history of sedimentary sequences to be examined in considerable detail. Good examples of how apatite fission track analysis can now be applied to sedimentary sequences have been provided by Green (1989) from Namurian and Triassic sandstones of the East Midlands shelf of the U.K and by Kamp et al. (1992) on the Westland foreland basin, South Island, New Zealand

\subsubsection{Thermal History of Mountain Belts}

The most widespread application of fission track analysis has been in obtaining low temperature cooling histories from mountain belts. One of the main reasons for this is that fission track derived cooling histories, usually in conjunction with other structural, sedimentological and geochronological data, can be used to constrain distribution and rates of uplift, erosion and denudation. These factors were identified by England and Richardson (1977) as being some of the most important in controlling the regional evolution of mountain belts. The majority of this thesis is aimed as obtaining such information from the Calabrian Arc basement complex, part of the Alpine orogenesis.

Other examples of the use of fission track analysis in mountain belts include studies of the western Alps, reviewed by Hurford et al. (1989) and Hurford (1991) and the northwest Himalaya and Karakoram (Zeitler et al., 1982; 1985; 1989; Searle, 1991). Other important studies have been carried out in New Zealand (White and Green, 1986; Kamp et 
al., 1989), the Andes (Kohn et al., 1984; Benjamin et al., 1987), the Rockies (Parrish, 1982; O’Sullivan and Decker, 1990) and the Pyrenees (Yelland, 1990). 


\section{CHAPTER 5}

\section{THE RESULTS OF FISSION TRACK ANALYSIS FROM THE BASEMENT COMPLEX OF THE CALABRIAN ARC, SOUTHERN ITALY}

\subsection{SAMPLING PROCEDURE}

A total of 80 samples for fission track analysis were collected over a course of two field seasons from the metamorphic and plutonic basement rocks of southern Italy and northeastern Sicily. Samples of about $2-3 \mathrm{~kg}$ were collected, after consideration of their potential for yielding apatite and zircon. Biotite-bearing plutonics and metasediments usually show the best yields for both minerals. Some fine grained phyllites were also sampled, especially those showing quartz veining, although these tend to be too fine grained for general use. As many samples as possible were collected from sites known to have been previously used for isotopic dating. However this was only done where exact location details were provided (from Civetta et al., 1973; Lorenzoni and ZanettinLorenzoni, 1976; Schenk, 1980; Nicoletti, 1984 and Del Moro et al., 1984). Other samples collected were chosen only if they could definitely be ascribed to a major basement rock group. This was achieved using the geological maps of De Roever (1972) (1:10,000), Amodio-Morelli et al. (1976) (1:500,000), Lorenzoni and Zanettin-Lorenzoni (1983) (1:200,000), Borsi et al., 1976, Lorenzoni and Zanettin-Lorenzoni (1976), Platt and Compagnoni (1990) and Messina et al. (1990). Samples of each major basement rock group were collected as extensively as possible with consideration taken of elevation, geographical spread and accessibility. Particular attention was given to the Aspromonte/ Peloritani region. Certain rocks from this region have been shown to exhibit "Alpine" metamorphism and deformation with young (25-30 Ma) Rb-Sr whole rock ages (Bonardi et al., 1987; Platt and Compagnoni, 1990).

Of the 80 samples collected, 65 yielded enough apatite or zircon to enable analyses to be undertaken. Sample details are described in Appendix II, which includes petrographic descriptions, location, elevation (metres) and previous references to the sample locality. Details of location and elevation were provided by 1:25,000 IGM (Istituto Geografico 
Militare) maps. These enable elevation to be estimated to within $\pm 5 \mathrm{~m}$. The approximate locations of the samples collected are shown in Figure 5.1. The first three letters of the sample number refer to the locality, the latter numbers to the elevation in metres.

\subsection{APATITE AND ZIRCON FISSION TRACK AGE DATA}

The apatite and zircon fission track age data for the Calabrian Arc basement rocks are given in Table 5.1 (apatite) and Table 5.2 (zircon). All ages given are quoted as a 'central age', with the standard error of the age quoted to $\pm 1 \sigma$. The spread of the ages is shown as an "age dispersion" or relative error (Galbraith pers. comm.). An arbitary figure of $\sim 20 \%$ is taken as the division between single grain ages (below) and mixed grain ages (above). The analyses were also subjected to a $\chi^{2}$ test (Galbraith, 1981). If analyses fail this test (at the $<5 \%$ level of confidence), the failure indicates that the result contains an extra-Poissonian scatter. This can be caused by poor counting, poor mica/crystal contact, underetching or because the individual grain ages belong to more than one age population, a so-called 'mixed age' (Chapter 4, section 4.2.6).

The fission track ages with their corresponding locations are shown in Figure 5.2 (Sila and Catena Costiera) and Figure 5.3 (Serre, Aspromonte and Peloritani). For reference the all the fission track age data is summarised in Tables 5.3 (by rock type) and 5.4 (by region).

The apatite fission track central ages range between $7.4 \pm 1 \mathrm{Ma}$ and $42.5 \pm 20.1$ Ma. In Table 5.3 the samples have been arranged according to the various rock groups described in Chapter 3. The samples dated from the Alpine Group of rocks show ages that range from $12.7 \pm 2.3 \mathrm{Ma}$ to $19.9 \pm 2.1 \mathrm{Ma}$ with a mean age of $15.7 \pm 2.5 \mathrm{Ma}$ (weighted mean of $15.7 \mathrm{Ma}$ ). The three ages from the Sila show slightly older ages between 18 and $19 \mathrm{Ma}$. The high-grade Hercynian metamorphic rocks show apatite fission track ages that range from $9.5 \pm 1.1 \mathrm{Ma}$ to $25.2 \pm 5.2 \mathrm{Ma}$ with a mean age of $20.0 \pm 4.6 \mathrm{Ma}$ (weighted mean of $18.3 \mathrm{Ma}$ ). The weighted mean is lowered by two younger ages of samples PAL$700(9.5 \pm 1.1 \mathrm{Ma})$ and TIR-700 (11.2 $\pm 1.3 \mathrm{Ma})$. The ages obtained from the Hercynian plutonic rocks range from $7.4 \pm 1.0 \mathrm{Ma}$ to $42.5 \pm 20.1 \mathrm{Ma}$ with a mean age of $24.7 \pm 8.1$ 
Ma (weighted mean of $21.7 \mathrm{Ma}$ ). Again there are two ages significantly younger that the rest: PAO-940 (12.5 $\pm 2.6 \mathrm{Ma})$ and CAL-100 (7.4 $\pm 1.0 \mathrm{Ma})$. Finally the apatite ages from the low-grade Hercynian metamorphic rocks show a very wide range of ages, varying from $7.8 \pm 0.6 \mathrm{Ma}$ to $32.8 \pm 1.4 \mathrm{Ma}$.

Some of the anomalous apatite fission track ages are grouped geographically. Samples PAL-750 (high-grade Hercynian metamorphic) and PAO-940 (Hercynian plutonic) are both from the Catena Costiera region and both show young ages. The two samples from the northern part of the Peloritani mountains of northeastern Sicily, CAL-100 (Hercynian plutonic) and MAZ-180 (low-grade Hercynian metamorphic), show ages of less than $8 \mathrm{Ma}$. Also three samples dated from the low-grade Hercynian metamorphic rocks and Hercynian plutonic rocks of the northeastern Sila (BOC-1300, MAN-650 and CEC1150) show young ages of $12.6 \pm 1.4 \mathrm{Ma}, 14.6 \pm 1.3 \mathrm{Ma}$ and $14.6 \pm 1.3 \mathrm{Ma}$ respectively.

The zircon fission track central ages derived from the rocks of the Calabrian Arc basement, in contrast to the apatite ages, show a much wider age scatter. They range from $14.4 \pm 1 \mathrm{Ma}$ to an 'Hercynian' age of $299.3 \pm 21 \mathrm{Ma}$. The age obtained from a metaporphyrite of the upper part of the Liguride Complex gives an age of $136.0 \pm 19.7 \mathrm{Ma}$. The samples from the Alpine Group of rocks show zircon fission track ages between $14.4 \pm$ 0.5 Ma and 32.8 $\pm 1.6 \mathrm{Ma}$. The two younger ages of samples COR-390 and COR-410 are both from the northern most part of the Serre. The high-grade Hercynian metamorphic rock samples show zircon ages ranging from $17.5 \pm 1.5 \mathrm{Ma}$ to $99.6 \pm 6 \mathrm{Ma}$. There are two anomalously high ages obtained from samples PAL-750 and SOF-450. The zircon ages from the Hercynian plutonic rocks range from $18.1 \pm 0.9 \mathrm{Ma}$ to $269.4 \pm 12.6 \mathrm{Ma}$. These ages can be split into two categories; the five ages between $18.1 \pm 0.9 \mathrm{Ma}$ and $36.0 \pm 1.3$ $\mathrm{Ma}$ and an older group of ages between $60.0 \pm 2.6 \mathrm{Ma}$ and $269.4 \pm 12.6 \mathrm{Ma}$. All the zircon ages from the Capo Vaticano igneous intrusion (ZAM-125, VAT-118, LIM-130) fall into the younger category.

Finally the zircon fission track ages from the low-grade Hercynian rocks give a range of ages between 134.6 \pm 4.2 Ma and 299.3 $\pm 21.4 \mathrm{Ma}$. Two samples (BOV-30 and BOC780 ) give "Hercynian" ages of $>288 \mathrm{Ma}$, while the others fall between $134.6 \pm 4.2 \mathrm{Ma}$ and 
$178.2 \pm 8.6 \mathrm{Ma}$.

\subsection{APATITE CONFINED TRACK LENGTH ANALYSIS RESULTS}

25 length analyses were obtained from the samples collected for age determination. The results are presented in Table 5.5, and the track length distributions, with locations, shown in Figure 5.4.

As with the age data, the apatite fission track length data is sub-divided by rock type. The samples from the Alpine Group rocks show high mean track lengths (14.34$15.16 \mu \mathrm{m})$ and low standard deviations $(0.88-1.36 \mu \mathrm{m})$. These fall into the so-called 'undisturbed volcanic' field of Gleadow et al. (1986). In a collision zone such a distribution is indicative of rapid cooling through the apatite partial annealing zone (from $125^{\circ} \mathrm{C}$ to $70^{\circ} \mathrm{C}$ ). The measurements made on the samples from the high-grade Hercynian metamorphic rocks give mean track lengths of between $12.49 \mu \mathrm{m}$ and $15.70 \mu \mathrm{m}$ and standard deviations between $0.72 \mu \mathrm{m}$ and $1.61 \mu \mathrm{m}$. With the exception of sample ATT1124, these are similar to the Alpine Group samples. VAL-590 yielded a high value because only seven tracks could be measured from this sample. The Hercynian plutonic rocks show slightly lower mean track lengths of between $9.81 \mu \mathrm{m}$ and $14.90 \mu \mathrm{m}$ and slightly higher standard deviations $(1.18-2.88 \mu \mathrm{m})$. These measurements fall into the 'undisturbed basement' field of Gleadow et al. (1986). There are three anomalous measurements from these Hercynian plutonic samples. SAV-990 and FER-1148 show very low mean track lengths and very high standard deviations and CEC-1150 gives a very high mean track length $(14.90 \mu \mathrm{m})$ related to a low apatite fission track age (14.6 Ma). Finally the three measurements on the low-grade Hercynian metamorphic rocks range from $12.06 \mu \mathrm{m}$ to $13.75 \mu \mathrm{m}$ with the standard deviations varying from 1.79 to $2.47 \mu \mathrm{m}$, although MAN-650 gives a slightly high mean track length of $13.75 \mu \mathrm{m}$, also related to a low apatite fission track age of $14.6 \mathrm{Ma}$ 


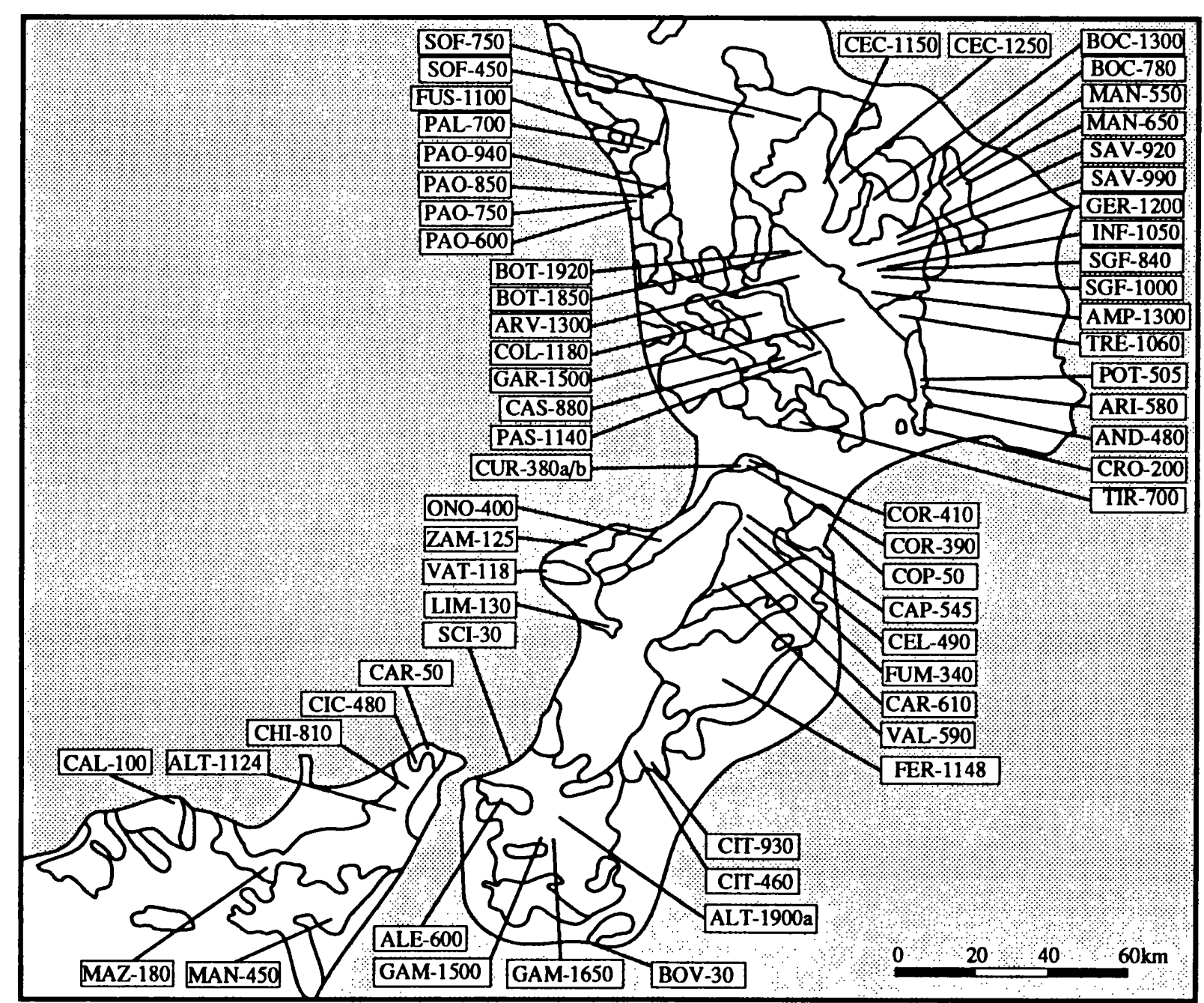

Figure 5.1 Map showing approximate locations of samples collected for fission track analysis from the metamorphic basement rocks of the Calabrian Arc. 
Table 5.1 Apatite fission track data collected from the metamorphic basement complex of the Calabrian Arc

\begin{tabular}{|c|c|c|c|c|c|c|c|c|}
\hline $\begin{array}{l}\text { Sample } \\
\text { Number }\end{array}$ & $\begin{array}{l}\text { No. of } \\
\text { Crystals } \\
\text { Counted }\end{array}$ & $\begin{array}{c}\text { Spontaneous } \\
\rho_{\mathrm{s}} \\
\left(\mathrm{N}_{\mathrm{s}}\right)\end{array}$ & $\begin{array}{c}\text { Induced } \\
\rho_{\mathbf{i}} \\
\left(\mathbf{N}_{\mathbf{i}}\right)\end{array}$ & $\mathrm{P} \chi^{2}$ & $\begin{array}{c}\rho_{8} / \rho_{i} \\
( \pm 1 \sigma)\end{array}$ & $\begin{array}{c}\text { Dosimeter } \\
\text { Pd }\end{array}$ & $\begin{array}{c}\text { Fission Track } \\
\text { Central Age } \\
\mathrm{Ma}( \pm 1 \sigma)\end{array}$ & $\begin{array}{c}\text { Age } \\
\text { Dispersion }\end{array}$ \\
\hline AL-100 & 20 & $\begin{array}{c}0.09073 \\
(71)\end{array}$ & $\begin{array}{l}2.423 \\
(1896)\end{array}$ & $40 \%$ & $0.037 \pm 0.005$ & 1.088 & $7.4 \pm 1.0$ & $21.6 \%$ \\
\hline MAZ-180 & 13 & $\begin{array}{c}0.3814 \\
(196)\end{array}$ & $\begin{array}{l}9.509 \\
(4886)\end{array}$ & $75 \%$ & $0.040 \pm 0.003$ & 1.077 & $7.8 \pm 0.6$ & $0 \%$ \\
\hline CAR-50 & 20 & $\begin{array}{c}0.6449 \\
(820)\end{array}$ & $\begin{array}{l}5.997 \\
(7625)\end{array}$ & $15 \%$ & $0.108 \pm 0.004$ & 1.269 & $24.8 \pm 1.1$ & $7.9 \%$ \\
\hline CIC -480 & 20 & $\begin{array}{c}0.8563 \\
(880)\end{array}$ & $\begin{array}{l}5.577 \\
(5731)\end{array}$ & $70 \%$ & $0.154 \pm 0.006$ & 1.273 & $35.1 \pm 1.3$ & $0.2 \%$ \\
\hline ATT-1124 & 20 & $\begin{array}{c}0.1418 \\
(187)\end{array}$ & $\begin{array}{l}1.302 \\
(1717)\end{array}$ & $98 \%$ & $0.109 \pm 0.008$ & 1.283 & $25.1 \pm 2.0$ & $0 \%$ \\
\hline MAN-450 & 1 & $\begin{array}{c}0.8123 \\
(18)\end{array}$ & $\begin{array}{l}7.581 \\
(168)\end{array}$ & $n / a$ & $0.107 \pm 0.027$ & 1.095 & $21.1 \pm 5.2$ & $\mathrm{n} / \mathrm{a}$ \\
\hline ZAM-125 & 20 & $\begin{array}{l}0.6176 \\
(1029)\end{array}$ & $\begin{array}{c}6.711 \\
(11182)\end{array}$ & $60 \%$ & $0.092 \pm 0.003$ & 1.277 & $20.9 \pm 0.7$ & $0.2 \%$ \\
\hline VAT-118 & 20 & $\begin{array}{c}0.2294 \\
(326)\end{array}$ & $\begin{array}{l}2.331 \\
(3312)\end{array}$ & $97 \%$ & $0.098 \pm 0.006$ & 1.279 & $22.6 \pm 1.3$ & $0 \%$ \\
\hline LIM-130 & 20 & $\begin{array}{c}0.4659 \\
(431)\end{array}$ & $\begin{array}{l}0.483 \\
(4469)\end{array}$ & $20 \%$ & $0.096 \pm 0.005$ & 1.084 & $18.8 \pm 1.0$ & $3.2 \%$ \\
\hline FER-1148 & 20 & $\begin{array}{l}0.6614 \\
(1081)\end{array}$ & $\begin{array}{l}5.259 \\
(8595)\end{array}$ & $45 \%$ & $0.126 \pm 0.004$ & 1.272 & $28.5 \pm 1.0$ & $5.0 \%$ \\
\hline$R-610$ & 20 & $\begin{array}{c}0.3923 \\
(828)\end{array}$ & $\begin{array}{l}4.382 \\
(9250)\end{array}$ & $60 \%$ & $0.090 \pm 0.003$ & 1.322 & $21.1 \pm 0.8$ & $2.3 \%$ \\
\hline VAL-590 & 20 & $\begin{array}{c}0.04053 \\
(75)\end{array}$ & $\begin{array}{c}0.4010 \\
(742)\end{array}$ & $99 \%$ & $0.101 \pm 0.012$ & 1.277 & $23.2 \pm 2.8$ & $0 \%$ \\
\hline FUM-340 & 20 & $\begin{array}{c}0.05995 \\
(45)\end{array}$ & $\begin{array}{c}0.5755 \\
(432)\end{array}$ & $85 \%$ & $0.104 \pm 0.016$ & 1.265 & $23.7 \pm 3.7$ & $0 \%$ \\
\hline CEL-490 & 20 & $\begin{array}{c}0.3035 \\
(190)\end{array}$ & $\begin{array}{l}3.125 \\
(1956)\end{array}$ & $99 \%$ & $0.097 \pm 0.007$ & 1.281 & $22.4 \pm 1.7$ & $0 \%$ \\
\hline P-545 & 50 & $\begin{array}{c}0.02169 \\
(64)\end{array}$ & $\begin{array}{c}0.2027 \\
(598)\end{array}$ & $70 \%$ & $0.107 \pm 0.014$ & 1.307 & $24.9 \pm 3.3$ & $11.7 \%$ \\
\hline OR-390 & 20 & $\begin{array}{c}0.2444 \\
(243)\end{array}$ & $\begin{array}{l}3.753 \\
(3732)\end{array}$ & $80 \%$ & $0.065 \pm 0.004$ & 1.267 & $14.7 \pm 1.0$ & $0.2 \%$ \\
\hline COR -410 & 20 & $\begin{array}{c}0.3114 \\
(439)\end{array}$ & $\begin{array}{l}4.644 \\
(6548)\end{array}$ & $50 \%$ & $0.067 \pm 0.003$ & 1.285 & $15.5 \pm 0.8$ & $1.4 \%$ \\
\hline$R-380 a$ & 20 & $\begin{array}{c}0.4953 \\
(629)\end{array}$ & $\begin{array}{l}6.604 \\
(8388)\end{array}$ & $55 \%$ & $0.075 \pm 0.003$ & 1.282 & $17.1 \pm 0.7$ & $0.5 \%$ \\
\hline J-380b & 50 & $\begin{array}{c}0.02265 \\
(34)\end{array}$ & $\begin{array}{c}0.4050 \\
(608)\end{array}$ & $97 \%$ & $0.056 \pm 0.010$ & 1.287 & $12.9 \pm 2.3$ & $0 \%$ \\
\hline TIR-700 & 20 & $\begin{array}{c}0.1704 \\
(76)\end{array}$ & $\begin{array}{l}2.949 \\
(1315)\end{array}$ & $95 \%$ & $0.058 \pm 0.007$ & 1.080 & $11.2 \pm 1.3$ & $0 \%$ \\
\hline GER-1200 & 20 & $\begin{array}{c}0.4351 \\
(652)\end{array}$ & $\begin{array}{l}5.117 \\
(7668)\end{array}$ & $55 \%$ & $0.085 \pm 0.004$ & 1.271 & $19.4 \pm 0.8$ & $0.1 \%$ \\
\hline$\checkmark-990$ & 10 & $\begin{array}{c}0.2477 \\
(82)\end{array}$ & $\begin{array}{l}1.260 \\
(417)\end{array}$ & $80 \%$ & $0.197 \pm 0.024$ & 1.143 & $40.3 \pm 4.9$ & $0 \%$ \\
\hline AMP-1300 & 20 & $\begin{array}{c}0.4023 \\
(229)\end{array}$ & $\begin{array}{l}2.730 \\
(1554)\end{array}$ & $95 \%$ & $0.147 \pm 0.010$ & 1.312 & $34.4 \pm 2.5$ & $0 \%$ \\
\hline INF-1050 & 30 & $\begin{array}{c}0.2109 \\
(217)\end{array}$ & $\begin{array}{l}1.549 \\
(1594)\end{array}$ & $80 \%$ & $0.136 \pm 0.010$ & 1.297 & $31.4 \pm 2.3$ & $0.1 \%$ \\
\hline BOV-30 & 20 & $\begin{array}{c}0.8337 \\
(933)\end{array}$ & $\begin{array}{l}5.825 \\
(6519)\end{array}$ & $15 \%$ & $0.143 \pm 0.005$ & 1.287 & $32.8 \pm 1.4$ & $9.0 \%$ \\
\hline ALT-1900a & 20 & $\begin{array}{c}0.2818 \\
(192)\end{array}$ & $\begin{array}{l}2.847 \\
(1940)\end{array}$ & $98 \%$ & $0.100 \pm 0.008$ & 1.275 & $22.7 \pm 1.7$ & $0 \%$ \\
\hline GAM-1500 & 20 & $\begin{array}{c}0.04286 \\
(26)\end{array}$ & $\begin{array}{c}0.3907 \\
(237)\end{array}$ & $55 \%$ & $0.110 \pm 0.023$ & 1.292 & $25.2 \pm 5.2$ & $0.8 \%$ \\
\hline SCI-30 & 20 & $\begin{array}{c}0.4365 \\
(266)\end{array}$ & $\begin{array}{l}5.459 \\
(3327)\end{array}$ & $85 \%$ & $0.080 \pm 0.005$ & 1.263 & $18.1 \pm 1.2$ & $0 \%$ \\
\hline PAO-600 & 20 & $\begin{array}{c}0.2189 \\
(114)\end{array}$ & $\begin{array}{l}2.725 \\
(1419)\end{array}$ & $98 \%$ & $0.080 \pm 0.008$ & 1.049 & $14.7 \pm 1.5$ & $0 \%$ \\
\hline PAO-750 & 25 & $\begin{array}{c}0.1843 \\
(135)\end{array}$ & $\begin{array}{l}2.653 \\
(1944)\end{array}$ & $50 \%$ & $0.069 \pm 0.006$ & 1.058 & $13.2 \pm 1.2$ & $0 \%$ \\
\hline PAO-850 & 7 & $\begin{array}{c}0.2072 \\
(33)\end{array}$ & $\begin{array}{l}3.083 \\
(491)\end{array}$ & $90 \%$ & $0.067 \pm 0.012$ & 1.050 & $12.7 \pm 2.3$ & $0 \%$ \\
\hline
\end{tabular}




\begin{tabular}{|c|c|c|c|c|c|c|c|c|}
\hline PAO-940 & 5 & $\begin{array}{c}0.1179 \\
(24)\end{array}$ & $\begin{array}{l}1.783 \\
(363)\end{array}$ & $90 \%$ & $0.066 \pm 0.014$ & 1.049 & $12.5 \pm 2.6$ & $0 \%$ \\
\hline PAL-700 & 30 & $\begin{array}{c}0.0767 \\
(87)\end{array}$ & $\begin{array}{l}1.546 \\
(1754)\end{array}$ & $70 \%$ & $0.050 \pm 0.005$ & 1.062 & $9.5 \pm 1.1$ & $0.5 \%$ \\
\hline CEC-1250 & 50 & $\begin{array}{c}0.04547 \\
(66)\end{array}$ & $\begin{array}{c}0.3982 \\
(578)\end{array}$ & $95 \%$ & $0.114 \pm 0.015$ & 1.049 & $21.5 \pm 2.8$ & $0 \%$ \\
\hline CEC-1150 & 20 & $\begin{array}{c}0.2094 \\
(190)\end{array}$ & $\begin{array}{l}2.147 \\
(1948)\end{array}$ & $99 \%$ & $0.098 \pm 0.007$ & 1.049 & $14.6 \pm 1.3$ & $0 \%$ \\
\hline BOT-1850 & 20 & $\begin{array}{c}0.2139 \\
(117)\end{array}$ & $\begin{array}{l}2.093 \\
(1145)\end{array}$ & $90 \%$ & $0.102 \pm 0.001$ & 1.049 & $19.3 \pm 1.9$ & $0 \%$ \\
\hline ARV-1300 & 20 & $\begin{array}{c}0.08478 \\
(60)\end{array}$ & $\begin{array}{c}0.9707 \\
(687)\end{array}$ & $80 \%$ & $0.087 \pm 0.011$ & 1.117 & $17.5 \pm 2.4$ & $0.2 \%$ \\
\hline POT-505 & 13 & $\begin{array}{c}0.7220 \\
(199)\end{array}$ & $\begin{array}{l}6.085 \\
(1677)\end{array}$ & $99 \%$ & $0.119 \pm 0.009$ & 1.049 & $22.4 \pm 1.7$ & $0 \%$ \\
\hline ARI-580 & 20 & $\begin{array}{l}0.135 \\
(147)\end{array}$ & $\begin{array}{l}0.959 \\
(1044)\end{array}$ & $99 \%$ & $0.141 \pm 0.012$ & 1.049 & $26.5 \pm 2.4$ & $0 \%$ \\
\hline AND-480 & 20 & $\begin{array}{c}0.6178 \\
(338)\end{array}$ & $\begin{array}{l}4.723 \\
(2584)\end{array}$ & $97 \%$ & $0.131 \pm 0.007$ & 1.050 & $25.5 \pm 1.5$ & $0 \%$ \\
\hline CRO-200 & 20 & $\begin{array}{c}0.5205 \\
(328)\end{array}$ & $\begin{array}{l}3.985 \\
(2511)\end{array}$ & $95 \%$ & $0.131 \pm 0.008$ & 1.103 & $25.9 \pm 1.6$ & $0 \%$ \\
\hline TRE-1060 & 20 & $\begin{array}{c}0.4348 \\
(280)\end{array}$ & $\begin{array}{l}3.402 \\
(2191)\end{array}$ & $96 \%$ & $0.128 \pm 0.008$ & 1.049 & $23.6 \pm 1.5$ & $0 \%$ \\
\hline SGF-1000 & 9 & $\begin{array}{c}0.1150 \\
(25)\end{array}$ & $\begin{array}{l}1.007 \\
(219)\end{array}$ & $20 \%$ & $0.114 \pm 0.024$ & 1.118 & $24.1 \pm 5.2$ & $6.6 \%$ \\
\hline SGF-840 & 20 & $\begin{array}{l}0.172 \\
(156)\end{array}$ & $\begin{array}{l}1.087 \\
(986)\end{array}$ & $99 \%$ & $0.158 \pm 0.014$ & 1.022 & $29.0 \pm 2.5$ & $0 \%$ \\
\hline BOC-1300 & 14 & $\begin{array}{c}0.1745 \\
(94)\end{array}$ & $\begin{array}{l}2.547 \\
(1372)\end{array}$ & $99 \%$ & $0.069 \pm 0.007$ & 1.022 & $12.7 \pm 1.4$ & $0 \%$ \\
\hline MAN-650 & 20 & $\begin{array}{c}0.2138 \\
(146)\end{array}$ & $\begin{array}{l}2.910 \\
(1987)\end{array}$ & $75 \%$ & $0.074 \pm 0.006$ & 1.106 & $14.6 \pm 1.3$ & $3.4 \%$ \\
\hline MAN-550 & 2 & $\begin{array}{c}1.842 \\
(74)\end{array}$ & $\begin{array}{l}7.419 \\
(298)\end{array}$ & $<1 \%$ & $0.248 \pm 0.032$ & 1.048 & $42.5 \pm 20.1$ & $64.2 \%$ \\
\hline SAV-920 & 20 & $\begin{array}{c}0.1288 \\
(109)\end{array}$ & $\begin{array}{c}0.7764 \\
(657)\end{array}$ & $99 \%$ & $0.166 \pm 0.017$ & 1.021 & $30.4 \pm 3.2$ & $0 \%$ \\
\hline COL-1180 & 9 & $\begin{array}{c}0.1416 \\
(51)\end{array}$ & $\begin{array}{l}1.472 \\
(530)\end{array}$ & $99 \%$ & $0.096 \pm 0.014$ & 1.048 & $18.1 \pm 2.7$ & $0 \%$ \\
\hline CAS-880 & 10 & $\begin{array}{c}0.1313 \\
(28)\end{array}$ & $\begin{array}{l}1.350 \\
(288)\end{array}$ & $96 \%$ & $0.097 \pm 0.019$ & 1.110 & $18.7 \pm 3.8$ & $0 \%$ \\
\hline PAS-1140 & 14 & $\begin{array}{c}0.2557 \\
(108)\end{array}$ & $\begin{array}{l}2.251 \\
(951)\end{array}$ & $85 \%$ & $0.114 \pm 0.012$ & 1.021 & $19.9 \pm 2.1$ & $0.9 \%$ \\
\hline GAR-1500 & 20 & $\begin{array}{c}0.2184 \\
(137)\end{array}$ & $\begin{array}{l}2.204 \\
(1383)\end{array}$ & $85 \%$ & $0.990 \pm 0.009$ & 1.021 & $17.5 \pm 1.6$ & $7.2 \%$ \\
\hline COP-50 & 20 & $\begin{array}{c}0.3069 \\
(207)\end{array}$ & $\begin{array}{l}2.728 \\
(1840)\end{array}$ & $95 \%$ & $0.113 \pm 0.008$ & 1.069 & $18.8 \pm 1.5$ & $09 \%$ \\
\hline ONO-400 & 20 & $\begin{array}{c}0.09835 \\
(126)\end{array}$ & $\begin{array}{l}0.9226 \\
(1182)\end{array}$ & $65 \%$ & $0.107 \pm 0.010$ & 1.073 & $20.5 \pm 1.9$ & $0.1 \%$ \\
\hline CIT-930 & 20 & $\begin{array}{c}0.2127 \\
(226)\end{array}$ & $\begin{array}{l}2.237 \\
(2376)\end{array}$ & $80 \%$ & $0.095 \pm 0.007$ & 1.048 & $17.9 \pm 1.3$ & $0 \%$ \\
\hline CIT -460 & 20 & $\begin{array}{c}0.2452 \\
(126)\end{array}$ & $\begin{array}{l}2.238 \\
(1150)\end{array}$ & $99 \%$ & $0.110 \pm 0.010$ & 1.066 & $21.0 \pm 2.0$ & $0 \%$ \\
\hline ALE-600 & 20 & $\begin{array}{c}0.4396 \\
(305)\end{array}$ & $\begin{array}{l}3.808 \\
(2642)\end{array}$ & $95 \%$ & $0.115 \pm 0.007$ & 1.103 & $23.2 \pm 1.4$ & $0 \%$ \\
\hline
\end{tabular}

Notes:

(i). track densities ( $\rho$ ) are as measured $\left(\times 10^{6} \mathrm{tr} \mathrm{cm}^{-2}\right)$; numbers of tracks counted $(\mathrm{N})$ shown in brackets;

(ii). analyses by external detector method using 0.5 for the $4 \pi / 2 \pi$ geometry correction factor;

(iii). ages calculated using dosimeter glasses: CN5 with $\zeta_{\mathrm{CN} 5}=359.78 \pm 4.23$ and SRM612 with $\zeta_{\text {SRM612 }}=356.74 \pm 14.91$;

(iv). $\mathrm{P}^{2}$ is the probability for obtaining the $\chi^{2}$ value for $\mathrm{v}$ degrees of freedom, where $\mathrm{v}=$ no. crystals -1 ; 
Table 5.2 Zircon fission track data collected from the metamorphic basement complex of the Calabrian Arc

$$
\begin{aligned}
& \text { Sample } \\
& \text { Number }
\end{aligned}
$$

\begin{abstract}
No. of
Crystals Counted
\end{abstract}

Spon $\rho_{s} / \rho_{i}$
$( \pm 1 \sigma)$

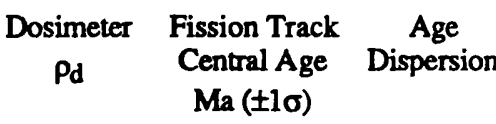

Dosimeter Fission Track

Pd Central Age Disperion

\begin{tabular}{|c|c|c|c|c|c|c|c|c|}
\hline MAZ-180 & 20 & $\begin{array}{l}2.521 \\
(5691)\end{array}$ & $\begin{array}{l}0.7530 \\
(1700)\end{array}$ & $80 \%$ & $3.348 \pm 0.093$ & 0.06361 & $134.6 \pm 4.2$ & $0 \%$ \\
\hline CAR-50 & 20 & $\begin{array}{l}1.245 \\
(3760)\end{array}$ & $\begin{array}{l}0.4405 \\
(1330)\end{array}$ & $50 \%$ & $2.827 \pm 0.090$ & 0.06285 & $112.5 \pm 4.0$ & $0.1 \%$ \\
\hline CIC -480 & 20 & $\begin{array}{l}2.936 \\
(6628)\end{array}$ & $\begin{array}{l}0.7464 \\
(1685)\end{array}$ & $18 \%$ & $3.934 \pm 0.107$ & 0.06133 & $152.1 \pm 5.0$ & $4.5 \%$ \\
\hline CHI-810 & 20 & $\begin{array}{l}0.3970 \\
(1358)\end{array}$ & $\begin{array}{c}0.5873 \\
(2009)\end{array}$ & $50 \%$ & $0.676 \pm 0.024$ & 0.06159 & $26.5 \pm 1.1$ & $3.9 \%$ \\
\hline ATT-1124 & 20 & $\begin{array}{l}0.3051 \\
(1162)\end{array}$ & $\begin{array}{l}0.4209 \\
(1603)\end{array}$ & $20 \%$ & $0.725 \pm 0.028$ & 0.06032 & $28.1 \pm 1.3$ & $8.5 \%$ \\
\hline ZAM-125 & 20 & $\begin{array}{l}0.3292 \\
(3164)\end{array}$ & $\begin{array}{l}0.4210 \\
(4047)\end{array}$ & $10 \%$ & $0.782 \pm 0.019$ & 0.06310 & $31.4 \pm 1.0$ & $6.6 \%$ \\
\hline VAT-118 & 20 & $\begin{array}{l}0.3440 \\
(2463)\end{array}$ & $\begin{array}{l}0.3984 \\
(2853)\end{array}$ & $20 \%$ & $0.863 \pm 0.024$ & 0.06184 & $34.0 \pm 1.2$ & $5.4 \%$ \\
\hline LIM-130 & 20 & $\begin{array}{l}0.3580 \\
(1874)\end{array}$ & $\begin{array}{l}0.4160 \\
(2178)\end{array}$ & $75 \%$ & $0.860 \pm 0.027$ & 0.06563 & $36.0 \pm 1.3$ & $0 \%$ \\
\hline FER-1148 & 20 & $\begin{array}{l}1.541 \\
(5421)\end{array}$ & $\begin{array}{l}0.6095 \\
(2144)\end{array}$ & $10 \%$ & $2.529 \pm 0.065$ & 0.06260 & $99.6 \pm 3.5$ & $7.6 \%$ \\
\hline CAR-610 & 20 & $\begin{array}{l}0.2595 \\
(1283)\end{array}$ & $\begin{array}{l}0.4170 \\
(2062)\end{array}$ & $80 \%$ & $0.622 \pm 0.022$ & 0.06234 & $24.7 \pm 1.0$ & $0.2 \%$ \\
\hline VAL-590 & 20 & $\begin{array}{l}0.1378 \\
(1338)\end{array}$ & $\begin{array}{l}0.2043 \\
(1984)\end{array}$ & $99 \%$ & $0.674 \pm 0.024$ & 0.06209 & $26.7 \pm 1.0$ & $0 \%$ \\
\hline FUM-340 & 20 & $\begin{array}{l}0.2353 \\
(1095)\end{array}$ & $\begin{array}{l}0.3260 \\
(1517)\end{array}$ & $55 \%$ & $0.722 \pm 0.029$ & 0.06512 & $30.0 \pm 1.3$ & $1.6 \%$ \\
\hline CEL-490 & 20 & $\begin{array}{l}0.3376 \\
(1183)\end{array}$ & $\begin{array}{l}0.5037 \\
(1765)\end{array}$ & $75 \%$ & $0.670 \pm 0.025$ & 0.06537 & $27.9 \pm 1.1$ & $0.1 \%$ \\
\hline CAP-545 & 20 & $\begin{array}{c}0.0606 \\
(437)\end{array}$ & $\begin{array}{c}0.0934 \\
(674)\end{array}$ & $99 \%$ & $0.648 \pm 0.040$ & 0.06058 & $25.0 \pm 1.6$ & $0 \%$ \\
\hline COR-390 & 20 & $\begin{array}{l}0.3462 \\
(1966)\end{array}$ & $\begin{array}{l}0.7949 \\
(4514)\end{array}$ & $85 \%$ & $0.436 \pm 0.012$ & 0.06411 & $17.8 \pm 0.6$ & $0 \%$ \\
\hline COR-410 & 20 & $\begin{array}{l}0.3419 \\
(1430)\end{array}$ & $\begin{array}{l}0.9647 \\
(4035)\end{array}$ & $40 \%$ & $0.354 \pm 0.011$ & 0.06386 & $14.4 \pm 0.5$ & $2.3 \%$ \\
\hline TIR-700 & 20 & $\begin{array}{l}0.4266 \\
(1808)\end{array}$ & $\begin{array}{l}0.7271 \\
(3069)\end{array}$ & $40 \%$ & $0.590 \pm 0.018$ & 0.06007 & $22.6 \pm 0.8$ & $4.1 \%$ \\
\hline AMP-1300 & 15 & $\begin{array}{l}1.1175 \\
(3320)\end{array}$ & $\begin{array}{c}0.3936 \\
(1112)\end{array}$ & $30 \%$ & $2.986 \pm 0.103$ & 0.06108 & $114.9 \pm 4.6$ & $4.5 \%$ \\
\hline SAV-990 & 10 & $\begin{array}{l}4.351 \\
(2109)\end{array}$ & $\begin{array}{c}0.4765 \\
(231)\end{array}$ & $90 \%$ & $9.130 \pm 0.633$ & 0.03442 & $197.6 \pm 14.3$ & $0 \%$ \\
\hline INF-1050 & 17 & $\begin{array}{c}1.932 \\
(4040)\end{array}$ & $\begin{array}{c}0.5049 \\
(1056)\end{array}$ & $30 \%$ & $3.826 \pm 0.132$ & 0.06083 & $146.9 \pm 5.9$ & $5.2 \%$ \\
\hline BOV-30 & 10 & $\begin{array}{l}4.3840 \\
(4615)\end{array}$ & $\begin{array}{c}0.5700 \\
(600)\end{array}$ & $<1 \%$ & $7.692 \pm 0.334$ & 0.06335 & $299.3 \pm 21.4$ & $17.0 \%$ \\
\hline SCI-30 & 20 & $\begin{array}{l}0.4740 \\
(1720)\end{array}$ & $\begin{array}{l}0.5065 \\
(1838)\end{array}$ & $20 \%$ & $0.936 \pm 0.031$ & 0.06487 & $38.8 \pm 1.6$ & $8.1 \%$ \\
\hline PAO-600 & 20 & $\begin{array}{c}0.3257 \\
(794)\end{array}$ & $\begin{array}{c}0.3339 \\
(814)\end{array}$ & $95 \%$ & $0.975 \pm 0.049$ & 0.03711 & $23.1 \pm 1.2$ & $0 \%$ \\
\hline PAO-750 & 20 & $\begin{array}{l}0.5606 \\
(1351)\end{array}$ & $\begin{array}{c}0.4760 \\
(1147)\end{array}$ & $20 \%$ & $1.178 \pm 0.047$ & 0.03763 & $28.3 \pm 1.4$ & $7.6 \%$ \\
\hline PAO-850 & 20 & $\begin{array}{c}0.2591 \\
(592)\end{array}$ & $\begin{array}{c}0.2516 \\
(575)\end{array}$ & $95 \%$ & $1.023 \pm 0.060$ & 0.03563 & $23.4 \pm 1.5$ & $0 \%$ \\
\hline PAO-940 & 20 & $\begin{array}{c}0.3569 \\
(875)\end{array}$ & $\begin{array}{l}0.4524 \\
(1109)\end{array}$ & $75 \%$ & $0.789 \pm 0.036$ & 0.03598 & $18.1 \pm 0.9$ & $1.0 \%$ \\
\hline FUS-1100 & 3 & $\begin{array}{l}3.069 \\
(340)\end{array}$ & $\begin{array}{c}0.5144 \\
(57)\end{array}$ & $75 \%$ & $5.965 \pm 0.854$ & 0.03607 & $136.0 \pm 19.7$ & $0 \%$ \\
\hline PAL-650 & 20 & $\begin{array}{c}1.301 \\
(2883)\end{array}$ & $\begin{array}{c}0.3096 \\
(686)\end{array}$ & $20 \%$ & $4.203 \pm 0.179$ & 0.03398 & $90.2 \pm 4.6$ & $8.8 \%$ \\
\hline SOF-450 & 20 & $\begin{array}{l}1.574 \\
(3901)\end{array}$ & $\begin{array}{c}0.3792 \\
(940)\end{array}$ & $70 \%$ & $4.150 \pm 0.150$ & 0.03789 & $99.6 \pm 4.3$ & $4.2 \%$ \\
\hline SOF-750 & 20 & $\begin{array}{l}1.964 \\
(4326)\end{array}$ & $\begin{array}{c}0.3147 \\
(693)\end{array}$ & $70 \%$ & $6.242 \pm 0.255$ & 0.03485 & $137.5 \pm 6.3$ & $0.2 \%$ \\
\hline CEC-1250 & 11 & $\begin{array}{l}3.180 \\
(2290)\end{array}$ & $\begin{array}{c}0.5568 \\
(401)\end{array}$ & $5 \%$ & $5.711 \pm 0.309$ & 0.03694 & $128.9 \pm 9.5$ & $14.5 \%$ \\
\hline
\end{tabular}
$\mathrm{Ma}( \pm 1 \sigma)$ 


\begin{tabular}{|c|c|c|c|c|c|c|c|c|}
\hline CEC-1150 & 17 & $\begin{array}{r}2.832 \\
(5177)\end{array}$ & $\begin{array}{l}0.332 \\
(607)\end{array}$ & $70 \%$ & $8.530 \pm 0.366$ & 0.03459 & $185.7 \pm 8.8$ & $0.8 \%$ \\
\hline BOT-1920 & 20 & $\begin{array}{l}0.6732 \\
(1669)\end{array}$ & $\begin{array}{l}0.4982 \\
(1235)\end{array}$ & $40 \%$ & $1.351 \pm 0.051$ & 0.03407 & $29.3 \pm 1.3$ & $4.6 \%$ \\
\hline BOT-1850 & 20 & $\begin{array}{l}0.9077 \\
(1999)\end{array}$ & $\begin{array}{l}0.4795 \\
(1056)\end{array}$ & $95 \%$ & $1.893 \pm 0.072$ & 0.03737 & $45.0 \pm 1.9$ & $0 \%$ \\
\hline ARV-1300 & 20 & $\begin{array}{c}0.510 \\
(1109)\end{array}$ & $\begin{array}{l}0.5091 \\
(1107)\end{array}$ & $40 \%$ & $1.002 \pm 0.043$ & 0.03772 & $24.1 \pm 1.2$ & $7.2 \%$ \\
\hline POT-505 & 2 & $\begin{array}{l}1.606 \\
(467)\end{array}$ & $\begin{array}{c}0.2029 \\
(59)\end{array}$ & $40 \%$ & $7.915 \pm 1.094$ & 0.03546 & $176.8 \pm 24.7$ & $0 \%$ \\
\hline AND-480 & 20 & $\begin{array}{l}4.090 \\
(9460)\end{array}$ & $\begin{array}{l}0.9265 \\
(2143)\end{array}$ & $50 \%$ & $4.414 \pm 0.106$ & 0.03520 & $98.5 \pm 3.1$ & $0 \%$ \\
\hline CRO-200 & 20 & $\begin{array}{c}1.252 \\
(2635)\end{array}$ & $\begin{array}{c}0.4608 \\
(970)\end{array}$ & $85 \%$ & $2.717 \pm 0.102$ & 0.03477 & $60.0 \pm 2.6$ & $0 \%$ \\
\hline TRE-1060 & 20 & $\begin{array}{l}2.200 \\
(4605)\end{array}$ & $\begin{array}{c}0.2097 \\
(608)\end{array}$ & $65 \%$ & $7.569 \pm 0.327$ & 0.03494 & $166.7 \pm 8.0$ & $1.2 \%$ \\
\hline SGF-1000 & 20 & $\begin{array}{r}2.315 \\
(2789)\end{array}$ & $\begin{array}{c}0.2913 \\
(351)\end{array}$ & $90 \%$ & $7.946 \pm 0.450$ & 0.03416 & $171.0 \pm 10.3$ & $0 \%$ \\
\hline SGF-840 & 12 & $\begin{array}{l}2.217 \\
(2548)\end{array}$ & $\begin{array}{c}0.2810 \\
(323)\end{array}$ & $90 \%$ & $7.889 \pm 0.466$ & 0.03424 & $170.3 \pm 10.6$ & $0 \%$ \\
\hline BOC-1300 & 12 & $\begin{array}{c}3.063 \\
(4836)\end{array}$ & $\begin{array}{c}0.3661 \\
(578)\end{array}$ & 95\% & $8.367 \pm 0.368$ & 0.03381 & $178.2 \pm 8.6$ & $0 \%$ \\
\hline BOC-780 & 7 & $\begin{array}{c}2.493 \\
(1830)\end{array}$ & $\begin{array}{c}0.1975 \\
(145)\end{array}$ & $70 \%$ & $12.621 \pm 1.089$ & 0.03669 & $289.0 \pm 25.6$ & $0 \%$ \\
\hline MAN-650 & 20 & $\begin{array}{r}1.733 \\
(2689)\end{array}$ & $\begin{array}{c}0.2527 \\
(392)\end{array}$ & $99 \%$ & $6.860 \pm 0.371$ & 0.03746 & $162.0 \pm 9.4$ & $0 \%$ \\
\hline MAN-550 & 5 & $\begin{array}{l}2.783 \\
(925)\end{array}$ & $\begin{array}{c}0.3159 \\
(105)\end{array}$ & $60 \%$ & $8.810 \pm 0.907$ & 0.03468 & $192.2 \pm 20.2$ & $0 \%$ \\
\hline SAV-920 & 20 & $\begin{array}{r}4.228 \\
(7085)\end{array}$ & $\begin{array}{c}0.3616 \\
(606)\end{array}$ & $99 \%$ & $11.691 \pm 0.495$ & 0.03685 & $269.4 \pm 12.6$ & $0 \%$ \\
\hline COL-1180 & 20 & $\begin{array}{l}0.5264 \\
(1254)\end{array}$ & $\begin{array}{c}0.3652 \\
(870)\end{array}$ & $65 \%$ & $1.441 \pm 0.064$ & 0.03572 & $32.8 \pm 1.6$ & $2.1 \%$ \\
\hline CAS-880 & 20 & $\begin{array}{l}0.5466 \\
(1302)\end{array}$ & $\begin{array}{l}0.4424 \\
(1054)\end{array}$ & $90 \%$ & $1.235 \pm 0.051$ & 0.03529 & $27.8 \pm 1.3$ & $0.1 \%$ \\
\hline PAS-1140 & 20 & $\begin{array}{l}0.5085 \\
(1310)\end{array}$ & $\begin{array}{l}0.4433 \\
(1142)\end{array}$ & $40 \%$ & $1.147 \pm 0.046$ & 0.03372 & $24.5 \pm 1.2$ & $6.6 \%$ \\
\hline GAR-1500 & 9 & $\begin{array}{c}0.4203 \\
(227)\end{array}$ & $\begin{array}{c}0.4425 \\
(239)\end{array}$ & $70 \%$ & $0.950 \pm 0.088$ & 0.03511 & $21.3 \pm 2.0$ & $0 \%$ \\
\hline COP-50 & 20 & $\begin{array}{c}0.3412 \\
(775)\end{array}$ & $\begin{array}{c}0.3161 \\
(718)\end{array}$ & $99 \%$ & $1.080 \pm 0.056$ & 0.03364 & $23.1 \pm 1.3$ & $0 \%$ \\
\hline ONO-400 & 20 & $\begin{array}{l}0.4360 \\
(1425)\end{array}$ & $\begin{array}{l}0.3225 \\
(1054)\end{array}$ & $80 \%$ & $1.352 \pm 0.055$ & 0.03390 & $29.2 \pm 1.3$ & $0.1 \%$ \\
\hline CIT-930 & 20 & $\begin{array}{c}1.692 \\
(3163)\end{array}$ & $\begin{array}{c}0.1952 \\
(365)\end{array}$ & $75 \%$ & $8.666 \pm 0.479$ & 0.03555 & $193.8 \pm 11.4$ & $0.1 \%$ \\
\hline GAM-1650 & 5 & $\begin{array}{c}0.3638 \\
(262)\end{array}$ & $\begin{array}{c}0.4943 \\
(356)\end{array}$ & $60 \%$ & $0.736 \pm 0.060$ & 0.03729 & $17.5 \pm 1.5$ & $0 \%$ \\
\hline
\end{tabular}

\section{Notes:}

(i). track densities ( $\rho$ ) are as measured $\left(x 10^{7} \mathrm{t} \mathrm{cm}^{-2}\right)$; numbers of tracks counted $(\mathrm{N})$ shown in brackets;

(ii). analyses by external detector method using 0.5 for the $4 \pi / 2 \pi$ geometry correction factor;

(iii). ages calculated using dosimeter glass: $\mathrm{CN} 2$ with $\zeta_{\mathrm{CN} 2}=127.72 \pm 3.38$

(iv). $\mathrm{P} \chi^{2}$ is the probability for obtaining $\chi^{2}$ value for $v$ degrees of freedom, where $v=$ no. crystals -1 ; 


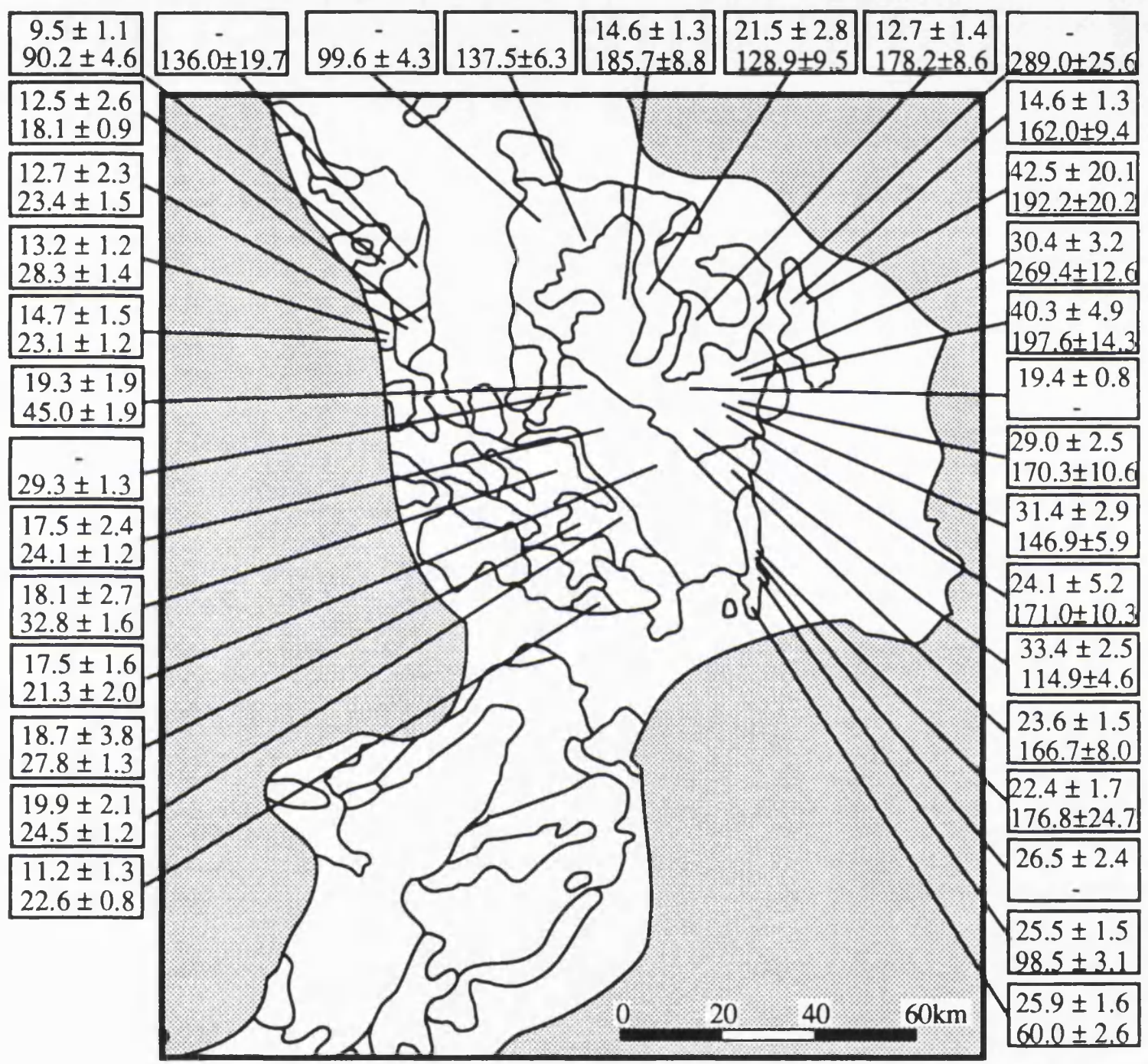

Figure 5.2 Fission Track Data from the Sila and the Catena Costiera

Key: Apatite Age $\pm 1 \sigma$ Zircon Age $\pm 1 \sigma$ 


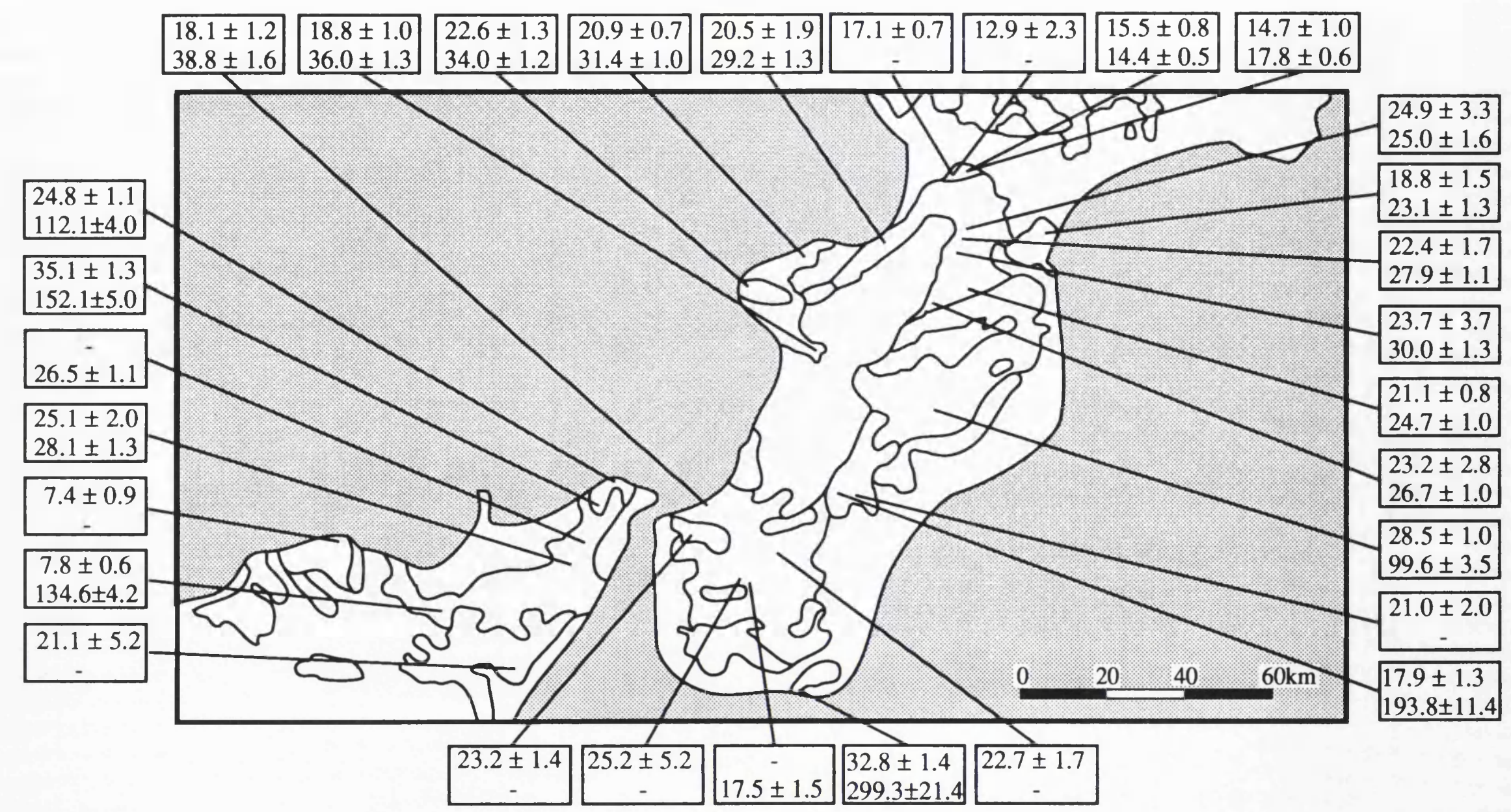

Figure 5.3 Fission Track Data from the Serre, Aspromonte and Peloritani Mountains Key: 
Table 5.3 Summary of Fission Track Results from the Calabrian Arc Basement Units

\begin{tabular}{|c|c|c|c|c|c|}
\hline Sample & Location & Rock Type & $\begin{array}{c}\text { Geological } \\
\text { Unit }\end{array}$ & $\begin{array}{c}\text { Apatite } \\
\text { Age } \\
\end{array}$ & $\begin{array}{c}\text { Zircon } \\
\text { Age } \\
\end{array}$ \\
\hline \multicolumn{6}{|c|}{ ALPINE GROUP } \\
\hline $\begin{array}{l}\text { CUR-380b } \\
\text { PAO-750 } \\
\text { PAO-850 } \\
\text { COL-1180 } \\
\text { COR-390 } \\
\text { COR-410 } \\
\text { CUR-380a } \\
\text { PAO-600 } \\
\text { CAS-880 } \\
\text { PAS-1140 } \\
\text { FUS-1100 }\end{array}$ & $\begin{array}{l}\text { Curinga } \\
\text { Paola } \\
\text { Paola } \\
\text { Colosimi } \\
\text { Cortale } \\
\text { Cortale } \\
\text { Curinga } \\
\text { Paola } \\
\text { Castagna } \\
\text { Lago di Passante } \\
\text { Fuscaldo }\end{array}$ & $\begin{array}{l}\text { Biotite Schist } \\
\text { Phillite } \\
\text { Chloritic Phyllite } \\
\text { Phillite } \\
\text { Retrograde Mylonitic Gneiss } \\
\text { Retrograde Augen Gneiss } \\
\text { Garnetiferous Gneiss } \\
\text { Proto-Mylonite } \\
\text { Retrograde Proto-Mylonite } \\
\text { Protomylonitic Granite } \\
\text { Metabasite }\end{array}$ & $\begin{array}{l}\text { Bagni } \\
\text { Bagni } \\
\text { Bagni } \\
\text { Bagni } \\
\text { Castagna } \\
\text { Castagna } \\
\text { Castagna } \\
\text { Castagna } \\
\text { Castagna } \\
\text { Castagna } \\
\text { Liguride Complex }\end{array}$ & $\begin{array}{l}12.9 \pm 2.3 \\
13.2 \pm 1.2 \\
12.7 \pm 2.3 \\
18.1 \pm 2.7 \\
14.7 \pm 1.0 \\
15.5 \pm 0.8 \\
17.1 \pm 0.7 \\
14.7 \pm 1.5 \\
18.7 \pm 3.8 \\
19.9 \pm 2.1 \\
-\end{array}$ & $\begin{array}{r}28.3 \pm 1.4 \\
23.4 \pm 1.5 \\
32.8 \pm 1.6 \\
17.8 \pm 0.6 \\
14.4 \pm 0.5 \\
23.1 \pm 1.2 \\
27.8 \pm 1.3 \\
24.5 \pm 1.2 \\
136.0 \pm 19.7\end{array}$ \\
\hline \multicolumn{6}{|c|}{ HERCYNIAN GROUP } \\
\hline $\begin{array}{l}\text { PAL-750 } \\
\text { SOF-450 } \\
\text { ARV-1300 } \\
\text { CAR-610 } \\
\text { VAL-590 } \\
\text { FUM-340 } \\
\text { CEL-490 } \\
\text { CAP-545 } \\
\text { COP-50 } \\
\text { ONO-400 } \\
\text { BOT-1920 } \\
\text { BOT-1850 } \\
\text { GAR-1500 } \\
\text { TR-700 } \\
\text { ATT-1124 } \\
\text { ALT-1900a } \\
\text { AME-1500 } \\
\text { SCI-30 } \\
\text { GAM-1650 }\end{array}$ & $\begin{array}{l}\text { Palazzello } \\
\text { San Sofia dEpiro } \\
\text { Lago Arvo } \\
\text { Cardinale } \\
\text { Vallelonga } \\
\text { Fossa Umbrita } \\
\text { Celia } \\
\text { Torre Capona } \\
\text { Copanello } \\
\text { San Onofrio } \\
\text { Mt. Botte Donato } \\
\text { Mt. Botte Donato } \\
\text { Mt. Gariglione } \\
\text { Tiriolo } \\
\text { Mt. Attenamare } \\
\text { Montalto } \\
\text { Gambarie } \\
\text { Scilla } \\
\text { Gambarie }\end{array}$ & $\begin{array}{l}\text { Biotite Gneiss } \\
\text { Garnetiferous Gneiss } \\
\text { Biotite, Chlorite Schist } \\
\text { Meta-Tonalite } \\
\text { Meta-Tonalite } \\
\text { Granulite (Kinzigite) } \\
\text { Granulite Paragneiss } \\
\text { Metabasite } \\
\text { Biotite Orthogneiss } \\
\text { Garnet Sillimanite Gneiss } \\
\text { Sillimanite Gneiss } \\
\text { Sillimanite Gneiss } \\
\text { Gneiss } \\
\text { Gametiferous Leucogneiss } \\
\text { Biotite Schist } \\
\text { Proto-Mylonitic Gneiss } \\
\text { Retrograde Amphibolite } \\
\text { Granodioritic Gneiss } \\
\text { Protomylonitic Gt Gneiss }\end{array}$ & $\begin{array}{l}\text { High-Grade Met } \\
\text { High-Grade Met } \\
\text { High-Grade Met } \\
\text { High-Grade Met } \\
\text { High-Grade Met } \\
\text { High-Grade Met } \\
\text { High-Grade Met } \\
\text { High-Grade Met } \\
\text { High-Grade Met } \\
\text { High-Grade Met } \\
\text { High-Grade Met } \\
\text { High-Grade Met } \\
\text { High-Grade Met } \\
\text { High-Grade Met } \\
\text { High-Grade Met } \\
\text { High-Grade Met } \\
\text { High-Grade Met } \\
\text { High-Grade Met } \\
\text { High-Grade Met }\end{array}$ & $\begin{array}{r}9.5 \pm 1.1 \\
17.5 \pm 2.4 \\
21.1 \pm 0.8 \\
23.2 \pm 2.8 \\
23.7 \pm 3.7 \\
22.4 \pm 1.7 \\
24.9 \pm 3.3 \\
18.8 \pm 1.5 \\
20.5 \pm 1.9 \\
19.3 \pm 1.9 \\
17.5 \pm 1.6 \\
11.2 \pm 1.3 \\
25.1 \pm 2.0 \\
22.7 \pm 1.7 \\
25.2 \pm 5.2 \\
18.1 \pm 1.2 \\
-\end{array}$ & $\begin{array}{r}90.2 \pm 4.6 \\
99.6 \pm 4.3 \\
24.1 \pm 1.2 \\
24.7 \pm 1.0 \\
26.7 \pm 1.0 \\
30.0 \pm 1.3 \\
27.9 \pm 1.1 \\
25.0 \pm 1.6 \\
23.1 \pm 1.3 \\
29.2 \pm 1.3 \\
29.3 \pm 1.3 \\
45.0 \pm 1.9 \\
21.3 \pm 2.0 \\
22.6 \pm 0.8 \\
28.1 \pm 1.3 \\
- \\
38.8 \pm 1.6 \\
17.5 \pm 1.5\end{array}$ \\
\hline $\begin{array}{l}\text { PAO-940 } \\
\text { ZAM-125 } \\
\text { VAT-118 } \\
\text { LIM-130 } \\
\text { SOF-750 } \\
\text { POT-505 } \\
\text { AND-480 } \\
\text { CRO-200 } \\
\text { GER-1200 } \\
\text { AMP-1300 } \\
\text { INF-1050 } \\
\text { FER-1148 } \\
\text { CAL-100 } \\
\text { CAR-50 } \\
\text { CIC-480 } \\
\text { CHI-810 } \\
\text { CIT-930 } \\
\text { CIT-460 } \\
\text { ALE-600 } \\
\text { SAV-990 } \\
\text { SAV-920 } \\
\text { CEC-1250 } \\
\text { CEC-1150 } \\
\text { TRE-1050 } \\
\text { SGF-1000 } \\
\text { SGF-840 } \\
\text { MAN-550 }\end{array}$ & $\begin{array}{l}\text { Paola } \\
\text { Zambrone } \\
\text { Capo Vaticano } \\
\text { Limbadi } \\
\text { San Sofia dEpiro } \\
\text { Fiumara Potamo } \\
\text { Andali } \\
\text { Cropani } \\
\text { Germano } \\
\text { Lago Ampollino } \\
\text { Infantino } \\
\text { Ferdinandea } \\
\text { Capo di Calava } \\
\text { Capo Rascalmo } \\
\text { Mt. Ciccia } \\
\text { Pzo. Chiarino } \\
\text { Cittanova } \\
\text { Cittanova } \\
\text { San Alessio } \\
\text { Savelli } \\
\text { Savelli } \\
\text { Lago Cecita } \\
\text { Lago Cecita } \\
\text { Trepido } \\
\text { San Giovanni in Fiore } \\
\text { San Giovanni in Fiore } \\
\text { Mandatomicio }\end{array}$ & $\begin{array}{l}\text { Granitic Gneiss } \\
\text { Foliated Granitic Gneiss } \\
\text { Granitic Gneiss } \\
\text { Granitic Gneiss } \\
\text { Leucogranitic Gneiss } \\
\text { Leucogranitic Gneiss } \\
\text { Quartz Monzonite } \\
\text { Granitic Gneiss } \\
\text { Granitic Gneiss } \\
\text { Leucogranitic Gneiss } \\
\text { Granitic Gneiss } \\
\text { Granitic Gneiss } \\
\text { Leucogranite } \\
\text { Leucogranitic Gneiss } \\
\text { Alkali Granitic Gneiss } \\
\text { Leucogranitic Gneiss } \\
\text { Leucogranitic Gneiss } \\
\text { Leucogranitic Gneiss } \\
\text { Leucogranitic Gneiss } \\
\text { Granitic Gneiss } \\
\text { Granitic Gneiss } \\
\text { Granitic Gneiss } \\
\text { Granitic Gneiss } \\
\text { Granitic Gneiss } \\
\text { Alkali Granitic Gneiss } \\
\text { Granitic Gneiss } \\
\text { Gametiferous Granite }\end{array}$ & $\begin{array}{l}\text { Plutonic } \\
\text { Plutonic } \\
\text { Plutonic } \\
\text { Plutonic } \\
\text { Plutonic } \\
\text { Plutonic } \\
\text { Plutonic } \\
\text { Plutonic } \\
\text { Plutonic } \\
\text { Plutonic } \\
\text { Plutonic } \\
\text { Plutonic } \\
\text { Plutonic } \\
\text { Plutonic } \\
\text { Plutonic } \\
\text { Plutonic } \\
\text { Plutonic } \\
\text { Plutonic } \\
\text { Plutonic } \\
\text { Plutonic } \\
\text { Plutonic } \\
\text { Plutonic } \\
\text { Plutonic } \\
\text { Plutonic } \\
\text { Plutonic } \\
\text { Plutonic } \\
\text { Plutonic }\end{array}$ & $\begin{array}{r}12.5 \pm 2.6 \\
20.9 \pm 0.7 \\
22.6 \pm 1.3 \\
18.8 \pm 1.0 \\
22.4 \pm 1.7 \\
25.5 \pm 1.5 \\
25.9 \pm 1.6 \\
19.4 \pm 0.8 \\
34.4 \pm 2.5 \\
31.4 \pm 2.3 \\
28.5 \pm 1.0 \\
7.4 \pm 1.0 \\
24.8 \pm 1.1 \\
35.1 \pm 1.3 \\
- \\
17.9 \pm 1.3 \\
21.0 \pm 2.0 \\
23.2 \pm 1.4 \\
40.3 \pm 4.9 \\
30.4 \pm 3.2 \\
21.5 \pm 2.8 \\
14.6 \pm 1.3 \\
23.6 \pm 1.5 \\
24.1 \pm 5.2 \\
29.0 \pm 2.5 \\
42.5 \pm 20.1\end{array}$ & $\begin{array}{r}18.1 \pm 0.9 \\
31.4 \pm 1.0 \\
34.0 \pm 1.2 \\
36.0 \pm 1.3 \\
137.5 \pm 6.3 \\
176.8 \pm 24.7 \\
98.5 \pm 3.1 \\
60.0 \pm 2.6 \\
\mathrm{~m} \\
114.9 \pm 4.6 \\
146.9 \pm 5.9 \\
99.6 \pm 3.5 \\
\mathrm{mt} \\
112.5 \pm 4.0 \\
152.1 \pm 5.0 \\
26.5 \pm 1.1 \\
193.8 \pm 11.4 \\
- \\
197.6 \pm 14.3 \\
269.4 \pm 12.6 \\
128.9 \pm 9.5 \\
185.7 \pm 8.8 \\
166.7 \pm 8.0 \\
171.0 \pm 10.3 \\
170.3 \pm 10.6 \\
192.2 \pm 20.2\end{array}$ \\
\hline $\begin{array}{l}\text { ARI-580 } \\
\text { BOV-30 } \\
\text { MAZ-180 } \\
\text { MAN-450 } \\
\text { BOC-1300 } \\
\text { BOC-780 } \\
\text { MAN-650 } \\
\end{array}$ & $\begin{array}{l}\text { Arietta } \\
\text { Bova Marina } \\
\text { Mazzara } \\
\text { Mandanici } \\
\text { Bocchigliero } \\
\text { Bocchigliero } \\
\text { Mandatorricio }\end{array}$ & $\begin{array}{l}\text { Chlorite, Muscovite Schist } \\
\text { Augen Gneiss } \\
\text { Phillite } \\
\text { Phillite } \\
\text { Bi, Ms, Chl Augen Gneiss } \\
\text { Conglomerate } \\
\text { Biotite, Muscovite Schist }\end{array}$ & $\begin{array}{l}\text { Low-Grade Met } \\
\text { Low-Grade Met } \\
\text { Low-Grade Met } \\
\text { Low-Grade Met } \\
\text { Low-Grade Met } \\
\text { Low-Grade Met } \\
\text { Low-Grade Met }\end{array}$ & $\begin{array}{r}26.5 \pm 2.4 \\
32.8 \pm 1.4 \\
7.8 \pm 0.6 \\
21.1 \pm 5.2 \\
12.7 \pm 1.4 \\
- \\
14.6 \pm 1.3\end{array}$ & $\begin{array}{r}299.3 \pm 21.4 \\
134.6 \pm 4.2 \\
- \\
178.2 \pm 8.6 \\
289.0 \pm 25.6 \\
162.0 \pm 9.4\end{array}$ \\
\hline
\end{tabular}


Table 5.4 Summary of Fission Track Results from the Calabrian Arc Basement Units (Grouped by region)

\begin{tabular}{|c|c|c|c|c|c|}
\hline ple & ocation & Rock Type & $\begin{array}{c}\text { Geological } \\
\text { Unit }\end{array}$ & $\begin{array}{c}\text { Apatite } \\
\text { Age }\end{array}$ & $\begin{array}{c}\text { Zircon } \\
\text { Age }\end{array}$ \\
\hline $\begin{array}{l}\text { Catena Co } \\
\text { PAO-600 } \\
\text { PAO-750 } \\
\text { PAO-850 } \\
\text { PAO-940 } \\
\text { FUS-1100 } \\
\text { PAL-750 }\end{array}$ & $\begin{array}{l}\text { tlera } \\
\text { Paola } \\
\text { Paola } \\
\text { Paola } \\
\text { Paoloa } \\
\text { Fuscaldo } \\
\text { Palazzello }\end{array}$ & $\begin{array}{l}\text { Proto-Mylonite } \\
\text { Phillite } \\
\text { Chloritic Phyllite } \\
\text { Granitic Gneiss } \\
\text { Metabasite } \\
\text { Biotite Gneiss }\end{array}$ & $\begin{array}{l}\text { Castagna (AG) } \\
\text { Bagni (AG) } \\
\text { Bagni (AG) } \\
\text { Plutonic } \\
\text { Liguride Complex } \\
\text { Figh-Grade Met }\end{array}$ & $\begin{array}{c}14.7 \pm 1.5 \\
13.2 \pm 1.2 \\
12.7 \pm 2.3 \\
12.5 \pm 2.6 \\
9.5 \pm 1.1\end{array}$ & $\begin{array}{r}23.1 \pm 1.2 \\
28.3 \pm 1.4 \\
23.4 \pm 1.5 \\
18.1 \pm 0.9 \\
136.0 \pm 19.7 \\
90.2 \pm 4.6\end{array}$ \\
\hline $\begin{array}{l}\text { SIla } \\
\text { COL-1180 } \\
\text { CAS-880 } \\
\text { PAS-1140 } \\
\text { ARV-1300 } \\
\text { BOT-1920 } \\
\text { BOT-1850 } \\
\text { GAR-1500 } \\
\text { TIR-700 } \\
\text { SOF-450 } \\
\text { SOF-750 } \\
\text { POT-505 } \\
\text { AND-480 } \\
\text { CRO-200 } \\
\text { GER-1200 } \\
\text { AMP-1300 } \\
\text { INF-1050 } \\
\text { SAV-990 } \\
\text { SAV-920 } \\
\text { CEC-1250 } \\
\text { CEC-1150 } \\
\text { TRE-1050 } \\
\text { SGF-1000 } \\
\text { SGF-840 } \\
\text { MAN-550 } \\
\text { ARI-580 } \\
\text { BOC-1300 } \\
\text { BOC-780 } \\
\text { MAN-650 }\end{array}$ & $\begin{array}{l}\text { Colosimi } \\
\text { Castagna } \\
\text { Lago di Passante } \\
\text { Lago Arvo } \\
\text { Mt. Botte Donato } \\
\text { Mt. Botte Donato } \\
\text { Mt. Gariglione } \\
\text { Tiriolo } \\
\text { San Sofia dEpiro } \\
\text { San Sofia dEpiro } \\
\text { Fiumara Potamo } \\
\text { Andali } \\
\text { Cropani } \\
\text { Germano } \\
\text { Lago Ampollino } \\
\text { Infantino } \\
\text { Savelli } \\
\text { Savelli } \\
\text { Lago Cecita } \\
\text { Lago Cecita } \\
\text { Trepido } \\
\text { San Giovanni in Fiore } \\
\text { San Giovanni in Fiore } \\
\text { Mandatoricio } \\
\text { Arietta } \\
\text { Bocchigliero } \\
\text { Bocchigliero } \\
\text { Mandatoricio }\end{array}$ & $\begin{array}{l}\text { Phillite } \\
\text { Retrograde Proto-Mylonite } \\
\text { Protomylonitic Granite } \\
\text { Biotite, Chlorite Schist } \\
\text { Sillimanite Gneiss } \\
\text { Sillimanite Gneiss } \\
\text { Gneiss } \\
\text { Gametiferous Leucogneiss } \\
\text { Garnetiferous Gneiss } \\
\text { Leucogranitic Gneiss } \\
\text { Leucogranitic Gneiss } \\
\text { Quartz Monzonite } \\
\text { Granitic Gneiss } \\
\text { Granitic Gneiss } \\
\text { Leucogranitic Gneiss } \\
\text { Granitic Gneiss } \\
\text { Granitic Gneiss } \\
\text { Granitic Gneiss } \\
\text { Granitic Gneiss } \\
\text { Granitic Gneiss } \\
\text { Granitic Gneiss } \\
\text { Alkali Granitic Gneiss } \\
\text { Granitic Gneiss } \\
\text { Gametiferous Granite } \\
\text { Chlorite, Muscovite Schist } \\
\text { Bi, Ms, Chl Augen Gneiss } \\
\text { Conglomerate } \\
\text { Biotite, Muscovite Schist }\end{array}$ & $\begin{array}{l}\text { Bagni (AG) } \\
\text { Castagna (AG) } \\
\text { Castagna (AG) } \\
\text { High-Grade Met } \\
\text { High-Grade Met } \\
\text { High-Grade Met } \\
\text { High-Grade Met } \\
\text { High-Grade Met } \\
\text { High-Grade Met } \\
\text { Plutonic } \\
\text { Plutonic } \\
\text { Plutonic } \\
\text { Plutonic } \\
\text { Plutonic } \\
\text { Plutonic } \\
\text { Plutonic } \\
\text { Plutonic } \\
\text { Plutonic } \\
\text { Plutonic } \\
\text { Plutonic } \\
\text { Plutonic } \\
\text { Plutonic } \\
\text { Plutonic } \\
\text { Plutonic } \\
\text { Low-Grade Met } \\
\text { Low-Grade Met } \\
\text { Low-Grade Met } \\
\text { Low-Grade Met }\end{array}$ & $\begin{array}{r}18.1 \pm 2.7 \\
18.7 \pm 3.8 \\
19.9 \pm 2.1 \\
17.5 \pm 2.4 \\
- \\
19.3 \pm 1.9 \\
17.5 \pm 1.6 \\
11.2 \pm 1.3 \\
- \\
22.4 \pm 1.7 \\
25.5 \pm 1.5 \\
25.9 \pm 1.6 \\
19.4 \pm 0.8 \\
34.4 \pm 2.5 \\
31.4 \pm 2.3 \\
40.3 \pm 4.9 \\
30.4 \pm 3.2 \\
21.5 \pm 2.8 \\
14.6 \pm 1.3 \\
23.6 \pm 1.5 \\
24.1 \pm 5.2 \\
29.0 \pm 2.5 \\
42.5 \pm 20.1 \\
26.5 \pm 2.4 \\
12.7 \pm 1.4 \\
14.6 \pm 1.3\end{array}$ & $\begin{array}{r}32.8 \pm 1.6 \\
27.8 \pm 1.3 \\
24.5 \pm 1.2 \\
24.1 \pm 1.2 \\
29.3 \pm 1.3 \\
45.0 \pm 1.9 \\
21.3 \pm 2.0 \\
22.6 \pm 0.8 \\
99.6 \pm 4.3 \\
137.5 \pm 6.3 \\
176.8 \pm 24.7 \\
98.5 \pm 3.1 \\
60.0 \pm 2.6 \\
\mathrm{~m} \pm \\
114.9 \pm 4.6 \\
146.9 \pm 5.9 \\
197.6 \pm 14.3 \\
269.4 \pm 12.6 \\
128.9 \pm 9.5 \\
185.7 \pm 8.8 \\
166.7 \pm 8.0 \\
171.0 \pm 10.3 \\
170.3 \pm 10.6 \\
192.2 \pm 20.2 \\
178.2 \pm 8.6 \\
289.0 \pm 25.6 \\
162.0 \pm 9.4\end{array}$ \\
\hline $\begin{array}{l}\text { Northern S } \\
\text { CUR-380b } \\
\text { COR-390 } \\
\text { COR-410 } \\
\text { CUR-380a } \\
\text { CAR-610 } \\
\text { VAL-590 } \\
\text { FUM-340 } \\
\text { CEL-490 } \\
\text { CAP-545 } \\
\text { COP-50 } \\
\text { ONO-400 } \\
\text { ZAM-125 } \\
\text { VAT-118 } \\
\text { LIM-130 }\end{array}$ & $\begin{array}{l}\text { erre and Capo Vatica } \\
\text { Curinga } \\
\text { Cortale } \\
\text { Cortale } \\
\text { Curinga } \\
\text { Cardinale } \\
\text { Vallelonga } \\
\text { Fossa Umbrita } \\
\text { Celia } \\
\text { Torre Capona } \\
\text { Copanello } \\
\text { San Onofrio } \\
\text { Zambrone } \\
\text { Capo Vaticano } \\
\text { Limbadi }\end{array}$ & $\begin{array}{l}\text { Biotite Schist } \\
\text { Retrograde Mylonitic Gneiss } \\
\text { Retrograde Augen Gneiss } \\
\text { Garnetiferous Gneiss } \\
\text { Meta-Tonalite } \\
\text { Meta-Tonalite } \\
\text { Granulite (Kinzigite) } \\
\text { Granulite Paragneiss } \\
\text { Metabasite } \\
\text { Biotite Orthogneiss } \\
\text { Garnet Sillimanite Gneiss } \\
\text { Foliated Granitic Gneiss } \\
\text { Granitic Gneiss } \\
\text { Granitic Gneiss }\end{array}$ & $\begin{array}{l}\text { Bagni (AG) } \\
\text { Castagna (AG) } \\
\text { Castagna (AG) } \\
\text { Castagna (AG) } \\
\text { High-Grade Met } \\
\text { High-Grade Met } \\
\text { High-Grade Met } \\
\text { High-Grade Met } \\
\text { High-Grade Met } \\
\text { High-Grade Met } \\
\text { High-Grade Met } \\
\text { Plutonic } \\
\text { Plutonic } \\
\text { Plutonic }\end{array}$ & $\begin{array}{l}12.9 \pm 2.3 \\
14.7 \pm 1.0 \\
15.5 \pm 0.8 \\
17.1 \pm 0.7 \\
21.1 \pm 0.8 \\
23.2 \pm 2.8 \\
23.7 \pm 3.7 \\
22.4 \pm 1.7 \\
24.9 \pm 3.3 \\
18.8 \pm 1.5 \\
20.5 \pm 1.9 \\
20.9 \pm 0.7 \\
22.6 \pm 1.3 \\
18.8 \pm 1.0\end{array}$ & $\begin{array}{l}17 . \overline{8} \pm 0.6 \\
14.4 \pm 0.5 \\
24 . \overline{7} \pm 1.0 \\
26.7 \pm 1.0 \\
30.0 \pm 1.3 \\
27.9 \pm 1.1 \\
25.0 \pm 1.6 \\
23.1 \pm 1.3 \\
29.2 \pm 1.3 \\
31.4 \pm 1.0 \\
34.0 \pm 1.2 \\
36.0 \pm 1.3\end{array}$ \\
\hline $\begin{array}{l}\text { ATT-1124 } \\
\text { ALT-1900a } \\
\text { AME-1500 } \\
\text { SCI-30 } \\
\text { GAM-1650 } \\
\text { FER-1148 } \\
\text { CAR-50 } \\
\text { CIC-480 } \\
\text { CHI-810 } \\
\text { CIT-930 } \\
\text { CIT-460 } \\
\text { ALE-600 } \\
\text { CAL-100 } \\
\text { MAZ-180 } \\
\text { BOV-30 } \\
\text { MAN-450 }\end{array}$ & $\begin{array}{l}\text { Mt. Attenamare } \\
\text { Montalto } \\
\text { Gambarie } \\
\text { Scilla } \\
\text { Gambarie } \\
\text { Fertinandea } \\
\text { Capo Rascalmo } \\
\text { Mt. Ciccia } \\
\text { Pzo. Chiarino } \\
\text { Cittanova } \\
\text { Cittanova } \\
\text { San Alessio } \\
\text { Capo di Calava } \\
\text { Mazzara } \\
\text { Bova Marina } \\
\text { Mandanici }\end{array}$ & $\begin{array}{l}\text { Peloritani } \\
\text { Biotite Schist } \\
\text { Proto-Mylonitic Gneiss } \\
\text { Retrograde Amphibolite } \\
\text { Granodioritic Gneiss } \\
\text { Protomylonitic Gt Gneiss } \\
\text { Granitic Gneiss } \\
\text { Leucogranitic Gneiss } \\
\text { Alkali Granitic Gneiss } \\
\text { Leucogranitic Gneiss } \\
\text { Leucogranitic Gneiss } \\
\text { Leucogranitic Gneiss } \\
\text { Leucogranitic Gneiss } \\
\text { Leucogranite } \\
\text { Phillite } \\
\text { Augen Gneiss } \\
\text { Phillite }\end{array}$ & $\begin{array}{l}\text { High-Grade Met } \\
\text { High-Grade Met } \\
\text { High-Grade Met } \\
\text { High-Grade Met } \\
\text { High-Grade Met } \\
\text { Plutonic } \\
\text { Plutonic } \\
\text { Plutonic } \\
\text { Plutonic } \\
\text { Plutonic } \\
\text { Plutonic } \\
\text { Plutonic } \\
\text { Plutonic } \\
\text { Low-Grade Met } \\
\text { Low-Grade Met } \\
\text { Low-Grade Met }\end{array}$ & $\begin{array}{r}25.1 \pm 2.0 \\
22.7 \pm 1.7 \\
25.2 \pm 5.2 \\
18.1 \pm 1.2 \\
28.5 \pm 1.0 \\
24.8 \pm 1.1 \\
35.1 \pm 1.3 \\
- \\
17.9 \pm 1.3 \\
21.0 \pm 2.0 \\
23.2 \pm 1.4 \\
7.4 \pm 1.0 \\
7.8 \pm 0.6 \\
32.8 \pm 1.4 \\
21.1 \pm 5.2\end{array}$ & $\begin{array}{r}28.1 \pm 1.3 \\
- \\
38.8 \pm 1.6 \\
17.5 \pm 1.5 \\
99.6 \pm 3.5 \\
112.5 \pm 4.0 \\
152.1 \pm 5.0 \\
26.5 \pm 1.1 \\
193.8 \pm 11.4 \\
- \\
- \\
\mathrm{mt} \\
134.6 \pm 4.2 \\
299.3 \pm 21.4 \\
-\end{array}$ \\
\hline
\end{tabular}




\section{Table 5.5 Apatite Confined Track Length Analyses}

\begin{tabular}{lcccc}
\multicolumn{1}{c}{$\begin{array}{c}\text { Sample } \\
\text { Number }\end{array}$} & $\begin{array}{c}\text { Mean Confined } \\
\text { Track Length } \\
(\mu \mathrm{m} \pm 1 \text { s.e. })\end{array}$ & $\begin{array}{c}\text { Standard } \\
\text { Deviation } \\
(\mu \mathrm{m})\end{array}$ & $\begin{array}{c}\text { No. of } \\
\text { Tracks } \\
\text { Measured }\end{array}$ & $\begin{array}{c}\text { Apatite Fissio } \\
\text { Track Age } \\
(\mathrm{Ma} \pm 1 \sigma)\end{array}$ \\
\hline Alpine Group & & & & \\
COR-390 & $14.98 \pm 0.20$ & 0.88 & 21 & $14.7 \pm 1.0$ \\
COR-410 & $15.16 \pm 0.17$ & 1.36 & 69 & $15.5 \pm 0.5$ \\
CUR-380a & $14.34 \pm 0.15$ & 0.90 & 35 & $17.1 \pm 0.7$
\end{tabular}

Hercynian High-Grade Metamorphic Rocks

$\begin{array}{lcccc}\text { ATT-1124 } & 12.49 \pm 0.24 & 1.61 & 45 & 25.1 \pm 2.0 \\ \text { SCI-30 } & 13.94 \pm 0.13 & 1.25 & 100 & 18.1 \pm 1.2 \\ \text { TIR-700 } & 14.32 \pm 0.12 & 0.72 & 36 & 11.2 \pm 1.3 \\ \text { VAL-590 } & 15.70 \pm 0.39 & 0.96 & 7 & 23.2 \pm 2.8 \\ \text { CAR-610 } & 14.34 \pm 0.13 & 1.28 & 100 & 21.1 \pm 0.8 \\ \text { ONO-400 } & 15.35 \pm 0.22 & 0.96 & 20 & 20.5 \pm 1.9 \\ \text { BOT-1850 } & 14.69 \pm 0.30 & 1.18 & 17 & 19.3 \pm 1.9\end{array}$

Hercynian Plutonic Rocks

$\begin{array}{lcccc}\text { ZAM-125 } & 13.77 \pm 0.13 & 1.27 & 100 & 20.9 \pm 0.7 \\ \text { VAT-118 } & 14.45 \pm 0.24 & 1.98 & 70 & 22.6 \pm 1.3 \\ \text { LIM-130 } & 14.09 \pm 0.15 & 1.45 & 100 & 18.8 \pm 1.0 \\ \text { AND-480 } & 14.06 \pm 0.13 & 1.28 & 100 & 25.5 \pm 1.5 \\ \text { INF-1050 } & 13.98 \pm 0.23 & 1.59 & 47 & 31.4 \pm 2.3 \\ \text { GER-1200 } & 13.90 \pm 0.17 & 1.67 & 100 & 19.4 \pm 0.8 \\ \text { CAR-50 } & 14.12 \pm 0.16 & 1.14 & 50 & 24.8 \pm 1.1 \\ \text { CIC-480 } & 13.20 \pm 0.18 & 1.76 & 100 & 35.1 \pm 1.3 \\ \text { SAV-990 } & 9.81 \pm 0.29 & 2.88 & 100 & 40.3 \pm 4.9 \\ \text { SAV-920 } & 13.33 \pm 0.35 & 1.94 & 31 & 30.4 \pm 3.2 \\ \text { CEC-1150 } & 14.90 \pm 0.21 & 1.18 & 31 & 14.6 \pm 1.3 \\ \text { FER-1148 } & 12.13 \pm 0.24 & 2.42 & 100 & 28.5 \pm 1.0\end{array}$

Hercynian Low-Grade Metamorphic Rocks

$\begin{array}{lcccc}\text { ARI-580 } & 12.06 \pm 0.25 & 2.47 & 100 & 26.5 \pm 2.4 \\ \text { BOV-30 } & 12.83 \pm 0.19 & 1.90 & 100 & 32.8 \pm 1.4 \\ \text { MAN-650 } & 13.75 \pm 0.19 & 1.79 & 94 & 14.6 \pm 1.3\end{array}$




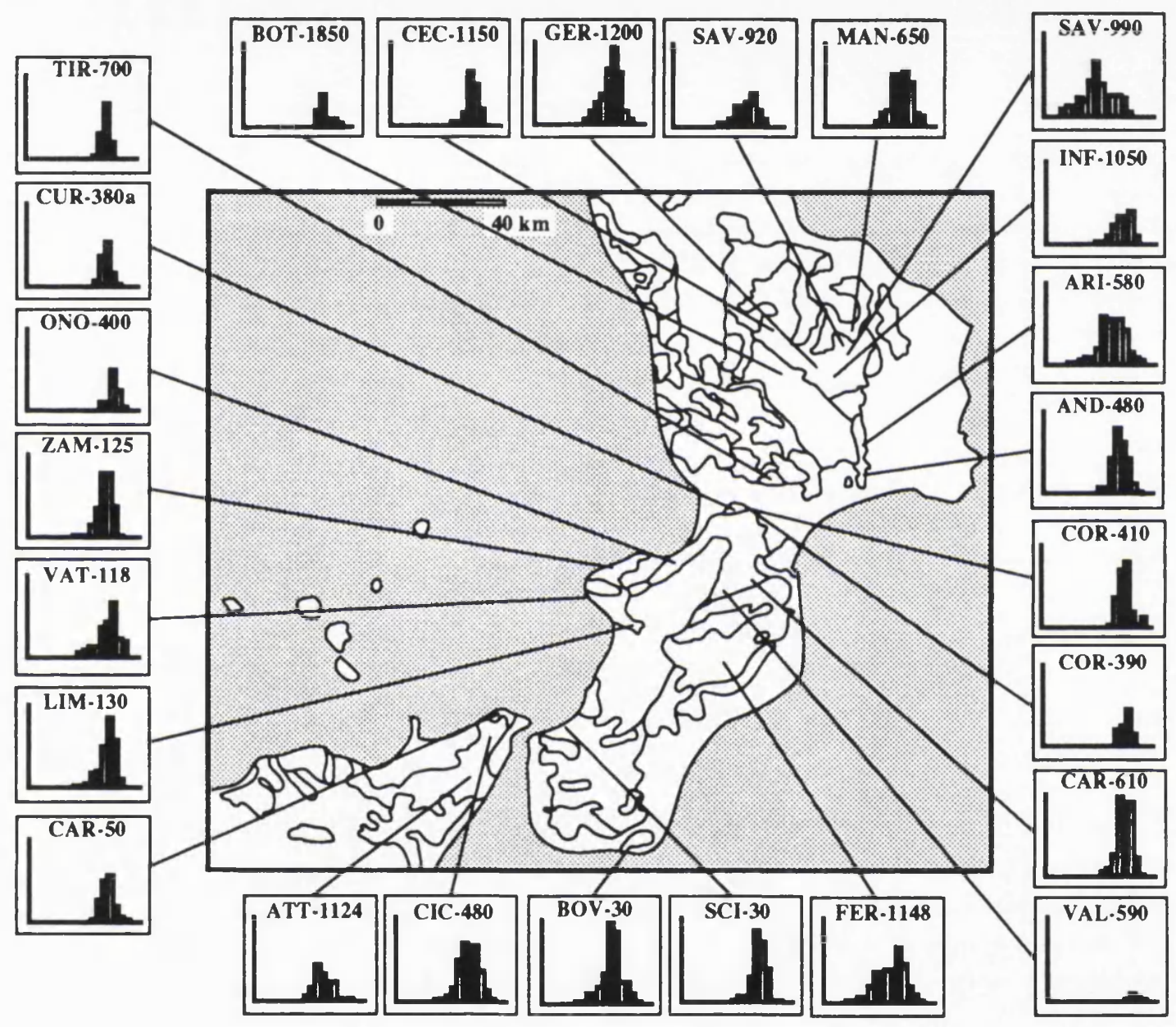

Figure 5.4 Map showing the individual track length distributions of samples taken from the basement units of the Calabrian Arc. (For details of track lengths see Table 5.5) 


\section{CHAPTER 6 \\ ANALYSIS OF FISSION TRACK RESULTS FROM THE \\ BASEMENT COMPLEX OF THE CALABRIAN ARC}

\subsection{QUALITATIVE ANALYSIS}

\subsubsection{Closure Temperature Derived Cooling Histories}

The derivation of low-temperature cooling histories from the results of fission track analysis can be achieved by using the concept of closure temperature (see Chapter 3 , section 3.3.2). For steady cooling rates of between 5 and $30^{\circ} \mathrm{C} / \mathrm{m}$.y. the following closure temperature values are applicable: for Apatite: $100 \pm 20^{\circ} \mathrm{C}$ and for Zircon: $200-250^{\circ} \mathrm{C}(225$ $\pm 25^{\circ} \mathrm{C}$ ). The determination of these values is discussed in more detail in Chapter 4 , section 4.3.

\section{The Alpine Group Rocks}

The T-t plots derived from the Alpine Group rocks are shown in Figures 6.1 and 6.4. The low-temperature cooling pattern revealed by the fission track results shows a significant increase in the rate of cooling between $\sim 30 \mathrm{Ma}$ and the present day. This rate of cooling does vary between individual samples. Most of the samples show cooling rates of between 10 and $15^{\circ} \mathrm{C} / \mathrm{m}$.y. However two samples, COR-410 and COR-390 from the northern Serre region, give fission track results that indicate very rapid cooling at rates of up to $30^{\circ} \mathrm{C} / \mathrm{m}$.y. The Alpine Group rocks are overlain unconformably by Tortonian (6.511.2Ma) sediments, implying rapid cooling had ceased by this time.

The one sample from the Liguride Complex (FUS-1100), a strongly altered metaporphyrite of "ophiolitic" affinity (De Roever, 1972), shows a much older zircon fission track age of $136 \pm 19 \mathrm{Ma}$. This implies that although this rock has undergone high-pressure metamorphism, it could not have taken place at excessively high temperature. If the zircon fission track age represents a pure cooling age then the "Alpine" metamorphic temperature cannot have exceeded $200^{\circ} \mathrm{C}$. However if the zircon age has been partially reset by annealing similar to that seen in apatite, the event that caused the resetting may have reached 


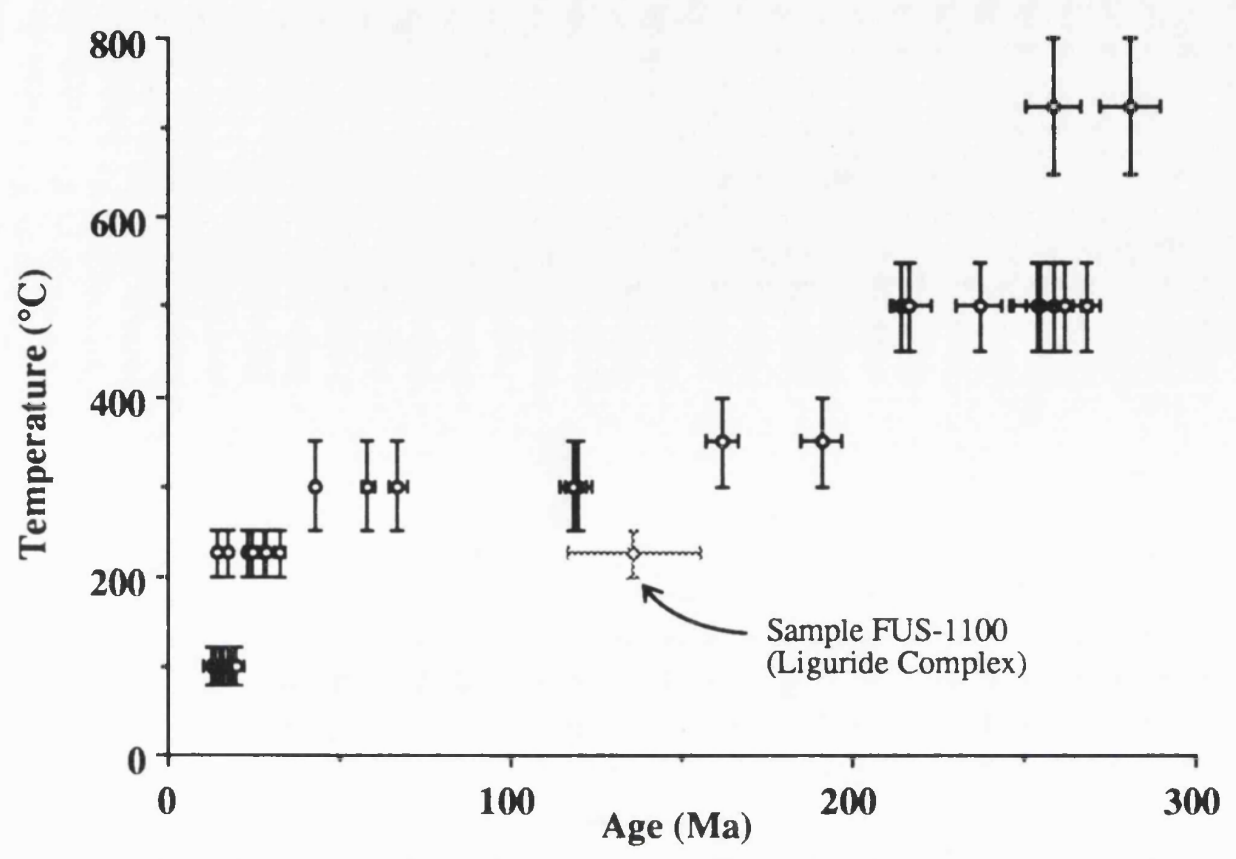

Figure 6.1 Time-temperature plot for the Alpine Group rocks and one sample from the Liguride Complex incorporating both isotopic and fission track age data

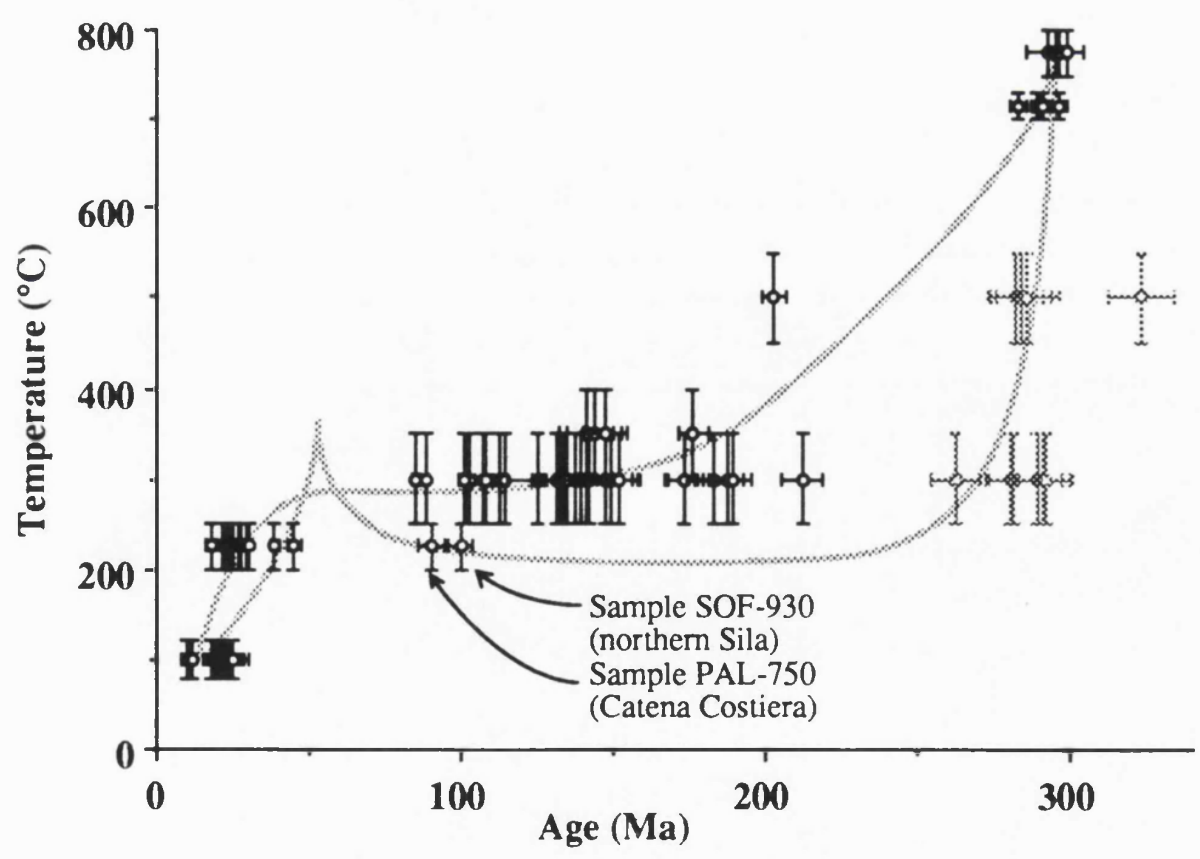

Figure 6.2 Time-temperature plot for the High-grade Hercynian metamorphic rocks incorporating both isotopic and fission track age data (see chapter 3 for details of the isotopic age data) 
a temperature in excess of $200^{\circ} \mathrm{C}$. If the thermal event was very short-lived a temperature of over $250^{\circ} \mathrm{C}$ is possible.

\section{The High-Grade Hercynian Metamorphic Rocks}

The low-temperature cooling histories revealed from the high-grade Hercynian metamorphic rocks (Figures 6.2 and 6.4) are similar to those obtained from the Alpine Group rocks, although both the zircon and apatite fission track ages are generally slightly older. The implication of this is that the cooling between the zircon and apatite fission track closure temperatures took place slightly earlier in the high-grade Hercynian metamorphic rocks than in the Alpine Group rocks. This fits in with the generally accepted tectonostratigraphy that places the high-grade Hercynian rocks above the Alpine Group rocks (Chapter 3) (i.e. the high-grade rocks cooled through the relevant temperature isograds before the tectonically lower Alpine Group rocks and therefore show older fission track ages). Apatite and zircon fission track ages obtained from samples taken from a traverse across the northern Serre show a decrease in overall age across the boundary of the highgrade Hercynian rocks into the Alpine Group rocks. This is demonstrated in Figure 6.6.

The average low-temperature cooling rates obtained for the high-grade Hercynian rocks, as deduced from Figure 6.4 , are mainly in the region of $5-15^{\circ} \mathrm{C} / \mathrm{m} . \mathrm{y}$., similar to the majority of Alpine Group samples. However two samples, SOF-450 and PAL-750, show significantly higher than average zircon ages. These ages are open to two interpretations. First the two samples may have undergone slow cooling above $\sim 150^{\circ} \mathrm{C}$. This would imply that prior to the late Tertiary cooling event seen in most other samples of this rock type, these rocks lay at a high crustal level (i.e. between $120^{\circ} \mathrm{C}$ and $200^{\circ} \mathrm{C}$ ). The second explanation of such ages is that they are the result of partial, not total, thermal resetting caused by a Tertiary thermal event. However this would still require the samples to lie at a higher crustal level than the other high-grade Hercynian metamorphic rocks during the thermal event. 


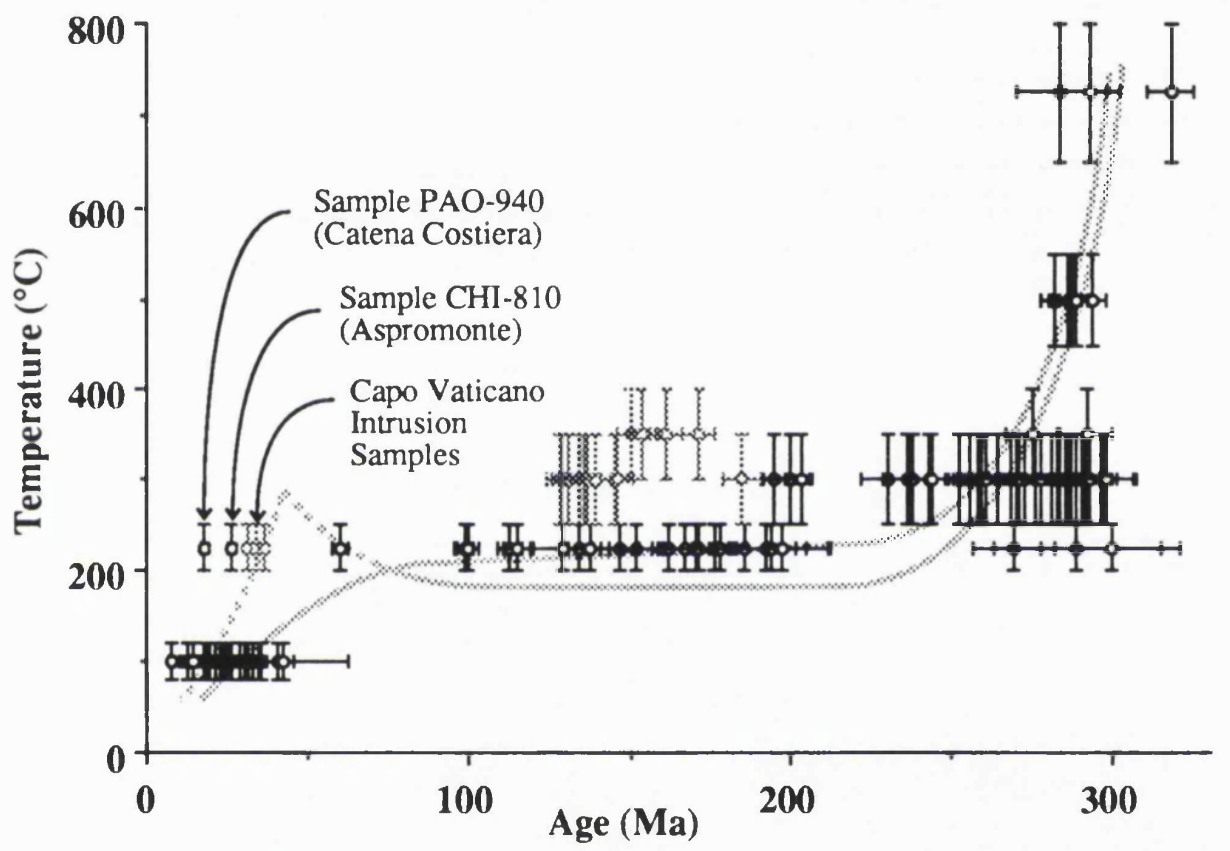

Figure 6.3 Time-temperature plot for the Hercynian plutonic and low-grade metamorphic rocks 


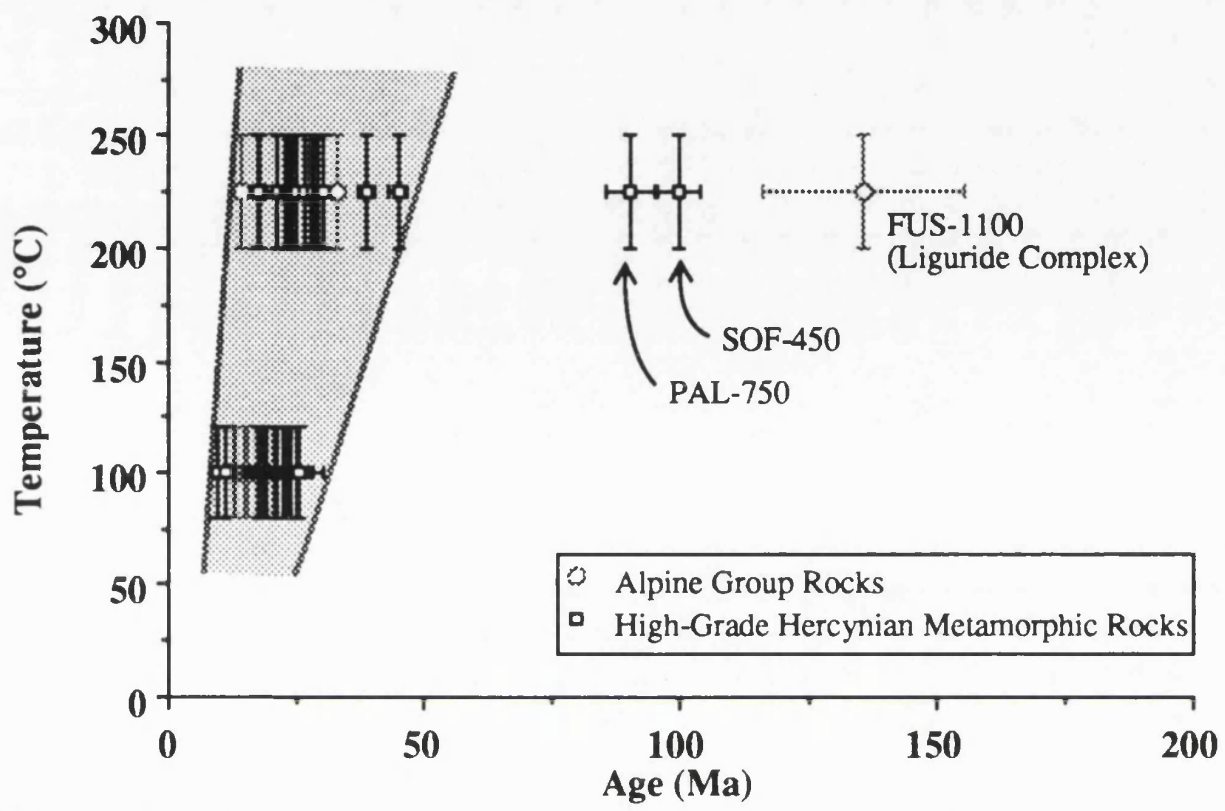

Figure 6.4 Low-temperature time-temperature plot, incorporating the results of fission track analysis, comparing the Alpine Group rocks with the high-grade Hercynian metamorphic rocks

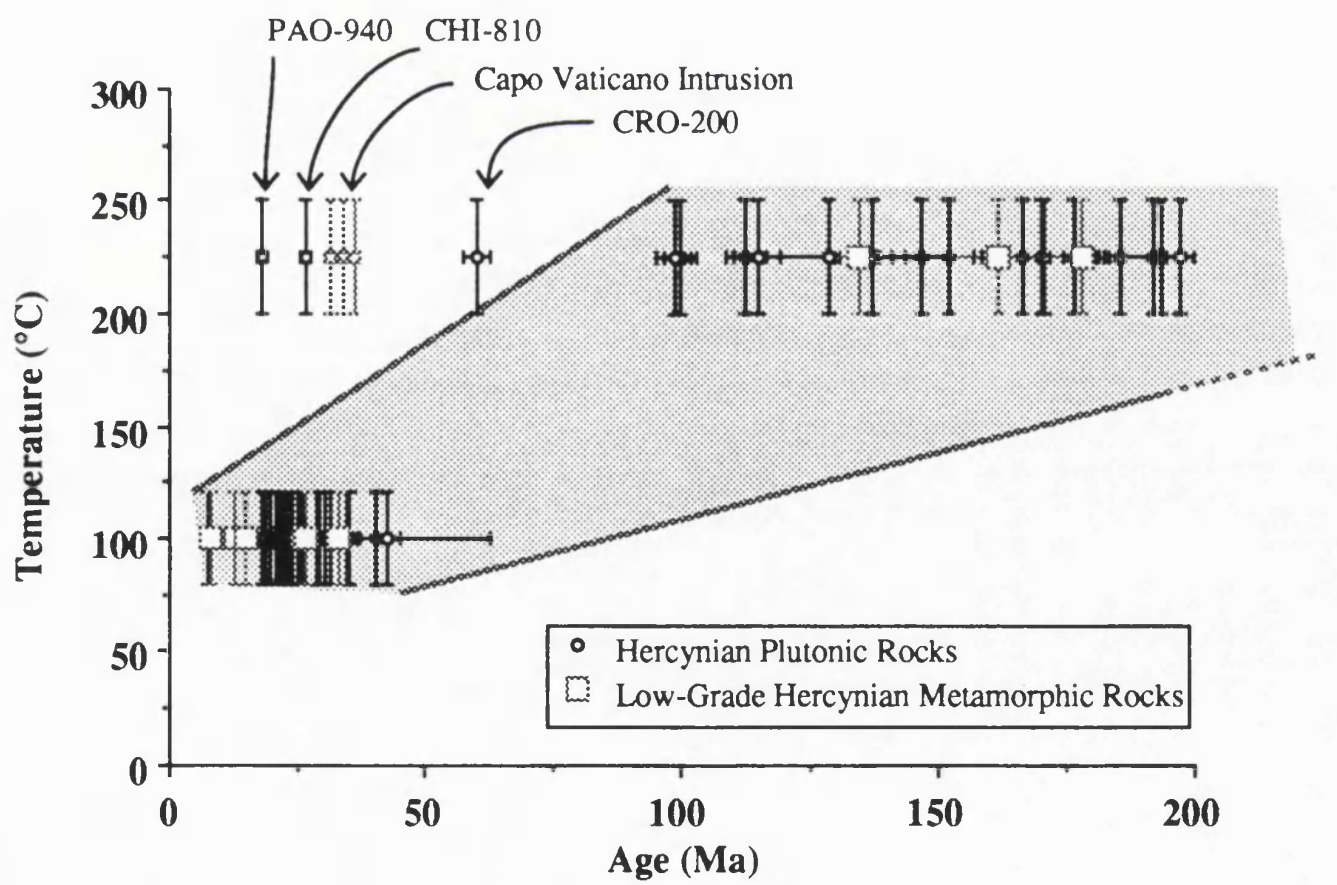

Figure 6.5 Low temperature time-temperature plot, incorporating the results of fission track analysis, comparing the Hercynian plutonic rocks with the low-grade Hercynian metamorphic rocks 


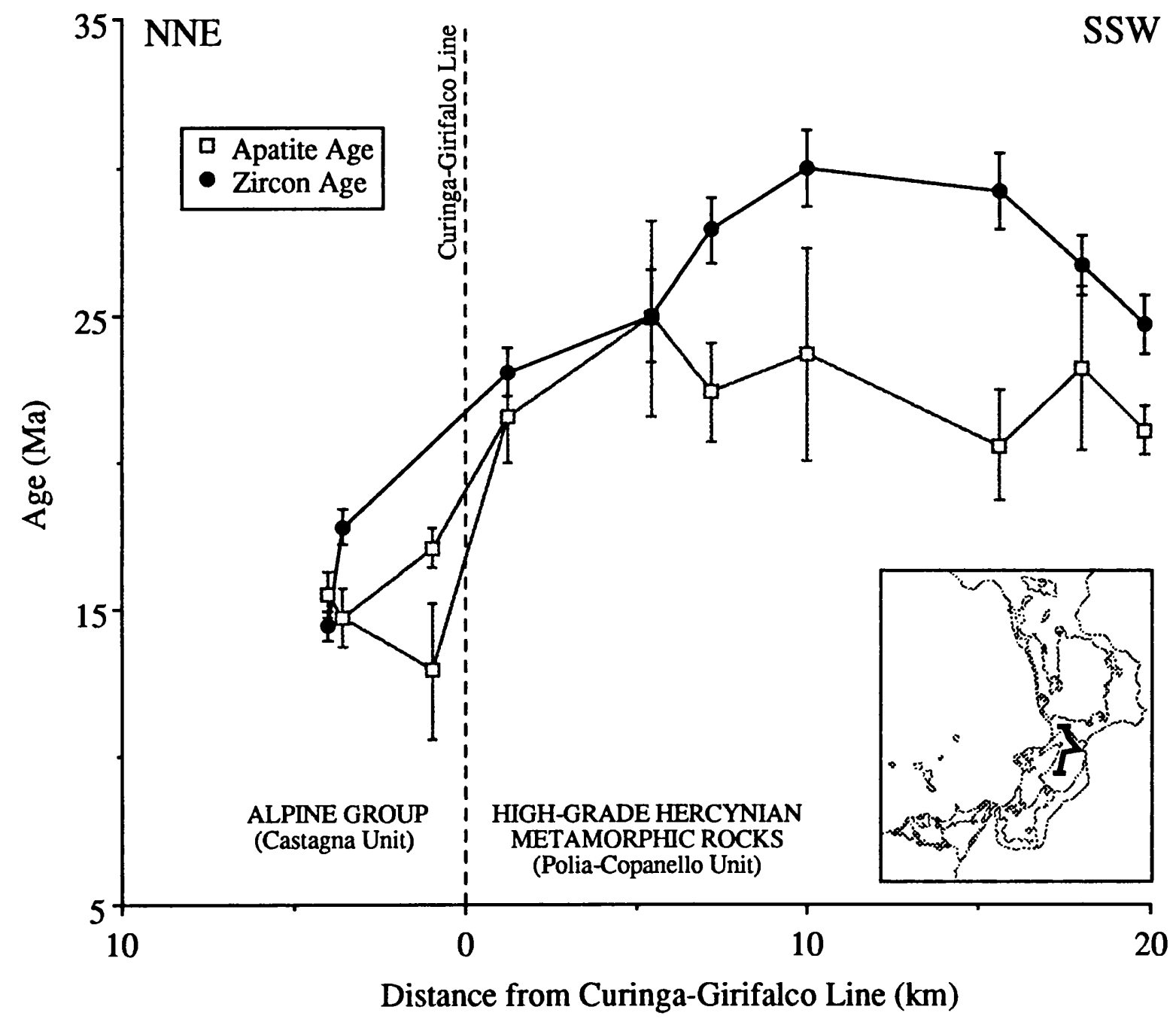

Figure 6.6 Traverse across the Serre, southern Calabria showing variation of fission track ages between the Alpine Group samples and the high-grade Hercynian metamorphic samples 


\section{The Hercynian Plutonic and Low-Grade Hercynian Metamorphic Rocks}

Figures 6.3 and 6.5 reveal the low-temperature thermal data of the Hercynian plutonic rocks and low-grade Hercynian metamorphic rocks. There is a marked difference from the cooling data obtained from the Alpine Group rocks and high-grade Hercynian metamorphic rocks. First, all but five of the zircon ages are over $98 \mathrm{Ma}$.

Three of the five exceptions were exclusively from samples collected and dated from the Capo Vaticano intrusion. These samples show similar zircon ages to the rocks of the high-grade Hercynian metamorphic rocks into which they intrude. One plutonic sample from the Aspromonte-Peloritani region (CHI-810) shows a low zircon fission track age of $\sim 26.5 \mathrm{Ma}$, indicating rapid cooling since then of an average rate of $\sim 10^{\circ} \mathrm{C} / \mathrm{m}$.y. Unfortunately no apatite fission track age is available for this sample. An even younger zircon age of $\sim 18.1 \mathrm{Ma}$ is seen from one plutonic sample in the Catena Costiera (PAO-940). That requires a minimum cooling rate of $\sim 14^{\circ} \mathrm{C} / \mathrm{m}$.y. to expose the sample at the present surface. The $12.5 \pm 2.6 \mathrm{Ma}$ apatite age for this sample shows that this sample had to cool at a rate of $\sim 20^{\circ} \mathrm{C} / \mathrm{m} . \mathrm{y}$. between the zircon and apatite fission track closure temperatures in the period between 18 and 12Ma. The Capo Vaticano intrusion samples cooled at a rate of $\sim 7-$ $10^{\circ} \mathrm{C} / \mathrm{m} . \mathrm{y}$. between the same temperature range at a slightly earlier time between $36 \mathrm{Ma}$ and $18 \mathrm{Ma}$.

The data from the other samples of these rock groups, on first inspection suggest slow cooling rates between the zircon and apatite closure temperatures of between 0.5 and $2^{\circ} \mathrm{C} / \mathrm{m}$.y., with increased cooling rates between the apatite closure temperature and the surface during the late Tertiary of up to $6^{\circ} \mathrm{C} / \mathrm{m}$.y. However, if the zircon ages reflect partial annealing, such deductions of cooling rates would not be valid. Of note are three zircon ages of over $269 \mathrm{Ma}$. This shows that these samples have resided at temperatures of less than $200^{\circ} \mathrm{C}$ since the end of the Hercynian orogeny. Also of note are several very young apatite ages below 14Ma. Three of these ages (CEC-1150, BOC-1300 and MAN-650) lie in close proximity in the northern part of the Sila massif, and the other young ages, two from northern Sicily (CAL-100 and MAZ-180) and one from the Catena Costiera (PAO940) lie adjacent to the Tyrrhenian Sea. The geological implications and relevance of these 
and some of the other anomalous ages and samples will be discussed later in Chapter 8.

The age when the samples reached the surface can be further constrained from the age of the oldest undeformed sediments unconformably overlying the basement rocks. The Hercynian plutonic and low-grade metamorphic rocks are unconformably overlain by the Stilo Capo d'Orlando Formation. The basal sediments of this formation are dated at between $29 \mathrm{Ma}$ and $27 \mathrm{Ma}$ (Weltje, in press). This poses something of a problem, because the average apatite age of the Hercynian plutonic rocks is $24.7 \mathrm{Ma}$, younger that the sediments deposited upon them. However the only age from near the unconformity (BOV30) gives a more acceptable apatite age of $32.8 \pm 1 \mathrm{Ma}$, indicating a cooling rate of $\sim 12^{\circ} \mathrm{C} / \mathrm{m}$.y. between $32 \mathrm{Ma}$ and $24 \mathrm{Ma}$. The most probable explanation for the age discrepancy is that the areas undergoing cooling were geologically distinct from the areas of sedimentation during this period.

The major feature of the low temperature thermal data is the difference between the Alpine Group and high-grade Hercynian rocks, and the Hercynian plutonic and low grade Hercynian metamorphic rocks. This is especially true of the zircon fission track data. The change from low zircon ages (between $\sim 20$ and 40Ma) to high ages (between $90 \mathrm{Ma}$ and $300 \mathrm{Ma}$ ) is very abrupt across the boundary between the high-grade Hercynian metamorphic rocks and the late-Hercynian plutonic rocks. This can be readily seen from a traverse of sample ages taken east-west across the Sila Massif, shown in Figure 6.7. The older zircon ages from the Hercynian plutonic and low-grade metamorphic rocks indicates that these rocks occupied a higher tectonic position during cooling. This is independent of whether the zircon fission track ages represent cooling ages or are partially reset ages. The former would mean these samples passed through the zircon closure temperature much earlier than the majority of the Alpine Group and high-grade Hercynian rocks. The latter would require that the Hercynian plutonic and low-grade metamorphic rocks experienced lower temperatures, during any thermally induced resetting event, than the totally reset samples of the Alpine Group and high-grade Hercynian rocks. This agrees with the tectonostratigraphic scheme of Messina et al. $(1991 \mathrm{a} / \mathrm{b})$ that is outlined in Chapter 3.

In section 5.1, which deals with the sample collecting procedure, it is mentioned 


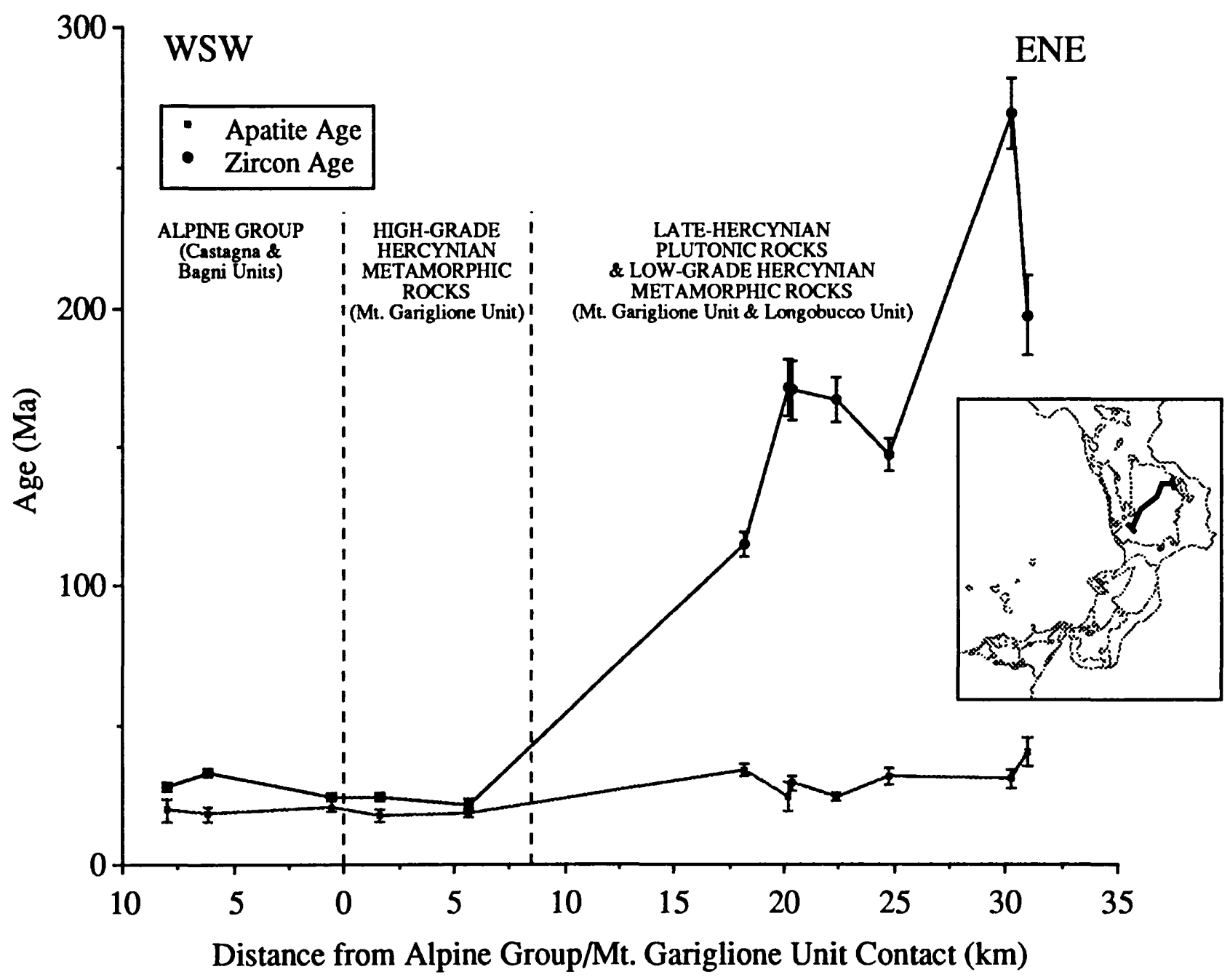

Figure 6.7 Traverse across the Sila Grande, central Calabria showing variation of fission track ages across the boundary between the high-grade Hercynian metamorphic rocks and the late-Hercynian plutonic rocks. 
that some samples were deliberately collected from sites previously used for isotopic dating by other authors. Those that yielded fission track data along with the isotopic data from the same sites are listed in Table 6.1. These data enable cooling curves to be plotted for individual samples, which are shown in Figure 6.8. This plot assumes all the ages represent pure cooling ages. Similar trends to those already outlined are seen. Also clearly shown is the similarity between the cooling curves of the Hercynian plutonic rocks of the Capo Vaticano quartz-dioritic intrusion and the high-grade Hercynian metamorphic rock samples.

So far the cooling histories of the crystalline basement rocks of the Calabrian Arc have been discussed purely in terms of the closure temperatures of the apatite and zircon fission track systems. However, an additional qualitative constraint on the cooling histories of the samples is available: the measurement of confined fission track length distributions in apatite.

\subsubsection{Constraints Provided by Apatite Fission Track Length Analysis}

The results of apatite fission track length analysis, described in section 5.3, can also be examined using graphical methods. Two plots, age against mean track length and age against the standard deviation of the track length distribution, are illustrated in Figures 6.9 and 6.10. What these plots attempt to show is the grouping of the different rock groups. In Figure 6.9 the Alpine Group and high-grade Hercynian metamorphic samples, with the exception of sample ATT-1124, show high mean track lengths and low fission track ages. This suggests a rapid cooling between $125^{\circ} \mathrm{C}$ and $70^{\circ} \mathrm{C}$ at the times indicated by the apatite fission track ages. In contrast, the Hercynian plutonic and low-grade metamorphic rocks show shorter mean track lengths and higher fission track ages. This suggests a slightly older and slower cooling between $125^{\circ} \mathrm{C}$ and $70^{\circ} \mathrm{C}$. Similar trends are seen in Figure 6.10, although there is more scatter, with some overlap between the high-grade Hercynian metamorphic samples and Hercynian plutonic samples.

In Figure 6.11, the mean track length is plotted against the standard deviation of the track length distribution. Included in this graph are the definitions proposed by Gleadow et 
Table 6.1 Individual samples from which both fission track data and isotopic age data have been obtained

\begin{tabular}{llll} 
Sample No. & $\mathrm{Rb}-\mathrm{Sr}(\mathrm{Bi})$ & $\mathrm{K}-\mathrm{Ar}(\mathrm{Bi})$ & $\mathrm{Rb}-\mathrm{Sr}(\mathrm{M})$ \\
\hline \multicolumn{2}{l}{ Alpine Group } & & \\
CUR-380a & $43 \pm 1$ & & \\
CUR-380b & $43 \pm 1$ & & $268 \pm 4$ \\
COR-390 & & $268 \pm 4$ \\
\end{tabular}

$\mathrm{K}-\mathrm{Ar}(\mathrm{Ms}) \quad \mathrm{Rb}-\mathrm{Sr}(\mathrm{Fs}) \quad \mathrm{U}-\mathrm{Pb}(\mathrm{Zr}) \quad \mathrm{U}-\mathrm{Pb}(\mathrm{Mz})$ Reference

FT (apatite)

FT (zircon)

High-Grade Hercynian Metamorphic Rocks

$\begin{array}{lcc}\text { CAR-610 } & 136 \pm 5 & \\ & 133 \pm 1 & \\ \text { VAL-590 } & 142 \pm 6 & \\ & 85 \pm 1 & \\ \text { FUM-340 } & 112 \pm 1 & \\ \text { CEL-490 } & 114 \pm 1 & \\ \text { CAP-545 } & 108 \pm 1 & \\ \text { SCI-30 } & & 135 \pm 5\end{array}$

$268 \pm 4$

$268 \pm 4$

Hercynian Plutonic Rocks

\begin{tabular}{|c|c|c|c|c|}
\hline $\begin{array}{l}\text { ZAM-125 } \\
\text { VAT-118 } \\
\text { LIM-130 }\end{array}$ & & $\begin{array}{l}125 \pm 4 \\
181 \pm 6 \\
133+4\end{array}$ & & $\begin{array}{l}151 \pm 5 \\
147 \pm 4\end{array}$ \\
\hline CEC- 1250 & $\begin{array}{c}282 \pm 8 \\
284 \pm 14\end{array}$ & & & \\
\hline CAR-50 & $\begin{array}{l}287 \pm 5 \\
280 \pm 8\end{array}$ & & $286 \pm 10$ & \\
\hline $\begin{array}{l}\text { ALE-600 } \\
\text { CIT-460 }\end{array}$ & $\begin{array}{l}283 \pm 4 \\
291 \pm 4 \\
281 \pm 8\end{array}$ & & $\begin{array}{c}296 \pm 71 \\
289 \pm 5 \\
282 \pm 9\end{array}$ & \\
\hline CIC -480 & $292 \pm 9$ & & & \\
\hline FER-114 & $259 \pm 9$ & $273 \pm 9$ & & $275 \pm 8$ \\
\hline
\end{tabular}

Low-Grade Hercynian Metamorphic Rocks

MAN-450

$217 \pm 3$

Schenk (1980)

c6

$7.1 \pm 0.7$

$12.9 \pm 2.3$

$14.7 \pm 1.0$

$17.8 \pm 0.6$

orsi et al. (1976)

Schenk (1980)

Borsi et al. (1976)

Schenk (1980)

Schenk (1980)

$144 \pm 1$

$295 \pm 2$

$293 \pm 7$

$292 \pm 2$

$296 \pm 2$

$296 \pm 2$

Rottura (1985)

$21.1 \pm 0.8$

$24.7 \pm 1.0$

$23.2 \pm 2.8$

$26.7 \pm 1.0$

$23.7 \pm 3.7$

$22.4 \pm 1.7$

$24.9 \pm 3.3$

$30.0 \pm 1.3$

$27.9 \pm 1.1$

$25.0 \pm 1.6$

$38.8 \pm 1.6$

Civetta et al. (1973)

Borsi (1968)

Wieland (1979)

Del Moro et al. (1984)

Atzori et al. (1990)

Del Moro et al. (1984)

$$
\text { "s }
$$

Atzori et al. (1990)

Atzori et al. (1990)

Borsi et al. (1976)

Nicolletti (1984)

$31.4 \pm 1.0$

$34.0 \pm 1.2$

$36.0 \pm 1.3$

$128.9 \pm 9.5$

$112.5 \pm 4.0$

$23.2+1.4$

$21.0 \pm 2.0$

$35.1 \pm 1.3$

$28.5 \pm 1.0$

$152.1 \pm 5.0$

$99.6 \pm 3.5$

Zuppetta et al. (1984)

$21.1 \pm 5.2$ 


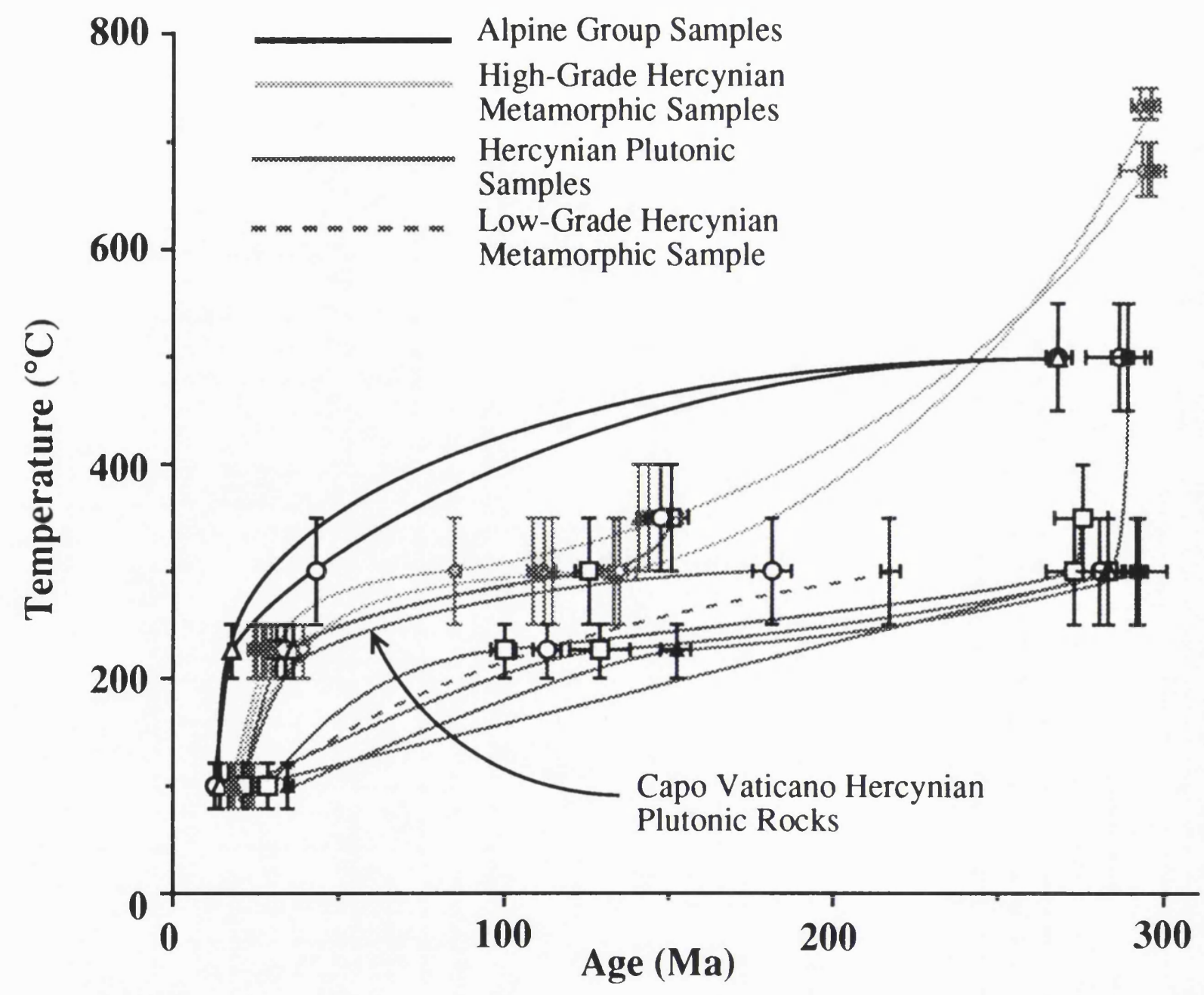

Figure 6.8 Time-temperature plots with selected cooling curves from the individual sample data given in Table 6.1 


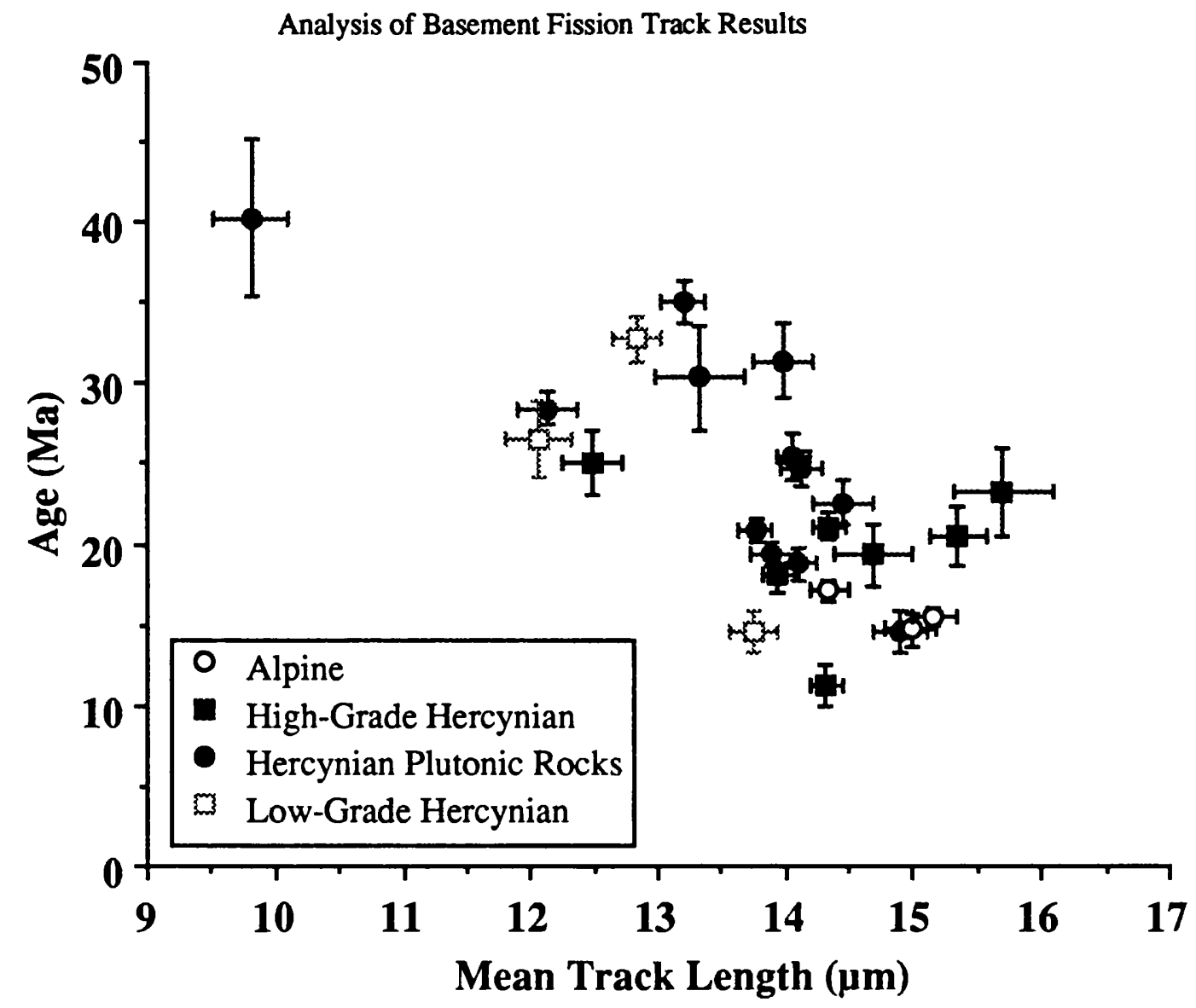

Figure 6.9 Plot of mean apatite fission track length versus the apatite fission track age for samples of the Calabrian Arc basement complex

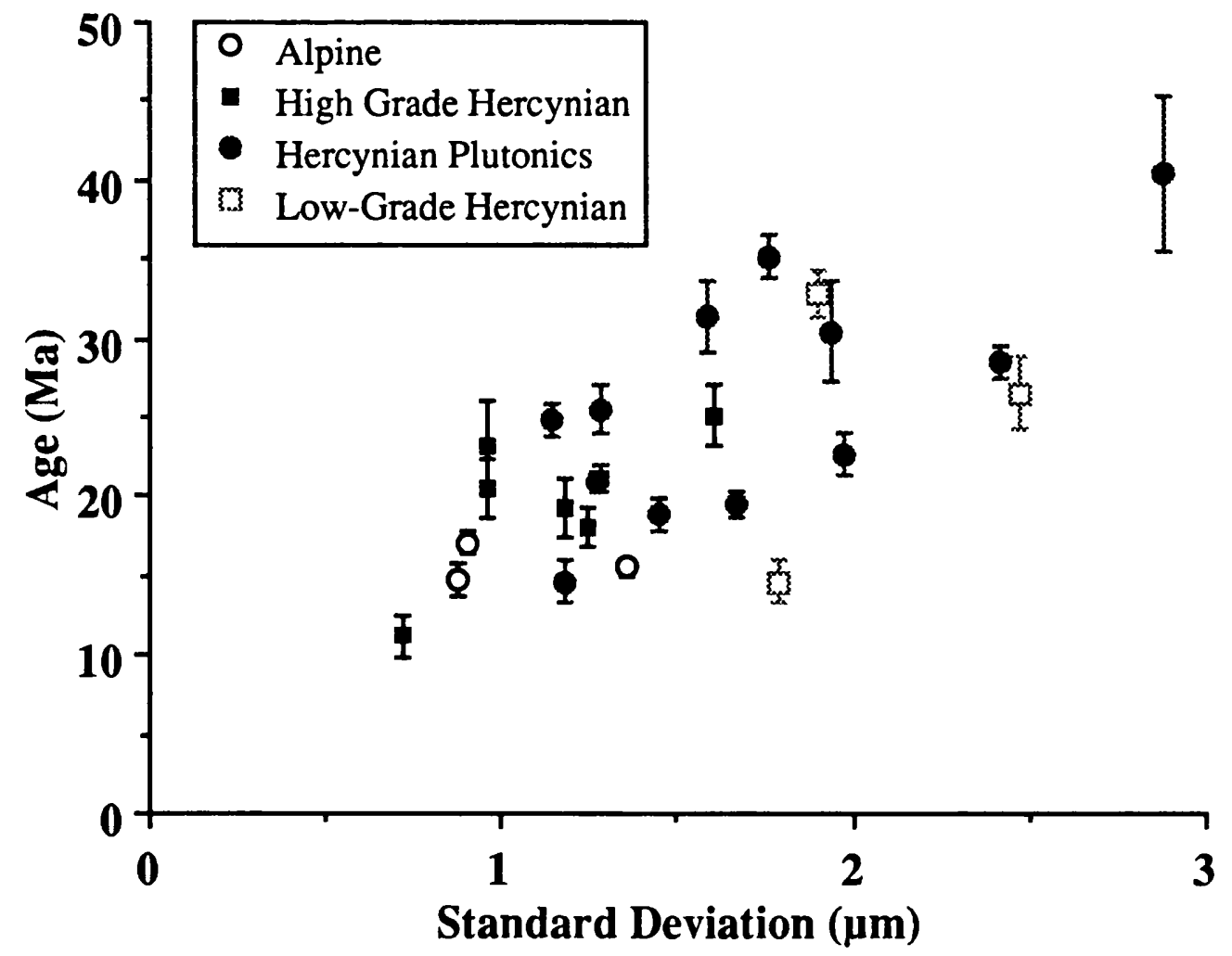

Figure 6.10 Plot of mean apatite fission track length versus the standard deviation of the track length distribution 


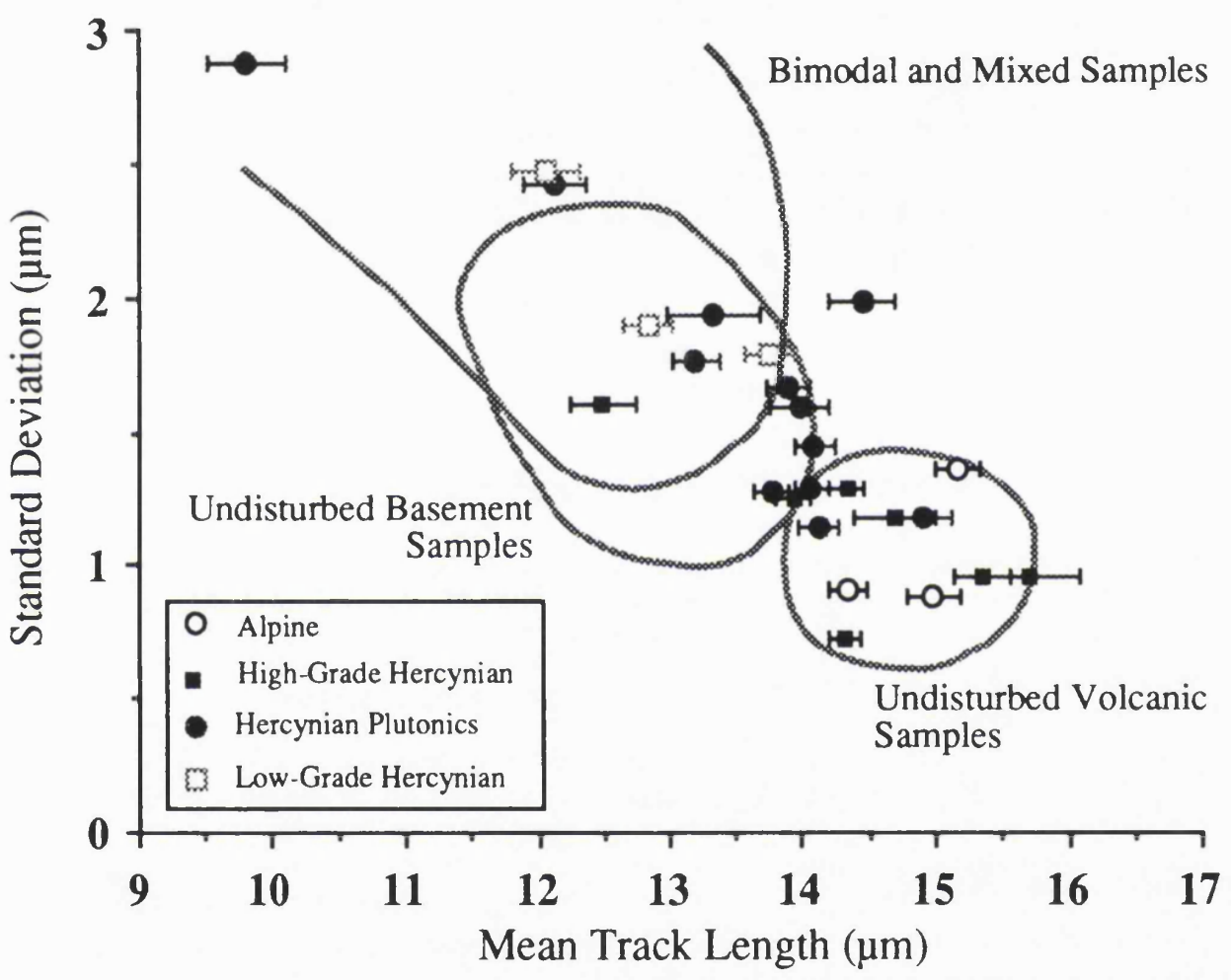

Figure 6.11 Plot comparing mean track length with standard deviation of track length distribution for the basement units of the Calabrian Arc (definitions of distribution types after Gleadowet al., 1986) 
al. (1986). What this graph shows is that many samples fall within the 'undisturbed basement' and undisturbed volcanic' fields. This implies that the apatite crystals from these samples originate from single populations and have experienced simple cooling histories. However three samples do plot in the 'mixed' field suggesting two populations of track lengths may be present, implying a complex cooling history, or that the apatite crystals originate from more than one population.

If some of these samples do have two track length populations it is possible to proffer an alternative interpretation similar to that of Brown et al. (1990) from southwest Africa. The data of Figures 6.9 and 6.10 reveal a distinct pattern, with a continuous trend between the youngest ages, which have the highest mean track length with lowest standard deviations and the older ages that have progressively shorter mean track lengths and increasing standard deviations. According to Gleadow and Fitzgerald (1987) and Brown et al. (1990), such a pattern indicates a period of thermal annealing, in this case between $\sim 15$ and $20 \mathrm{Ma}$, affecting the samples to varying degrees, followed by a period of rapid cooling. The samples with the high mean track lengths and young ages have been totally annealed, and contain only one component of fission tracks, accumulated after the annealing event, whereas the samples with lower track lengths and higher ages represent samples at higher crustal levels that have not been totally annealed.

\subsection{QUANTITATIVE ANALYSIS}

The recent advances in the mathematical modelling of the apatite annealing process now allow the quantitative analysis of apatite fission track data to provide detailed thermal histories. The various techniques that have been proposed have already been outlined in Chapter 4, section 4.3.3. The apatite fission track data obtained in this study were used in a computational inverse modelling approach, using the Monte Carlo method (K.Gallagher, pers. comm.). The description and use of this program is also outlined in Chapter 4, section 4.3.3. The technique was used to constrain the qualitative low-temperature thermal histories, especially below $\sim 130^{\circ} \mathrm{C}$, and more importantly the variation in cooling rates at these temperatures. 
The way the modelling program is applied to the sample data is outlined in Figure 6.12. This example uses sample ONO-400, a garnet sillimanite gneiss from the Hercynian high-grade metamorphic suite of rocks. The time-temperature history is constrained at two end points. The zircon age $(29.2 \pm 1.3 \mathrm{Ma})$ with an estimated closure temperature of 200 $250^{\circ} \mathrm{C}$, and the present day surface temperature, taken as $12^{\circ} \mathrm{C}$. The thermal history of the sample must have passed between these two points. The model was then further limited by using two more time-temperature boxes chosen to allow as many possible thermal histories to be tested (the first box was limited by the annealing range of apatite, $80 \pm 60^{\circ} \mathrm{C}$, and the sample apatite fission track age, $20 \pm 4 \mathrm{Ma}$ ). For this sample, 200 random Monte Carlo runs were made. For each run the calculation parameters used were: 10 time intervals for the total thermal history and 20 isothermal intervals between each of the four T-t points chosen for each run. This allowed the calculation of each run using the 'equivalent-time' method (see Chapter 4, section 4.3.3, after Duddy et al., 1988). Figure 6.12 (a) shows the runs that predict results compatible with the age, mean track length and standard deviation within error of the sample data. All the predicted T-t paths that fit the data show a similar trend, indicating a simple two stage cooling history. Between 28 and $18 \mathrm{Ma}$, there was steady cooling at a rate of $\sim 18^{\circ} \mathrm{C} / \mathrm{Ma}$, down to a temperature of $30-50^{\circ} \mathrm{C}$. The predicted $\mathrm{T}-\mathrm{t}$ paths then show slower cooling between $\sim 18 \mathrm{Ma}$ and the present day, at cooling rates of between $1-2^{\circ} \mathrm{C} / \mathrm{Ma}$. Figure 6.12 (b) shows the runs that predict results that fit none of the sample data constraints. Most of these runs fall in the lower half of the T-t boxes, with a relative absence of failed runs in the regions of the predicted best fitting cooling history. Finally Figure 6.12 (c) shows the single run that predicts the best fit to the sample apatite data, with an example of the track length histogram that would be expected from this thermal history, compared to the true track length distribution (lighter shading).

Figure 6.13 shows the predicted cooling histories that fit the age, length and standard deviation for the Alpine Group and high-grade Hercynian metamorphic samples. The runs that predict the sample data show some variation between individual samples, although some general trends can be identified. The samples from the Alpine Group (COR390, COR-410, CUR-380a) indicate a rapid cooling between 16-20Ma, at rates of up to 
Figure 6.12 Time-temperature plots for sample ONO-400 (High-Grade Hercynian Metamorphic) derived from numerical modelling.

a) shows plots that agree with both age and length data

b) shows plots that fit neither age nor length data

c) shows plot giving the best fit to the sample data

a)

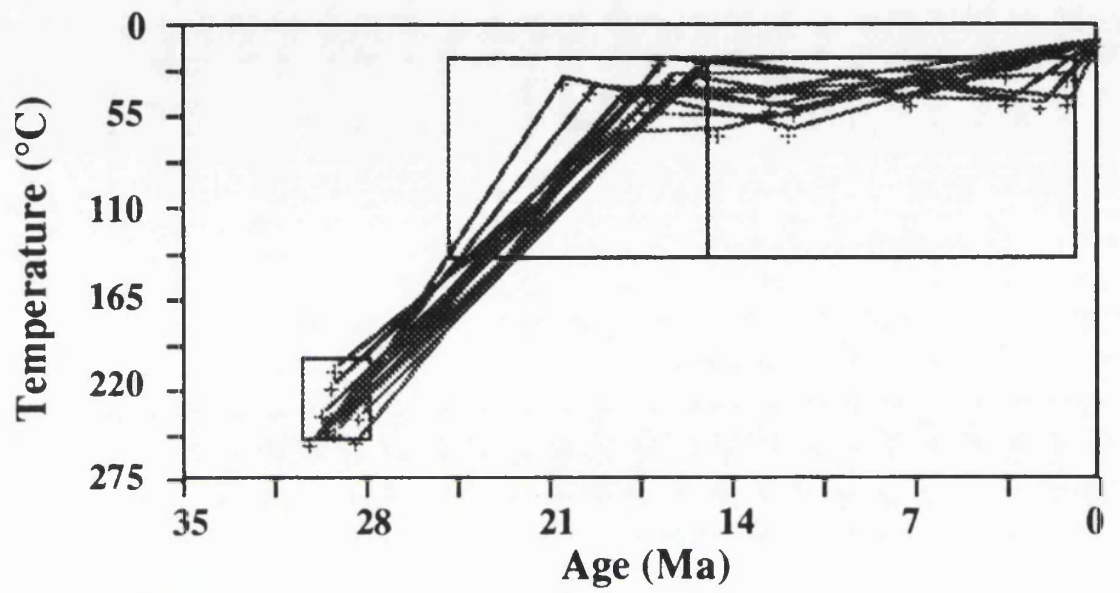

b)

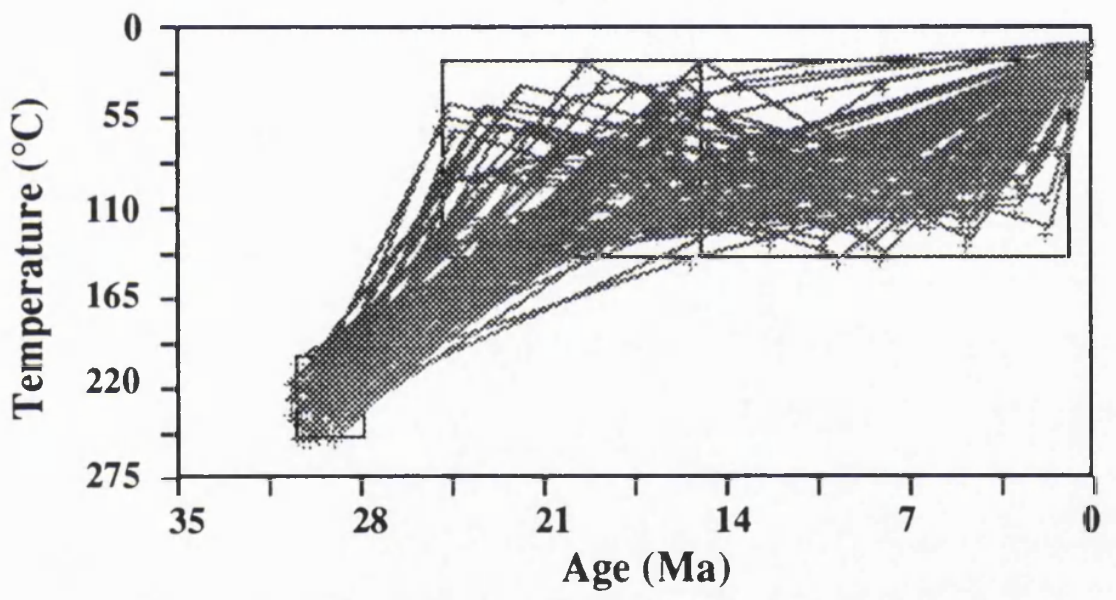

c)

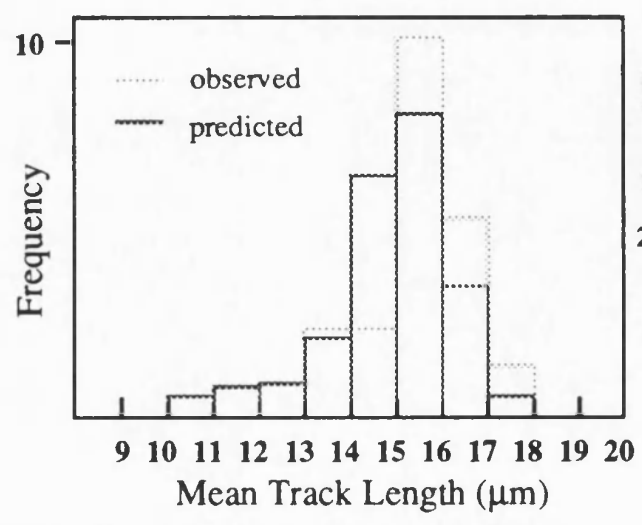

Data predicted from the above best fit $\mathrm{T}-\mathrm{t}$ Plot (after 400 Monte Carlo runs)

Age : $21.89 \mathrm{Ma}$

Mean length: 15.0

S.D. : 1.12

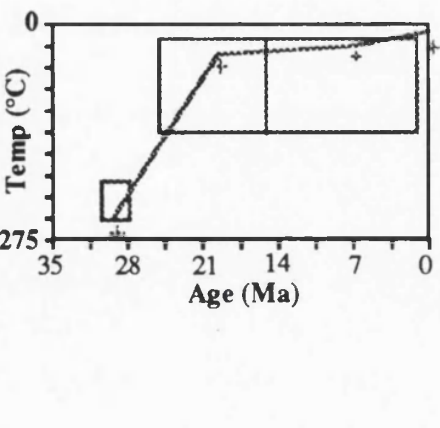

Actual ONO-400 sample data

Age : $20.5 \pm 1.9 \mathrm{Ma}$

Mean length: $15.35 \pm 0.5$

S.D. : 0.96 
Figure 6.13 Alpine Group and high-grade Hercynian metamorphic time-temperature plots derived from numerical modelling.

(Each plot shows the time-temperature histories that fit both the age and length data acquired from each sample to within the errors quoted, after 200 Monte Carlo runs )

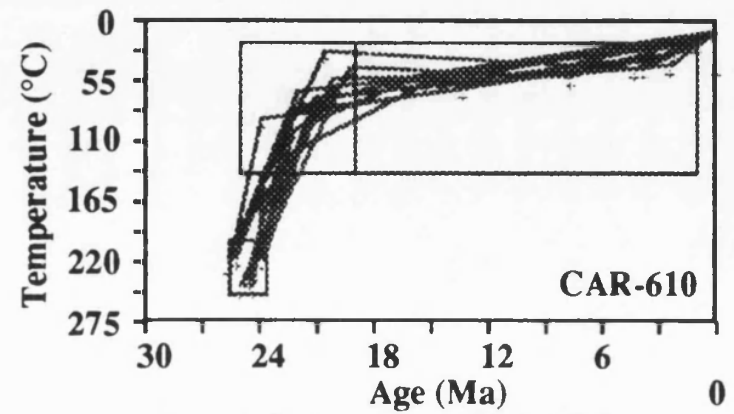

Sample Data : Age : $21.1 \pm 0.8$

MTL : $14.34 \pm 0.5$

$\mathrm{SD}: 1.28 \pm 0.5$
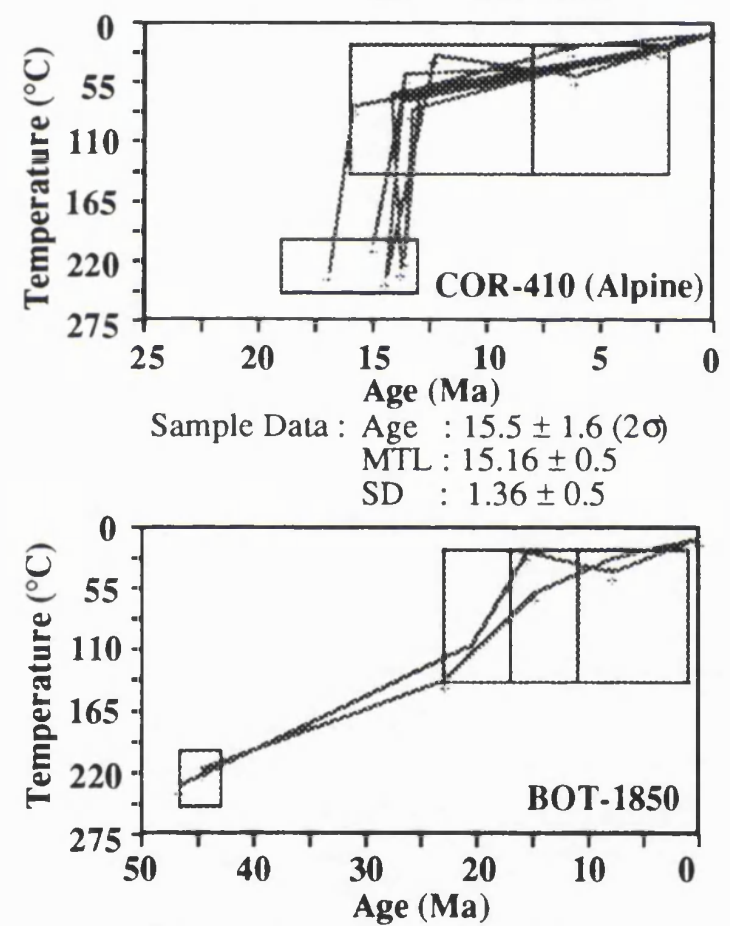

Sample Data : Age : $19.3 \pm 1.9$

MTL : $14.69 \pm 0.5$

$\mathrm{SD}: 1.18 \pm 0.5$

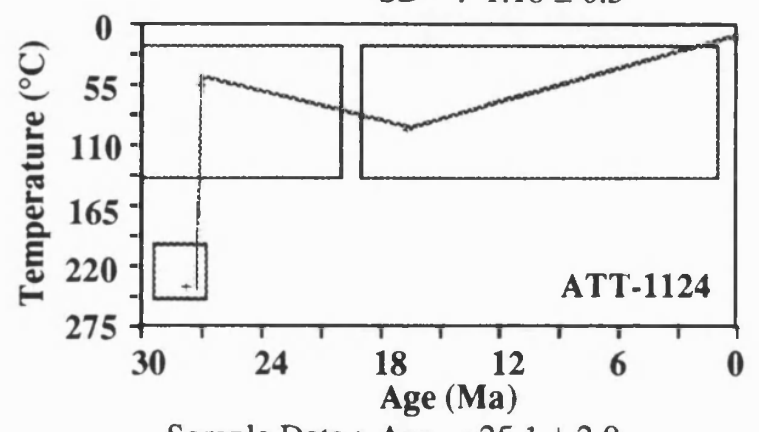

Sample Data : Age : $25.1 \pm 2.0$

MTL: $12.49 \pm 1.0$

$\mathrm{SD}: 1.61 \pm 1.0$

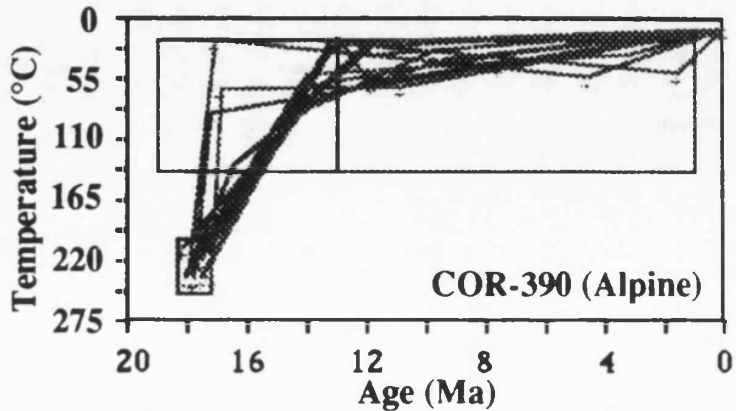

Sample Data : Age : $14.7 \pm 1.0$

MTL : $14.98 \pm 0.5$

$\mathrm{SD}: 0.88 \pm 0.5$

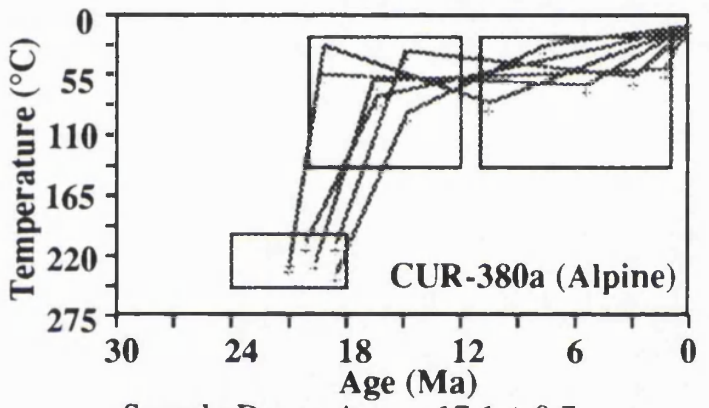

Sample Data : Age : $17.1 \pm 0.7$

MTL : $14.34 \pm 0.5$

SD : $0.90 \pm 0.5$

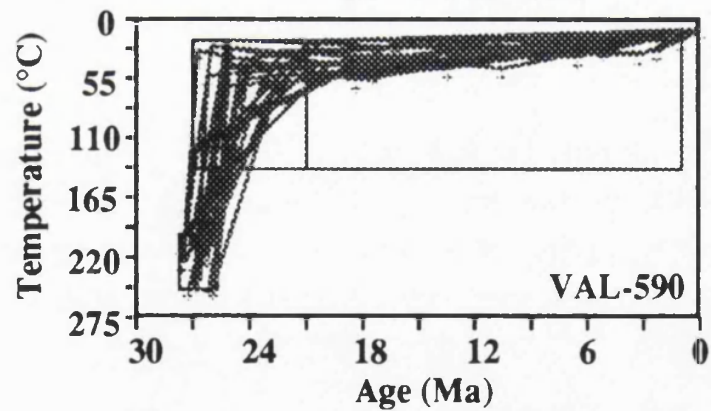

Sample Data : Age : $23.2 \pm 2.8$

MTL : $15.70 \pm 1.0$

SD : $0.96 \pm 0.5$

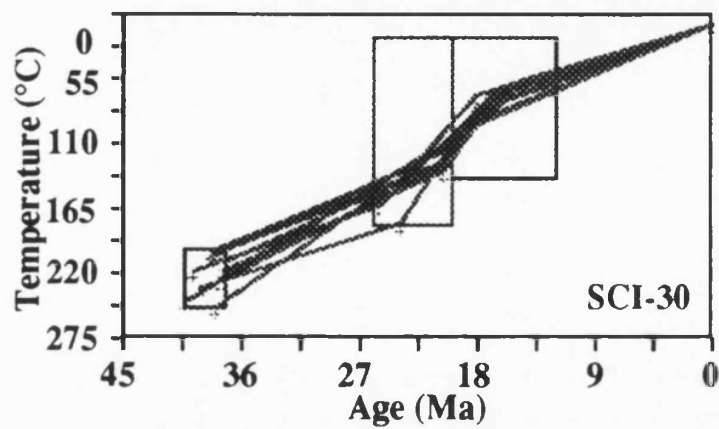

Sample Data : Age : $18.1 \pm 1.2$

MTL : $13.94 \pm 0.5$

SD : $1.25 \pm 0.5$ 
$50^{\circ} \mathrm{C} / \mathrm{Ma}$, then slow cooling from about temperatures of $50-60^{\circ} \mathrm{C}$ to the surface between $\sim 14 \mathrm{Ma}$ and the present day. However, the high-grade metamorphic rocks show an increased cooling rate at a slightly earlier time, between $20 \mathrm{Ma}$ and $30 \mathrm{Ma}$. One sample of particular note is ATT-1124. Here the one run from 200 that agrees with the sample data shows an extremely rapid cooling event occurred at 27Ma, suggesting almost instantaneous cooling from $230^{\circ} \mathrm{C}$ to $50^{\circ} \mathrm{C}$. To fit the low sample mean track length a subsequent minor heating event is also required by the model.

The predicted T-t histories for the Hercynian plutonic and low-grade Hercynian metamorphic samples are shown in Figure 6.14. Several of these plots show the advantage of using quantitative analysis rather than closure temperatures, especially for the samples with high zircon ages. The true apatite data from samples AND-480, SAV-920 and MAN650 all require increases in the cooling rate between $\sim 30$ and $20 \mathrm{Ma}$ from temperatures of $160^{\circ} \mathrm{C}$ to the surface. Without the quantitative model, no evidence for this increased cooling rate would be available, although some increase in the cooling rate between the apatite closure temperature and the surface would be detectable. Sample FER-1148, that also has a high zircon fission track age, does not show such an obvious increase in the cooling rate between 30 and 20Ma. With this sample a simple gradual cooling path can be invoked to explain the apatite fission track data. Several samples from which apatite data has been subjected in numerical modelling do not have the $\mathrm{T}$-t constraint of a zircon fission track age. As a result two of these samples ARI-580 and BOV-30 show a large variety of T-t histories that fit the sample data. However the most important aspect revealed by these numerically derived cooling histories is that they show most of the Hercynian plutonic and low-grade Hercynian metamorphic samples analysed experienced some degree of increased cooling between $\sim 30$ and $20 \mathrm{Ma}$. Whereas previously the samples from the Capo Vaticano intrusion appeared anomalous, when modelled quantitatively they show some compatibility with the other plutonic rocks. The young zircon ages obtained from these samples indicates only that the late Tertiary cooling event was initiated at slightly higher original temperatures in these rocks when compared to the other Hercynian plutonic rocks. This suggests they were at a deeper crustal level prior to $\sim 35 \mathrm{Ma}$. 
Figure 6.14 Hercynian plutonic and low-grade metamorphic time-temperature plots derived from numerical modelling

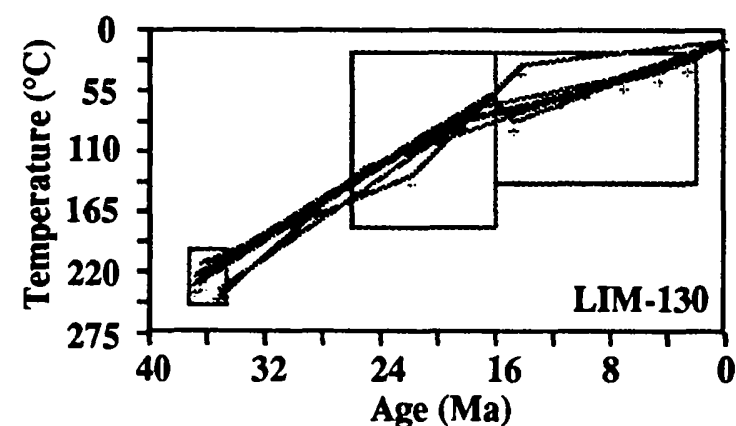

Sample Data : Age : $18.8 \pm 1.0$

MTL : $14.09 \pm 1.0$

$\mathrm{SD}: 1.45 \pm 0.5$

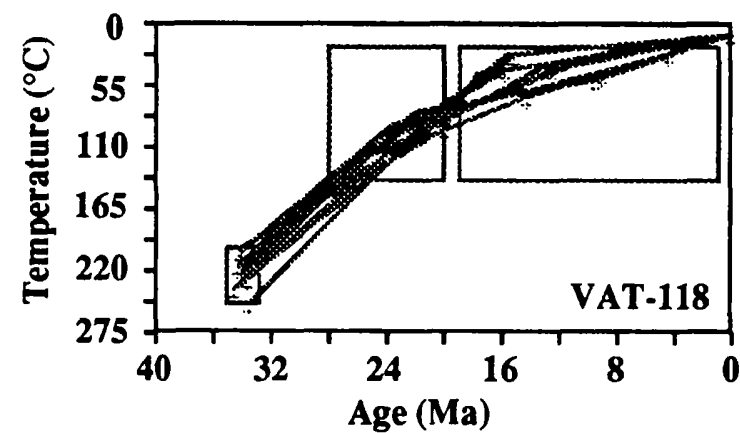

Sample Data : Age : $22.6 \pm 1.3$

MTL : $14.45 \pm 0.5$

$\mathrm{SD}: 1.98 \pm 0.5$

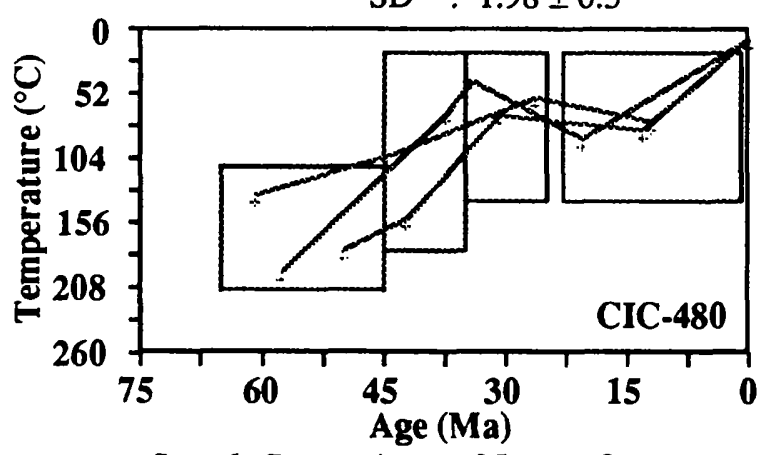

Sample Data : Age : $35.1 \pm 1.3$

MTL : $13.20 \pm 0.5$

$\mathrm{SD}: 1.76 \pm 0.5$

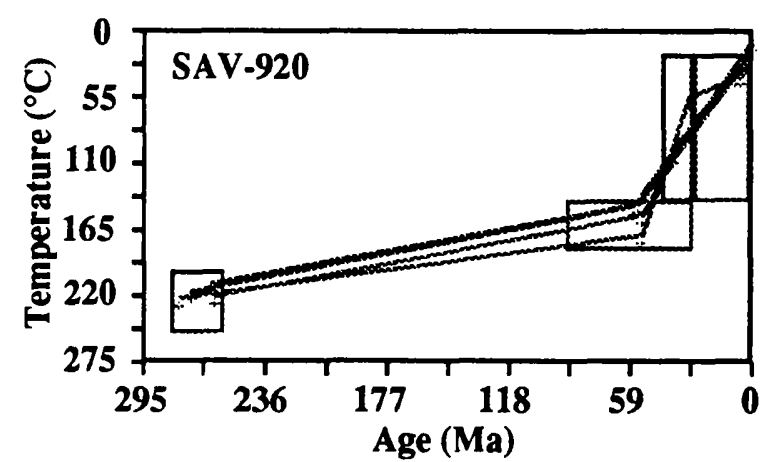

Sample Data : Age : $30.4 \pm 3.2$

MTL : $13.33 \pm 1.0$

$\mathrm{SD}: 1.94 \pm 1.0$

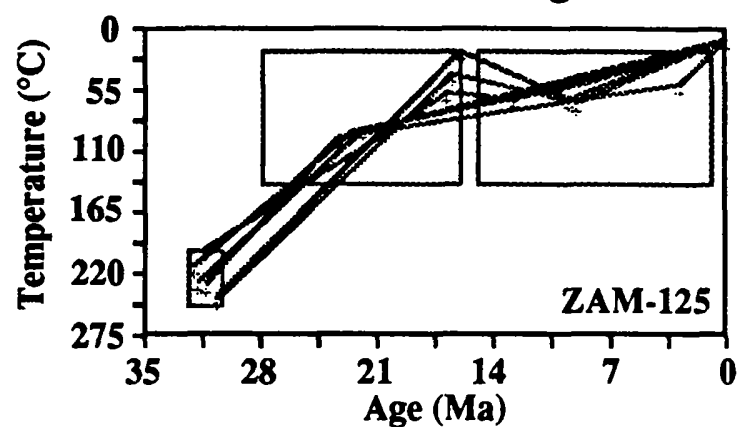

Sample Data : Age : $20.9 \pm 0.7$

MTL : $13.77 \pm 0.5$

SD $: 1.27 \pm 0.5$

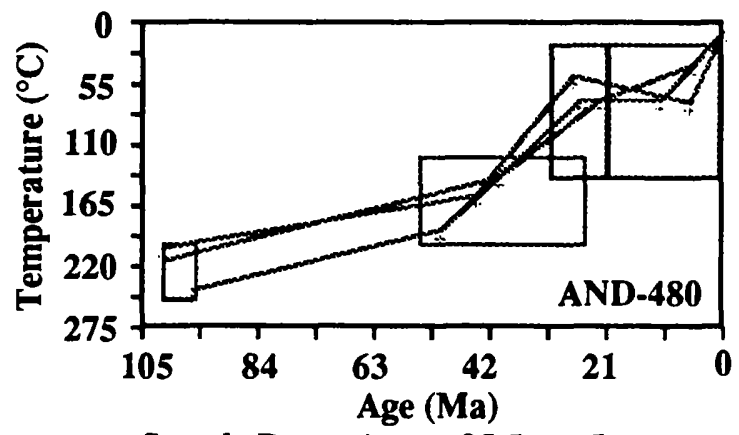

Sample Data : Age : $25.5 \pm 1.5$

MTL : $14.06 \pm 1.0$

$\mathrm{SD}: 1.28 \pm 0.5$

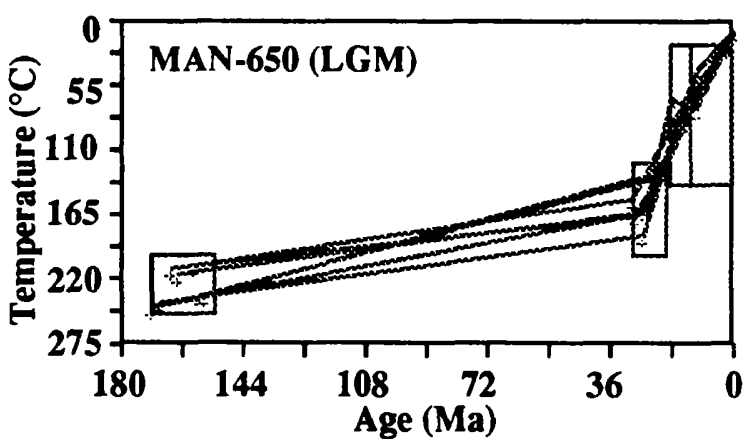

Sample Data : Age : $14.6 \pm 1.3$

MTL : $13.75 \pm 0.5$

SD : $1.79 \pm 0.5$

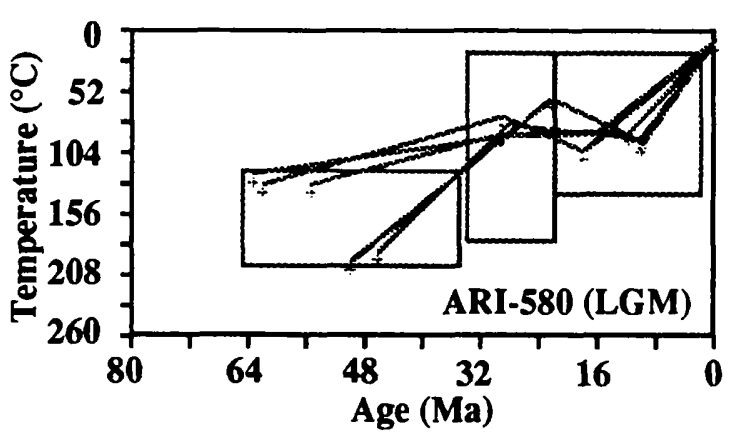

Sample Data : Age : $26.5 \pm 2.4$

MTL : $12.06 \pm 0.5$

SD. : $2.47 \pm 0.5$ 
Figure 6.14 (continued)

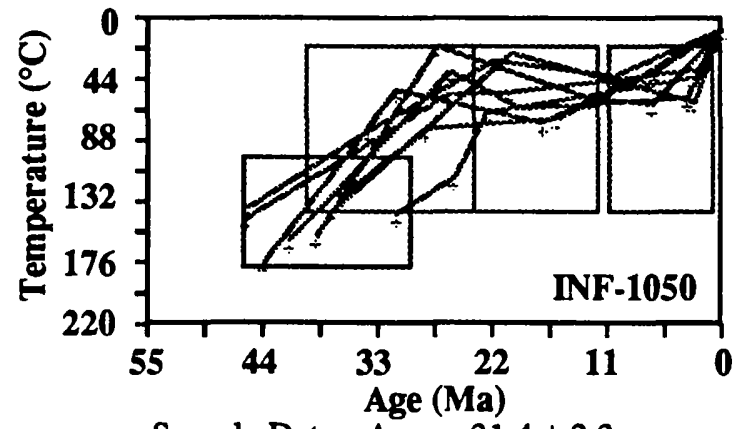

Sample Data : Age : $31.4 \pm 2.3$

MTL : $13.98 \pm 0.5$

SD $: 1.59 \pm 0.5$

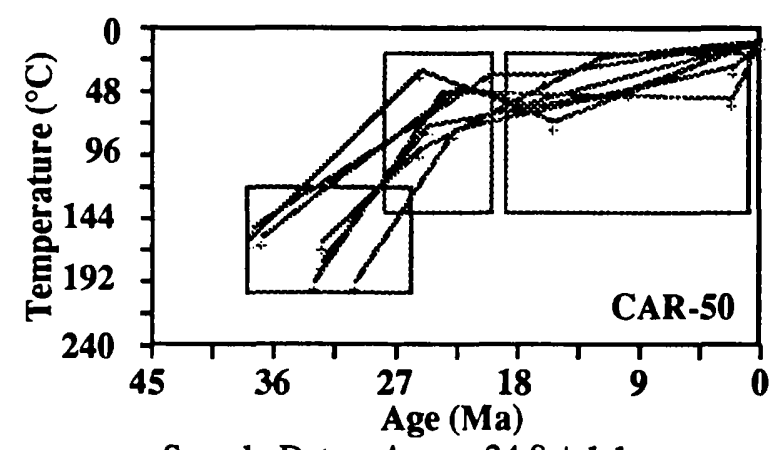

Sample Data : Age : $24.8 \pm 1.1$

MTL : $14.12 \pm 0.5$

SD $: 1.14 \pm 0.5$

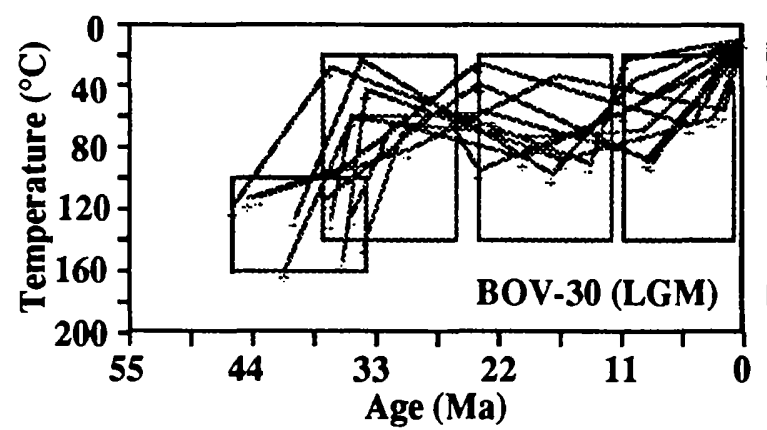

Sample Data : Age : $32.8 \pm 1.4$

MTL : $13.94 \pm 0.5$

SD $: 1.25 \pm 0.5$

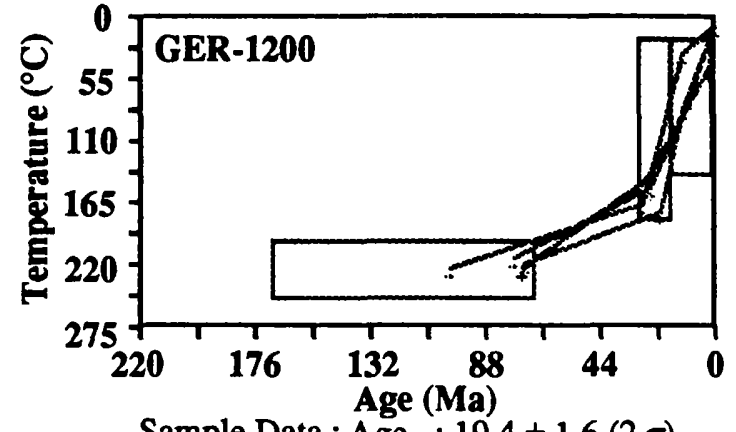

Sample Data : Age : $19.4 \pm 1.6(2 \sigma)$

MTL : $13.90 \pm 1.0$

SD $: 1.67 \pm 1.0$

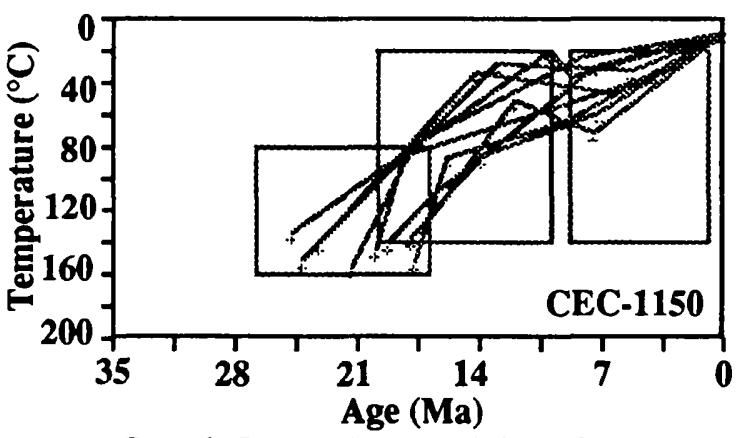

Sample Data : Age : $14.6 \pm 1.3$

MTL : $14.90 \pm 1.0$

SD : $1.18 \pm 0.75$

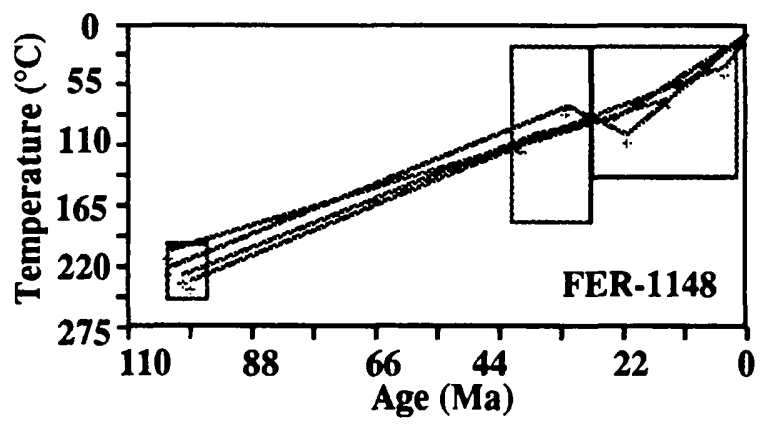

Sample Data : Age : $28.5 \pm 1.0$

MTL : $12.13 \pm 1.0$

SD : $2.42 \pm 1.0$ 
Some examples of comparisons between the predicted best fitting time-temperature history and track length distributions provided by the modelling program and the observed sample data and track length distributions are given in Figure 6.15. By using a track length distribution histogram, the fit of the predicted and observed data can be more readily illustrated. All these examples demonstrate reasonable fits to the data, especially if consideration is taken of the errors that can occur when counting sample track lengths.

When the predicted low-temperature cooling histories obtained from the apatite age and length data from all the different rocks groups is compared some similarity is seen. Although individual samples show some local minor variation, the majority of the samples from the high-grade Hercynian metamorphic rocks, the Hercynian plutonic rocks and the low-grade Hercynian metamorphic rocks have apatite data that is consistent with significantly increased cooling between $\sim 35 \mathrm{Ma}$ and $20 \mathrm{Ma}$. However the apatite data from the Alpine Group samples and several other samples such as MAN-650 and CEC-1150 requires the main period of increased cooling to happen between $\sim 20 \mathrm{Ma}$ and $15 \mathrm{Ma}$. What appears to be significant is that the lower the sample in the tectono-stratigraphic section (according to Messina et al., 1991a/b) then the more recent the main cooling event appears to be.

One other time-temperature constraint that can be applied to the modelling program is provided by basement unconformities seen throughout the Calabrian Arc. The age of the oldest sediment above the unconformity represents the time when erosion ceased and reburial of the unconformity began. As sediment is deposited at the surface, it represents the surface temperature. Thus this T-t point can be incorporated into the model. However, areas of sedimentation are often distinct from areas of exhumation and erosion over short distances. Therefore such a T-t constraint is only valid directly below an unconformity. Therefore if the basement rocks were immediately beneath the unconformity then the modelling program should predict T-t paths that are close to the surface (low temperatures) at the time in question. The oldest undisturbed sediments found overlying the crystalline basement rocks are $\sim 29 \mathrm{Ma}$ (the Stilo-Capo d'Orlando Formation). However this formation is restricted to southern Calabria and northeastern Sicily. In the major part of the Calabrian 
Figure 6.15 Some examples of best fit data predicted by using the Monte Carlo numerical modelling for apatite fission track thermal histories

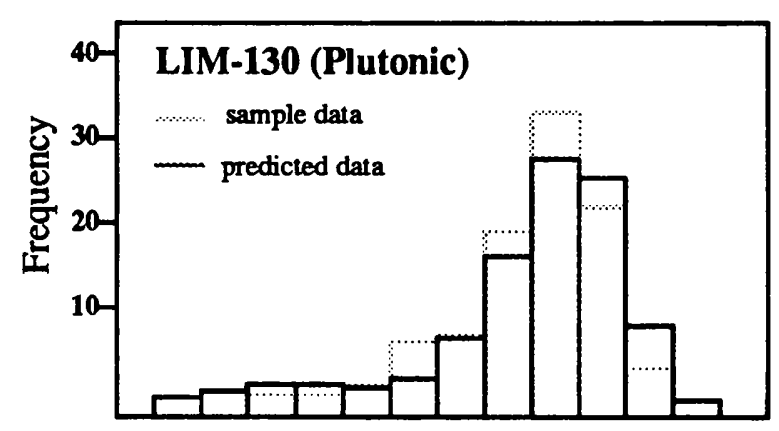

$\begin{array}{llllllllllllll}6 & 7 & 8 & 9 & 10 & 11 & 12 & 13 & 14 & 15 & 16 & 17 & 18 & 19\end{array}$

Mean Track Length $(\mu \mathrm{m})$

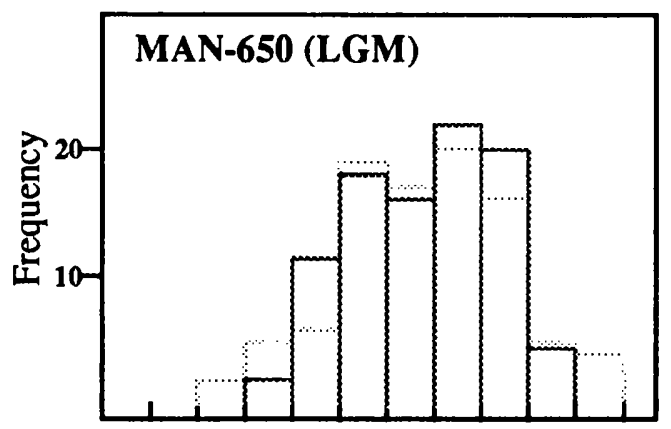

$\begin{array}{lllllllllll}8 & 9 & 10 & 11 & 12 & 13 & 14 & 15 & 16 & 17 & 18\end{array}$

Mean Track Length $(\mu \mathrm{m})$
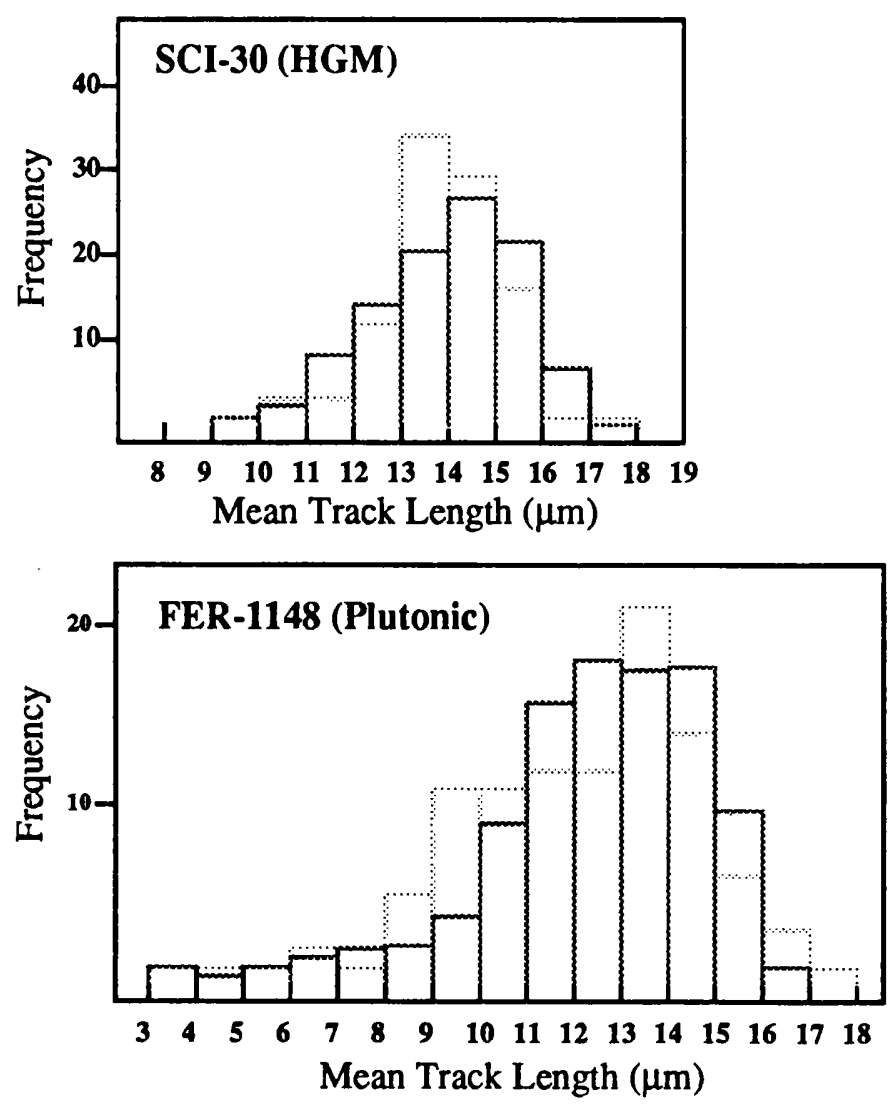

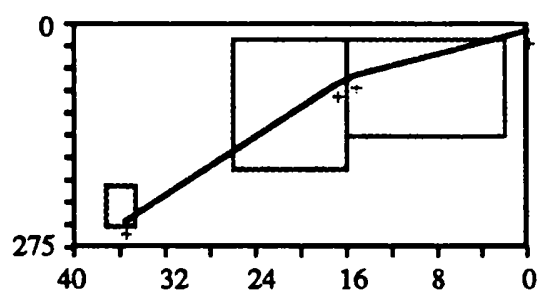

Predicted Data Sample Data Age : $19.07 \mathrm{Ma} \quad 18.8 \pm 1.0 \mathrm{Ma}$ MTL : $14.08 \quad 14.09 \pm 1.0$ SD $: 2.01 \quad 1.45 \pm 0.5$

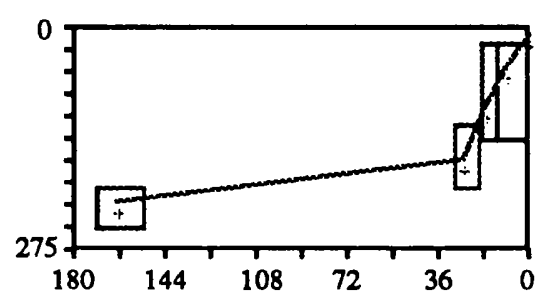

Predicted Data Sample Data Age : $14.80 \mathrm{Ma} \quad 14.6 \pm 1.3 \mathrm{Ma}$ MTL : $13.80 \quad 13.75 \pm 0.5$ SD : $1.52 \quad 1.79 \pm 0.5$

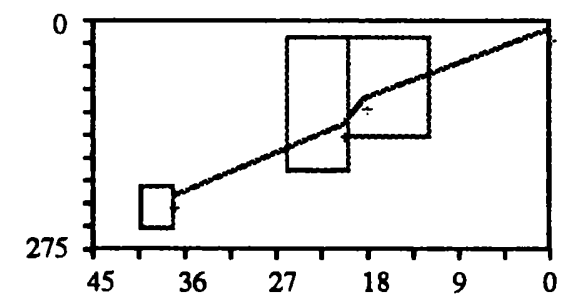

Predicted Data Sample Data Age : $18.02 \mathrm{Ma} \quad 18.1 \pm 1.2 \mathrm{Ma}$ MTL : $14.03 \quad 13.94 \pm 0.5$ $\mathrm{SD}: 1.48 \quad 1.25 \pm 0.5$

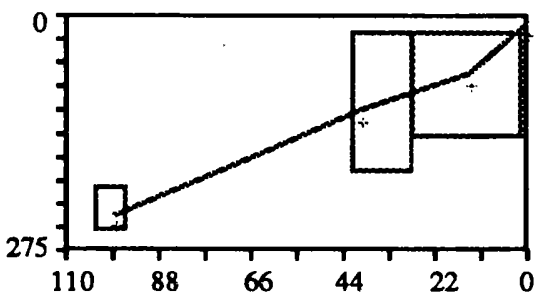

Predicted Data Sample Data Age : $28.51 \mathrm{Ma} \quad 28.5 \pm 1.0 \mathrm{Ma}$ MTL : $12.52 \quad 12.13 \pm 1.0$ SD : $2.24 \quad 2.42 \pm 1.0$ 
Arc the oldest undisturbed sediment is Tortonian in age ( 11 Ma). The predicted models from samples from southern Calabrian and northeastern Sicily, apart from BOV-30, show little evidence of a $\sim 29 \mathrm{Ma}$ unconformity. This indicates that these samples are from areas that have not experienced erosion and reburial. However some of the Monte Carlo modelling runs, such as CAR-610, VAL-590, LIM-130, VAT-118 and ZAM-125 indicate near surface temperatures at around $11 \mathrm{Ma}$. The results of incorporating an unconformity $\mathrm{T}$ $\mathrm{t}$ constraint into the Monte Carlo runs of these samples are shown in Figure 6.16. What is seen is that by incorporating the $\sim 11 \mathrm{Ma}$ unconformity constraint is that the apatite data from some of the samples requires a reheating event of up to $\sim 60^{\circ} \mathrm{C}$ in some samples, followed by a more recent cooling phase.

\subsection{COOLING HISTORIES : THEIR GEOLOGICAL INTERPRETATION}

\section{AND SIGNIFICANCE}

\subsubsection{Cooling, Exhumation and the Geotherm}

So far in this thesis both the previously obtained isotopic age data and the newly acquired fission track age and track length data have been used to estimate cooling histories and closure temperatures. The problems of interpreting isotopic closure temperatures either as indicating cooling paths or thermal resetting events were discussed in Chapter 3 , section 3.3.2 where it was shown that time-temperature information alone can be useful. T-t information enables comparisons between different rock groups to be made, based on factors such as cooling rate. Also, although not relevant in this study, high temperature isotopic systems such as $\mathrm{U}-\mathrm{Pb}$ dating of zircon and monazite can date the timing of peak metamorphism or plutonic intrusion. This information is important for constraining tectonic models of collisional orogens.

If the change of temperature with depth in the Earth's crust (the crustal geotherm) is known, time-temperature histories can be converted to time-depth histories. As temperature profiles are referenced from the Earth's surface then cooling should signify the progress of a particular sample or rock group towards this surface. This process is termed exhumation or unroofing. It is often assumed that amount of cooling and cooling rates derived from 
Figure 6.16 Some predicted best fit time-temperature plots incorporating unconformity constraints.

HGM : High-grade Hercynian metamorphic rock sample

Plutonic : Hercynian plutonic rock sample
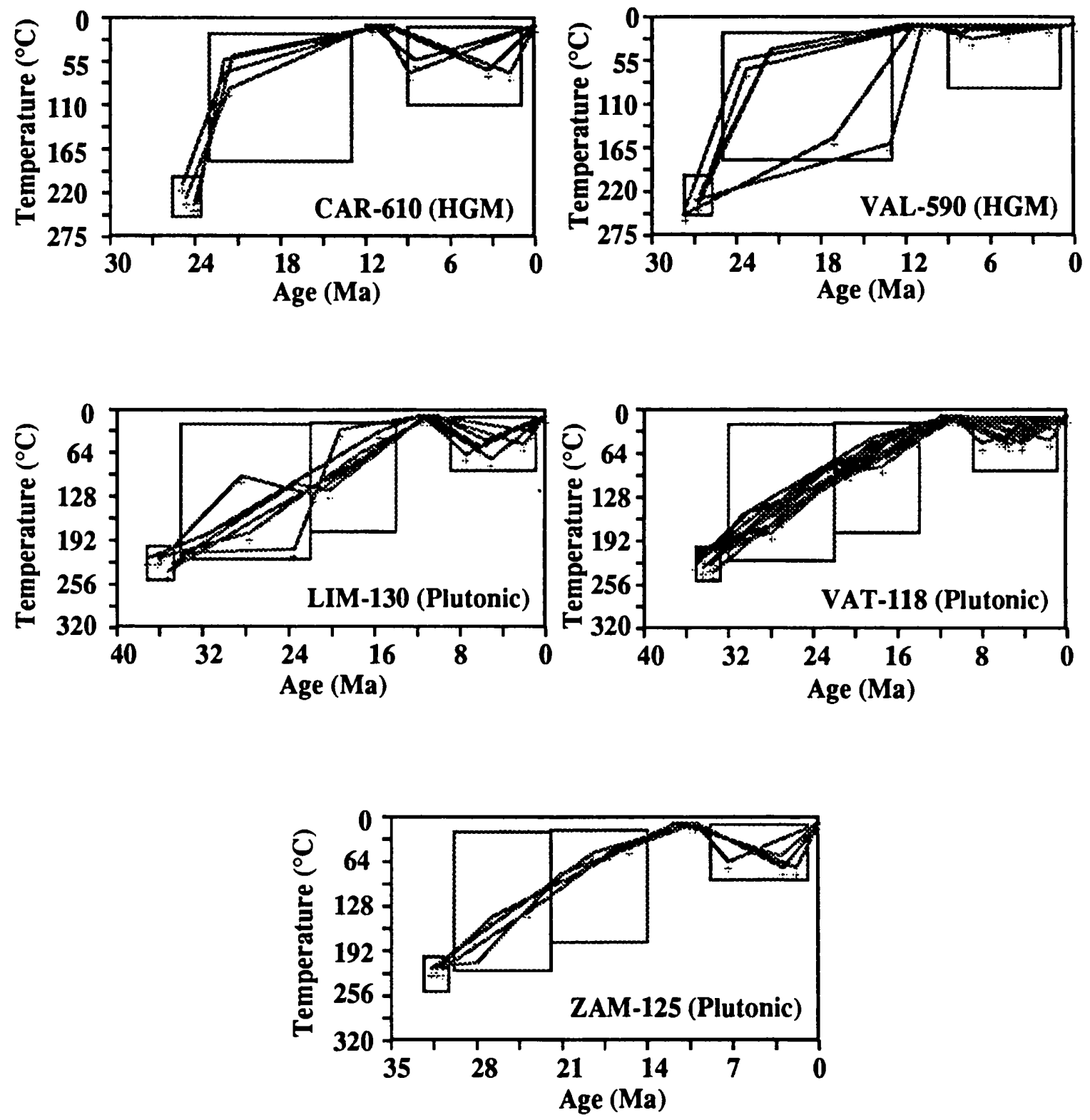
isotopic age data is proportionally related to amount of exhumation and exhumation rate, especially in active orogenic belts. However such an assumption is clearly incorrect. It first assumes that the crustal geotherm or thermal structure of the crust remains constant through time. However in rapidly evolving orogenic belts, such as the Calabrian Arc, the geotherm can be affected in various ways. These include fluid flow in the rock column (e.g. Connolly and Thompson, 1989) and intrusive bodies that can cause rapid increases in the geothermal gradient (e.g. Harrison and Clarke, 1979). Major thrusting can cause the development of inverse temperature gradients, with the emplacement of hot material on cool material. This can lead cooling within a sample without any need for exhumation, although erosional exhumation does usually accompany overthrusting (England and Richardson, 1977, Davy and Gillet, 1986). Parrish (1982; 1985) and Koons (1987) have also shown that if exhumation is sufficiently rapid then temperature isotherms will be bought closer to the surface before the crustal geotherm can re-equibrilate. This results in compression of isotherms and therefore an increased geothermal gradient. Parrish (1985), from data obtained from the Coast Mountains of British Columbia, proposes that at exhumation rates of less than $300 \mathrm{~m} / \mathrm{Ma}$, no compression will occur. However if the rate exceeds $500 \mathrm{~m} / \mathrm{Ma}$ compression of the isotherms will occur, leading to over-estimations of exhumation amounts and rates derived from cooling histories.

If these uncertainties can be accounted for and the geotherm can reasonably be assumed to have remained unchanged through time, the cooling rate will only be proportional to the exhumation rate if the geotherm is linear with depth. However in rapidly deforming and eroding orogenic belts some of the factors mentioned above can also influence this linearity, especially thrusting and intrusions.

Hubbard et al. (1991) have also shown that even if the geotherm is well constrained by observed data, simple thermal models show that the time-dependent exhumational history can still only be poorly constrained. To further constrain exhumational histories, especially from high temperature isotopic data, the most reliable method is to combine metamorphic pressure-temperature data with temperature-time data.

The above discussion is generally only relevant at the relatively elevated 
temperatures of the crustal geotherm. At lower temperatures the influence of many of the above factors that alter the geotherm is much reduced. This therefore means that lowtemperature cooling histories, such as those derived from apatite and zircon fission track analysis, the main influence on the amount and rate of cooling is exhumation, not changes in the crustal geotherm.

\subsubsection{Definition and Processes of Exhumation}

The definition of the term "exhumation" and the confusion surrounding the use of the term "uplift" has been the subject of several recent review articles (England and Molnar, 1990 and Leeder, 1991). The word "uplift"' is usually used to imply displacement in the opposite direction to gravity. However to define such a displacement, a frame of reference is required. There are two possible frames of reference that can be used; the surface of the Earth and the geoid or mean sea level. According to England and Molnar (1990) this allows the definition of three types of displacement opposed to the gravity vector:

Surface Uplift : Displacement of Earth's surface with respect to the geoid.

Uplift of Rocks : Displacement of rocks with respect to the geoid.

Exhumation : Displacement of rocks with respect to the Earth's surface.

Where Surface Uplift $=$ Uplift of Rocks - Exhumation.

As the temperature datum for crustal geotherms is referenced from the surface of the Earth it follows that any rock displaced through a particular temperature isochron, is being displaced with respect to the Earth's surface. Therefore cooling histories provide information on exhumation and exhumation rates only.

Exhumation (or unroofing) occurs by two main processes, erosion or denudation and extensional tectonism. It may also occur by diapirism, both mud and magmatic, however this is relatively minor and will not be discussed here.

Erosion and denudation are in themselves two different processes (Leeder, 1991). Erosion is referenced from the surface, thus any lowering of that surface, usually via sediment transport, is classed as erosion. Denudation refers to both surface and subsurface loss of material, thus loss of material may occur via weathering and other chemical 
processes, without any lowering of the surface (erosion). To produce an increase in the rate of erosion several processes can be postulated. Generally increased erosion is assumed to be the result of an increase in surface height and topography. Processes that can cause such surface uplift are outlined by Leeder (1991) and include crustal thickening by magmatic intrusion, lithospheric thickening by shortening, lithospheric shortening and mantle detachment, magmatic underplating, sediment underplating and flexure caused by crustal loading. However these are not the only causes. Erosion rates can vary by an order of magnitude with a change in climate (i.e. increased rainfall or glaciation). Jamieson and Beaumont $(1988 ; 1989)$ show that when high surface uplift and high climatically induced erosion, such as in South Island, New Zealand, are combined extremely high rates of exhumation can occur.

P-T-t paths that show very high decompression rates and very rapid cooling rates have been identified in numerous orogenic belts that cannot be explained by isostatically controlled surface uplift and erosion models. To explain this data, exhumation related to extensional tectonism has been invoked. Tectonic exhumation is now widely recognised as an important mechanism in many mountain belts (e.g. Platt, 1986; Wheeler, 1991; Treloar et al., 1991). Such extensional tectonism occurs very rapidly with respect to geological time compared to erosion or changes in the crustal geotherm. The result is that it will produce extremely rapid exhumation rates that can account for the observed P-T-t data.

\subsubsection{Exhumation Data from the Crystalline Basement Rocks of the}

\section{Calabrian Arc Provided by Fission Track Analysis}

The problems outlined above with regards to the relationship between cooling histories and exhumation histories means large uncertainties should be attached to any conversions between the two. However a vitrinite reflectance study of the Gela oilfield of southern Sicily indicates a Late Tertiary geothermal gradient of between $17^{\circ} \mathrm{C} / \mathrm{km}$ and $21^{\circ} \mathrm{C} / \mathrm{km}$ (Pieri and Mattavelli, 1986). This is close to the average continental geothermal gradient of $25^{\circ} \mathrm{C} / \mathrm{km}$. This has been applied to the individual sample cooling curves of Figure 6.9, to give an approximate indication of the amount of exhumation that has occurred, especially 


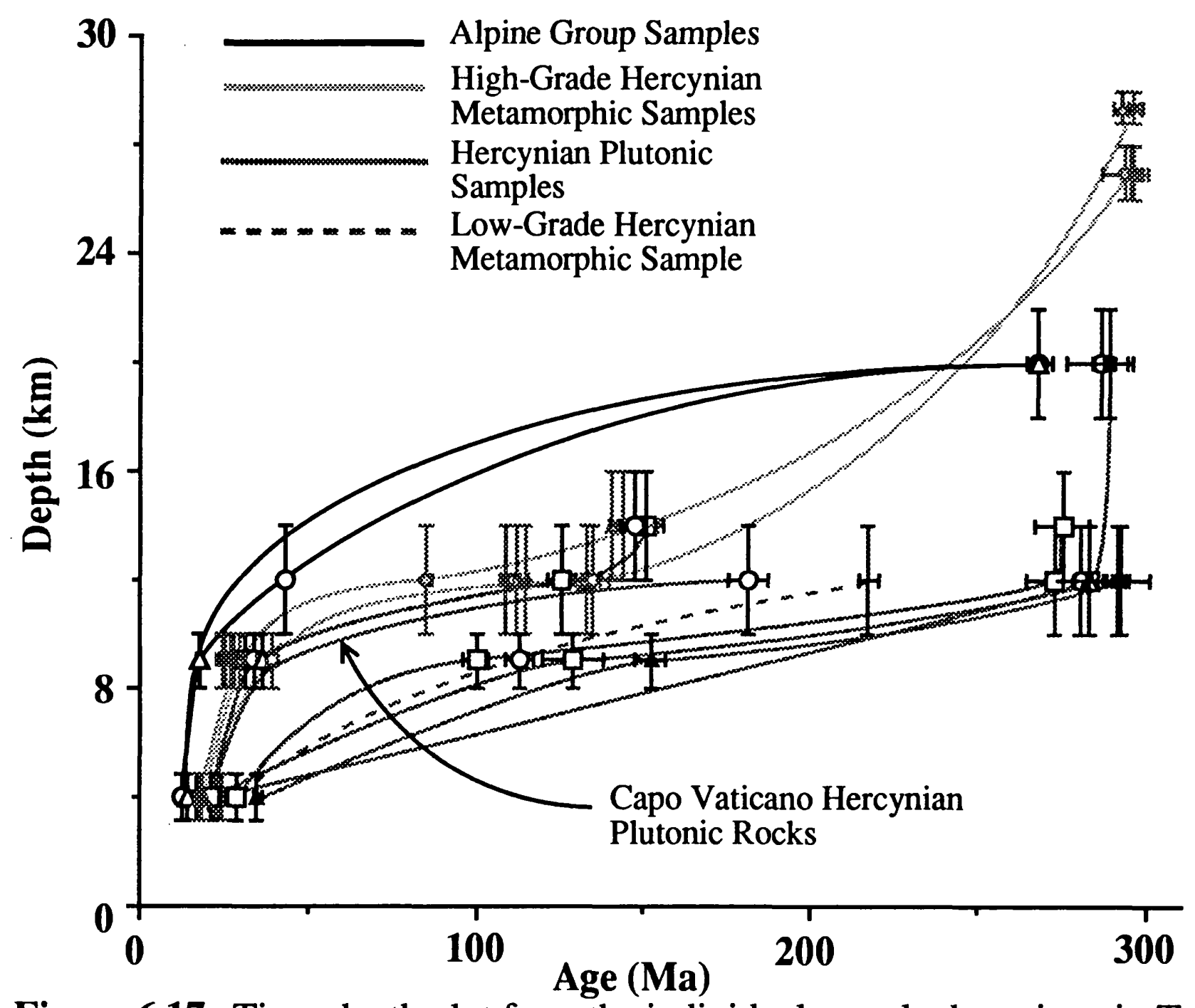

Figure 6.17 Time-depth plot from the individual sample data given in Table 6.1. An average continental geothermal gradient of $25^{\circ} \mathrm{C} / \mathrm{km}$ is used to convert temperature to depth 
during the late Tertiary (Figure 6.17). The deeper and older the exhumation path, the more approximate is the estimate. What this plot suggests is that the Alpine Group and highgrade Hercynian metamorphic rocks have been exhumed from depths of around 6-10km since $-30 \mathrm{Ma}$, whereas the Hercynian plutonics, with the exception of the Capo Vaticano quartz-diorite intrusion, and the low-grade Hercynian metamorphic samples have been exhumed from depths of $<6 \mathrm{~km}$ during the same time period.

In areas of significant topographic relief it is possible to assess the magnitude and rates of exhumation without reference to a temperature profile. This can be done by using fission track age-elevation relationships. This technique was first employed by Wagner et al. (1979) who observed that the apatite fission track age increased with elevation within the Bergell intrusive complex of the western Alps. From the gradient of the subsequent plot of age versus elevation it was then possible to calculate a rate of exhumation. However Parrish (1985) states that this approach still requires the assumption that the temperature isotherms are horizontal and static during the period of exhumation. If such isotherms are not static, then the depth to a particular isotherm, for instance the zircon fission track closure temperature, will vary. This leads to over- or under-estimations of the true exhumation history of the area in question. Also if analysed samples are taken over a wide area, or from more than one rock group, then the age-elevation profile may be offset by post-exhumational structures. This is particularly true in the Calabrian Arc. Here much neotectonic fault activity, surface uplift and block rotation has occurred that post-dates the main periods of cooling. This has the effect of offsetting most of the fission track ageelevation data obtained from the region. This is evident in the age-elevation plots for both apatite and zircon, calculated from the fission track results of the crystalline basement rocks, illustrated in Figures 6.18 to Figure 6.21.

However the recent Pleistocene surface uplift has been the subject of several detailed studies that have published information quantifying the rate and amount of surface uplift in the Calabrian Arc (Ghisetti, 1981; Cosentino et al., 1989; Barrier et al., 1987). Many of these measurements are obtained from marine terraces that provide a direct measure of surface uplift. Therefore any sample collected from directly below a marine 


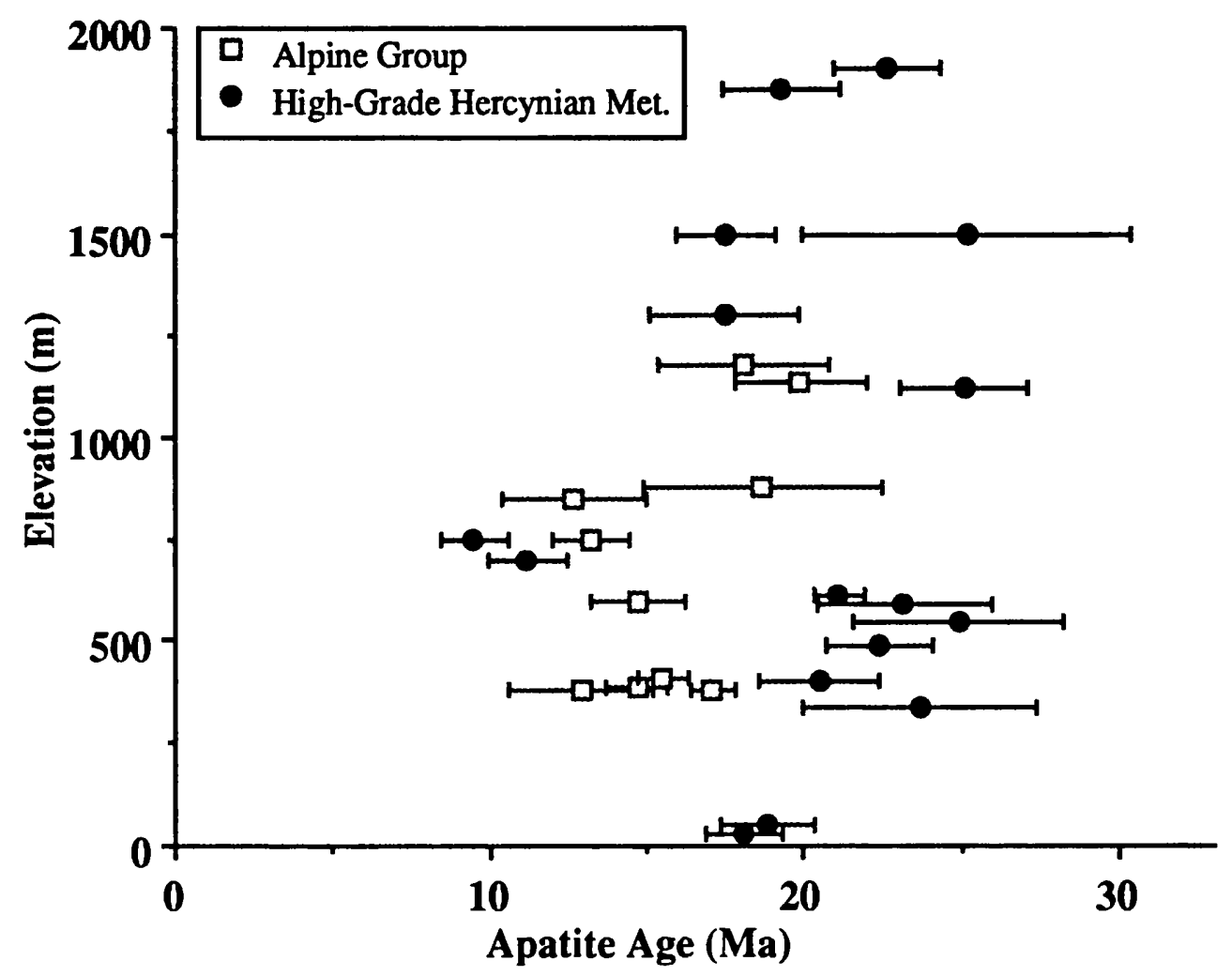

Figure 6.18 Apatite age vs elevation for Alpine Group and high-grade Hercynian metamorphic rocks

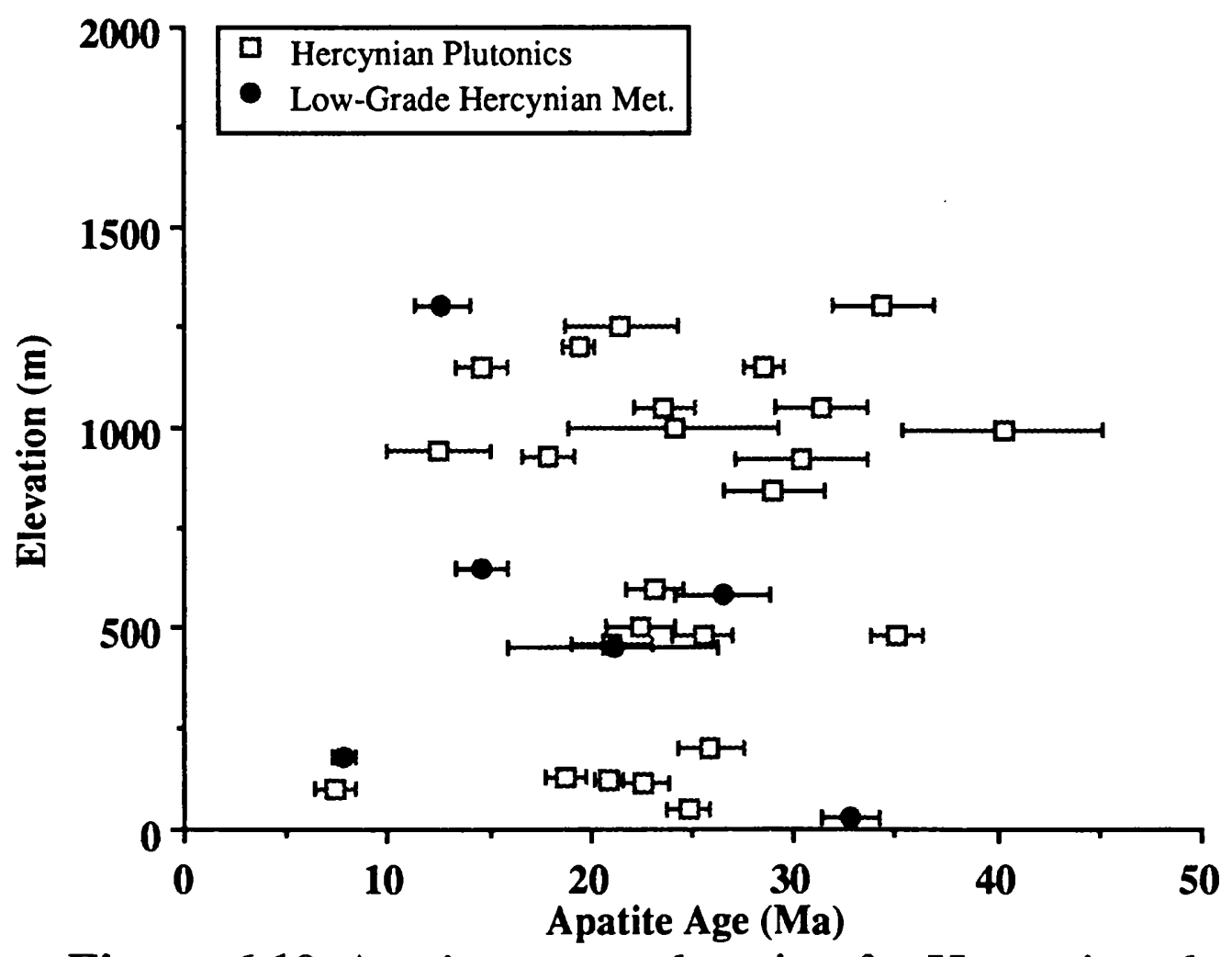

Figure 6.19 Apatite age vs elevation for Hercynian plutonic and low-grade Hercynian metamorphic rocks 


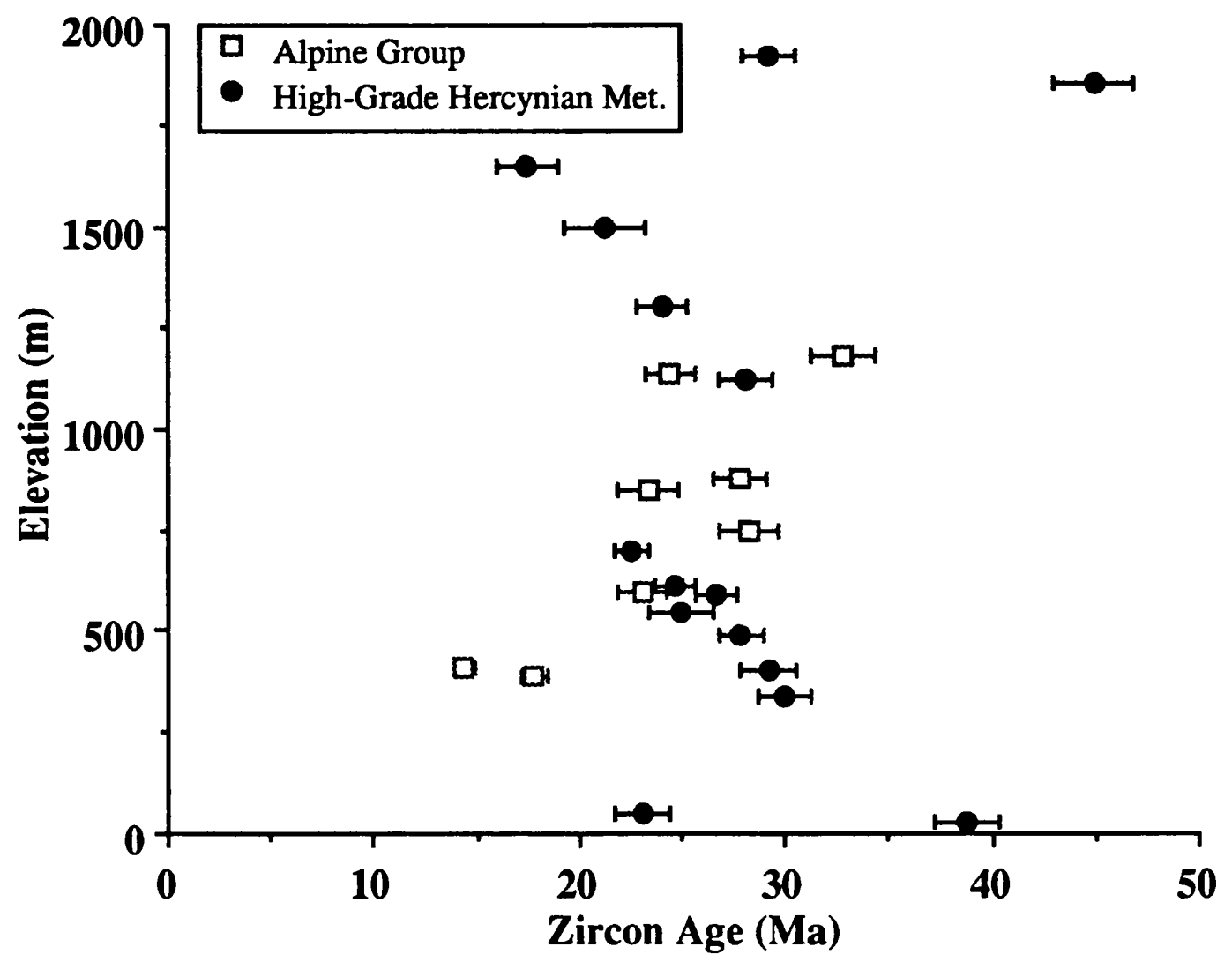

Figure 6.20 Zircon age vs elevation for Alpine Group and high-grade Hercynian metamorphic rocks

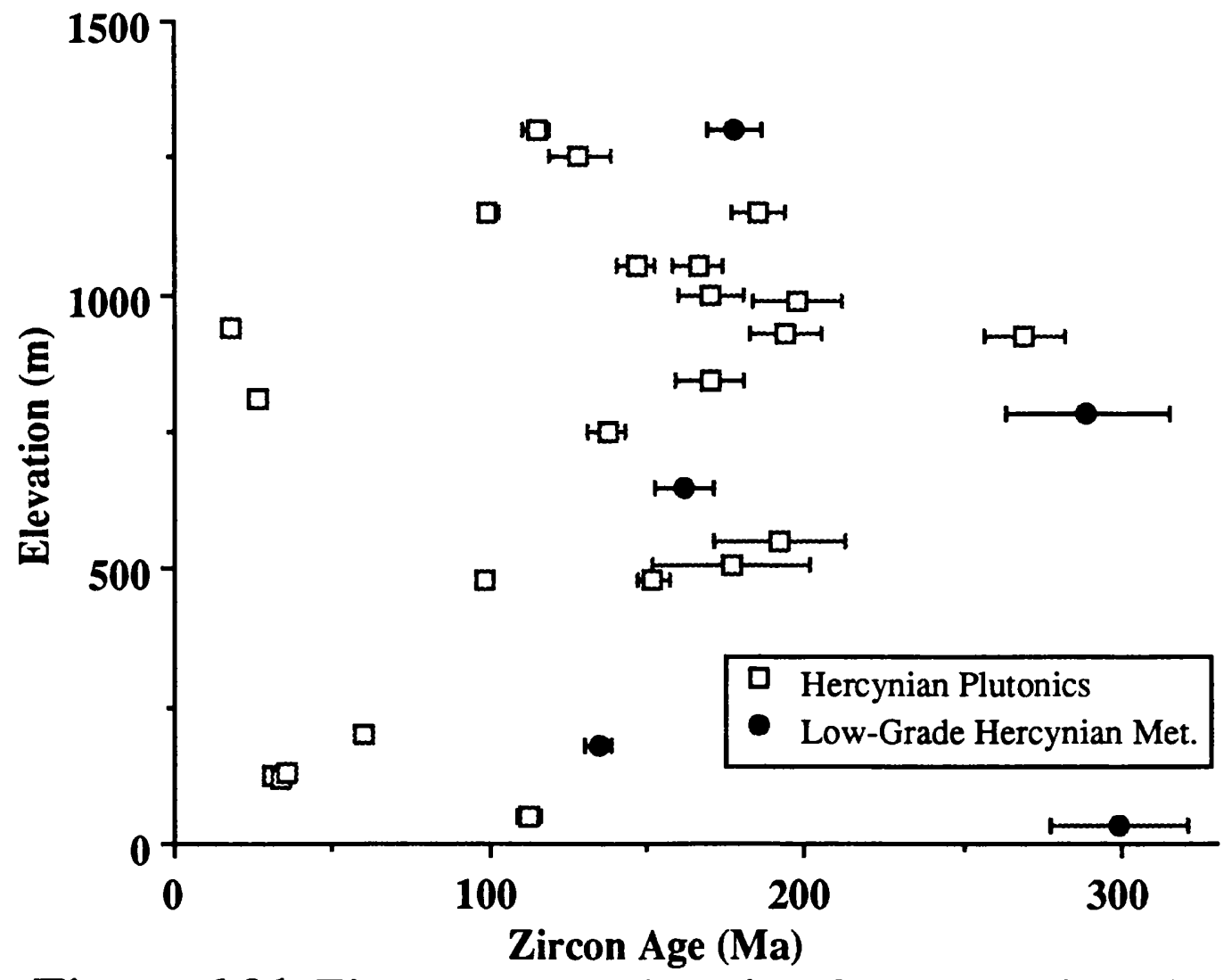

Figure 6.21 Zircon age vs elevation for Hercynian plutonic and low-grade Hercynian metamorphic rocks 
terrace can be assumed to have experienced no denudation (hence exhumation) during the period of Pleistocene surface uplift. Thus the amount of uplift experienced by such a sample relative to sea level (uplift of rock) will equal the amount of surface uplift (from the relationship: surface uplift = uplift of rocks - exhumation, England and Molnar, 1990). Using this relationship the original position of a sample in an age-elevation profile prior to the recent surface uplift can be calculated by subtracting the known surface uplift rates from the present sample height. Therefore although zero exhumation can be assumed for the local elevated marine terraces, on a regional scale exhumation will occur localised along river valleys. Ergenzinger et al. (1978) estimate that $\sim 300 \mathrm{~m}$ of erosion, averaged over the whole region, has occurred in the last $2 \mathrm{Ma}$ in Calabria. Such exhumation will be compensated by isostasy, which also acts on a regional scale ( $>10^{4} \mathrm{~km}^{2}$ England and Molnar, 1990). Therefore the marine terraces will also be affected by this isostatic response, hence their measured uplift is a measure of the uplift of rock, and will be an overestimation of the regional surface uplift. However this additional isostatic uplift component is the same at all elevations, thus can effectively be ignored when comparisons between samples are made.

Figure 6.22 demonstrates an age/elevation plot with a correction given to the elevation, by subtracting the surface uplift rates of Ghisetti (1981). These uplift figures have only been obtained with sufficient accuracy from southern Calabria and therefore limit the number of samples they can be applied to. The recent surface uplift was initiated at $\sim 2 \mathrm{Ma}$, so this time component should also subtracted from the age. The data from the Alpine Group and high-grade Hercynian metamorphic rocks still show little obvious trend. However the Hercynian plutonic samples do show a significant trend of increasing age with elevation suggesting significant exhumation between $\sim 15 \mathrm{Ma}$ and $25 \mathrm{Ma}$. The calculated exhumation rates from this data show a wide variation caused by wide scatter and age errors. The possible exhumation rates during this period could fall anywhere between $250 \mathrm{~m} / \mathrm{m} . \mathrm{y}$. and $50 \mathrm{~m} / \mathrm{m} . \mathrm{y}$. 


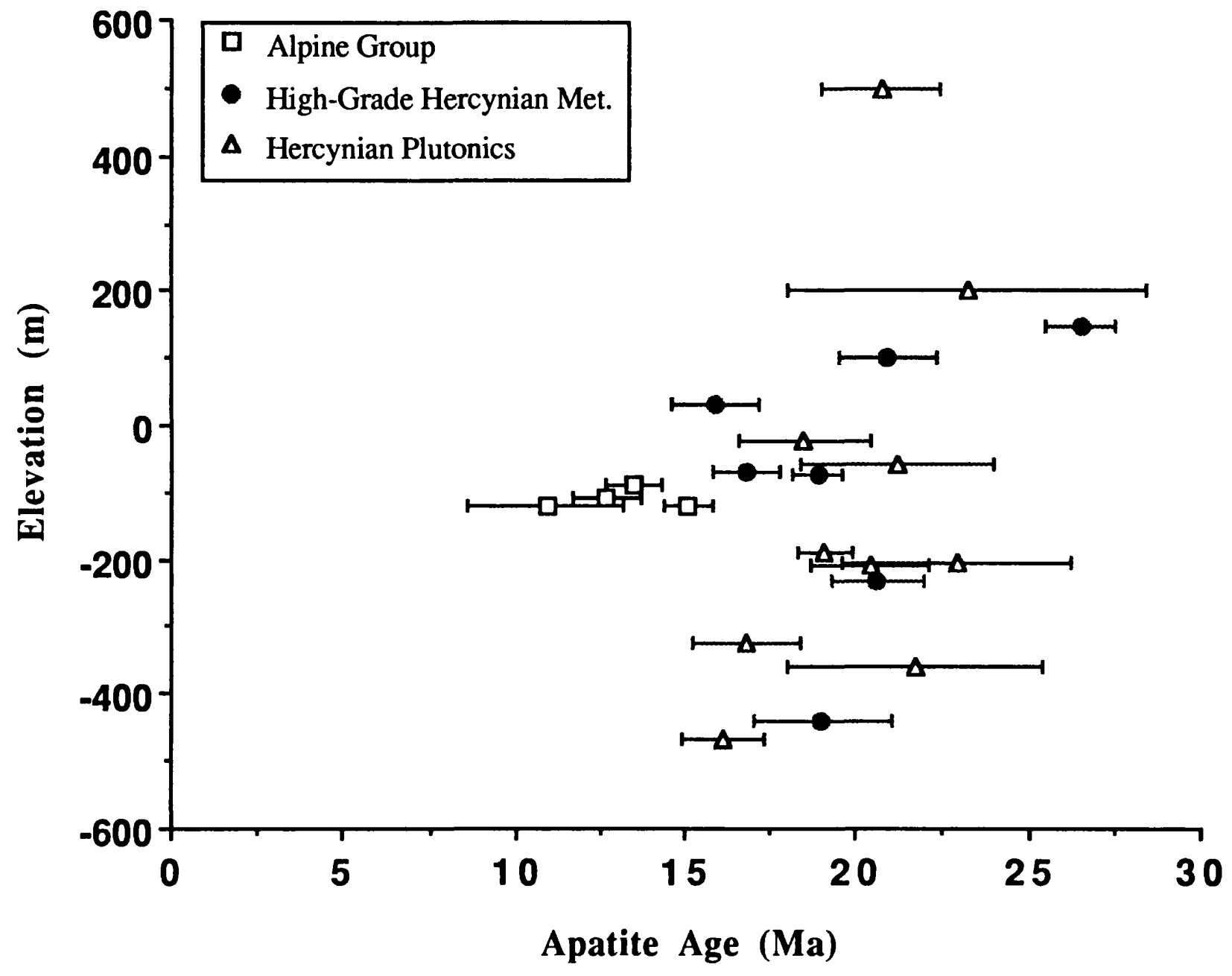

Figure 6.22 Apatite age vs elevation with Pleistocene uplift component removed (N.B. As the Pleistocene has been removed the individual apatite ages are all reduced by 2 m.y.) 


\subsection{SUMMARY OF RESULTS}

Qualitative analysis of the fission track data initially revealed that the basement rocks of the Calabrian Arc appeared to be divided into two main groups, based on different low-temperature cooling histories.

The Alpine Group and high-grade Hercynian metamorphic sample data reveal cooling from above the zircon fission track closure temperature $\left(>250^{\circ} \mathrm{C}\right)$ to below the apatite fission track closure temperature $\left(<\sim 80^{\circ} \mathrm{C}\right)$ between $\sim 30 \mathrm{Ma}$ and $\sim 15 \mathrm{Ma}$ with cooling rates of between 5 and $15^{\circ} \mathrm{C} / \mathrm{m}$.y. The Alpine group samples underwent cooling slightly after cooling of the high-grade metamorphic rocks. The exceptions to this are the Alpine Group samples of the northern Serre. These samples reveal a more recent rapid cooling between $15 \mathrm{Ma}$ and $18 \mathrm{Ma}$.

The qualitative analysis of the data obtained from the Hercynian plutonic and lowgrade metamorphic rocks indicates much slower cooling between $250^{\circ} \mathrm{C}$ and $\sim 150^{\circ} \mathrm{C}$ that occurred at a rate of between $0.5^{\circ} \mathrm{C} / \mathrm{m}$.y and $2^{\circ} \mathrm{C} / \mathrm{m}$.y. during the Mesozoic. A more rapid cooling phase in these rocks, from $\sim 150^{\circ} \mathrm{C}$ to the surface $\left(12^{\circ} \mathrm{C}\right)$, occurred between $\sim 30 \mathrm{Ma}$ and the present. The Hercynian Capo Vaticano intrusion differs by showing young zircon ages compatible with the data from the high-grade Hercynian rocks. Three samples with younger than average apatite ages, below $14 \mathrm{Ma}$, occur in close proximity in the northern Sila, suggesting a local geological event.

Although the younger zircon fission track ages are almost certainly cooling ages, it is possible that some of the older zircon ages obtained from the Hercynian plutonic and lowgrade metamorphic rocks may have been partially reset by a re-heating event at around 50Ma. Other geological evidence to substantiate or refute this model will be discussed in Chapter 8.

Localised very rapid cooling that indicates the possibility of extensional exhumation is seen in the Aspromonte-Peloritani and northern Serre. Also sharp boundaries between high and low zircon ages indicative of the effects of Oligocene and younger faulting are seen in the Aspromonte-Peloritani, Catena Costiera and Sila regions.

Quantitative analysis of apatite fission track length and age data, using a Monte 
Carlo approach reveals similar results to qualitative analysis. The predicted T-t histories of the Alpine Group samples of the northern Serre require a rapid increase in the cooling rate between 15 and $18 \mathrm{Ma}$ at rates of up to $50^{\circ} \mathrm{C} / \mathrm{m} . \mathrm{y}$. A similar, but slightly older, increase in the cooling rate is required by the sample data obtained from the high-grade Hercynian metamorphic rocks. The data from sample ATT-1124, in the Aspromonte-Peloritani region requires an almost instantaneous cooling from $230^{\circ} \mathrm{C}$ to $50^{\circ} \mathrm{C}$, implying an extensional, tectonic exhumation event. Similar increases in the cooling rate between $\sim 30$ and $20 \mathrm{Ma}$ are required by the sample data of the Hercynian plutonic and low-grade Hercynian metamorphic rocks, although the increase in cooling rate occurred at slightly lower temperatures.

Overall analysis reveals that the majority of the crystalline basement samples have experienced an increase in the low-temperature cooling rate between $\sim 30 \mathrm{Ma}$ and $15 \mathrm{Ma}$. The initiation of this cooling event started at the highest temperature in the Alpine group rocks, and at progressively lower temperatures in the high-grade Hercynian rocks, the Hercynian plutonic rocks and the low-grade Hercynian rocks. This implies that when the cooling event was initiated the Alpine Group rocks were, tectono-stratigraphically, the lowest rock group, with the highest being the low-grade Hercynian metamorphic rocks with their associated Mesozoic cover. This agrees with the recent tectono-stratigraphic scheme of Messina et al. (1991a/b), outlined in Chapter 3. The implications of the apatite and zircon fission track data collected for this thesis with respect to both the geology and tectonic evolution of the Calabrian Arc will be discussed in Chapter 8. 


\section{CHAPTER 7}

\section{THE STILO-CAPO D'ORLANDO FORMATION}

\section{A STUDY USING FISSION TRACK ANALYSIS}

\subsection{INTRODUCTION}

During the analysis of the fission track data obtained from the crystalline basement rocks of the Calabrian Arc, the effects of exhumation on the cooling history of a rock sample, particularly at low temperatures, were discussed. The most important part of exhumation is erosion. However, if erosion is to be invoked as a cause of exhumation, and hence cooling, evidence of erosional activity needs to be sought by examining the sedimentary record. Important phases of erosion, especially in collisional orogens, are usually marked by increased terrigenous sedimentation or "molasse".

The initial fission track ages obtained from the basement units of the Calabrian Arc suggested what has been confirmed subsequently by detailed analysis, an increase in the cooling rate between $\sim 30 \mathrm{Ma}$ and $15 \mathrm{Ma}$. If cooling was caused by erosional exhumation, then a period of increased sedimentation at this age would be expected. Increased sedimentation in the study area is found only in southern Calabria and northeastern Sicily. It is in the form of a thick sequence of coarse terrigenous deposits labelled the Stilo-Capo d'Orlando Formation.

Although other provenance studies have confirmed that these sediments were derived from the basement rocks of the Calabrian Arc, a fission track study was carried out. This was done for several reasons: first, it enables chronological constraints to be applied to the provenance of the formation that can be collated with data already obtained. Here fission track analysis has considerable advantages over other isotopic age dating techniques, because fission track ages are unaffected by the weathering process, as demonstrated by Gleadow and Lovering (1974), and the method is grain discrete, allowing the identification of different age populations. However, because apatite fission tracks begin to anneal at temperatures $>\sim 70^{\circ} \mathrm{C}$ most fission track provenance studies have been restricted to zircon, where fission tracks are stable up to $\sim 175^{\circ} \mathrm{C}$, although un-annealed or 
partially annealed apatites can provide some provenance information. The second reason for a fission track study is because the analysis of data from conglomerate clasts within the Stilo-Capo d'Orlando Formation may be used to determine cooling histories of parts of the basement rocks now removed by erosion, the so-called "lost cover" (Haughton et al., 1991). Finally quantitative apatite fission track analysis can be used to describe the timetemperature history of the formation and the presence of any significant post-depositional heating, hence burial.

\subsection{GEOLOGICAL OUTLINE OF THE STILO-CAPO D'ORLANDO FORMATION}

The Stilo-Capo d'Orlando Formation (defined by Bonardi et al., 1980) is a dominantly terrigenous sequence of rocks that crops out along the Ionian Sea coast of southern Calabria and in northeastern Sicily (Figure 7.1). Previous nomenclature for these rocks includes the "Oligo-Miocene molassique" of Caire (1961), the "Flysch di Stilo" of Bonardi et al. (1971), the "Flysch tardiorogeno di Capo d'Orlando" of Ogniben (1973) and the “Reitano-Capo d'Orlando Flysch" of Wezel (1976).

\subsubsection{Stratigraphy}

The formation is transgressive upon low-grade Hercynian metamorphic rocks of the Calabrian Arc metamorphic basement complex, including pre-orogenic Mesozoic-Lower Oligocene cover rocks (Frazzano and Palizzi Formations). It is overlain by a chaotic unit of Cretaceous-Palaeogene scaly clays, termed the "Argille Scagliose" (Amodio-Morelli et al., 1976). The contact is in different places both gradual and abrupt. These rocks may represent a tectonic mélange, which acted as a decollement surface within an accretionary wedge, as proposed for similar rocks further north in the southern Apennines (Roure et al., 1991). However, Weltje (in press) has not observed any basal shear planes, instead proposing that the scaly clays are re-mobilised slope sediments.

Information on the age of the Stilo-Capo d'Orlando Formation has been derived by various authors using planktonic foraminifera. Bonardi et al. (1980) suggested an age of 


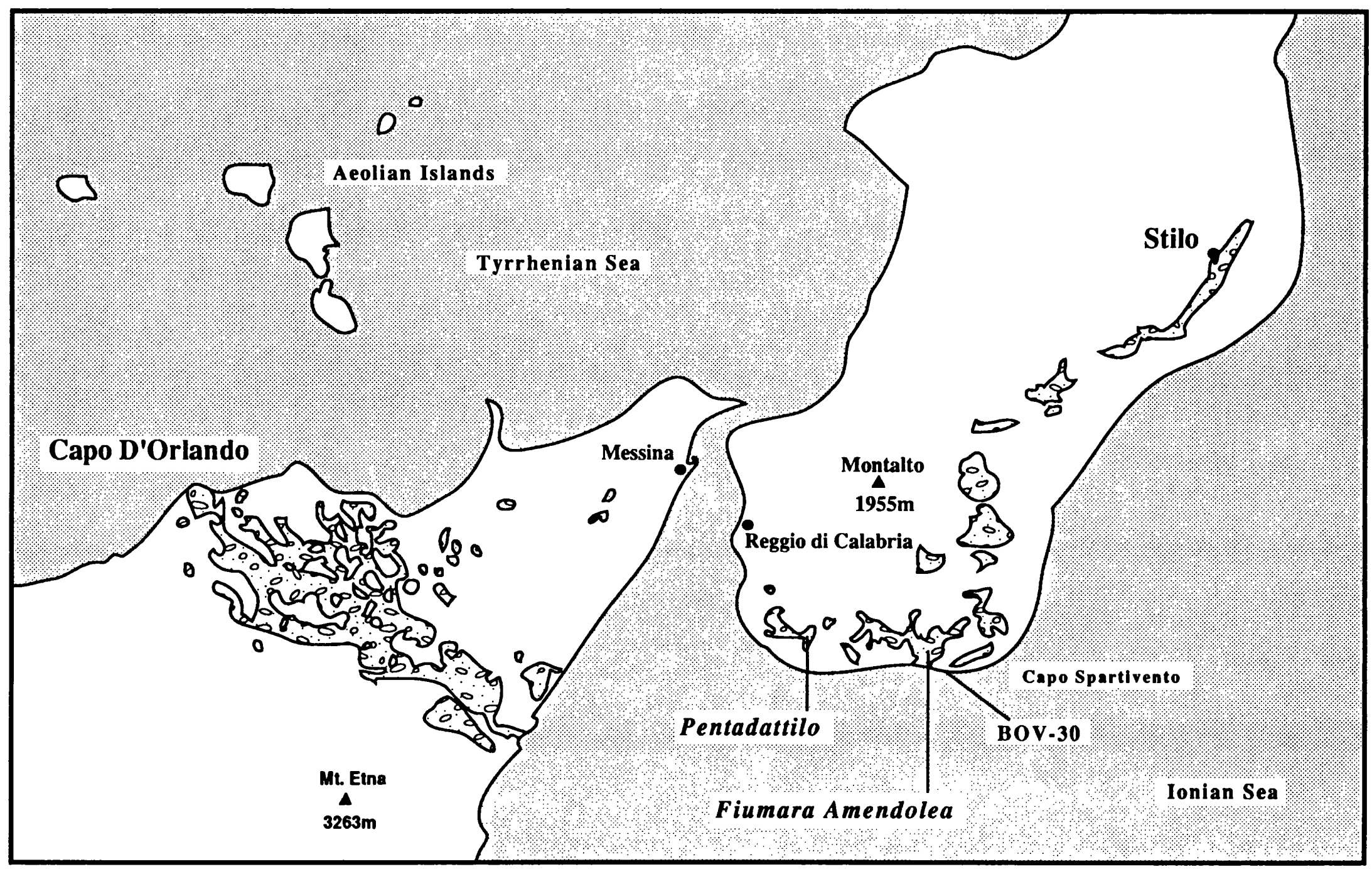

Figure 7.1 Map showing the areas of outcrop of the Stilo-Capo d'Orlando Formation. Also indicated are the two sample collection localities (after Amodio-Morelli et al.,1976) 
Early to Middle Miocene ( $24 \mathrm{Ma}$ to $\sim 11 \mathrm{Ma})$. More recently Barrier et al. (1987) and Courme and Mascle (1988) have recognised Upper Oligocene faunal assemblages. The most recent work by Weltje (in press) defines the age of the Stilo-Capo d'Orlando Formation as Late Early Oligocene to Late Early Miocene ( $29 \mathrm{Ma}$ to $\sim 16 \mathrm{Ma}$ ) to using dinoflagellate cysts and coccoliths in association with the previously published ages from planktonic foraminfera.

\subsubsection{Sedimentology}

The lower part of the Stilo-Capo d'Orlando Formation is dominated by conglomerates, breccias and coarse-grained sandstones, which pass upwards and laterally into finer grained sandstones, siltstones and mudstones. Cavazza (1989) has presented some simplified stratigraphic columns (Figure 7.2) which illustrate that the formation shows a somewhat finer grained nature in Sicily, although coarse-grained units are still common. Recently, Weltje (in press) has presented results of a detailed examination of the sedimentology of the Stilo-Capo d'Orlando Formation, concentrating solely on the outcrop in southern Calabria. This study shows that the Stilo-Capo d'Orlando Formation is dominated by strong lateral and vertical variability, and is fragmented by numerous postdepositional normal and strike-slip faults. Because of such fragmentation correlating between individual sequences is difficult and therefore Weltje (in press) instead defines the most commonly observed lithofacies in the formation. These are summarised below:
A) Breccia - Laterally discontinuous subaerial scree
B) Disorganised Conglomerate - Subaerial to subaqueous alluvial fan / fan delta deposits
C) Conglomerate-Sandstone Couplets - Subaqueous debris flows
D) Sandstone - Fluvio-deltaic and distal braid plain deposits
E) Pebbly Sandstone - subaqueous deltaic deposits
F) Pebbly Sandstone-Mudstone Couplets - High density turbidites, shallow to deep marine delta slope and submarine canyon deposits
G) Sandstone-Mudstone Couplets - Lagoonal to deep marine sands and muds
H) "Silexite" (laminated chert) - deep marine biogenic deposit 


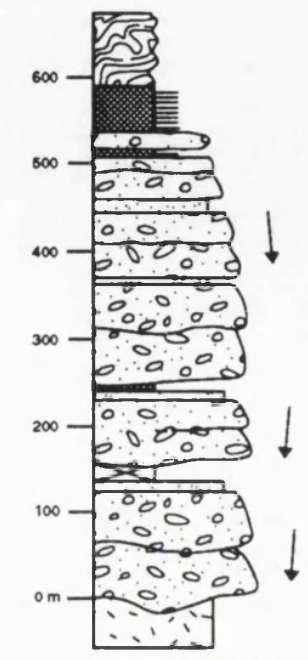

Amendolea (SW Calabria)

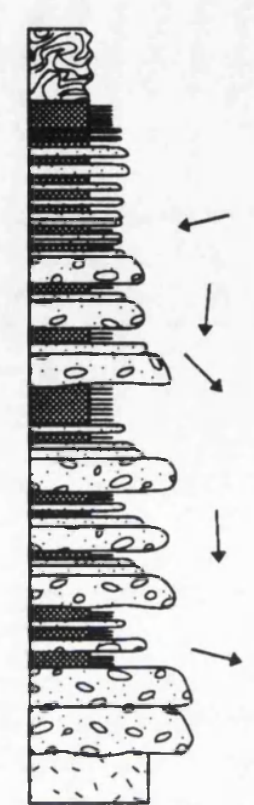

Francavilla (NE Sicily)

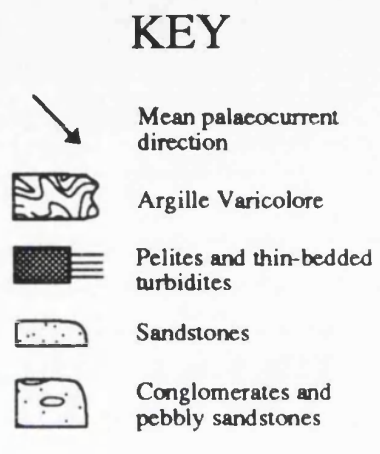

I'] Metamorphic basement

Figure 7.2 Two simplified stratigraphic columns (after Cavazza, 1989), demonstrating the somewhat finer grained nature of the Stilo-Capo d'Orlando Formation in Sicily
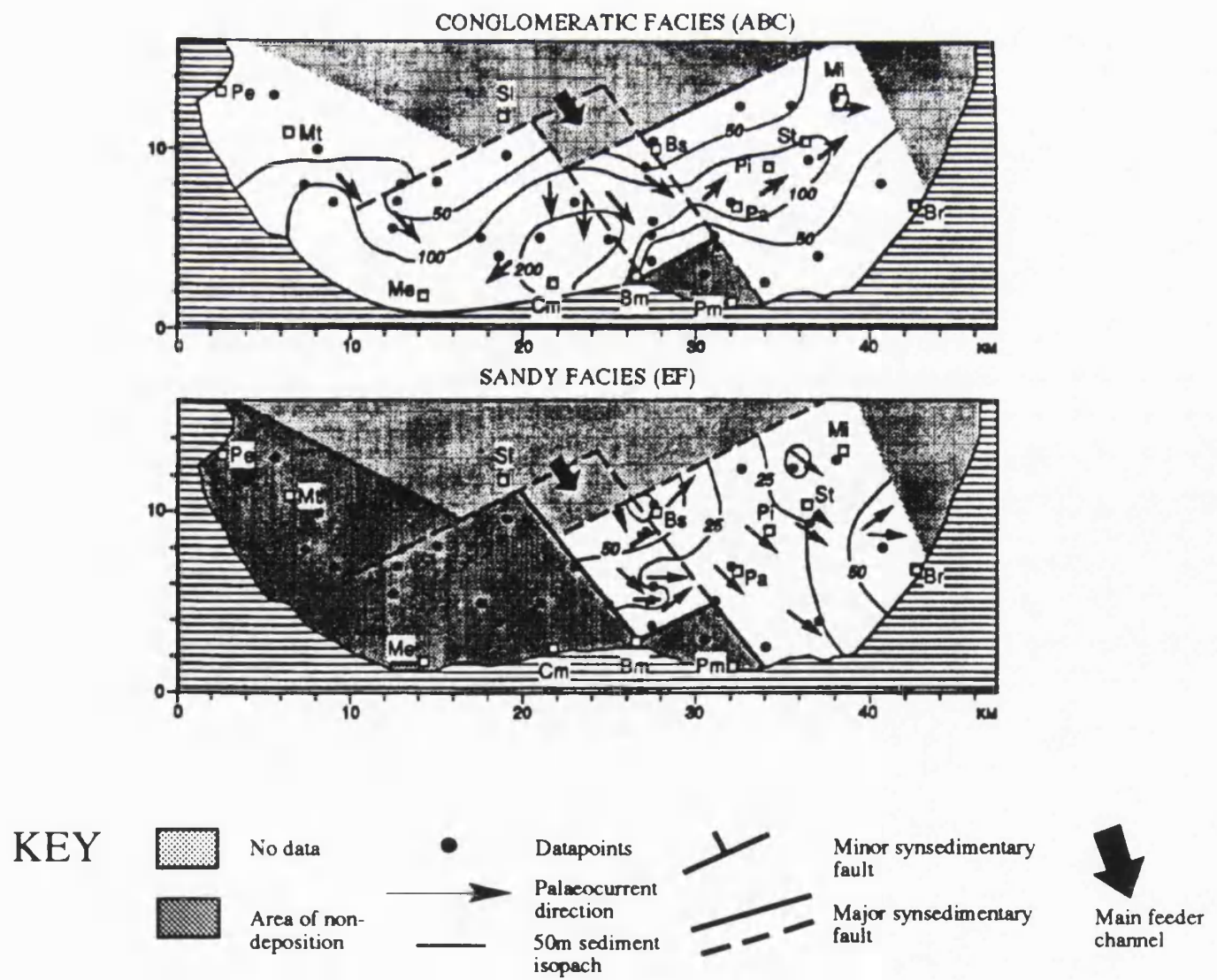

Figure 7.3 Simplified map showing sediment isopachs, palaeocurrents and synsedimentary faults of the Stilo-Capo d'Orlando Formation south of the Aspromonte (After Weltje, in press) 
I) Carbonate/Calcareous Mudstone - shallow marine intrabasinal ridge

Weltje (in press) has also reconstructed detailed palaeocurrent charts, using the orientation of gravelly foresets, clast imbrication, trough and planar cross bedding. These are summarised in Figure 7.3 for the area to the south of the Aspromonte. This figure also illustrates sediment isopachs and the synsedimentary structural constraints of the formation.

\subsubsection{Depositional Environments and Facies}

The depositional environment of the Stilo-Capo d'Orlando Formation is traditionally interpreted as an alluvial fan sequences in a post- or syn-orogenic molasse basin (Bonardi et al., 1980; Giunta, 1985; Barrier et al., 1987; Cavazza, 1989). A comprehensive summary has recently been provided by Weltje (in press).

Sedimentation began with local deposition of coarse grained subaerial alluvial fans. Such proximal coarse grained facies require high rates of erosion and supply, and indicate significant erosional exhumation of their source area. These deposits rapidly evolve into shallow marine fan deltaic deposits, with steep subaqueous slopes, causing deposition of mass flow deposits (debris flows) with laterally equivalent finer grain deposits further into the depositional basin. The "silexite" and calcareous mudstones that occur at the top of the sequence represent an end to significant terrigenous input. The "silexite" is dated as Middle Burdigalian ( 19Ma).

The fan-deltaic deposition can be subdivided into two sub-basins, based upon palaeocurrent directions and conglomerate and sandstone petrologies (Cavazza, 1989; Weltje, in press). These are informally labelled the southern and northern deltaic systems.

\subsubsection{Tectonic Environment}

The lateral variability within the Stilo-Capo d'Orlando Formation suggests that the sedimentation is strongly influenced by intrabasinal faulting. Two main syn-sedimentary fault systems are recognised. A NE-SW trending set, approximately parallel to the external Calabrian accretionary complex and a NW-SE trending set, which correspond with major strike-slip faults. Similar faults are also observed in the Neogene Crotone Basin (Van Dijk 
and Okkes, 1991). Today these faults are still active and dominated by normal displacements (Ghisetti and Vezzani, 1982). Weltje (in press) suggests that these faults underwent alternating extension and compression during the deposition of the Stilo-Capo d'Orlando Formation. Evidence for this is based upon the recognition of two tectonosedimentary cycles in the sequences of the Stilo-Capo d'Orlando Formation in southern Calabria.

The first cycle was initiated by exhumation and subsequent extension seen in the Aspromonte. The position of the coarse conglomeratic bodies in controlled by NE-SW normal faulting at the base of the Stilo-Capo d'Orlando Formation (Figure 7.3). In contrast, the NW-SE fault systems control the location of the point sources for the conglomeratic alluvial fans and fan-deltas. After a phase of finer grained sandstone deposition tectonic inversion occurred. This resulted in a significant change in the sediment dispersal pattern, caused by NW-directed backthrusting event that inverted previous listric extensional faults.

The second sedimentary cycle is observed only in the northern deltaic system, whereas fine grained sedimentation continued in the southern deltaic system. This cycle was marked by fault-controlled coarse grained sediments, which thin laterally towards the east and southwest. The shift from extension to compression and the end of the second cycle is evident in both deltaic systems. This again involved inversion of the intrabasinal listric faults, and the subsequent tilting of the formation towards the south. This second inversion event was coeval with continental collision in Sicily.

From the above evidence Weltje (in press) suggests that the Stilo-Capo d'Orlando Formation was deposited in a series of "mixed-mode" piggyback basins, controlled by two intersecting fault systems, a NW-SE system that controlled the positions of the sub-basins and the feeder systems (fan deltas), and a NE-SW system which controlled the axial dispersion of the coarse grained sediments. The basins are thought initially to have been associated with back-arc extension linked to subduction beneath Sardinia. When Calabria detached and became incorporated in the Apennine-Maghrebide accretionary system they evolved into piggy-back basins. The alternating cycles of extension and compression are 
explained by adjustments in the critical taper of the accretionary wedge (Platt, 1986). It should be noted that these basins only represent a minor part of the total sediment supplied from the Calabrian Arc basement. The majority of the material was transported out of these basins and deposited in the foredeep of the Apennine-Maghrebide accretionary complex in formations that include the Reitano Flysch (Loiacono and Puglisi, 1983; Giunta, 1985).

Finally, during the late Burdigalian ( 19-17Ma) the Stilo-Capo d'Orlando Formation was incorporated into compressional thrusting towards the southeast (Bonardi $e t$ al., 1980; Meulenkamp et al., 1986; Van Dijk and Okkes, 1991). This is related to a major shortening phase seen throughout the region. In southern Calabria this is represented by an unconformity overlain by Langhian calcarenites ("Calcarenites de Floresta", Barrier et al., 1987).

\subsection{PREVIOUS WORK ON THE SEDIMENTARY PROVENANCE OF}

\section{THE STILO-CAPO D'ORLANDO FORMATION}

Previous work by Ferla and Alaimo (1976), Bonardi et al. (1980), and Cavazza (1988; 1989) suggests that most of the Stilo-Capo d'Orlando Formation has been derived from a crystalline source area. The most comprehensive provenance study has been made by Cavazza (1989). This involved an extensive petrological study on sandstones with a grain size of $<2 \mathrm{~mm}$ and conglomerates with a grain size between $1 \mathrm{~cm}$ and $10 \mathrm{~cm}$. A QFL Plot for the sandstones (after Cavazza, 1989) is shown in Figure 7.4 from which two petrofacies can be recognised: a northern facies, rich in feldspars, north of Allaro and a southern facies, richer in quartz, south of Fiumara Amendolea. The detrital modes in the sandstones can be matched to modal analyses made on the nearby basement rocks. The northern petrofacies has a $\mathrm{Q} / \mathrm{F}$ ratio of 0.77 that matches well with the corresponding $\mathrm{Q} / \mathrm{F}$ ratio of the Serre basement $(0.49-0.58)$. The southern petrofacies Q/F ratio of 1.21 compares favourably to the $\mathrm{Q} / \mathrm{F}$ ratio of between 0.68 and 1.55 obtained from various rocks of the Aspromonte crystalline basement. This is thought to be largely a result of the more granitic nature of the basement in the Serre, compared with the high-grade metamorphic rocks seen in the Aspromonte. 


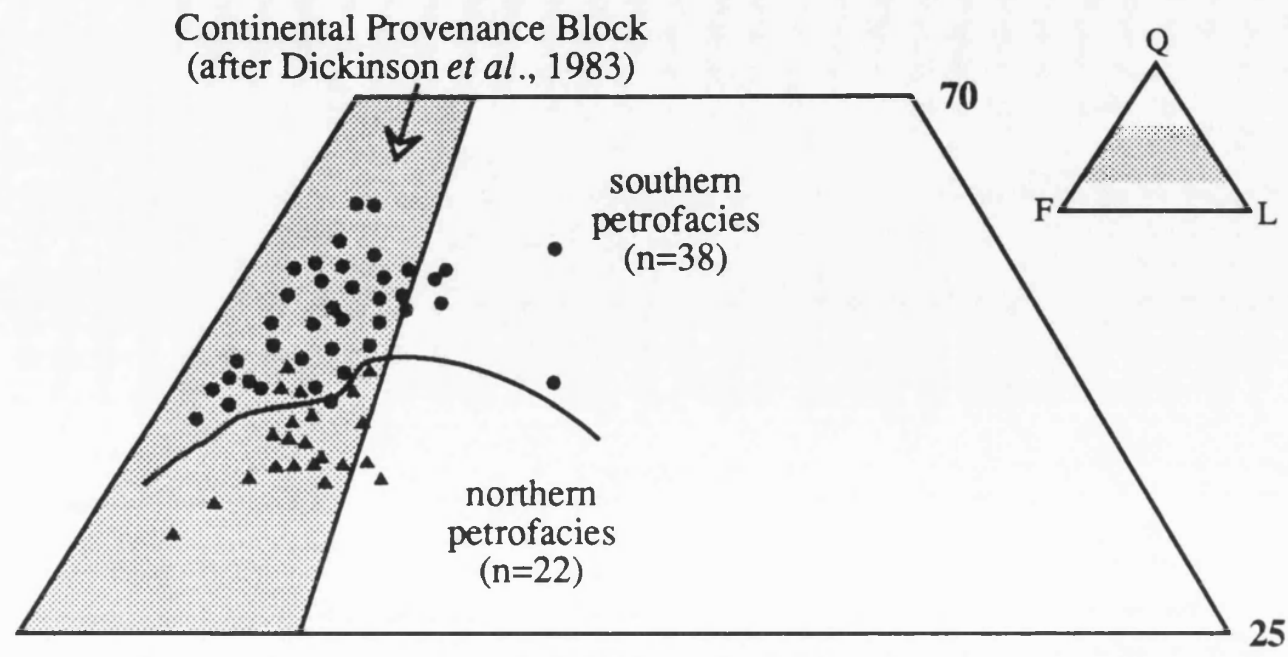

Figure 7.4 QFL ternary plot of Stilo-Capo d'Orlando Formation sandstone samples (after Cavazza, 1989), showing discrimination of southern and northern petrofacies.

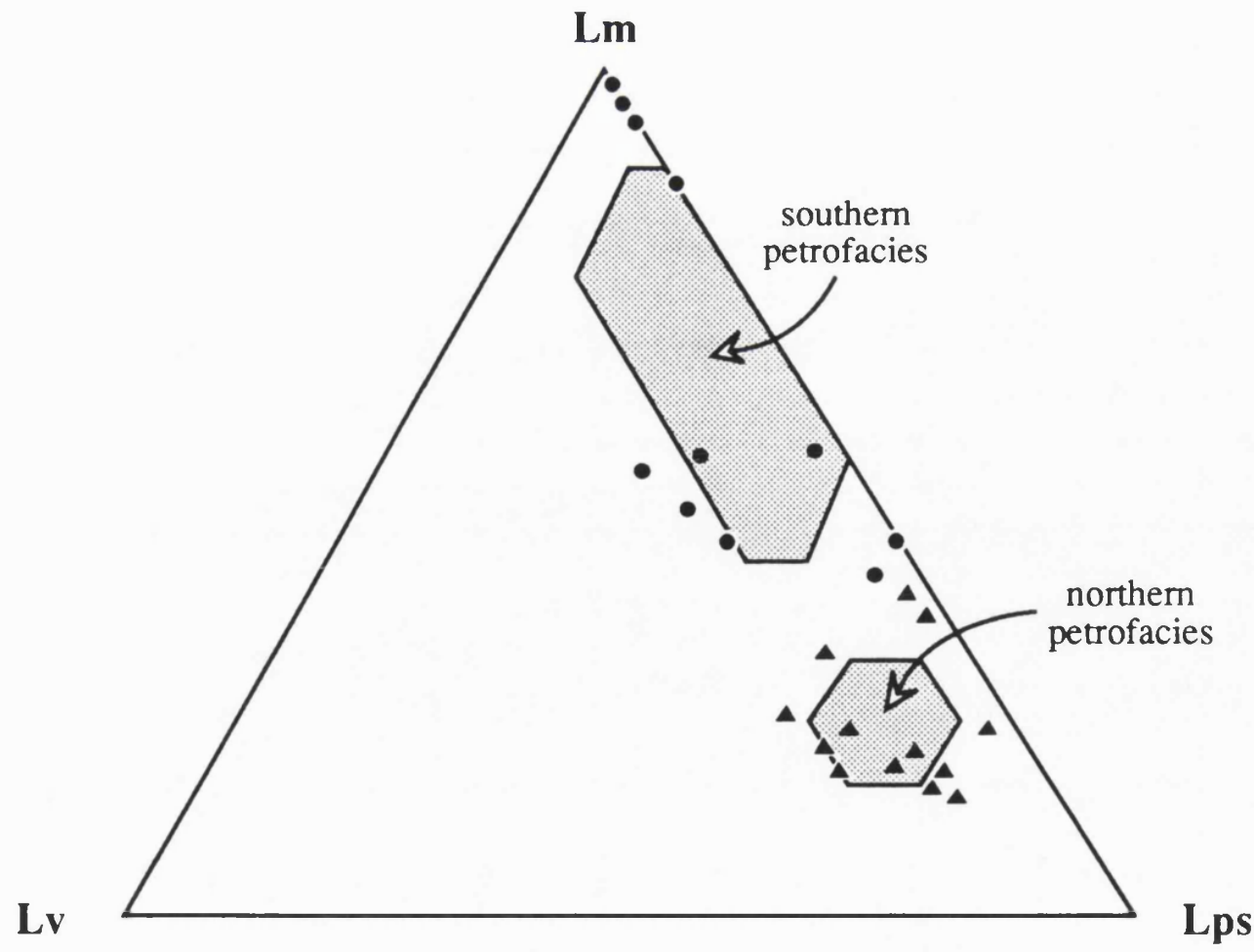

Figure 7.5 Ternary plot for Stilo-Capo d'Orlando Formation conglomerates (after Cavazza, 1989).

(Lm-metamorphic Clasts; Lv-volcanic clasts; Lps- plutonic+sedimentary clasts) 
However, the main feature of the provenance of the Stilo-Capo d'Orlando Formation is the diversity of different clasts found within the conglomeratic units. The clasts consist predominantly of plutonic, extrusive and metamorphic rocks with subordinate limestones. A detailed petrological and chemical study of the igneous and volcanic clasts was carried out by Ferla and Alaimo (1976). They distinguished a suite of intrusives consisting of calc-alkaline granites and a suite of dacitic to andesitic extrusives. A detailed investigation was also carried out by Cavazza (1989) which also included analysis of metamorphic clasts. Figure 7.5 illustrates the components of volcanic, metamorphic and plutonic+sedimentary clasts, again suggesting a division into two petrofacies.

The origin of the volcanic clasts, first mentioned by Ferla and Alaimo (1976) is uncertain. A single $\mathrm{K}-\mathrm{Ar}$ (whole rock) age determination from an extrusive clast within the Stilo-Capo d'Orlando Formation in Sicily gives an age of $200 \mathrm{Ma}$ (Atzori et al., 1984). This was interpreted as representing Permian or Triassic volcanism later subjected to a hydrothermal event at around 200Ma that reset the $\mathrm{K}-\mathrm{Ar}$ age. Such volcanism is associated with the end of the Hercynian Orogeny and the opening of the Tethyan ocean (Atzori et al., 1984), and is common in other parts of western Europe. The nearest recognised Permian volcanic complexes are found in Sardinia (e.g. the Gallura Complex, Westphal et al., 1976) and Corsica (e.g. the Cinto Complex, Durand-Delga, 1978). Wezel (1976) suggests such volcanic rocks are derived from the Oligo-Miocene calc-alkaline volcanic rocks of Sardinia. However this source can effectively be ruled out as deposition of the Stilo-Capo d'Orlando Formation began well before the earliest recognised Oligo-Miocene volcanism in Sardinia. The most likely source for these clasts is the Devonian calc-alkaline volcanism recognised within the Palaeozoic phyllitic cover sequences of the southern Peloritani mountains (Ferla, 1978; Ferla et al., 1983). These show a range of compositions ranging from basalt to rhyodacite, and have experienced a greenschist facies metamorphic overprint associated with the Hercynian orogeny. These rocks represent the upper part of the basement sequence, and are unlikely to have experienced Alpine tectonism as witnessed in the Aspromonte and northern Peloritani Mountains (Platt and Compagnoni, 1990; Messina et al., 1990). Also, as they represent the uppermost part of the sequence, they are more 
likely to have been eroded during the exhumation event recognised between $30 \mathrm{Ma}$ and 20 Ma in the Aspromonte, and other parts of the Calabrian Arc (Chapter 6), and subsequently incorporated into the Stilo-Capo d'Orlando Formation.

\subsection{ANALYSIS OF THE FISSION TRACK RESULTS}

Fission track analysis has been applied to seven conglomerate clasts and two sandstone samples of the Stilo-Capo d'Orlando Formation. The samples were collected from two localities in southern Calabria, Fiumara Amendolea and Pentadattilo (Figure 7.1), situated to the south of the Aspromonte mountains.

\subsubsection{Analysis of Fission Track Results from Seven Conglomerate Clasts}

Seven representative conglomerate clasts were collected from the Stilo-Capo d'Orlando Formation. The clasts are part of the disorganised conglomerate lithofacies of Weltje (in press) that occur at the base of the formation. The sample localities (Pentadattilo and Fiumara Amendolea) represent deposits derived from the southern feeder system of Weltje (op. cit.). The conglomerate bodies represent the lowermost part of the sequence and are early Upper Oligocene Age (calcareous nannofossil zone NP23, Weltje, in press). This indicates an age of between 29.5 Ma and 27.5 Ma (Harland et al., 1989). A summary of their petrology and grade of metamorphism is shown below:

\begin{tabular}{|c|c|}
\hline Sample Number & Petrology \& Metamorphism \\
\hline SCO-1 & Granite (Lwr Greenschist Facies) \\
\hline SCO-2 & Meta-Dacite (Greenschist Facies) \\
\hline SCO-3 & Meta-Dacite (Greenschist Facies) \\
\hline SCO-4 & Andalusite-bearing Granite \\
\hline SCO-5 & Meta-Dacite (Greenschist Facies) \\
\hline SCO-7 & Meta-Andesite (Lwr Greenschist Facies) \\
\hline SCO-8 & Biotite Schist (?Amphibolite Facies) \\
\hline
\end{tabular}

The apatite and zircon fission track data collected from the seven conglomerate clasts are shown in Tables 7.1 and 7.2.

What is immediately noticeable is how much older the apatite fission track ages are in comparison to the ages obtained from the crystalline basement rocks (Chapter 6). The 
Fission Track Analysis of the Stilo-Capo d'Orlando Formation

\section{Table 7.1 Results of Apatite Fission Track Analysis on Conglomerate Clasts}

\begin{tabular}{|c|c|c|c|c|c|c|c|c|}
\hline $\begin{array}{l}\text { Sample } \\
\text { Number }\end{array}$ & $\begin{array}{l}\text { No. of } \\
\text { Crystals } \\
\text { Counted }\end{array}$ & $\begin{array}{c}\text { Spontaneous } \\
\rho_{\mathbf{s}} \\
\left(\mathrm{N}_{\mathrm{s}}\right)\end{array}$ & $\begin{array}{c}\text { Induced } \\
\rho_{\mathbf{i}} \\
\left(\mathrm{N}_{\mathrm{i}}\right)\end{array}$ & $\mathrm{P} \chi^{2}$ & $\begin{array}{c}\rho_{\mathbf{s}} / \rho_{\mathbf{i}} \\
( \pm 1 \sigma)\end{array}$ & $\begin{array}{c}\text { Dosimeter } \\
\rho_{d}\end{array}$ & $\begin{array}{c}\text { Fission Track } \\
\text { Central Age } \\
\mathrm{Ma}( \pm 1 \sigma)\end{array}$ & $\begin{array}{c}\text { Age } \\
\text { Dispersion }\end{array}$ \\
\hline SCO-1 & 20 & $\begin{array}{l}1.104 \\
(1263)\end{array}$ & $\begin{array}{l}3.600 \\
(4119)\end{array}$ & $10 \%$ & $0.307 \pm 0.010$ & 1.317 & $71.2 \pm 3.0$ & $9.7 \%$ \\
\hline SCO-2 & 13 & $\begin{array}{c}0.4540 \\
(166)\end{array}$ & $\begin{array}{l}1.203 \\
(440)\end{array}$ & $10 \%$ & $0.377 \pm 0.034$ & 1.092 & $67.1 \pm 9.2$ & $27.9 \%$ \\
\hline $\mathrm{SCO}-3$ & 17 & $\begin{array}{l}1.016 \\
(384)\end{array}$ & $\begin{array}{l}3.113 \\
(1177)\end{array}$ & $\begin{array}{l}<1 \% \\
\text { (fail) }\end{array}$ & $0.326 \pm 0.019$ & 1.021 & $71.8 \pm 9.3$ & $45.1 \%$ \\
\hline SCO-5 & 20 & $\begin{array}{c}0.5789 \\
(647)\end{array}$ & $\begin{array}{c}0.6558 \\
(733)\end{array}$ & $40 \%$ & $0.882 \pm 0.048$ & 1.114 & $174.3 \pm 9.9$ & $5.4 \%$ \\
\hline SCO-7 & 20 & $\begin{array}{c}0.1367 \\
(139)\end{array}$ & $\begin{array}{c}0.6040 \\
(614)\end{array}$ & $>99 \%$ & $0.226 \pm 0.021$ & 1.049 & $42.6 \pm 4.0$ & $0 \%$ \\
\hline SCO-8 & 20 & $\begin{array}{r}2.032 \\
(1292)\end{array}$ & $\begin{array}{l}3.909 \\
(2485)\end{array}$ & $60 \%$ & $0.520 \pm 0.018$ & 1.022 & $94.8 \pm 3.4$ & $0.4 \%$ \\
\hline
\end{tabular}

\section{Notes:}

(i). track densities $(\rho)$ are as measured $\left(x 10^{6} \mathrm{t} \mathrm{cm}^{-2}\right)$; numbers of tracks counted $(N)$ shown in brackets;

(ii). analyses by external detector method using 0.5 for the $4 \pi / 2 \pi$ geometry correction factor;

(iii). ages calculated using dosimeter glasses: CN5 with $\zeta_{\mathrm{CN} 5}=359.78 \pm 4.23$ and SRM612 with $\zeta$ SRM612 $=356.74 \pm 14.91$;

(iv). $P \chi^{2}$ is the probability for obtaining the $\chi^{2}$ value for $v$ degrees of freedom, where $v=$ no. crystals -1 ;

\section{Table 7.2 Results of Zircon Fission Track Analysis on Conglomerate Clasts}

\begin{tabular}{|c|c|c|c|c|c|c|c|c|}
\hline $\begin{array}{l}\text { Sample } \\
\text { Number }\end{array}$ & $\begin{array}{l}\text { No. of } \\
\text { Crystals } \\
\text { Counted }\end{array}$ & $\begin{array}{c}\text { Spontaneous } \\
\rho_{\mathbf{s}} \\
\left(\mathrm{N}_{\mathbf{s}}\right)\end{array}$ & $\begin{array}{c}\text { Induced } \\
\rho_{\mathrm{i}} \\
\left(\mathrm{N}_{\mathrm{i}}\right)\end{array}$ & $\mathrm{P} \chi^{2}$ & $\begin{array}{l}\rho_{\mathrm{s}} / \rho_{\mathrm{i}} \\
( \pm 1 \sigma)\end{array}$ & $\begin{array}{c}\text { Dosimeter } \\
\rho_{d}\end{array}$ & $\begin{array}{c}\text { Fission Track } \\
\text { Central Age } \\
\mathrm{Ma}( \pm 1 \sigma)\end{array}$ & $\begin{array}{c}\text { Age } \\
\text { Dispersion }\end{array}$ \\
\hline SCO-1 & 20 & $\begin{array}{r}1.398 \\
(4318)\end{array}$ & $\begin{array}{c}0.2875 \\
(888)\end{array}$ & $60 \%$ & $4.863 \pm 0.180$ & 0.06462 & $197.6 \pm 7.9$ & $0.3 \%$ \\
\hline SCO-2 & 20 & $\begin{array}{l}1.641 \\
(6203)\end{array}$ & $\begin{array}{l}0.3549 \\
(1342)\end{array}$ & $70 \%$ & $4.622 \pm 0.139$ & 0.06436 & $187.2 \pm 6.3$ & $0.1 \%$ \\
\hline SCO-3 & 20 & $\begin{array}{l}3.140 \\
(6045)\end{array}$ & $\begin{array}{c}0.2810 \\
(541)\end{array}$ & $98 \%$ & $11.174 \pm 0.501$ & 0.03433 & $240.4 \pm 11.8$ & $0 \%$ \\
\hline $\mathrm{SCO}-4$ & 6 & $\begin{array}{l}3.669 \\
(1677)\end{array}$ & $\begin{array}{c}0.3632 \\
(166)\end{array}$ & $95 \%$ & $10.102 \pm 0.822$ & 0.03659 & $231.8 \pm 19.4$ & $0 \%$ \\
\hline SCO-5 & 20 & $\begin{array}{c}2.263 \\
(11940)\end{array}$ & $\begin{array}{l}0.2418 \\
(1276)\end{array}$ & $10 \%$ & $9.357 \pm 0.276$ & 0.03581 & $208.6 \pm 8.7$ & $8.7 \%$ \\
\hline SCO-8 & 20 & $\begin{array}{l}2.410 \\
(3571)\end{array}$ & $\begin{array}{c}0.2294 \\
(340)\end{array}$ & $98 \%$ & $10.503 \pm 0.596$ & 0.03624 & $238.6 \pm 14.4$ & $0 \%$ \\
\hline
\end{tabular}

\section{Notes:}
(i). track densities $(\rho)$ are as measured $\left(x 10^{7} \leftarrow \mathrm{cm}^{-2}\right)$; numbers of tracks counted $(\mathrm{N})$ shown in brackets;
(ii). analyses by external detector method using 0.5 for the $4 \pi / 2 \pi$ geometry correction factor;
(iii). ages calculated using dosimeter glass: $\mathrm{CN} 2$ with $\zeta_{\mathrm{CN} 2}=127.72 \pm 3.38$
(iv). $\mathrm{P} \chi^{2}$ is the probability for obtaining $\chi^{2}$ value for $\mathrm{v}$ degrees of freedom, where $\mathrm{v}=$ no. crystals -1 ; 
oldest reliable apatite fission track age from the basement rocks is that of SAV-990 with an age of $40.3 \pm 4.6 \mathrm{Ma}$. However the Stilo-Capo d'Orlando Formation conglomerate clasts show a variation in apatite fission track ages ranging from $42 \mathrm{Ma}$ to $174 \mathrm{Ma}$.

It is seen that two of these clasts show significant age dispersions of above $20 \%$ (SCO-2 and SCO-3). Sample SCO-2 passes the $\chi^{2}$-test, thus the high age dispersion is most likely to be caused by procedural errors, such as poor counting or underetching.

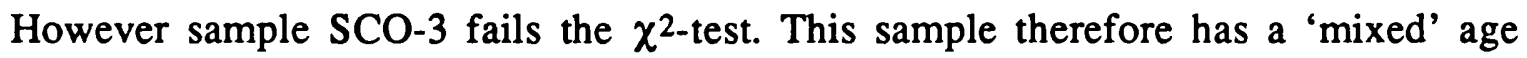
population.

The zircon fission track ages seem to correlate more readily with the ages obtained from the Hercynian plutonic and low-grade metamorphic rocks of the Calabrian Arc crystalline basement and fall within a relatively narrow band between $187 \mathrm{Ma}$ and $240 \mathrm{Ma}$.

Besides the apatite fission track ages, four apatite length analyses were also obtained from the conglomerate clasts. This data, shown with track length distribution histograms, is given in Figure 7.6. The track length distributions all show some evidence of right-handed or negative skew, a characteristic of slowly cooled basement rocks (Gleadow et al., 1986).

The mean track length and standard deviations are plotted against the apatite fission track age in Figures 7.7 and 7.8. Also shown are the apatite data collected from the conglomerates together with that obtained from the metamorphic basement samples (Figures 6.9 and 6.10, Chapter 6). Despite the small number of data from the Stilo-Capo d'Orlando Formation one observation that can be made is that the data does not show much variation in mean track length or standard deviation with the fission track age.

The apatite data from these four conglomerate clasts have been quantitatively analysed, using the Monte Carlo modelling technique described in Chapter 4, section 4.3.3. and applied to the crystalline basement apatite fission track data in Chapter 6. The predicted thermal histories data are constrained using the zircon age and closure temperature and the present-day surface temperature. The most important T-t constraint that can be applied to these models is the age of deposition ( $29-28 \mathrm{Ma})$ when the clasts would have been at the surface. A variety of time-temperature boxes can then be applied between these 
Figure 7.6 Apatite fission track length data for some conglomerate clasts of the Stilo-Capo d'Orlando Formation

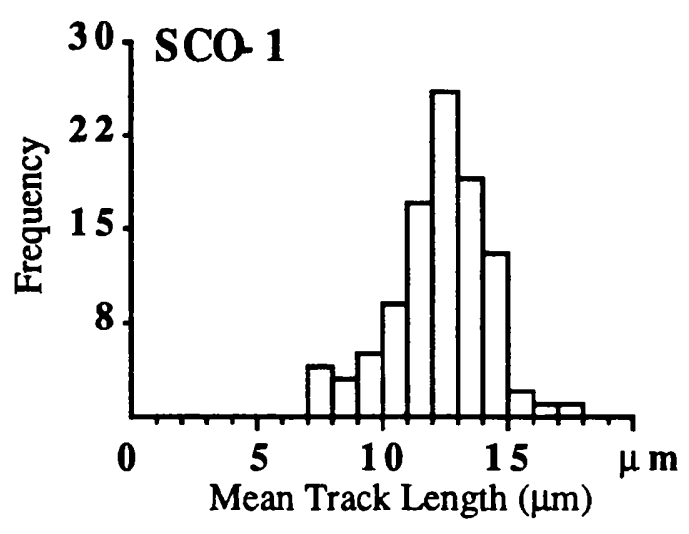

Mean Length $12.27 \pm 0.2 \mu \mathrm{m}$ Standard Deviation $1.97 \mu \mathrm{m}$

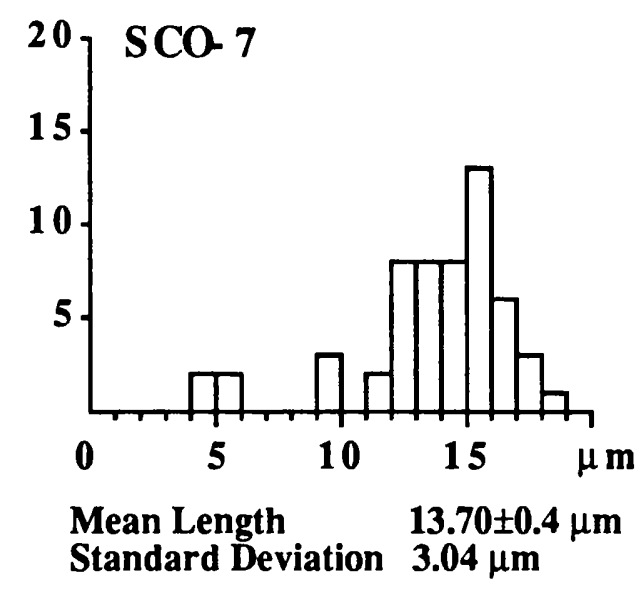

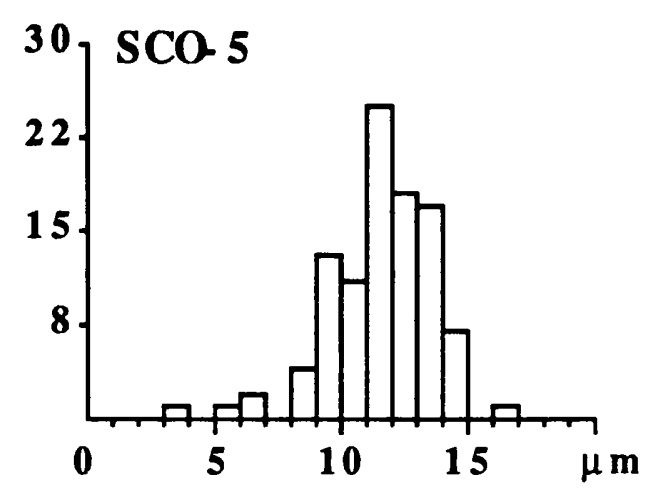

Mean Length $\quad 11.56 \pm 0.2 \mu \mathrm{m}$ Standard Deviation $2.03 \mu \mathrm{m}$

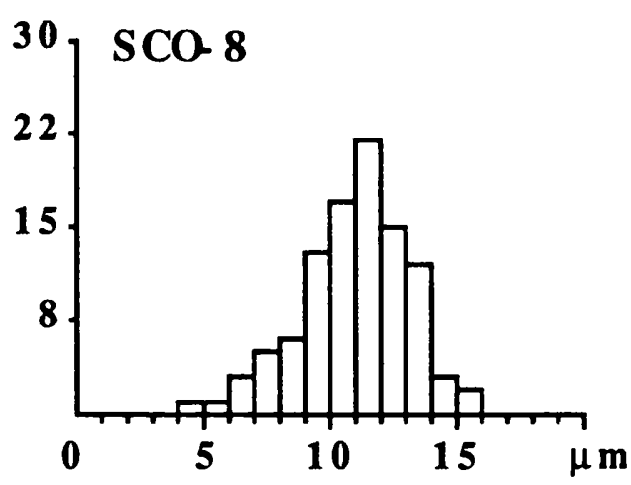

Mean Length $\quad 10.93 \pm 0.2 \mu \mathrm{m}$ Standard Deviation $2.17 \mu \mathrm{m}$ 


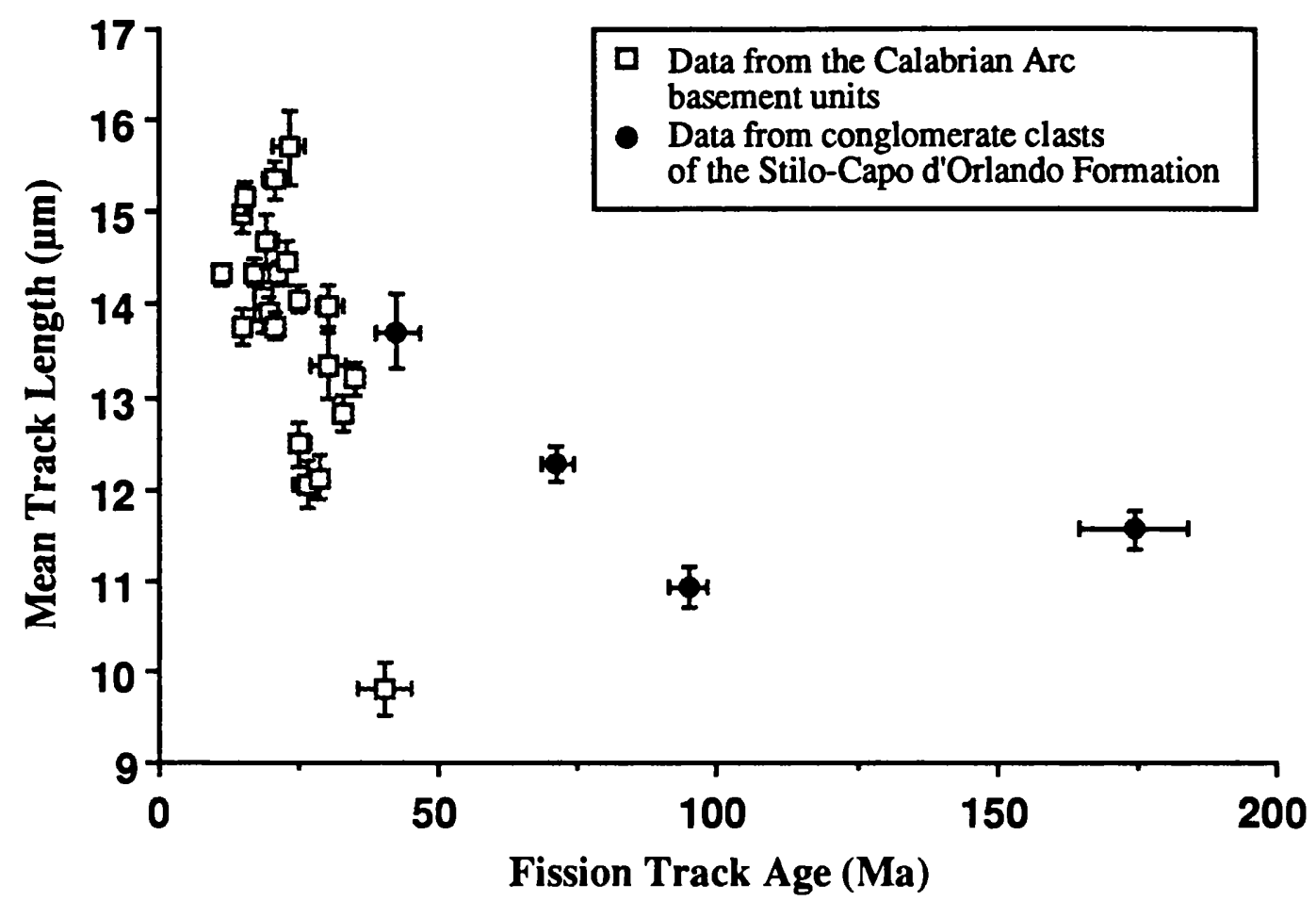

Figure 7.7 Mean apatite fission track length vs apatite fission track age plot, showing a comparison between samples from the basement units and four conglomerate clasts from which such data could be gathered

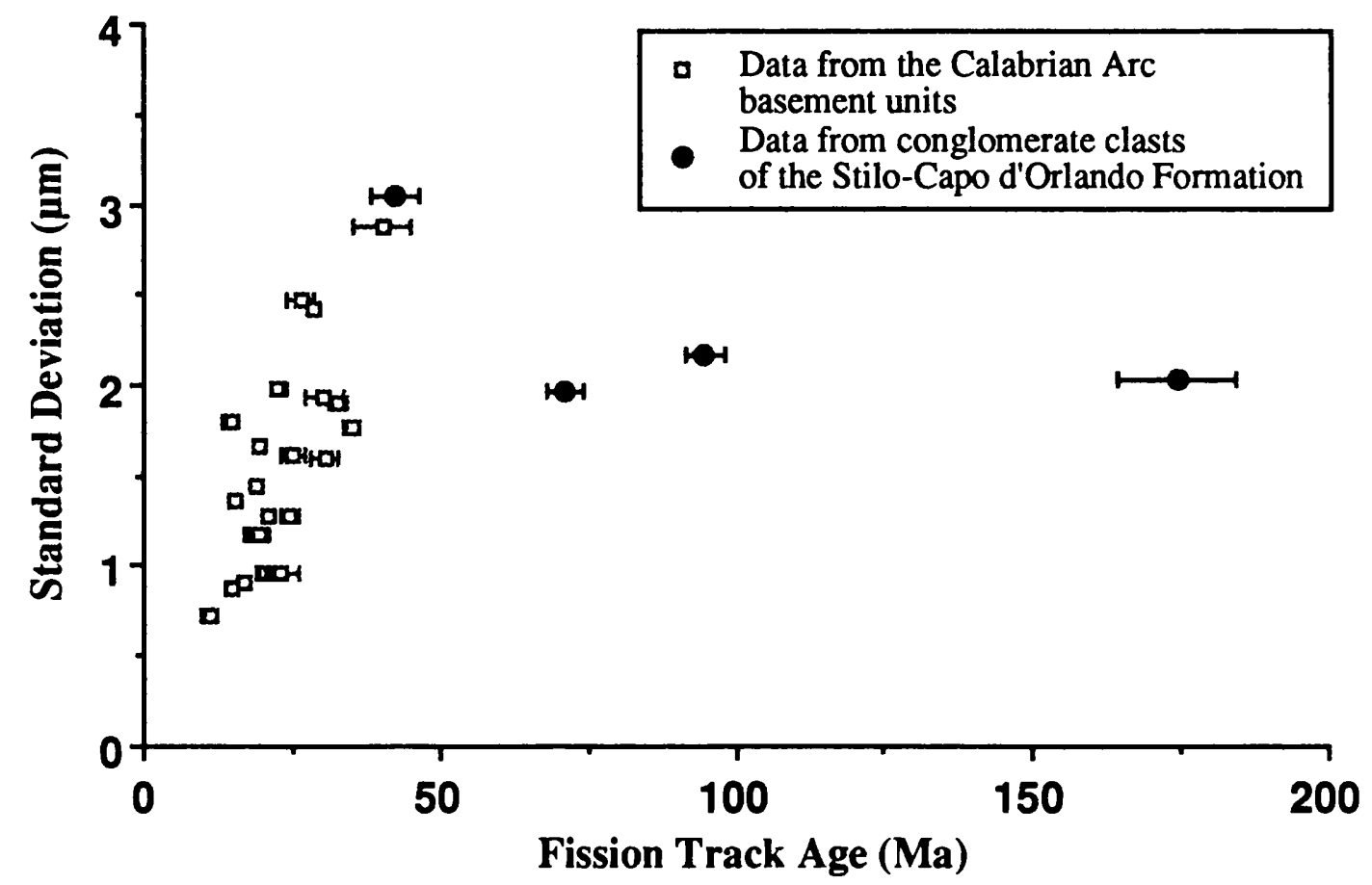

Figure 7.8 Standard deviation of the apatite track length distribution vs apatite fission track age, comparing the basement unit data with that from four conglomerate clasts of the Stilo-Capo d'Orlando Formation 
points until the predicted thermal histories show a fit to the sample age and length data. No zircon age was available for sample SCO-7, thus fewer T-t constraints can be applied. The resultant predicted T-t histories compatible with the sample data are illustrated in Figures 7.9 and 7.10 .

Clast samples SCO-1 and SCO-8 only require protracted cooling prior to their time of deposition, but the predicted T-t history for sample SCO-5 requires a significant cooling event at $\sim 200 \mathrm{Ma}$ in order to produce the obtained data. The resolution on predicted T-t model with sample SCO-7 is poor due to the lack of a zircon fission track T-t constraint. According to the model predictions, all the clasts require some degree of reheating after deposition. This contradicts previous opinions on the history of the Stilo-Capo d'Orlando Formation, and suggests that the conglomerate bodies from which the clasts were collected have experienced significant burial and re-emergence since $\sim 27 \mathrm{Ma}$.

\subsubsection{Analysis of Fission Track Results from Two Sandstone Samples}

Two medium to fine grained sandstone samples, taken from finer grained lenses within the conglomerates, were collected from the lower part of the Stilo-Capo d'Orlando Formation. The results of apatite and zircon fission track analysis from these samples are given in Table 7.3, with the apatite track length data illustrated in Figure 7.11.

The apatite fission track ages both fail the $\chi^{2}$-test and have age dispersions of greater than $20 \%$, indicating the samples have a mixed age population.

Qualitative analysis of the track length data shows that both sample SCO-6 and SCO-9 are very similar, both showing unimodal, negatively skewed distributions. The distributions fall into the slowly cooled basement category of Gleadow et al. (1986).

As the data from the sandstones is likely to have originated from more than one source and the individual crystal age data show a wide dispersion, graphical representation of the data is the most convenient way to analyse this data. Figure 7.12 shows a combination of a relative probability distribution curve for the apatite fission track age combined with an age frequency histogram.

The probability distribution curves are a result of combining the individual crystal 
Figure 7.9 Predicted cooling histories for conglomerate clasts of the Stilo-Capo d'Orlando Formation (Monte Carlo runs that fit both the length and age data of the sample to the errors quoted).

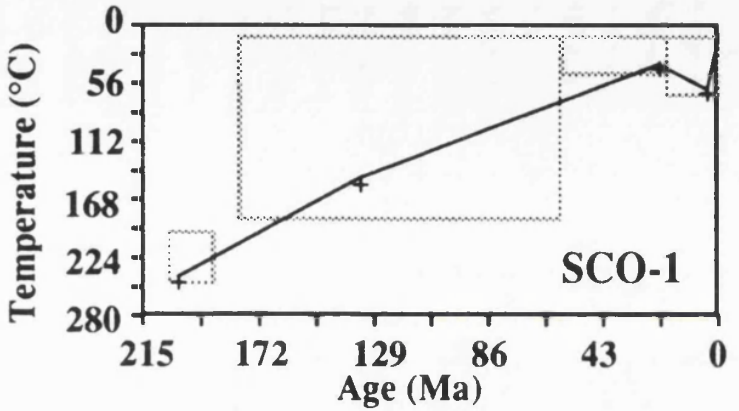

Sample Data : Age $-71.2 \pm 3.0$

MTL - $12.27 \pm 1.0$

SD $-1.97 \pm 1.0$

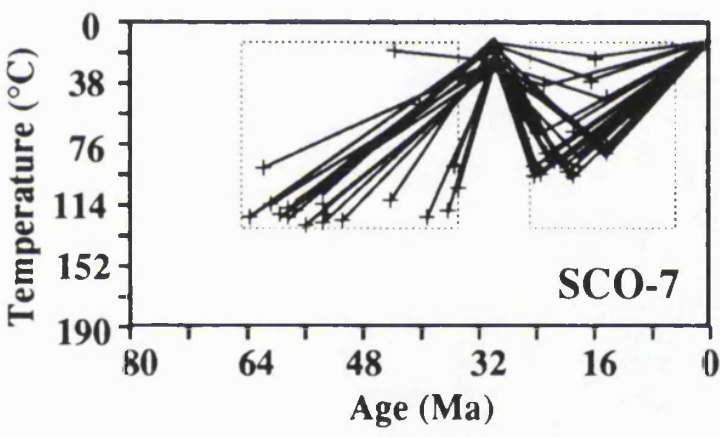

Sample Data : Age $-42.6 \pm 4.0$

MTL - $13.70 \pm 1.0$

SD $-3.04 \pm 1.5$

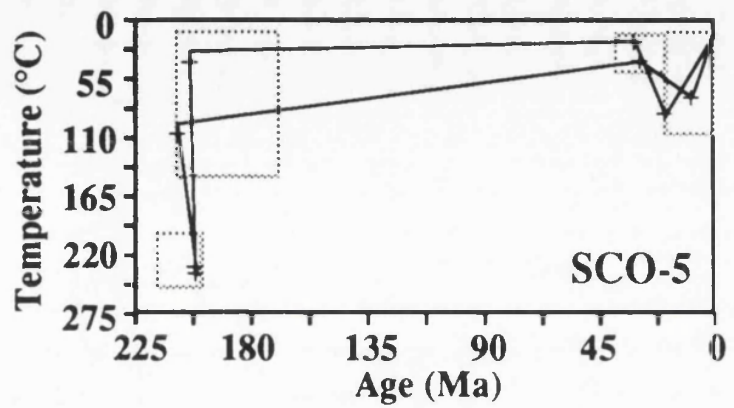

Sample Data : Age - $174.3 \pm 9.6$

MTL - $11.56 \pm 1.0$

$\mathrm{SD}-2.03 \pm 1.0$

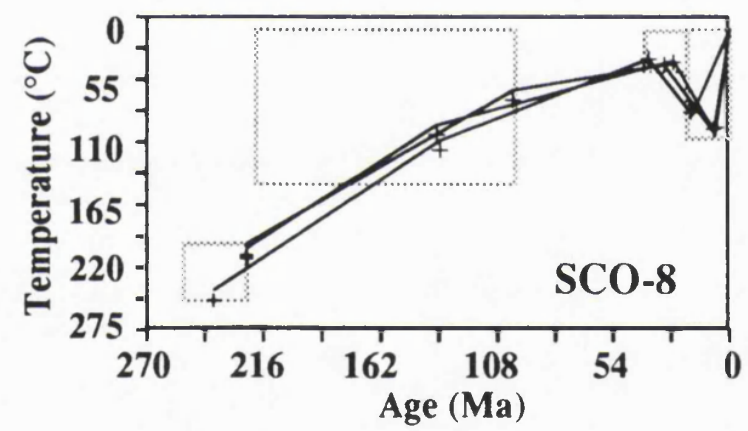

Sample Data : Age $-94.8 \pm 3.4$

MTL - $10.93 \pm 1.0$

$\mathrm{SD}-2.17 \pm 1.0$ 
Figure 7.10 Predicted Monte Carlo runs that show the best fit to the sample apatite fission track data

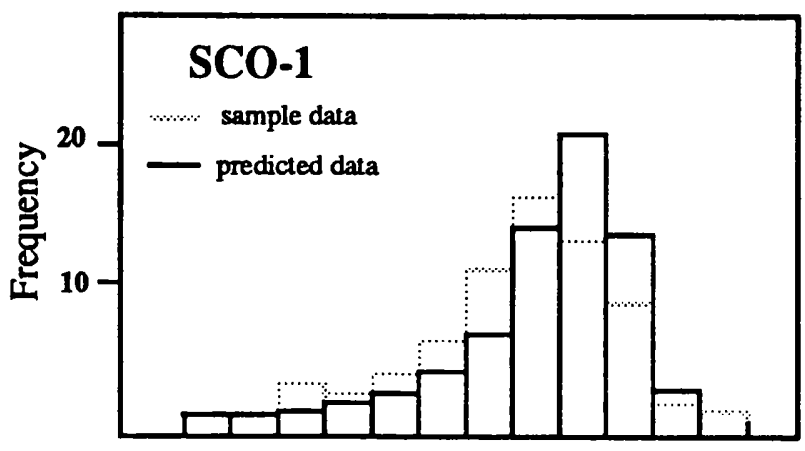

$\begin{array}{lllllllllllll}6 & 7 & 8 & 9 & 10 & 11 & 12 & 13 & 14 & 15 & 16 & 17 & 18\end{array}$ Mean Track Length $(\mu \mathrm{m})$
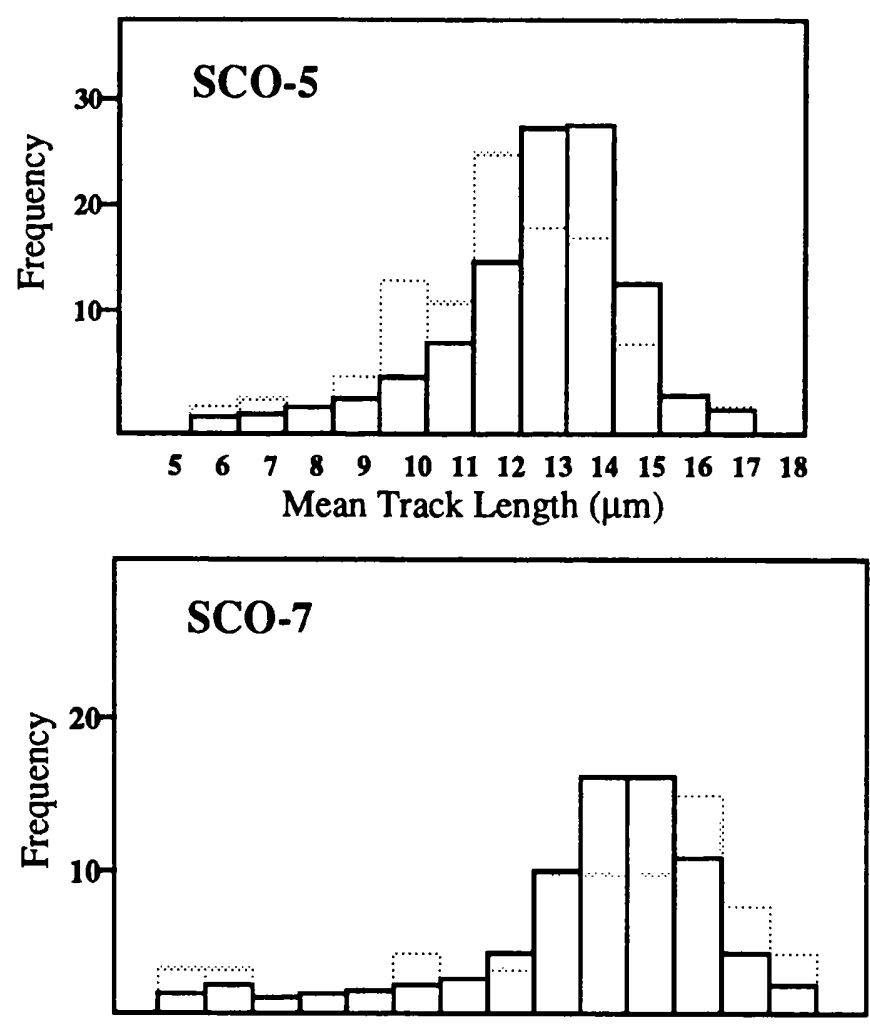

$\begin{array}{lllllllllllllll}4 & 5 & 6 & 7 & 8 & 9 & 10 & 11 & 12 & 13 & 14 & 15 & 16 & 17 & 18\end{array}$ Mean Track Length $(\mu \mathrm{m})$

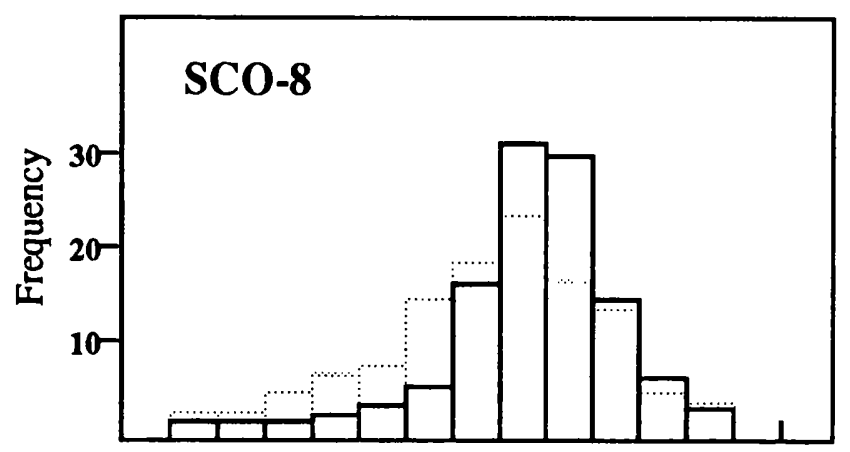

$\begin{array}{lllllllllllllll}4 & 5 & 6 & 7 & 8 & 9 & 10 & 11 & 12 & 13 & 14 & 15 & 16 & 17 & 18\end{array}$ Mean Track Length $(\mu \mathrm{m})$

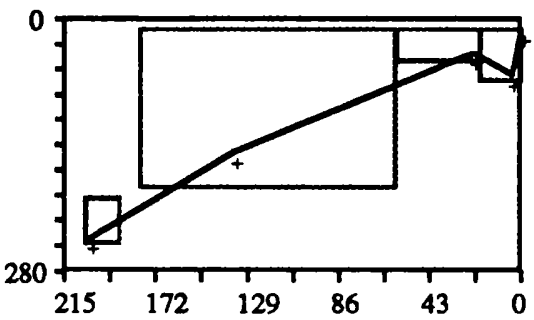

Predicted Data Sample Data

Age : $69.66 \mathrm{Ma} \quad 71.2 \pm 3.0 \mathrm{Ma}$

MTL : $12.86 \quad 12.27 \pm 1.0$

$\mathrm{SD}: 1.73 \quad 1.97 \pm 1.0$

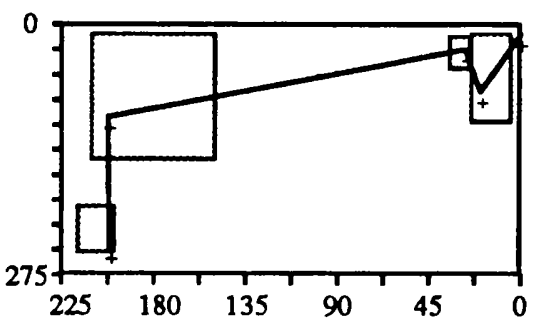

Predicted Data Sample Data

Age : $165.88 \mathrm{Ma} \quad 174.3 \pm 19.8 \mathrm{Ma}$

MTL : $12.52 \quad 11.56 \pm 1.0$

SD : $1.66 \quad 2.03 \pm 1.0$

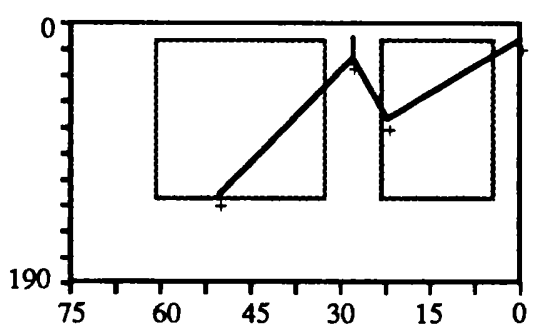

Predicted Data Sample Data

Age : $42.09 \mathrm{Ma} \quad 42.6 \pm 4.0 \mathrm{Ma}$

MTL : $13.76 \quad 13.70 \pm 1.0$

SD $: 1.69 \quad 3.04 \pm 1.5$

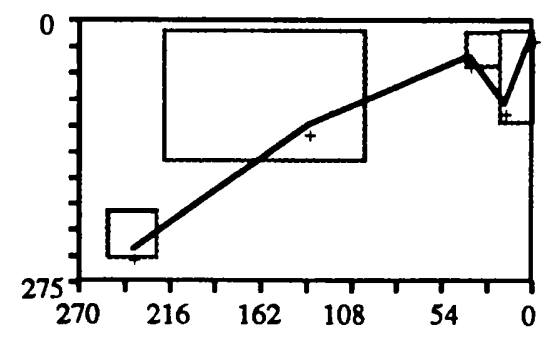

Predicted Data Sample Data

Age : $95.11 \mathrm{Ma} \quad 94.8 \pm 6.8 \mathrm{Ma}$

MTL : $11.90 \quad 10.93 \pm 1.0$

SD : $1.51 \quad 2.17 \pm 1.0$ 
Table 7.3 Results of Apatite and Zircon Fission Track Analysis from two sandstone samples of the Stilo-Capo d'Orlando Formation

\begin{tabular}{|c|c|c|c|c|c|c|c|c|}
\hline $\begin{array}{l}\text { Sample } \\
\text { Number }\end{array}$ & $\begin{array}{l}\text { No. of } \\
\text { Crystals } \\
\text { Counted }\end{array}$ & $\begin{array}{c}\text { Spontaneous } \\
\boldsymbol{\rho}_{\mathbf{s}} \\
\left(\mathrm{N}_{\mathbf{s}}\right)\end{array}$ & $\begin{array}{c}\text { Induced } \\
\rho_{\mathrm{i}} \\
\left(\mathrm{N}_{\mathrm{i}}\right)\end{array}$ & $\mathrm{P} \chi^{2}$ & $\begin{array}{r}\rho_{\mathrm{s}} / \rho_{\mathrm{i}} \\
( \pm \mathrm{l} \sigma)\end{array}$ & $\begin{array}{c}\text { Dosimeter } \\
\text { Pd }\end{array}$ & $\begin{array}{c}\text { Fission Track } \\
\text { Central Age } \\
\mathrm{Ma}( \pm 1 \sigma)\end{array}$ & $\begin{array}{c}\text { Age } \\
\text { Dispersion }\end{array}$ \\
\hline
\end{tabular}

\begin{tabular}{|c|c|c|c|c|c|c|c|c|}
\hline \multicolumn{9}{|c|}{ APATITE } \\
\hline SCO-6 & 50 & $\begin{array}{c}0.5402 \\
(713)\end{array}$ & $\begin{array}{l}2.514 \\
(3318)\end{array}$ & $\begin{array}{l}<5 \% \\
\text { (fail) }\end{array}$ & $0.215 \pm 0.009$ & 1.021 & $39.4 \pm 2.3$ & $24.4 \%$ \\
\hline SCO-9 & 99 & $\begin{array}{l}0.9439 \\
(3476)\end{array}$ & $\begin{array}{c}2.863 \\
(10545)\end{array}$ & $\begin{array}{l}<1 \% \\
\text { (fail) }\end{array}$ & $0.330 \pm 0.006$ & 1.055 & $58.8 \pm 3.3$ & $49.0 \%$ \\
\hline \multicolumn{9}{|c|}{ ZIRCON } \\
\hline SCO-6 & 99 & $\begin{array}{c}3.328 \\
(33604)\end{array}$ & $\begin{array}{l}0.4901 \\
(4948)\end{array}$ & $\begin{array}{l}<1 \% \\
\text { (fail) }\end{array}$ & $6.791 \pm 0.103$ & 0.03642 & $135.9 \pm 7.8$ & $50.6 \%$ \\
\hline SCO-9 & 99 & $\begin{array}{c}2.211 \\
(23819)\end{array}$ & $\begin{array}{c}0.2986 \\
(3217)\end{array}$ & $\begin{array}{l}<1 \% \\
\text { (fail) }\end{array}$ & $7.404 \pm 0.139$ & 0.03590 & $152.0 \pm 6.4$ & $30.9 \%$ \\
\hline
\end{tabular}

Notes:

(i). track densities $(\rho)$ are as measured $\left(x 10^{7} \mathrm{tr}^{-2}\right)$; numbers of tracks counted $(N)$ shown in brackets;

(ii). analyses by external detector method using 0.5 for the $4 \pi / 2 \pi$ geometry correction factor;

(iii). ages calculated using dosimeter glass: $\mathrm{CN} 5$ with $\zeta_{\mathrm{CN} 5}=359.78 \pm 4.23 ; \mathrm{CN} 2$ with $\zeta_{\mathrm{CN} 2}=127.72 \pm 3.38$

(iv). $\mathrm{P} \chi^{2}$ is the probability for obtaining $\chi^{2}$ value for $v$ degrees of freedom, where $v=$ no. crystals -1 ;

Figure 7.11 Apatite fission track length data for two sandstone samples of the Stilo-Capo d'Orlando Formation

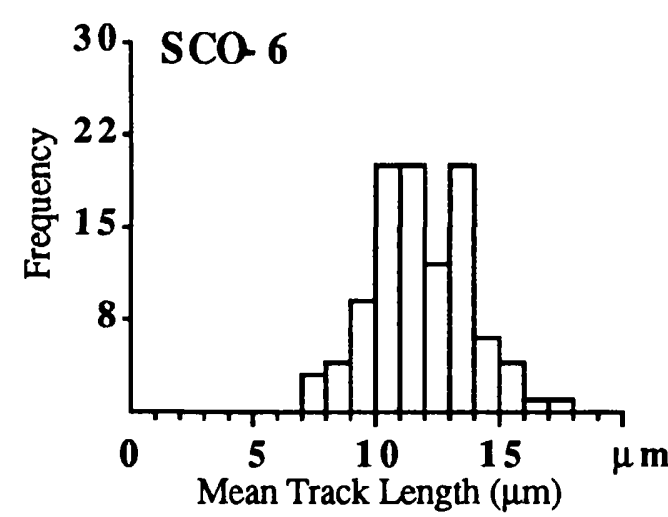

Mean Length Standard Deviation
$11.83 \pm 0.2 \mu \mathrm{m}$

$2.03 \mu \mathrm{m}$

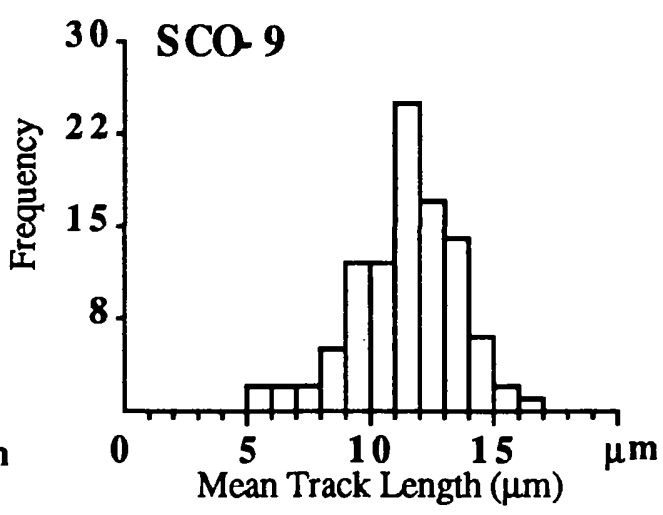

Mean Length $\quad 11.45 \pm 0.2 \mu \mathrm{m}$

Standard Deviation $2.07 \mu \mathrm{m}$ 

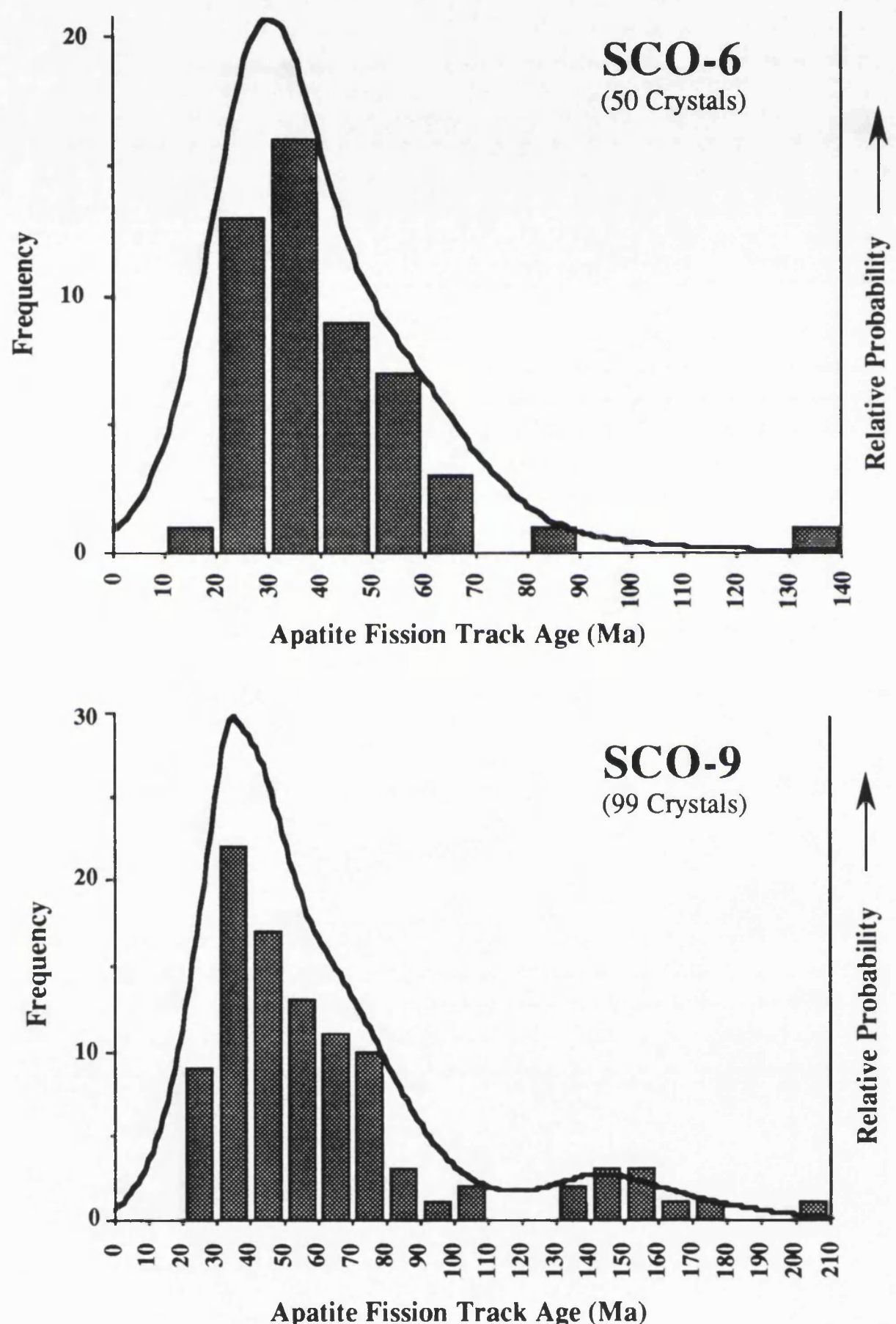

Figure 7.12 Probability distribution curves (age spectra) superimposed on age frequency histograms for the apatite age data of sandstone samples SCO-6 and SCO-9. 
age spectra (age plus $1 \sigma$ standard error) with weighting to account for variations in the age errors between individual grains. What the curve shows is the relative probability of finding a crystal within a given age interval. However such curves do not differentiate between the individual crystal age errors and the variation in overall single crystal ages. This can result in peaks occurring where there are several crystals with ages of high precision that may not be representative of the sample age population as a whole. This problem can be reduced by the inclusion of an age / frequency histogram.

Knowing that the stratigraphic age of both the sandstone samples is between 27.5 and 29.5 Ma, it is obvious that a number of individual crystal ages are younger than the stratigraphic age. This indicates that the sample having experienced a partial annealing event since deposition. Such an event causes shortening of tracks which is directly related to reduction in track density (Green, 1989) resulting in reduction of the fission track age. The reason why only some of the ages have been reduced to below the stratigraphic age is explained in two ways. First it may be a function of the original individual crystal age distribution, with thermal annealing reducing the crystal ages by the same amount. The other possibility is that it may be caused by variation in apatite composition. It is known that apatites with high fluorine content (low $\mathrm{Cl} / \mathrm{Cl}+\mathrm{F})$ anneal more quickly than those with higher chlorine content (high $\mathrm{Cl} / \mathrm{Cl}+\mathrm{F}$ ) (Green et al., 1989). If the sample has been totally annealed then all individual crystal ages will be below the stratigraphic age, with a narrow single age population. Here this has clearly not occurred, therefore the samples have only been partially annealed.

A partial annealing event often obscures any information on the provenance of the sample in question. However sample SCO-9 clearly shows the remnants of two original age modes, the higher age mode now almost obscured. This indicates that the source material for this sample had two age modes. However, the ages themselves are not informative, as they are likely to have been reduced from the original provenance ages that would have been preserved immediately following deposition.

The data can also be plotted using the radial plot (Galbraith, 1988; 1990). These plots are more informative than the previous age-frequency plots, because they distinguish 
between the individual errors on each crystal and the variation in the individual crystal ages in the sample as a whole, on a single diagram. The apatite fission track data radial plots for samples SCO-6 and SCO-9 are shown in Figure 7.13. Included in these plots is the stratigraphic age of the samples. With both samples the presence of single crystal ages below this stratigraphic age is clearly evident. Little extra information can be interpreted from these plots that has not already been demonstrated from Figure 7.12. However sample SCO-6 does indicate a grouping of data points at about $65 \mathrm{Ma}$.

The apatite fission track age and length data can also be used to predict thermal hitories by applying the Monte Carlo modelling approach, as used previously.

Figures 7.14 and 7.15 show the results from running the modelling program on sample SCO-6. When the samples were deposited between 29.5 and $27.5 \mathrm{Ma}$ they would have been at surface temperatures (usually defined as $12^{\circ} \mathrm{C}$ ). This adds an important constraint to the T-t histories experienced by the samples and is included in the models.

The Monte Carlo runs that predict the sample length and age data to within the errors stated, are shown in Figure 7.14. This plot includes only one T-t box after the age of deposition (plus the present day surface temperature constraint). Despite a wide range of thermal histories before deposition, all the paths require some degree of reheating after deposition in order to fit the sample data. The predicted maximum temperature values range from $\sim 80^{\circ} \mathrm{C}$ to $\sim 100^{\circ} \mathrm{C}$. However with only one $\mathrm{T}$-t constraint between the time of deposition and the present day, there is no allowance for the possibility that the sample may have been at a lower maximum temperature over a longer time period. This is a function of the apatite annealing model which is both time and temperature dependent.

The program was also run with two T-t constraints after the age of deposition. The results shown in Figure 7.15. Figure 7.15(a) shows all the runs that predict the sample length data but not the age data. Here the data still requires that the T-t history shows significant reheating after the deposition of the sediment. Figure 7.15(b) shows the runs that predict the sample age and length data. It reveals that regardless of the T-t history of the sample prior to deposition, heating of the sample is still required after deposition. What is additionally shown using two post-depositional T-t constraints is that some of the T-t paths 
a) $\mathrm{SCO}-6$
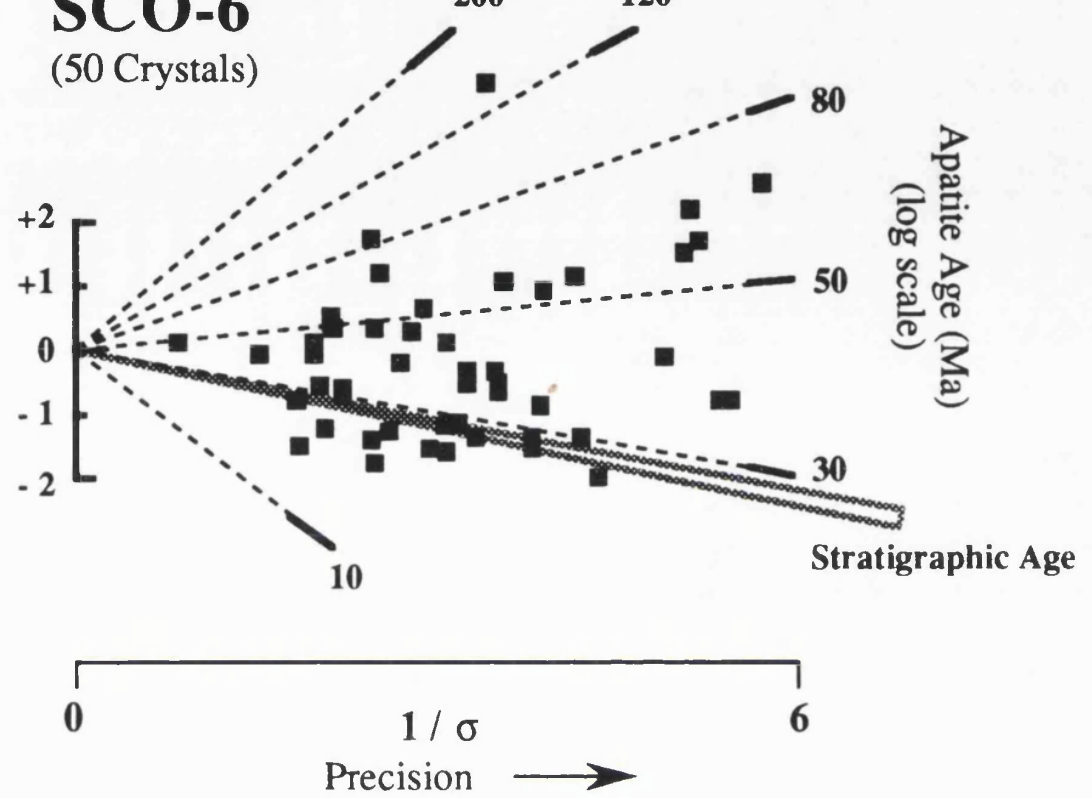

b) $\mathrm{SCO-9}$

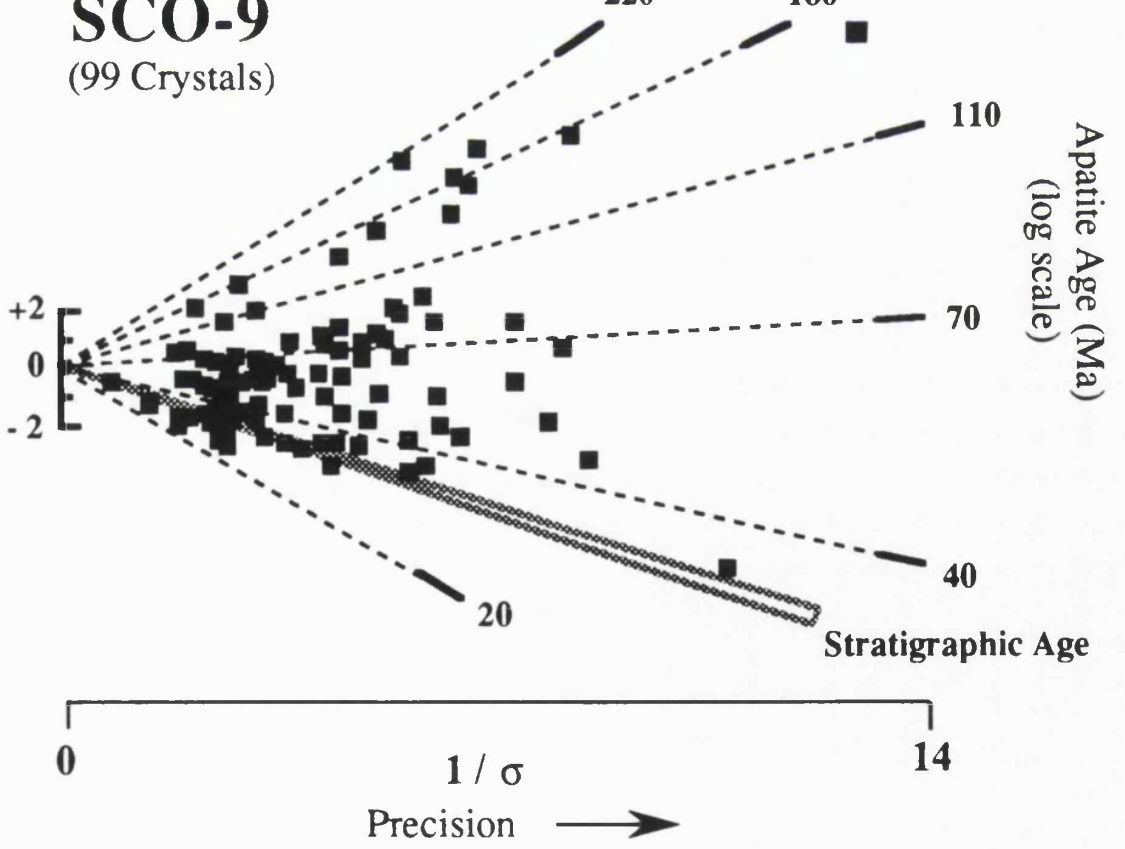

Figure 7.13 Radial Plots for the apatite data of the two sandstone samples collected from the Stilo-Capo d'Orlando Formation, shown with the stratigraphic age of the samples collected. 


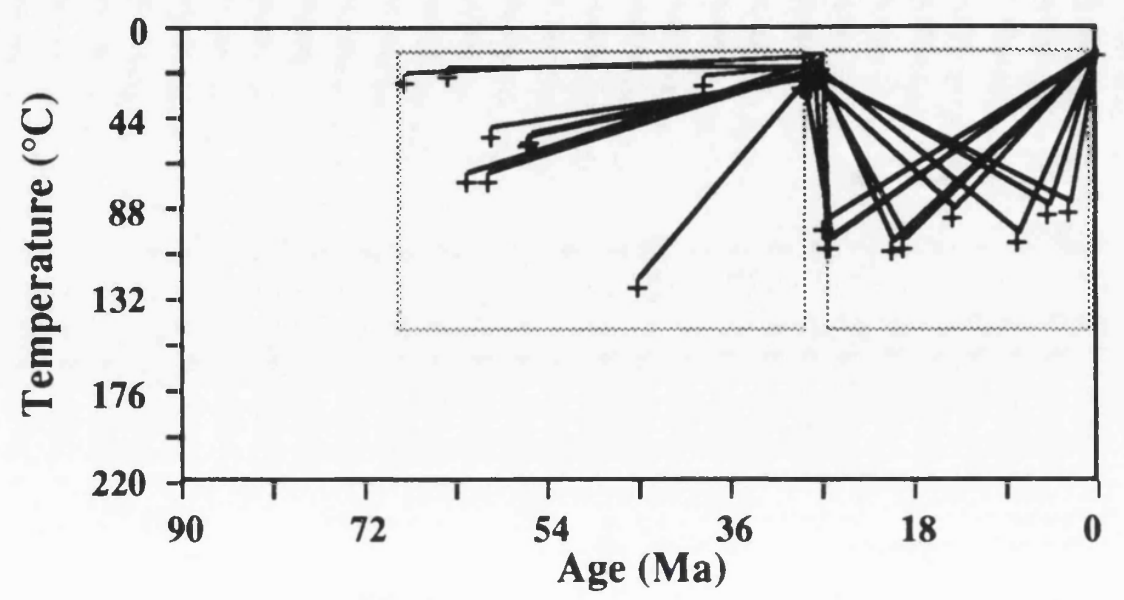

Figure 7.14 Monte Carlo runs that fit the length and age data for sample SCO-6 using one T-t box to constrain the $\mathrm{T}$-t history after deposition at $\sim 28 \mathrm{Ma}$.

a)

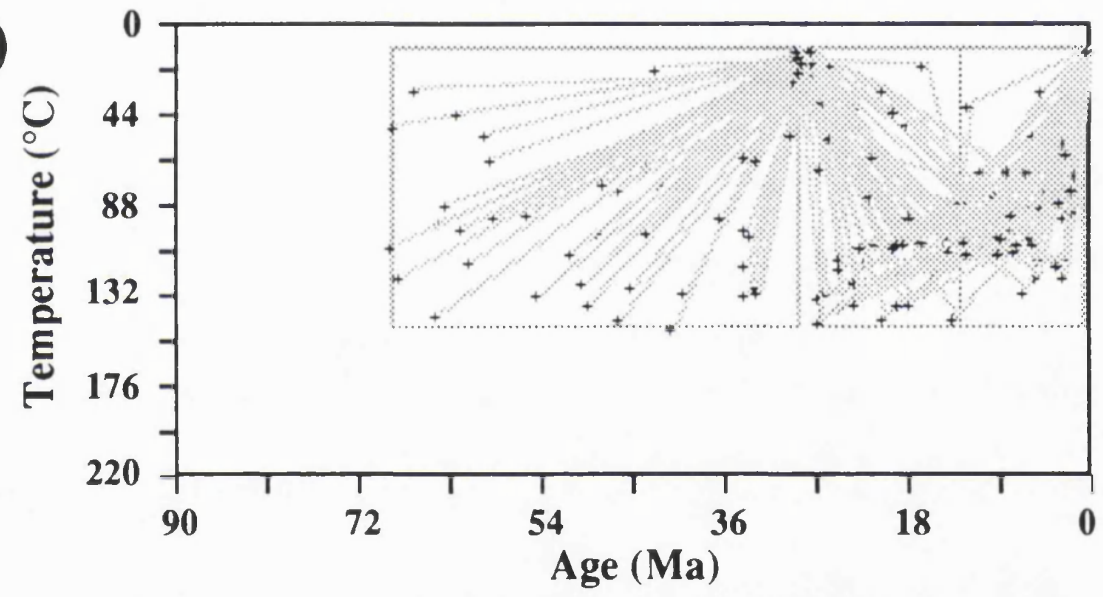

b)

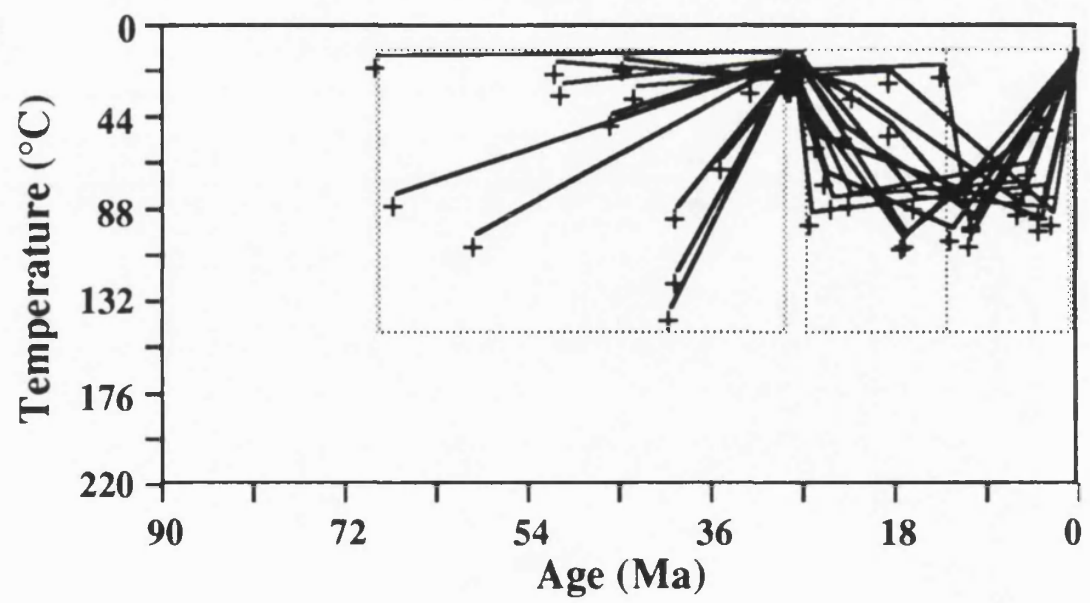

Figure 7.15 Monte Carlo runs that fit (a) the length data and (b) the length and age data for sample SCO-6 using two T-t boxes to constrain the T-t history after deposition at $\sim 28 \mathrm{Ma}$. 
that predict the sample data require a longer period of heating at a lower maximum temperature of about $75-80^{\circ} \mathrm{C}$. However the data is not of sufficiently high precision to allow the distinction between whether the samples experienced a short-lived high temperature heating event or a longer-lived lower temperature heating event. The timing of the maximum palaeotemperature after sediment deposition is not predicted well by the model. The Monte Carlo run that predicts most closely the SCO-6 sample data is shown in Figure 7.16.

The results of the same procedure carried out on sample SCO-9 are illustrated in Figure 7.17. With one post depositional T-t constraint the best-fitting Monte Carlo runs show remarkably similar $\mathrm{T}$-t histories after deposition, regardless of the $\mathrm{T}$-t history prior to deposition. The maximum temperature required by the model to predict the SCO-9 sample data ranges between $\sim 95^{\circ} \mathrm{C}$ and $105^{\circ} \mathrm{C}$. However by putting an additional post-depositional $\mathrm{T}-\mathrm{t}$ box into the model, the predicted palaeotemperature maximums become lower with a wider spread, varying from $\sim 80^{\circ} \mathrm{C}$ to $110^{\circ} \mathrm{C}$. The timing of the maximum palaeotemperature is again difficult to ascertain, although the majority of the predictive runs show that it occurs after about $18 \mathrm{Ma}$.

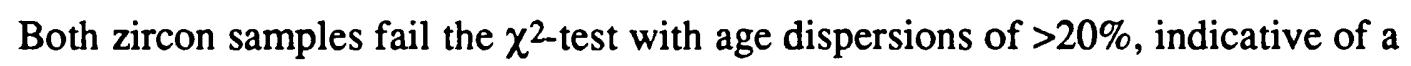
mixed population of single crystal ages. The zircon fission track ages were calculated using a multi-etch procedure similar to that described by Naeser et al. (1987). This involves counting approximately 20 crystals in five separate mounts with each mount subjected to a different etch-time in a molten sodium hydroxide / potassium hydroxide eutectic at $\sim 220^{\circ} \mathrm{C}$. This procedure is employed to allow for variations in age and uranium content of the zircons, common in a detrital sandstones that can have a strong influence on the time required for optimum etching.

The zircon fission track data from the sandstone samples can be represented graphically in the same ways as the apatite fission track data, as illustrated in Figures 7.18 and 7.19. What can be seen from both plots is that the majority of the single crystal age fall between $60 \mathrm{Ma}$ and $300 \mathrm{Ma}$. No crystals with ages below the stratigraphic age are found, indicating the ages have not been significantly reset by any re-heating event. The 

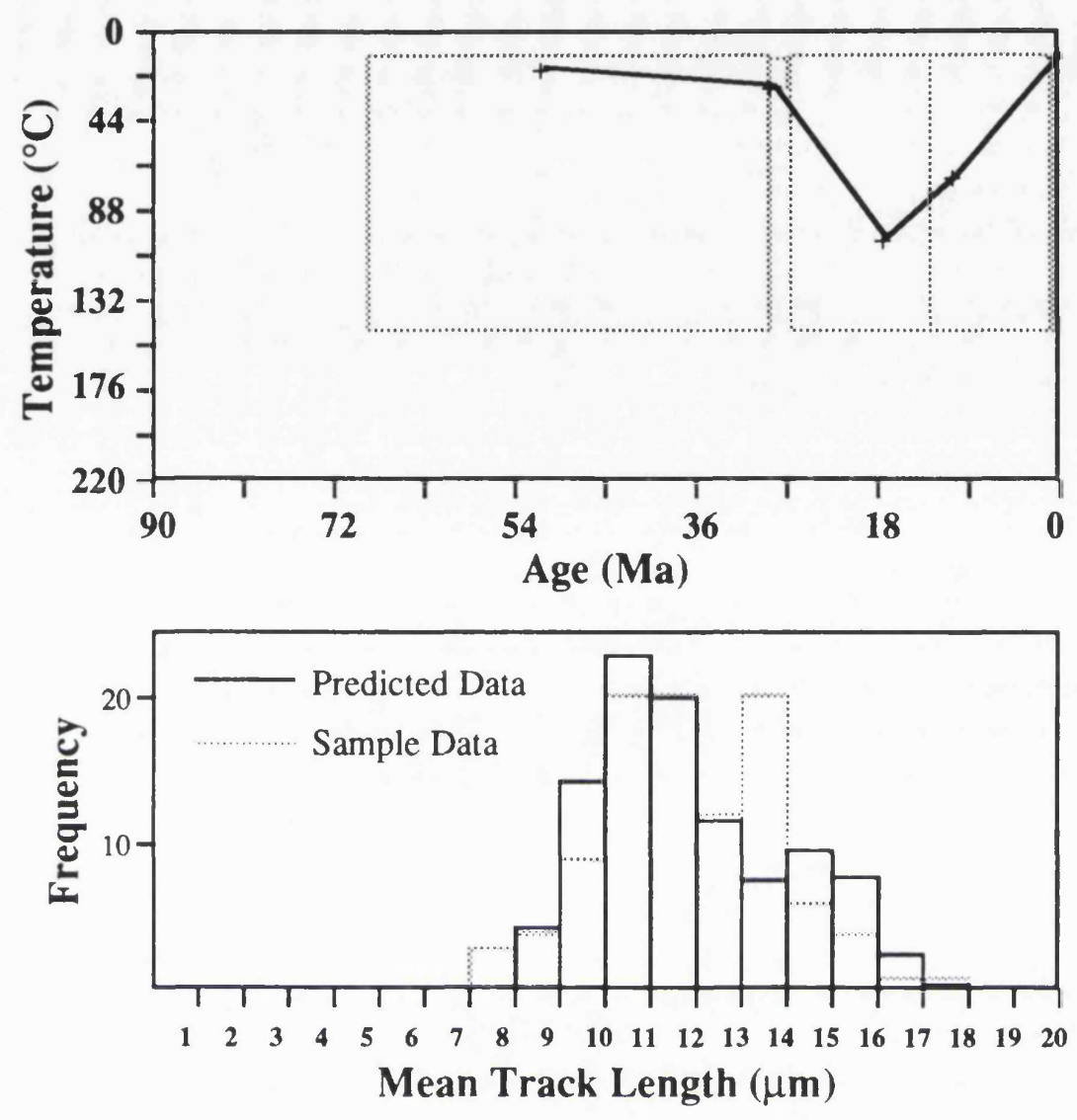

Data predicted by the best Monte Carlo run Age : $37.96 \mathrm{Ma}$

Mean Track Length : $11.86 \mu \mathrm{m}$

S.D. : $2.05 \mu \mathrm{m}$

\section{SCO-6 Sample Data}

Age : $39.4 \pm 2.3 \mathrm{Ma}$

Mean Track Length : $11.83 \pm 1.0 \mu \mathrm{m}$

S.D. : $2.03 \pm 1.0 \mu \mathrm{m}$

Figure 7.16 An illustration of the Monte Carlo run that shows the best fit to the SCO-6 sample data, including a comparison of the predicted and observed track length distributions 
a)

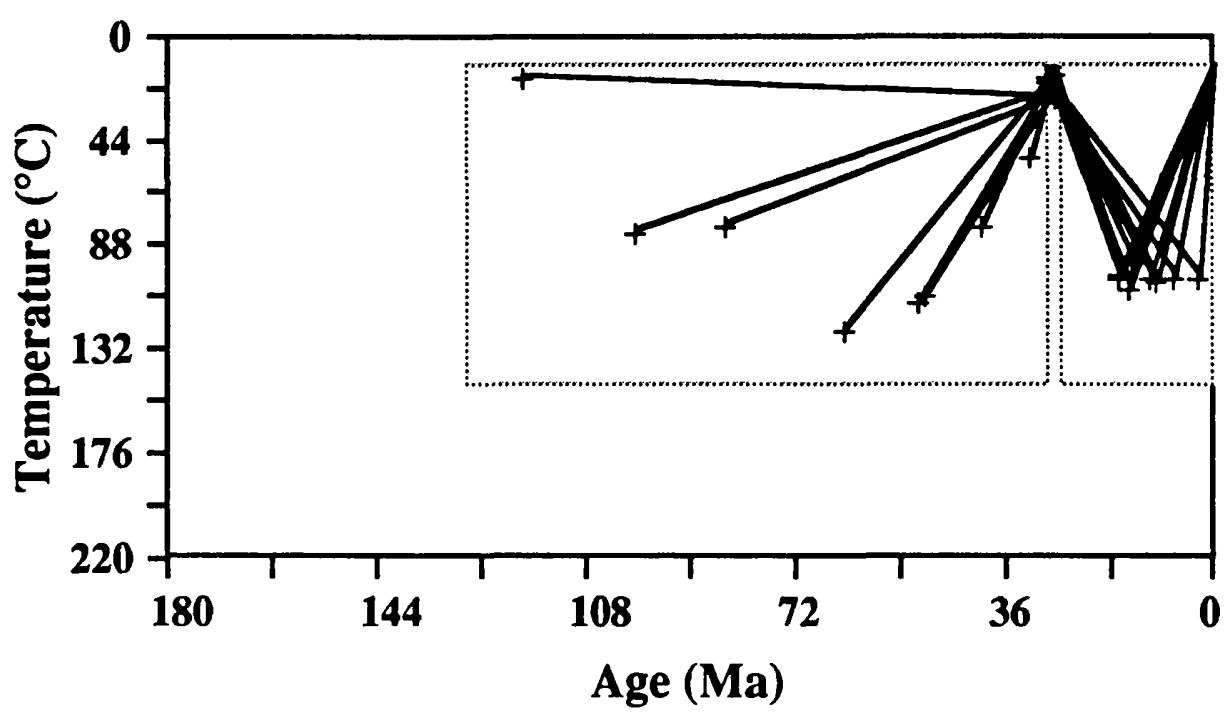

b)

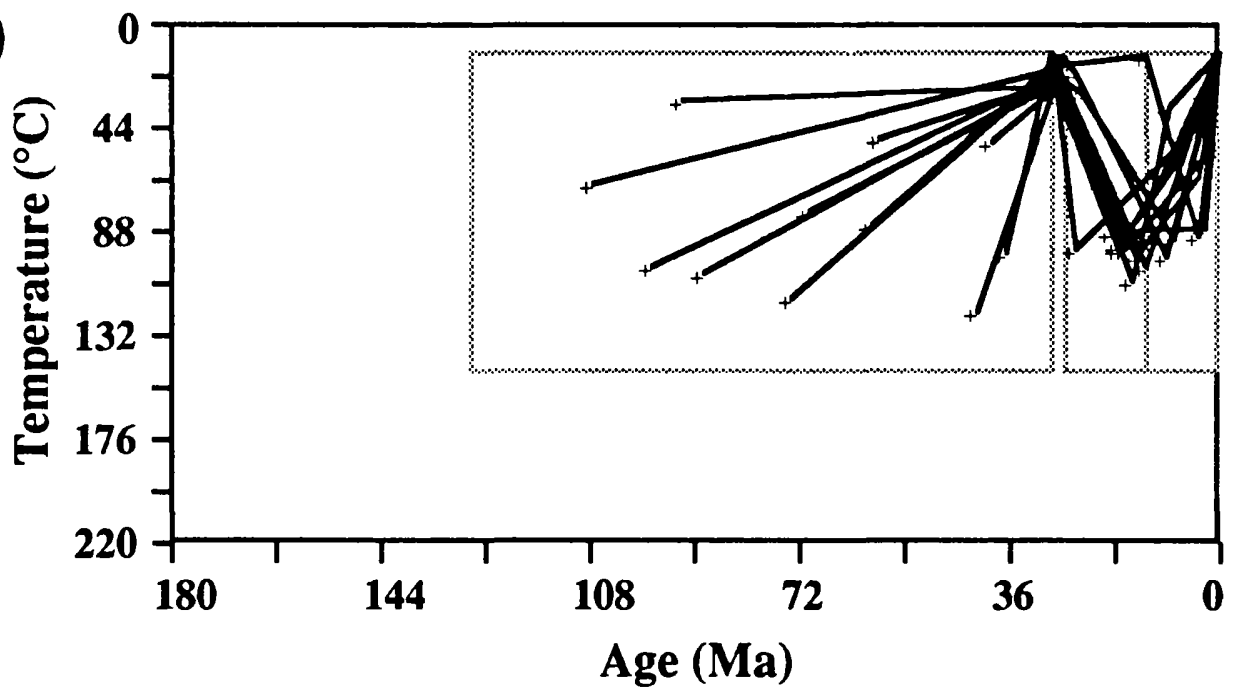

Figure 7.17 Monte Carlo runs that fit the length and age data of sandstone sample SCO-9.

a) With one T-t box to constrain the T-t history after deposition at $\sim 28 \mathrm{Ma}$.

b) With two T-t boxes to constrain the T-t history after deposition at $\sim 28 \mathrm{Ma}$. 

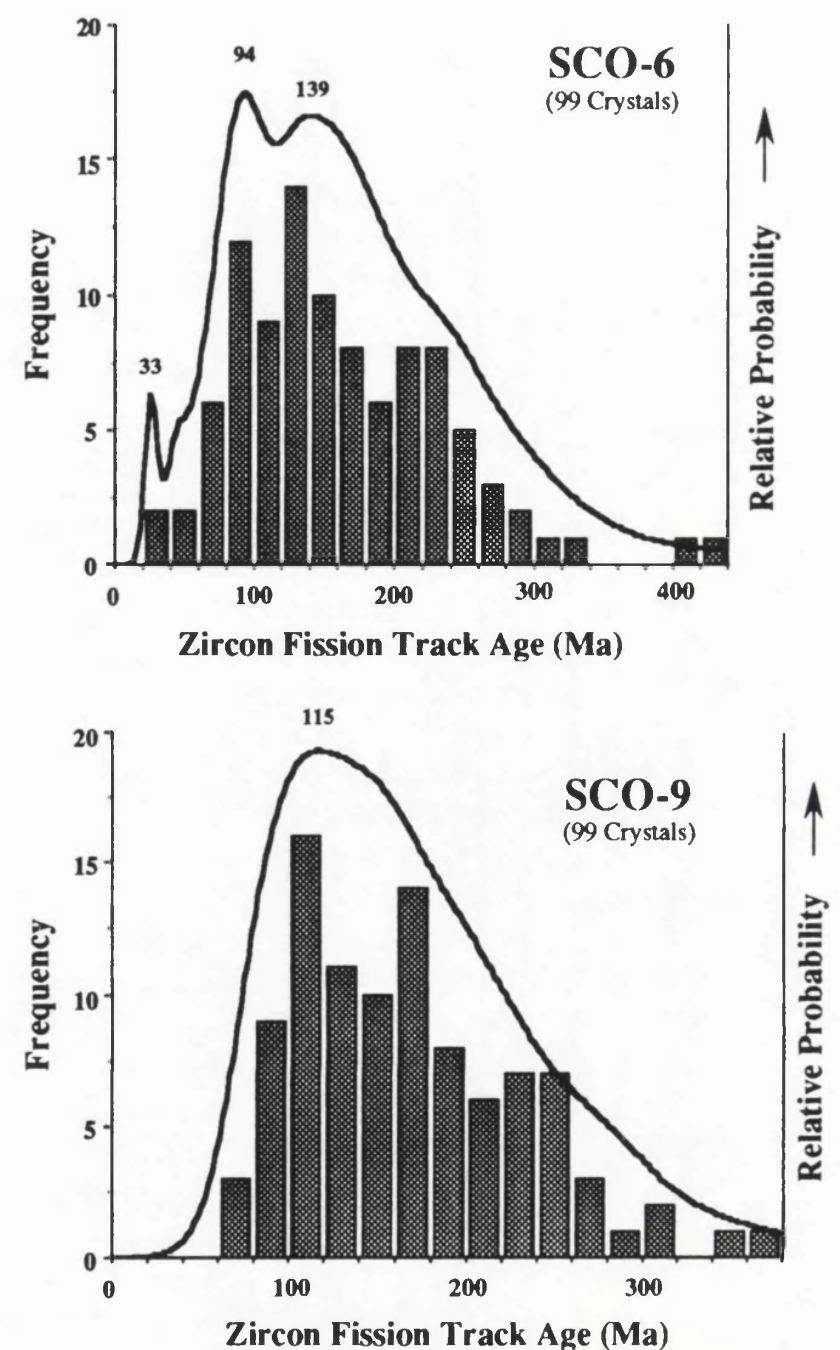

Figure 7.18 Probability distribution curves (age spectra) superimposed on age frequency histograms for the zircon age data of samples SCO- 6 and SCO-9. a) $\mathrm{SCO}-6$

(99 Crystals)

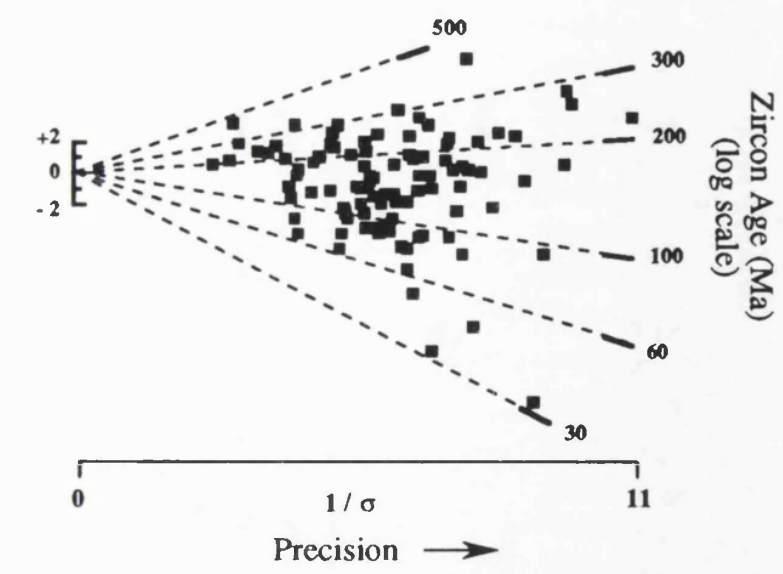

b) $\mathrm{SCO}-9$

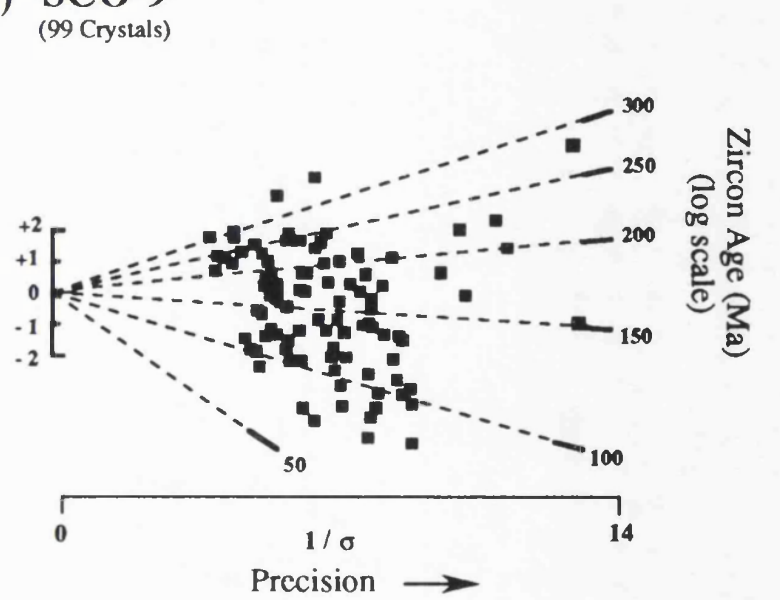

Figure 7.19 Radial Plots for the zircon data of the two sandstone samples collected from the Stilo-Capo d'Orlando Formation. 
quantitative analysis of the apatite data has already shown that the maximum palaeotemperature of the sediment after deposition was $\sim 100^{\circ} \mathrm{C}$, well below the temperature required to anneal tracks in zircon $\left(>200^{\circ} \mathrm{C}\right)$.

The 'age spectra' for sample SCO-6, which was calculated using $1 \sigma$ errors on the single crystal ages, has three peaks. However these peaks are not indicative of the overall age population, and show the disadvantages of using such a graph. The peak at $33 \mathrm{Ma}$ is produced by two crystals (out of 99), both with high precision ages, and therefore has little significance. The twin peaks at $94 \mathrm{Ma}$ and $139 \mathrm{Ma}$ are also an artifact of high precision ages, although the majority of the crystal ages fall within this age range and a single maximum peak at $\sim 117 \mathrm{Ma}$ would probably be more representative of the age distribution. With this taken into account, the age spectra for sample SCO-9 is remarkably similar to sample SCO-6.

Radial plots of the same data also shows that all the ages, bar eight, fall between $60 \mathrm{Ma}$ and $300 \mathrm{Ma}$, with an almost even spread between these bounding two ages. Of the other eight ages, probably the only ones with any reasonable significance are the two $\sim 30$ Ma high precision ages of sample SCO-6 (32.7 $13.7 \mathrm{Ma}$ and $33.2 \pm 4.7 \mathrm{Ma}$ respectively).

\subsection{A DISCUSSION OF THE FISSION TRACK RESULTS OBTAINED FROM THE STILO-CAPO D'ORLANDO FORMATION}

The initial aims of this study were to constrain the provenance of the Stilo-Capo d'Orlando Formation and the exhumation history of the detrital source rocks. Fission track data from the samples have also indicated that the lower parts of the formation have been subjected to significant post-depositional heating, up to temperatures as high as $100^{\circ} \mathrm{C}$.

\subsubsection{Constraints on Provenance}

Previous petrological studies describing the provenance of the parts of the StiloCapo d'Orlando Formation sampled in this study (Cavazza, 1989; Weltje, in press) assign the source of the detritus to the present day crystalline and metamorphic rocks of the Aspromonte mountains, directly north of the present day outcrop. 
While the zircon fission track data from both conglomerates and sandstones is compatible with such an interpretation, the apatite data appears to contradict it. Although the apatite fission track results have been influenced by a partial annealing event, they still show ages greater than any seen in the present day exposed basement rocks (Chapter 6). Two explanations may explain this apparent anomaly.

First, the analysed samples may not have originated from the Aspromonte basement and could have been transported from further afield. This explanation can be ruled out for several reasons. First, some of the conglomerate clasts from the sampled sequences are up to 3 or 4 metres in diameter. Clasts of this size require very steep slopes to travel only a short distance, thus they must have a local origin. Second, the only alternative source area is the Sardinian-Corsican basement. This region has distinct petrological markers, including kinzigites (biotite, sillimanite, garnet meta-sediments), that have not been identified within the Stilo-Capo d'Orlando Formation detritus (Cavazza, 1989).

The second explanation is that the older apatite ages were derived from the structurally highest part of the Aspromonte basement, now removed by erosion. Prior to the major phase of exhumation recognised in the Aspromonte at $\sim 30 \mathrm{Ma}$, the rocks above the apatite annealing zone $\left(\sim 70^{\circ} \mathrm{C}\right)$ would have retained older, if not original, apatite fission track age, recording the last thermal event to affect the rocks. With the initiation of increased erosional exhumation, these rocks would be the first to be removed and subsequently redeposited, in this case at the base of the Stilo-Capo d'Orlando Formation. With further erosion the original apatite annealing zone would be exposed. Below this zone the apatite ages will be reduced. When the depth of erosion reaches the original $120^{\circ} \mathrm{C}$ isotherm, below which no apatite fission tracks are retained, rocks will have zero or very young ages, which when analysed at the present day should show ages close to the age of deposition. This process is shown diagrammatically in Figure 7.20. Unfortunately the apatites in the samples analysed have been partially reset since deposition and more detailed interpretation of the nature of the basement is difficult. However, the two apatite age modes in sandstone sample SCO-9 (Figure 7.12) may indicate crystals above and below the $70^{\circ} \mathrm{C}$ isotherm prior to exhumation. 


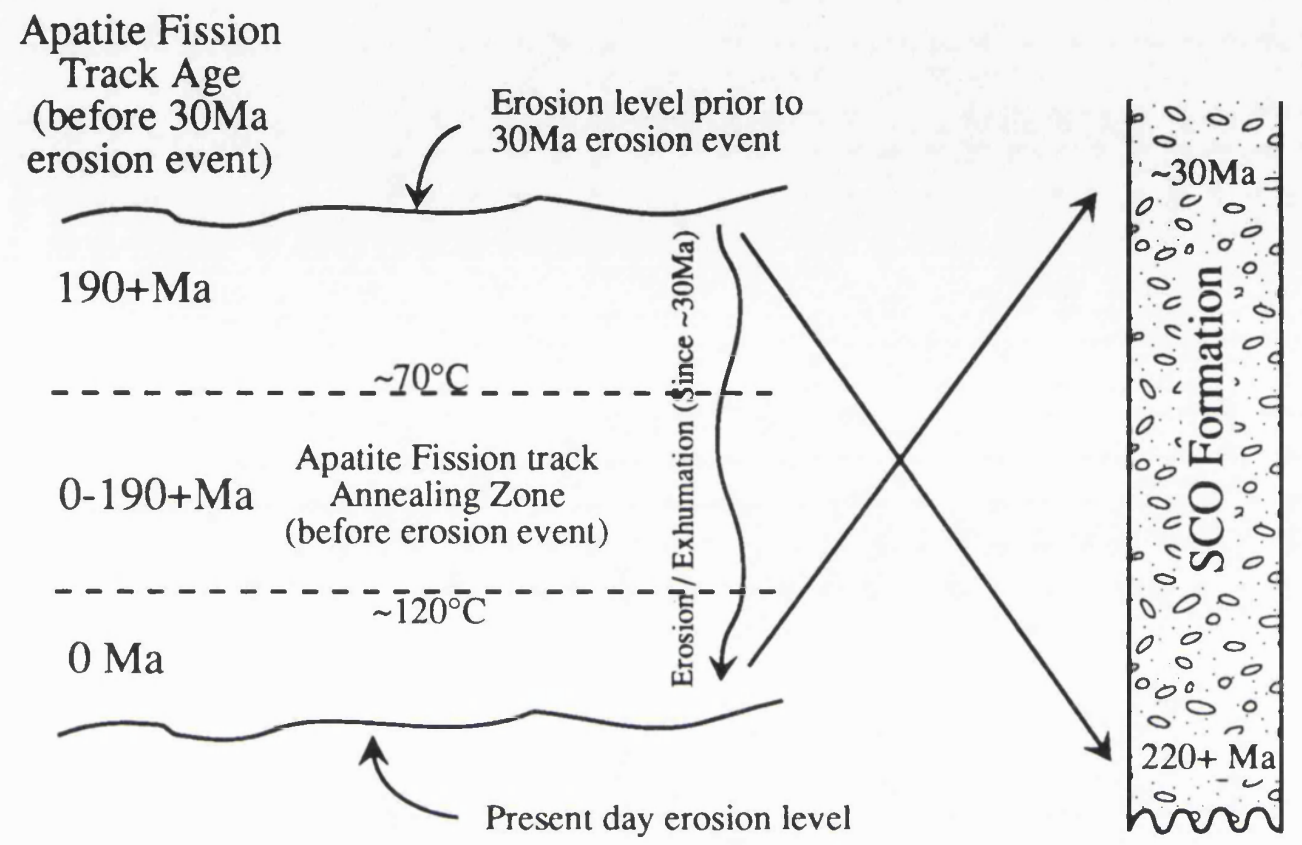

Figure 7.20 Diagram to illustrate why the basement rocks and detritus preserved in the Stilo-Capo d'Orlando Formation show apatite fission track ages greater than those obtained from the present day basement rocks.

(Note that the detritus deposited in the SCO Formation that originally lay below the apatite annealing zone, will now show ages similar or slightly greater than the stratigraphic age of the formation) 
The predicted T-t history for the apatite fission track data of conglomerate sample SCO-5 (a greenschist facies meta-dacite) indicates a thermal event at $\sim 200 \mathrm{Ma}$. This correlates with the $220 \mathrm{Ma} \mathrm{K}-\mathrm{Ar}$ (whole rock) age obtained by Civetta (1977) on a similar extrusive clast, which he relates to hydrothermal activity. This event may also explain why the zircon fission track ages obtained from the conglomerate clasts cluster between $187 \mathrm{Ma}$ and $240 \mathrm{Ma}$.

As mentioned earlier, the zircon data does not contradict the idea of a local source in the Aspromonte. However the two $30 \mathrm{Ma}$ ages in sandstone sample SCO-6 do present something of a problem. If these ages are reliable, which statistically they are, then they need to have been exhumed from temperatures greater than $200^{\circ} \mathrm{C}$ to the surface, eroded and deposited in the Stilo-Capo d'Orlando Formation within a maximum of 5Ma. This could be achieved either by very rapid erosion associated with rapid surface uplift, perhaps the result of a major down-cutting river, or more likely by rapid exhumation caused by extensional tectonism, recognised between $25 \mathrm{Ma}$ and $30 \mathrm{Ma}$ by Platt and Compagnoni (1990) in the Aspromonte region.

\subsubsection{Origin of the Volcanic Conglomerate Clasts}

The other major problem concerning the provenance of the Stilo-Capo d'Orlando Formation is the origin of the volcanic clasts within the conglomerate bodies. The various postulated sources and their relative merits were discussed in section 7.3. This study has confirmed that they were not derived from the Oligo-Miocene volcanic rocks of Sardinia. Petrological studies show that all the volcanic clasts collected have undergone some degree of metamorphism, usually in the greenschist facies. Such an event is not recorded in the Permian volcanic rocks of Sardinia and Corsica. A K-Ar (biotite) age has been determined for sample SCO-7, a lower greenschist facies meta-andesite. Although not too much should be read into a single age without a re-analysis, the result of $297 \pm 8 \mathrm{Ma}$, does suggest the metamorphism occurred during the Hercynian Orogeny. The age correlates well with Rb-Sr ages obtained for the post-metamorphic magmatism seen in the Calabrian Arc (295 \pm 2 Ma to $270 \pm 5 \mathrm{Ma}$, Atzori et al., 1984). Therefore this metamorphic event certainly occurred prior 
to the Permian volcanism seen in Sardinian and Corsica, ruling these rocks out as a possible source. The most probable source for the volcanic clasts is the metamorphosed ?Devonian-Carboniferous volcanic rocks seen in the Peloritani mountains of NE Sicily (Ferla, 1978; Ferla et al., 1983; Atzori et al., 1983; 1984). Chemically similar low-grade andesitic meta-volcanic rocks have also been identified in the Bagni Unit of the Alpine Group and in the low-grade Hercynian metamorphic rocks in the Longobucco area of the northern Sila (Atzori et al., 1984).

\subsubsection{Re-heating of the Stilo-Capo d'Orlando Formation}

As demonstrated from both qualitative and quantitative analysis of the apatite data from the conglomerate clasts and sandstone samples, the Stilo-Capo d'Orlando Formation has experienced maximum palaeotemperatures somewhere between $80^{\circ} \mathrm{C}$ and $100^{\circ} \mathrm{C}$ since deposition although it should be mentioned that this interpretation does rely on the accurate determination of the stratigraphic age as determined by Weltje (in press). This lowtemperature thermal event means that the sediments have been buried and then re-exposed since deposition.

The burial of the samples from which these results were obtained, from the base of the Stilo-Capo d'Orlando Formation, could have been achieved by two processes: either burial as a result of sedimentation, or burial beneath a major tectonic overthrust. If an average geothermal gradient of $25^{\circ} \mathrm{C} / \mathrm{km}$ is assumed, then the maximum palaeotemperature of $80^{\circ} \mathrm{C}$ indicates burial to $\sim 2-3 \mathrm{~km}$. The maximum thickness of the Stilo-Capo d'Orlando Formation is estimated at $750 \mathrm{~m}$ (Cavazza, 1989). Therefore further overburden is required. The "Argille Scagliose" is one candidate for this additional overburden. These CretaceousEocene argillites were backthrust over the Stilo-Capo d'Orlando Formation and in places over the crystalline basement during the Aquitanian (20-22Ma) (Barrier et al., 1987). The maximum thickness of these deposits is unknown. Upper Miocene calc-arenites and flysch could also have acted as overburden to the Stilo-Capo d'Orlando Formation (Barrier et al., op. cit.). Extensive neotectonic faulting causing fragmentation of the formation and subsequent removal of overburden due to erosion means that any burial history of the Stilo- 
Capo d'Orlando Formation is difficult to evaluate from stratigraphic information. These rocks are exposed at the present day because of significant amounts of recent erosion driven by recent tectonic surface uplift identified in the region (Ergenzinger et al., 1978; Tortorici, 1980; Ghisetti, 1981; Hearty et al., 1986; Montenant and Barrier, 1987; Cosentino et al., 1989). Since the samples in question were collected adjacent to major down cutting rivers or torrente, it is possible to postulate the amounts of erosion required to expose the previously buried and re-heated Stilo-Capo d'Orlando Formation samples.

This interpretation involves several uncertainties. These include the stratigraphic age of the samples, the validity and assumptions made in the apatite annealing model of Laslett et al. (1987) and Duddy et al. (1988) and the limited amount of material to which the interpretation has been applied. A more detailed study, with many more samples analysed using fission track analysis is required to assess the exact nature of this re-heating or burial event.

\subsection{SUMMARY}

The fission track data confirms previous interpretations that clasts in the Stilo-Capo d'Orlando Formation were derived from the local basement rocks of the Aspromonte and Peloritani mountains.

The Stilo-Capo d'Orlando Formation is syn-orogenic, and records the initiation and very early stages of a major phase of erosion within the basement rocks. This phase of erosion correlates with the increase in the rate of exhumation recorded in the fission track data from the basement (Chapter 6). However the study of the Stilo-Capo d'Orlando Formation does not provide any information on amounts of erosion. The majority of the sediment eroded from the basement rocks bypassed the Stilo-Capo d'Orlando Formation basins and was deposited in the far more extensive Apennine / Maghrebide foredeep, with the Stilo-Capo d'Orlando Formation basin acting as a 'temporary reservoir' for the eroded sediment (Weltje, in press).

The chronological, petrological and thermal constraints provided by this study of the Stilo-Capo d'Orlando Formation will now be used in discussing the geological and 
tectonic implications of this thesis: the cooling and exhumation history of the basement rocks of the Calabrian Arc. 


\section{CHAPTER 8 \\ DISCUSSION AND GEOLOGICAL INTERPRETATION}

\subsection{INTRODUCTION}

In the preceding chapters the analysis of apatite and zircon fission track data, in conjunction with re-calculated and re-interpreted isotopic geochronological data, allowed the determination of detailed cooling histories of the crystalline basement rocks and associated cover sediments of the Calabrian Arc. Previous work that specifically mentions the cooling history of the Calabrian Arc basement rocks is limited to two papers by Schenk (1980; 1989). In these studies cooling information was obtained from petrological and high closure temperature isotopic age data collected only from high-grade Hercynian rocks in the Serre region of Calabria.

In contrast, the cooling histories derived in this thesis cover a much broader range of rocks. All the main tectono-stratigraphic divisions of the metamorphic basement complex have been sampled and analysed, covering the majority of the Calabrian Arc. The application of apatite and zircon fission track analysis has revealed for the first time a detailed Tertiary low temperature cooling history of the Calabrian Arc basement rocks.

The purpose of this chapter is to provide explanations and geological interpretations of these cooling histories. With other geological information the Tertiary geological evolution of the Calabrian Arc can the be assessed. This information will then be compared to other similar regions of the western Mediterranean, including the Italian Apennines, Corsica and Sardinia. The combination of this information can be used to revise the previously proposed models for the Oligo-Miocene evolution of the western Mediterranean. 


\subsection{IMPLICATIONS OF THE DERIVED LOW-TEMPERATURE}

\section{COOLING HISTORIES ON THE EXHUMATIONAL HISTORY OF THE}

\section{CALABRIAN ARC}

\subsubsection{Introduction}

The interpretation of low-temperature cooling histories and their relationship to exhumation was summarised in Chapter 6, section 6.3. The main purpose of this section is to apply this interpretation to the cooling histories obtained by the qualitative and quantitative analysis of fission track data from the rocks of the Calabrian Arc, the subject of Chapter 6.

Most interpretations of low-temperature cooling histories assume that they are controlled by changes in the amount and especially the rate of exhumation. However, as mentioned in Chapter 6, section 6.3, this assumption relies on the crustal geotherm remaining constant through time. If this assumption is to be made for the cooling histories obtained from the basement rocks of the Calabrian Arc then the effects on the geotherm caused by cooling without exhumation ("in situ cooling") during the time periods represented by the derived cooling histories need to be assessed.

Within a collision environment, such as that of the Tertiary Calabrian Arc, several mechanisms may result in cooling of rocks without any significant exhumation of the rock column. Minor in situ cooling can occur during a major phase of thrusting. Here hot rocks are placed upon cold rocks, with the creation of "saw-tooth geotherms" (England and Richardson, 1977; Davy and Gillet, 1986). The re-equilibration of the crustal geotherm means that the hot rocks of the upper thrust sheet can show some in situ cooling. However re-equilibration of the geotherm takes a considerable amount of time (up to 20Ma), and because of the development of topography during thrusting, major erosional exhumation will also occur. This mechanism can effectively be ruled out in the rocks of the Calabrian Arc as significant changes in cooling histories occur over much shorter time intervals than can be explained by this mechanism. The passage of hot fluids or the intrusion of hot plutonic rock may also cause a sudden increase in the geotherm with subsequent cooling, without any need for exhumation. However within the Calabrian Arc there is no evidence to suggest there has been any major movement of hot fluids subsequent to metamorphism 
in the Alpine Group rocks. Major Tertiary plutonism is also absent, apart from recent volcanic activity in the Aeolian Islands and Mt. Etna. Finally the penetration of cold fluids, such as meteoric ground water may cause cooling of rocks. However within an environment of crystalline rocks such processes will be restricted to the upper portions of the rock column. Other major influences on the crustal geotherm through time, including mantle processes and changes in plate regime have only a very minor influence at temperatures below $250^{\circ} \mathrm{C}$. It therefore seems reasonable to assume that the Tertiary cooling observed from the basement rocks of the Calabrian Arc can be attributed to the various processes of exhumation. Therefore the quantitative and qualitative analysis of the fission track results described in terms of time and temperature at the end of Chapter 6 are discussed in terms of exhumation.

As suggested in the summary of data analysis in Chapter 6, the exhumational history of the different rocks groups can be linked to the tectono-stratigraphy suggested by Messina et al. (1990a/b). The basic tectono-stratigraphy has the low-grade Hercynian rocks and their associated Mesozoic cover as the uppermost rock group. Intruded between these rocks and the underlying high-grade metamorphic rocks are the late Hercynian plutonic rocks. The structurally lowest units are represented by the Alpine Group rocks.

The apatite and zircon fission track data has revealed that on a regional scale (i.e. ignoring local anomalous results) the crystalline basement samples experienced a major increase in the rate of cooling and hence exhumation from between $~ 30 \mathrm{Ma}$ (mid-Oligocene) to around 15Ma (Middle Miocene).

The precise timing of this increase in the rate of exhumation varies between the different rock groups. The low-grade Hercynian metamorphic and late Hercynian Plutonic rocks exhibit an increased exhumation rate between $\sim 30 \mathrm{Ma}$ and 20Ma. High zircon ages imply that these rocks lay between $\sim 200^{\circ} \mathrm{C}$ and $130^{\circ} \mathrm{C}$ prior to this exhumation event. The high-grade Hercynian metamorphic rocks and the Capo Vaticano plutonic rocks also show an increased rate of exhumation between $\sim 30 \mathrm{Ma}$ and $20 \mathrm{Ma}$. However these rocks lay below the zircon fission track closure temperature $\left(>250^{\circ} \mathrm{C}\right)$ prior to the exhumation event. The apatite age and length data from these samples also reveal that these rocks cooled 
through the apatite annealing zone (between $120^{\circ} \mathrm{C}$ and $70^{\circ} \mathrm{C}$ ) more rapidly and slightly more recently than the low-grade Hercynian metamorphic and late Hercynian Plutonic rocks. The Alpine group rocks also reveal a major late Tertiary exhumation event. However in these rocks it occurs slightly more recently, between $20 \mathrm{Ma}$ and 15Ma, and the apatite fission track length data indicates that it occurred at a higher exhumation rate. This data can be explained by using a simple qualitative exhumation model.

Prior to the late Tertiary exhumation event, initiated at $\sim 30 \mathrm{Ma}$, a situation as illustrated in Figure 8.1a would have been prevalent. The Alpine Group rocks, high-grade Hercynian metamorphic rocks and Capo Vatican Plutonic must have been at temperatures below the closure temperature of the zircon fission track system $\left(>250^{\circ} \mathrm{C}\right)$. The rest of the Hercynian plutonic rocks and the presently exposed low-grade Hercynian metamorphic rocks must have lain between the apatite fission track annealing zone and the zircon fission track closure temperature (between $\sim 200^{\circ} \mathrm{C}$ and $130^{\circ} \mathrm{C}$ ). The material within and above the apatite annealing zone would have been made up of low-grade Hercynian metamorphic rocks and its associated unmetamorphosed Mesozoic cover, part of which is now the main constituent of the Oligo-Miocene Stilo-Capo d'Orlando Formation (see Chapter 7).

At $\sim 30 \mathrm{Ma}$ a significant geological event must have occurred to cause a sustained phase of much increased exhumation. Between $~ 30 \mathrm{Ma}$ and 20Ma the low-grade Hercynian rocks and Hercynian plutonic rocks passed through the apatite annealing zone, hence registering apatite fission track ages from this time. However the high-grade Hercynian metamorphic rocks passed through both the zircon fission track closure temperature and the apatite annealing zone during this period. If the geotherm was relatively similar throughout the region this implies that the high grade Hercynian metamorphic rocks have undergone a greater total amount of exhumation since $\sim 30 \mathrm{Ma}$. The apatite track length data from these rocks reveals that they passed through the apatite annealing zone at a faster rate and slightly more recently than the low-grade Hercynian rocks and Hercynian plutonic rocks above. Figure $8.1 \mathrm{~b}$ shows that these results and the present position of the basement rocks can be explained by greater and more rapid exhumation towards the present day northwest. The last rock group to pass through the zircon closure temperature and apatite 


\section{Figure 8.1 Simplified Exhumation Model}

a) Relative positions of basement units prior to $30 \mathrm{Ma}$ NW

\section{SE}

Mesozoic sedimentary cover and

Low-grade Hercynian metamorphic rocks (LGM)

\begin{tabular}{|c|c|}
\hline Hercynian plutonierocks (HPR) & $\begin{array}{l}\text { No registration of } \\
\text { apatite fission tracks }\end{array}$ \\
\hline Capo Vaticano plutonic rocks & $\sim 250^{\circ} \mathrm{C}$ \\
\hline High-grade Hercynian metamorphic rocks (HGM) & $\begin{array}{l}\text { No registration of } \\
\text { zircon fission tracks }\end{array}$ \\
\hline Alpine Group rocks (AG) & \\
\hline
\end{tabular}

b) Exhumation between $30 \mathrm{Ma}$ and $15 \mathrm{Ma}$

(Diagram represents position of basement units at $\sim 25 \mathrm{Ma}$ )

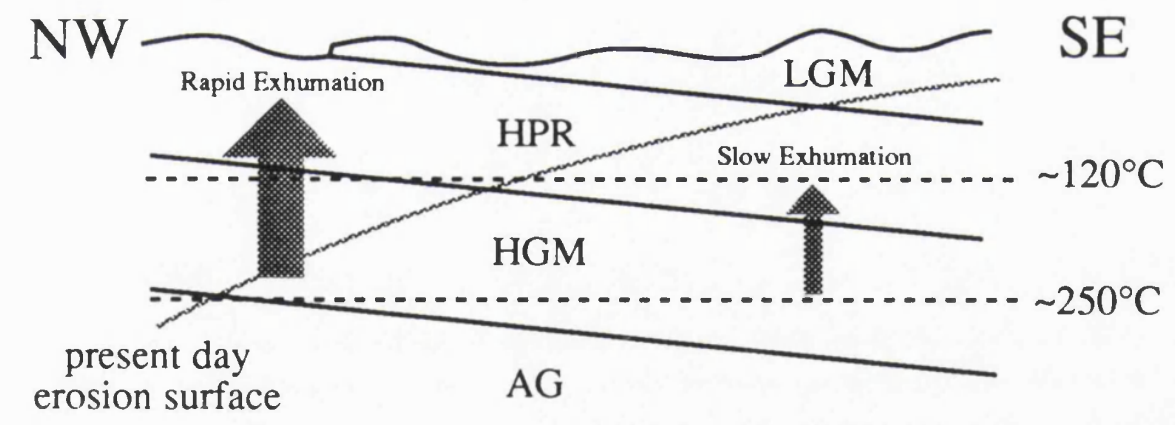

c) Present day positions of basement units

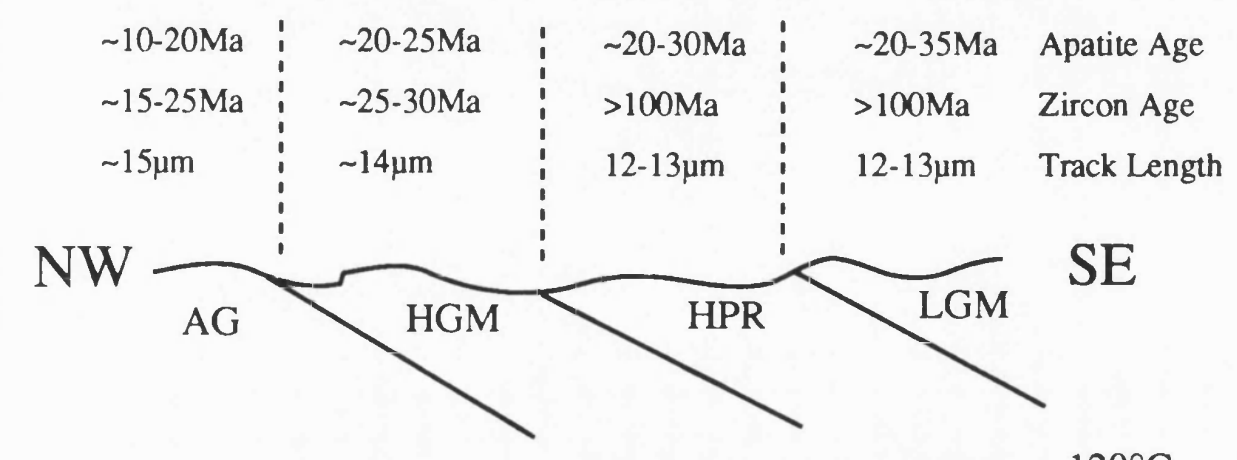


annealing zone must have been the Alpine Group. This is implied by the younger zircon and apatite fission track ages. High apatite mean track lengths obtained from the Alpine Group rocks also indicate that they passed through the apatite annealing zone at the fastest rate of all the rock groups studied, although this data was obtained exclusively from the samples of the northern Serre. At around 15Ma the major exhumation event ceases. The amounts of exhumation involved with this model are difficult to quantify, as it requires detailed information on the state of the crustal geotherm. A standard crustal geotherm of $30^{\circ} \mathrm{C} / \mathrm{km}$ would require over $8 \mathrm{~km}$ of overburden to be removed from above the high-grade Hercynian metamorphic rocks. A lower geotherm of between $15^{\circ} \mathrm{C} / \mathrm{km}$ and $20^{\circ} \mathrm{C} / \mathrm{km}$, typical of many areas of subduction, would require in excess of $12 \mathrm{~km}$ of overburden to be removed. After the Middle Miocene exhumation continues, but uniformly across the region and at a much slower rate. The situation from $\sim 15 \mathrm{Ma}$ to present is shown in Figure 8.1c.

This model is very simplified, however it represents a good regional working model for the overall exhumation history of the Calabrian Arc since the mid-Oligocene. Not all of the fission track data obtained from the region is compatible with this model. Explanations for some of this anomalous data will be discussed in section 8.3. The main questions now to be asked are: how was such exhumation accomplished? and what was the cause of the major late Tertiary exhumation event that affected all the rocks analysed? The latter question will be dealt with in section 8.4, in conjunction with a revised model for the Tertiary tectonic evolution of the Calabrian Arc.

Addressing the first question: exhumation is attributable to two processes: i) erosion / denudation and ii) extensional tectonism / normal faulting.

\subsubsection{Evidence for Erosional Processes}

During Tertiary collision in the Calabrian Arc, sediments produced by major phases of erosion resulted in the deposition of terrigenous or "molasse" sedimentary deposits in intramontane or foreland basins.

Within the area of study, the only evidence for a major phase of erosion of the basement rocks during the Oligocene is the terrigenous Stilo-Capo d'Orlando Formation of 
southern Calabria and northeastern Sicily. The base of this formation is dated at $28 \pm 1 \mathrm{Ma}$ from nannoflora. The provenance and sedimentary history of these rocks with respect to the erosion of the Calabrian Arc basement rocks was discussed at some length in Chapter 7. One interesting aspect of these rocks is that no detrital input from the Alpine Group rocks, Liguride complex or "kinzigites" (garnet-biotite-sillimanite paragneiss) from the highgrade Hercynian rocks is recognised. Cavazza (1989) suggested that these rocks were amalgamated into the Calabrian Arc during the Miocene, being too far away to act as source rocks for the Stilo-Capo d'Orlando Formation during the late Oligocene. However the exhumational model based on the fission track data implies this model is unlikely. A more likely explanation is that these rocks were not exposed during the late Oligocene and were therefore not a sediment source.

Outside the area of study, evidence for a major phase of late Oligocene erosion is seen in the deformed sediments of the Sicilian Maghrebides and southern Apennines. The Troina-Tusa Flysch of Sicily (Wezel, 1976) is thought to represent the southerly, more distal, equivalent of the Stilo-Capo d'Orlando Formation. The lower parts of this formation are composed of marly arenites, dated as nannofossil zone NP19 (Lower Oligocene) by Courme and Mascle (1988). However the upper part of the formation, from zone NP23 (Upper Oligocene), shows an influx of high energy turbiditic terrigenous sedimentation. The lithic detritus consists mainly of andesitic volcanic fragments with some plutonicmetamorphic derived material. Wezel (1976) proposed that this material was derived from the Calabrian-Peloritani basement rocks. The andesitic material was originally thought to derive either from the Oligocene volcanic rocks or the Permian volcanic complexes seen today in Sardinia and Corsica. However it seems more likely that it is the same andesitic material as recognised in the Stilo-Capo d'Orlando Formation (Chapter 7, section 7.5.2). This has been identified as Palaeozoic volcanic rock derived from the low-grade Hercynian rocks of the Calabrian Arc.

The Upper Oligocene-Miocene Numidian Flysch of Sicily (Wezel, 1976; Giunta, $1985)$ consists of almost totally pure ( $>95 \%)$ quartzose sandstones, deposited on the African Adrian margin in a more southerly sedimentary basin than the Troina-Tusa Flysch. 
However the quartzose material is unlikely to have derived from an eroding crystalline massif, as the sediments are highly mature. It is now generally agreed that these sandstones were derived from the African plate, and represent submarine fan deposits originating from a major river system, probably the equivalent of the present day Nile Delta (Wezel, 1976; Dewey et al., 1989). In contrast, Parize et al. (1986) have proposed a northerly provenance for the Numidian Flysch of Sicily. Equivalent deposits are also found in the southern Apennines, and are labelled as the Irpinian Flysch (Pescatore, 1978).

In the southern Apennines detritus from the Calabrian Arc crystalline basement rocks is recognised in the Lower Oligocene upper part of the Saraceno Formation (Knott, 1987) and in the Upper Oligocene to Miocene Albidona Formation (Zuppeta et al., 1984). Knott (1987) states that this represents the progressive denudation of the Longobucco Unit, part of the Calabrian Arc basement complex. However the more rapidly deposited sediments of the Albidona Formation indicate that a period of increased erosional activity occurred in the sediment source area during the Upper Oligocene. The palaeogeography of flysch deposition with respect to the Calabrian Arc basement and African-Adrian margin during the Oligo-Miocene is shown in Figure 8.2 (modified after Wezel, 1976).

The sedimentary record shows that there is clear evidence for a phase of increased erosion in the Upper Oligocene that can be correlated with the increase in exhumation deduced from the results of fission track analysis. The cause of this increase in the rate of erosion now needs to be discussed. The rate of erosion can be affected by several factors. These include the surface height with respect to the geoid, the surface relief or topography, the climate, the amount of vegetation, the rock type and the scale of the drainage basin. However for an increase in the rate of erosion to occur only two main processes can be invoked, a change in climate or a change in surface height.

If a major change in climate caused an increase in erosion at $\sim 30 \mathrm{Ma}$ there should be evidence within the fossil record. Two main ways in which this can be assessed are by using the palaeobotany of fossil plants (Wolfe, 1978) and by assessing marine palaeotemperatures using oxygen isotope ratios of planktonic foraminifera (Savin et al., 1975). Wolfe (1978) from analysis of leaf floras of the northern hemisphere infers that the 


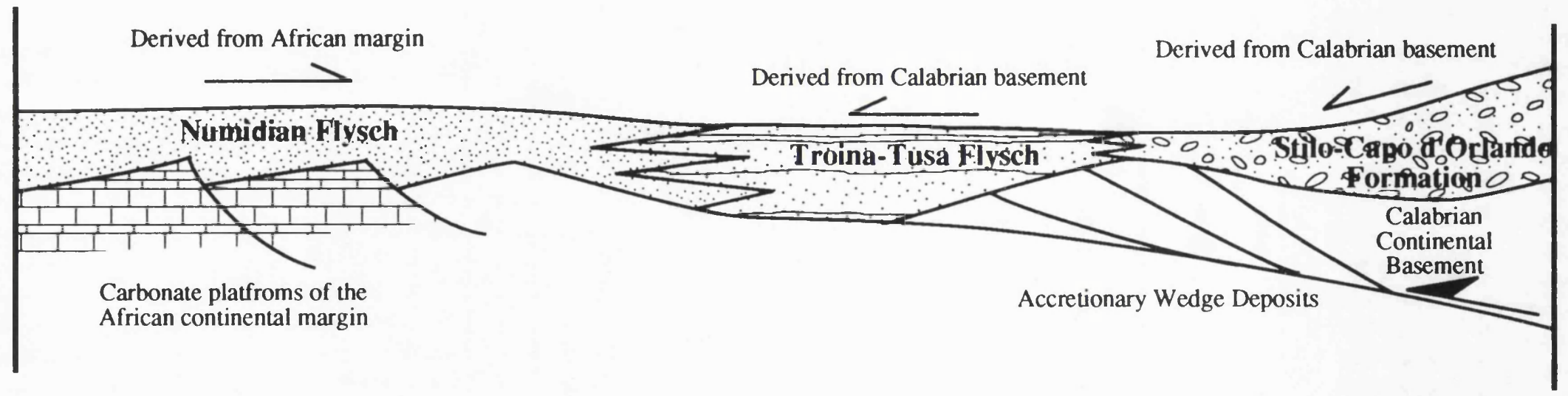

Figure 8.2 Hypothetical reconstruction of the palaeogeography of flysch depostion with respect to the Calabrian Arc and African continental margin during the Oligo-Miocene. (after Wezel, 1976) 
biggest change in climate during the Tertiary occurred in the early Oligocene (at $\sim 35 \mathrm{Ma}$ ). This change was marked by a sharp drop in the mean annual temperature. Subsequent to this only minor temperature fluctuations are inferred. The change therefore appears to have developed too early to have caused the increased erosion of the Calabrian Arc basement rocks. In addition, any climate change or any local climate patterns that may have developed would have need to have been sustained for the whole period over which increased erosion occurred, upwards of 10Ma.

Therefore the second process, an increase in surface height, appears to be the most likely candidate for the increase in erosion rate. Leeder (1991) lists a number of tectonic processes that may cause surface uplift. These include magma associated uplift, lithospheric thickening by shortening, mantle detachment, sediment underplating and magma underplating. During the interval in question the basement rocks of the Calabrian Arc were in a compressional tectonic environment. Therefore the most likely causes for an increase in surface height surface are lithospheric thickening by shortening and sediment underplating. Summerfield (1991), using the example of passive margin rift flanks, has also shown that once relief is created, erosion accompanied by isostatic compensation of the rock column can be sustained for considerable periods of time, without the need for any further tectonic activity.

\subsubsection{Evidence of Extensional Tectonism}

The other main process that can result in the exhumation of a rock column is extensional tectonism. Extension within collision zones is widely documented in the literature (see review by Dewey, 1988). Recently a paper by Platt and Compagnoni (1990) has demonstrated the presence of post-Hercynian extensional shear zones within the high-grade Hercynian basement rocks of the Aspromonte in southern Calabria.

Parts of the high-grade Hercynian rocks of Aspromonte are affected by a greenschist facies metamorphic overprint with related ductile deformation, initially identified by Bonardi et al. (1984) and described in detail by Platt and Compagnoni (1990). Two stages of metamorphic overprint are distinguished. The first stage shows a moderately 
high pressure assemblage (kyanite, garnet, chloritoid, blue green amphibole, albite and zoisite) with peak conditions of $500^{\circ} \mathrm{C} \pm 30^{\circ} \mathrm{C}$ and $5 \pm 1 \mathrm{kbar}$ thought to be associated with crustal thickening. The second stage is characterised by biotite and/or chlorite, white mica and albite/oligoclase. $\mathrm{Rb}$-Sr Isotopic age data (Bonardi et al., 1987) gives mica ages of 25 30Ma that are likely to be related to the second phase of metamorphism. The second stage of metamorphism was accompanied by intense ductile deformation, that produced flat-lying mylonites which have a north-south stretching lineation. The majority of kinematic indicators show that the shear sense was to the north.

Platt and Compagnoni (1990) also identify a major mylonite zone on the Mont'Antenna ridge that separates high-grade Hercynian metamorphic rocks with no evidence of metamorphic overprint from rocks that are thoroughly retrogressed. The features suggest the mylonite zone acted as a low-angle ductile normal fault, bringing rocks from lower in the metamorphic pile into contact with rocks that had been less deeply buried.

Similar greenschist facies metamorphic retrogression with related ductile and cataclastic deformation has also been identified across the Straits of Messina, in the Peloritani Mountains of northeast Sicily (Messina et al., 1990).

The zircon fission track age data collected from the Aspromonte and Peloritani regions show abrupt age differentials between the retrogressed and un-retrogressed metamorphic rocks of the region (Figure 8.3). Ages within the undeformed high-grade Hercynian metamorphic rocks are in excess of $112 \mathrm{Ma}$, whereas those obtained from the retrogressed rocks range from $18 \mathrm{Ma}$ to $28 \mathrm{Ma}$. This suggests the shear zones were still active at around 20-25Ma. No similar offsets in the apatite fission track age data were obtained. The ages showing that extension and shearing were largely complete by $20 \mathrm{Ma}$.

A characteristic of extensional tectonism is that extremely rapid exhumation should be recorded in the footwall of major shear zones. This offers an explanation for the result of the quantitative analysis of the apatite age and length data on sample ATT-1124 that requires almost instantaneous cooling of $\sim 150^{\circ} \mathrm{C}$ at $\sim 27 \mathrm{Ma}$.

In the Catena Costiera of northwestern Calabrian undeformed and un-retrogressed 
Figure 8.3 Map of the basement rocks of the Aspromonte showing young zircon ages coinciding with identified areas of "Alpine" retrograde metamorphism. (Apatite ages are also shown in brackets)

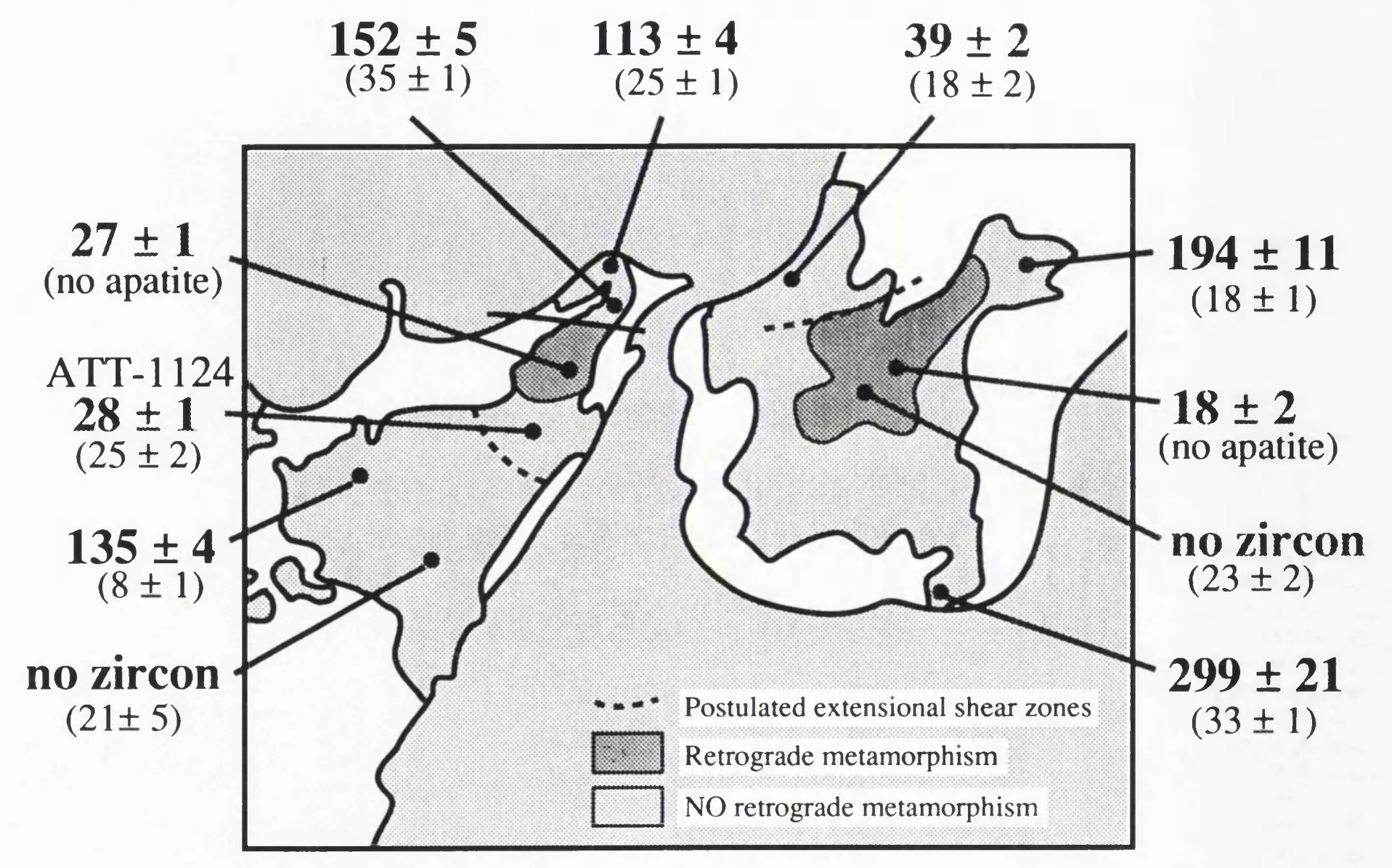


high-grade Hercynian metamorphic rocks overlying high-pressure Liguride Complex and retrogressed Alpine Group rocks along a tectonic contact have been documented and mapped by Dubois (1970), De Roever (1972) and Colonna and Compagnoni (1982). The contact of the two rock units is marked by intense cataclasis and mylonitisation, with the base of the high-grade Hercynian metamorphic rocks altered to phyllonite (De Roever, 1972). The kinematics of this deformation has not been investigated in detail, but WNWESE stretching lineations identified by De Roever are in the same direction as those in the Alpine Group rocks below, implying the deformation was produced during the same tectonic event.

The zircon fission track ages show a similar pattern to that of the Aspromonte region. Those obtained from the Alpine Group rocks show ages ranging from 18Ma to 29Ma. However sample PAL-750, an undeformed high-grade Hercynian metamorphic rock from the Catena Costiera, gives a zircon fission track age of $90 \pm 5 \mathrm{Ma}$. The apatite fission track ages for all these samples lie between 10Ma and 15Ma. This implies that the zone of contact between the Alpine Group and high-grade Hercynian metamorphic rocks in the Catena Costiera was active sometime between 10Ma and 29Ma. The similarity of this data to that from the Aspromonte suggests this contact may be extensional in nature. However further work on the kinematics of this contact will be necessary to confirm this.

Finally, in the northern Serre of central Calabria is the Curinga-Girifalco line (Schenk, 1980). This juxtaposes un-retrogressed high-grade Hercynian metamorphic rocks above from Alpine Group rocks of the Castagna Unit beneath. It is usually regarded as an overthrust of the high-grade metamorphic rocks over the Alpine Group rocks. However the results of fission track analysis have revealed that the footwall rocks of the Alpine group underwent a rapid phase of exhumation at around 15-18Ma (see Chapter 6, Figures 6.6 and 6.14). At this time no significant exhumation is identified in the hanging wall high-grade metamorphic rocks. These results imply that this fault was extensional in nature, and active around 15-18 million years ago. Again further work on the kinematics of this fault are required to confirm this observation. 


\subsubsection{Discrimination Between Erosional and Extensional Processes}

Discrimination between the contributions made by erosion and extension in the exhumation history of the Calabrian Arc is very difficult. From the discussion above it appears that the two were coeval, with sedimentation occurring in the Stilo-Capo d'Orlando Formation while extensional tectonism was still active in the Aspromonte region.

No evidence of Oligocene extensional tectonism has yet been described from the Hercynian Plutonic and low-grade Hercynian metamorphic rocks, suggesting exhumation in these rocks was dominated by erosion.

The majority of the apatite fission track data, analysed both qualitatively and quantitatively, also shows no evidence of exhumation driven by extensional tectonism. This would seem to imply that the later stages of the increased exhumation in the Calabrian Arc were driven by erosion.

\subsubsection{Summary}

The discussion above has largely answered the question of how the Upper Oligocene to Serravallian increase in the exhumation rate recognised in the Calabrian Arc basement rocks using fission track analysis was accomplished. However the question of what caused the increase in the rate of exhumation has only been touched upon at the end of section 8.2.2, when discussing the cause for increases in erosion. Here it was concluded that the increase in the erosion rate was most likely caused by an increase in surface height surface due to lithospheric thickening by shortening and/or sediment underplating. This information along with the information provided on extensional tectonism within the basement rocks will be used to provide new constraints the model for the evolution of the Calabrian Arc particularly between the Oligocene and Upper Miocene (section 8.4). This will then allow the question of what caused the increase in the exhumation rate in the Calabrian Arc basement rocks during the early Upper Oligocene to be addressed more fully. 


\subsection{OTHER FACTORS INFLUENCING THE RESULTS OF FISSION}

\section{TRACK ANALYSIS}

The widespread neotectonism and volcanism of the Calabrian Arc that occurred after the increased exhumation event identified by fission track analysis appears to have had some influence on the results of fission track analysis. The disruption of age-elevation profiles by neotectonic faulting has already been highlighted in Chapter 6, section 6.3.3. However several areas where the effects of neotectonics may have influenced the fission track data set have also been identified.

In the traverse of fission track ages taken across the Sila Massif (Chapter 6, Figure 6.7) an abrupt change in the zircon age is seen at the contact between the high-grade Hercynian metamorphic and the late Hercynian plutonic rocks. This offset can be explained by the simple exhumation model proposed for the basement rocks in section 8.2.1, whereby prior to the Oligocene exhumation event, the plutonic rocks lay above the zircon fission track closure temperature and the high-grade Hercynian metamorphic rocks were below this temperature. However the zircon fission track system also has an annealing zone between total track retention and total track annealing similar to that of apatite. Therefore gradual change in zircon fission track ages across the boundary in question would be expected. However the abrupt change in zircon fission track ages also coincides with the Petilia-Sosti Line, a major neotectonic sinistral strike-slip fault identified by Van Dijk and Okkes (1990; 1991). This is illustrated in Figure 8.4.

Other areas where fission track data may have been influenced by neotectonism include those in the northern Sila. Here three samples, CEC-1150, BOC-1300 and MAN650 give anomalously young apatite fission track ages of between 13Ma and 15Ma. Such ages may be a result of Neogene thrusts in the area, including the Acri-Cavaleto Thrust, identified by Dubois (1970) which was active during the Tortonian ( 11Ma) (Van Dijk and Okkes, 1991).

In northern Sicily two samples (CAL-100 and MAZ-180) give very young apatite fission track ages of 7Ma. Unfortunately no apatite fission track length data could be obtained from these samples. However the proximity of these samples to the recent 


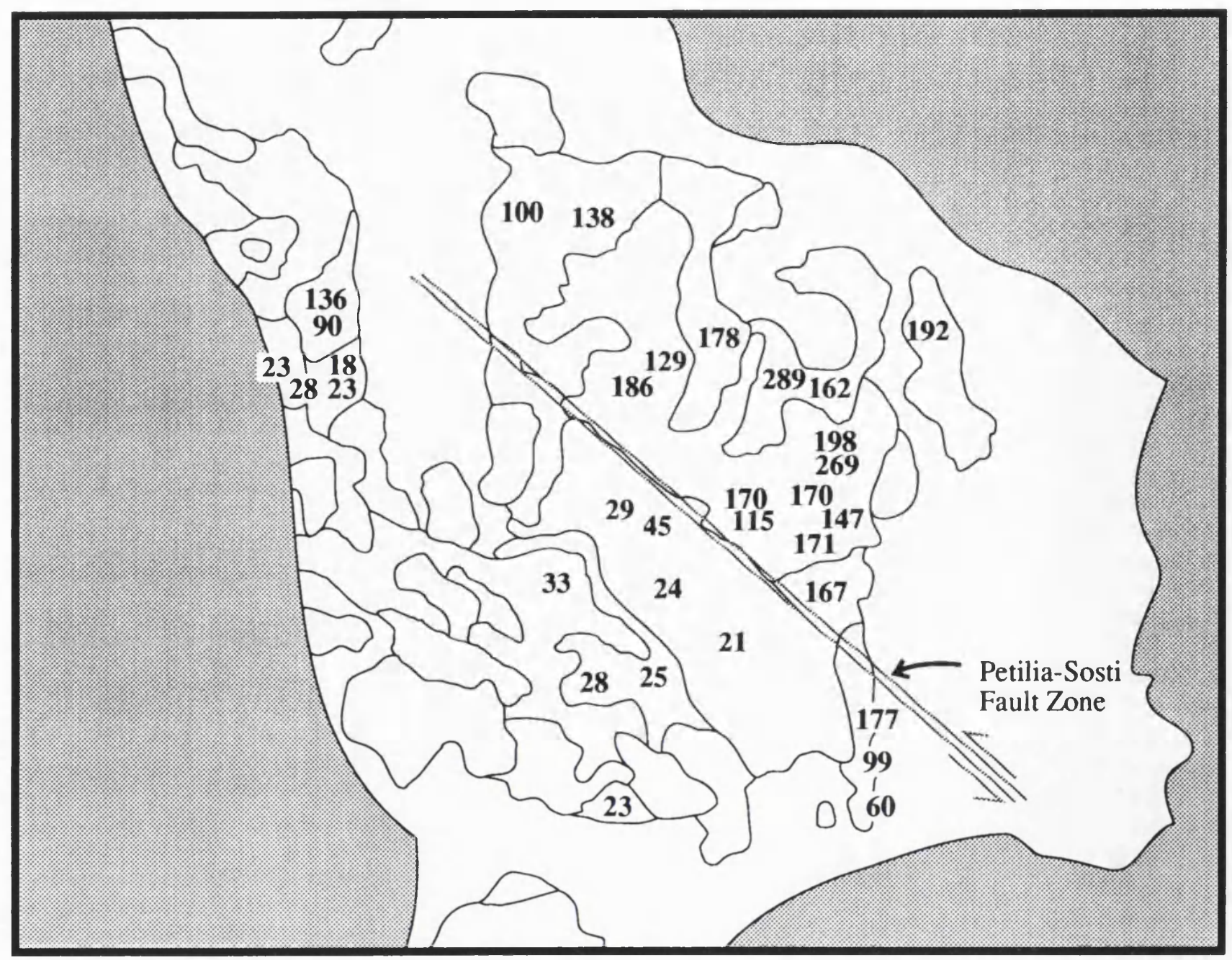

Figure 8.4 Map to illustrate the change in the zircon fission track age across the Petilia-Sosti Line, a Neogene strike-slip fault. 
volcanism of the Aeolian Islands (Sample CAL-100 is only $10 \mathrm{~km}$ from the island of Vulcano) suggests that these samples may have suffered recent increased heat flow. This would cause partial track annealing and hence resetting of the apatite fission track age.

\subsection{A REVISED MODEL FOR THE LATE TERTIARY TECTONIC EVOLUTION OF THE CALABRIAN ARC}

\subsubsection{Introduction}

Before this study was carried out the only constraints available on the Oligo-Miocene evolution of the Calabrian Arc were provided by studies of the sedimentary record (e.g. Wezel, 1976; Cavazza, 1989; Weltje, in press) and a few isotopic age dates from the crystalline basement rocks of the Aspromonte (Bonardi et al., 1987). However detailed analysis of apatite and zircon fission track data from the basement rocks of the Calabrian Arc and Stilo-Capo d'Orlando Formation has identified a major period of increased exhumation between $\sim 30 \mathrm{Ma}$ and $\sim 15 \mathrm{Ma}$. The role of increased erosion and extensional tectonism in producing the increase in exhumation rate has already been discussed. Now this information, along with information obtained by other authors can be used to constrain the Late Tertiary tectonic evolution of the Calabrian Arc, with particular reference to the Oligo-Miocene.

\subsubsection{Pre-Oligocene Evolution (Before 30Ma)}

It is now generally accepted that the tectonic evolution of the Calabrian Arc prior to 30Ma consisted of northwest directed subduction of Neotethyan ocean crust beneath the Calabrian basement rocks (Chapter 1, Knott, 1987; 1988, Dewey et al., 1989). This produced an accretionary wedge, now represented by the Liguride Complex. Figure 8.5 shows a simplified cross-section of the tectonic environment between about 50Ma and 40Ma. At this time the Liguride Complex rocks were part of an orogenic wedge in the sense of Platt $(1986 ; 1987)$. The buttress of this wedge was probably represented by a shear zone that separated the subducting Neotethyan slab and deforming accretionary wedge deposits beneath from crystalline basement rocks above. The basement rocks are shown in the 


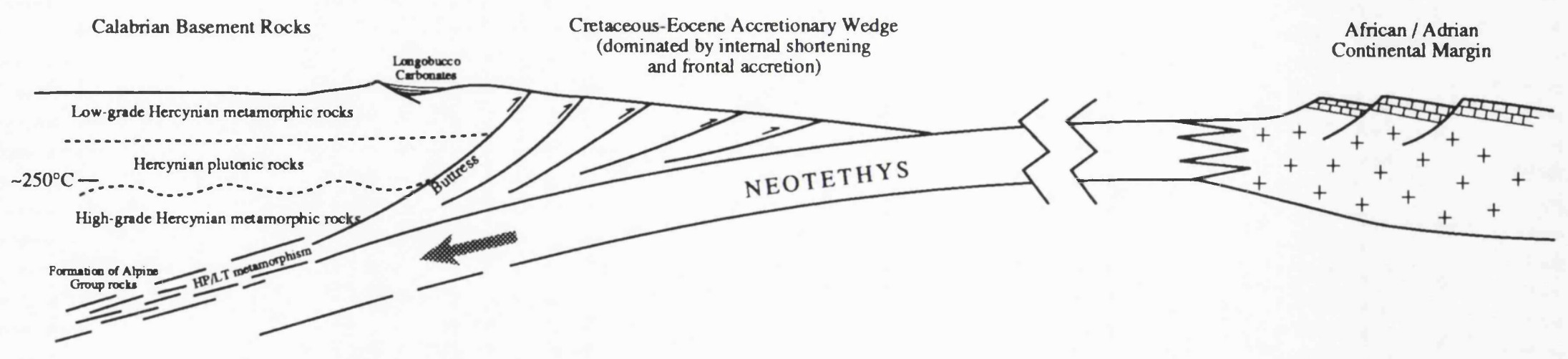

Figure 8.5 A simplified reconstruction showing the postulated tectonic environment of the Calabrian Arc between 50Ma and 40Ma. 
position they would have occupied prior to the Oligocene exhumation event (after Figure 8.1a).

Dietrich (1988) has proposed that the Alpine Group rocks were formed by retrogressive metamorphism and deformation related to movement along the decollement between the overlying basement rocks and the subducting lithosphere below. This conclusion is backed up by microstructures indicating east directed shear. The retrograde metamorphism of the Alpine Group rocks is largely of greenschist facies, although parts of the Castagna Unit show high pressure-low temperature glaucophane and lawsonite assemblages and the Bagni Unit has a lawsonite metamorphic overprint. This implies burial to depths of up to $30 \mathrm{~km}$. The protolith for the Castagna unit rocks were high-grade Hercynian metamorphic rocks. Therefore, because these rocks were part of the overriding plate, to achieve burial to $30 \mathrm{~km}$ requires that they were "plucked" from the overriding plate and incorporated into the down-going slab.

The high-grade Hercynian metamorphic basement rocks that today lie above the Alpine Group rocks, show no evidence of such retrograde metamorphism and no evidence of significant exhumation until $30 \mathrm{Ma}$. This implies that the juxtaposition of the Alpine Group rocks and the high-grade Hercynian metamorphic rocks occurred more recently than 30Ma. This has already been implied in section 8.2.3, for the rocks of the Catena Costiera and the northern Serre, using constraints from fission track analysis.

The isotopic age data obtained from the Alpine Group rocks, examined in detail in Figure 3.6, Chapter 3, Section 3.3.4, suggests that the data can be explained if the rocks were subjected to a short-lived thermal or resetting event between $40 \mathrm{Ma}$ and $60 \mathrm{Ma}$. It is most likely that this is related to the movement between the high-grade Hercynian metamorphic rocks and the subducting Neotethyan plate. Also partial resetting of the lowtemperature isotopic systems is one possible interpretation for the isotopic age data of the high-grade Hercynian metamorphic rocks (Figure 3.7, Chapter 3, section 3.3.4).

The pre-Oligocene evolution of the Liguride Complex accretionary wedge has been discussed in detail by De Roever (1972) and Knott 1987; 1988). In northern Calabria high pressure-low temperature metamorphic assemblages of glaucophane and lawsonite indicate 
that material was subducted to depths of up to $30 \mathrm{~km}$. Knott (1988) suggests that the accretionary wedge achieved this thickness by large scale underplating. However, models of the dynamics of an active orogenic wedge show that underplating causes it to overthicken, resulting in erosion and extensional tectonism (Platt, 1986; 1987). If this occurred prior to $30 \mathrm{Ma}$, then it should be recognisable by the isotopic age data, fission track analysis and within the sedimentary record. However no such evidence is seen. Therefore it is unlikely any significant underplating of the Liguride Complex accretionary wedge occurred before $30 \mathrm{Ma}$ and evolution of the wedge was probably dominated by frontal accretion and internal shortening. However subsequent exhumation, be it by erosion or extensional tectonism, must have occurred because the high pressure rocks are today exposed at the surface.

\subsubsection{Oligo-Miocene Evolution (30 to $20 \mathrm{Ma}$ )}

From the use of apatite and zircon fission track analysis it has been shown that the exhumation rate of the majority of low-grade Hercynian metamorphic, Hercynian plutonic and high-grade Hercynian metamorphic rocks of the present day Calabrian Arc crystalline basement increased substatially during the mid Oligocene ( $\sim 30 \mathrm{Ma})$. The exhumation model derived from this data in section 8.2 and the present day outcrop pattern, suggests exhumation, either by erosion or extension was more active towards the NW (i.e. the rear of the orogenic wedge) during this time.

Knott (1988), using evidence from the sedimentary record, has demonstrated that frontal accretion of the Liguride accretionary complex was still active between $30 \mathrm{Ma}$ and $20 \mathrm{Ma}$. The syn-orogenic sediments derived from the basement rocks at this time, including the Stilo-Capo d'Orlando Formation and the Troina-Tusa Flysch, interpreted as foreland basin deposits (Wezel, 1976), were derived from the north. This is further evidence for the European origin of the Calabrian Arc basement units.

However, why should the stable accretionary wedge that existed prior to $30 \mathrm{Ma}$ suddenly show increased exhumation due to erosion and extensional tectonism? The most likely explanation is that underplating of accretionary sediments was initiated beneath the 
Calabrian Arc basement and Liguride Complex accretionary complex at around 30Ma. The process of underplating is incompletely understood, but is thought to be triggered by physical changes caused by increased pressure and temperature. The buoyancy forces of subducted accretionary sediments and continental basement may inhibit subduction into the mantle (Platt, 1986).

As mentioned in the last section, Platt $(1986 ; 1987)$ has demonstrated that underplating beneath an orogenic wedge increases the surface slope. Gravitational forces will then cause the upper part of the wedge to extend, in order to maintain a critical taper. If underplating continues, the overlying wedge will continue to extend, resulting in the exhumation of material. The most largest amount and most rapid exhumation will occur at the rear of the wedge. This agrees remarkably well with the exhumational model for the basement rocks of the Calabrian Arc (Figure 8.1b, Section 8.2.1). The fission track data indicates that the largest amount and fastest rate of exhumation occurred towards the present day northwest, towards the rear of the Calabrian orogenic wedge. Depending upon the bulk density of the wedge and the degree of isostatic compensation, sediment underplating and thickening of the orogenic wedge will also increase the surface height, resulting in increased rates of erosion.

Extension of an overthickened orogenic wedge will produce low angle extensional faults that place low pressure rocks directly upon high pressure rocks. It is likely that faults of this nature are responsible for the juxtaposition of the unretrogressed high-grade Hercynian rocks upon the Alpine Group and Liguride complex high pressure-low temperature rocks. As has been shown in section 8.2.3 these faults have been active since 30Ma. A simplified cross-section showing the tectonic environment of the Calabrian Arc at around $25 \mathrm{Ma}$, incorporating the above mention factors, is illustrated in Figure 8.6.

\subsubsection{Miocene-Recent Evolution (Post $20 \mathrm{Ma}$ )}

The evolution of the rocks of the Calabrian Arc from the Miocene to Recent has been dominated by the collision of the Calabrian orogenic wedge with the carbonate platforms of the Adrian/African continental margin and the subsequent formation of the Tyrrhenian Sea. 


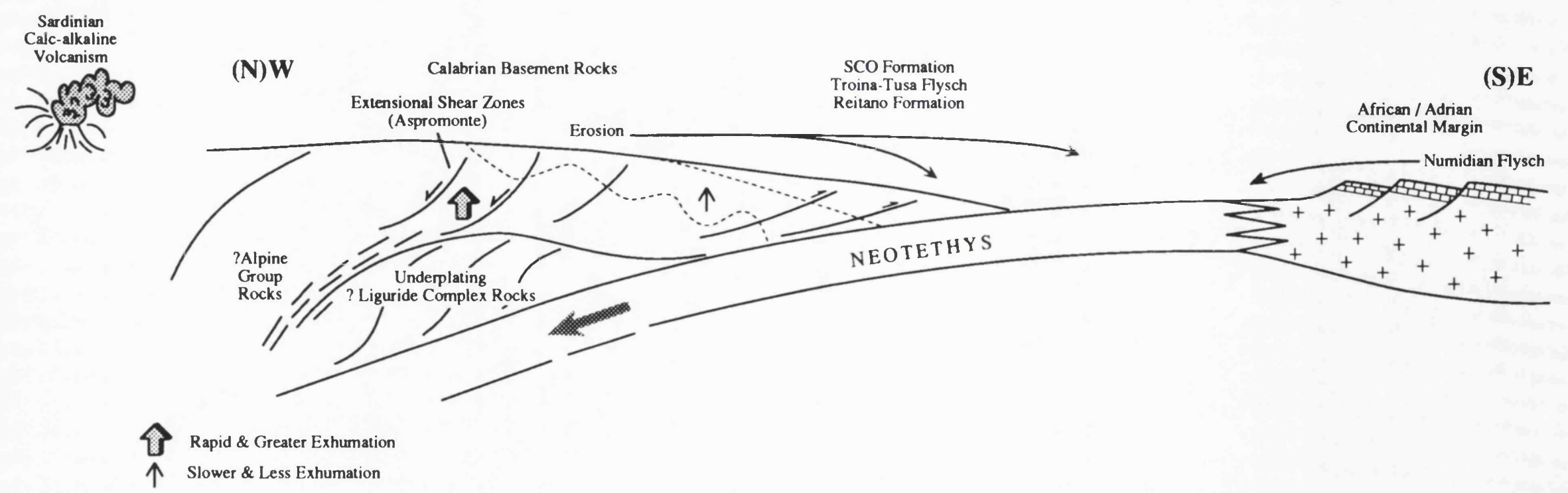

Figure 8.6 A simplified reconstruction of the tectonic environment of the Calabrian Arc at $\sim 25 \mathrm{Ma}$. 
These events resulted in the large scale disruption of the original geometry of the Calabrian orogenic wedge.

The initial collision of the Calabrian Arc basement rocks and the Liguride accretionary complex with the platform carbonates of the Adria margin is dated as Burdigalian (around 18 to 19Ma) (Knott, 1987; 1988; Dewey et al., 1989; Van Dijk and Okkes, 1990;1991; Weltje, in press). In the Catena Costiera of northwestern Calabria Adrian/African continental margin carbonates are found in tectonic windows beneath the Liguride Complex and crystalline basement rocks. The carbonates show intense deformation and low-grade metamorphism, but no evidence of subduction to depths of up to $30 \mathrm{~km}$, as witnessed in the overlying Liguride Complex rocks. This suggests the Liguride Complex and Calabrian Arc basement complex, especially in northern Calabria, were emplaced upon the Adrian/African margin as relatively thin thrust nappes. This is supported by Dietrich (1988) who has indicated that in parts the Calabrian basement nappe may only be $700 \mathrm{~m}$ in thickness.

Initiation of extension in the Tyrrhenian Sea postdates the onset of collision by a few million years. The first post-rift sediments, near the Sardinian margin are dated as Tortonian ( 11Ma) (Kastens et al., 1988; Chapter 2, Section 2.11). Malinverno and Ryan (1986) and Van Dijk and Okkes (1991) suggest rifting initiated slightly earlier, during the Middle Miocene ( 14-15Ma). The formation and evolution of the Tyrrhenian Sea, synchronous with compression in the Apennines and Maghrebides has formed the subject of numerous tectonic models. These have been briefly reviewed in Chapter 1, Section 1.2. More detailed reviews have been carried out by Malinverno and Ryan (1986), Channell and Mareschal (1989) and Van Dijk and Okkes (1991).

An alternative model uses concepts developed by Platt (1986) and Jamieson and Beaumont (1989) from work on the mechanics of orogenic wedges. Jamieson and Beaumont (1989) have modelled the encounter of an orogenic wedge with a simple rifted margin. This mirrors the scenario of the Calabrian orogenic wedge colliding with the Adria/African continental margin during the Burdigalian. With this model initial collision is marked by overthrusting, creating a thin-skinned thrust belt ahead of the advancing 
orogenic wedge. The basement ramp part of the rifted margin then prevents the further advance of the orogen until it reaches a critical topography. However to overcome gravitational forces considerable horizontal confining pressures must be maintained. Therefore if the basal drag exerted by subduction is decreased or removed the orogenic wedge will undergo extensional collapse. This model of collision followed subsequently by extensional collapse is compatible with initial extension in the Tyrrhenian Sea following initial collision of the Calabrian orogenic wedge with the Adria/Africa margin. The main aspects of this model, with comparison to the situation of the Calabrian orogenic wedge are illustrated in Figure 8.7.

According to Jamieson and Beaumont (1989) the model has several other consequences. First, relatively little overall exhumation of the orogen will occur, apart from localised exhumation near to extensional faults. This is consistent with the results of fission track analysis on basement rocks of the Calabrian Arc; the majority of samples show no evidence of exhumation between 15 and $11 \mathrm{Ma}$. However some extensional reactivation of the contact between the Alpine Group and high-grade Hercynian metamorphic rocks at about this time is seen along the Curinga-Girifalco Line and possibly in the Catena Costiera (Section 8.2.3). Second, isostatic rebound of the deflected rifted margin lithosphere will cause uplift and erosion of the foreland basin. This may explain the significant southerly tilting of the Oligo-Miocene Stilo-Capo d'Orlando sediments in southern Calabrian (Weltje, in press).

It has been argued by Malinverno and Ryan (1986) that gravitational forces alone are not sufficient to create the current spreading seen in the Tyrrhenian Sea. However the model of Channell and Mareschal (1989), where asymmetric lithospheric thickening causes subsequent mantle lithosphere delamination, can be invoked for the subsequent evolution of the Tyrrhenian Sea in to a major extensional basin. 
Figure 8.7a Post-orogenic unloading of an orogen by extension. Stipple shows material removed or redistributed. (after Jamieson \& Beaumont, 1989)

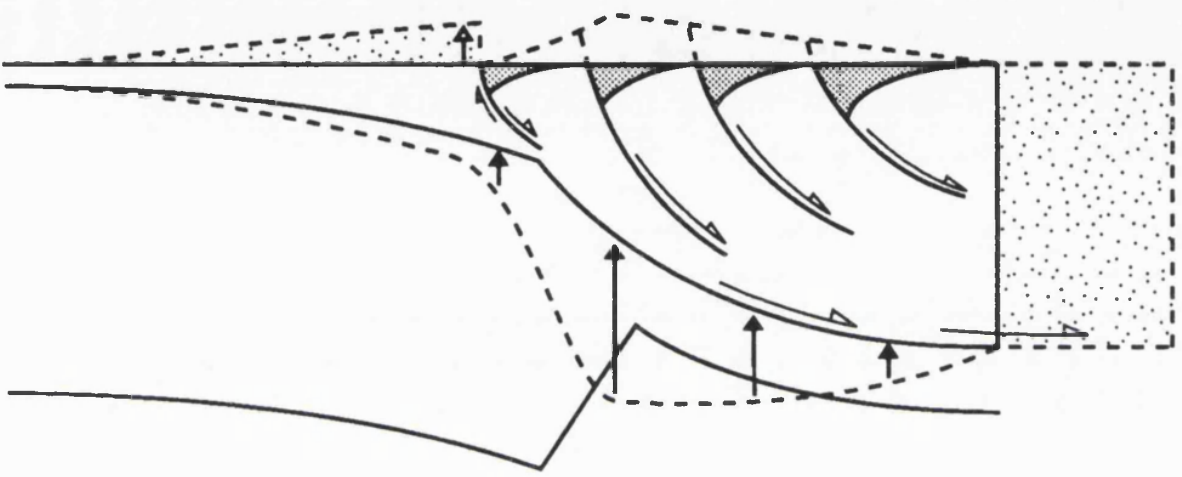

When plate velocities decrease mass is removed from the rear of the orogen by extension. Foreland basin rebound is also seen, a result of isostatic rebound of the downgoing lithospheric root.

In this scenario, the orogen will undergo subsidence, but relatively little overall exhumation. This will result in anomalously old cooling ages.

This model is similar to the situation of the Calabrian Arc and the formation of the Tyrrhenian Sea since $15 \mathrm{Ma}$.

\section{Figure 8.7b}

Foreland Basin Rebound

(e.g. southern Apennines

Sicilian Maghrebides)

Tyrrhenian Sea

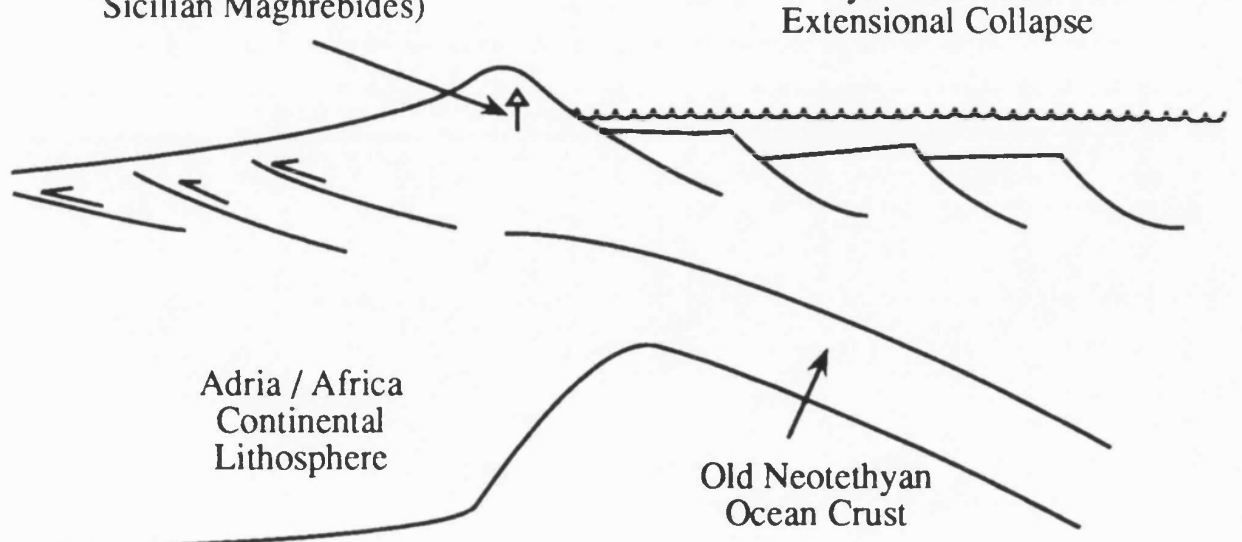




\subsection{THE CALABRIAN ARC IN WESTERN MEDITERRANEAN}

\section{OROGENESIS DURING THE OLIGO-MIOCENE}

The period of significantly increased exhumation between around 30Ma and 15Ma, identified from the detailed analysis of apatite and zircon fission track data from the basement rocks of the Calabrian Arc and Stilo-Capo d'Orlando Formation and interpreted as being caused by underplating beneath an active orogenic wedge, can be correlated with several important geological events recognised from other parts of the western Mediterranean. These include Oligo-Miocene calc-alkaline volcanism on Sardinia, the rotation of the Corsican-Sardinian massif, the opening of the Ligurian-Provencal basin and deformation in the northern Italian Apennines.

The Sardinian volcanism occurred between 29Ma and 14Ma. The products are calcalkaline and are thought to be related to northwards subduction beneath Sardinia at this time (Coulon et al., 1978; Dupuy et al., 1979; Savelli et al., 1979).

The rotational history of the Sardinian-Corsican block away from the French mainland has been documented by a number of authors (Westphal $e$ t al., 1976; Montigny $e t$ al., 1981; Waters, 1990). The results of this work, from the palaeomagnetic analysis of Oligo-Miocene volcanic rocks, show a $30-40^{\circ}$ rotation between $29 \mathrm{Ma}$ and $19 \mathrm{Ma}$. The major part of this rotation is thought to have occurred between 21Ma and 19Ma (Waters, 1990). The rotation of Sardinia and Corsica is coeval with the opening of the Ligurian-Provencal basin (Guieu and Roussel, 1990) during the Oligocene.

It is now generally accepted that the development of the Ligurian Sea was the result of western Pacific-type back-arc basin extension. This is a result of northwest-directed subduction of Neotethyan ocean crust beneath Calabria, Sardinian and Corsica that produced Sardinian calc-alkaline volcanism, rotation of Sardinia and Corsica away from the French mainland, and underplating beneath the Calabrian/Liguride orogenic wedge.

In plate tectonics, extension behind a subduction zone is still not fully understood, but is thought to be caused either by convection induced beneath the overthrusting plate, or by outward trench migration caused by the sinking of the underthrusting plate into the asthenosphere due to gravity ("roll-back model" - Dewey, 1980). The occurrence of large 
scale underplating beneath the Calabria, Sardinia Arc during the Oligo-Miocene implies that "roll-back" was the likely subduction mechanism responsible for the extension of the Ligurian-Provencal Basin coeval with the development of the Calabrian orogenic wedge.

However studies of Liguride Complex rocks from Calabria and the southern and northern Apennines propose that accretion of Neotethys related to northwest directed subduction has been active since the Cretaceous (Knott, 1987; 1988; Carmignani and Kligfield, 1990; Roure et al., 1991). The lack of evidence of exhumation related to underplating suggests that the accretion process between the Cretaceous and middle Oligocene was dominated by frontal accretion and internal shortening (Section 8.4.2). However, there is also no evidence of arc-related volcanism, extension in the LigurianProvencal basin or trench migration related to rotation of Sardinian and Corsica during the same period. This appears to suggests that subduction of oceanic lithosphere could not have been active before the Oligocene. Accretion of the Liguride rocks could be accompished by thin-skinned thrust-tectonics

The main question now to be asked is what caused the initiation of "roll-back" of Neotethyan oceanic lithosphere with its related volcanism, back-arc extension, arc rotation and exhumation related to underplating of the orogenic wedge at around $30 \mathrm{Ma}$. The mechanics of "roll-back" reveal that if the velocity of the subducting plate is reduced or zero, then gravity will take over as the predominant force affecting the subducting slab. This will initiate "roll-back" and trench migration. If the upper plate is fixed relative to the downgoing slab, back-arc extension will occur. (Figure 8.8).

Initiation of the geological events described may be related to a change in velocity of Neotethyan subduction. Malinverno and Ryan (1986) have demonstrated that one way in which this can be achieved is if continental rocks overriding the subduction zone collide with a promontory of continental crust on the subducting plate. Once this collision has occurred any remaining oceanic lithosphere will continue to underthrust by gravity driven "roll-back" and cause the rocks overriding the oceanic lithosphere to migrate outwards. This migration will then cause extension in the overriding plate with the eventual formation of a back-arc basin. This model is illustrated in Figure 8.9. 
Figure 8.8 A simplified explanation of "roll-back"

a) Velocity of subducting plate great enough to overcome gravitational pull NO back-arc extension, NO trench migration.

(If the velocity of the slab is sufficient compression may occur in the over-riding plate) Trench

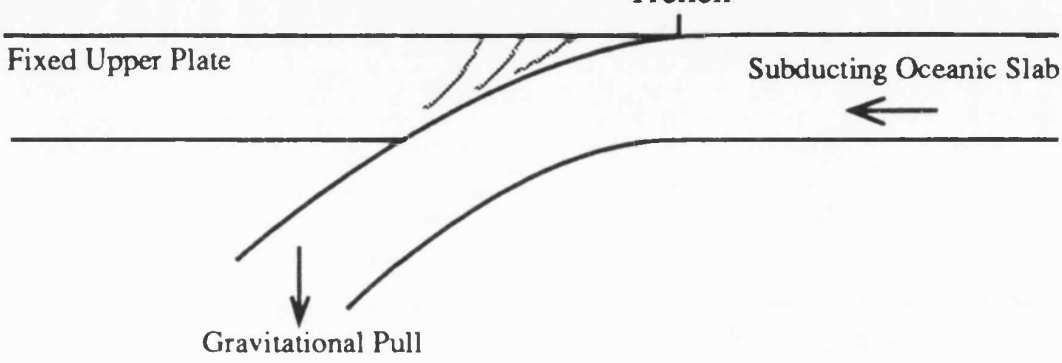

b) Velocity of subducting slab insufficient to overcome gravitational pull This results in "roll-back" of subducting slab, causing trench migration and back-arc extension

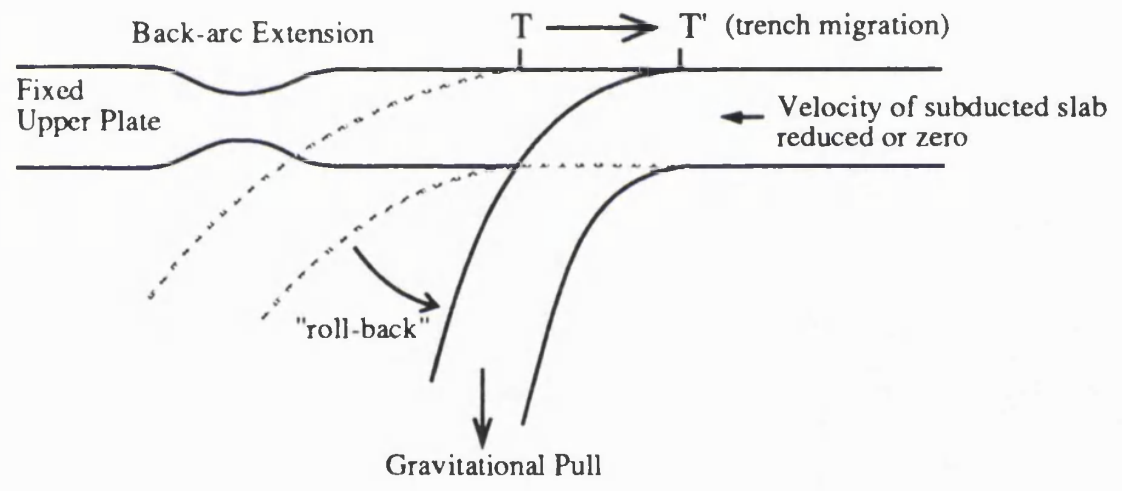

Figure 8.9 Simple model of development of a basin due to outward arc migration (after Malinverno and Ryan, 1986)

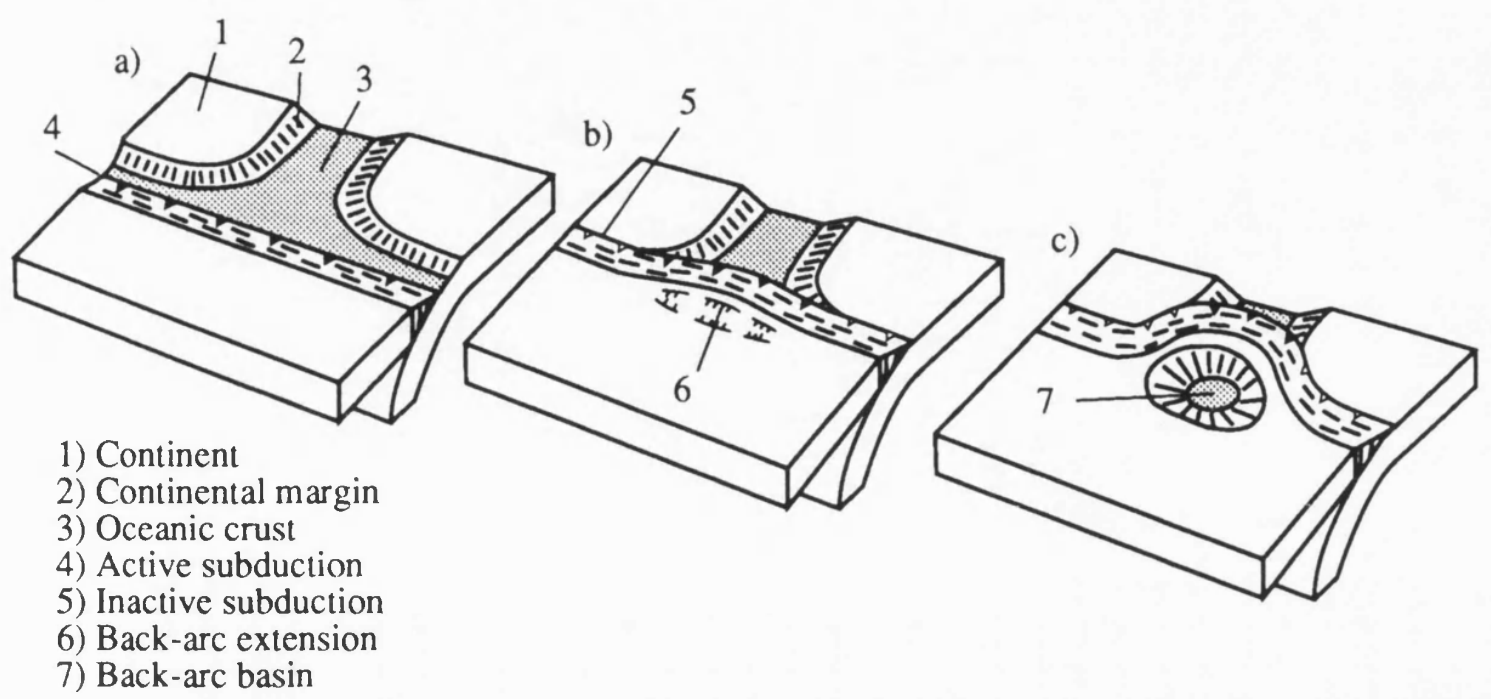


It is proposed that such a mechanism is responsible for the back-arc extension of the Ligurian-Provencal basin and the rotation / migration of Calabria, Sardinia and Corsica during the Oligo-Miocene. The model is shown in Figure 8.10. The first collision of the Liguride Complex accretionary wedge deposits with the continental margin deposits of the Adrian/African plate occurred in the northern Apennines. Compressional structures have been dated at 27Ma by Carmignani and Kligfield (1990) in the Alpi Apuane complex of northern Italy, although initial collision may well have predated this. This collision causes convergence to stop. The remaining oceanic lithosphere of Neotethys to the south of the collision point would then have proceeded to subduct by gravity-driven subduction "rollback". The overriding plate, consisting of Calabrian, Corsica and Sardinia, would then have migrated to the southeast, resulting in the formation of the Ligurian-Provencal backarc basin behind. The final consumption of Neotethys took place when the Liguride accretionary complex collided with the Adria/Africa margin in Calabria at $\sim 18-19 \mathrm{Ma}$ (Section 8.4.4). 
Figure 8.10 Hypothetical tectonic model explaining the evolution of the western Mediterranean between $40 \mathrm{Ma}$ and $20 \mathrm{Ma}$ by arc-migation.

a) $35 \mathrm{Ma}$

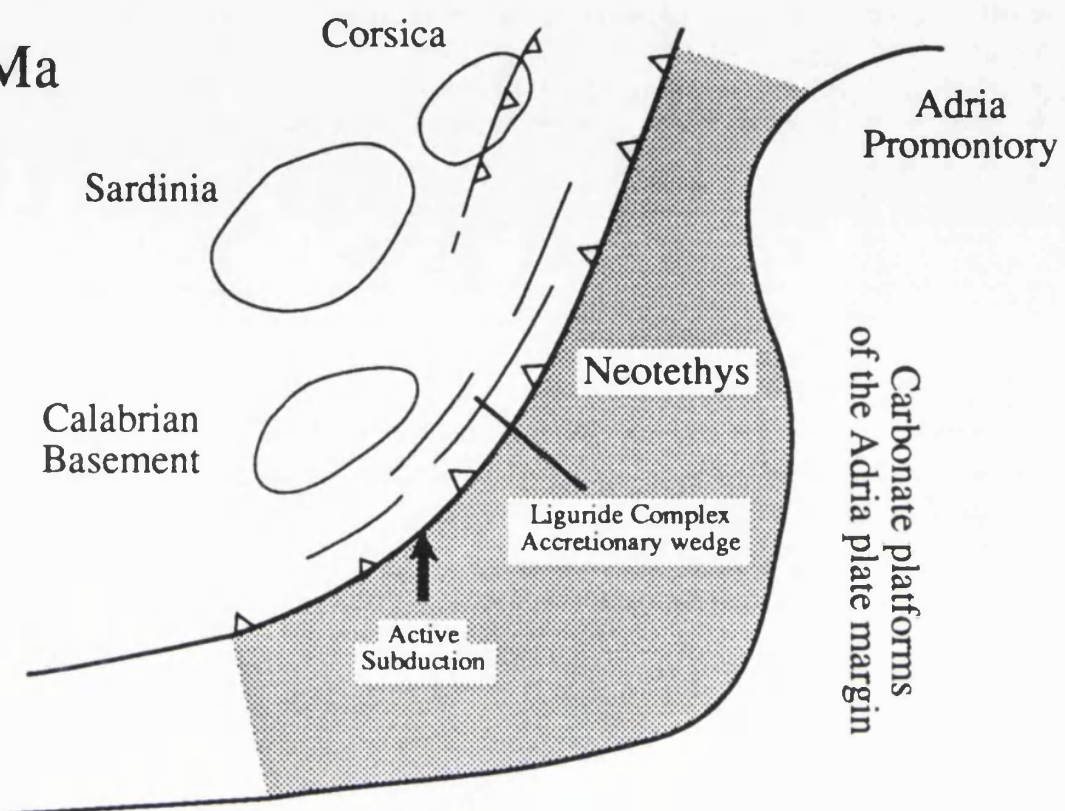

b) $25 \mathrm{Ma}$

Collision in northern Apennines causes subduction rate of Neotethys to slow down. The remaining oceanic crust undergoes "roll-back" causing the migration of Calabria, Sardinia and Corsica to the SE.
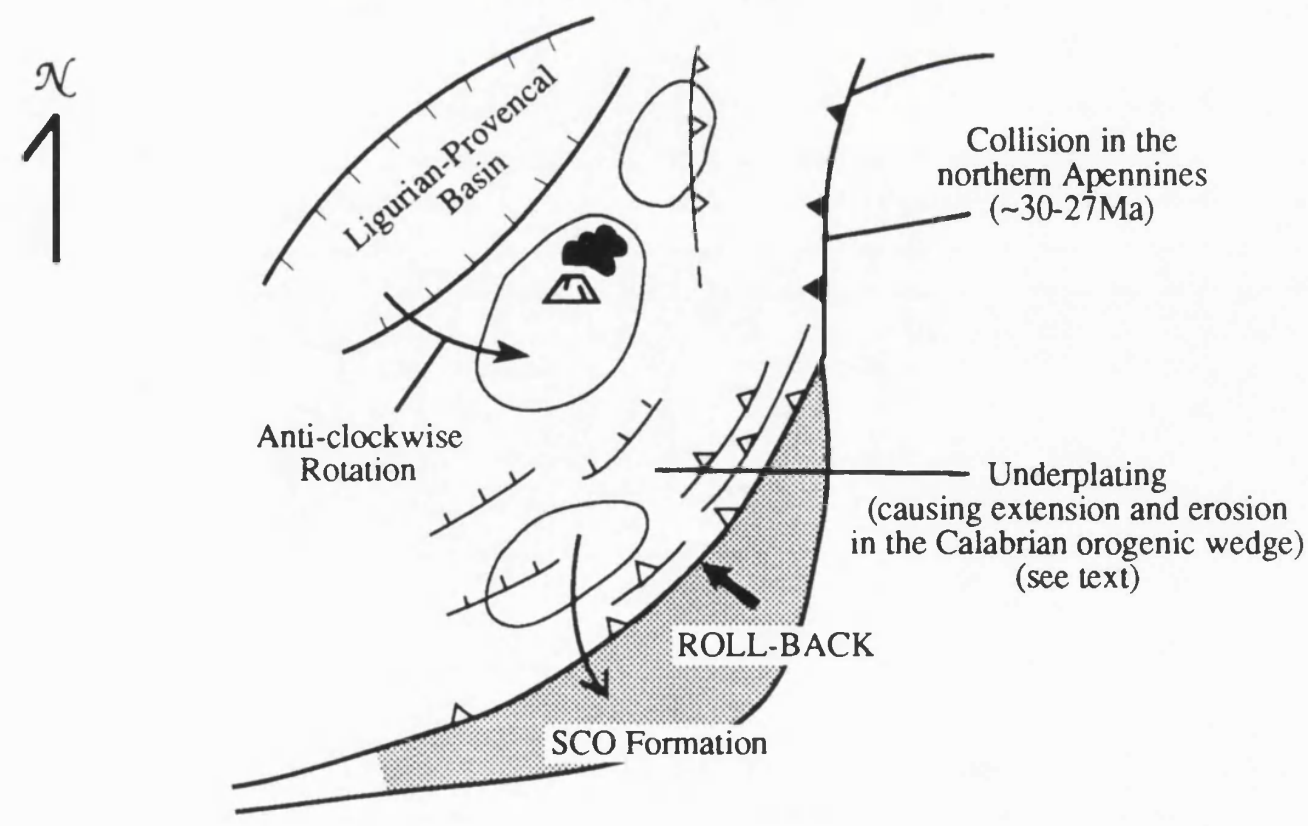


\section{CHAPTER 9}

\section{SUMMARY}

\subsection{THESIS CONCLUSIONS}

Two fission track studies have been undertaken which provide new constraints on the low temperature thermo-tectonic evolution of the Calabrian Arc of southern Italy and northeastern Sicily. The first study and the major part of this work involved fission track analysis of 65 samples from the crystalline basement rocks that from a large part of the Calabrian Arc. This yielded 57 apatite fission track ages, 54 zircon fission track ages and 25 apatite fission track length analyses. The second study involved fission track analysis of 7 conglomerate clasts and 2 sandstone samples from the Stilo-Capo d'Orlando Formation, an Oligo-Miocene terrigenous cover sequence. This yielded 8 apatite fission track ages, 8 zircon fission track ages and 6 apatite track length analyses.

For the purposes of this thesis the crystalline basement rocks of the Calabrian Arc have been subdivided using a tectonostratigraphic scheme based on the work of Messina et al. $(1991 \mathrm{a} / \mathrm{b})$. This divides the basement into four groups. The uppermost group are termed the low-grade Hercynian metamorphic rocks. These rocks are intruded by late Hercynian plutonic rocks. Below the plutonic rocks, and separated from them by an intrusive contact, are high-grade Hercynian metamorphic rocks. The lowest tectono-stratigraphic unit is formed of strongly retrogressed metamorphic rocks known as the Alpine Group.

Qualitative analysis of the fission track age data using the closure temperature concept provides low temperature cooling histories of the crystalline basement rocks. A closure temperature value of $100 \pm 20^{\circ} \mathrm{C}$ was used for the apatite fission track system and a value of $225 \pm 25^{\circ} \mathrm{C}$ was assigned to the zircon fission track system.

Analysis of the apatite and zircon fission track age data of the low-grade Hercynian metamorphic rock samples and the majority of Hercynian plutonic rocks indicates that both of these rock groups underwent slow cooling between $250^{\circ} \mathrm{C}$ and $\sim 150^{\circ} \mathrm{C}$ at rates of between $0.5^{\circ} \mathrm{C} / \mathrm{m} . \mathrm{y}$. and $2^{\circ} \mathrm{C} / \mathrm{m}$.y. before $\sim 40 \mathrm{Ma}$, with a more rapid cooling phase between $\sim 150^{\circ} \mathrm{C}$ and the surface (taken as $12^{\circ} \mathrm{C}$ ) since about $35 \mathrm{Ma}$. 
In contrast the majority of the high-grade Hercynian metamorphic rocks, three samples from a Hercynian pluton known as the Capo Vaticano intrusion and the Alpine Group rocks gave fission track ages signifying that these rock groups cooled from below $250^{\circ} \mathrm{C}$ to less than $80^{\circ} \mathrm{C}$ between about $35 \mathrm{Ma}$ and $15 \mathrm{Ma}$ at cooling rates of between $5^{\circ} \mathrm{C} / \mathrm{m} . \mathrm{y}$. and $15^{\circ} \mathrm{C} / \mathrm{m} . \mathrm{y}$.

The 25 apatite track length analyses obtained from the crystalline basement rocks provide important information on the rate of cooling of the rocks through the apatite annealing zone, from $125^{\circ} \mathrm{C}$ to $70^{\circ} \mathrm{C}$. Overall the lowest mean track lengths were obtained from the low-grade Hercynian metamorphic rocks and the Hercynian plutonic rocks. These results indicate relatively slow cooling from $125^{\circ} \mathrm{C}$ to $70^{\circ} \mathrm{C}$. The high-grade Hercynian rocks and the samples from the Capo vaticano intrusion have higher mean track lengths suggesting a higher rate of cooling. Finally the length data from the Alpine Group rocks, the lowest tectono-stratigraphic unit, revealed very high mean track lengths that suggest very rapid cooling from $125^{\circ} \mathrm{C}$ to $70^{\circ} \mathrm{C}$.

Using the quantitative relationship of apatite fission track annealing to temperature and time, as derived by Laslett et al. (1987) from experimental work on the Durango apatite, inverse modelling of apatite age and track length data was attempted in order to provide detailed time-temperature paths for the crystalline basement rocks. The timetemperature paths produced from the sample data revealed similar results to qualitative analysis. The Alpine Group sample data required the most rapid cooling, constrained to between $15 \mathrm{Ma}$ and $20 \mathrm{Ma}$. To produce the high-grade Hercynian apatite sample data also required rapid cooling but over a longer and slightly earlier time interval between $28 \mathrm{Ma}$ and $18 \mathrm{Ma}$. The apatite sample data obtained from the Capo Vaticano intrusion show steady cooling between $\sim 34 \mathrm{Ma}$ and $\sim 16 \mathrm{Ma}$. The apatite data obtained from the other Hercynian plutonic rocks and three samples from the low-grade Hercynian rocks produced varied timetemperature histories. Several samples require increased cooling between $\sim 45 \mathrm{Ma}$ and $\sim 20$ Ma, while several others record a rapid cooling phase between $\sim 30 \mathrm{Ma}$ and $20 \mathrm{Ma}$.

The discovery of this phase of increased cooling in the majority of the crystalline basement rocks of the Calabrian Arc between $\sim 35 \mathrm{Ma}$ and $15 \mathrm{Ma}$ has been attributed to the 
processes of exhumation. The influx of large amounts of terrigenous sediments, derived from the Calabrian basement rocks, from around $30 \mathrm{Ma}$ indicates that erosion is an important contributor to the increased exhumation. There is also evidence to suggest that some of the increased exhumation was related to extensional tectonism. This explains the few anomalous fission track results obtained from the Aspromonte-Peloritani region, the northern Serre and the Catena Costiera. Fission track data indicates that extensional tectonism occurred in the basement rocks between $\sim 25 \mathrm{Ma}$ and $\sim 10 \mathrm{Ma}$.

A smaller study using fission track analysis was made of the coarse basal sediments of the Stilo-Capo d'Orlando Formation. The fission track data from both conglomerate clasts and two sandstone samples confirms that the Calabrian Arc basement rocks were the most likely source of the samples analysed. However, the apatite ages obtained from the Stilo-Capo d'Orlando Formation samples are significantly older than any apatite fission track ages obtained from the crystalline basement rocks. This suggests that the detritus in the basal part of the formation was derived from basement rocks that have subsequently been removed by erosion and lay above the apatite annealing zone prior to its deposition into the Stilo-Capo d'Orlando Formation.

The origin of the volcanic clasts of the Stilo-Capo d'Orlando Formation, also found in the Troina-Tusa Flysch of Sicily, has been resolved by using fission track analysis. Apatite fission track ages of between $43 \mathrm{Ma}$ and $174 \mathrm{Ma}$ suggests that the greenschist facies metamorphism of these rocks occurred during the Hercynian orogeny and indicates these rocks are pre-Hercynian. The only known source for these rocks in southern Italy are the Devonian volcanic rocks described from the low-grade Hercynian metamorphic rocks of northeastern Sicily.

Finally, qualitative and quantitative analysis of the apatite fission track data obtained from the two sandstone samples, and the stratigraphic ages obtained by Weltje (in press), suggest that the Stilo-Capo d'Orlando Formation has undergone significant reheating since deposition. Quantitative modelling suggests temperatures of between $80^{\circ} \mathrm{C}$ and $100^{\circ} \mathrm{C}$ may have been reached.

Fission track analysis has provided important new constraints concerning thermo- 
tectonic evolution of the crystalline basement rocks and the Stilo-Capo d'Orlando Formation of the Calabrian Arc of southern Italy, particularly for the Oligocene and Miocene, between about $35 \mathrm{Ma}$ and $15 \mathrm{Ma}$. The final part of the thesis used these constraints to provide a revised model for the Oligo-Miocene tectonic evolution of the rocks of the present day Calabrian Arc which can be related to the overall plate dynamics of the western Mediterranean orogeny at this time.

\subsection{SOME SUGGESTIONS FOR FURTHER WORK}

One of the main problems highlighted in this thesis has been assessing the extent of OligoMiocene extensional tectonism within the Calabrian Arc. The fission track data collected has revealed that, locally, this appears to make an important contribution to exhumation during Oligo-Miocene times. The only other evidence for extensional tectonism within Calabria at this time are north directed structures identified by Platt and Compagnoni (1990) within mylonites of the Aspromonte region. However offsets in the zircon fission track age data, evidence of very rapid cooling and the widespread presence of mylonites in other parts of the Calabrian Arc basement suggest extensional tectonism may have been widespread. Areas that merit further detailed structural investigation in conjunction with more detailed geochronology include the Curinga-Girifalco Line, the Peloritani Mountains of northeastern Sicily, and the contact between the Alpine Group rocks and the high-grade Hercynian metamorphic rocks in the Catena Costiera and Sila. Only with information from these rocks can the true extent of extensional tectonism be assessed.

The presence of retrograde high pressure minerals within the Liguride Complex and Alpine Group rocks suggests significant amounts of exhumation. However apart from the fission track data of this study and a handful of isotopic ages, the pressure-temperaturetime history of these rocks has not been investigated in detail. More high-temperature isotopic data, fission track data from the Liguride Complex rocks and detailed petrological data from the Alpine Group rocks are needed to provide much needed constraints on the post-Cretaceous evolution of these rocks.

The suggestion of post-depositional heating in the lower part of the Stilo-Capo 
d'Orlando Formation is based on apatite fission track data from only a few samples. A much more detailed study with many more samples is required to assess the full extent of this re-heating or burial event. The interpretation is also strongly dependent on micropalaeontological age data. This data needs to be more tightly constrained, preferably using microfossils from the sample collection site. 
Preparation of Samples for Fission Track Analysis and Analytical Procedures 


\section{i) Separation of Apatite and Zircon:}

Samples are first washed and dried, then split and crushed using a Sturtevant ${ }^{\circledR}$ jaw crusher. The resultant rock fragments are then put through a standard Bico® disc mill reducing the sample to sand-grain sized fragments. The heavy mineral fraction of the sample that includes both zircon and apatite mineral grains, is then separated using a Wilfley® shaking table. The heavy mineral concentrate is dried and larger grains that remain, such as mica flakes, removed using a $500 \mu \mathrm{m}$ sieve.

To separate any remaining quartzo-feldspathic minerals, the $<500 \mu \mathrm{m}$ fraction of heavy mineral separates is passed through the heavy liquid bromoform (specific gravity = $2.88-2.91 \mathrm{~g} / \mathrm{cm}^{2}$ ). The remaining heavy mineral grains are then washed with acetone and dried.

The heavy minerals that have magnetic characteristics, including biotite, magnetite, muscovite, ore minerals, pyroxenes and amphiboles are removed using a Frantz@ magnetic separator. Magnetic separation is done progressively, starting with steep slopes and low coil ampage $\left(30^{\circ}, 0.25 \mathrm{Amps}\right)$ and finishing with shallow slopes and high coil ampage $\left(5^{\circ}\right.$, 2.0Amps). The non-magnetic mineral separate should largely contain apatite and zircon, if present, although it may also contain quartzo-feldspathics, pyrite, fluorite and andalusite.

Apatite (s.g. $=3.1-3.35 \mathrm{~g} / \mathrm{cm}^{2}$ ) is separated from zircon (s.g. $=4.6-4.7 \mathrm{~g} / \mathrm{cm}^{2}$ ) using the heavy liquid di-iodomethane (s.g. $=3.35 \mathrm{~g} / \mathrm{cm}^{2}$ ). If necessary the sample may be purified by repeating heavy liquid and magnetic separation.

\section{ii) Mounting of Apatite Grains:}

Apatite crystals are mounted in Araldite ${ }^{\circledR}$ epoxy resin. First a 2:1 microscope slide is degreased using acetone and the relevant sample number is marked using a diamond pen. This is then placed on a hot-plate at between $85-90^{\circ} \mathrm{C}$. Araldite $®$ is then thoroughly mixed using 5 parts resin to 1 part hardener by volume in a plastic container. Then, in a fume cabinet, a few drops of Araldite ${ }^{\circledR}$ are placed on to the microscope slide, with the number side down, and stirred gently to release any air bubbles. A portion of the sample apatite fraction is then poured onto the Araldite $®$. Using a clean needle the crystals are stirred in to 
spread-out the individual grains. The Araldite $®$ is then allowed to harden and cure by increasing the temperature of the hot-plate to $120-130^{\circ} \mathrm{C}$.

\section{iii) Mounting of Zircon Grains:}

Zircon, and also sphene, crystals are mounted in melted FEP Teflon plastic. First a hotplate is heated to $290 \pm 5^{\circ} \mathrm{C}$ in a fume cabinet (The mounting procedure must be carried out within a fume cabinet because molten FEP Teflon produces the toxic gas perfluorobutadiene). Two microscope slides are then de-greased using acetone. On one slide a portion of the sample zircon crystals are placed and arranged using a needle or fine brush. The slide is then tapped to allow the zircon crystals to settle on their prismatic faces. This slide is then placed on the hot-plate for 2 mins Then using tweezers, a $1.5 \mathrm{~cm}$ square of $0.5 \mathrm{~mm}$ thick translucent FEP Teflon is placed on top of the zircon crystals. The second preheated slide is then placed on top of the FEP Teflon. This is then pressed down firmly using tweezers until the FEP Teflon is observed to melt (by going water clear and flowing slightly at the edges). After $\sim 20$ secs the sandwich of slides and FEP Teflon can be removed. After $\sim 2$ mins the top slide should separate easily from the FEP Teflon. The sample number can then be carefully marked on the top surface of the FEP Teflon using a needle, and then the FEP Teflon square with mounted zircon crystals can be removed.

\section{iv) Polishing Apatite Mounts:}

The Araldite ${ }^{\circledR}$ apatite mounts are first hand-ground using wet $180 / 320$ grade grinding paper. Then using a Streuers ${ }^{\circledR}$ polishing machine, the mounts are polished using $1 \mu \mathrm{m}$ alumina slurry on a nylon polishing cloth for $\sim 5$ mins at 200 r.p.m. The mount should then be inspected, and the process repeated until sufficient internal cross-sections of the apatite crystals are achieved. The mount and polishing machine are then thoroughly cleaned. To remove any remaining polishing scratches the mounts are polished using $0.3 \mu \mathrm{m}$ alumima slurry on a felt polishing cloth for $\sim 5$ mins or until a satisfactory finish is achieved. 


\section{v) Polishing Zircon Mounts:}

The FEP Teflon zircon mounts are attached to aluminium blocks using double-sided adhesive tape. They are first lightly hand-ground using wet 1000 grade grinding paper. Then using a Streuers $®$ polishing machine, the mounts are polished with $\sim 2-3 \mathrm{~cm}$ of $1 \mu \mathrm{m}$ diamond paste on a DUR polishing cloth. The lap is first wetted with DP Blue lubricant, then the mounts are polished for $\sim 30$ mins at 125 r.p.m. with a lubricant drip rate of 1-2 drops/sec. After this time the mount surface should be perfectly flat, with any polishing scratches just visible. To apply a final finish and remove any remaining polishing scratches the zircon mounts are re-polished as above, but with $0.25 \mu \mathrm{m}$ diamond paste. Care should be taken during zircon polishing to avoid removing the thin lip of FEP Teflon that holds the zircon crystal in place, as there is no adhesion between the crystal and the mount.

\section{vi) Etching the Apatite and Zircon Mounts}

The basic fundamentals of etching to reveal fission tracks are discussed in Chapter 4, section 4.2.2. The apatite mounts were etched for 20-25 seconds in $5 \mathrm{M} \mathrm{HNO}_{3}$. The Zircon mounts are etched in a molten 1:1 Molar, binary eutectic of $\mathrm{KOH}$ and $\mathrm{NaOH}$ at $220 \pm 5^{\circ} \mathrm{C}$, in a platinum crucible. Etch times can vary from 2 hours to 72 hours. Therefore a step etching procedure was used for all samples, until the desired amount of etching is achieved. Finally all etched zircon mounts are thoroughly soaked and washed to remove all traces of alkali.

\section{vii) Thermal Neutron Irradiation:}

All fission track samples in this study are dated using the External Detector Method (Chapter 4). This method involves attaching a mica detector against each mineral mount. The apatite mounts should be ground using a coarse grinding cloth until they measure $14 \times 20 \mathrm{~mm}$. The FEP Teflon zircon mounts can be cut to a similar size using scissors. A small piece of unscratched mica should be cut using sharp scissors or a scalpel blade to the same size as the sample mount and numbered using a sharp needle. For each sample a corner should be cut off to enable the correct orientation of the mica to be determined when it is removed after irradiation. The mica is attached firmly to the sample mount using 
Scotch ${ }^{\circledR}$ adhesive tape. The samples with attached mica detectors are then placed in a purpose built Poly-holder (Figure I.1), along with the relevant dosimeter glasses, with a Carbonate

careful note taken of the positions of each sample. Spacers are then added at either end of the stack, and the $\mid$ Poly- holder screwed until finger tight. The $\mid$ Poly- holder is then placed Carbonate

Carbonate

into an aluminium holder. The samples in this study were sent to the HIFAR reactor, at Lucas Heights, New South Wales, Australia for irradiation. For each batch the thermal neutron fluence dose required was clearly stated; for apatite this is $1.2 \times 10^{16} \mathrm{n} \mathrm{cm}^{-2}$ and for zircon a fluence of $1.0 \times 10^{15} \mathrm{n} \mathrm{cm}^{-2}$ is applied.

When the sample batches are returned, the mounts are very carefully removed. The micas are carefully separated from the zircon or apatite mounts and are then ready for etching. To aid the location of the induced mica image of an apatite or zircon crystal, a sharp needle should be used before removal of the mica detector to make a hole in the mica and an impression on the sample mount (Figure I.2).

\section{viii) Etching External Mica Detectors:}

The tracks recorded in the mica detectors are revealed by etching in $40 \%$ hydrofluoric acid (Note: HF is an extremely dangerous chemical and should be handled with great care in a fume cabinet, preferably with supervision). Into a PVC dish (HF will attack glass), HF to a depth of $\sim 5 \mathrm{~mm}$ is poured. Then using tweezers the mica detectors are placed into the acid. They are then be left for 45 mins, assuming a temperature of $20^{\circ} \mathrm{C}$. If the temperature is higher than this, the optimum etch time becomes much shorter, so care should be taken. The micas are then removed, rinsed in distilled water, and allowed to soak, preferably overnight. After soaking, excess water and HF can be driven off by placing the micas on a hot plate (Note: mica detectors should be handled very carefully, as they are easily cleaved. This can result in the loss of any recorded tracks rendering the mount useless).

\section{ix) Fission Track Counting (Dosimeters):}

The determination of the $\rho_{D}$ value in the fission track age equation (Chapter 4, Eqn. 4.12) requires measuring the $235 \mathrm{U}$ induced fission track density recorded in the mica detector 
attached to the relevant dosimeter glass (CN5 / SRM612 for apatite, CN2 for zircon).

The relevant micas are placed onto a microscope slide using a small amount of Araldite $\circledast$ epoxy resin, making sure the numbered side is placed downwards. The mica is then viewed using a Zeiss Axioplan@ microscope at a magnification of $\times 1250$, using either reflected or transmitted light, according to preference. Then using a calibrated $10 \times 10$ graticule grid inserted into the eyepiece the tracks are counted. This is repeated for 100 fields of view after which the track density is calculated.

\section{x) Fission Track Counting (The External Detector Method):}

With the external detector method, the two values, $\rho$ (spontaneous tracks) and $\rho$ i (induced tracks) required in the fission track age equation (Chapter 4, Eqn. 4.12), are obtained from the sample mount and mica detector respectively.

With apatite, the sample mount and mica detector are placed on the same slide as illustrated in Figure I.2, using Araldite ${ }^{\circledR}$ epoxy resin. Zircon mounts can be more simply placed on double-sided adhesive tape.

The samples are counted using a Zeiss Axioplan $®$ microscope with automated stage at a magnification of $\times 1250$. Dry objectives are used with apatite and mica detectors and oil objectives are used with zircon.

Before counting, the automated stage is calibrated and aligned to allow automatic identification of the induced $235 \mathrm{U}$ fission tracks for each crystal within the etched external mica detector. Once this is done 20 suitable apatite or zircon crystals are selected (less if little apatite is present, more if the spontaneous fission track density is very low). For both minerals prismatic sections (i.e. cut parallel to the c-axis) should be selected that show well etched fission tracks in all directions. Apatite prismatic sections are identified by the alignment of fission track etch pits.

Using a $10 \times 10$ calibrated graticule inserted into the eyepiece, an area of the crystal is selected for counting. Areas close to the exterior surfaces of the crystal should be avoided. The shape of the count area is noted and the number of tracks counted, using a hand-counter. This value is the spontaneous track count (Ns) from which the track density 
(rs) can be calculated. Using the automated stage, the induced $235 \mathrm{U}$ tracks from the relevant crystal are located within the mica detector. The tracks should form a shape with the mirror image of the selected crystal. If they do not then the crystal/mica contact may have been poor during irradiation and the crystal should be rejected. A count area with the mirror image of that selected for the crystal is used and the number of induced track counted. This gives a value for $\mathrm{Ni}$ from which pi can be calculated. This procedure is then repeated for each selected crystal. The fission track central age can then be calculated using an Apple Macintosh ${ }^{\circledR}$ program written by Tony Hurford and Rex Galbraith of the London Fission Track Research Group.

\section{xi) Measurement of Apatite Fission Track Lengths:}

The most important factor in measuring apatite track lengths is to ensure the selection of horizontal confined tracks in a prismatic section of apatite. Also important is to ensure that the sample is adequately etched in all directions. The lengths are measured by using a drawing tube attached to a Zeiss Axioplan ${ }^{\circ}$ microscope at $\times 1250$ magnification and a Houston Instruments ${ }^{\circledR}$ digitizing tablet. An LED attached to the tablet cursor enables easy identification through the microscope drawing tube. First the tablet is calibrated using a standard ruled microscope slide. Then 100 track lengths are measured or as many as can be identified within a sample. Measurement is achieved by placing the cursor at either end of a confined track, view through the drawing tube. The mean track length and track distribution is calculated using an Apple Macintosh $\circledast$ SE computer connected to the digitising tablet. 


\section{Figure I.1}

Sample package for thermal neutron irradiation

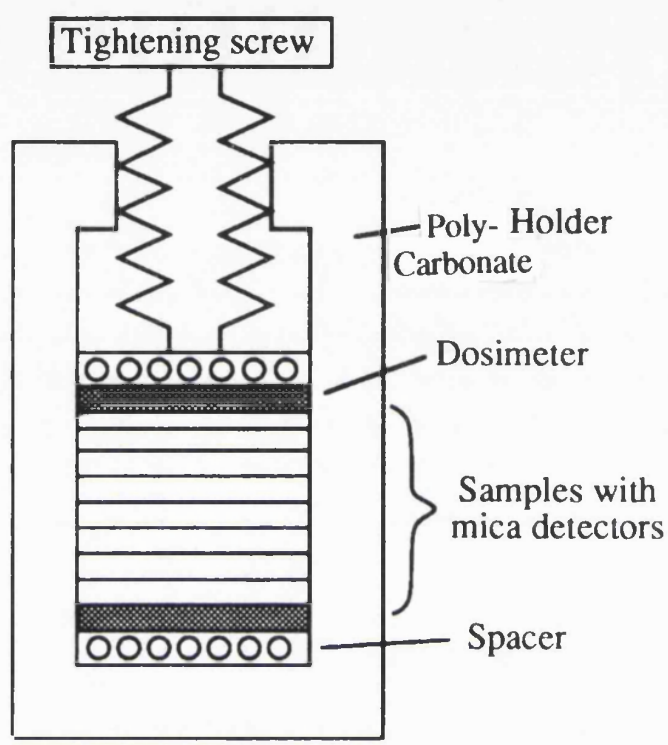

\section{Figure I.2}

Apatite Slide Mount for EDM Analysis
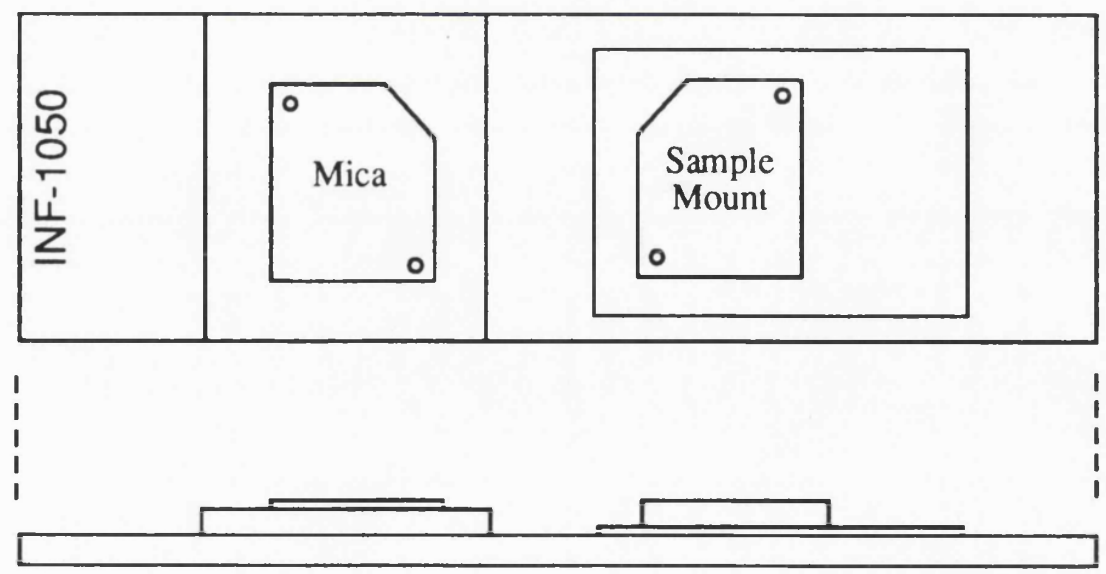


\section{APPENDIX II}

Details of Samples Collected from the Calabrian Arc Crystalline Basement Rocks for the Purpose of Fission track Analysis 


\title{
Notes:
}

Height usually to nearest $10 \mathrm{~m}$

Main Geological Units after Messina et al. (1991a/b)

Units in brackets after Amodio-Morelli et al. (1976)

$\mathrm{n} / \mathrm{k}$ : Metamorphic grade not known or difficult to ascertain

\section{ALE-600}

Location: SS184, $\sim 500 \mathrm{~m}$ E of San Alessio in Aspromonte

Height: $600 \mathrm{~m}$

Geological Unit: Hercynian plutonic ("peraluminous suite")

Rock Type: Gneissose leucogranite

Metamorphism: $n / k$

Yield: Apatite only

Comments: Nr. Sample site of Del Moro et al. (1984)

$$
\mathrm{Rb}-\mathrm{Sr}(\mathrm{Bi})-283 \pm 4 \mathrm{Ma}
$$

$\mathrm{Rb}-\mathrm{Sr}$ (Ms)- $296 \pm 71 \mathrm{Ma}$

\author{
ALT-1900a \\ Location: Road to Montalto, $\sim 200 \mathrm{~m}$ past summit track \\ Height: $1900 \mathrm{~m}$ \\ Geological Unit: High-grade Hercynian metamorphic (Aspromonte Unit) \\ Rock Type: Mylonitised leucogranite \\ Metamorphism: Strong Greenschist facies overprint \\ Yield: Apatite only
}

AME-1500

Location: $200 \mathrm{~m}$ from Aspromonte Dam construction site, new roadside outcrop.

Height: $1500 \mathrm{~m}$

Geological Unit: High-grade Hercynian metamorphic (Aspromonte Unit)

Rock Type: Retrograde Amphibolite

Metamorphism: Amphibolite facies with Greenschist facies overprint.

Yield: Apatite only

Comments: locality much affected by mylonitisation

\author{
AMP-1300 \\ Location: San Giovanni in Fiore-Lago Ampollino road, $1 \mathrm{~km} \mathrm{~S} \mathrm{of} \mathrm{turning} \mathrm{to} \mathrm{Lorica,}$ \\ opposite small natural spring \\ Height: $1300 \mathrm{~m}$ \\ Geological Unit: Hercynian plutonic (Mt. Gariglione Unit) \\ Rock Type: Fine grained aplitic dyke \\ Metamorphism: $n / k$ \\ Yield: Apatite and zircon \\ Comments: Sample severely weathered
}

\author{
AND-480 \\ Location: Small roadside outcrop 500m SE of Andali \\ Height: $480 \mathrm{~m}$ \\ Geological Unit: Hercynian plutonic (Polia-Copanello Unit) \\ Rock Type: Quartz monzonite \\ Metamorphism: $n / k$ \\ Yield: Apatite and zircon
}



ARI-580
Location: SS109, $500 \mathrm{~m} \mathrm{~N}$ of junction to Arietta
Height: $580 \mathrm{~m}$
Geological Unit: Low-grade Hercynian metamorphic
Rock Type: Chlorite, muscovite Schist
Metamorphism: Greenschist facies
Yield: Apatite only
ARV-1300
Location: S shore road of Lago Arvo, $\sim 1 \mathrm{~km}$ E of SS108bis junction
Height: $1300 \mathrm{~m}$
Geological Unit: High-grade Hercynian metamorphic (Mt. Gariglione Unit)
Rock Type: Biotite, chlorite Schist
Metamorphism: Greenschist facies
Yield: Apatite and zircon

\author{
ATT-1124 \\ Location: Roadside outcrop at summit of Mt. Attenamare (1128m) \\ Height: $1124 \mathrm{~m}$ \\ Geological Unit: High-grade Hercynian metamorphic \\ Rock Type: Biotite-rich schist \\ Metamorphism: Greenschist facies \\ Yield: Apatite and Zircon \\ Comments: Quartz shows dynamic recrystallisation
}

BOC-1300

Location: Road to Serra Toppale, off SS282, $8 \mathrm{~km} \mathrm{~W}$ of Bocchigliero

Height: $1300 \mathrm{~m}$

Geological Unit: Low-grade Hercynian metamorphic

Rock Type: Biotite, muscovite, chlorite porphyritic schist

Metamorphism: Greenschist facies

Yield: Apatite and zircon

\title{
BOC-780
}

Location: SS282 roadside $\sim 500 \mathrm{~m}$ E of Bocchigliero

Height: $780 \mathrm{~m}$

Geological Unit: Low-grade Hercynian metamorphic cover -Triassic/Jurassic

Rock Type: Red conglomerate

Metamorphism: none

Yield: Zircon only

Comments: Stop 1 of Acquafredda et al. (1988b)

BOT -1850

Location: Small roadside quarry, $\sim 1 \mathrm{~km} E$ of Mt. Botte Donato ski-lift, on road to Lorica

Height: $1850 \mathrm{~m}$

Geological Unit: High-grade Hercynian metamorphic (Mt. Gariglione Unit)

Rock Type: Sillimanite gneiss

Metamorphism: Amphibolite facies

Yield: Apatite and zircon

BOT-1920

Location: $\sim 10 \mathrm{~m}$ below summit cairn of Mt. Botte Donato

Height: $1920 \mathrm{~m}$

Geological Unit: High-grade Hercynian metamorphic (Mt. Gariglione Unit)

Rock Type: Sillimanite gneiss

Metamorphism: Amphibolite facies

Yield: Zircon only 
BOV-30

Location: SS106, $1 \mathrm{~km}$ E of Bova Marina, at narrow cliff-cut section

Height: $30 \mathrm{~m}$

Geological Unit: Low-grade Hercynian metamorphic (Stilo Unit)

Rock Type: Augen gneiss

Metamorphism: Greenschist facies, dynamic recrystallisation

Yield: Apatite and zircon

Comments:

CAL-100

Location: W end of tunnel at Capo di Calava, SS113 (NE Sicily)

Height: $100 \mathrm{~m}$

Geological Unit: Hercynian plutonic

Rock Type: Gneissose leucogranite

Metamorphism: $n / k$

Yield: Apatite and zircon

CAP.545

Location: Roadside outcrop between Polia and Filadelfia, $200 \mathrm{~m} \mathrm{~N}$ of mineral water bottling site

Height: $545 \mathrm{~m}$

Geological Unit: High-grade Hercynian metamorphic (Polia-Copanello Unit)

Rock Type: Banded paragneiss

Metamorphism: Amphibolite to Granulite facies

Yield: Apatite and zircon

Comments: Sample site KAL-145/147 of Schenk (1980)

$$
\begin{aligned}
& \mathrm{Rb}-\mathrm{Sr}(\mathrm{Bi})-108 \pm 1 \mathrm{Ma} \\
& \mathrm{Rb}-\mathrm{Sr}(\mathrm{Fs})-147 \pm 7 \mathrm{Ma} \\
& \mathrm{U}-\mathrm{Pb}(\mathrm{Mz})-296 \pm 2 \mathrm{Ma}
\end{aligned}
$$

\section{CAR-50}

Location: SS113d., Small track leading to Capo Rascalmo (NE Sicily)

Height: $50 \mathrm{~m}$

Geological Unit: Hercynian plutonic

Rock Type: Leucogranite ("peraluminous suite")

Metamorphism: ?Greenschist facies overprint

Yield: Apatite and zircon

Comments: Biotite partially altered to chlorite

\section{CAR-610}

Location: New road cutting, $1 \mathrm{~km} \mathrm{NE}$ of Cardinale

Height: $610 \mathrm{~m}$

Geological Unit: High-grade Hercynian metamorphic ("Cardinale sub-unit")

Rock Type: Meta-tonalite

Metamorphism: $n / k$

Yield: Apatite and zircon

Comments: Sample site KAL-730 of Schenk (1980)

$$
\begin{aligned}
& \mathrm{Rb}-\mathrm{Sr}(\mathrm{Bi})-133 \pm 1 \mathrm{Ma} \\
& \mathrm{U}-\mathrm{Pb}(\mathrm{Zr})-295 \pm 2 \mathrm{Ma}
\end{aligned}
$$

\section{CAS-880}

Location: SS109, $\sim 500 \mathrm{~m}$ E of Castagna, nr new road cutting

Height: $880 \mathrm{~m}$

Geological Unit: Alpine Group (Castagna Unit)

Rock Type: Proto-mylonitic retrograde paragneiss

Metamorphism: Dynamic greenschist facies

Yield: Apatite and zircon 


\section{CEC-1150}

Location: SS117, $1 \mathrm{Km}$ S of Lago Cecita Dam

Height: $1150 \mathrm{~m}$

Geological Unit: Hercynian plutonic (Longobucco Unit)

Rock Type: Gneissose granite

Metamorphism: $n / k$

Yield: Apatite and zircon

\section{CEC-1250}

Location: SS282, 21/2km E of Lago Cecita Dam, nr. Fossiata picnic area

Height: $1250 \mathrm{~m}$

Geological Unit: Hercynian plutonic (Longobucco Unit)

Rock Type: Gneissose granite

Metamorphism: $n / k$

Yield: Apatite and zircon

Comments: Nr. sample sites of Borsi and Dubois (1968) and Weiland (1989) that give Rb-

$\mathrm{Sr}$ (Biotite) ages of $282 \pm 8 \mathrm{Ma}$ and $284 \pm 14 \mathrm{Ma}$ respectively

\section{CEL-490}

Location: New road from Celia to Chaple S. Croce, $\sim 50 \mathrm{~m}$ after $\mathrm{LH}$ hairpin bend

Height: $490 \mathrm{~m}$

Geological Unit: High-grade Hercynian metamorphic (Polia-Copanello Unit)

Rock Type: Granulitic paragneiss

Metamorphism: Granulite facies

Yield: Apatite and zircon

Comments: Sample site KAL-808 of Schenk (1980)

$$
\begin{aligned}
& \mathrm{Rb}-\mathrm{Sr}(\mathrm{Bi})-114 \pm 1 \mathrm{Ma} \\
& \mathrm{Rb}-\mathrm{Sr}(\mathrm{Fs})-144 \pm 1 \mathrm{Ma} \\
& \mathrm{U}-\mathrm{Pb}(\mathrm{Zr})-296 \pm 2 \mathrm{Ma}
\end{aligned}
$$

\section{CHI-810}

Location: Righthand side of SP50bis., $\sim 1 / 2 \mathrm{~km}$ past $4 \mathrm{~km}$ post, $\mathrm{nr}$ Pzo. Chiarino $(841 \mathrm{~m})$

(NE Sicily)

Height: $810 \mathrm{~m}$

Geological Unit: Hercynian plutonic

Rock Type: Foliated leucogranite

Metamorphism: $n / k$

Yield: Zircon only

Comments: Quartz shows dynamic recrystallisation

\section{CIC-480}

Location: Minor road between Castanea and Messina, $\sim 200 \mathrm{~m} \mathrm{~N}$ of Mt. Ciccia

Height: $480 \mathrm{~m}$

Geological Unit: Hercynian plutonic ("peraluminous suite")

Rock Type: Alkali granitic gneiss

Metamorphism: $n / k$

Yield: Zircon only

Comments: Strong foliation of quartz around feldspar porphyroblasts 


\section{CIT-460}

Location: SS111, roadside $\sim 500 \mathrm{~m}$ S of Cittanova

Height: $460 \mathrm{~m}$

Geological Unit: Hercynian plutonic (Stilo Unit)

Rock Type: leucogranite

Metamorphism: $n / k$

Yield: Apatite only

Comments: Nr. sample site of Del Moro et al. (1984)

$\mathrm{Rb}-\mathrm{Sr}(\mathrm{Bi})-291 \pm 4 \mathrm{Ma}$

\section{CIT-930}

Location: SS111 (Cittanova-Locri), $\sim 500 \mathrm{~m} \mathrm{~N}$ of Passo di Mercante (952m)

Height: $930 \mathrm{~m}$

Geological Unit: Hercynian plutonic (Stilo Unit)

Rock Type: leucogranite

Metamorphism: $n / k$

Yield: Apatite and zircon

COL-1180

Location: SS 108bis. $\sim 2 \mathrm{~km}$ NE of Colosimi

Height: $1180 \mathrm{~m}$

Geological Unit: Alpine Group (Bagni Unit)

Rock Type: Phillite

Metamorphism: Lower greenschist facies

Yield: Apatite and zircon

Comments: Sample collected with quartz vein

\section{COP-50}

Location: Old road, $\sim 1 \mathrm{~km}$ past Tunnel on SS 106 at Copanello

Height: $50 \mathrm{~m}$

Geological Unit: High-grade Hercynian metamorphic (Polia-Copanello Unit)

Rock Type: Biotite orthogneiss

Metamorphism: ?Amphibolite facies

Yield: Apatite and zircon

\section{COR-390}

Location: Immediately S of roadbridge over Fiumara Pesipe, $11 / 2 \mathrm{~km} \mathrm{~S}$ of Cortale

Height: $390 \mathrm{~m}$

Geological Unit: Alpine Group (Castagna Unit)

Rock Type: Retrograde paragneiss with mylonitisation

Metamorphism: Granulite facies with dynamic Greenschist facies overprint

Yield: Apatite and zircon

Comments: Excellent relict garnets

Sample site KAL-51 of Schenk (1980)

$$
\mathrm{Rb}-\mathrm{Sr}(\mathrm{Ms})-268 \pm 4 \mathrm{Ma}
$$

\section{COR-410}

Location: $500 \mathrm{~m} \mathrm{~N}$ of roadbridge over Fiumara Pesipe, $1 \mathrm{~km} \mathrm{~S}$ of Cortale

Height: $410 \mathrm{~m}$

Geological Unit: Alpine Group (Castagna Unit)

Rock Type: Retrograde augen gneiss

Metamorphism: Amphibolite/Granulite facies with dynamic ?Greenschist facies overprint Yield: Apatite and zircon

Comments: Quartz strongly recrystallised, some relict garnet 
CRO-200

Location: $\sim 1 \mathrm{~km}$ along small road to Soveria Simeri off SS180, $1 \mathrm{~km} \mathrm{~S} \mathrm{of} \mathrm{Cròpani,} \mathrm{next} \mathrm{to}$ Torrente Scilotraco Rocca

Height: $200 \mathrm{~m}$

Geological Unit: Hercynian plutonic (Polia-Copanello Unit)

Rock Type: Gneissose granite

Metamorphism: $n / k$

Yield: Apatite and zircon

CUR-380a

Location: Roadside quarry on Curinga-S.Pietro road, $11 / 2 \mathrm{~km}$ ENE of Curinga

Height: $380 \mathrm{~m}$

Geological Unit: Alpine Group (Castagna Unit)

Rock Type: Garnet bearing gneissose granite

Metamorphism: $n / k$

Yield: Apatite only

Comments: Sample site KAL-42 of Schenk (1980)

$\mathrm{Rb}-\mathrm{Sr}(\mathrm{Bi})-43 \pm 1 \mathrm{Ma}$

$\mathrm{Rb}-\mathrm{Sr}(\mathrm{Ms})-268 \pm 4 \mathrm{Ma}$

CUR-380b

Location: Roadside quarry on Curinga-S.Pietro road, $11 / 2 \mathrm{~km}$ ENE of Curinga

Height: $380 \mathrm{~m}$

Geological Unit: Alpine Group (Bagni Unit)

Rock Type: Phillitic biotite schist

Metamorphism: Greenschist facies

Yield: Apatite only

Comments: Sample site KAL-42 of Schenk (1980)

$\mathrm{Rb}-\mathrm{Sr}(\mathrm{Bi})-43 \pm 1 \mathrm{Ma}$

$\mathrm{Rb}-\mathrm{Sr}$ (Ms)- $268 \pm 4 \mathrm{Ma}$

\section{FER-1148}

Location: $100 \mathrm{~m} \mathrm{E}$ of junction between SS110 and SS110dir to Ferdinandea village

Height: $1148 \mathrm{~m}$

Geological Unit: Hercynian plutonic (Stilo Unit)

Rock Type: Gneissose granite

Metamorphism: $\mathrm{n} / \mathrm{k}$

Yield: Apatite and zircon

Comments: Sample site of Nicoletti (1984)

$\mathrm{K}-\mathrm{Ar}(\mathrm{Bi})-273 \pm 9 \mathrm{Ma}$
$\mathrm{K}-\mathrm{Ar}(\mathrm{Ms})-275 \pm 8 \mathrm{Ma}$

FUM-340

Location: Bridge over Fossa Umbrita on road between Monterosso and Polia, nr. Font.na del Papa

Height: $340 \mathrm{~m}$

Geological Unit: High-grade Hercynian metamorphic (Polia-Copanello Unit)

Rock Type: Garnet, biotite granulite ("kinzigite")

Metamorphism: Granulite Facies

Yield: Apatite and zircon

Comments: Sample site KAL-85 of Schenk (1980)
$\mathrm{Rb}-\mathrm{Sr}(\mathrm{Bi})-112 \pm 1 \mathrm{Ma}$
$\mathrm{Rb}-\mathrm{Sr}(\mathrm{Fs})-141 \pm 1 \mathrm{Ma}$
$\mathrm{U}-\mathrm{Pb}(\mathrm{Mz})-292 \pm 2 \mathrm{Ma}$ 


\section{FUS-1100}

Location: Fuscaldo-Palazzello road, $\sim 500 \mathrm{~m}$ from pass $(1135 \mathrm{~m})$

Height: $110 \mathrm{~m}$

Geological Unit: Liguride Complex (Metabasite Unit)

Rock Type: Meta-porphyrite

Metamorphism: $n / \mathbf{k}$

Yield: Zircon only

GAM-1650

Location: Along new road to Dam construction site, $\sim 10 \mathrm{~km}$ SE of Gambarie (Aspromonte)

Height: $1650 \mathrm{~m}$

Geological Unit: High-grade Hercynian metamorphic (Aspromonte Unit)

Rock Type: Proto-mylonitic garnet gneiss

Metamorphism: High-grade (?Amphibolite facies) with greenschist facies dynamic

overprint

Yield: Zircon only

\section{GAR-1500}

Location: Small Quarry on road to Mt. Gariglione, 2km from SS179dir.

Height: $1500 \mathrm{~m}$

Geological Unit: High-grade Hercynian metamorphic (Mt. Gariglione unit)

Rock Type: Biotite paragneiss

Metamorphism: Amphibolite facies

Yield: Apatite and zircon

GER-1200

Location: $\sim 500 \mathrm{~m}$ along road to Germano from the SS107

Height: $1200 \mathrm{~m}$

Geological Unit: Hercynian plutonic (Mt. Gariglione Unit)

Rock Type: Andalucite bearing gneissose granite/granodiorite

Metamorphism: $n / k$

Yield: Apatite and zircon

\section{INF-1050}

Location: Roadside outcrop $\sim 1 \mathrm{~km}$ along road to Infantino from old SS107

Height: $1050 \mathrm{~m}$

Geological Unit: Hercynian plutonic (Mt. Gariglione Unit)

Rock Type: Gneissose Granite

Metamorphism: $\mathrm{n} / \mathrm{k}$

Yield: Apatite and zircon

Comments: Sample contains small mafic xenolith

\section{LIM-130}

Location: Large granite quarry, $\sim 3 \mathrm{~km}$ S of Nicotera Marina, nr Limbadi

Height: $130 \mathrm{~m}$

Geological Unit: Hercynian plutonic (Polia-Copanello Unit)

Rock Type: Gneissose granite

Metamorphism: $n / k$

Yield: Apatite and zircon

Comments: Sample contains small mafic xenolith

Nr. sample site 3 of Civetta et al. (1973)

$\mathrm{K}-\mathrm{Ar}(\mathrm{Bi})-133 \pm 4 \mathrm{Ma}$ 


\author{
MAN-450 \\ Location: SW side of bridge over torrente, $\sim 2 \mathrm{~km}$ NW of Mandanici village (NE Sicily) \\ Height: $450 \mathrm{~m}$ \\ Geological Unit: Low-grade Hercynian metamorphic ("Mandanici Unit") \\ Rock Type: Fine-grained phillite with quartz veining \\ Metamorphism: Greenschist Facies \\ Yield: Small quantity of apatite \\ Comments: Near locality of sample isotopically dated by Zuppetta et al. (1984) with a K-Ar \\ (bioite) age of $217 \pm 3 \mathrm{Ma}$
}

\author{
MAN-550 \\ Location: SS108ter., $\sim 1 \mathrm{~km} \mathrm{NE}$ of Cantonara Montagna, 3km SSE of Mandatorricio \\ Height: $550 \mathrm{~m}$ \\ Geological Unit: Hercynian plutonic \\ Rock Type: Garnetiferous granite \\ Metamorphism: $n / k$ \\ Yield: Apatite (1 crystal) and zircon
}

MAN-650

Location: Junction of SS108ter. and SS383, 3km S of Mandatorricio

Height: $650 \mathrm{~m}$

Geological Unit: Low-grade Hercynian metamorphic

Rock Type: Biotite, muscovite schist

Metamorphism: Greenschist facies

Yield: Apatite and zircon

MAZ-180

Location: $\sim 500 \mathrm{~m}$ North of Pillbox on route N185, $\mathrm{nr}$ Mazzara (NE Sicily).

Height: $180 \mathrm{~m}$

Geological Unit: Low-grade Hercynian metamorphic

Rock Type: Fine-grained phillite with some minor quartz veining

Metamorphism: Greenschist Facies

Yield: Very small amount of apatite

Comments: None

ONO-400

Location: Cutting on slip road from A3 motorway to Vibo Valentia, nr. San Onófrio

Height: $400 \mathrm{~m}$

Geological Unit: High-grade Hercynian metamorphic (Polia-Copanello Unit)

Rock Type: Garnet, biotite, sillamanite gneiss ("kinzigite")

Metamorphism: Amphibolite/Granulite facies

Yield: Apatite and zircon

PAL-750

Location: $\sim 1 \mathrm{~km}$ before Palazzello vbillage on Fuscaldo-Palazzello road

Height: $750 \mathrm{~m}$

Geological Unit: High-grade Hercynian metamorphic (Mt. Gariglione Unit)

Rock Type: Biotite gneiss

Metamorphism: $n / k$

Yield: Apatite and zircon 
PA0.600

Location: Old Paola-Passo Crocetta road, $200 \mathrm{~m}$ from junction with SS107

Height: $600 \mathrm{~m}$

Geological Unit: Alpine Group (Castagna Unit)

Rock Type: Protomylonitic leucogranite

Metamorphism: Pervasive Greenschist facies dynamic overprint

Yield: Apatite and zircon

Comments: Stop 5 of Colonna \& Compagnoni (1982)

PAO-750

Location: Old Paola-Passo Crocetta road, At bridge over Fiume Scirrocco

Height: $750 \mathrm{~m}$

Geological Unit: Alpine Group (Bagni Unit)

Rock Type: Chloritic phillite

Metamorphism: Greenschist facies

Yield: Apatite and zircon

Comments: Stop 6 of Colonna \& Compagnoni (1982)

PA0-850

Location: Old Paola-Passo Crocetta road, $\sim 1 \mathrm{~km}$ below Passo Crocetta

Height: $850 \mathrm{~m}$

Geological Unit: Alpine Group (Bagni Unit)

Rock Type: Chloritic phillite

Metamorphism: Greenschist facies

Yield: Apatite and zircon

Comments: Stop 7 of Colonna \& Compagnoni (1982)

PAO-940

Location: Passo Crocetta at road junction to Falconara Albanese

Height: $940 \mathrm{~m}$

Geological Unit: Hercynian plutonic (Mt. Gariglione Unit)

Rock Type: Gneissose granite

Metamorphism: $n / k$ (NO greenschist facies overprint)

Yield: Apatite and zircon

Comments: Strong foliation

Stop 8 of Colonna \& Compagnoni (1982)

\section{PAS-1140}

Location: $\sim 1 \mathrm{~km}$ to $\mathrm{W}$ of road over Lago di Passante dam

Height: $1140 \mathrm{~m}$

Geological Unit: Alpine Group (Castagna Unit)

Rock Type: Proto-mylonitic paragneiss

Metamorphism: Dynamically recrystallised quartz

Yield: Apatite and zircon

POT-505

Location: SS109, at bridge across Fiumara Potamo, 3km S of Filippa

Height: $505 \mathrm{~m}$

Geological Unit: Hercynian plutonic (Polia-Copanello Unit)

Rock Type: Gneissose leucogranite

Metamorphism: $n / k$

Yield: Apatite and zircon 


\section{SAV-920}

Location: SS108ter. roadside, $\sim 2 \mathrm{~km} \mathrm{SW}$ of Savelli

Height: $920 \mathrm{~m}$

Geological Unit: Hercynian plutonic

Rock Type: Biotite, amphibole granodiorite

Metamorphism: Some biotite altered to chlorite (?Greenschist facies overprint)

Yield: Apatite and zircon

SAV-990

Location: $1 \mathrm{~km} \mathrm{~N}$ of Savelli on SS108ter. road to Campana, nr. Font.na Pedagese

Height: $990 \mathrm{~m}$

Geological Unit: Hercynian plutonic (Longobucco Unit)

Rock Type: Gneissose granite

Metamorphism: Greenschist facies overprint (biotite altering to chlorite)

Yield: Apatite and zircon

\section{SCI-30}

Location: SS18 Scilla-Bagnara road, large quarry $\sim 2 \mathrm{~km}$ NE of Scilla (Torrente Praialonga)

Height: $30 \mathrm{~m}$

Geological Unit: High-grade Hercynian metamorphic (Aspromonte Unit)

Rock Type: Granodioritic gneiss

Metamorphism: $n / k$

Yield: Apatite and zircon

Comments: Nr. sample site of Rottura (1985)

$$
\mathrm{K}-\mathrm{Ar}(\mathrm{Bi})-135 \pm 5 \mathrm{Ma}
$$

\section{SGF-1000}

Location: Lago Ampollino-San Giovanni in Fiore road, roadside outcrop 3km SW of San

Giovanni in Fiore

Height: $100 \mathrm{~m}$

Geological Unit: Hercynian plutonic

Rock Type: Alkali granite

Metamorphism: $n / k$

Yield: Apatite and zircon

Comments: Locality show evidence of palaeomagnetic drilling

\section{SGF-840}

Location: Large Quarry, $1 \mathrm{~km}$ to south of San Giovanni in Fiore

Height: $840 \mathrm{~m}$

Geological Unit: Hercynian plutonic (Longobucco Unit)

Rock Type: Granite

Metamorphism: $n / \mathbf{k}$

Yield: Apatite and zircon

SOF-450

Location: $3 \mathrm{~km}$ W of San Sofia D'Epiro village, $\mathrm{nr}$ C.Sisca

Height: $450 \mathrm{~m}$

Geological Unit: High-grade Hercynian metamorphic (San Sofia D'Epiro Unit)

Rock Type: Garnet gneiss

Metamorphism: Amphibolite/Granulite facies

Yield: Zircon only

Comments: No evidence of a later metamorphic overprint 


\section{SOF-750}

Location: 200m along road to Acri, off San Sofia D'Epiro-S.Demetrio road.

Height: $750 \mathrm{~m}$

Geological Unit: High-grade Hercynian metamorphic (San Sofia D'Epiro Unit)

Rock Type: Gneissose leucogranite

Metamorphism: Evidence of Greenschist facies overprint (biotite altered to chlorite)

Yield: Zircon only

\section{TIR-700}

Location: Roadside on SS19, $2 \mathrm{~km}$ N of Tiriolo

Height: $700 \mathrm{~m}$

Geological Unit: ?High grade Hercynian metamorphic/ Hercynian plutonic (Tiriolo Unit)

Rock Type: Garnetiferous gneissose leucogranite

Metamorphism: Amphibolite/Granulite facies with dynamic overprint

Yield: Apatite and zircon

\section{TRE-1050}

Location: SS179 between Trepido and Cotronei, $\sim 3 \mathrm{~km}$ SE of Trepido

Height: $1050 \mathrm{~m}$

Geological Unit: Hercynian plutonic (Longobucco Unit)

Rock Type: Granite

Metamorphism: $n / k$

Yield: Apatite and zircon

\section{VAL-590}

Location: Roadside, $\sim 200 \mathrm{~m}$ NW of Vallelonga, next to sewage works

Height: $590 \mathrm{~m}$

Geological Unit: High-grade Hercynian metamorphic (Polia-Copanello Unit)

Rock Type: Meta-tonalite

Metamorphism: $n / k$

Yield: Apatite and zircon

Comments: Quartz dynamically recrystallised

Sample site KAL-887 of Schenk (1980)

$$
\mathrm{Rb}-\mathrm{Sr}(\mathrm{Bi})-85 \pm 1 \mathrm{Ma}
$$

$\mathrm{U}-\mathrm{Pb}(\mathrm{Zr})-293 \pm 7 \mathrm{Ma}$

\section{VAT-118}

Location: Small track, $\sim 100 \mathrm{~m}$ below Capo Vaticano lighthouse

Height: $118 \mathrm{~m}$

Grid Reference:

Rock Type: Gneissose granite

Metamorphism: $n / k$

Yield: Apatite and zircon

Comments: Nr. sample sites 20 \&23 of Civetta et al. (1973)

$$
\begin{aligned}
& \mathrm{K}-\mathrm{Ar}(\mathrm{Bi})-181 \pm 6 \mathrm{Ma} \\
& \mathrm{K}-\mathrm{Ar}(\mathrm{Ms})-147 \pm 4 \mathrm{Ma}
\end{aligned}
$$

\section{ZAM-125}

Location: Roadside, $\sim 1 \mathrm{~km}$ S of Zambrone Marina, $\sim 3 \mathrm{~km}$ N of Zambrone village

Height: $125 \mathrm{~m}$

Geological Unit: Hercynian plutonic (Polia-Copanello Unit)

Rock Type: Foliated gneissose granite

Metamorphism: $n / k$

Yield: Apatite and zircon

Comments: Nr. sample sites 17 \& 18 of Civetta et al. (1973)

$$
\begin{aligned}
& \mathrm{K}-\mathrm{Ar}(\mathrm{Bi})-125 \pm 4 \mathrm{Ma} \\
& \mathrm{K}-\operatorname{Ar}(\mathrm{Ms})-151 \pm 5 \mathrm{Ma}
\end{aligned}
$$




\section{APPENDIX III}

Apatite and Zircon Zeta Calibration Values 


\title{
Apatite CN5 Zeta Values
}

\begin{tabular}{|c|c|c|c|c|c|c|c|c|}
\hline $\begin{array}{l}\text { Irradiation } \\
\text { Number }\end{array}$ & Standard & $\begin{array}{l}\text { No. of } \\
\text { Crystals } \\
\text { Counted }\end{array}$ & $\begin{array}{c}\text { Spontaneous } \\
\rho_{s} \\
\left(\mathrm{~N}_{8}\right)\end{array}$ & $\begin{array}{c}\text { Induced } \\
\qquad \rho_{i} \\
\left(N_{i}\right)\end{array}$ & $\mathrm{P} \chi^{2}$ & $p_{s} / p_{i}$ & $\begin{array}{c}\text { Dosimeter } \\
\text { Pd }\end{array}$ & Zeta $( \pm 1 \sigma)$ \\
\hline OZ-1 & Durango & 8 & $\begin{array}{l}0.196 \\
(209)\end{array}$ & $\begin{array}{c}1.12 \\
(1283)\end{array}$ & $40 \%$ & 0.163 & 1.08 & $357.73 \pm 27.00$ \\
\hline OZ-1 & Mt. Dromedary & 28 & $\begin{array}{l}0.789 \\
(989)\end{array}$ & $\begin{array}{c}1.63 \\
(2040)\end{array}$ & $10 \%$ & 0.485 & 1.08 & $379.87 \pm 15.36$ \\
\hline OZ-2 & Fish Canyon & 20 & $\begin{array}{l}0.218 \\
(281)\end{array}$ & $\begin{array}{c}1.54 \\
(1990)\end{array}$ & $55 \%$ & 0.141 & 1.17 & $337.74 \pm 21.86$ \\
\hline OZ-2 & Mt. Dromedary & 20 & $\begin{array}{l}0.697 \\
(822)\end{array}$ & $\begin{array}{c}1.43 \\
(1685)\end{array}$ & $60 \%$ & 0.488 & 1.16 & $350.43 \pm 15.42$ \\
\hline $\mathrm{OZ}-2$ & Durango & 20 & $\begin{array}{l}0.186 \\
(451)\end{array}$ & $\begin{array}{c}1.16 \\
(2819)\end{array}$ & $98 \%$ & 0.160 & 1.17 & $336.87 \pm 17.50$ \\
\hline OZ-3 & Fish Canyon & 20 & $\begin{array}{l}0.198 \\
(297)\end{array}$ & $\begin{array}{c}1.35 \\
(2024)\end{array}$ & $99 \%$ & 0.147 & 1.06 & $359.48 \pm 22.74$ \\
\hline OZ-3 & Durango & 17 & $\begin{array}{l}0.189 \\
(324)\end{array}$ & $\begin{array}{c}1.17 \\
(2003)\end{array}$ & $99 \%$ & 0.162 & 1.06 & $367.91 \pm 22.45$ \\
\hline OZ-3 & Mt. Dromedary & 20 & $\begin{array}{l}0.718 \\
(722)\end{array}$ & $\begin{array}{c}1.40 \\
(1412)\end{array}$ & $97 \%$ & 0.511 & 1.06 & $368.55 \pm 17.41$ \\
\hline OZ-3 & Mt. Dromedary & 20 & $\begin{array}{l}0.725 \\
(905)\end{array}$ & $\begin{array}{c}1.42 \\
(1775)\end{array}$ & $99 \%$ & 0.510 & 1.02 & $383.78 \pm 16.32$ \\
\hline OZ-4 & Fish Canyon & 20 & $\begin{array}{l}0.192 \\
(234)\end{array}$ & $\begin{array}{c}1.32 \\
(1609)\end{array}$ & $70 \%$ & 0.145 & 1.08 & $355.19 \pm 25.19$ \\
\hline OZ-4 & Mt. Dromedary & 20 & $\begin{array}{r}0.945 \\
(1545)\end{array}$ & $\begin{array}{c}1.75 \\
(2867)\end{array}$ & $<1 \%$ & 0.539 & 1.08 & $357.33 \pm 18.66$ \\
\hline OZ-4 & Durango & 10 & $\begin{array}{l}0.180 \\
(217)\end{array}$ & $\begin{array}{c}1.01 \\
(1221)\end{array}$ & $99 \%$ & 0.178 & 1.08 & $327.96 \pm 24.46$ \\
\hline OZ-17 & Fish Canyon & 20 & $\begin{array}{l}0.209 \\
(336)\end{array}$ & $\begin{array}{c}1.64 \\
(2637)\end{array}$ & $99 \%$ & 0.127 & 1.33 & $331.17 \pm 19.51$ \\
\hline OZ-17 & Durango & 8 & $\begin{array}{l}0.216 \\
(172)\end{array}$ & $\begin{array}{c}1.45 \\
(1150)\end{array}$ & $90 \%$ & 0.150 & 1.17 & $360.44 \pm 29.72$ \\
\hline $\mathrm{OZ}-20 \mathrm{~B}$ & Durango & 19 & $\begin{array}{l}0.131 \\
(344)\end{array}$ & $\begin{array}{c}0.88 \\
(2298)\end{array}$ & $85 \%$ & 0.150 & 1.18 & $357.00 \pm 21.01$ \\
\hline OZ-21 & Mt. Dromedary & 20 & $\begin{array}{l}0.905 \\
(594)\end{array}$ & $\begin{array}{c}2.02 \\
(1329)\end{array}$ & $75 \%$ & 0.447 & 1.13 & $393.51 \pm 19.92$ \\
\hline OZ-61 & Mt. Dromedary & 20 & $\begin{array}{l}0.863 \\
(625)\end{array}$ & $\begin{array}{c}1.68 \\
(1218)\end{array}$ & $95 \%$ & 0.513 & 1.05 & $369.23 \pm 18.68$ \\
\hline OZ-61 & Durango & 20 & $\begin{array}{l}0.157 \\
(264)\end{array}$ & $\begin{array}{c}0.91 \\
(1531)\end{array}$ & $80 \%$ & 0.172 & 1.05 & $348.32 \pm 23.57$ \\
\hline
\end{tabular}

\section{Notes:}

(i). track densities $(\rho)$ are as measured $\left(x 10^{6} \mathrm{tr} \mathrm{cm}^{-2}\right)$; numbers of tracks counted $(\mathrm{N})$ shown in brackets;

(ii). analyses by external detector method using 0.5 for the $4 \pi / 2 \pi$ geometry correction factor;

(iii). $P \chi^{2}$ is the probability for obtaining the $\chi^{2}$ value for $v$ degrees of freedom, where $v=$ no. crystals -1 ;

\author{
Standard Mean Zeta (CN5) $=357.92 \pm 17.80$ \\ Weighted Mean Zeta $($ CN5) $=359.78 \pm 4.23$
}




\section{Apatite SRM612 Zeta Values}

\begin{tabular}{|c|c|c|c|c|c|c|c|c|}
\hline $\begin{array}{l}\text { Irradiation } \\
\text { Number }\end{array}$ & Standard & $\begin{array}{l}\text { No. of } \\
\text { Crystals } \\
\text { Counted }\end{array}$ & $\begin{array}{c}\text { Spontaneous } \\
\rho_{\mathbf{s}} \\
\left(\mathbf{N}_{\mathbf{s}}\right)\end{array}$ & $\begin{array}{c}\text { Induced } \\
\stackrel{\rho_{i}}{\left(N_{i}\right)}\end{array}$ & $\mathbf{P} \chi^{2}$ & $\rho_{s} / \rho_{i}$ & $\begin{array}{c}\text { Dosimeter } \\
\text { Pd }\end{array}$ & Zeta $( \pm 1 \sigma)$ \\
\hline OZ-20B & Durango & 19 & $\begin{array}{l}0.131 \\
(344)\end{array}$ & $\begin{array}{c}0.88 \\
(2298)\end{array}$ & $85 \%$ & 0.150 & 1.28 & $328.07 \pm 19.29$ \\
\hline OZ-21 & Mt. Dromedary & 20 & $\begin{array}{l}0.905 \\
(594)\end{array}$ & $\begin{array}{c}2.02 \\
(1329)\end{array}$ & $75 \%$ & 0.447 & 1.42 & $313.46 \pm 15.79$ \\
\hline OZ-222 & Durango & 20 & $\begin{array}{l}0.135 \\
(368)\end{array}$ & $\begin{array}{c}0.93 \\
(2549)\end{array}$ & $98 \%$ & 0.144 & 1.21 & $359.93 \pm 20.45$ \\
\hline OZ-23 & Mt. Dromedary & 20 & $\begin{array}{l}0.885 \\
(712)\end{array}$ & $\begin{array}{c}2.14 \\
(1712)\end{array}$ & $99 \%$ & 0.414 & 1.25 & $384.23 \pm 17.63$ \\
\hline OZ-24 & Durango & 20 & $\begin{array}{l}0.137 \\
(318)\end{array}$ & $\begin{array}{c}0.97 \\
(2247)\end{array}$ & $80 \%$ & 0.142 & 1.24 & $358.16 \pm 21.81$ \\
\hline OZ-34 & Mt.Dromedary & 17 & $\begin{array}{l}0.887 \\
(614)\end{array}$ & $\begin{array}{c}2.08 \\
(1443)\end{array}$ & $99 \%$ & 0.426 & 1.11 & $423.23 \pm 20.94$ \\
\hline
\end{tabular}

\section{Notes:}

(i). track densities $(\rho)$ are as measured $\left(\times 10^{6} \mathrm{tr}^{-2}\right.$ ); numbers of tracks counted $(\mathrm{N})$ shown in brackets;

(ii). analyses by external detector method using 0.5 for the $4 \pi / 2 \pi$ geometry correction factor;

(iii). $\mathrm{P} \chi^{2}$ is the probability for obtaining the $\chi^{2}$ value for $\mathrm{v}$ degrees of freedom, where $\mathrm{v}=$ no. crystals -1 ;

$\begin{array}{ll}\text { Standard Mean Zeta (SRM612) } & =361.18 \pm 39.41 \\ \text { Weighted Mean Zeta (SRM612) } & =356.74 \pm 14.91\end{array}$




\title{
Zircon CN2 Zeta Values
}

\begin{tabular}{|c|c|c|c|c|c|c|c|c|}
\hline $\begin{array}{l}\text { Irradiation } \\
\text { Number }\end{array}$ & Standard & $\begin{array}{l}\text { No. of } \\
\text { Crystals } \\
\text { Counted }\end{array}$ & $\begin{array}{c}\text { Spontaneous } \\
\rho_{s} \\
\left(\mathbf{N}_{s}\right)\end{array}$ & $\begin{array}{c}\text { Induced } \\
\rho_{\mathbf{i}} \\
\left(\mathbf{N}_{\mathfrak{i}}\right)\end{array}$ & $\mathrm{P} \chi^{2}$ & $\rho_{s} / \rho_{i}$ & $\begin{array}{c}\text { Dosimeter } \\
\text { Pd }\end{array}$ & Zeta $( \pm 1 \sigma)$ \\
\hline OZ-14 & Fish Canyon & 15 & $\begin{array}{c}6.61 \\
(2406)\end{array}$ & $\begin{array}{c}5.02 \\
(1829)\end{array}$ & $50 \%$ & 1.316 & 0.354 & $120.25 \pm 4.45$ \\
\hline OZ-14 & Tardree & 20 & $\begin{array}{c}5.81 \\
(2629)\end{array}$ & $\begin{array}{c}3.01 \\
(1362)\end{array}$ & $<1 \%$ & 1.930 & 0.354 & $165.54 \pm 9.55$ \\
\hline OZ-14 & Mt. Dromedary & 20 & $\begin{array}{c}14.9 \\
(5071)\end{array}$ & $\begin{array}{c}3.66 \\
(1247)\end{array}$ & $20 \%$ & 4.067 & 0.354 & $138.38 \pm 5.19$ \\
\hline OZ-16 & Tandree & 20 & $\begin{array}{c}7.86 \\
(3625)\end{array}$ & $\begin{array}{c}2.59 \\
(1196)\end{array}$ & $45 \%$ & 3.031 & 0.352 & $110.70 \pm 4.32$ \\
\hline OZ-16 & Buluk & 12 & $\begin{array}{l}1.03 \\
(885)\end{array}$ & $\begin{array}{c}1.27 \\
(1096)\end{array}$ & $70 \%$ & 0.807 & 0.352 & $114.30 \pm 5.66$ \\
\hline OZ-16 & Fish Canyon & 20 & $\begin{array}{c}5.05 \\
(3406)\end{array}$ & $\begin{array}{c}4.22 \\
(2845)\end{array}$ & $15 \%$ & 1.197 & 0.352 & $132.89 \pm 4.32$ \\
\hline OZ-16 & Mt. Dromedary & 16 & $\begin{array}{c}15.5 \\
(3173)\end{array}$ & $\begin{array}{r}4.04 \\
(828)\end{array}$ & $3 \%$ & 3.832 & 0.352 & $144.29 \pm 7.12$ \\
\hline OZ-20A & Tandree & 20 & $\begin{array}{c}5.80 \\
(3509)\end{array}$ & $\begin{array}{c}2.06 \\
(1246)\end{array}$ & $45 \%$ & 2.816 & 0.374 & $111.87 \pm 4.29$ \\
\hline OZ-20A & Mt. Dromedary & 20 & $\begin{array}{c}23.6 \\
(4846)\end{array}$ & $\begin{array}{c}4.96 \\
(1017)\end{array}$ & $45 \%$ & 4.765 & 0.374 & $111.45 \pm 4.42$ \\
\hline OZ-20A & Fish Canyon & 20 & $\begin{array}{c}2.60 \\
(2041)\end{array}$ & $\begin{array}{c}2.42 \\
(1898)\end{array}$ & $25 \%$ & 1.075 & 0.374 & $138.76 \pm 5.19$ \\
\hline OZ-20A & Buluk & 6 & $\begin{array}{l}0.861 \\
(453)\end{array}$ & $\begin{array}{r}1.25 \\
(660)\end{array}$ & $80 \%$ & 0.686 & 0.374 & $123.34 \pm 7.90$ \\
\hline OZ-35 & Fish Canyon & 20 & $\begin{array}{c}4.82 \\
(4129)\end{array}$ & $\begin{array}{c}3.91 \\
(3346)\end{array}$ & $6 \%$ & 1.234 & 0.326 & $139.07 \pm 4.38$ \\
\hline OZ-35 & Mt. Dromedary & 20 & $\begin{array}{c}20.4 \\
(5285)\end{array}$ & $\begin{array}{c}3.98 \\
(1030)\end{array}$ & $70 \%$ & 5.131 & 0.325 & $119.25 \pm 4.79$ \\
\hline OZ-35 & Buluk & 20 & $\begin{array}{c}1.03 \\
(1321)\end{array}$ & $\begin{array}{c}1.36 \\
(1738)\end{array}$ & $90 \%$ & 0.760 & 0.327 & $130.68 \pm 5.52$ \\
\hline$O Z-45$ & Buluk & 10 & $\begin{array}{l}0.944 \\
(481)\end{array}$ & $\begin{array}{c}1.20 \\
(1018)\end{array}$ & $90 \%$ & 0.473 & 0.596 & $115.27 \pm 6.61$ \\
\hline$O Z-45$ & Tardree & 20 & $\begin{array}{c}6.52 \\
(3675)\end{array}$ & $\begin{array}{c}5.07 \\
(2858)\end{array}$ & $90 \%$ & 1.286 & 0.593 & $154.63 \pm 4.52$ \\
\hline OZ-64 & Mt. Dromedary & 10 & $\begin{array}{c}14.8 \\
(1781)\end{array}$ & $\begin{array}{r}3.20 \\
(385)\end{array}$ & $80 \%$ & 4.626 & 0.372 & $115.60 \pm 6.90$ \\
\hline OZ-64 & Buluk & 9 & $\begin{array}{l}0.969 \\
(385)\end{array}$ & $\begin{array}{c}1.51 \\
(602)\end{array}$ & $75 \%$ & 0.640 & 0.365 & $138.96 \pm 9.49$ \\
\hline
\end{tabular}

\section{Notes:}

(i). track densities ( $\rho$ ) are as measured $\left(x 10^{6} \mathrm{tr}^{-2}\right)$; numbers of tracks counted $(\mathrm{N})$ shown in brackets;

(ii). analyses by external detector method using 0.5 for the $4 \pi / 2 \pi$ geometry correction factor;

(iii). $\mathrm{P} \chi^{2}$ is the probability for obtaining the $\chi^{2}$ value for $\mathrm{v}$ degrees of freedom, where $\mathrm{v}=$ no. crystals -1 ;

\author{
Standard Mean Zeta $(\mathrm{CN} 2)=129.18 \pm 16.00$ \\ Weighted Mean Zeta $(\mathrm{CN} 2)=127.72 \pm 3.38$
}




\section{REFERENCES}

ACQUAFREDDA, P., LORENZONI, S. \& ZANETTIN-LORENZONI, E. (1988a). La sequenza Paleozoica dell'unita di Bocchigliero (Sila, Calabria). Rend. Soc. Geol. It., 11, p5-22.

ACQUAFREDDA, P., LORENZONI, S. \& ZANETTIN-LORENZONI, E. (1988b). Guida all'escursione del gruppo Paleozoico in Calabria. Rend. Soc. Geol. It., 11, p39-50.

ALVAREZ, W., COCOZZA, T. \& WEZEL, F.C. (1974). Fragmentation of the Alpine Orogenic Belt by microplate dispersal. Nature, 248, p309-314.

AMODIO-MORELLI, L., BONARDI, G., COLONNA, V., DIETRICH, D., GIUNTA, G., IPPOLITO, F., LIGUORI, V., LORENZONI, S., PAGLIONICO, A., PERRONE, V., PICCARRETA, V., RUSSO, M., SCANDONE, P., ZANETTIN-LORENZONI, E., \& ZUPPETTA, A. (1976). L'Arco Calabro-Peloritano nell'orogene Appenninico-Maghrebide. Mem. Geol. Soc. Ital., 17, p1-60.

ATZORI, P., DEL MORO, A. \& ROTTURA, A. (1990). Rb/Sr radiometric data from medium- to high-grade metamorphic rocks (Aspromonte Nappe) of the north-eastem Peloritani Mountains (Calabrian Arc), Italy. Eur. J. Mineral., 2, p363-371

ATZORI, P., FERLA, P., PAGLIONICO, A., PICCARRETA, G. \& ROTTURA, A. (1984). Remnants of the Hercynian orogen along the 'Calabrian-Peloritan Arc', southern Italy: a review. J. Geol. Soc. Lond., 141, p137-145.

ATZORI, P., \& LO GUIDICE (1982). Gli gneiss occhiadini del Messinese: caratterizzazioni geopetrografica e petrochemica. Period. Miner., 51, p15-34.

BALDI, P., ACHILLI, V., MULGARIA, F. \& BROCCIO, F. (1983). Geodetic surveys in Messina Straits area. Bull. Geod., 57, p283-293.

BAR, M., KOLODNY, Y. \& BENTOR, Y.K. (1974). Dating faults by fission track dating of epidotes - an attempt. Earth Planet. Sci. Lett., 22, p157-162.

BARBERI, F., GASPARINI, P., INNOCENTI, F. \& VILLARI, L. (1973). Volcanism of the southern Tyrrhenian Sea and its geodynamic implications. J. Geophys. Res., 78, p5221-5232. 
BARBERI, F., BIZOUARD, H., CAPALDI, G., FERRARA, G., GASPARINI, P., INNOCENTI, F., JORON, J.L., LAMBRET, B., TREUIL, M. \& ALLEGRE, C. (1978). Age and nature of basalts from the Tyrrhenian abyssal plain. In: Hsu, K. Montadert, L. et al., Initial Reports of the DSDP, Vol 42, Part 1. U.S. Govt. Printing Office, Washington D.C. p509-514. BARRIER, P., DI GERONIMO, I. \& MONTENANT, C. (eds.) (1987). Le Détroit de Messine (Italie) : Evolution tectono-sedimentaire récente (Pliocene et Quaternaire) et environnement actuel. Doc. et Trav. I.GAL., Paris, No.11, pp272.

BECCALUVA, L., GABIANELLI, G., LUCCHINI, F., ROSSI, P.L., SAVELLI, C. \& ZEDA, O. (1981).

Magmatic character and $\mathrm{K} / \mathrm{Ar}$ ages of volcanics dredged from the Eolian seamounts (Tyrrhenian Sea). In: Wezel, F.C. (ed.) Sedimentary Basins of Mediterranean Margins. CNR, Italian Project of Oceanography, Bologna. p361-368.

BELDERSON, R.H., KENYON, N.H. \& STRIDE, A.H. (1974). Calabrian Ridge, a newly discovered branch of the Mediterranean Ridge. Nature, 247, p453-454

BENJAMIN, M.T., JOHNSON, N.M. \& NAESER, C.W. (1987). Recent rapid uplift in the Bolivian Andes:

Evidence from fission track dating. Geology, 15, p680-683

BIGAZZI, G. (1981). The problem of the decay constant $\lambda_{\mathrm{f}}$ of $238 \mathrm{U}$. Nucl. Tracks, 5, p35-44.

BIGAZZI, G., MARTON, P., NORELLI, P. \& ROZLOZNIK, L. (1990). Fission track dating of Carpathian obsidians and provenance identification. Nucl. Tracks, 17, p391-396.

BIJA-DUVAL, B., DERCOURT, J. \& LE PICHON, X. (1976). From the Tethys Ocean to the Mediterranean Sea. In: Bija Duval, B. \& Montadert, L. (eds.). Structural History of the Mediterranean Basin, Tecnoprint, Split. p250-334.

BOCCALETTI, M., CELLO, G. \& TORTORICI, L. (1987). Transtensional tectonics in the Sicily Channel. J. Struct. Geol., 9, p869-876.

BOCCALETTI, M., \& MANETTI, P. (1978). The Tyrrhenian Sea and adjoining regions. In Nairn et al. (eds.). The Ocean Basins and Margins, Volume 4B: The Western Mediterranean. Plenum Press, New York. p149-200. BOCCALETTI, M., NICOLICH, R. \& TORTORICI, L. (1984). The Calabrian Arc and the Ionian Sea in the dynamic evolution of the central Mediterranean. Mar. Geol., 55, p219-245. 
BODECHTAL, J. \& MÜNZER, U. (1978). Satellite lineaments of the Central Mediterranean Region (Sicily/Calabria). In: Closs, H., Roeder, R. \& Schmidt, K. (eds.). Alps, Apennines, Hellenides. IUCG 38, p339-340.

BOHR, N. \& WHEELER, J.A. (1939). The mechanism of nuclear fission. Phys. Rev., 5, p426-450.

BONARDI, G., PESCATORE, T., SCANDONE, P. \& TORRE, M. (1971). Problemi paleogeogafici connessi con la succesione mesozoico-terziaria di Stilo (Calabia meridionale). Boll. Soc. Natur. Napoli, 80, p147-159. BONARDI, G., GIUNTA,G., PERRONE, V., RUSSO, M. \& ZUPPETTA, A. (1980). Osservazione sull'evoluzione dell'Arco Calabro-Peloritano nel Miocene inferiore : La formazione di Stilo-Capo D'Orlando. Boll. Soc. Geol. It., 99, p365-393.

BONARDI, G., COMPAGNONI, R., MESSINA, A. \& PERRONE, V. (1984). Riequilibrazione metamorfiche di probabile età alpina nell'Unità dell'Aspromonte-Arco Calabro-Peloritano. Rend. Soc. It. Min. Pet., 39, p613-628.

BONARDI, G., COMPAGNONI, R., DEL MORO, A., MESSINA, A. \& PERRONE, V. (1987). Riequilibrazione tettono-metamorfiche alpine nell'Unità dell'Aspromonte, Calabria meridionale. Rend. Soc. It. Min. Pet., 42, p301.

BORSI, S. \& DUBOIS, R. (1968). Données géochronologique sur l'histoire Hercynienne et Alpine de la Calabre centrale. C. R. Acad. Sc. Paris, 266(D), p72-75.

BORSI, S., MERLIN, O.P., LORENZONI, S., PAGLIONICO, A. \& ZANETTIN-LORENZONI, E. (1976). Stilo Unit and "Dioritic-Kinzigitic" Unit in the Le Serre (Calabria, Italy); Geological, petrological, geochronological characters. Boll. Soc. Geol. It., 95, p219-244.

BOTTARI, A., CACCAMO, D., CEFALI, F., Lo GIUDICE, E. \& NERI, G. (1986). Recent shallow seismicity in the southern Calabro-Peloritan Arc region. Ann. Geophys., 4(B), p91-98.

BOUILLIN, J-P. (1984). Nouvelle interprétation de la liaison Apennin-Maghrébides en Calabre; conséqences sur la palaéogéographie Tethysienne entre Gibralter et les Alpes. Rev. Géol. Dynam. Géog. Phys., 25, p321-338. BOUILLIN, J-P., MAJESTÈ-MENJOULAS, C., OLLIVIER-PIERRE, M.-F., TAMBAREAU, Y. \& VILLATTE, J. (1985). Transgression de l'Oligocene inferier (Formation de Palizzi) sur un karst à remplissage bauxitique dans les zones internes Calabro-Péloritaines (Italie). C. R. Acad. Sci. Paris, 301(2), p415-420 
BOUILLIN, J-P., DURAND-DELGA, M. \& OLIVIER, P. (1986). Betic-Rifian and Tyrrhenian arcs: distinctive features, genesis and development stages. In: Wezel, F.C. (ed.). The Origin of Arcs. Elsevier Science Publ., Amsterdam. p281-304.

BROWN, R.W. (1991). Backstacking apatite fission track "stratigraphy" : A method for resolving the erosional and isostatic rebound components of tectonic uplift histories. Geology, 19, p74-77.

BROWN, R.W., RUST, D.J., SUMMERFIELD, M.A., GLEADOW, A.J.W. \& DE WIT, M.C.J. (1990). An early Cretaceous phase of accelerated erosion on the south-westem margin of Africa: evidence from apatite fission track analysis and the offshore sedimentary record. Nucl. Tracks, 17, p339-350.

CAIRE, A. (1961). Remarques sur l'evolution tectonique de la Sicile. Bull. Soc. Géol. France 7(III), p545-558. CALANCHI, N. (1987). Nature and provenance of Plio-Pleistocene pyroclastic layers of the Strait of Messina (Southern Italy). In: Barrier, P., Di Geronimo, I. \& Montenant, C. (eds.) (1987). Le Détroit de Messine (Italie) : Evolution tectono-sedimentaire récente (Pliocene et Quaternaire) et environnement actuel. Doc. et Trav. I.G.A.L., Paris, No.11, p91-96.

CAPUTO, M., PIERI, L., BARBARELLA, M., GUBELliNI, A., RUSSO, P. \& CONSOLE, R. (1981).

Geophysical and geodetic observations in the Messina Straits. Tectonophysics, 74, p147-154.

CARLSON, W.D. (1990). Mechanisms and kinetics of apatite fission-track annealing. Amer. Mineral., 75, p11201139.

CARMIGNANI, L. \& KLIGFIELD, R. (1990). Crustal extension in the northern Apennines: the transition from compression to extension in the Alpi Apuane Core Complex. Tectonics, 9, p1275-1303.

CARRARA, A. \& ZUFFA, G.G. (1976). Alpine structures in northwestem Calabria, Italy. Bull. Geol. Soc. Am., 87, p1229-1246.

CATALANO, R. \& D'ARGENIO, B. (1978). Facies analysis and palaeogeography in Western Sicily. Geol. Rom., $17, \mathrm{p} 145-159$

CAVAZZA, W. (1988). La formazione di Stilo-Capo d'Orlando: Un possible strumento per lo studio dell'evoluzione strutturale dell'Arco Calabro-Peloritano. Rend. Soc. Geol. It., 11, p35-38.

CAVAZZA, W. (1989). Detrital modes and provenance of the Stilo-Capo d'Orlando Formation (Miocene), southern Italy. Sedimentology, 36, p1077-1090.

CELLO, G., GUERRA, L., TORTORICI, L., TURCO, E. \& SCARPA, R. (1982). Geometry of the neotectonic stress field in southern Italy: geological and seimological evidence. J. Struct.Geol., 4, p385-393. 
CELlO, G., SPADEA, P., TORTORICI, L. \& TURCO, E. (1983). Plio-Pleistocene Volcaniclastic deposits of southem Calabria. Boll. Soc. Geol. It., 102, p87-93.

CHANNELL, J.E.T., D'ARGENIO, B. \& HORVÁTH, F. (1979). Adria, the African promontory, in Mesozoic Mediterranean palaeogeography. Earth Sci.Rev., 15, p213-292.

CHANNELL, J.E.T. \& MARESCHAL, J.C. (1989). Delamination and assymetric crustal thickening in the development of the Tyrrhenian Rift. In: Coward, M.P. \& Dietrich, D. (eds.). Alpine Tectonics. Geol. Soc. Lond. Spec. Pub., 45, p285-302

CHANNELL, J.E.T., OLDOW, J.S., CATALANO, R. \& D'ARGENIO, B. (1990). Palaeomagnetically determined rotations in the western Sicilian fold and thrust belt. Tectonics, 9, p641-660.

CHERCHI, A. \& MONTADERT, L. (1982). Oligo-Miocene rift of Sardinia and the early history of the Western Mediterranean Basin. Nature, 298, p736-739.

CHESTER, D.K., DUNCAN, A.M., GUEST, J.E. \& KILBURN, C.R.J. (1985). Mount Etna: the anatomy of a volcano. Chapman \& Hall, London. pp404.

CIVETTA, L., CORTINI, M. \& GASPARINI, P. (1973). Interpretation of a discordant K-Ar age pattern (Capo Vaticano, Calabria). Earth Planet. Sci Lett., 20, p113-118.

CLIFF, R.A. (1985). Isotopic dating in metamorphic belts. J. Geol. Soc. Lond., 142. p97-110.

COHEN, C.R. (1980). Plate tectonic model for the Oligo-Miocene evolution of the Western Mediterranean. Tectonophysics, 68, p283-311.

COLELLA, A. \& D'ALESSANDRO, A. (1988). Sandwaves, echinoderm traces and their bathyal depositional setting (Monte Torre Palaeostrait, Plio-Pleistocene, southem Italy. Sedimentology, 35, p219-237. COLELLA, A., DE BOER, P.L. \& NIO, S.D. (1987). Sedimentology of a marine intermontane Pleistocene Gilbert-type fan-delta complex in the Crati Basin, Calabria, southern Italy. Sedimentology, 34, p721-736. COLONNA,V. \& COMPAGNONI, R. (1982). Guida all'escursione sulle unita cristalline della Catena Costiera (Calabria). Rend. Soc. It. Min. Pet., 38, p1141-1152.

CONNOLLY, J.A.D. \& THOMPSON, A.B. (1989). Fluid and enthalpy production during regional metamorphism. Contrib. Min. Pet., 102, p347-366.

COPELAND, P., PARRISH, R.R. \& HARRISON, T.M. (1988). Identification of inherited radiogenic $\mathrm{Pb}$ in monazite and its implications for U-Pb systematics. Nature, 333, p760-763. 
CORRIGAN, J. (1991). Inversion of apatite fission track data for thermal history information. J. Geophys. Res., 96 (B), p10,347-10,360.

COSENTINO, D., GLIOZZI, E. \& SALVINI, F. (1989). Britule deformation in the Upper Pleistocene deposits of the Crotone Peninsula, Calabria, Southem Italy. Tectonophysics, 163, p205-217.

COULON, C. \& DUPUY, C. (1977). Charactères minéralogiques et geochimiques de la suite andesitique de Sardaigne : Le probleme de la zonation spatiale. Bull. Soc. Géol. France 19, p857-863.

COURME, M-D. \& MASCLE, G. (1988). Nouvelles données stratigraphiques sur les séries Oligo-Miocènes des unités Siciliennes : Conséquences palaéogéographique. Bull. Soc. Géol. France, (8)IV, p105-118.

COWAN, G.A. \& ADLER, H.H. (1976). The variability of the natural abundance of 235U. Geochim. Cosmochim. Acta., 40, p1487-1490.

COWARD, M.P. \& DIETRICH D. (1989). Alpine Tectonics - an overview. In: Coward, M.P. \& Dietrich, D. (eds.). Alpine Tectonics. Geol. Soc. Lond. Spec. Pub., 45, p1-32.

CRISTOFOLINI, R., GHISETTI, F., SCARPA, R. \& VEZZANI, L. (1985). Character of the stress field in the Calabrian Arc and southem Apennines (Italy), as deduced by geological, seismological and volcanological information. Tectonophysics, 117, p39-58.

CROWLEY, K.D. (1986). Neutron dosimetry in fission track analysis. Nucl. Tracks, 11, p237-243.

CROWLEY, K.D., CAMERON, M. \& SCHAEFER, R.L. (1991). Experimental studies of annealing of etched fission tracks in fluorapatite. Geochim. Cosmochim. Acta, 55, p1449-1465.

D'AMICO, C., ROTTURA, A., MACCARRONE, E. \& PUGLISI, G. (1982). Per-aluminous granitic suite of Calabria-Peloritani Arc (southern Italy). Rend. Soc. It. Miner. Petrol., 38, p35-52.

D'ARGENIO,B. \& ALVAREZ, W. (1980). Stratigraphic evidence for crustal thickness changes on the southern Tethyan margin during the Alpine Cycle. Bull. Geol. Soc. Am., 91, p681-689.

DAVY, P. \& GILLET, P. (1986). The stacking of thrust slices in collision zones and its thermal consequences. Tectonics, 5, p913-929.

DEL MONTE, M. (1972). Il vulcanismo del Mar Tirreno. Nota preliminaire in vulcani Marsili e Palinuro. $G$. Geol., 38, p231-252.

DEL MORO, A., PUXEDDU, M., RADICATI DI BROZOLO, F. \& VILLA, I.M. (1982a). Rb-Sr and K-Ar ages on minerals at temperatures of $300-400^{\circ} \mathrm{C}$ from deep wells in the Lardello geothermal field. Contrib. Min. Pet., 81, p340-349. 
DEL MORO, A., PARDINI, G., MACCARRONE, E. \& ROTTURA, A. (1982b). Studio radiometrico Rb-Sr di granitoidi peraluminosi dell'Arco Calabro-Peloritano. Rend. Soc. It. Miner. Petrol., 38, p1015-1026.

DEL PEZZO, E., MARESCA, R., MARTINI, M. \& SCARPA, R. (1984). Seismicity of the Aeolian Islands, southern Italy. Ann. Geophys., 2, p173-180.

DE ROEVER, E.W.F. (1972). Lawsonite-albite facies metamorphism near Fuscaldo, Calabria (southern Italy), its geological significance and petrological aspects. GUA Pap. Geol. S.1(3). pp171.

DEWEY, J.F. (1980). Episodicity, sequency and style at convergent plate boundaries. In: Strangway, D.W. (ed.). The Continental Crust and its Mineral Deposits. Spec. Pap. Geol. Assoc. Can., 20, p553-573.

DEWEY, J.F. (1988). Extensional collapse of orogens. Tectonics, 7, p1123-1139.

DEWEY, J.F., HELMAN, M.L., TURCO, E., HUTTON, D.W.H. \& KNOTT, S.D. (1989). Kinematics of the westem Mediterranean. In: Coward, M.P. \& Dietrich, D. (eds.). Alpine Tectonics. Geol. Soc. Lond. Spec. Pub., 45, p265-283.

DIETRICH, D. (1988). Sense of overthrust shear in the Alpine nappes of Calabria (southern Italy). J. Struct. Geol., 10, p373-381.

DIETRICH, D., LORENZONI, S., SCANDONE, P., ZANETTIN-LORENZONI, E. \& DI PIERRO, M. (1976). Contribution to the knowledge of the tectonic units of Calabria. Relationships between composition of K-white micas and metamorphic evolution. Boll. Soc. Geol. It., 95, p193-217.

DODSON, M.H. (1973). Closure temperature in cooling geochronological and petrological systems. Contrib. Mineral. Petrol., 40, p259-274.

DODSON, M.H. (1979). Theory of cooling ages. In: Jäger, E. \& Hunziker, J.C. (eds.). Lectures in Isotope Geology, Springer-Verlag, Berlin. p194-202.

DONELICK, R.A. (1991). Crystallographic orientation dependence of mean etchable fission track length in apatite: an empirical model and experimental observations. Amer. Mineral., 76, p83-91.

DUBOIS, R. (1966). Les gneiss oeillés de la Sila méridionale (Calabre centrale, Italie). C.R. Acad. Sci. Paris. 262(D), p1188.

DUBOIS, R. (1970). Phases de serrage, nappes de socle et métamorphisme Alpin a la jonction Calabre-Apennin: La suture Calabro-Apenninique. Rev. Géol. Dynam. Géog. Phys., 2, p221-254.

DUDDY, I.R., GREEN, P.F. \& LASLETT, G.M. (1988). Thermal annealing of fission tracks in apatite, 3. Variable temperature behavior. Chem. Geol. (Isotope Geoscience Section), 73, p25-38. 
DUPUY, C., DOSTAL, J. \& COULON, C. (1979). Geochemistry and origin of andesitic rocks from north-westem Sardinia. J. Volcanol. Geotherm. Res., 6, p375-389.

DURAND-DELGA, M. (1978). Corse: Guides Géologique Régionaux. Masson, Paris.

DURAND-DELGA, M. (1988). Evolution au Neogène du système Alpin d'Algerie. Ric. Sci. Suppl., 68, p11-13.

EL-ALI, H. \& GIESE, P. (1978). A geothermal profile between the Adriatic and the Tyrrhenian Sea. In Closs, H., Roeder, D. \& Schmidt, K. (eds.). Alps, Apennines, Hellenides. IUCG 38, p324-327.

ENGLAND, P.C. \& RICHARDSON, S.W. (1977). The influence of erosion upon the mineral facies of rocks from different metamorphic environments. J. Geol. Soc. Lond., 134, p201-213.

ENGLAND, P.C. \& MOLNAR, P. (1990). Surface uplift, uplift of rocks, and exhumation of rocks. Geology, 18, p1173-1177.

ERGENZINGER, P., GÖRLER, K., IBBEKEN, H., OBENHAUF, P. \& RUMOHR, J. (1978). Calabrian Arc and Ionian Sea : Vertical movements, erosional and sedimentary balance. In Closs, H., Roeder, R. \& Schmidt, K. (eds.). Alps, Apennines, Hellenides. IUCG 38, p359-373.

FAURE, M. (1980). Microtectonique et charriage Est-Ouest des nappes alpines profondes de Sila (Calabre, Italie meridionale). Rev. Géol. Dynam. Géog. Phys., 22, p135-146.

FAURE, G. (1986). Principles of Isotope Geology. John Wiley, New York. pp589.

FERLA, P. \& ALAIMO, R. (1976). I graniti e le rocce porfiriche calc-alcaline e K-andesitiche nel conglomerato transgressivo del Miocene Inferiore dei Monti Peloritani. Mem. Soc. Geol. It., 17, p123-133.

FERLA, P., LORENZONI, S. \& ZANETTIN-LORENZONI, E. (1983). Geological constitution and evolution of the Calabro-Peloritan Hercynian Range. Rend. Soc. It. Miner. Petrol., 38, p951-962.

FERRARA, G. \& LONGINELLI, A. (1961).Eta'di due rocce granitiche della zona della Serre in Calabria. Boll. Soc. Geol. It., 80, p25.

FERRARA, G., IPPOLITO, F., STAUFFER, H. \& TONGORGI, E. (1959). Determinazione con metodi del piombo dell'eta di un filone pegmatitico presso Delianuova (Aspromonte, Calabria). Boll. Soc. Geol. It., 78, p74.

FINETTI, I \& MORELLI, C. (1973). Geophysical exploration of the Mediterranean Sea. Boll. Geof. Teor. Appl., 15, p263-344. 
FLEISCHER, R.L. \& HART, H.R. (1972). Fission track dating: techniques and problems. In: Bishop, W.W., Miller, J.A. \& Cole, S. (eds.). Calibration of Hominoid Evolution. Scottish Academic Press, Edinburgh. p135-170.

FLEISCHER, R.L. \& PRICE, P.B. (1964). Glass dating by fission fragment tracks. J. Geophys. Res., 69, p331339.

FLEISCHER, R.L., PRICE, P.B. \& WALKER, R.M. (1964). Track registration in various solid-state nuclear track detectors. Physics Review, 133, pA1443-A1449.

FLEISCHER, R.L., PRICE, P.B. \& WALKER, R.M. (1965). Effects of temperature, pressure and ionisation on the formation and stability of fission tracks in minerals and glasses. J. Geophys. Res., 70, p1497-1502. FLEISCHER, R.L., PRICE, P.B., WALKER, R.M., MAURETTE, M. \& MORGAN, M. (1967). Tracks of heavy primary cosmic rays in meteorites. J. Geophys, Res., 72, p355-366.

FLEISCHER, R.L., PRICE, P.B. \& WALKER, R.M. (1975). Nuclear Tracks in Solids: Principles and Applications. University of California Press, Berkeley.

FLEROV, G.N. \& PETRZAKH, K.A. (1940). Spontaneous fission of uranium. J. Phys., 3, p275-280.

GALBRAITH, R.F. (1981). On statistical models of fission track counts. J. Math. Geol., 13, p471-478.

GALBRAITH, R.F. (1984). On statistical estimation in fission track dating. J. Math. Geol, 16, p653-669.

GALBRAITH, R.F. (1986). Allocation of grains in the population method of fission track dating. Nucl. Tracks, 10, p361-363.

GALBRAITH, R.F. (1988). Graphical display of estimates having different standard errors. Technometrics, 30, p271281.

GALBRAITH, R.F. (1990). The radial plot: graphical assessment of spread in ages. Nucl. Tracks, 17, p207-214.

GALBRAITH, R.F. \& GREEN, P.F. (1990). Estimating the component ages in a finite mixture. Nucl. Tracks, 17, p197-206.

GALBRAITH, R.F. \& LASLETT, G.M. (1985). Some remarks on statistical estimation in fission track dating. Nucl. Tracks, 10, p361-363.

GALBRAITH, R.F. \& LASLETT, G.M. (1988). Some calculations relevant to thermal annealing of fission tracks in apatite. Proc. R. Soc. Lond., A419, p305-321.

GASPIRINI, C., IANNACCONE, G. \& SCARPA, R. (1985). Fault-plane solutions and seismicity of the Italian peninsula. Tectonophysics, 117, p59-78. 
GHISETTI, F. (1981). Upper Pliocene-Pleistocene uplift rates as indicators of neotectonic pattern: An example from southern Calabria (Italy). Z. Geomorph., 40, p93-118.

GHISETTI, F. (1984). Recent deformation and the seismogenic source in the Messina Strait (southern Italy). Tectonophysics, 109, p191-208.

GHISETTI, F. \& VEZZANI, L. (1981). Contribution of structural analysis to understanding the geodynamic evolution of the Calabrian Arc (southern Italy). J. Struct. Geol., 3, p371-381.

GHISETTI, F. \& VEZZANI, L. (1982). Different styles of deformation in the Calabrian Arc (southern Italy) : Implications for seismotectonic zoning. Tectonophysics, 85, p149-165.

GILCHRIST, A.R. \& SUMMERFIELD, M.A. (1990). Differential denudation and flexural isostacy in formation of rifted-margin upwarps. Nature, 346, p739-742.

GIUNTA, G. (1985). Problematiche ed ipotesi sul Bacino Numidico nelle Maghrebidi siciliane. Boll. Soc. Geol. It., 104, p239-256.

GLEADOW, A.J.W. (1978). Fission track evidence for thermal evolution of rifted continental margins. U.S. Geol. Surv. Open File Report, 78-701, p146-148.

GLEADOW, A.J.W. (1981). Fission track dating methods: what are the real alternatives? Nucl. Tracks, 5, p3-14. GLEADOW, A.J.W. \& FITZGERALD, P.G. (1987). Uplift history and structure of the Transantartic Mountains: new evidence from fission track dating of basement apatites in the Dry Valleys area, southern Victoria Land. Earth Planet. Sci. Lett., 82, p1-14.

GLEADOW, A.J.W. \& LOVERING, J.F. (1974). The effect of weathering on fission track dating. Earth Planet. Sci. Lett., 22, p163-168.

GLEADOW, A.J.W. \& LOVERING, J.F. (1977). Geometry factor for external track detectors in fission track dating. Nucl. Tracks, 1, p99-106.

GLEADOW, A.J.W., DUDDY, I.R., GREEN, P.F. \& LOVERING, J.F. (1986). Confined fission track lengths in apatite: A diagnostic tool for thermal history analysis. Contrib. Mineral. Petrol., 94, p405-415.

GLEADOW, A.J.W., DUDDY, I.R. \& LOVERING, J.F. (1983). Fission-track analysis: A new tool for the evaluation of thermal histories and hydrocarbon potential. APEA Journal, 23, p93-102.

GLEADOW, A.J.W., HURFORD, A.J. \& QUAIFE, R.D. (1976). Fission track dating of zircon: improved etching conditions. Earth. Planet. Sci. Lett., 33, p273-276. 
GORLER, K. (1978). Critical review of postulated nappe structures in southem Calabria. In Closs, H., Roeder, D. \& Schmidt, K. (eds.). Alps, Apennines, Hellenides. IUCG 38, p349-354.

GORLER, K. \& GIESE, P. (1978). Aspects of the evolution of the Calabrian Arc. In Closs, H., Roeder, D. \& Schmidt, K. (eds.). Alps, Apennines, Hellenides. IUCG 38, p374-388.

GRANDJACQUET, C. \& MASCLE, G. (1978). The structure of the Ionian Sea, Sicily and Calabria-Lucania. In Nairn, A.E.M. et al. (eds.). The Ocean Basins and Margins, Volume 4B : The Western Mediterranean. Plenum Press, New York. p257-330

GREEN, P.F. (1981). A new look at statistics in fission track dating. Nucl. Tracks, 5, p77-86.

GREEN, P.F. (1988). The relationship between track shortening and fission track age reduction in apatite: combined influences of inherent instability, annealing anisotropy, length bias and system calibration. Earth Planet. Sci. Lett., 89, p335-352.

GREEN, P.F. (1989). Thermal and tectonic history of the East Midlands shelf (onshore UK) and surrounding regions assessed by apatite fission track analysis. J. Geol. Soc. Lond., 146, p755-773.

GREEN, P.F. \& DURRANI, S.A. (1978). A quantitative assessment of geometry factors for use in fission track studies. Nucl. Tracks, 2, p207-213.

GREEN, P.F. \& HURFORD, A.J. (1984). Thermal neutron dosimetry for fission track dating. Nucl. Tracks, 9, p231-241.

GREEN, P.F., DUDDY, I.R., GLEADOW, A.J.W., TINGATE, P.R. \& LASLETT, G.M. (1986). Thermal annealing of fission tracks in apatite: 1. A qualitative description. Chem. Geol. (Isotope Geoscience Section), 59, p237-253.

GREEN, P.F., DUDDY, I.R., LASLETT, G.M., HEGARTY. K.A., GLEADOW, A.J.W. \& LOVERING, J.F. (1986). Thermal annealing of fission tracks in apatite: 4. Quantitative modelling techniques and extension to geological timescales. Chem. Geol. (Isotope Geoscience Section), 79, p155-188.

GUIEU, G. \& ROUSSEL, J. (1990). Arguments for the pre-rift uplift and rift propagation in the Ligurian-Provencal Basin (northwestern Mediterranean) in the light of Pyrenean Provencal Orogeny. Tectonics, 9, p1113-1142. HACCARD, D., LORENZ, C. \& GRANDJACQUET, C. (1972). Essai sur l'evolution tectogenetique de al liaison Alpes-Apennines (de la Ligurie a la Calabre). Mem. Soc. Geol.It., 11, p309-341.

HARLAND, W.B., ARMSTRONG, R.L., COX, A.L., CRAIG, L.E., SMITH, A.G. \& SMTTH, D.G. (1989). A Geological Time Scale, 1989. Cambridge University Press, pp263. 
HARRISON, T. M. (1981). Diffusion in ${ }^{40} \mathrm{Ar}$ in homblende. Contrib. Min. Pet., 78, p324-331.

HARRISON, T.M. \& CLARKE, G.K.C. (1979). A model of the thermal effects of igneous intrusion and uplift as applied to the Quotton pluton, British Columbia. Can. J. Earth Sci., 16, 411-420.

HARRISON, T.M. \& MCDOUGALL, I. (1980). Investigation of an intrusive contact in NW Nelson, New Zealand. II. Diffusion of radiogenic and excess ${ }^{40} \mathrm{Ar}$ in homblende revealed by ${ }^{40} \mathrm{Ar} / 39 \mathrm{Ar}$ age spectrum analysis. Geochim. Cosmochim. Acta, 44, p2005-2020.

HARRISON, T.M., ARMSTRONG, R.L., NAESER, C.W. \& HARAKEL, J.E. (1979). Geochronology and thermal history of the Coast Plutonic complex, near Prince Rupert, B.C. Can. J. Earth Sci., 16, p400-410. HAUGHTON, P.D.W., ROGERS, G. \& HALLIDAY, A.N. (1990). Provenance of Lower Old Red Sandstone conglomerates, SE Kincardineshire: evidence for the timing of Caledonian terrane accretion in central Scotland. J. Geol. Soc. Lond., 147, p105-120.

HEARTY, P.J., BONFIGLIO, L., VIOLANTI, D. \& SZABO, B.J. (1986). Age of late Quaternary marine deposits of southern Italy determined by aminostratigraphy, faunal correlation and U-series dating. Riv. Ital. Paleontol. Stratigr., 92, p148-164.

HILL, K.C. (1990). Time of uplift and thermal history of the fold-belt in Papua New Guinea, from apatite fission track analysis. $\mathrm{Nucl}$. Tracks, $17, \mathrm{p} 417$ (abstract)

HILL, K.C. \& HAYWARD, A.B. (1988). Structural constraints on the Tertiary plate tectonic evolution of Italy. Mar. Petrol. Geol., 5, p2-15.

HUBBARD, M., ROYDEN, L. \& HODGES, K. (1991). Constraints on unroofing rates in the High Himalaya, Eastern Nepal. Tectonics, 10, p287-298.

HURFORD, A.J. (1986a). Cooling and uplift patterns in the Lepontine Alps, South Central Switzerland and an age of vertical movement on the Insubric line. Contrib. Mineral. Petrol., 92, p413-427

HURFORD, A.J. (1986b). Application of the fission-track dating method to young sediments : Principles, methodology and examples. In Hurford, A.J., Jăger, E. \& Ten Cate, J.A.M. (eds.). Dating Young Sediments. Proceedings of the Workshop, Beijing, China, September 1985. CCOP-UNESCO Technical Publication 16, Bangkok. p199-233.

HURFORD, A.J. (1990a). Standardization of fission track dating calibration: recommendation by the Fission Track Working Group of the I.U.G.S. Subcommision on Geochronology. Chem. Geol. (Isotope Geoscience Section), 80, p171-178. 
HURFORD, A.J. (1990b). International Union of Geological Sciences Subcommision on Geochronology recommendation for the standardization of fission track dating calibration and data reporting. Nucl. Tracks, 17, p233-236.

HURFORD, AJ. (1991). Uplift and cooling pathways derived from fission track analysis and mica dating: a review. Geol. Rundsch., 80, p349-368.

HURFORD, AJ. \& CARTER, A. (1991). The role of fission track dating in discrimination of provenance. In: Moreton, A.C., Todd, S.P. \& Haughton, P.D.W. (eds.). Developments in Sedimentary Provenance Studies. Spec. Pub. Geol. Soc. Lond., 57, p67-78.

HURFORD, A.J. \& GREEN, P.F. (1981). Standards, dosimetry and uranium-238 $\lambda_{\mathrm{f}}$ decay constant: a discussion. Nucl. Tracks, 5, p73-75.

HURFORD, A.J. \& GREEN, P.F. (1982). A users' guide to fission-track dating calibration. Earth Planet. Sci.

Lett., 59, p343-354.

HURFORD, A.J. \& GREEN, P.F. (1983). The zeta age calibration of fission-track dating. Isotope Geoscience, 1, p285-317.

HURFORD, A.J., FLISCH, M. \& JÄGER, E. (1989). Unravelling the thermo-tectonic evolution of the Alps : A contribution from fission-track analysis and mica dating. In Coward, M.P., Dietrich, D. \& Park, R.G. (eds.). Alpine Tectonics. Geol. Soc. Lond. Spec. Pub., 45, p369-398.

HURFORD, A.J.., GLEADOW, A.J.W. \& NAESER, C.W. (1976). Fission track dating of pumice from the KBS Tuff, East Rudolf, Kenya. Nature, 263, p738-740.

HURFORD, A.J., FITCH, F.J. \& CLARKE, A. (1984). Resolution of the age structure of the detrital zircon populations of two Lower Cretaceous sandstones from the Weald of England by fission track dating. Geol. Mag., 121, p269-277.

INCORONATO, A., TARLING, D.H. \& NARDI, G. (1985). Palaeomagnetic study of an allochthonous terrane: the Scisti Silicei Formation, Lagonegro Basin, Southern Italy. Geophys. J.R. Astron. Soc., 83, p721-729. IPPOLITO,F., D'ARGENIO, B., PESCATORE, T. \& SCANDONE, P. (1976). Structural- stratigraphic units and tectonic framework of the southem Apennines. In Squyres, C.H. (ed.). The Geology of Italy: Volume 2, p317-328.

JAMIESON, R.A. \& BEAUMONT, C. (1988). Orogeny and metamorphism: a model for deformation and pressuretemperature-time paths with applications to the central and southern Appalachians. Tectonics, 7, p417-445 
JAMIESON, R.A. \& BEAUMONT, C. (1989). Deformation and metamorphism inconvergent orogens: a model for uplift and exhumation of metamorphic terrains. In: Daly, J.S., Cliff, R.A. \& Yardley, B.W.D. (eds.). Evolution of Metamorphic Belts. Spec. Pub. Geol. Soc. Lond., 43, p117-129.

KAMP, P.J.J., GREEN, P.F. \& WHITE, S.H. (1989). Fission track analysis reveals character of collisional tectonics in New Zealand. Tectonics, 8, p169-195.

KAMP, P.J.J., GREEN, P.F. \& TIPPET, J.M. (1992). Tectonic architecture of the mountain front-foreland basin transition, South Island, New Zealand, assessed by fission track analysis. Tectonics, 11, p98-113.

KASTENS, K., MASCLE, J. et al. (1987). Proceedings of the Ocean Drilling Program, Initial reports (Part B), v.107.

KASTENS, K., MASCLE, J. et al. (1988). ODP leg 107 in the Tyrrhenian Sea: Insights into passive margin and back-arc basin evolution. Bull. Geol. Soc. Am., 100, p1140-1156.

KNOTT, S.D. (1987). The Liguride Complex of southern Italy - A Cretaceous to Palaeogene accretionary wedge. Tectonophysics, 142, p217-226.

KNOTT, S.D. (1988). Structure, sedimentology and petrology of an ophiolitic flysh terrain in Calabria, southern Italy. unpublished D.Phil. Thesis, University of Oxford.

KNOTT, S.D. \& TURCO, E. (1991). Late Cenozoic kinematics of the Calabrian Arc, southern Italy. Tectonics, 10, p1164-1172.

KOHN, B.P. \& EYAL, M. (1981). History of uplift of the crystalline basement of Sinai and its relation to opening of the Red Sea as revealed by fission track dating of apatites. Earth Planet. Sci. Lett., 52, p129-141.

KOHN, B.P., SHAGAM, R., BANKS, P.O. \& BURKLEY, L.A. (1984). Mesozoic-Pleistocene fission track ages on rocks of the Venezuelan Andes and their tectonic implications. Mem. Geol. Soc. Am., 162, p365-384. KOONS, P.O. (1987). Some thermal and mechanical consequences of rapid uplift: an example from the Southern Alps, New Zealand. Earth Planet. Sci. Lett., 86, p307-319.

KRISHNASWAMI, S., LAL, D., PRABHU, N. \& MACDOUGALL, D. (1974). Characteristics of fission tracks in zircon: applications to geochronology and cosmology. Earth Planet. Sci. Lett., 22, p51-59.

LAKATOS, S. \& MILLER, D.S. (1972). Evidence for the effect of water content on fission track annealing in volcanic glass. Earth Planet. Sci. Lett., 14, p128-130.

LASLETT, G.M., KENDALL, W.S., GLEADOW, A.J.W. \& DUDDY, I.R. (1982). Bias in measurement of fission track length distributions. Nucl. Tracks, 6, p79-85. 
LASLETT, G.M., GLEADOW, A.J.W. \& DUDDY, I.R. (1984). The relationship between fission track length and track density in apatite. Nucl. Tracks, 9, p29-38.

LASLETT, G.M., GREEN, P.F., DUDDY, I.R. \& GLEADOW, A.J.W. (1987). Thermal annealing of fission tracks in apatite: 2. A quantitative analysis. Chem. Geol. (Isotope Geoscience Section), 65, p1-13.

LEEDER, M.R. (1991). Denudation, vertical crustal movements and sedimentary basin infill. Geol. Rundsch., 80, p441-458.

LE PICHON, X., BERGERAT, F. \& ROULET, M-J. (1988). Plate kinematics and tectonics leading to the alpine belt formation. A new analysis. Geol. Soc. Am. Spec. Paper, 218, p111-131.

LEWIS, C.L.E., CARTER, A. \& HURFORD, A.J. (1992). Low-temperature effects of the Skye Tertiary intrusions on Mesozoic sediments in the Sea of Hebrides Basin. In: Parnell, J. (ed.). Basins on the Atlantic Seaboard: Petroleum Geology, Sedimentology and Basin Evolution. Spec. Pub. Geol. Soc. Lond., 62, p175-188. LOIACONO, F. \& PUGLISI, D. (1983). Studio sedimentologico-petrografico del Flysch di Reitano (Oligo-Miocene inferiore, Sicilia). Boll. Soc. Geol. It., 102, p307-328.

LORENZONI, S., ORSI, G. \& ZANETTIN-LORENZONI, E. (1980). The Hercynian Range in southeastem Aspromonte (Italy). Its relationship with the Alpine Stilo Unit. N. Jb. Geol. Paläont. Mh., 7, p404-416.

LORENZONI, S. \& ZANETTIN-LORENZONI, E. (1976). The granitic-kinzigitic klippe of Tiriolo-Miglierina (Catanzaro, southern Italy) and its significance in the interpretation of the geological history of Calabria. $N$. Jb. Geol. Paläont. Mh., H8, p479-488.

LORENZONI, S. \& ZANETTIN-LORENZONI, E. (1983). Note illustrative della Carta Geologica della Sila alla scala 1:200.000. Mem. Sci. Geol. Padova, 36, p317-342.

LOWRIE, W. (1986). Paleomagnetism and the Adriatic promontory: a reappraisal. Tectonics, 5, p797-807.

LUGEON, M. \& ARGAND, E. (1906). La racine de la nappe sicilienne et l'arc de charriage de la Calabre. C.R. Acad. Sci. Paris, 142, p1107-1109.

LUTZ, T.M. \& OMAR, G. (1991). An inverse method of modelling thermal histories from apatite fission-track data. Earth Planet. Sci. Lett., 104, p181-195.

McGOLDRICK, P.J. \& GLEADOW, A.J.W. (1977). Fission track dating of Lower Palaeozoic sandstones at Tatong, North Central Victoria. J. Geol. Soc. Australia, 12, p461-464. 
MACCARRONE, E., PAGLIONICO, A., PICCARRETA, G. \& ROTTURA, A. (1983). Granulite-amphibolite facies metasediments from the Serre (Calabria, southern Italy) : Their protoliths and the processes controlling their chemistry. Lithos, 16, p95-111.

MALINVERNO, A. (1981). Quantitative estimates of age and Messinian paleobathymetry of the Tyrrhenian Sea after seismic reflection, heat flow and geophysical models. Boll. Geof. Teor. Appl., 23, p159-171.

MALINVERNO, A. \& RYAN, W.B.F. (1986). Extension in the Tyrrhenian Sea and shortening in the Apennines as a result of arc migration driven by sinking of the lithosphere. Tectonics, 5, p227-245.

MEMBREY, F., CHAMBAUDET, A., FROMM, M. \& SAOULI, R. (1990). Track etching model for normal incident heavy ion recording in isotropic dielectric detectors. Nucl. Tracks, 17, p183-190.

MESSINA, A., COMPAGNONI, R., RUSSO, S., DE FRANCESCO, A.M. \& GIACOBBE, A. (1990). Alpine metamorphic overprint in the Aspromonte Nappe of northeastem Peloritani Mts. (Calabria-Peloritani Arc, southern Italy). Boll. Soc. Geol. It., 109, p655-673.

MESSINA, A., COMPAGNONI, R., DE VIVO, B., PERRONE, V., RUSSO, S., BARBERI, M. \& SCOTT, B. (1991a). Geological and petrochemical study of the Sila Massif plutonic rocks (northern Calabria, Italy). Boll. Soc. Geol. It., 110, p165-206.

MESSINA, A., RUSSO, S., PERRONE, V. \& GIACOBBE, A. (1991b). Calc-alkaline Late Variscan two micacordierite-Al silicate-bearing intrusions of the Sila batholith (northern sector of the Calabrian-Peloritan Arc Italy). Boll. Soc. Geol. It., 110, p365-389.

MEULENKAMP, J.E., HILGEN, F. \& VOOGT, E. (1986). Late Cenozoic sedimentary-tectonic history of the Calabrian Arc. G. Geol., 48, p345-359.

MONTENANT, C. \& BARRIER, P. (1987). Approche quantitative des mouvements verticeux quaternaires dans le Strait de Messine. In: Barrier, P., Di Geronimo, I. \& Montenant, C. (eds.) (1987). Le Détroit de Messine (Italie) : Evolution tectono-sedimentaire récente (Pliocene et Quaternaire) et environnement actuel. Doc. et Trav. I.G.A.L., Paris, No.11, p185-190.

MONTIGNY, R., EDEL, J.B. \& THUIZAT, R. (1981). Oligo-Miocene rotation of Sardinia: K-Ar ages and palaeomagnetic data of Tertiary volcanics.Earth Planet. Sci. Lett., 54, p261-271.

MORELLI, C. (1970). Physiography, gravity and magnetism of the Tyrrhenian Sea. Boll. Geof. Teor. Appl., 12, p275-309. 
MORELLI, C., PISANI, H. \& GANTAR, C. (1975). Geophysical anomalies and tectonics in the western Mediterranean. Boll. Geof. Teor. Appl., 17, p67

MORESI, M., PAGLIONICO, A., PICCARETTA, G. \& ROTTURA, A. (1980). Geochemical features of granuliteamphibolite metabasites from the Serra, Calabria (Southem Italy). N. Jb. Miner. Abh., 138, p49-63.

MORETTI, I. \& ROYDEN, L. (1988). Deflection, gravity anomalies and tectonics of doubly subducted continental lithosphere ; Adriatic and Ionian Seas. Tectonics, 7, p875-893.

MOUSSAT,E., MASCLE, G. \& ANGELIER, J. (1985). Régimes de palaéoconstraintes et déformation de l'arc Tyrrhenian. C. R. Acad. Sci. Paris, 300(II), p417-422.

MULGARIA, F., BALDI, P., ACHILLI, V. \& BROCCIO, F. (1984). Recent crustal deformations and tectonics of the Messina Straits area. Geophys. J. R. Astr. Soc., 76, p369-381.

NAESER, C.W. (1967). The use of apatite and sphene for fission track age determinations. Bull. Geol. Soc. Am., 78, p1523-1526.

NAESER, C.W. (1979).Fission track dating and geologic annealing of fission tracks. In: Jăger, E. \& Hunziker, J.C. (eds.). Lectures in Isotope Geology. Springer-Verlag, Berlin, p154-169.

NAESER, C.W. (1981). The fading of fission tracks in the geological environment - data from deep drill holes. Nucl. Tracks, 5, p248-250.

NAESER, C.W. \& FAUL, H. (1969). Fission trackannealing in apatite and sphene. J. Geophys. Res., 74, p705710.

NAESER, C.W., IZETT, G.A. \& OBRADOVICH, J.D. (1973). Zircon fission track ages of Pearlette family ash beds in Meade County, Kansas. Geology, 1, p187-189.

NAESER, C.W., IZETT, G.A. \& OBRADOVICH, J.D. (1980). Fission track and K/Ar ages of natural glasses. U.S.G.S. Bulletin, 1489, pp31.

NAESER, N.D. AND McCULLOH, T.H. (1989). Thermal History of Sedimentary Basins: Methods and Case Histories. Springer-Verlag, New York.

NAESER, N.D., ZEITLER, P.K., NAESER, C.W. \& CERVENY, P.F. (1987). Provenance studies by fission track dating of zircon - etching and counting procedures. Nucl. Tracks, 13, p121-126.

NAGPAUL, K.N., MEHTA, P.P. \& GUPTA, M.L. (1974). Annealing studies on radiation damages in biotite, apatite and sphene, and corrections to fissio track ages. Pure Appl. Geophys., 112, p131-139. 
NATIONAL BUREAU OF STANDARDS (1970). Certificates of analysis for standard reference materials 610 to 617. Washington, D.C.

NICOLETTI, M. \& ARDANESE, L.R. (1984). Datazione K-Ar di fasi minerali della granodiorite dell'Unita di Stilo (Le Serre, Calabria). Rend. Soc. It. Miner. Petrol., 39, p477-482.

NINKOVICH, D. (1968). Pleistocene volcanic eruptions in New Zealand recorded in deep-sea sediments. Earth Planet. Sci. Lett., 4, p89-102.

OBRADOVICH, J.D., NAESER, C.W., IZETT, G.A., PASINI, G. \& BIGAZZI, G. (1982). Age constraints on the proposed Plio-Pleistocene boundary stratotype of Vrica, Italy. Nature, 298, p55-59.

OGNIBEN, L. (1969). Schema introduttivo alla geologica del confine calabro-lucano. Mem. Soc. Geol. It., 8, p453763.

OGNIBEN, L. (1973). Schema Geologica della Calabria : (English Abstract). Geol. Romana, 12, p553-576.

OGNIBEN, L. \& VEZZANI, L. (1976). Nappe structure in Sicily, Calabria and Lucania, Italy. In Squyres, C.H. (ed.). The Geology of Italy : Volume 2, p83-104.

OHNENSTETTER, M., VIDAL, P., CORNICHET, J., HERMITTE, D. \& MACE, J. (1981). Crystallization and age of zircon from Corsican ophiolite albitites: Consequences for oceanic expansion in Jurassic times. Earth Planet. Sci. Lett., 54, p397-408.

OLDOW, J.S., CHANNELL, J.E.T., CATALANO, R. \& D'ARGENIO, B. (1990). Contemporaneous thrusting and large scale rotations in the western Sicilian fold and thrust belt, Tectonics, 9, p661-682.

O'SULLIVAN, P.B. \& DECKER, J. (1990). Apatite fission track evidence for Paleocene and Oligocene uplift events in the northeastern Brooks Range, Alaska. Nucl. Tracks, 17, p367-371.

PARIZE, O., BEAUDOIN, B., BUROLLET, P-F., COJAN, I. \& PINAULT, M. (1986). La provenance du matériel gréseux numidien est septentrionale (Sicile et Tunisie). C.R. Acad. Sci. Paris, 303 (II), p1671-1674.

PARRISH, R.R. (1982). Cenozoic thermal and tectonic history of the Coast Mountains of British Columbia as revealed by fission track and geological data and quantitative thermal analysis. Ph. D. Thesis, University of British Columbia.

PARRISH, R.R. (1985). Some cautions which should be exercised when interpreting fission track and other dates with regard to uplift rate calculations. Nucl.Tracks, 10, p425.

PARRISH, R.R. \& TIRRUL, R. (1989). U-Pb age of the Baltoro granite, northwest Himalaya, and implications for zircon inheritance and monazite U-Pb systematics. Geology, 17, p1076-1079. 
PESCATORE, T. (1978). Evoluzione tettonica del bacino irpino (Italie meridionale) durante il Miocene. Boll. Soc. Geol. It., 97, p783-805.

PESCATORE, T. \& SENATORE, M.R. (1986). A comparison between a present day (Taranto Gulf) and a Miocene (Irpinian Basin) foredeep of the southern Apennines (Italy). In Allen, P.A. \& Homewood, P. (eds.). Foreland Basins. Spec. Publs. Int. Ass. Sediment., 8, p169-182.

PIERATTINI, D., SCANDONE, P. \& CORTINI, M. (1975). Età di messa in posto ed età di metamorphismo delle 'limburgiti' nord-calabrese. Boll. Soc. Geol. It., 94, p367-376.

PIERI, M. \& MATTAVELLI, L. (1986). Geologic framework of Italian petroleum resources. Bull. Am. Ass. Petrol. Geol., 70, p103-130.

PLATT, J.P. (1986). Dynamics of orogenic wedges and the uplift of high pressure metamorphic rocks. Bull. Geol. Soc. Am., 97, p1037-1053.

PLATT, J.P. (1987). The uplift of high-pressure-low-temperature metamorphic rocks. Phil. Trans. R. Soc. Lond., A321, p87-103.

PLATT, J.P. \& COMPAGNONI, R. (1990). Alpine ductile deformation and metamorphism in a Calabrian basement nappe (Aspromonte, south Italy). Ecl. Geol. Helv., 83, p41-58.

PRICE, P.B. \& WALKER, R.M. (1962). Observation of fossil particle tracks in natural micas. Nature, 196, p732. PRICE, P.B. \& WALKER, R.M. (1963). Fossil tracks of charged particles in mica and the age of minerals. J. Geophys. Res., 68, p4847-4862.

PURDY, J.W. \& JÄGER, E. (1976). K-Ar ages on rock forming minerals from the Central Alps. Mem. Geol. Miner. Padova, 30. pp30.

RECQ, M., REHAULT, J.P., STEINMETZ, L. \& FABBRI, A. (1984). Amincissement de la croûte et accrétion au centre du Bassin Tyrrhénien d'après la sismique réfraction. Mar. Geol., 55, p447-477.

REHAULT, J.P., MASCLE, J. \& BOILLOT, G. (1984). Evolution geodynamique de Mediterranee depuis l'Oligocene. Mem. Soc. Geol. It., 27, p85-96

REHAULT, J.P., MUSSAT, E. \& FABBRI, A. (1987). Structural evolution of the Tyrrhenian back-arc basin. Mar. Geol., 74, p123-150.

RICOU, L.E. \& SIDDANS, A.W.B. (1986). Collision tectonics in the western Alps. In: Coward, M.P. \& Ries, A.C. (eds.). Collision Tectonics. Spec. Pub. Geol. Soc. Lond., 19, p229-244 
ROSSI, S., AUROUX, C. \& MASCLE, J. (1983). The Gulf of Taranto (southern Italy) : Seismic stratigraphy and shallow structure. Mar. Geol., 51, p327-346.

ROTTURA, A. (1985). The tonalitic gneisses from Palmi-Bagnara, Calabrian Arc (Southern Italy): geochemistry, their protoliths, and tectono-metamorphic evolution. N. Jb. Miner. Abh., 152, p187-210.

ROURE, F., HOWELL, D.G., MULLER, C. \& MORETTI, I. (1990). Late Cenozoic subduction complex of Sicily. J. Struct. Geol., 12, p259-266.

ROURE , F., CASERO, P. \& VIALLY, R. (1991). Growth processes and melange formation in the southern Apennines accretionary wedge. Earth Planet. Sci. Lett., 102, p395-412.

SAVELLI, C., BECCALUVA, L., DERIU, M., MACCIOTA, G. \& MACCIONI, L. (1979). K-Ar geochronology and evolution of the Tertiary "calc-alkaline volcanism of Sardinia (Italy). J. Volcanol. Geotherm. Res., 5 , p257-269.

SAVIN, S.M., DOUGLAS, R.G. \& STEHLI, F.G. (1975). Tertiary marine palaeotemperatures. Bull. Geol. Soc. Am., 86, p1499-1510.

SCANDONE, P. (1979). Origin of the Tyrrhenian Sea and Calabrian Arc. Boll. Soc. Geol. It., 98, p27-34.

SCANDONE, P. (1982). Structure and evolution of the Calabrian Arc. Earth Evol. Sci., 3, p172-180.

SCANDONE, P. \& PATACCA, E. (1984). Tectonic evolution of the central Mediterranean area. Ann. Geophys., 2, p139-142.

SCHENK, V. (1980). U-Pb and Rb-Sr radiometric dates and their correlation with metamorphic events in the granulite facies basement of the Serre, southern Calabria (Italy). Cont. Mineral. Petrol., 73, p23-38.

SCHENK, V. (1981). Synchronous uplift of the lower crust of the Ivrea Zone and of southern Calabria and its possible consequences for the Hercynian Orogeny in southem Europe. Earth Planet. Sci. Lett., 56, p305-320.

SCHENK, V. (1984). Petrology of felsic granulites, metapelites, metabasics, ultramafics and metacarbonates from southern Calabria (Italy) : Prograde metamorphism, uplift and cooling of a former lower crust. J. Petrol., 25, p255-298

SCHENK, V. (1989). P-T-t path of the lower crust in the Hercynian fold belt of southern Calabria. In: Daly, J.S., Cliff, R.A. \& Yardley, B.W.D. (eds.). Evolution of Metamorphic Belts. Spec. Pub. Geol. Soc. Lond., 43, p337-342. 
SCHENK, V. AND SCHREYER (1978). Granulite facies metamorphism in the northern Serre, Calabria, southern Italy. In: Closs, H., Roeder, D. \& Schmidt, K. (eds.). Alps, Apennines, Hellenides. IUCG 38, p341-348 SCHÜTTE, K.-G. (1978). Crustal structures of southern Italy. In: Closs, H., Roeder, D. \& Schmidt, K. (eds.). Alps, Apennines, Hellenides. IUCG 38, p315-320.

SCHWARZ, G. (1978). Magnetic measurements in northern Calabria. In: Closs, H., Roeder, D. \& Schmidt, K. (eds.). Alps, Apennines, Hellenides. IUCG 38, p321-323

SEARLE, M.P. \& TIRRUL, R. (1991). Structural and thermal evolution of the Karakoram crust. J. Geol. Soc. Lond., 148, p65-82.

SELLI, R. (1970). Cenni morfologici generali sul Mar Tirreno. G. Geol., 37, p5-24

SELLI, R. (1981). Thoughts on the geology of the Mediterranean region. In Wezel, F.C. (ed.). Sedimentary Basins of Mediterranean Margins. C.N.R., Italian Project of Oceanography, Tecnoprint, Bologna. p489-501. SEWARD, D. (1974) Age of New Zealand Pleistocene substages by fission-track dating of glass shards from tephra horizons. Earth Planet. Sci. Lett., 24, p242-248.

SILK, E.C.H. \& BARNES, R.S. (1959). Examination of fission fragment tracks with an electron microscope. Phil. Mag., 4, p970.

SNOEK, M. (1978). Isostatic behavior of the crust and upper mantle in southern Italy, the Tyrrhenian Sea and Sicily. In: Closs, H., Roeder, D. \& Schmidt, K. (eds.). Alps, Apennines, Hellenides. IUCG 38, p330-332. STUMP, E., FITZGERALD, P.G. \& GLEADOW, A.J.W. (1990). Comparisons through fission track analysis of portions of Australia and Antartica prior to continental drift. Nucl. Tracks, 17, p359-365.

SUMMERFIELD, M.A. (1991). Sub-aerial denudation of passive margins: regional elevation versus local relief models. Earth Planet. Sci. Lett., 102, p460-469.

THEIL, K. \& HUR, W. (1976). The 238U spontaneous fission decay constant re-determined by fission tracks. Earth Planet. Sci. Lett., 30, p50-56.

TORTORICI, L. (1981). Analisi delle deformazioni fragili dei sedimenti postorogeni della Calabria settentrionale. Boll. Soc. Geol. It., 100, p291-308.

TRELOAR, P.J., REX, D.C. \& WILLIAMS, M.P. (1991). The role of erosion and extension in unroofing the Indian Plate thrust stack, Pakistan Himalaya. Geol. Mag., 128, p465-478.

TURNER, D.L. \& FORBES, R.B. (1976). K-Ar studies in two deep basement drillholes: a new estimate of argon blocking temperature for biotite. Trans. Am. Geophys. Union, 57, p353. 
UNDERHILL, J.R. (1989). Late Cenozoic deformation of the Hellenide foreland, western Greece. Bull. Geol. Soc. Am., 101, p613-634.

VAN BEMMELEN, R.W. (1972). Driving forces of Mediterranean orogeny. Test case I: Tyrrhenian area. Geol. Mijnbouw, 51, p548-573.

VAN DIJK, J.P. (1991). Basin dynamics and sequence stratigraphy in the Calabrian Arc (Central Mediterranean): records and pathways of the Crotone Basin. Geol. Mijnbouw, 70, p187-201.

VAN DIJK, J.P. \& OKKES, F.W.M. (1990). The analysis of shear zones in Calabria. Riv. Ital. Stratigr. Palaeontol., 96, p241-270

VAN DIJK, J.P. \& OKKES, F.W.M. (1991). Neogene tectonostratigraphy and kinematics of Calabrian basins: implications for the geodynanics of the Central Mediterranean. Tectonophysics, 196, p23-60.

WAGNER, G.A \& REIMER, G.M. (1972). Fission track tectonics: the tectonic interpretation of fission track apatite ages. Earth Planet. Sci. Lett., 14, p263-268.

WAGNER, G.A., REIMER, G.M., CARPENTER, G.S., FAUL, H., VAN DER LINDEN, R. \& GIJBELS, R. (1975). The spontaneous fission rate of $238 \mathrm{U}$ and fission track dating. Geochim. Cosmochim. Acta., 39 , p1279-1286.

WAGNER, G.A., MLLER, D.S. \& JÄGER, E. (1979). Fission track ages on apatite of Bergell rocks from the Central Alps and Bergell boulders in Oligocene sediments. Earth Planet. Sci. Lett., 45, p355-360.

WANG, C.-Y., HWANG, W.-T. \& SHI, Y. (1989). Thermal evolution of a rift basin: the Tyrrhenian Sea. J. Geophys. Res., 94(B), p3991-4006.

WATERS, C.N. (1990). The Cenozoic tectonic evolution of Alpine Corsica. J. Geol. Soc. Lond., 147, p811-824. WEIGAL, W. (1978). A tectonic model of the northern Ionian Sea from refraction seismic data. In: Closs, H., Roeder, D. \& Schmidt, K. (eds.). Alps, Apennines, Hellenides. IUCG 38, p328-329.

WEILAND, B. (1979). Age determinations in the Longobucco Unit, Calabria, Italy. ECOG VI, Lillehammer. Abstracts.

WELTJE, G.J. (in press). Oligocene to Early Miocene sedimentation and tectonics in the southern part of the Calabrian-Peloritan Arc (Aspromonte, Southern Italy): A record of mixed-mode piggy-back basin evolution. Basin Research., in press.

WESTPHAL, M., ORSINI, J. \& VELLUTINI, P. (1976). Le microcontinent Corse-Sarde, sa position initiale: donnees palaeomagnetiques et raccords geologique. Tectonophysics, 30, p141-157. 
WEZEL, F.C. (1976). Flysch successions and the tectonic evolution of Sicily during the Oligocene and Early

Miocene. In: Squyres, C.H. (ed.). The Geology of Italy : Volume 2, p105-127.

WEZEL, F.C. (1981). The structure of the Calabro-Sicilian Arc : Krikogenesis rather than subduction. In Wezel,

F.C. (ed.). Sedimentary Basins of Mediterranean Margins. C.N.R., Italian Project of Oceanography,

Tecnoprint, Bologna. p485-487.

WEZEL, F.C. (1982). The structure of the Calabro-Sicilian Arc: A result of post-orogenic intra-plate deformation.

In Legget, J.K. (ed.). Trench-Forearc Geology. Geol. Soc. Lond. Spec. Pub., 10, p345-354.

WEZEL, F.C. (1985). Structural features and basin tectonics of the Tyrrhenian Sea. In: Stanley, D.J. \& Wezel, F.C.

(eds.). Geological Evolution of Mediterranean Basins. Springer, New York, p153-194.

WHEELER, J. (1991). Structural evolution of a subducted continental sliver: the northern Dora Maira massif, Italian Alps. J. Geol. Soc. Lond., 148, p1101-1113.

WHITE, S.H. \& GREEN, P.F. (1986). Tectonic development of the Alpine fault zone, New Zealand: a fission track study. Geology, 14, p124-127.

WOLFE, J.A. (1980). A paleobotanical interpretation of Tertiary climates in the northern hemisphere. American Scientist, 66, p694-703.

YELLAND, A.J. (1990). Fission track thermotectonics in the Pyrenean orogen. Nucl. Tracks, 17, p293-300.

YOUNG, J.R., TEALE, T. \& BOWN, P. (1986). Revision of the stratigraphy of the Longobucco Group (Liassic, southern Italy): based on new data from nannofossils and ammonites. Ecl. Geol. Helv., 79, p117-135. ZANETTIN-LORENZONI, E. (1982). Relationships of main structural elements of Calabria (southern Italy). $N . J b$. Geol. Paläont. Mh., 7, p403-418.

ZEITLER, P.K. (1985). Cooling History of the NW Himalaya. Tectonics, 4, p.127-151.

ZEITLER, P.K. (1989). The geochronology of metamorphic processes. In: Daly, J.S., Cliff, R.A. \& Yardley,

B.W.D. (eds.). Evolution of Metamorphic Belts. Spec. Pub. Geol. Soc. Lond., 43, p131-147.

ZEITLER, P.K., JOHNSON, N.M., NAESER, C.W. \& TAHIRKHELI, R.A.K. (1982). Fission-track evidence for Quaternary uplift of the Nanga Parbat region, Pakistan. Nature, 298, p255-257.

ZUFFA, G.G., GAUDIO, W. \& ROVITO, S. (1980). Detrital mode evolution of the rifted continental margin Longobucco sequence (Jurassic), Calabrian Arc, Italy. J. Sed. Pet., 50, p51-61.

ZUPPETTA, A., RUSSO, M., CAPALDI, G. \& TUCCILO, L. (1984). Evidenze di un evento tettonico triassico nell'Unità dei Borghi (Monte Peloritani - Sicilia). Boll. Soc. Geol. It., 103, p111-120. 